
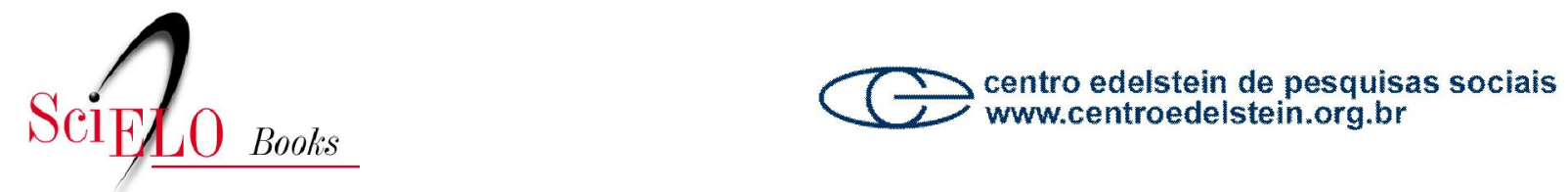

\title{
Diálogos em Psicologia Social
}

\author{
Ana Maria Jacó-Vilela \\ Leny Sato \\ orgs.
}

JACÓ-VILELA, AM., and SATO, L., orgs. Diálogos em psicologia social [online]. Rio de Janeiro: Centro Edelstein de Pesquisas Sociais, 2012. 482 p. ISBN: 978-85-7982-060-1. Available from

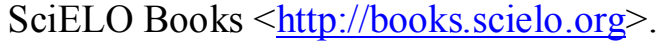

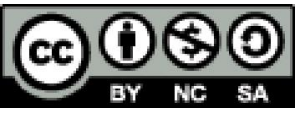

All the contents of this chapter, except where otherwise noted, is licensed under a Creative Commons Attribution-Non Commercial-ShareAlike 3.0 Unported.

Todo o conteúdo deste capítulo, exceto quando houver ressalva, é publicado sob a licença Creative Commons Atribuição Uso Não Comercial - Partilha nos Mesmos Termos 3.0 Não adaptada.

Todo el contenido de este capítulo, excepto donde se indique lo contrario, está bajo licencia de la licencia Creative Commons Reconocimento-NoComercial-CompartirIgual 3.0 Unported. 


\section{Ana Maria Jacó-Vilela \\ Leny Sato \\ Organizadoras}

\section{Diálogos em Psicologia Social}

Rio de Janeiro

2012 
Esta publicação é parte da Biblioteca Virtual de Ciências Humanas do Centro Edelstein de Pesquisas Sociais - www.bvce.org

Copyright (c) 2012, Ana Maria Jacó-Vilela e Leny Sato

Copyright (c) 2012 desta edição on-line: Centro Edelstein de Pesquisas Sociais Ano da última edição: 2007, Editora Evangraf Ltda.

Nenhuma parte desta publicação pode ser reproduzida ou transmitida por qualquer meio de comunicação para uso comercial sem a permissão escrita dos proprietários dos direitos autorais. A publicação ou partes dela podem ser reproduzidas para propósito não comercial na medida em que a origem da publicação, assim como seus autores, seja reconhecida.

ISBN: 978-85-7982-060-1

Centro Edelstein de Pesquisas Sociais www. centroedelstein. org.br

Rua Visconde de Pirajá, 330/1205

I panema - Rio de Janeiro - RJ

CEP: 22410-000. Brasil

Contato: bvce@centroedelstein.org.br 


\section{SUMÁRIO}

APRESENTAÇÃO ....................................................................................... VI

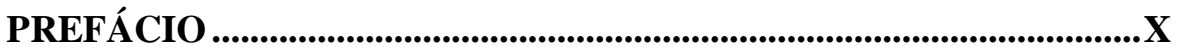

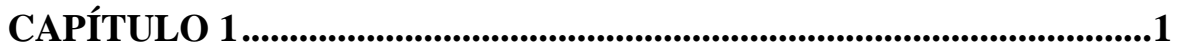

A razão inconstante: ciência, saber e legitimação social

Kenneth Rochel de Camargo Jr.

PSICOLOGIA SOCIAL:

O LUGAR DA CRÍTICA, DA MEMÓRIA E DA AFETIVIDADE

CAPÍTULO 2

O que é mesmo Psicologia Social?

Uma perspectiva crítica de sua história e seu estado hoje

Pedrinho Guareschi

CAPÍTULO 3

Psicologia social da memória:

sobre memórias históricas e memórias geracionais

Celso Pereira de Sá

PSICOLOGIA SOCIAL E PROCESSO EDUCACIONAL — IMPLICAÇÕES IDEOLÓGICAS E ÉTICAS

CAPÍTULO 4 .58

Armadilhas e alternativas nos processos educacionais e na formação de professores: uma análise na perspectivada psicologia sócio-histórica

Wanda Maria Junqueira de Aguiar

CAPÍTULO 5 .71

Interfaces entre educação não formal e juventude 


\section{ÉTICAS, VIOLÊNCIAS E DIREITOS HUMANOS}

CAPÍTULO 6 87

Transcendência e violência

Jurandir Freire Costa

CAPÍTULO 7 103

Juventude, política e religião: um pretexto para discutir ética, violência e direitos humanos na sociedade contemporânea

Luiz Alberto Oliveira Gonçalves

CAPÍTULO 8 123

Direitos humanos e responsabilidade ética no exercício da psicologia Andrea Ferrero

\section{GÊNERO E SEXUALIDADE: HISTÓRIA, CONDIÇÕES E LUGARES}

\section{CAPÍTULO 9}

Gênero em contextos rurais: a liberdade de ir e vir e o controle da sexualidade das mulheres no sertão de Pernambuco

Rosineide de L. M. Cordeiro

CAPÍTULO 10 147

Sexualidade, gênero e gerações: continuando o debate

Maria Juracy Filgueiras Toneli

\section{HISTÓRIA E FORMAÇÃO DO PSICÓLOGO}

CAPÍTULO 11 168

A formação de psicólogos na Argentina:

a Psicologia Social de Pichon-Rivière

Hugo Klappenbach 
Palavra e saberes psicológicos na história da cultura brasileira

Marina Massimi

CAPÍTULO 13

Por uma epistemologia historicamente orientada da psicologia

Iray Carone

INFÂNCIAS, ADOLESCÊNCIAS E FAMÍLIAS

CAPÍTULO 14

A criança negra no Brasil

Mary Del Priore

CAPÍTULO 15 .254

Infância, adolescência e a família:

práticas $p s i$, sociedade contemporânea e produção de subjetividade

Neuza Guareschi

CAPÍTULO 16 .269

A produção das infâncias e adolescências pelo Direito

Edinete Maria Rosa Eda Terezinha de Oliveira Tassara MÍDIA, PODER E SUBJETIVIDADE

CAPÍTULO 17 285

Infância na mídia brasileira e ideologia

Fúlvia Rosemberg Marcelo P. de Andrade

CAPÍTULO 18 .308

Emoções e mídia

Ronald João Jacques Arendt 


\section{VIOLÊNCIA E POLÍTICA: A DEMOCRACIA E AS REORDENAÇÕES DO POLÍTICO NO BRASIL CONTEMPORÂNEO}

CAPÍTULO 19 323

Sociedade civil versus violência (hipóteses brasileiras)

Céli Regina Jardim Pinto

PROCESSOS ORGANIZATIVOS, COMUNIDADES E PRÁTICAS SOCIAIS

CAPÍTULO 20 335

A democracia e a organização social de base

Aécio Gomes de Matos

CAPÍTULO 21 352

Processos organizativos e ação pública:

as possibilidades emancipatórias do lugar

Peter Kevin Spink

CAPÍTULO 22 370

Intervenção psicossocial e compromisso: desafios às políticas públicas Maria de Fátima Quintal de Freitas

\section{QUESTÕES CANDENTES NO DIÁLOGO DA PSICOLOGIA COM A SAÚDE COLETIVA}

CAPÍTULO 23 387

Sobre a promoção da saúde: tensões entre o risco na modalidade da aventura e as estratégias contemporâneas de biocontrole

Mary Jane P. Spink

CAPÍTULO 24 408

A psicologia e os desafios contemporâneos da reforma psiquiátrica

Maria Cristina Campello Lavrador 
CAPÍTULO 25.

.420

Médicos, mulheres e cesáreas: a construção do parto normal com "um risco" e a medicalização do parto no Brasil

Alessandra Sampaio Chacham

VISADAS SOBRE O TRABALHO CONTEMPORÂNEO

CAPÍTULO 26.

.452

Trabalho, organizações e instituições

José Newton Garcia de Araújo

CAPÍTULO 27

.469

O trabalho na perspectiva das políticas públicas

Odair Furtado 


\section{APRESENTAÇÃO}

O título desse livro expressa tanto o produto como o processo que culminou em sua elaboração.

Diálogos em Psicologia Social é o tema do XIV Encontro Nacional da ABRAPSO. A definição do tema bem como os tipos de diálogos que se queriam presentes foram construídos paulatinamente, num processo dialógico.

Desde que essa diretoria da ABRAPSO iniciou o trabalho de organização do XIV Encontro Nacional, desencadeamos um processo de consulta, discussão e definição de detalhes do próprio Encontro. Com intensa participação das diretorias regionais e das coordenações dos núcleos criaram-se as Comissões Científica e Organizadora. Embora esta, por suas próprias funções, tenha sido composta por sócios da ABRAPSO de universidades do Rio de Janeiro, a Comissão Científica foi composta por sócios da ABRAPSO indicados pela Diretoria, pelos Vice-Presidentes Regionais e pelos Coordenadores de Núcleo. Construímos, assim, uma Comissão composta por 16 membros, oriundos de diferentes universidades de todo o país. Esta Comissão funciona como Conselho Editorial deste livro.

A Diretoria da ABRAPSO sugeriu que o tema do Encontro fosse “Diálogos em Psicologia Social”. Com a Comissão Científica já funcionando, evidenciou-se serem diversos os objetos dos diálogos que se entendiam importantes: epistemológicos, metodológicos, éticos, políticos, estéticos e com as políticas públicas.

Com essa primeira definição, continuamos o intenso processo de troca e reflexão entre os membros da Comissão Científica para a composição do elenco dos eixos temáticos que vieram a aglutinar as contribuições da psicologia social na atualidade. Foram definidos dez eixos que cumpriram o papel de aglutinar as contribuições na forma de pôsteres, sessões temáticas e mesas-redondas. Os eixos temáticos e o escopo de sua continência são: 
1. Educação: abriga contribuições que se situem na interface da Psicologia Social e Educação, abrangendo tanto a educação escolar quanto a educação no sentido lato que se dá nas demais esferas da vida social, envolvendo o atual debate sobre educação como direito, dispositivo de cidadania e, fundamentalmente, condição de aprofundamento da democracia;

2. Ética, violências e direitos humanos: acolhe trabalhos que focalizem três eixos de reflexão que norteiam a convivência entre pessoas em diversas esferas da vida social: os valores éticos, as distintas formas de violência material e simbólica e os direitos humanos;

3. Gênero, sexualidade, etnia e geração: acolhe experiências, estudos e/ou pesquisas que focalizam o poder, em sua dimensão relacional, que se organiza em posições identitárias e práticas interpessoais, institucionais e culturais, marcadas por categorias e sistemas sociais tais como: idadegeração, orientação sexual, raça-etnia, sexo-gênero;

4. Histórias, teorias e metodologias: recebe trabalhos sobre as diferentes histórias da psicologia social, suas teorias e metodologias. Acolhe contribuições que as tratem de forma singularizada ou em estreito dialogo. Diferentes perspectivas epistemológicas são bem-vindas;

5. Infâncias, adolescências e famílias: visa a abordagem da construção social dos conceitos de infância, adolescência e família, bem como novas formas de relações familiares, juventude e identidades;

6. Mídia, comunicação e linguagem: trata das contribuições sobre os processos que envolvem a produção discursiva em contextos midiáticos e os processos de subjetivação mediados pela comunicação globalizada na sociedade contemporânea;

7. Política: recepciona contribuições que focalizem fenômenos políticos como comportamento eleitoral, movimentos sociais e ações coletivas, discursos políticos e participação social/esfera pública, desde a articulação entre psicologia social e política; 
8. Processos organizativos, comunidades e práticas sociais: visa fortalecer o dialogo entre três linhas importantes de estudo e intervenção em psicologia social: as comunidades, os grupos sociais formais e informais e os diferentes tipos e práticas organizativas. Acolhe trabalhos que se insiram em qualquer uma dessas linhas ou busquem articulá-las;

9. Saúde: abriga contribuições que se situem na interface da psicologia social e saúde, abrangendo tanto saúde coletiva, saúde pública, quanto saúde mental, envolvendo o atual debate sobre saúde como direito e dispositivo de cidadania;

10. Trabalho: congrega contribuições que focalizem as diversas configurações do trabalho, do emprego e do desemprego na sociedade contemporânea.

O processo de definição desses eixos foi momento propício para que se explicitassem os grandes temas que imantam as linhas de pesquisa na psicologia social brasileira.

Posteriormente, a Comissão Científica procedeu à indicação de nomes de pesquisadores que pudessem compor os simpósios e proferir a conferência de abertura. Novamente, aqui, a potencialidade de estabelecimento de diálogo expressando as diferenças teórico-metodológicas, as diversas construções de objetos, a sua consequente diversidade de encaminhamentos no trabalho de pesquisa e de intervenção foram também contempladas.

Acrescentamos um simpósio, sobre "Psicologia Social”. Finalmente, com a conferência de abertura pretendeu-se que os diversos diálogos pudessem ser acolhidos.

Esse livro apresenta textos integrais de todos os simpósios e da conferencia de abertura, totalizando vinte e sete artigos. A partir da leitura dos títulos das contribuições, no sumário, já é possível vislumbrar os caminhos tomados nas diversas apresentações. 
Consideramos que esse livro apresenta, além da contribuição singular e importante de cada autor, uma mostra do atual debate da psicologia social entre nós.

Os Diálogos em Psicologia Social não se tornariam públicos sem o apoio e o esforço de Pedrinho Guareschi, a quem agradecemos.

Ana Maria Jacó-Vilela

Leny Sato 


\section{PREFÁCIO}

Transfiguro a realidade e então outra realidade, sonhadora e sonâmbula, me cria.

Clarice Lispector

Os Encontros Nacionais da ABRAPSO estão inscritos no calendário da psicologia brasileira e latino-americana. Nesses quase trinta anos de história, consolidaram um determinado modo de produzir conhecimentos/de intervir comprometido com a crítica às condições de possibilidades que instituem realidades díspares e, ao mesmo tempo, com a invenção de possibilidades outras a serem criadas no diálogo com as pessoas com as quais se trabalha.

Diálogos nos encontros, Encontros que buscam renovar diálogos. Reflexões históricas e conceituais em pauta, assim como discussões sobre temáticas e campos consolidados no universo psi estão propostos para este XIV Encontro Nacional da ABRAPSO. Somam-se a estes o debate sobre temáticas atuais que ocupam o espaço da mídia cotidianamente e se apresentam a cada um de nós com a arrogância que lhes é própria. Violências várias, direitos anunciados e a muitos negados, políticas plurais a serem reivindicadas e produzidas.

O caos urbano, as (in)visibilidades, os discursos recorrentes, as práticas mesmas a reiterar naturalizações forçadas, os abandonos, as promessas, as reincidências, as histórias não contadas, as memórias falseadas... Lista infindável do que se apresenta como provocação a clamar a responsividade que nos conota, demandando a transfiguração que Clarice Lispector anuncia na epígrafe.

Transfiguração a provocar, por sua vez, ainda que sonhada e sonambulamente, a criação de novas Marias e Clarices, eticamente comprometidas com o choro que irriga e fertiliza o solo necessário à germinação de realidades outras. Que esse XIV Encontro nos provoque 
nesse sentido, que nos engravide do desejo da história, do debate, da luta, da necessidade de reinvenção de saberes/fazeres, é o que todos esperamos.

Andréa Vieira Zanella

Universidade Federal de Santa Catarina 


\section{A RAZÃO INCONSTANTE: CIÊNCIA, SABER E LEGITIMAÇÃO SOCIAL}

Kenneth Rochel de Camargo Jr. Universidade do Estado do Rio de Janeiro

\section{Apresentação}

D roponho uma tese: a de que um modelo científico ultrapassado do ponto 1 de vista do desenvolvimento da pesquisa sobrevive na concepção do senso comum sobre a ciência, e que esta permanência tem consequências de várias ordens, da epistemologia à política. Este modelo ultrapassado é o do determinismo da mecânica clássica, que além de ser um modelo sobre como as coisas são, também é um modelo de como conhecê-las; segundo esse modelo, a realidade é a causa única do conhecer, e o conhecimento verdadeiro e, portanto confiável, é apenas o que segue esse modelo. Este pressupõe ainda que esse conhecimento verdadeiro é o que determina a atuação racional humana. Apresento um instrumental de análise crítica, baseado no trabalho de Ludwik Fleck, que permite, a meu ver, expor esse componente anacrônico, bem como possibilitar o estabelecimento de um diálogo efetivo sobre diferentes modos de conhecer, a partir de uma versão empiricamente abordável do que entendo por "conhecimento”. Trago por fim um exemplo dessa permanência com base nos discursos correntes sobre a genética.

\section{Da razão inconstante}

Este texto trata das implicações concretas de um conjunto de questões teóricas, mais exatamente epistemológicas, partindo de um fato da vida na sociedade contemporânea: há um conjunto de intervenções, quer na vida de indivíduos, quer em coletividades, que é operado por agentes profissionais socialmente tidos como legítimos para operar essas 
intervenções, que se apresenta como a aplicação de um conhecimento confiável. Científico, exato, objetivo e verdadeiro, os adjetivos se multiplicam para reforçar a ideia de confiabilidade.

Como exemplo, pensemos na minha área de origem, a Saúde Pública. De forma minimalista, poderíamos dizer que este rótulo abarca um conjunto de saberes e práticas que se ocupam da saúde de populações. Em sua origem histórica, no preventivismo clássico, esta relação era o fundamento de intervenções maciças sobre a sociedade, eventualmente com grau importante de eficácia, mesmo que de modo brutal — veja-se, por exemplo, a relação das medidas de saneamento urbano de Oswaldo Cruz com o "bota-abaixo" de Pereira Passos. Ainda que matizada, esta vertente de intervenção está ainda hoje presente com maior ou menor intensidade de um modo difuso nessa área, quer mais explicitamente, como no caso das atividades de Planejamento e Administração em Saúde, quer mais indiretamente, no caso das recomendações derivadas dos estudos epidemiológicos.

Dito de outra forma, parte importante do conhecimento produzido ou utilizado neste campo tão complexo está a serviço de práticas normativas, o que traz invariavelmente a necessidade de um propósito ético como ideal regulador. A utilização acrítica do conhecimento técnico em intervenções nos coletivos humanos é um tema já bastante abordado, tanto nas discussões sobre o caráter tecnocrático de uma ou outra política governamental, quanto num nível mais micro no exame das relações de poder entre especialistas e população como, por exemplo na extensa literatura sobre o processo de medicalização social. Contudo, o fato da produção sobre este tema ser extensa não quer dizer que se esteja atentando devidamente para as suas implicações.

Uma linha estratégica de investigação neste sentido é a das várias abordagens sobre o processo de produção e validação do conhecimento científico. Esta abordagem é estratégica precisamente por ser este tipo de saber o que determina o sentido e a lógica das intervenções sobre o socius nos moldes criticados. "Está mais do que na hora de recuperar uma 
característica central do iluminismo: a crítica, mesmo se, como se verá, o seu exercício devesse hoje denunciar a unilateralidade do iluminismo e da civilização forjada pela modernidade” (PLASTINO, 1996:197). Essa unilateralidade se exprime sobretudo numa Razão que se exime do exercício reflexivo da crítica no sentido Kantiano do exame livre e público. Assimétrica, diria Latour; inconstante, no seu exercício parcial, escotomizado; ao colocar seus próprios fundamentos a salvo de qualquer ameaça, torna-se Poder absoluto, porque é incontestável.

Os danos causados por esta lógica que supõe uma Razão onipotente e ao mesmo tempo perscrutadora de tudo e a salvo de qualquer inquirição são bastante evidentes, por exemplo, nas consequências sociais e políticas do primado das ideias neoliberais na gestão da economia em diversos países da América Latina. Menos óbvias, mas nem por isto menos importantes, são os impactos contínuos da tradução não mediada do conhecimento produzido em condições controladas no laboratório para o cotidiano das populações.

Tome-se como exemplo as primeiras afirmações feitas sobre a AIDS, no início da década de 80. A divulgação da expressão "grupo de risco” e os conceitos a esta associados, trouxeram o reforço de velhos preconceitos e a falsa sensação de segurança para aqueles que não se identificaram com as categorias taxonômicas de então, com impactos negativos que se fazem sentir ainda hoje, mais de vinte anos depois.

Estas observações não têm por objetivo por em causa a utilidade do saber científico no enfrentamento (entre outros aspectos) dos desafios da saúde coletiva, mas, demonstrar que, como propôs Boaventura de Souza Santos, “(...) só aplicando a ciência contra a ciência é possível levá-la a dizer não só o que sabe de si, mas tudo aquilo que tem de ignorar a seu respeito para poder saber da sociedade o que esperamos que ela saiba" (Santos, 1988:13) Ainda segundo este mesmo autor, “A luta pela ciência pós-moderna e pela aplicação edificante do conhecimento científico é, simultaneamente, a luta por uma sociedade que as torne possíveis e maximize a sua vigência” (Idem, ibidem:161). Em anos recentes, uma forma 
quase canônica de "aplicar a ciência contra a ciência” emergiu dos science studies, definidos como se segue por um de seus principais autores: "Há cerca de vinte anos, eu e meus amigos estudamos estas situações estranhas que a cultura em que vivemos não sabe como classificar. Por falta de opções, nos denominamos sociólogos, historiadores, economistas, cientistas políticos, filósofos, antropólogos. Mas, a estas disciplinas veneráveis, acrescentamos sempre o genitivo: das ciências e das técnicas. Science studies é a palavra inglesa; ou ainda vocábulo por demasiado pesado: 'Ciências, técnicas, sociedades'. Qualquer que seja a etiqueta, a questão é sempre de reatar o nó górdio atravessando, tantas vezes quanto forem necessárias, o corte que separa os conhecimentos exatos e o exercício do poder, digamos a natureza e a cultura” (LATOUR, 1994:8-9).

Há várias narrativas disponíveis sobre a história das ciências, mesmo descartando-se as que são simplesmente ruins, variantes da "história dos vencedores” ou Whig history dos anglófonos. Desde a apresentação de uma grande revolução que introduz a ciência moderna, como propõe Hall (1988) até a versão que questiona a própria ideia de revolução científica (SHAPIN, 1996). Quer tratem de múltiplos começos ou uma origem singular, de pequenas modificações ou drástica ruptura a partir de um movimento inaugural, ainda assim parece ser possível apontar para um acordo em torno da ideia de que o longo período que vai do fim da Idade Média ao início da Modernidade, surgiu e desenvolveu-se na Europa uma nova forma de produzir conhecimento, a Ciência Moderna, que definiu não apenas um conjunto de técnicas e métodos como também uma nova visão de mundo. Essa visão progressivamente “coloniza” a cultura geral, tornando-se hegemônica nas sociedades ocidentais. As evidências desse processo de colonização estendem-se por toda parte, inclusive nos usos correntes de determinadas palavras e expressões. Como já mencionei anteriormente, os adjetivos “científico”, “verdadeiro”, “real” e “objetivo” e seus cognatos são considerados na linguagem comum como parte de uma mesma família semântica, usados de forma intercambiável, senão mesmo como sinônimos. Não é difícil entender a razão disto: a concepção que chamarei 
provisoriamente de "popular" da ciência (alimentada pelos próprios cientistas, diga-se de passagem) a toma como a atividade de retratar fielmente um real que é pré-existente e externo, numa forma simplista de realismo. Sendo assim, as formas de validação de conhecimentos operadas pela produção científica definiriam o padrão de excelência para tais processos de validação.

\section{Ciência e determinismo}

De modo resumido, esta concepção pode ser descrita como generalista (só se ocupa de leis e descrições universais), mecanicista (o universo pode ser descrito, compreendido - e eventualmente assimiladoa um gigantesco mecanismo) e analítica (o todo é expresso pela soma das partes e, portanto, para estudá-lo deve-se isolar partes progressivamente menores para estudo) (CAMARGO JR., 2003:107). Como consequência, o processo de conhecer a conduta da pesquisa implica necessariamente numa operação de redução —a criação de um modelo esquemático dos aspectos que se deseja estudar, deixando de fora detalhes e relações que, supostamente, não estão diretamente relacionados ao mecanismo em estudo (HARRÉ, 1988; SANTOS, 1988). Contudo, com frequência desliza-se da redução para o reducionismo a projeção do modelo esquemático sobre a situação estudada, assumindo o primeiro como a verdade essencial do segundo (HARRÉ, 1988; SANTOS, 1988). Vê-se, portanto, que as operações metodológicas do conhecer têm como ponto de articulação uma representação de mundo e uma epistemologia que partilham um traço comum: o determinismo; o triunfo e a ambição desse modo de produção encontraram expressão definitiva nas palavras de Laplace (1749-1827) em 1886:

Uma inteligência que, por um dado instante, conhecesse todas as forças pelas quais a natureza é animada e a situação respectiva dos seres que a compõem e que, além disso, fosse vasta o suficiente para submeter estes dados à análise, abraçaria na mesma fórmula os movimentos dos maiores corpos do universo e aqueles do menor átomo: nada seria incerto para ela, e o futuro, como o passado, seriam presente a seus olhos (1886:vi-vii). 
O determinismo, ao menos na forma colocada por Laplace, foi considerado impossível pela própria Física em função de desenvolvimentos posteriores (termodinâmica, mecânica quântica, dinâmica não linear), mas seu apelo enquanto visão de mundo persiste. No que nos interessa em particular, podemos perceber a força das concepções deterministas examinando mais atentamente a epistemologia associada ao realismo simples anteriormente descrito. De forma sumária, poderíamos dizer que para esta epistemologia, a confiabilidade do conhecimento científico estaria dada por um lado por uma descrição exata dos objetos e relações da realidade externa, e por outro pelo exame racional rigoroso dos dados da experiência (TAYLOR, 1998:114). Ora, cada um destes termos está centrado em concepções deterministas; por um lado, a percepção do real é determinada por este de forma unidirecional; por outro, o critério de racionalidade está condicionado à aplicação inflexível, automática e mesmo mecânica (BATES, 2001) de regras lógicas imutáveis —um algoritmo. Isto é, a concepção de "racionalidade" neste caso implica na exclusão de qualquer atributo humano - agência, vontade, valor — de sua operação. E, por fim, a própria epistemologia associada também é algorítmica, ou seja, determinista na sua operação, assumindo a possibilidade de um critério de demarcação único que separe, de modo inexorável e automático, ciência e pseudociência, ciência e metafísica ou qualquer outra oposição que se queira enfatizar.

Esta visão esquemática da ciência foi sendo progressivamente criticada e mesmo erodida ao longo das últimas quatro décadas, ao menos. Mais e mais autores colocam em questão esta imagem mecânica da ciência propondo em lugar de um processo de descoberta de "coisas" desde sempre existentes, a ideia de contínua construção de objetos e conhecimentos (para um sumário histórico das várias posições e tendências, ver Latour e Callon, 1991). Este "construcionismo" (ainda que seja também passível de críticas, v. p. ex. HACKING, 1999) coloca em questão a perspectiva da ciência clássica (objetividade-realismo-verdade por aproximação do "real"), e por consequência a perspectiva de validação do conhecimento passa a ser um 
problema. Com efeito, Rorty, por exemplo, chega a propor o fim da epistemologia como consequência da virada pragmática (RORTY, 1988).

Kuhn, em entrevista publicada postumamente, ilustra este dilema com o seguinte comentário acerca de um convite que recebera para participar de um julgamento envolvendo o criacionismo, no Arizona: "Olha, esse eu recusei por uma razão que eu acho excelente. [As pessoas que me procuraram estavam resistindo aos criacionistas, eu era simpático à causa deles, mas] eu acho que não tinha a menor chance... Quer dizer, eu estava sendo usado pelos criacionistas, pelo amor de Deus! Pelo menos em algum grau. Eu não acho que havia qualquer jeito de alguém que não acredita numa Verdade, e em se aproximar cada vez mais dela, e que pensa que a essência da demarcação da ciência é a solução de enigmas, conseguir dar o recado. Eu pensei que ia fazer mais mal do que bem, e foi isso que eu disse a eles” (BALTAS, GAVROGLU e KINDI, 2000: 321-322).

Está posto, portanto, para nós, que adotamos em algum grau visões de mundo que põem em questão as visões essencialistas da ciência e da epistemologia, um problema: como recusar os absolutos e ainda assim pensar em validação de conhecimentos?

Espero sinalizar com um caminho possível para responder essa questão; inicialmente, invoco a contribuição de um autor considerado por muitos um pioneiro, avant la lettre, dos science studies contemporâneos.

\section{A atualidade das contribuições de Ludwik Fleck}

Falo de Ludwik Fleck (1896-1961), médico polonês, herdeiro da escola polonesa de filosofia médica que floresceu ao final do século XIX (LÖWY, 1994). Pesquisador na área de imunologia, Fleck elaborou uma reflexão original sobre a produção de conhecimentos em seu próprio domínio de pesquisa, tomando como estudo de caso a definição moderna da sífilis como doença e a elaboração de um teste laboratorial então tido como altamente específico para a mesma. Fleck denominou sua abordagem de epistemologia comparativa, e o próprio título de sua opus magna é 
altamente revelador: A gênese e o desenvolvimento de um fato científico (FLECK, 1979; ver também COHEN \& SCHNELLE, 1986; sobre a atualidade e importância de Fleck, ver ainda HACKING, 1999 e KUHN, 1979 e 1996:viii-ix). Fleck era polonês, e judeu; a publicação de seu livro em alemão, na Suíça, em 1935 (um ano depois da publicação da Logik de Popper) passou praticamente despercebida, e embora Fleck tenha sobrevivido ao horror dos campos de concentração (Auschwitz e Buchenwald), e fosse reconhecido como pesquisador relevante na Polônia do pós-guerra e posteriormente em Israel, sua contribuição ao estudo das ciências só ressurge nos anos 60, por uma breve citação de Kuhn, que o declara seu precursor e estimula mais tarde a publicação, já em fins da década de 70, de uma tradução em inglês do "Gênese".

Dois conceitos são centrais em Fleck: o coletivo de pensamento (Denkkollektiv) e o estilo de pensamento (Denkstil). O primeiro é definido como “(...) uma comunidade de pessoas intercambiando ideias mutuamente ou mantendo interação intelectual; também veremos por implicação que esta também provê o "suporte" especial para o desenvolvimento histórico de qualquer campo do pensamento, bem como do nível de cultura e conhecimento dados" (FLECK, 1979:39) e o segundo como “(...) uma constrição definida do pensamento, e até mais; (...) a totalidade da preparação ou disponibilidade intelectual para uma forma particular de ver e agir ao invés de qualquer outra” (FLECK, 1979:64). Note-se que o estilo de pensamento não é uma característica opcional que pode ser voluntariamente adotada, mas antes uma imposição feita pelo processo de socialização representado pela inclusão em um coletivo de pensamento cabe aqui lembrar que uma das referências citadas por Fleck é Durkheim, ainda que criticando-o juntamente com outros antropólogos e sociólogos seus contemporâneos pelo seu "respeito excessivo, beirando a reverência piedosa, pelos fatos científicos” (FLECK, 1979:47).

Fleck distingue duas áreas de importância no interior de um coletivo de pensamento na ciência moderna (FLECK, 1979:111-2), uma compreendendo os experts que efetivamente produzem conhecimento, por ele chamada de 
círculo esotérico (ele ainda detalha mais esta região, descrevendo o círculo mais interno de experts especializados e o círculo externo de experts generalistas), e a outra constituída pelos "leigos educados", o círculo exotérico. Esta topografia permite a distinção entre formas diferentes de comunicação (FLECK, 1979:112); a ciência dos experts é caracterizada pelo periódico técnico/científico e pelo livro de referência, o primeiro representando o diálogo intenso, fragmentado, pessoal e crítico dentro de um campo dado do conhecimento, e o segundo a organização sinóptica deste (FLECK, 1979:118); o círculo exotérico é alimentado pelos periódicos de ciência popular ou de divulgação, que são uma “(...) exposição artisticamente atraente, vívida e legível (...) com uma atribuição de valores apodíctica para simplesmente aceitar ou rejeitar um dado ponto de vista” (FLECK, 1979:112). Finalmente, a introdução ao círculo esotérico — comparada por Fleck a um ritual de iniciação (FLECK, 1979:54)— é baseada num quarto tipo de meio textual científico, o manual básico (FLECK, 1979:112).

Fleck apresenta ainda uma contribuição importante para a história das ciências, ao mostrar como concepções iniciais, supostamente "não científicas", que ele denomina protoideias, são instrumentais para o desenvolvimento da pesquisa, e como as mesmas persistem como parte do acervo de conhecimentos das disciplinas, colocando em questão a ideia de uma ciência em permanente superação e ruptura com o passado (FLECK, 1979:23-5). Ainda neste sentido, Fleck descreve o que chama de tenacidade dos sistemas de pensamento, que resistem ativamente à mudança, resistência traduzida na expressão poética harmonia das ilusões (FLECK, 1979:27-8). Ele prossegue listando operações em graus progressivos adotadas por um coletivo de pensamento para proteger seu estilo de pensamento de mudanças, indo da impossibilidade da percepção de observações que violem o estilo de pensamento a criativas tentativas de adaptar a contradição (FLECK, 1979:28-33).

Outra observação relevante é quanto àquilo que outros autores denominaram de carga teórica das observações (theory-ladenness of observations), caracterizada por Fleck em observações que faz quanto à 
representação do corpo humano em altas anatômicos. Ele descreve como à época de Vesalius a suposição que os órgãos genitais masculinos e femininos eram fundamentalmente homólogos e levou aquele autor a descrever e desenhar no seu De humani corporis fabrica uma espécie de duto deferente que levaria a "semente" dos ovários ao útero. Fleck complementa essa observação da seguinte forma: "Quando eu selecionei essa ilustração para o presente trabalho, fiquei tentado adicionar uma imagem 'correta' e 'fiel' para comparação. Folheando modernos atlas anatômicos e manuais de ginecologia, encontrei muitas ilustrações boas mas nem uma natural. Todas foram retocadas em sua aparência, e eram esquemática, quase simbolicamente, verdadeiras com relação à teoria mas não à natureza. Encontrei uma fotografia em particular num manual de técnicas de dissecção. Esta, também, foi adaptada à teoria com linhas de orientação e setas indicativas adicionadas a ela para torná-la graficamente adequada ao uso no ensino. Desta forma me convenci, uma vez mais, que não é possível fazer tal comparação. São apenas teorias, não ilustrações, que podem ser comparadas” (FLECK, 1979:33-5).

Uma última referência à discussão desse autor diz respeito à sua descrição do avanço ou progresso de um determinado campo de investigação. Fleck distingue na gênese dos fatos científicos os elementos sujeitos à agência do pesquisador, que denomina de conexões ativas, e aqueles que surgem independentemente (e mesmo em oposição) àquela, às quais chama conexões passivas — como exemplo, ele cita a relação entre os pesos atômicos do hidrogênio e o do oxigênio; estabelecer-se o primeiro como um é arbitrário, mas a relação entre ambos é dada passivamente pelo processo da pesquisa (FLECK, 1979:94-96). Para Fleck, o avanço da investigação implica no aumento das conexões passivas, mas também das ativas; é impossível separá-las totalmente.

Dessa apresentação sumária do pensamento complexo, porém claro, de um autor seminal pretendo retirar um conjunto de ferramentas fundamentais para a tarefa proposta para este texto. 


\section{Uma epistemologia de/em processo}

Antes de prosseguir, é necessário apresentar de modo explícito a definição de um dos objetos fundamentais da discussão que proponho: o conhecimento. Este texto trata do conhecimento proposicional ou factual (HUEMER, 2002:435). Usualmente a discussão desta definição desemboca na chamada análise tripartite (conhecimento é (a) uma crença; (b) verdadeira e (c) justificada — ver ZAGZEBSKI, 1999 e WELBOURNE, 2000), por si só objeto de outros tantos problemas, a ponto de Hacking incluir "conhecimento" na sua lista de "elevator words", palavras que são chamadas a trabalhar num patamar superior ao usualmente utilizado para descrever fatos e ideias, (HACKING, 1999: 22-23). Sem entrar ainda nos detalhes desta discussão, chamo a atenção para o fato de que o quê é designado por "conhecimento proposicional" se resume a simples asserções com uma presumida base factual. Neste sentido, um exemplo específico da medicina seria algo como "o HIV é a causa da AIDS", ou "pneumococos usualmente respondem à penicilina”. Essa simplicidade, contudo é enganosa. Consideremos a primeira asserção acima. Paula Treichler fez um exercício de "desempacotamento" das várias outras asserções que se ocultam por trás de uma frase aparentemente elementar:

1. HIV causa a AIDS;

2. HIV é o nome que a cultura científica dá ao vírus amplamente acreditado como sendo a causa da AIDS;

3. HIV é o nome acordado por uma comissão internacional para resolver a amarga disputa sobre a 'descoberta' de um vírus considerado por muitos como um fator causal na infecção e deficiência imune que leva à condição clínica específica diagnosticada como AIDS;

4. HIV é o acrônimo adotado em 1986 pela comunidade científica internacional para denominar o vírus hipotetizado como causador de imunodeficiência em humanos e eventualmente AIDS, outro acrônimo, adotado em 1982 para designar uma coleção de mais de cinquenta 
condições clínicas amplamente diversas acreditadas como tendo a possibilidade de desenvolverem-se como resultado de um sistema imune severamente deficiente;

5. HIV é uma entidade microscópica hipotética chamada vírus (do Latim virus, veneno) inventado por cientistas no século XIX como uma forma de conceptualizar a causa técnica e as consequências de tipos específicos de doença infecciosa. Um vírus não pode se reproduzir fora de células vivas; ele entra na célula hospedeira de um outro organismo e utiliza a maquinaria bioquímica daquela célula para replicar-se (no caso do HIV, frequentemente por anos após a entrada inicial), ponto no qual o DNA da célula, ao qual o vírus está integrado, é transcrito em RNA, que por sua vez torna-se proteína. Nosso conhecimento sobre essa 'história de vida' foi produzido por um intenso esforço de pesquisa nacional focalizado tanto no HIV quanto em medicamentos desenhados para interferir destrutivamente sua história de vida em vários pontos; como o objeto relevante de esforços de investigação científica e pesquisa farmacêutica e um recipiente relevante do financiamento de pesquisas sobre AIDS, o HIV é, portanto, como Joseph Sonnabend coloca, 'metaforicamente representativo de outros interesses (TREICHLER, 1999:168-169).

Retornarei a este ponto mais adiante, quando discuto os emaranhados lógico-cognitivos que se escondem por trás de cada asserção da ciência contemporânea.

De forma resumida, apresento a seguir uma redescrição da análise tripartite em termos (espero) menos problemáticos. Em primeiro lugar, já que se trata do exame do conhecimento proposicional, ao invés da referência a "crenças” (termo que traz em si a problemas adicionais), o que está em jogo são proposições ou asserções. Adicionalmente, seguindo Welbourne (2000), estas são comunicáveis, compartilháveis e compartilhadas, e ao invés de "verdadeiras" e "justificadas”, reconhecendo o papel tanto das contingências históricas quanto da agência humana em sua formulação, seria mais adequado referir-se a estas asserções como aceitas 
como válidas por grupos específicos de investigação ou pesquisa, segundo procedimentos de validação também aceitos pelos mesmos grupos, que ao fim apontam para a construção de agregados coerentes que são por sua vez aninhados numa rede de asserções similares, previamente validadas aquilo que Bates (1998a e 1998b) chama de "unproblematic background knowledge" (conhecimento de fundo não problemático), ou UBK.

Mas mesmo "asserção" pode ser um equívoco neste contexto; embora adequada para exercícios filosóficos, a concepção de um processo de validação que toma asserções isoladas, uma por vez, aceitando-as ou rejeitando-as com base em um dado conjunto de regras não encontra grande correspondência com o modo pelo qual as comunidades de investigação ou pesquisa operam. E há uma falha fundamental nesta ideia, no sentido de que o tipo de asserção em jogo, aqui não tem sentido em si mesma (se é que alguma tem), mas depende de uma rede de outras asserções para terem sentido. Fleck exemplifica esta ideia com sua discussão sobre a sífilis:

A asserção 'Schaudinn identificou a Spirochetta pallida como o agente da sífilis' é equívoca tal como está, uma vez que a 'sífilis como tal' não existe. Havia apenas o conceito disponível então corrente sobre cuja base a contribuição de Schaudinn ocorreu, um acontecimento que apenas desenvolveu mais este conceito. Arrancada deste contexto, 'sífilis' não tem sentido específico, e 'identificou' por si mesmo não é mais explícito do que 'maior' e 'à esquerda' nos exemplos acima [referindo-se a um exemplo prévio em sua argumentação] (FLECK, 1979:39) —veja-se também o exemplo já citado de Treichler.

Um outro ponto digno de nota é a ênfase nas interações sociais; este é de fato um ponto de convergência para a maioria das referências teóricas deste texto. Instâncias sociais é tanto o depositário do conhecimento quanto as arenas onde novos agregados de asserções são aceitos e assimilados ao UBK ou descartados. Mas “instâncias sociais” é uma expressão por demais difusa para ser útil aqui; podemos pensar nos coletivos de pensamento de Fleck ou nas comunidades epistêmicas de Knorr-Cetina como uma descrição mais adequada e precisa das mesmas. E isto, por sua vez, traz 
outra característica importante para consideração: nas sociedades complexas há um grande número de tais comunidades, e mesmo no caso postulado de uma "comunidade científica” global que partilha grandes porções de um UBK amplo e abrangente, há zonas heterogêneas, como a supracitada Knorr-Cetina, por exemplo, aponta (KNORR-CETINA, 1999). Isto significa que a substituição de uma cadeia de asserções no UBK local de um dado grupo pode não ter efeito imediato em outro, mesmo um intimamente relacionado.

Finalmente, esta redefinição não é um mero exercício intelectual; ela tem implicações bastante concretas para o estudo das interações complexas que continuamente expandem e remodelam o UBK, ou a coleção e UBKs, da ciência contemporânea. No mínimo, esta definição aumenta tanto o escopo quanto os requerimentos desta tarefa. Preliminarmente, a perspectiva histórica é fundamental. Adicionalmente, a análise de conceitos isolados, em si, não é suficiente; uma abordagem mais abrangente é claramente necessária. Não se trata simplesmente de elaborar um dicionário, onde para cada termo da ciência do passado ou do saber exótico produz-se um correspondente na ciência do presente; é fundamental apreender um outro modo de pensar, num trabalho semelhante ao do antropólogo que se aventura em culturas que não a sua, como propôs Kuhn: “eu já sugeri que o passado de uma ciência deveria ser abordado como uma cultura estranha, que o historiador primeiro luta para entrar, e posteriormente para tornar acessível a outros” (KUHN, 1978:368). Esta última citação, por fim, abre a possibilidade de uma epistemologia não normativa, que esteja focalizada em entender e descrever como grupos específicos operam a validação do conhecimento, ao invés de começar sua tarefa pela prescrição de como isto deveria ser feito em geral.

\section{O senso comum sobre a ciência}

Um elemento importante do estilo de pensamento ou UBK partilhado por importantes segmentos da chamada “sociedade ocidental” (importantes numericamente e pelo poder que detém) é fundado na protoideia de causalidade 
determinista originalmente formulada pela ciência moderna. Deve-se ter em mente que, embora este seja um elemento do senso comum, sua característica de protoideia faz com que seja possível encontrá-lo em ação mesmo dentro dos domínios esotéricos de uma disciplina — mesmo quando conflita com a sua abordagem metodológica predominante; retorno à consideração anterior sobre a heterogeneidade interna das comunidades epistêmicas.

A lógica causal determinista tem implicações epistemológicas. Por um lado, ela fornece um modelo de mundo dividido em eventos atômicos que se seguem uns aos outros de forma linear. Por outro, por implicação, ela sanciona um modelo específico de validar conhecimentos, baseado em dados empíricos analisados por uma lógica impessoal, levando à formulação de leis gerais, sendo as matematicamente expressáveis consideradas como mais relevantes, desde Galileu. Esse modelo, por fim, pressupõe uma ciência unificada pelo seu modelo de validação, supostamente aplicável a qualquer objeto, de partículas infinitamente pequenas aos objetos astronômicos extremamente grandes, passando pelos seres humanos em escala individual ou coletiva.

Esta lógica causal tem implicações pragmáticas. O modelo da ciência unificada leva ao estabelecimento de hierarquias entre diferentes formas de saber. Aquilo que é passível de expressão numérica é tido como intrinsecamente mais "científico" do que o que não o é; designar algo como "subjetivo" deixa de ser uma descrição e passa a ser uma atribuição de menor valor - naturalmente, frente ao que é "objetivo". As ciências sociais e humanas, que pelas características intrínsecas de seus objetos de estudo produzem conhecimentos necessariamente a partir de modelos hermenêuticos (TAYLOR, 1998), passam a ser vistas como "menores" frente aos modelos explicativos das ciências da natureza. Na área de saúde, por exemplo, a hierarquização de saberes significa a desqualificação relativa de profissionais e práticas que atentam para o "subjetivo".

Esta lógica causal tem, por fim, implicações políticas. A epistemologia realista pressupõe uma realidade única da qual é porta-voz exclusiva. O 
conhecimento correto das causas dos problemas definirá inevitavelmente a sua solução correta. O portador desse conhecimento possui, portanto a autoridade epistêmica para determinar que soluções devam ser implementadas. Essa é a tentação tecnocrática que se manifesta, por exemplo, no atual debate — na verdade, na sua ausência - sobre essa misteriosa entidade sociopolítica, a Economia (tomada aqui não como disciplina homônima, mas o seu objeto). A acreditar no que dizem sábios acadêmicos e colunistas especializados, o mercado triunfou, não há mais o que discutir sobre a gestão das trocas econômicas. Roma locuta, causa finita. O debate político — como garantir melhor vida para os povos, seja lá como se defina isso - foi substituído pela reafirmação de princípios disciplinares da economia. E esses princípios nem ao menos refletem a riqueza interna das ciências econômicas; somos levados a acreditar que a economia neoclássica mostrou-se mais “científica” do que teorias concorrentes, tornando-se hegemônica por conta disso (FULLBROOK, 2004).

Fica claro, portanto, que a reflexão crítica sobre esta concepção do senso comum tem uma função também política, seguindo a ideia do construcionismo reformista tal como enunciada por Hacking (1999). É preciso apontar que o imperador está nu. Trazendo, contudo, uma nota de cautela, vinda de ninguém menos que Bruno Latour. Em texto recente, ao discutir como as estratégias da abordagem crítica da ciência vêm sendo cooptadas pela coalizão conservadora-religiosa-fundamentalista que chegou ao poder com Bush Segundo, Latour sinaliza que o perigo neste caso provém não de argumentos ideológicos apresentados como fatos, mas de excessiva desconfiança de matérias de fato razoáveis disfarçadas como vieses ideológicos condenáveis - em suas palavras, "porque minha língua queima para dizer que o aquecimento global é um fato caso se goste ou não?” (LATOUR, 2005). Como pesquisador e professor, defendo a ideia de que há um valor intrínseco no conhecimento. E como profissional de saúde, defendo também a ideia de que há efetivamente saberes e práticas cuja aplicação judiciosa contribui para uma vida melhor. Em suma, critiquemos a Razão, sem esquecer que seu sono, como disse Goya, produz monstros... 


\section{Consequências da visão do senso comum —o "genocentrismo"}

Para melhor ilustrar a discussão anterior, proponho que consideremos um exemplo concreto das repercussões do modelo de causalidade deterministas num debate contemporâneo. Tomemos o caso da genética. Apenas a título de ilustração da pervasividade dessa temática, abro o jornal de hoje na seção de ciência, e lá está a manchete que fala da "descoberta do gene que torna as pessoas canhotas(...)"

Como marcos dessa "virada genética" do debate público eu apontaria para dois eventos com intensa cobertura midiática: o anúncio da clonagem de um mamífero (a ovelha "Dolly") em julho de 1996 e o sequenciamento completo do genoma humano em junho de 1999, ambos acompanhados de uma sobrecarga informacional que trouxe implícita a sugestão de revoluções científicas e promessas renovadas de avanços diagnósticos e terapêuticos inimagináveis.

A ideia de que características diversas dos seres vivos são passadas de uma geração a outra não é nova e antecede a própria ciência moderna; milênios de experiências de domesticação e reprodução seletiva de plantas e animais estão na própria origem daquilo que chamamos civilização (DIAMOND, 1999). A síntese moderna dos achados de Mendel, Darwin e da biologia molecular do século XX, contudo, é considerada, com justiça, um dos grandes feitos da ciência moderna. Os processos de desenvolvimento biológico, nos quais o material genético (leia-se DNA) desempenha papel chave, é um dos exemplos mais notáveis de um modelo complexo, também para a investigação científica (KAY, 2000; LEWONTIN, 2000; KELLER, 2002): múltiplas interações, desde o nível mais microscópico possível (interações entre sítios específicos de moléculas complexas) até o mais abrangente (todas as interações entre organismos e ambiente, considerando que este último também é produto dos primeiros), uma infinidade de eventos que se influenciam mutuamente, com o surgimento a cada nível de articulação de propriedades emergentes, não 
mapeáveis linearmente aos eventos subjacentes. Em uma palavra, complexidade, em toda a extensão do conceito.

Isto não impediu, contudo, que essa complexa dinâmica fosse capturada pelo estilo de pensamento determinista. A complexidade inerente ao campo de saberes relacionado à genética faz com que especialista numa dada subárea, por exemplo, genética molecular, mesmo fazendo parte do círculo esotérico de sua subdisciplina, possa ser parte do círculo exotérico de outra, por exemplo, a genética de populações. Isso torna mais difícil para os participantes da comunidade epistêmica avaliar criticamente o conjunto geral da área, tornando-os mais suscetíveis à interferência das protoideias de cunho determinista no seu estilo de pensamento. E o modelo determinista resiste tenazmente à modificação. As interações complexas são transformadas num sistema simples, com séries de causas lineares, tentativamente expressas pelo conjunto de asserções que se segue:

- cada gene determina um traço elementar, atomístico de um organismo;

- a coleção de genes determina, em correspondência um para um, o conjunto de características que constituem a totalidade desse mesmo organismo;

- cada organismo é, portanto um agregado destas características (a espécie é definida por um conjunto genérico de caracteres, cada indivíduo pelos valores efetivos que cada caractere assume entre os valores possíveis);

- o DNA contém um "programa” que codifica todo o organismo;

- cada característica singular de um organismo é o resultado do processo competitivo de seleção natural.

Cada afirmação dessas é criticada por algum dos autores já citados; além de Kay, Lewontin e Keller, Eldredge (2004) critica especificamente o 
panadaptacionismo expresso pela última asserção. Não obstante, esse modelo segue sendo difundido, em especial através de publicações de divulgação científica, assegurando sua repercussão nos vários círculos exotéricos, incluindo-se aqueles, como descrito anteriormente, de especialistas das várias subáreas do campo. Essa assimilação seletiva e simplificada do desenvolvimento tecnológico na área de genética tem levado a um reforço de concepções reducionistas e deterministas de concepções gerais sobre o ser humano e a sociedade, num revival da sociobiologia da década de 70, ficando clara a articulação políticoideológica destas concepções com a perspectiva conservadora: o gene egoísta articula-se admiravelmente bem com o agente maximizador de utilidade da economia neoclássica. Essas concepções também se refletem nas representações do processo saúde doença, se expressando entre outras formas na asserção genérica "o gene da doença X", que traz como corolário (quase invariavelmente citado explicitamente nas matérias sobre o tal gene) a ideia de que uma cura radical e definitiva para a doença $\mathrm{X}$ se aproxima no horizonte. Desse modo, padrões recorrentes na história da medicina e de sua relação com a sociedade são novamente acionados, destacando-se em particular a ideia da panaceia salvadora (o "magic bullet" da literatura de língua inglesa) e o reforço da autoridade cognitiva, como já referi anteriormente; como praticamente todos os aspectos da vida humana são reduzidos "aos nossos genes" (expressão frequente no discurso público), segue-se que os especialistas biológicos são os detentores socialmente legítimos dos segredos últimos da vida e da morte.

Esse rápido exercício demonstra, a meu ver, tanto as consequências da concepção determinista, mesmo ao se superpor a uma lógica de investigação que a superou historicamente, como a potencialidade do instrumental teórico apontado em fazer frente a ela.

\section{Conclusão}

A concepção epistemológica delineada neste texto impõe certo grau de indefinição; mais uma vez, não me cabe (e não me parece factível) 
prescrever critérios fixos e definidos de validação, sendo necessário ao invés disso investigar como as diferentes comunidades epistêmicas operacionalizam seus critérios; neste caso, é necessário até mesmo delimitar os próprios contornos destas comunidades epistêmicas: quem são seus constituintes, e como se organizam.

Paralelamente, é necessário o esforço de superação das incomensurabilidades entre diferentes sistemas teóricos, bem como da exposição pública dos diferentes processos de validação, criando múltiplos diálogos entre os "especialistas" e com aqueles que demandam seus serviços. Este processo traz, a meu ver, dois riscos que demandam constante atenção crítica. Em primeiro lugar, há o problema apontado por Latour (1987) da crítica assimétrica, isto é, ao confrontarem-se duas perspectivas epistemológicas diferentes, faz-se a utilização rigorosa de um instrumental crítico apenas com relação àquela que é estranha ao pesquisador. Um exemplo disto me foi dado por Mirko Grmek, historiador da medicina, em comunicação pessoal: ao estudar as controvérsias entre os grandes nomes da medicina parisiense nos séculos XVIII e XIX, Grmek percebeu que ao criticarem uns aos outros, estes autores formulavam críticas rigorosas, consistentes, penetrantes e que resistiram à passagem do tempo, sendo ainda válidas em termos do pensamento contemporâneo. Ao defenderem suas próprias propostas, contudo, seguiam um padrão de qualidade bem mais baixo, com resultados intelectualmente pífios. Boa parte do confronto entre os apologistas de diferentes racionalidades terapêuticas no presente, por exemplo, me parece seguir este mesmo padrão.

Em segundo lugar, e talvez mais importante, está o desafio de ao mesmo tempo respeitar e incluir o conhecimento do outro sem perder de vista a legitimidade de uma dada comunidade, de seus métodos de validação e de seu próprio UBK (retomando a expressão de Bates). A introdução da ideia de assimetrias epistemológicas pode parecer incompatível até mesmo com uma concepção radical de democracia: nas palavras de um autor que se debruçou sobre este tema: "nos escritos das pessoas preocupadas com a ameaça política à democracia colocada pela existência do conhecimento de peritos, a 
expertise é tratada como um tipo de possessão que privilegia seus possuidores com poderes que o povo não pode controlar com sucesso, e não pode adquirir ou compartilhar" (TURNER, 2001:123). Este mesmo autor propõe a perspectiva da construção social, por mostrar o caráter instável e convencional mesmo da ciência, como uma saída para este dilema, apontando que a ideia da expertise só é um problema se supõe a existência de um padrão mais elevado (e, acrescentaria eu, absoluto) pelo qual o processo banal de avaliar peritos como (por exemplo) bombeiros ou eletricistas possa ser efetuado, que colocaria este processo fora do alcance das pessoas comuns (TURNER, 2001:145-146).

Acredito que as considerações que Turner faz apontam para uma perspectiva no mínimo semelhante à de Boaventura de Souza Santos (1988), em particular naquilo que este chama de "segunda ruptura epistemológica", o reencontro do conhecimento científico com o senso comum. Podemos, enfim, ao menos imaginar os termos de tal processo, uma negociação entre vários participantes para a construção, quando possível, de processos consensuais de validação de conhecimentos (no sentido anteriormente proposto, de agregados de sentenças sujeitas a processos socialmente aceitos de exame e produção de coerências), ou ao menos de explicitação e delimitação de divergências incontornáveis. Este me parece o caminho de alcançar a meta, ainda seguindo Santos (1988) de produzir um conhecimento prudente para uma vida decente.

Referências

BALTAS, A; GAVROGLU, K \& KINDI, V. A discussion with Thomas S. Kuhn. In: KUHN, T.S. The road since Structure. Chicago: The University of Chicago Press, 2000 [1995].

BATES, D. Closing the circle: how Harvey and his contemporaries played the game of truth, part 1. Hist Sci, xxxvi: 213-232, 1998a

. Closing the circle: how Harvey and his contemporaries played the game of truth, part 2. Hist Sci, xxxvi: 245-267, 1998b. 
. Medicine and the soul of science. Montreal: McGill University [mimeo], 2001.

CAMARGO JR, K.R. Debate sobre o artigo de Ana Maria C. Aleksandrowicz. Cadernos de Saúde Pública, V. 16, n.4: p.913-915, 2000.

Biomedicina, saber \& ciência: uma abordagem crítica. São Paulo: Hucitec, 2003.

DIAMOND, J. Guns, germs and steel. New York: W.W. Norton \& Co, 1999.

ELDREDGE, N. Why we do it. New York: W.W. Norton \& Co, 2004.

FLECK, L. Genesis and development of a scientific fact. Chicago: University of Chicago Press, 1979[1935].

FULLBROOK, E (ed.) A guide to what's wrong to economics. London: Anthem Press, 2004.

HACKING, I. The social construction of what? Cambridge, Massachusetts: Harvard University Press, 1999.

HALL, A.R. A revolução na ciência: 1500-1570. Lisboa: Edições 70, 1988.

HARRÉ, R As filosofias da ciência. Lisboa: Edições 70, 1988.

HUEMER, M. - ed. Epistemology: Contemporary Readings. London: Routledge, 2002.

KAY, L.E. Who wrote the book of life? Stanford: Stanford University Press, 2000.

KELLER, E.F. Making sense of life. Cambridge, Massachusetts: Harvard University Press, 2002.

KNORR-CETINA, K. Epistemic cultures. Cambridge, Massachusetts: Harvard University Press, 1999.

KUHN, T.S. Foreword. In: FLECK, L. Genesis and development of a scientific fact. Chicago: University of Chicago Press, 1979. . The structure of scientific revolutions, 3 rd ed. Chicago: University of Chicago Press, 1996. 
. Black-body theory and the quantum discontinuity, 1894-1912. Chicago: University of Chicago Press, 1978.

LAPLACE, P.S. Théorie analytique des probabilités. Paris: GauthierVillars, 1886.

LATOUR, B. Science in action: how to follow scientists an engineers through society. Cambridge, Massachusetts: Harvard University Press, 1987.

. Jamais fomos modernos. Rio de Janeiro: Editora 34, 1994.

. Why has critique run out of steam? From matters of fact to matters of concern. Critial Inquiry. V.30, n.2, 2005. Disponível em:

www.uchicago.edu/research/jnl-crit-inq/issues/v30/30n2.Latour.html

Acesso em 19/09/2006.

et CALLON, M. "Introduction". In LATOUR, B e CALLON, M (org.) La science telle qu'elle se fait. Paris: La Découverte, 1991.

LEWONTIN, R. It ain't necessarily so. New York: New York Review of Books, 2000.

LÖWY, I. Ludwik Fleck e a presente história das ciências. História, Ciências, Saúde - Manguinhos, V. 1, n.1: p. 7-18, 1994.

PLASTINO, C.A Os horizontes de Prometeu. Physys V.6, n.1/2: p.195-216, 1996.

RORTY, R. A filosofia e o espelho da natureza. Lisboa: Publicações Dom Quixote, 1988.

SANTOS, B. S. Introdução a uma ciência pós-moderna. Rio de Janeiro: Ed. Graal, 1988.

SHAPIN, S. The scientific revolution. Chicago: The University of Chicago Press, 1996.

TAYLOR, C. "Interpretation and the sciences of man" In: KLEMKE, E.D, HOLLINGER, R. \& RUDGE, D.W. - eds. Introductory readings in the philosophy of science. Amherst: Prometheus Books, 1998.

TREICHLER, P. How to have theory in an epidemic: cultural chronicles of AIDS. Durham: Duke University Press, 1999. 
TURNER, S. What is the problem with experts? Social Studies of Science, v. 31, n.1: p.123-149, 2001.

WELBOURNE, M. Knowledge. Montréal \& Kingston: McGill-Queen's University Press, 2000.

ZAGZEBSKI, L. "What is Knowledge?” in GRECO, J. \& SOSA, E. The Blackwell Guide to Epistemology. Oxford, UK: Blackwell Publishers Ltd., 1999. 


\title{
PSICOLOGIA SOCIAL: \\ O LUGAR DA CRÍTICA, \\ DA MEMÓRIA E DA AFETIVIDADE
}

CAPÍTULO 2

\author{
O QUE É MESMO PSICOLOGIA SOCIAL? \\ UMA PERSPECTIVA CRÍTICA DE SUA HISTÓRIA E SEU \\ ESTADO HOJE
}

\begin{abstract}
Pedrinho Guareschi
Pontifícia Universidade Católica do Rio Grande do Sul

\section{Introdução}

T o contexto de “diálogos” que a Associação Brasileira de Psicologia 1 Social ABRAPSO está estabelecendo, pretendo, correndo certamente alguns riscos, trazer aos colegas que trabalham na área algumas reflexões que julgo, no meu entender, pertinentes e atuais. São inúmeras as contribuições que estão sendo trazidas à discussão dentro do amplo espectro da Psicologia Social. Penso não estar exagerando ao dizer que muitos estudiosos ou professores da área começam a trabalhar sofregamente nesse campo sem ter tido tempo de fazer uma reflexão crítica dos inúmeros enfoques nela presentes. Torna-se difícil, desse modo, estabelecer uma visão de conjunto e muito mais árduo ainda discernir as conexões existentes entre uma teoria e outra. Priorizam-se, muitas vezes, aspectos secundários e não se consegue montar um fio condutor que nos oriente e nos ilumine a caminhada.

Nesse mundo das teorias, pretendo enfrentar aqui uma questão central, que é: qual o cerne, qual o âmago da Psicologia Social? Há muitos anos venho já lidando com essa disciplina. Vou confessar que as possíveis respostas que ia, aos poucos, encontrando no decorrer de minha experiência 
acadêmica sobre o que seria a Psicologia Social não me satisfaziam plenamente. Seria fácil, até mesmo simplório, responder a essa pergunta dizendo que “são muitas psicologias sociais”. Mas essa não seria uma maneira de fugir da questão, talvez por medo de enfrentá-la? Afinal, se trabalhamos e pesquisamos dentro de uma determinada área, temos no mínimo a obrigação de buscar relativa clareza sobre as delimitações, nunca absolutamente precisas, do campo que investigamos. Por mais que defendamos uma transdisciplinaridade na compreensão dos fenômenos temos, no nosso caso, de ter relativa clareza sobre que dimensão, isto é, sob que "luz" nós nos propomos iluminar esse fenômeno, com outras palavras: como a Psicologia Social o enfoca?

Não só por honestidade, mas também por obrigação, pretendo enfrentar essa questão. Arrisco então, essa reflexão cuidadosa e, enquanto possível, metódica e didática. Vou discutir duas questões: qual o campo da Psicologia Social e, avançando um pouco mais, perguntar sobre as diversas teorias que surgiram no desenvolvimento dessa Psicologia Social, e quais seus pressupostos e como elas tentaram dar conta do psicossocial?

Na primeira, perguntamos e discutimos as origens e o que seria a Psicologia Social. Analisamos os pressupostos que se faziam presentes em seu início e como foi seu desenvolvimento e sua atribulada história. Na segunda, discutimos como a Psicologia Social foi se estruturando e quais os elementos centrais que foram se incorporando em sua constituição.

Penso valer a pena enfrentar essa discussão. Ajudará a progredir em nossa ciência da Psicologia Social. É minha convicção que tal discussão ajudará a esclarecer muitos pontos e nos ajudará a avançar na discussão teórica de nossa disciplina.

Concordo com Moscovici quando afirma que é tempo de parar com pesquisas pontuais e dar mais espaço à reflexão:

poderíamos aventurar dar a sugestão de que é tempo de parar com a coleta de informações. Como diz Poincaré, um acúmulo de fatos não constitui uma ciência, assim como um monte de pedras não se torna 
uma casa. Temos as pedras, não temos a casa. É preciso parar e começar a pensar (MOSCOVICI, 2002, p.145).

\section{Em busca de uma Psicologia Social: origens, contexto e trajetória}

Nessa primeira parte vou procurar responder às seguintes perguntas:

- Como iniciou e foi se constituindo uma Psicologia Social?

- Quais os pressupostos subjacentes ao início da Psicologia Social?

- Como foi sua atribulada história?

- Como diferentes enfoques foram se confrontando e se estruturando?

Essa primeira parte discute Psicologia Social desde Wundt, em 1872, até a década de 1950, com sua consolidação hegemônica nos Estados Unidos.

É fundamental, para se compreender a história da Psicologia Social e a própria Psicologia Social, que se tenha em mente dois “movimentos” ou dimensões, que estiveram presentes em sua origem e em seu desenvolvimento: a influência do materialismo cientificista; a influência do individualismo cartesiano.

\subsection{O materialismo cientificista}

Se aceitarmos, como é relativamente pacífico, que a Psicologia começou com Wundt, temos de aceitar, consequentemente, que foi lá também que teria iniciado a Psicologia Social, pois ela historicamente foi considerada como um alongamento dessa psicologia. E, seguindo a mesma lógica, temos que aceitar que a Psicologia Social começou dentro do quadro amplo da modernidade com seus pressupostos metafísicos, epistemológicos e éticos; ética, aliás sempre negada, até que Bauman ao final do séc. XX, mostra com clareza que a modernidade tinha uma ética e qual era essa ética. 
Enfatizo essa questão da ética, pois ela é extremamente importante no campo da Psicologia, já que lida fundamentalmente com seres humanos. Para a modernidade o mundo era um relógio, o que era preciso, então, era apenas descobrir quais as leis implícitas, subjacentes e ocultas que governavam esse relógio. O segundo passo, dado por Comte, Durkheim e outros sociólogos, foi mostrar que a sociedade também era um relógio com suas leis subjacentes; o social era uma "coisa" como qualquer outra, e a sociedade era um sistema fechado, governado por leis determinantes e determinadas. Wundt, para os que o aceitam como o fundador da psicologia, não fez nada mais que dar o terceiro passo dentro dos pressupostos da modernidade; se o mundo é um relógio a sociedade é um relógio, então o ser humano também é um relógio; vamos colocá-lo dentro de um laboratório e descobrir suas leis implícitas. O problema todo se resume em fazer experimentos para descobrir essas leis. E esses experimentos estão sendo feitos por muitos até hoje!

É interessante, se não chocante, ver como foi exatamente isso que fez o Nazismo, conforme descreve muito bem Bauman ao analisar a ética da modernidade. Para ele, o Holocausto nazista nada mais foi que uma consequência coerente da modernidade. Quando os russos tomaram Auschwitz encontraram ainda nos barracões dos campos de concentração, ao redor de 80.000 pessoas, metade de sua capacidade total de 160.000. E dessas 80.000 a metade eram crianças, a maioria delas gêmeos, trigêmeos, quadrigêmeos etc. Mengele e sua equipe de 60 pesquisadores, especialistas e técnicos faziam com elas os experimentos estratégicos para poder encontrar "o homem ideal", o homem que seria o protótipo para a nova raça nazista que iria governar o mundo por no mínimo, mil anos. Eles se dedicavam, com insano esforço, em descobrir as "regularidades", as leis implícitas no "relógio" que é o ser humano. Tudo o que fosse dispensável ou o que já fosse constatado como descartável, comprovadamente não mais necessário à investigação, ia sendo dispensado como os ciganos, os judeus, os anões e os portadores de qualquer deficiência. É conhecida a comparação que Bauman faz ao descrever esses procedimentos "científicos": o mundo 
deveria ser como um jardim todo alinhado, organizado e limpo. Tudo o que fosse desordem, ervas daninhas, deveria ir para a fogueira. E a ética que governava esse empreendimento (aqui a questão) era a eficiência, o rigor científico, o funcionamento prático e útil. Exatamente o que o responsável pelas pesquisas realizadas com o jovem delinquente, narradas no filme "Laranja Mecânica", respondeu a quem questionou as possíveis implicações éticas de seus experimentos: "Se funciona, é bom!” Na ética, o que é "bom" é o que funciona, as técnicas rigorosamente seguidas à risca; consequentemente, se não funciona é "ruim”. Um tipo de pragmatismo e o cientificismo de mãos dadas.

Mas avancemos um pouco mais na discussão desse primeiro movimento. Devemos a Robert Farr (1998) e a seus 25 anos de pesquisa, ininterrupta e escrupulosa, o esclarecimento e a crítica mais aprimorada e metódica sobre as origens de nossa Psicologia Social. Principalmente em seu capítulo 2 (p.37-59), ele nos mostra como essa ideia parcial de ciência (experimental) tomou conta da psicologia como um todo, de tal modo que na sua expressão, para os experimentalistas, "a pele forma o limite de estudo" (FARR, 1998, p. 41).

Essa concepção de psicologia como uma ciência experimental passou, automaticamente, para a Psicologia Social. A Psicologia "científica", isto é, fisiológica e materialista se desenvolveu à base de experimentos, mas experimentos "fisiológicos", materiais, biológicos, comportamentais, que não iam além da pele. A Psicologia Social, como a Psicologia tout court, passou a fazer parte das Naturwissenchaften. Como diz Farr (1998, p. 59), "a herança de Wundt foi uma psicologia experimental que não era social”. Mas,

se a psicologia se tornou por primeiro uma ciência experimental na Alemanha, foi a Psicologia Social que se tornou depois uma ciência experimental nos Estados Unidos.

Watson e seus seguidores fizeram uma cruzada sistemática com o objetivo de livrar a psicologia de toda referência à consciência, à mente ou ao self. Para eles, só valia o observável, o externo, o material. O próprio 
Watson afirmava que a introspecção deveria ser banida da psicologia. Para quem lê o Manifesto Behaviorista, coordenado por Watson, fica evidente essa “materialização” do psicológico, pressuposto do materialismo cientificista de que estamos falando.

Eles podiam afirmar, então, com tranquilidade, baseados nesses pressupostos, que tinham enterrado o fantasma que atormentava Descartes, isto é, a questão do psíquico, da consciência. Ele, Descartes, para se livrar do psíquico (imaterial, simbólico, representacional) cindiu o ser humano ao meio: a ciência se ocuparia apenas do material, do biológico e a filosofia do imaterial. Mas acontece que não é por um ato voluntarista que se elimina uma realidade que durante séculos preocupa a humanidade. Por isso, o fantasma de Descartes continua a assombrar os estudos modernos. O behaviorismo, longe de enterrar esse fantasma, é apenas uma das faces desse dualismo cartesiano. Na herança cartesiana o psíquico, o self, pertence à filosofia mental. O self só poderia se tornar acessível através da introspecção. Mas isso, para os comportamentalistas não era ciência. Essa é a natureza do dualismo cartesiano que herdamos na psicologia. Quando ela se tornou,apenas, uma ciência do comportamento exterior , não avançou para além do dualismo cartesiano.

Já para Mead, a mente é um fenômeno puramente natural, como veremos. Para Watson, ela é apenas um fenômeno sobrenatural. Jovchelovitch (2007) discute com clareza as consequências desse dualismo cartesiano e mostra que tal dualismo não se sustenta diante de uma crítica bem fundamentada. Tal concepção ainda bebe dos pressupostos do materialismo cientificista para quem o ser humano, a sociedade e o mundo são iguais e devem ser tratados, epistemologicamente falando, do mesmo modo.

Como consequência, pode-se dizer que Watson reduziu a racionalidade humana à racionalidade dos ratos: sabemos agora muita coisa sobre as leis da aprendizagem que são comuns a ratos e a seres humanos. Mead comparou a psicologia de Watson à Rainha, em Alice no País das Maravilhas sem cabeça, sem nada acima da espinha dorsal. Para ele, Watson não tinha 
conseguido uma teoria da história natural da mente e da natureza especificamente autorreflexiva da inteligência humana.

Vimos as diferenças entre Mead e Watson. Mas quais as diferenças entre Wundt e Mead e Wundt e Watson? Wundt separou sua psicologia fisiológica de sua Psicologia Social; Mead, contudo, inter-relacionou a ambas, através de sua teoria do ato. Para ele, o ato é o dado fundamental, tanto na Psicologia Social como na individual, e tem uma fase, um aspecto tanto interno como externo. A questão surge no modo como essas duas fases se relacionam. Mead critica Wundt por pressupor a mente (a fase interna) em sua psicologia fisiológica, e critica Watson por abandoná-la em seu behaviorismo ficando apenas com a fase externa, o comportamento. Para Mead, ambas as perspectivas são parciais: quando falamos, falamos a nós mesmos e aos outros. É por isso que a natureza autorreflexiva da inteligência humana está mais estreitamente ligada à fala do que à visão. Essa é a essência da Psicologia Social de Mead.

Já a diferença entre Wundt e Watson é que Wundt era um pensador plural, não reducionista. Se ele começou a pesquisar a psicologia em laboratório, dentro dos pressupostos cientificistas da época, ele não reduziu a questão da psicologia apenas a esse espaço, mas ampliou-a acrescentando a dimensão filosófica e, principalmente, a dimensão social com os dez volumes sobre religião, mitos etc.

Nota-se, assim, como a Psicologia Social "dançou" entre dois polos sem poder dar conta nem de um, nem de outro. Foi Mead quem enfrentou esse problema e inter-relacionou a ambos com a teoria do self. De fato, Mead inovou e o que tentamos fazer hoje não está distante do que fez Mead.

Minha experiência mostra que muitos estudantes ao tomar contato com uma disciplina e suas diferentes teorias, onde sempre estão implícitos pressupostos metafísicos ou epistemológicos, não se dão conta de que nas diferentes origens ou tradições, dessa ciência, estavam presentes pressupostos, ou "eixos", bem distintos. Um desses eixos é o "materialismo cientificista” que estamos discutindo aqui. Para ele, não existe nada além da 
matéria, do biológico. Destutt de Tracy, por exemplo, ao discutir a ideologia coloca-a no campo da zoologia. Por quê? Porque a zoologia trata dos animais; um desses animais é o ser humano; o ser humano possui cérebro; e as ideias são emanações desse cérebro. Ora, sendo a ideologia o estudo das ideias e estando elas no cérebro que é parte do homem que é um animal como qualquer outro... logo a ideologia deve ser classificada no campo da zoologia. Se nosso pressuposto é o materialismo cientificista, e não existe nada além do material e físico, vamos, consequentemente, tirar as conclusões lógicas disso. Na Alemanha, na época de Wundt, essa era a discussão, entre as Naturwissenchaften e as Geisteswissenchaften. Para os primeiros, a "ciência” se fundamentava nesse pressuposto ontológico e epistemológico do materialismo. E como derivação disso, a metodologia era quantitativa, tentando medir essa matéria: daí a importância do laboratório. Uma pergunta que ainda poderia ser feita: até que ponto esse pressuposto não está ainda presente na "mente” de muitos de nossos “cientistas”?

Na França esse eixo passava pelo positivismo, que tinha como pressuposto que só existe “o que está aí”, e nada mais. Tudo o que não pudesse ser "apalpado”, medido, pesado, não tinha valor e não existia. O social, para eles, tinha o estatuto ontológico de "coisa”. Por insistência de uma mentalidade positivista, as ciências sociais tinham de tomar como modelo as ciências naturais.

\subsection{O individualismo cartesiano}

Há outro pressuposto, contudo, tão ou mais importante que o pressuposto materialista da modernidade, que penetrou e ainda está fortemente presente na psicologia e, evidentemente, na Psicologia Social: é o pressuposto do individualismo. Essa dimensão nós a devemos buscar em Descartes. Interessante notar que na famosa afirmação de Descartes cogito, ergo sum (penso - eu-, logo existo), a Psicologia não foi buscar primeiramente o "racional”, a racionalidade instrumental implícita do termo “cogito", mas fundamentalmente o fato de ela ser formulada tendo como sujeito a primeira pessoa do singular: penso, isto é, eu penso. E essa foi a segunda marca 
presente na Psicologia Social, quase que um paradoxo: como o social poderia se reduzir ao indivíduo?

Procurando contextualizar essa visão dominante, constata-se que o individualismo tornou-se uma ideologia dominante dentro da cultura ocidental, principalmente dos EE.UU. Com suas raízes no humanismo renascentista, ele se reforçou com a Reforma Protestante e a invenção da imprensa, que propiciou a informação e o relacionamento com as pessoas sem sua presença física. Os que protestavam (protestantes) contra os consensos anteriores e não queriam se conformar com imposições políticas e religiosas dos príncipes, ou da Igreja, mudaram-se para os EE.UU., onde esse individualismo se enraizou e deu seus frutos. Essas são algumas das razões, entre muitas outras, que ajudam a compreender a importância do individualismo na cultura ocidental, principalmente dos Estados Unidos.

Diversos pensadores do final do séc. XIX e início do séc. XX tinham-se defrontado com a questão do social, que eles denominaram, contudo, de "coletivo". O próprio Wundt, como vimos, chegou a escrever dez volumes sobre o que ele chamou de Psicologia Social. Foi, contudo, solenemente ignorado.

É importante constatar o seguinte: a variável individual/social foi, curiosamente, ligada à variável racional/irracional, outra dicotomia que afligia os pensadores do final do séc. XIX e início do séc. XX. E novamente entra aqui em jogo Descartes. Se fôssemos resumir esse complexo debate, com risco de reduzi-lo em sua importância, poderíamos dizer que a força do individualismo cartesiano venceu a batalha, e tudo o que fosse coletivo, "social”, ou mesmo cultural, passou a ser também irracional. Isso está claro em Le Bon, para quem todo coletivo era perigoso e devia ser evitado. Conotações negativas dessa "cultura" podem ser entrevistas nas obras de Freud, para quem a "civilização" devia ser mais aturada do que aceita. Moscovici $(1961,1985)$ discute essa questão da psicologia das massas e mostra como os psicólogos sociais acadêmicos se distanciaram desse campo 
por acharem que esses estudos eram mais "populares" que científicos, apontando também os perigos desse desinteresse.

Ernest Gellner, um filósofo que discute a poderosa influência do individualismo cartesiano nas ciências, faz um forte comentário ao mostrar como tudo o que fosse social ou cultural devia ser rejeitado. E qual a razão? "Deve ser rejeitado porque é uma cultura. Sua origem social e comum é sua mácula fatal” (1992, p.18). Isso é o que Moscovici chama de "o escândalo do pensamento social" (2002, p.167). Morton Prince, professor de psiquiatria de Harvard, convidou em 1921 Floyd. H. Allport, jovem instrutor em Harvard, a colaborar como coeditor do Journal of Abnormal and Social Psychology. O título já nos dá uma indicação avaliativa do que se pensava do "social" e da "cultura" da parte de determinados segmentos acadêmicos: o social não andaria longe do anormal.

Esses são alguns dos pressupostos que estão presentes na história e nas origens da Psicologia Social. Quando ela migrou e lançou fortes raízes no resto do mundo, principalmente nos EE.UU., se transferiu com esses dois pressupostos bem nítidos. E, pode-se até dizer que, em grande parte, eles influenciam ainda os dias de hoje. Sem uma compreensão mais nítida desses fatores, torna-se difícil discernir e criticar as diferentes visões existentes na contemporaneidade.

Sintetizando essa primeira etapa, podemos dizer que, no desenvolvimento da Psicologia Social, as principais questões foram:

- A psicologia surge como uma ciência experimental, dentro dos pressupostos das Naturwissenchaften. O próprio Wundt, contudo, fundador dessa psicologia experimental, criou também uma psicologia dentro das Geisteswissenchaften, a qual chamou de Psicologia Social, mas o problema de Wundt é que ele separou as duas; 
- No espírito da época, nas pegadas de Descartes, a Psicologia Social que se estruturou, foi uma psicologia individualista, onde o social não passava de soma de individuais.

- Há, contudo, tentativas de criação de uma Psicologia Social que desse conta do imaterial, psíquico, simbólico, representacional:

- A primeira delas são os 10 volumes de Wundt de Psicologia Social e os estudos de Durkheim sobre representações coletivas. Se Wundt, por um lado, separou o social do individual, Durkheim, por sua vez, “corporificou”, "reificou” seu socia, suprimindo o individual. McDougall fez uma interessante tentativa de ligar o fisiológico (biológico) e o coletivo em seus estudos sobre a mente grupal vendo o instinto como base da vida em sociedade. Mas sua tentativa morreu na casca; era muito difícil poder vingar, em função do peso da mentalidade da época.

- Uma segunda, e para mim muito importante, foi a de Mead com a teorização sobre o self. Ele construiu uma primeira síntese dialética entre o individual e o social, e entre o biológico e o psíquico: pensou o instinto como base da vida em sociedade, mas admitiu a realidade do simbólico (psíquico, mental): essa síntese seria o self.

- Para Farr (1998, pg. 76), também Freud, ter-se-ia aproximado e tentado construir essa síntese com seus conceitos de "id, ego, superego”, que estariam entre sua primeira tópica do préconsciente, consciente e inconsciente, por um lado, e de uma crítica psicanalítica da cultura e da sociedade, por outro. Muitos se surpreendem com essa afirmação de Farr. Não tenho posição formada sobre isso, mas é pelo menos, uma hipótese que mereceria uma discussão mais aprofundada. 
- Ao final do séc. XIX e início do séc. XX, para se poder dar conta do social, houve uma tentativa de criação de uma psicologia “coletiva”, das massas e da cultura. Tal psicologia, contudo, não foi à frente devido, é meu entender, ao fato de ter sido identificada como "irracional” e perigosa.

- Quando a Psicologia foi "transportada” da Alemanha aos EE.UU., foi levada como uma psicologia fisiológica, nada além da pele (behaviorismo). Quando transpôs a barreira da pele tornou-se psíquica, imaterial, mental, mas permaneceu, contudo, absolutamente individual. Não conseguiu incorporar o social.

- Dos EE.UU. ela passou a outros continentes como a América Latina e a Europa.Com respeito à Europa, foi montada uma espécie de "Plano Marshall acadêmico", numa investida conquistadora de implantar a psicologia de viés americano. Tal investida sofreu, contudo, principalmente por parte de Moscovici (1972), na França, fortes reações. Ele começou a estranhar e a duvidar que sua tendência individualista pudesse dar verdadeiramente conta do “social”. É nesse contexto que começa a pesquisar e a pensar numa nova teoria, no caso, das Representações Sociais, que procurasse superar dicotomias, como entre o individual e o social, o externo e o interno, o estruturante e o estruturado, o processo e a estruturação e, ao mesmo tempo, pudesse dar conta também de novos contextos sociais. É o que veremos a seguir.

\section{A estruturação da Psicologia Social: a incorporação de novos elementos (A Psicologia Social tomando corpo)}

Nessa segunda etapa de nossa caminhada, passo a discutir a Psicologia Social a partir da década de 1950, principalmente a partir de Serge Moscovici. Mostro como a Psicologia Social começou a questionar a si mesma 
e como novas dimensões foram sendo incorporadas a ela, redimensionando sua compreensão e abrangência. Percorro os seguintes pontos:

2.1) O “ambiente” da Psicologia Social na década de 1950

2.2) O "social” da Psicologia Social

2.3) O "simbólico" da Psicologia Social

\subsection{O “ambiente” da Psicologia Social na década de 1950}

Ao final da década de 50 e inícios da década de 60, Moscovici começa a questionar a Psicologia Social existente na Europa, mostrando-se insatisfeito com o que lá existia e se fazia. Inicia fazendo uma avaliação geral da situação da Psicologia Social na Europa. Em seu trabalho de 1972, "Sociedade e Teoria em Psicologia Social”, ele confessa a terrível situação em que eles se encontravam na Europa com respeito à Psicologia Social: "Em frente de nós, atrás de nós e ao nosso redor, havia —e ainda há- 'a Psicologia Social americana’” (2002, p. 111). E continua dizendo que, apesar do respeito que tinham por ela, sua aceitação estava se tornando progressivamente mais difícil, pois seus princípios "nos são estranhos, nossa experiência não condiz com a deles, nossa visão de homem, de realidade e de história é diferente” (p.112).

E ele vai assim desfilando, exemplo atrás de exemplo, as características dessa "Psicologia Social da ingenuidade" que não dava conta do "social" e que excluía a contradição. O que faltava à Psicologia Social, segundo ele, eram as contribuições de Marx, Freud, Piaget, Durkheim: a questão das desigualdades, o fenômeno da linguagem, a força das ideias na construção da sociedade, a realidade social. Ela deveria ser uma ciência mais do movimento, do que da ordem. E ainda:

a ciência é uma instituição social e, como tal, é um objeto de análise como qualquer outro, da mesma forma que os experimentos e seus sujeitos estão engajados na interação social, como todos os demais;... qual a finalidade da comunidade científica: apoiar a ordem, ou criticá-la e transformá-la? 
Procurando dar um exemplo de como uma ciência pode se tornar reducionista e servir para fins ideológicos, Moscovici comenta como alguns economistas projetaram as normas e atitudes de uma sociedade capitalista, baseados nos processos de troca. Suas reconstruções "psicológicas" pertencem a este contexto; a ação humana é concebida como determinada pelos imperativos de uma economia de mercado e de lucro. E comenta:

\begin{abstract}
Mas há ainda mais que isto. Tudo o que é social é simplesmente excluído deste tipo de economia. Investimentos coletivos, gastos que não são canalizados através do mercado, ou da chamada economia externa, não estão incluídos nos seus dispositivos... os objetivos se tornam definidos dentro de uma perspectiva individualística, são considerados como 'dados' na natureza do Homem. Como resultado de tudo isto, esta versão da economia concebe uma imensa área da conduta humana como irracional, uma vez que, dentro de sua prática, tudo o que vai além do individualismo e tudo o que diverge um pouco de um modelo de capitalismo, entra, por definição, no domínio da irracionalidade (MOSCOVICI, 2002, p.125-126, grifos no original).
\end{abstract}

Outro exemplo provocativo mostra preconceito contra o social, ou o grupo. Moscovici analisa como nos estudos de risco se descobriu que, quando em grupo, as pessoas tomam atitudes de maior risco do que quando sozinhas. A conclusão a que se chega é: logo, o grupo é “perigoso”. Mas o que se esquece de ver é que tais pessoas podem tomar atitudes mais arriscadas exatamente porque discutiram a questão, isto é, estabeleceram uma interação; e com base nessas discussões, arriscaram mais.

As duas conclusões a que Moscovici chega, não diferem do que vimos na primeira parte desse trabalho: uma racionalidade que é puramente cartesiana, mecânica; e cálculos (práticas) que são puramente individuais, limitados às relações entre, no máximo, dois indivíduos.

Os trabalhos e discussões que se faziam presentes nessa Psicologia Social podiam se resumir em dois enfoques principais.

Um primeiro que dava ênfase ao objeto, o que interessava era o objeto, que podia ser diferenciado em diferentes tipos até mesmo em social e não social, mas o sujeito seria sempre igual, indiferenciado. Por 
exemplo: na pesquisa psicossocial de influência sobre as pessoas, o que importa é a relevância dos objetos que podem causar estímulos diferentes nos sujeitos: importância das pessoas que falam, sua credibilidade etc. Um segundo enfoque dava ênfase ao sujeito, onde esse era classificado em inúmeros tipos diferenciados, mas o objeto não interessava era sempre o mesmo, indiferenciado. Nesse caso, em estudos sobre influência social não interessa quem fala, mas as características de quem recebe : se é sugestionável, crítico etc.

É nesse ponto que, a nosso ver, a Psicologia Social dá um salto. Um novo tipo de "social" se faz presente na Psicologia Social.

\subsection{O "social” da Psicologia Social}

Temos aqui um novo enfoque, que vem questionar teórica e epistemologicamente os dois anteriores: tudo tem a ver com tudo, não há nada "isolado", indiferenciado: "uma relação triangular complexa, em que cada um dos termos é totalmente determinado pelos outros dois... o triângulo Sujeito-Outro-Objeto é crucial para essa discussão, pois é o único esquema capaz de explicar e sistematizar os processos de interação" (MOSCOVICI, 2002, p. 152-3). Duas décadas depois, Bauer e Gaskell (1999), a partir desse esquema, acrescentam a dimensão do tempo em que esses triângulos vão se sucedendo, formando o que eles chamam de "modelo do toblerone": tempos dialéticos que se sucedem.

Ao discutir a relação entre indivíduo e sociedade, Moscovici diz (2002, p.157): “a sociedade não é vista como um produto dos indivíduos, nem os indivíduos vistos como produtos da sociedade... o problema das relações entre ser humano e sociedade se relaciona intrinsecamente com ambos os termos do rapport".

Aprofundando essa afirmação de Moscovici, podemos mergulhar um pouco mais na discussão do social e dos diferentes tipos de social. Isso porque há vários sociais, e o conceito de "social” pode, também, produzir equívocos, necessitando de uma análise criteriosa. O exame das diferentes 
teorias e autores mostra que podem ser identificadas ao menos três concepções de social.

Dentro de uma concepção individualista, cartesiana, onde o ser humano é entendido como um "indivíduo" (indivisum in se, sed divisum a quolibet alio), falando em termos bem precisos, não existe o social; o que existe é apenas o individual e o social, nessa visão, é uma soma de individuais. Tanto as pessoas, como os objetos, passam, consequentemente, a ser realidades discretas, separadas. Desse modo, somando-se diversos individuais, temos um grupo, que seria um amontoado de elementos, mas onde cada ser, indivíduo, mantém sua unidade e singularidade, sem se relacionar com os outros. Dentro dessa cosmovisão, há um entendimento específico do que seja “público”, ou "bem comum”: público é a soma de indivíduos; o "bem comum” passa a existir quando os diversos indivíduos, separadamente, estão bem. Foi por isso que Jeremy Bentham, junto com muitos teólogos do fim do séc. XIX argumentaram que, à medida que cada indivíduo competisse, procurasse seu próprio interesse e bem-estar, os problemas sociais automaticamente se resolveriam; não precisava o Estado intervir. O Estado, para um autêntico liberal, só tem sentido para defender os interesses particulares dos indivíduos. Assim também os outros serviços, como a segurança, a saúde, a educação. Tais realidades, para eles, são sociais apenas por estarem juntos. Na verdade são uma soma de realidades discretas.

Já numa cosmovisão totalitária e coletivista, onde o ser humano é assumido como "uma peça da máquina”, ou "uma parte de um todo”, o social é a grande, única e principal realidade existente: dele deriva o sentido para tudo o mais. O social tem o mesmo status de realidade que "coisa”; ele é, une chose, como dizia Durkheim. O grupo e o coletivo, são a verdadeira e única realidade. Os elementos desse grupo (as pessoas) passam a ter importância a partir de sua pertença aos grupos. As pessoas são "peças” da máquina: o que vale é a máquina. Não importa a consciência individual: importa a consciência coletiva. 
Na concepção que assumimos e defendemos aqui, em consonância com a afirmativa de Moscovici, acima citada, o social é entendido como uma relação, isto é, algo que não pode ser entendido sem outros; ele implica, em sua própria definição, outros. Possui, pode-se dizer, um direcionamento intrínseco, do próprio ser, em direção a outro(s) (relatio: ordo ad aliquid). É singular e, ao mesmo tempo, múltiplo. É esse o social que constitui o processo de mediação na complexidade entre o mundo interno e externo, entre o individual e o coletivo, entre o psíquico individual e a realidade psíquica social externa. Ele é o "entre" de todos esses processos. Esse conceito de social=relação é útil, do mesmo modo, para o entendimento do que sejam os grupos: eles se constituem a partir de relações; são as relações a matéria prima de um grupo (GUARESCHI, 2004).

\subsection{O social "simbólico" da Psicologia Social}

Há outro aspecto importante que deve ser levado em consideração para se compreender com clareza e discernimento específico da Psicologia Social. É necessário discutir alguns equívocos que são muito frequentes ao se usar termos como "cognitivo" e "simbólico".

O comportamento simbólico foi, muitas vezes, confundido com os processos psicológicos gerais chamados de "cognitivos". Com isso, mascara-se a distinção entre os dois termos. Quando os termos "afetivo", "motor motivacional" são substituídos pelo termo "cognitivo", o pressuposto subjacente é que não se fez mais do que passar de um nível a outro. O foco de análise permanece ainda no indivíduo, como uma unidade dentro do esquema clássico do estímulo-resposta.

Bem diverso é o pressuposto ao se falar do "simbólico". Os aspectos fundamentais do comportamento simbólico consistem de suas manifestações verbais e não verbais, que são compreendidas e se tornam "visíveis" somente em relação aos significados comuns que eles adquirem para os que recebem as mensagens e para aqueles que as emitem. Comportamento simbólico é fundamentado e torna-se possível pelas normas sociais e regras e por uma história comum que reflete o sistema de 
conotações implícitas e pontos de referência que, invariavelmente, se desenvolvem em todo ambiente social.

Por isso, a Psicologia Social é uma ciência do comportamento somente se isso for entendido como significando que seu interesse consiste em um modo muito específico deste comportamento —o modo simbólico. É isso que distingue a Psicologia Social da Psicologia geral. A grande diferença é que o simbólico é sempre social; não existe simbólico individual. Psicologia Social trata do simbólico que é um psíquico social.

Essa a Psicologia Social que foi tomando corpo a partir da década de 1950, trazendo novos elementos que, de um modo ou outro, foram ampliando seus primeiros passos. Várias teorias coexistem hoje. Seria importante um enfrentamento teórico entre essas teorias. Fica aqui um desafio para que isso se concretize.

Há uma afirmativa de Durkheim (1912/1995, p.440) que pode servir como um desafio a nossas elucubrações: "Um homem que não pensa com conceitos não seria um homem, pois ele não seria um ser social. Restrito apenas a percepções individuais, ele não seria diferente de um animal”. Para Moscovici (2002, p.180), essa afirmativa traça uma fronteira clara entre a psicologia individual e a Psicologia Social. O papel da Psicologia Social seria, então, conseguir uma compreensão mais profunda dessas representações públicas e culturais.

\section{Concluindo}

Voltemos ao início de nossa conversa. A proposta era de enfrentar a Psicologia Social, perguntando-se pelo seu surgimento, sua atribulada história, sobre as teorias que tentaram dar conta desse campo híbrido entre o indivíduo e a sociedade. Fomos avançando, mostrando como os diferentes enfoques acrescentavam e, ao mesmo tempo, reduziam seu poder explicativo.

Farr (1998) mostrou, em sua análise histórica já clássica, que “a individualização do social” tomou distintas correntes teóricas e configurou, 
de maneira diferente, a Psicologia Social durante o séc. XX. Devido a ideias teóricas e/ou empíricas, desenvolvidas pelo comportamentalismo, positivismo, cognitivismo, a natureza social do ser humano foi mal entendida, ignorada, ou mesmo rejeitada. As pessoas foram tratadas como átomos, separados artificialmente de seus contextos sociais.

Na esteira de Farr, sem querer fechar a reflexão, diria que a Psicologia Social, a meu ver, deveria se perguntar pelos possíveis reducionismos que, de um modo ou outro, foram se colocando em seu caminho, tais como:

- O comportamentalismo, que só via, na Psicologia Social, o que chega até à pele, não passando daí sem poder dar conta do psíquico e principalmente do simbólico, sempre social;

- O sociologismo ou um estruturalismo sistêmico, que materializava os fenômenos não permitindo que se visse sua historicidade e sua relatividade, excluindo, assim, o próprio ser humano de suas análises. Como dar conta do histórico, de que os fenômenos sociais são “construções simbólicas”?

- Visões individualistas dos fenômenos, que não conseguem dar conta do "social", chegando ao máximo à "soma de individuais”. O grande número de fenômenos, por um lado e a existência apenas de um outro, não são suficientes para garantir o "social"; a numerosidade pode quando muito construir um social que não passa da soma de individuais; e o simples fato de existir um "outro" de nada poderá servir se esse "outro" for também um indivíduo isolado e não existir uma relação intrínseca entre ambos; entre dois indivíduos pode existir uma relação que seja apenas extrínseca e ocasional. Como dar conta dos fenômenos "sociais" e imateriais, como os mitos, as religiões, as crenças, as representações sociais? 
- O cognitivismo que esqueceu o "social” e que reduziu o ser humano a um computador mais aprimorado. Como pode ele dar conta do social, na produção do conhecimento?

- Certo construcionismo, no qual, muitas vezes, não se vê como possa dar conta do fato de que os fenômenos implicam alguma constância e relativa institucionalização das práticas humanas, que possuem espessura e dureza ("thicken and harden” Jovchelovitch, 2007, p. 49), através de processos de transmissão e propiciam aos ambientes simbólicos sua dimensão de "tidos como indiscutíveis" ("taken for granted") e seu caráter factual.

Ficam essas considerações e questionamentos para aprofundarmos nossa reflexão sobre o que é mesmo uma psicologia social. É uma contribuição despretensiosa, que poderá ser muito bem aprofundada por algum colega interessado na questão.

Referências bibliográficas

BAUER, M. e GASKELL, G. Towards a paradigm for research on social representations. Journal for the Theory of Social Behavior, 29(2), p. 163-186, 1999.

BAUMAN, Z. Modernidade e Holocausto. Rio de Janeiro: Zahar Editora, 1989.

DURKHEIM, E. The Elementary Forms of Religious Life. Nova Iorque: Free Press, 1995.

. Individual and collective representations. Em: DURKHEIM, E. Sociology and Philosophy. Nova Iorque: Free Press, 1974.

FARR, R. As raízes da Psicologia Social moderna. Petrópolis: Vozes, 1998.

GUARESCHI, P. Psicologia Social Crítica como prática de libertação. Porto Alegre: Edicpurs, 2004.

JOVCHELOVITCH, S. Knowledge in Context representation, community and culture. Londres: Routledge, 2007. 
MOSCOVICI, S. L’Age des Foules: um traité historique de psychologie des masses. Paris: Fayard, 1981.

. The Age of the Crowd: a historical treatise on mass psychology. 1985.

. La Psychanalyse, son image et son public. Paris: PUF, 1961/1976.

. Society and Theory in Social Psychology, em: ISRAEL, J. e TAJFEL, H. The Context of Social Psychology. Londres: Academic Press, 1972.

- Representações Sociais Investigações em Psicologia Social. Petrópolis: Vozes, 2002. 


\title{
PSICOLOGIA SOCIAL DA MEMÓRIA: SOBRE MEMÓRIAS HISTÓRICAS E MEMÓRIAS GERACIONAIS
}

\author{
Celso Pereira de Sá \\ Universidade do Estado do Rio de Janeiro
}

constituição de uma “psicologia social da memória” —expressão
utilizada já em 1963 por J. Stoetzel (1976) em seu manual de psicologia social— tem tomado efetivamente corpo, na Europa, há cerca de duas décadas, com trabalhos como de D. Jodelet (1992) sobre as "memórias de massa”, dentre outros. No Brasil, uma acentuação do engajamento de psicólogos sociais nesse domínio começou a ocorrer não muito tempo depois, embora a contribuição pioneira de E. Bosi (1979) date antes disso.

O contexto acadêmico em que surge essa retomada do interesse pela memória por parte dos psicólogos sociais é o da “psicologia social sociológica europeia”, na esteira dos estudos sobre o pensamento social, dentre os quais se destaca a perspectiva das representações sociais, devida a S. Moscovici (1961/1976). Assim, como Moscovici derivou, não sem importantes adaptações, o conceito psicossocial de "representações sociais" de uma noção sociológica anterior, as "representações coletivas”, devida a E. Durkheim (1912/1985), a perspectiva psicossocial no campo da memória se deriva em grande parte da noção de "quadros sociais da memória” e, um tanto menos, da "memória coletiva”, da sociologia de M. Halbwachs (1925/1994, 1950/1997).

Não obstante, as contribuições para a constituição da psicologia social da memória não se esgotam (como também não ocorreu no caso das representações sociais) com essa apropriação de uma perspectiva sociológica. Uma segunda contribuição importante, conquanto menos geralmente 
reconhecida, e que tem um caráter tão pioneiro quanto aquela sociológica, é a perspectiva psicossocial prévia de F. C. Bartlett (1932/1995).

A importância dessas contribuições se faz sentir já quanto ao propósito básico da psicologia social da memória em se constituir como um domínio nãopsicologista e não sociologista, colocando-se assim em tão boa companhia quanto a da "construção social da realidade" de P. Berger e T. Luckmann (1973). Ela deve em grande parte o não psicologismo à sua derivação sociológica, pela qual, com Halbwachs, se concebe a memória em termos de uma construção social e não da retenção e reprodução de experiências passadas que permaneceriam intactas na mente (consciente ou inconsciente) dos indivíduos, como sustentam a filosofia de $\mathrm{H}$. Bergson e a psicanálise de S. Freud. Por outro lado, o não sociologismo resulta de uma opção por não se acompanhar Halbwachs em sua proposição de uma "memória do grupo", preferindo-se a fórmula, igualmente construtivista, mas não sociologista, de uma "memória no grupo", devida a Bartlett.

Três outras ordens de contribuições têm também desempenhado papéis significativos na constituição da psicologia social da memória. A primeira é representada pelas releituras da obra de Halbwachs empreendidas por sociólogos contemporâneos, como G. Namer (2000) e P. Jedlowski (2001), que têm atenuado o seu sociologismo original. A segunda tem sua origem na história e traz, além da proximidade com o campo da história oral, uma profícua problematização das relações entre história e memória, como o fazem J. Le Goff (1996) e P. Nora (1997). A terceira consiste no tratamento dado à memória por uma vertente da psicologia cognitiva que, como descreve U. Neisser (1996), se afastou da orientação experimental e passou a adotar uma estratégia observacional ou naturalista de pesquisa, numa ocasião anterior mesmo à retomada do interesse pela memória por parte dos psicólogos sociais.

É da articulação entre estas três ordens de contribuições — sociológica, histórica e psicológica - que trata o presente trabalho, para buscar dar conta da natureza em si da psicologia social da memória. E, como conceitos 
construídos em termos propriamente psicossociais, em resultado daquela articulação, focalizam-se aqui especificamente as "memórias históricas” e as “memórias geracionais”.

O termo “memória histórica” é encontrado em Halbwachs (2004), que o considerava uma contradição em termos — pois, no seu entender, a história só começa a ser escrita quando a memória está se extinguindo- e restringia a memória da história às memórias coletivas construídas em grupos sociais razoavelmente circunscritos. Para esse autor, portanto, a história de que se pode guardar uma memória seria apenas a “história vivida”, cuja duração não ultrapassa os limites e o período de existência de um grupo, e não a "história relatada”, de âmbito mais extenso no espaço e no tempo.

Para a psicologia social da memória, na articulação aqui desenvolvida, a memória social dos fatos históricos ou "memória histórica” comporta duas modalidades (SÁ, 2005; SÁ, no prelo 2) — “memória histórica oral” e “memória histórica documental”.A primeira das quais pode ser bem abarcada pela noção de memória coletiva, como queria Halbwachs, enquanto a segunda exige, para a sua consideração mais completa, o recurso também a outras categorias descritivas, assim como a outras formulações conceituais, como se argumenta a seguir.

Em primeiro lugar, cabe convir, a partir das distinções propostas por Jedlowski (2001) e por Sá (2005), que não só memórias coletivas, mas ainda memórias pessoais e memórias comuns estejam envolvidas na configuração de uma dada memória histórica. Há diferença das “memórias coletivas”, que têm como objeto o passado e a história dos grupos, cuja lembrança é cultivada — leia-se, construída — através da interação dos seus membros, as “memórias pessoais" se referem ao próprio passado das pessoas, embora possam envolver também lembranças de circunstâncias grupais e de fatos históricos dos quais elas tenham participado ou apenas ouvido falar. É certo que Halbwachs (1997) subordina as memórias individuais às coletivas, mas ele admite também que a determinação das lembranças, bem como dos esquecimentos, pela participação em diferentes grupos e pelo afastamento 
deles, ao longo da vida, possa resultar em configurações únicas de memórias em diferentes pessoas. Distinguíveis das memórias coletivas que resultam da discussão e elaboração dos fatos e informações pelos membros do grupo, são também as "memórias comuns", construídas por pessoas que não se encontram em interação, mas que devido à participação comum em um contexto sócio-histórico-cultural, são expostas aos mesmos fatos e informações e acabam por guardar deles as mesmas lembranças.

Em segundo lugar, a noção de "documento" pode e deve ser atualizada e ampliada, pois Halbwachs (op. cit.) tinha razão em dizer que os documentos encerrados em museus e bibliotecas, aos quais só um reduzido número de estudiosos tem acesso, não pode constituir por si só uma memória. Mas, como argumenta o historiador P. Nora (1997), há documentos —e aí se incluem não apenas textos escritos, mas também obras de arte, monumentos, espaços arquitetônicos etc.- sobre os quais parcelas de uma população investem uma "vontade de memória" e, por isso mesmo, eles são transformados em "lugares de memória"deixando de ser simples "lugares de história".

Propõe-se ainda, para fins da análise psicossocial aqui pretendida, uma segunda ampliação da noção histórica de documento, no sentido de englobar não apenas os traços e registros materiais deixados pelo passado, mas também tudo o que se tem crescentemente produzido e divulgado sobre ele, como livros didáticos de história, filmes cinematográficos, matérias nos meios de comunicação de massa etc. Tal ampliação implica que o conhecimento documental —não importando se verdadeiro, preciso ou não- acerca do passado e, em especial, dos fatos históricos se encontra hoje amplamente acessível a uma população e não apenas a reduzidas parcelas desta. Por exemplo, praticamente todos os cidadãos brasileiros que cumpriram o nível fundamental de ensino sabem que o Brasil foi descoberto por Pedro Álvares Cabral e mantêm em suas mentes — como se disso se lembrassem- as imagens das caravelas portuguesas aqui chegando pelo mar e dos nossos índios as observando da praia (SÁ, OLIVEIRA \& PRADO, 2005). 
Em continuidade, cabe considerar, como sustentado tanto por Halbwachs quanto por Bartlett, e depois por Moscovici, que conhecimento e memória estão intrinsecamente associados e, muitas vezes, mesclados a um tal ponto que o que é lembrado do passado e aquilo que se sabe sobre ele se tornam indistinguíveis. Daí que, mesmo quando o fato passado não pode ser objeto de lembranças pessoais ou grupais — como é o caso do descobrimento do Brasil-, os documentos que o fazem conhecer permitem uma apropriação que é frequentemente experimentada mais como uma memória do que como um saber. É nesse sentido que M. Ferro (1990) afirma que "a história como nos foi contada quando éramos crianças deixa sua marca em nós por toda a vida” (p. 9).

A mera disponibilidade de tais documentos — mesmo que ampliados para abarcar os produtos artísticos, educacionais e comunicacionais- não faz deles, entretanto, memórias, pois numa perspectiva psicossocial, somente quando os documentos são de alguma forma mobilizados — lidos, visitados, apreciados ou apenas referidos - por pessoas e grupos sociais, é que emerge um fenômeno de memória histórica documental. Isto implica que não são os documentos que ensejam unilateralmente a construção de memórias, mas sim as representações que os diversos conjuntos sociais por exemplo, as múltiplas e sucessivas classes de alunos de nível fundamental— fazem ativamente deles — por exemplo, do conteúdo dos manuais escolares acerca do descobrimento do Brasil. Daí decorre ainda que, no caso das obras de arte — como a tela "Guernica", de Picasso- e dos filmes — sobre a Guerra Civil Espanhola-, as memórias históricas documentais consistem em representações (sociais) formadas a partir de representações (artísticas).

O estudo de memórias históricas documentais pela psicologia social da memória exige, pois dada uma população e um fato, processo ou período histórico, que: sejam identificadas as fontes documentais de conhecimento histórico disponíveis; seja avaliado o grau de "mobilização funcional" da população em relação a tais documentos, incluindo a circunstância de que alguns deles se tenham constituído em "lugares de memória"; e, como 
convém a qualquer pesquisa de natureza psicossocial, seja dada a palavra a membros individuais e grupais da população, para se inferir como aquele fato, processo ou período é socialmente representado — constituindo, assim, memórias coletivas - ou simplesmente aludido, como costuma ocorrer nas memórias pessoais e comuns.

Além de breve, esta descrição da pesquisa de uma memória histórica é reconhecidamente incompleta. Faltou considerar que uma população é constituída por estratos de diferentes níveis de escolaridade e de diferentes orientações políticas, bem como por distintas coortes geracionais. No caso da primeira clivagem, cabe considerar que uma memória histórica que repouse sobre a leitura, a apreciação, a visita ou a simples referência a documentos depende da frequência, da extensão e da intensidade com que essas coisas sejam feitas, variáveis estas que tendem a se correlacionar positivamente com o aumento do nível de escolaridade das pessoas. Por outro lado, cumpre estar alerta para o fato de que, em qualquer nível de escolaridade, pessoas com diferentes orientações políticas, além de interpretarem de modos diversos os fatos, processos e períodos históricos que tenham testemunhado, selecionam diferencialmente os documentos que mobilizam para a construção das suas respectivas memórias. Finalmente, a questão da coexistência de distintas gerações numa população remete à proveitosa apropriação que a psicologia social da memória tem feito de estudos desenvolvidos na psicologia cognitiva de orientação naturalista, como já argumentado em outra parte (SÁ, no prelo 1) e no restante deste texto.

A vertente naturalista, minoritária, da psicologia cognitiva, que deixou o laboratório de pesquisa experimental e sua perspectiva da memória como processamento da informação, para se ocupar do estudo observacional da memória na vida cotidiana (NEISSER, 1996), tem desenvolvido várias linhas de pesquisa relevantes em termos psicossociais. Dentre estas, destacam-se as "memórias flash" (BROWN \& KULIK, 1996; BELLELLI, CURCI \& LEONE, 2000; DE ROSA, 2005), as “memórias autobiográficas" (CONWAY, 1995; BARCLAY, 1995) e as “memórias geracionais” (PENNEBAKER \& BASANICk, 1998; SCHUMAN, BELLI \& 
BISCHOPING, 1998). São estas as memórias geracionais, que constituem um dos interesses focais do presente trabalho, especialmente em sua articulação como estudo das memórias históricas.

O estudo das memórias geracionais buscou sua base conceitual no trabalho de K. Mannheim (1952/1982) sobre "o problema sociológico das gerações", de onde extraiu uma hipótese quanto à existência de um "período crítico" de idade, caracterizado pela maior retenção das experiências, que se situaria na adolescência e nos primeiros anos da vida adulta, ou seja, enquanto tais estratos etários estivessem se constituindo como uma geração dotada de identidade e características próprias e únicas. Tal hipótese, além de ter recebido confirmação através de diversos estudos, tem sido desdobrada para prover uma explicação para a ocorrência observada de ciclos — de vinte a trinta anos- na construção de monumentos e na produção de filmes a propósito de diferentes fatos, processos e períodos históricos. Nesse sentido, aqueles conjuntos de pessoas que mais intensamente se recordassem de tais fatos, processos ou períodos como algo do "seu tempo" seriam os mais prováveis produtores de novos "documentos", que terminariam por alimentar a memória histórica das gerações subsequentes.

Não obstante, o processo de constituição das gerações e a noção de "idade crítica" que dele se deriva não esgotam as implicações da variável geracional no estudo das memórias históricas. Como a composição etária de uma população em qualquer dada época é heterogênea, sempre estarão coexistindo distintas memórias geracionais acerca de qualquer determinado fato, processo ou período histórico, em função da idade em que cada coorte geracional o terá testemunhado ou, no mínimo, dele ter tido notícia. Por exemplo, ao estudar a memória de um período histórico decorrido entre quarenta e vinte anos atrás — como foi o caso do Regime Militar no Brasilhá que considerar, retornando a Mannheim, que o conjunto etário que então viveu a sua "idade crítica" tinha uma "situação de geração" —a peculiar configuração social, política, econômica e cultural em que tal geração estava se formando- diversa dos que testemunharam tal período histórico após 
terem concluído a sua própria definição geracional (em uma outra situação), o que poderá ter gerado consequências distintivas sobre as lembranças que as duas coortes tenham dele guardado. Por outro lado, tais "memórias adquiridas" pelos que, numa idade ou noutra, foram testemunhas dos fatos e processos do período histórico em questão podem apresentar diferenças significativas em relação às “memórias apropriadas” (ou seja, pelo ouvir falar posterior), que seriam características daqueles que nasceram após o término do período. Dessa forma, as memórias históricas acerca dos mesmos fatos e processos objetivos podem diferir bastante entre pessoas e grupos sociais pertencentes a estratos etários distintos em uma mesma população.

Além disso, não há uma necessária homogeneidade nas lembranças de cada um desses conjuntos etários acerca dos mesmos fatos, processos ou períodos históricos. Isto porque, de acordo com Mannheim, os jovens que vivenciam os mesmos problemas históricos concretos fazem parte de uma mesma “geração real”, mas há comumente dentro dessa geração grupos sociais que elaboram o material de suas experiências comuns através de diferentes modos específicos, constituindo assim "unidades de geração" separadas, cada uma delas com as suas próprias memórias coletivas características. Por outro lado, não é incomum que a memória de uma dessas unidades geracionais se torne hegemônica e influa sobre a construção de numerosas memórias pessoais e comuns dentro de um dado estrato etário. Por exemplo, a "bossa nova” que foi gestada em um grupo bastante circunscrito durante os chamados “anos dourados” — cuja memória histórica se está agora começando a pesquisar (SÁ et al., 2007)—, repercutiu com tal intensidade e alcance que passou a constituir uma característica distintiva de uma inteira geração carioca — e talvez mesmo brasileira — que se formou ao longo de tal período histórico. O fato de que o principal governante brasileiro daquele período, Juscelino Kubitschek, tenha sido uma vez chamado de “presidente bossa nova” ilustra bem como essa dimensão cultural popular veio a se integrar às demais realizações sociais, políticas e econômicas que caracterizaram o especial interregno que se seguiu ao suicídio de Getúlio Vargas e precedeu a instauração do Regime Militar. 
Concluindo, memórias históricas e memórias geracionais configuram áreas de estudo de inequívoca relevância para o desenvolvimento da psicologia social da memória. De fato, as memórias históricas, na modalidade "documentais" e da forma como foi aqui caracterizado o seu estudo psicossocial —ou seja, ampliando a noção de documentos e tomando-os como bases para a construção das memórias, mas não a sua essência—, se fazem amplamente presentes na interação social da vida cotidiana, principalmente naquela que tem lugar na chamada "esfera pública” (JEDLOWSKI, 2005). As memórias geracionais, por seu turno -e como aqui apropriadas em termos psicossociais—, são responsáveis por que os passados (alguns mais e outros menos) recentes sejam mantidos à tona, "à flor da pele", no presente de uma dada sociedade e daí possam ser continuamente "pinçados" pelas pessoas que os viveram — via de regra precedidos pela expressão "no meu tempo"- para reassegurar a espessura temporal que os diversos conjuntos sociais sentem necessidade de se atribuir. Finalmente, quando as memórias históricas documentais construídas em uma população são estudadas levando em consideração as diferenças com que elas se apresentam nas distintas coortes geracionais que então coexistem, a extrema riqueza e complexidade da memória como fenômeno psicossocial emergem, em nítido contraste com as frequentes simplificações sociologistas e psicologistas.

Referências bibliográficas

BARCLAY, C.R. Autobiographical remembering: narrative constraints on objectified selves. In RUBIN, D.C (Org.). Remembering our past: studies in autobiographical memory. Cambridge: Cambridge University Press, 1995, p. 94-125.

BARTLETT, F.C. Remembering: a study in experimental and social psychology. Cambridge: Cambridge University Press, 1995.

BELLELLI, G.; CURCI, A.; LEONE, G. Las memorias de "flash" como recuerdos colectivos. In ROSA, A.; BELLELLI, G.; BAKHURST, D (Orgs.). Memoria colectiva e identidad nacional. Madrid: Biblioteca Nueva, 2000, p. 181-205. 
BERGER, P.; LUCKMANN, T. A construção social da realidade. Petrópolis: Vozes, 1996. BOSI, E. Memória e sociedade: lembranças de velhos. São Paulo: T. A. Queiroz, 1979.

BROWN, R.; KULIK, J. Flashbulb memories. In NEISSER, U (Org.). Memory observed: remembering in natural contexts. New York: W. H. Freeman, 1996. p. 23-40.

CONWAY, M.A. Autobiographical knowledge and autobiographical memories. In RUBIN, D.C (Org.). Remembering our past: studies in autobiographical memory. Cambridge: Cambridge University Press, 1995, p. 67-93.

DE ROSA, A.S. O impacto das imagens e a partilha social das emoções na construção da memória social: uma chocante memória flash de massa do 11 de setembro até a guerra do Iraque. In: SÁ, C.P (Org.). Memória, imaginário e representações sociais. Rio de Janeiro: Museu da República, 2005, p. 121-164.

DURKHEIM, E. Les formes élémentaires de la vie religieuse. Paris: PUF. 1985.

FERRO, M. Cómo se cuenta la historia a los niños del mundo entero. México: Fondo de Cultura Económica, 1990.

HALBWACHS, M. Les cadres sociaux de la mémoire. Paris: Albin Michel, 1994.

. La mémoire collective. Paris: Albin Michel, 1997.

JEDLOWSKI, P. Memory and sociology: themes and issues. Time \& Society, London, v.10, n. 1, p. 29-44, 2001.

. Memória e mídia: uma perspectiva sociológica. In SÁ, C.P (Org.). Memória, imaginário e representações sociais. Rio de Janeiro: Museu da República, 2005, p. 87-98.

JODELET, D. Mémoire de masse: le côté moral et affective de l'histoire. Bulletin de Psychologie, Paris, v. 45, n. 405, p. 239-256, 1992.

LE GOFF, J. História e memória. Campinas: Ed. Unicamp, 1996.

MANNHEIM, K. O problema sociológico das gerações. In FORACCHI, M.M (Org.). Karl Mannheim. São Paulo: Ed. Ática, 1982, p. 67-95. 
MOSCOVICI, S. La psychanalyse, son image et son public. Paris: PUF, 1976.

NAMER, G. Halbwachs et la mémoire sociale. Paris: L'Harmattan, 2000.

NEISSER, U. Memory: what are the important questions? In NEISSER, U (Org.). Memory observed: remembering in natural contexts. New YorK: W. H. Freeman, 1995, p. 3-19.

NORA, P. Entre mémoire et histoire: la problématique des lieux. In NORA, P (Org.). Les lieux de mémoire. Paris: Gallimard, 1997, p. 23-43.

PENNEBAKER, J.W.; BASANICK, B. Creación y mantenimiento de memorias colectivas. In PÁEZ, D; VALENCIA, J.F.; PENNEBAKER, J.W.; RIMÉ, B.; JODELET. D (Orgs.). Memorias colectivas de procesos culturales y políticos. Bilbao: Universidad del País Vasco,1998, p. 31-47.

SÁ, C. P. As memórias da memória social. In SÁ, C.P (Org.). Memória, imaginário e representações sociais. Rio de Janeiro: Museu da República, 2005, p. 63-86.

(no prelo 1). Les défis d'une psychologie sociale de la mémoire. Maison des Sciences de l'Homme.

(no prelo 2). Sobre o campo de estudo da memória social: uma perspectiva psicossocial. Psicologia: Reflexão \& Crítica.

; OLIVEIRA, D.C.; PRADO, L.A. As memórias coletivas do descobrimento do Brasil: imagem comum e juízos diferenciados nas populações portuguesa e brasileira. In SÁ, C.P. ; CASTRO, P (Orgs.). Memórias do descobrimento do Brasil. Rio de Janeiro: Museu da República, 2005, p. 27-44.

et al. Análise psicossocial da memória histórica dos "anos dourados": política, cultura, cotidiano. Projeto de pesquisa, PPGPS/UERJ, Rio de Janeiro, 2007.

SCHUMAN, H., BELLI, R. F.; ISCHOPING, K (1998). La base generacional del conocimiento histórico. In PÁEZ, D; VALENCIA, J.F.; PENNEBAKER, J. W.; RIMÉ, B.; JODELET. D (Orgs.). Memorias colectivas de procesos culturales y políticos. Bilbao: Universidad del País Vasco, 1998, 83-120. 
STOETZEL, J. Psicologia social. São Paulo: Cia Ed. Nacional, 1976. 


\title{
PSICOLOGIA SOCIAL E PROCESSO EDUCACIONAL — IMPLICAÇÕES IDEOLÓGICAS E ÉTICAS
}

CAPÍTULO 4

\author{
ARMADILHAS E ALTERNATIVAS NOS \\ PROCESSOS EDUCACIONAIS E NA FORMAÇÃO DE \\ PROFESSORES: \\ UMA ANÁLISE NA PERSPECTIVADA PSICOLOGIA \\ SÓCIO-HISTÓRICA
}

\author{
Wanda Maria Junqueira de Aguiar \\ Pontifícia Universidade Católica de São Paulo
}

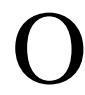
objetivo deste simpósio é, ao refletir sobre a realidade educacional, suas armadilhas e alternativas, destacar a necessidade de se lançar um olhar teórico-crítico tanto sobre as concepções de educação, escola e seus processos constitutivos como sobre a formação de professores. Para tanto, destacaremos a relevância do referencial teórico e metodológico, no caso a Psicologia Sócio-Histórica, baseada nos pressupostos do Materialismo Histórico e Dialético.

Colocar o processo educacional em foco - e com ele, a questão da formação de professores - gera várias indagações: $\mathrm{O}$ que entendemos por educação? Quais as nossas expectativas a respeito do processo educacional? Qual a nossa avaliação da sua atual condição? Como concebemos o papel do professor? Como avaliamos sua formação? Vemos necessidade de alguma transformação em suas práticas pedagógicas? Que tipo de transformação esperamos?

Claro que não poderíamos responder a todas essas perguntas, não só pela enormidade de questões envolvidas como pela sua complexidade. No 
entanto, acreditamos ser possível apresentar algumas reflexões que nos ajudem a focar e, quem sabe, apreender de um modo menos aparente os processos educacionais, desmontando armadilhas que nos conduzem, muitas vezes, a leituras ingênuas dos processos educacionais e a práticas conservadoras e alienadas.

Destacamos assim que, coerentemente com o referencial adotado, pensar Educação é pensar o desenvolvimento e a transformação do Homem. A possibilidade dessa compreensão se dá por via de uma das principais categorias do Materialismo Histórico, ou seja, a Historicidade.

Tal categoria nos permite apreender o homem no seu movimento dialético e multideterminado pelas mediações sociais e históricas. Como nos lembra Vigotski (2000) historicidade se desdobra em dois aspectos inseparáveis. Um apontando a existência de uma "dialética geral das coisas", ou seja, o homem se desenvolve nas e pelas contradições no movimento dialético constitutivo das mediações sociais, ao mesmo tempo que - considerando aqui o segundo momento- num processo histórico, temporal, com toda a materialidade que o caracteriza.

Com isso, afirmamos que o homem se constitui na relação de mediação com o social, relação em que homem e sociedade vivem a tensão constante de serem diferentes, opostos, mas de se constituírem mutuamente.

Assim, indivíduo e sociedade vivem uma relação na qual se incluem e se excluem ao mesmo tempo. Quando afirmamos se incluem, lembramos Vigotski (2001) ao afirmar que o indivíduo é “quase o social”; para ele não há invenções individuais no sentido estrito da palavra. Em todas as criações humanas existe sempre alguma colaboração anônima. E, quando afirmamos se excluem, se diferenciam, destacamos a singularidade do sujeito. Desse modo, conforme Aguiar e Ozella (2006), “(...) indivíduo e sociedade não mantêm uma relação isomórfica entre si, mas uma relação onde um constitui o outro”. Ainda segundo os autores, “(...) Vigotski (1999) afirma que o processo de internalização deveria ser chamado de "processo de revolução", pressupondo uma radical reestruturação da atividade psíquica 
neste movimento chamado de internalização". Estamos entendendo, desse modo, que o homem, ser social e singular, síntese de múltiplas determinações, nas relações com o social (universal) constitui sua singularidade através das mediações sociais (particularidades/circunstâncias específicas). Explicitando melhor esse processo de constituição da singularidade histórica, e de seu mecanismo de apreensão, afirmamos que ele ocorrerá "pela compreensão de como a singularidade se constrói na universalidade e ao mesmo tempo e do mesmo modo, como a universalidade se concretiza na singularidade, tendo a particularidade como mediação" (OLIVEIRA, 2001:1).

Será deste homem que vamos falar. É o homem sujeito e foco da educação. Homem que se constitui humano na história, no processo constante de objetivação e subjetivação.

Voltando à ideia de que Educação é transformação e desenvolvimento do homem, faz-se necessário completá-la afirmando que o processo educacional deve ser entendido, também e essencialmente, como aquele que permite ao homem, com toda a sua historicidade e singularidade, se apropriar do conhecimento produzido historicamente pela humanidade. É a educação que, como nos ensina Vigotski (2001), permitirá a "refundição do Homem”, a revolução nas suas funções psíquicas superiores.

Sem qualquer ingenuidade, e sem esquecer o peso das condições objetivas dadas pelo modo de produzir de uma sociedade, acreditamos que o processo educacional contribui para que se proporcionem ao sujeito condições de se afirmar enquanto tal, de não se sujeitar, de ter instrumentos para compreender e transformar a realidade e a si mesmo. A educação, conforme aponta Severino (2005) precisa gestar possibilidades de educandos e professores se apropriarem das relações de poder e desvendarem as armadilhas ideológicas. Segundo o autor, só assim a educação atuará como força de transformação.

Isto posto, sintetizando nossa concepção de educação, lembramos Paulo Freire ao afirmar que "a educação como prática política da liberdade, ao contrário daquela que é prática da dominação, implica a negação do 
homem abstrato, isolado, solto, desligado do mundo, assim, como também a negação do mundo como uma realidade ausente dos homens” (1996:70).

Essas colocações deixam claro que o olhar teórico e metodológico adotado é fundamental para a explicitação do homem, da educação e do que se espera desse processo. Mas onde ocorre esse processo? O que marca tais espaços?

Ao falar de educação podemos pensar numa grande diversidade de espaços e modalidades. No entanto, aqui vamos fazer um recorte e focar a escola como espaço privilegiado para a prática educativa.

Partimos do princípio de que, dependendo de como analisamos a instituição Escola, criamos maiores ou menores condições de apreendê-la na sua totalidade e contradições e, deste modo, ser capazes de uma intervenção mais ou menos qualificada. A nosso ver, será o referencial adotado que permitirá a apreensão da realidade escolar para além de sua aparência, entendida aqui como opaca, camufladora do real, enganosa.

Acreditamos que a psicologia sócio-histórica, tendo como base o materialismo histórico e dialético, permite-nos uma apreensão da escola e dos processos que nela se constituem e que, ao mesmo tempo, lhe dão vida e concretude.

Destacamos, assim, alguns pressupostos do materialismo histórico e dialético, vistos como essenciais para a apreensão da instituição Escola.

Em primeiro lugar apresentamos a noção de Processo. Como afirma Vigotski "Estudar uma coisa historicamente significa estudá-la no processo de mudança: esse é o requisito básico do método dialético" (2000:85). Assim, escola só poderá ser aprendida como uma instituição prenhe de contradições, em constante movimento. Sem essa compreensão corremos o risco de naturalizá-la, tomá-la em si, descolada das mediações que a constituem. Na perspectiva adotada, escola será compreendida como uma totalidade histórica e contraditoriamente constituída, na qual cada parte 
revela o todo transformado pela dialética de sua singularidade. Ao mesmo tempo, a totalidade expressa as partes, sem ser delas cópia ou somatório.

Ainda como um princípio do método proposto, fundamental para a apreensão da escola, retomamos a importância da relação aparência-essência. Como afirma Vigotski, parafraseando Marx, "se a ciência dos objetos coincidisse com a forma de suas manifestações externas, a ciência seria totalmente supérflua” (1996:150). Nossa tarefa é, portanto, explicar a realidade escolar para além da sua aparência, é apreender as suas mediações constitutivas. Neste momento apontamos o risco de uma análise impressionista, rasteira, que se deixe levar pelas primeiras impressões advindas do cotidiano, entendido, como nos ensina Heller (1989), pautado pelo senso comum, pelo espontaneísmo, pela não reflexão. Segundo Heller, este cotidiano é alienado, marcado pela repetição, pela mesmice. No entanto, contraditoriamente, existe a possibilidade de momentos de suspensão, momentos em que "sadias rebeliões" podem acontecer, momentos em que as contradições abrem espaço para o novo, para a revolução. Temos aí a possibilidade de práticas não cotidianas, ou seja, críticas, fundamentadas, reflexivas, e é preciso nelas investir todos nossos esforços.

Posto isto, destacamos a atividade docente como um dos espaços geradores da não cotidianidade, e, em contrapartida, da transmissão e produção do saber.

Ver e compreender o trabalho do professor como possibilidade de transformação do próprio docente e do aluno é compreender seu caráter contraditório. É apostar na possibilidade de que, mesmo sob determinadas condições objetivas e subjetivas, muitas vezes bastante adversas, mudanças podem ocorrer.

Mas como potencializar o professor, entendido como elemento fundamental nesse processo, para ser sujeito dessas tarefas? Como contribuir para que ele construa a crítica necessária às concepções mercantilizadas e burocratizadas do conhecimento, e se prepare para problematizar a gestão coletiva da vida escolar? 
Há aí uma questão a enfrentar, ou seja, a dificuldade de se realizar um trabalho de formação de professores que realmente acarrete mudanças na sua forma de agir/pensar e sentir, mudanças essas que, a nosso ver, só serão possíveis num contexto de ressignificação da totalidade institucional e política de apropriação de suas contradições e possibilidades de superação.

A literatura mostra uma infinidade de experiências de cursos, reciclagens etc. que, todavia, poucas transformações efetivas têm acarretado nas práticas docentes. O que ocorre? O que leva ou não à transformação?

A profissão docente, a partir da ótica de sua formação e do trabalho realizado, tem sido alvo de muitos estudos (OLIVEIRA, 2004; SANTO, 2004; TALAVERA; 2004; GATTI 2003), tanto no país como fora dele. De fato, as mudanças observadas no cenário mundial, que aconteceram de forma mais aguçada nas últimas duas décadas, colocaram novas questões quanto aos objetivos da escolarização, exigindo mudanças nas formas de organização do trabalho na escola. As novas demandas requerem uma intensificação do trabalho do professor e a ampliação de seu raio de ação, o que, na ausência de uma política clara de formação de docentes, tem gerado desgaste e insatisfação por parte do professorado. Alcançar tais metas implica uma reconfiguração de sua identidade profissional, capaz de colocá-lo em posição de lutar por melhoria de salários, de condições de trabalho e, inclusive, de uma formação de qualidade.

Desse modo, quando falamos em mudança e transformação é importante ficar claro que são múltiplos os aspectos determinantes, incluindo não só a história de vida e profissional do professor, como a realidade institucional escolar e social. Assim, as mudanças estão sendo pensadas como sendo gestadas num determinado espaço institucional, social, histórico, por sujeitos concretos.

Diante disso, apontamos como um objetivo muito próprio da psicologia, em especial da psicologia sócio-histórica, a busca de uma produção teórica que, ao compreender esse professor, sua subjetividade, gere práticas consequentes e coerentes com os pressupostos apontados. 
Referimo-nos a práticas que permitam a realização de um trabalho de intervenção junto a professores que possibilite a reflexão, a ressignificação e, assim, a produção de novos sentidos sobre a "vivência de ser professor".

Cabe aqui fazer um parêntese para explicar o nosso entendimento sobre a categoria sentido e seu par dialético, significado, dado que são as categorias básicas utilizadas para iluminarmos o movimento de constituição do sujeito.

A explicação torna-se fundamental, pois acreditamos que o movimento de transformação do sujeito, no caso o professor, ocorre nas relações com o social e a história, mas, sem dúvida, a partir da sua subjetividade historicamente constituída e assim, do conjunto dos sentidos por ele produzido.

Iniciamos pela categoria significado. Segundo Vigotski (2001), o significado, no campo semântico, corresponde às relações que a palavra pode encerrar; já no campo psicológico, é uma generalização, um conceito. Para este autor a atividade humana é sempre significada: o homem, no agir humano, realiza uma atividade externa e uma interna, e ambas as situações (divisão esta somente para fins didáticos) operam com os significados.

Os significados são, portanto, produções históricas e sociais. São eles que permitem a comunicação, a socialização de nossas experiências. Apesar de serem mais estáveis, “dicionarizados”, eles também se transformam no movimento histórico, momento em que sua natureza interior se modifica, alterando, consequentemente, a relação que mantêm com o pensamento, entendido como um processo.

Os significados referem-se, assim, aos conteúdos instituídos, mais fixos, compartilhados, que são apropriados pelos sujeitos, configurados a partir de suas próprias subjetividades.

Sabe-se, no entanto, que contêm mais do que aparentam e que, por meio de um trabalho de análise e interpretação, pode-se caminhar para as zonas mais instáveis, fluídas e profundas, ou seja, para as zonas de sentido. 
Afirma-se, assim, que o sentido é muito mais amplo que o significado, pois o primeiro constitui a articulação dos eventos psicológicos que o sujeito produz frente a uma realidade. Como coloca Gonzalez Rey (2003), o sentido subverte o significado, pois não se submete a uma lógica racional externa. A categoria sentido destaca a singularidade historicamente construída. Como coloca Namura:

A análise da relação do sentido com a palavra mostrou que o sentido de uma palavra nunca é completo, é determinado no fim das contas, por toda a riqueza dos momentos existentes na consciência. (...) o sentido da palavra é inesgotável porque é contextualizado em relação à obra do autor, mas também na compreensão do mundo e no conjunto da estrutura interior do indivíduo (2003:185).

O sentido coloca-se em um plano que se aproxima mais da subjetividade, que com mais precisão expressa o sujeito, a unidade de todos os processos cognitivos, afetivos e biológicos. No entanto, dada a sua complexidade, afirmamos como uma possibilidade, nos aproximarmos de algumas zonas de sentido.

Fica evidenciada, desse modo, a complexidade de tal categoria, fato que sem dúvida gera grande dificuldade nas formas de apreendê-la. É este, no entanto, o caminho que nos propomos a seguir: apreender o processo constitutivo dos sentidos, no caso, dos professores, bem como os elementos que engendram este processo. Queremos nos apropriar daquilo que diz respeito ao sujeito professor, para que, de posse deste conhecimento, possamos organizar intervenções mais profícuas, calcadas no sujeito concreto.

Vale destacar ainda a relevância da categoria subjetividade que, ao ser compreendida como a dimensão que articula e organiza a constituição dos sentidos e significados, nos permite, como afirma Martinez, "romper com a representação da psique como um conjunto de entidades estáticas, individuais e universais" (2005: 38). Tem-se claro, no entanto, que, se por um lado, subjetividade se refere a dimensão individual, ela se constitui na dialética com a objetividade, tendo a historicidade como um componente essencial. Segundo Bock e Gonçalves, 
a dimensão subjetiva é uma configuração dos sujeitos a partir de suas experiências no mundo social; é a dimensão dos registros simbólicos e emocionais que o sujeito vai construindo no decorrer de suas vivências; é o mundo psicológico propriamente dito (2005: 123).

Isto posto, ao focarmos o trabalho do professor, com a meta de gerar maior e melhor apreensão, por parte dos mesmos, de suas determinações constitutivas, não podemos jamais esquecer que suas expressões revelam ao mesmo tempo o social, a ideologia, a realidade institucional, dialeticamente transformadas em singularidade, em subjetividade.

Tendo em vista as proposições apresentadas, de que a atividade docente pode ser geradora de mudanças nos processos educacionais, e que, portanto, conhecer o sujeito professor, sua atividade, e sua dinâmica subjetiva é fundamental, retomamos algumas questões já apontadas. Como se dão tais mudanças? Que olhar deve ser lançado à atividade docente para que possamos apreendê-la na sua complexidade? Como produzir uma prática de formação docente que promova a vivência das contradições, sua apreensão e superação?

Sem ter a pretensão de responder a todas as questões, destacamos que num trabalho de formação de professores deve-se ter como meta o esforço de romper o cotidiano, de desmistificar velhas concepções, aprofundar compreensões rasteiras, ultrapassar a aparência. Para isso, torna-se fundamental a reflexão sobre o cotidiano, de modo a se escapar das armadilhas do pensamento do senso comum, dos preconceitos, das leituras naturalizantes da realidade social.

No esforço de penetrar no cotidiano, de desvendar suas contradições, suas determinações, é fundamental que o professor tenha clareza de que a luta pela competência, ou, pela superação das contradições vividas neste espaço, não se dá somente no plano individual, pela busca de técnicas milagrosas. Mas é fundamental compreender que a ação competente da escola é seu trabalho coletivo. 
Sabemos que essa é uma tarefa árdua. Como estabelecer um processo de interrogação explícita e ilimitada no espaço cotidiano de trabalho docente? Como produzir novos sentidos? Como sair do lamento e partir para construção de um projeto que tenha como norte a gestão coletiva do sentido escolar?

Neste momento vemos a necessidade de discutir o conceito de ressignificação. Seria simplista afirmar que, para se produzir novos sentidos, bastaria que os professores se apropriassem de suas determinações. Temos de considerar a dialética objetividade/subjetividade. Como aponta Aguiar, "nesse processo de objetivação/ subjetivação que é único, social e histórico a realidade social encontra múltiplas formas de ser configurada, com a possibilidade de que tal configuração ocorra sem desconstruir velhas concepções e emoções calcadas em preconceitos, visões ideologizadas, fragmentadas etc.” (2000, p. 180). Sabemos que muitas vezes, no seu cotidiano, o professor não se apropria de suas experiências, não valoriza os desafios, os questionamentos colocados tanto pelos alunos, como pela própria realidade. Parece estar imune ao novo que a realidade sempre trás. Aí se coloca nosso desafio.

Como uma contribuição para se analisar e apreender a atividade docente nas suas contradições e possibilidades, trazemos algumas reflexões produzidas por Yves Clot (2006) no que se refere à discussão sobre o " Real a Atividade” e a " Atividade Real”.

A partir das contribuições do autor, depreendemos que a atividade docente, como qualquer outra atividade, se encontra em desenvolvimento. No entanto, essa atividade, tecida por conflitos estabelecidos entre vários de seus aspectos, que podem, por vezes, se mostrarem contraditórios e/ou equivocados, pode ser 'impedida', ocasionando dano àqueles que a exercem. Dessa forma, a tentativa não é a de simplesmente descrever a atividade, mas de analisar a atividade docente como um processo de desenvolvimento, sobre o qual não se sabe, de antemão, que direção irá seguir e que não pode ser reduzido às ações observadas. 
Assim, esse autor afirma que o "real da atividade”, diferentemente da "atividade real” (aquela que se resume ao observável), envolve tanto o que foi realmente feito como tudo aquilo que poderia ter sido feito, que se procurou fazer sem o conseguir, que se queria ter podido fazer, que ainda se pretende fazer em outra ocasião. Envolve ainda, e especialmente, tudo o que se faz para não se fazer o que deve ser feito. Fazer ou realizar é, portanto, frequentemente, desfazer e refazer. Nesse caso, Clot 2006 considera que a atividade pode ser entendida como uma difícil escolha subjetiva, na medida em que cada pessoa avalia a si mesma e aos outros ao avaliar o real, buscando uma oportunidade de fazer o que deve ser feito. Considerando que as atividades não realizadas que não foram ou não puderam ser concretizadas (ou seja, as que fracassaram, portanto) — têm, inegavelmente, um impacto na atividade realizada, o autor propõe que elas sejam também incluídas na análise da atividade.

Em síntese, se a atividade realizada é apenas uma parte muito pequena do real da atividade, parece ser fecunda a proposta de, no intuito de irmos para além da aparência, de buscarmos as contradições, de efetivamente buscarmos os sentidos do professor, efetuarmos este esforço analítico, construtivo e interpretativo da atividade do professor.

Vemos nesta perspectiva a possibilidade de gerar um conhecimento que, compartilhado com os professores, pode se constituir num fator potencializador de reflexões sobre si mesmos e sobre as práticas desenvolvidas, gestando possibilidades de transformação.

Para finalizar retomamos a ideia de que, como nos lembra Vigotski ao escrever "O Significado da Crise da Psicologia”, é fundamental a existência de um método para apreendermos o real, na sua complexidade, nas suas contradições. Desse modo, reiteramos a importância da perspectiva teórica e metodológica adotada para a leitura dos processos educacionais apresentados, acreditando que a mesma nos permite uma análise que escapa das armadilhas, das dicotomias, das visões reducionistas, das naturalizações. 
Em última instância podemos afirmar que buscamos uma compreensão que permita redirecionar as atividades propostas em educação, de modo a apreender a totalidade dos fenômenos, suas contradições, sem perder de vista o sujeito real, concreto, propiciando assim uma prática educacional mais transformadora, ética e inclusiva.

Referências bibliográficas

AGUIAR, W.M.J. Professor e Educação: Realidades em Movimento, In: TANAMACHI, E.; PROENÇA, M.; ROCHA, M (Org.) Psicologia da Educação - desafios teórico-práticos. São Paulo: Ed. Casa do Psicólogo, 2000.

\& OZELLA S. Núcleos de significação como instrumento para a apreensão da constituição dos sentidos. Psicologia: Ciência $e$ Profissão. São Paulo, v.26, n.2,2006.

BOCK, A.M.B.; GONÇALVES, M.G.M. Subjetividade: o sujeito e a dimensão subjetiva dos fatos. In: GONZÁLEZ-REY, F (Org.) Subjetividade, complexidade e pesquisa em psicologia. São Paulo: Ed. Thomson, 2005.

CLOT, Y. A Função psicológica do trabalho. Rio de Janeiro: Ed. Vozes, 2006.

FREIRE, Paulo. Pedagogia do Oprimido, 17. ed. Rio de Janeiro: Ed. Paz e Terra, 2006.

GONZÁLEZ-REY, Fernando. Sujeito e subjetividade - uma aproximação histórico-cultural. São Paulo: Ed. Thomson, 2003.

HELLER A. O Cotidiano e a História. Rio de Janeiro: Ed. Paz e Terra, 1989.

NAMURA, Regina M. O Sentido do Sentido em Vigotski: uma aproximação com a estética e a ontologia do ser social. São Paulo: Tese de Doutorado (Psicologia Social). Pontifícia Universidade Católica de São Paulo, 2003. 
OLIVEIRA, B. A dialética do singular-particular-universal. In: ABRAPSO. Anais do V Encontro de Psicologia Social e Comunitária. Bauru, Agosto 2001.

SEVERINO, Antonio Joaquim. Educação, Sujeito e História. São Paulo, Ed. Olho d’água. 2002.

VIGOTSKI, L.S. A Formação Social da Mente. São Paulo: Ed. Martins Fontes, 2000.

. Teoria e Método em Psicologia. São Paulo: Ed. Martins Fontes, 1996.

. A Construção do Pensamento e da Linguagem. São Paulo: Ed. Martins Fontes, 2001.

. Tool and sign in the development of the child. [1930] In: The collected works of L.S. Vigotski. New York: Kluwer Academic /Plenum Press, 1999:1.

. Manuscritos de 29. In: CEDES, Educação e Sociedade - Revista Quadrimestral de Ciência da Educação, n.71, 2000. 


\title{
CAPÍTULO 5
}

\section{INTERFACES ENTRE EDUCAÇÃO NÃO FORMAL E JUVENTUDE ${ }^{1}$}

\author{
Cleci Maraschin \\ Universidade Federal do Rio Grande do Sul
}

\section{Introdução}

s circunstâncias de vida dos jovens brasileiros, principalmente aqueles
que vivem em comunidades com insuficientes condições materiais
apresentam uma série desafios às políticas públicas e às instituições sociais. Tomando como exemplo o contexto educacional, existe uma diminuição progressiva da escolarização formal do brasileiro à medida que esse passa da infância para a adolescência. Segundo dados do IBGE (1997), a taxa de escolarização (proporção de pessoas frequentando a escola em relação ao total da população da mesma faixa etária) das crianças e adolescentes no Brasil atinge o pico de $93 \%$ dos 7 aos 14 anos de idade, caindo em seguida para $73,3 \%$ de 15 a 17 anos de idade. Na região sul, a diferença é ainda maior: dos 7 ao 14 anos temos 94,9\% de taxa de escolarização, enquanto que dos 15 aos 17 anos a taxa cai para 70,4\%.

A partir desses dados, cabe problematizar a relação das instituições e dos jovens, suas propostas para essa faixa etária. Sabemos que as contingências socioeconômicas de vida de muitos jovens os levam a buscar

\footnotetext{
${ }^{1}$ Trabalho resultante de projeto de pesquisa-extensão intitulado "Vivenciando a cultura na Restinga”, apoiado pelo CNPq, com bolsa de Iniciação Científica e pelo MEC/SESU. Uma versão ampliada do mesmo foi publicada sob o título: Saberes e práticas de oficineiros análise de uma cognição situada em coautoria com Carolina Seibel Chassot (Graduanda em Psicologia na Universidade Federal do Rio Grande do Sul. Ex-bolsista de Iniciação Científica) e Deisimer Gorczevski (Doutora em Ciências da Comunicação pela Unisinos. Bolsista do CNPq. Educadora e Pesquisadora Social) na Revista Psico n 3, v. 3, p. 287 a 296, set. a dez. 2006.
} 
colocação no mercado de trabalho provocando um afastamento da escola. Entretanto, ao conversarmos com os oficineiros que participaram deste estudo, eles relataram uma espécie de enfraquecimento do laço do jovem com a instituição de ensino, que decorre também de propostas educativas que não fazem conexão com seus modos de viver.

Muitas propostas decorrentes de políticas públicas e de movimentos sociais voltados à juventude acabam tendo um caráter emergencial, procurando diminuir o "risco" ou a "vulnerabilidade" deste jovem, paradoxalmente ampliando sua estigmatização, ao fixá-lo em tal posição de risco ou vulnerabilidade (HUNING, 2003). Os jovens são vistos como sujeitos em constante "perigo" social para os quais é necessário tomar uma série de medidas socioeducativas. Os altos índices de morte por agente externo nessa faixa da população também contribuem para esta visão do jovem como sendo potencialmente vítima ou criminoso

O terceiro setor, assim como o governo, participa destas práticas protetivas buscando prevenir ou remediar situações de "risco". Isso muitas vezes é feito de forma assistencialista, com o trabalho de voluntários que chegam de outra realidade social e tentam "resolver" a vida destes jovens.

Para todas essas intervenções, sejam elas em âmbito escolar, governamental, jurídico, comunitário ou através de práticas do terceiro setor, pensamos que a análise dos saberes e práticas de oficineiros engajados na realização de oficinas para jovens em sua própria comunidade, pode ser importante para auxiliar na produção de novas formas de trabalho com a condição juvenil contemporânea. Este estudo apresenta-se com esta proposta, que visa contribuir na produção de conhecimento sobre a educação dos jovens em sentido ampliado, pensando principalmente nas práticas educativas informais e, mais especificamente, nas práticas oriundas das próprias comunidades em que vivem os jovens e que têm na apropriação de expressões artísticas e tecnológicas seu conteúdo principal.

Temos como objetivo principal identificar os saberes e as práticas pedagógicas e as concepções educativas postas em ação por educadores 
sociais, membros de um bairro periférico da cidade de Porto Alegre no desenvolvimento de oficinas com jovens de sua comunidade. Circunscrevemos este estudo dentro de uma perspectiva de uma cognição situada (VARELA, 2003) em uma rede heterogênea configurada por instituições, ferramentas e saberes. "Nessa perspectiva o ato de comunicar não se limita a uma transferência de informação de um remetente a um destinatário, mas pela modelagem mútua de um mundo comum por meio de uma ação conjugada” (p. 91). O oficinar e os oficineiros surgem a partir de uma rede contínua de gestos conversacionais, como uma teia sob a qual se desenham as possibilidades de relação e de identificação. A ideia principal é que a atividade cognitiva está ligada à história de vivências e é construtiva, pois os caminhos vão aparecendo conforme se caminha.

Interessa nesse estudo acompanhar a atividade cognitiva em ação no transcorrer da preparação, desenvolvimento e avaliação das oficinas, na forma como os oficineiros colocam questões pertinentes no transcurso da sua experiência que não são pré-definidas mas "en-agidas" (que emergem) de modo contextual. Existe assim uma ênfase na ação, construção sobre a representação. A cognição é tomada como uma ação produtiva que emerge em uma rede de elementos interconectados, capaz de sofrer alterações estruturais ao longo de uma história de convivência em um mundo partilhado.

\section{O campo empírico}

Este estudo toma como campo empírico o projeto de pesquisaextensão denominado "Vivenciando a Cultura na Restinga"" concebido com a proposta de constituir um trabalho coletivo entre oficineiros da comunidade e acadêmicos da universidade. Entre os objetivos do projeto de extensão estava a proposta de potencializar o trabalho dos educadores sociais (os oficineiros), além de produzir conhecimento na área a partir de uma experiência concreta de intervenção. Os objetivos dos oficineiros eram

2 O projeto foi contemplado pelo Edital MEC/SESU com o nome de "Juventude e Vulnerabilidade Social —Oficinando com Adolescentes”. A alteração do nome ocorreu quando o projeto passou a ser implementado em conjunto com os oficineiros do Bairro Restinga. 
também variados: busca de uma capacitação técnica; integração com outros oficineiros da comunidade e o contato com a universidade.

A equipe de trabalho foi composta por onze acadêmicos (graduandos, mestrandos, doutorandos e professores) de cursos de Psicologia, Sociologia, Comunicação e Educação, em torno de 20 pessoas, com ativa participação na comunidade através de associações, rádio e jornal comunitários, gestão comunitária do Estúdio Multimeios, grupos relacionados a discussão da violência e direitos humanos, que já trabalhavam com público juvenil.

Nos primeiros encontros foi possível perceber tensões entre os participantes da universidade e da comunidade. Os oficineiros criticavam a postura de alguns universitários, baseados em experiências anteriores nas quais a "universidade vem e não volta nunca mais", conforme a fala de um oficineiro na terceira reunião do coletivo. Essa fala reflete ações universitárias que demonstram falta de continuidade e de compromisso assumidos com a comunidade. Uma das primeiras ações de integração foi organizar uma visita à UFRGS, na qual os oficineiros puderam conhecer diferentes espaços da universidade, além de realizar contatos que deram origem a outros projetos e parcerias.

Outra dificuldade encontrada nessa fase inicial foi a expectativa, enunciada por muitos dos oficineiros, de que o projeto seria um treinamento em técnicas específicas de intervenção com os jovens. A proposta de encontrarem um curso pronto era diferente da ideia de um projeto construído coletivamente. Essa diferença gerou conflitos, mas foi enriquecedora na medida em que possibilitou a discussão dos objetivos de cada um dos grupos. Um resultado dessa possibilidade de autoria coletiva foi a alteração, por parte dos oficineiros, do próprio nome do projeto que inicialmente havia sido proposto como: "Juventude e Vulnerabilidade Social - Oficinando com Adolescentes", sendo renomeado para "Vivenciando a cultura na Restinga" (conforme nota de rodapé número 2). Podemos pensar que essa mudança também revela um modo de entender dos acadêmicos, muito próximo da ideia de uma juventude vulnerável. 
Um fator que foi apontado repetidamente pelos oficineiros como sendo uma dificuldade da sua prática era a falta de integração entre as oficinas na comunidade, que acabavam sendo pontuais e não conseguiam atingir um objetivo maior de produzir mudanças na vida dos jovens. Com isso em mente, o grupo trabalhou em conjunto e apresentou propostas de "oficinas interdisciplinares", nas quais oficineiros com diferentes práticas (dança, pintura, grafite, teatro etc.) trabalhariam de forma integrada com o propósito de construir espaços de reflexão sobre a vida do jovem da Restinga. O grupo definiu uma proposta de cinco oficinas-piloto (sendo uma na universidade e quatro na comunidade), para que os oficineiros se experimentassem nesse lugar de trabalho coletivo e pudessem planejar e avaliar suas atividades. Em cada oficina eram feitos registros (texto, fotografia, vídeo), que seriam utilizados como forma de avaliação e preparação para a oficina posterior.

O contexto dessa experiência envolveu, portanto, uma atividade educativa informal, proposta por membros da própria comunidade na qual vivem os jovens, e com propostas de ensino voltadas para a realidade local. Por esse motivo, nos pareceu fornecer uma circunstância rica para refletir sobre a oficina como uma intervenção que opera propostas socioeducativas capazes de distanciar-se da ideia do jovem como um sujeito em constante perigo social e por isso passível de medidas profiláticas.

Embora o contexto escolhido para essa análise não consista em uma observação "naturalística" dos fazeres dos oficineiros, uma vez que se trata de uma pesquisa-intervenção, pensamos que este permanece sendo um campo importante de análise. Primeiro porque, toda a observação já pode ser considerada uma intervenção (MARASCHIN, 2004) e, segundo, porque o conversar do coletivo pode produzir reflexões sobre a ação reconfigurando-as. Tomamos como foco de análise o ponto de vista dos oficineiros a partir de suas trajetórias no projeto como um modo de pensar a cognição posta em ação, vivida. 


\section{Organizando objetivos e perspectiva de análise}

Para Varela (2003) existem competências que se traduzem em uma "disposição" ou em um "conhecimento prático" baseados na experiência e que não podem ser traduzidos diretamente por proposições lógicas ou entendidos como uma representação. Não podemos tratar o conhecimento situado como uma "falha" "que pode ser eliminada progressivamente mediante o descobrimento de regras mais elaboradas" mas sim como " $a$ essência mesma da cognição criativa” (p. 176). Essa ideia nos possibilita tomar o saber-fazer dos oficineiros cognição enatuada, atribuindo-lhe um reconhecimento muitas vezes desconsiderado pelas teorias cognitivas que têm na formalização dos modelos seu foco principal.

O mesmo autor explica que o conhecimento é resultante de uma interpretação que emerge da capacidade de compreensão. A ação de interpretar pode ser entendida como "enatuar" ou "fazer emergir" o sentido a partir de uma rede de relações das quais participam o corpo, a linguagem, a história social, enfim, o que sintetiza como corporeidade. Se o interpretar está necessariamente arraigado à nossa corporeidade biológica, ele é vivido e experimentado dentro de um domínio de ação consensual e de história cultural.

Nosso objetivo é mapear como se produzem as interpretações em diferentes momentos de intervenção e de conversação entre oficineiros no contexto da experiência.

Relatos de campo foram registrados de várias formas: uma lista de mensagens eletrônicas foi mantida pelos participantes da equipe durante todo o transcorrer da experiência, registros escritos, filmagens e fotografias foram feitos pelos vários integrantes da equipe. Desses registros optamos por analisar os percursos de dois oficineiros. O motivo da escolha da análise das trajetórias em uma experiência como método de pesquisa foi o entendimento de que havia, nestes percursos, diferentes modos de interpretar. Além do que, esse modo de análise possibilita acompanhar os saberes e as práticas em seu próprio acontecer, o que certamente, está em congruência com o conceito de enação. 
Os critérios para a escolha dos oficineiros foram baseados em sua participação intensa em todas as etapas do projeto e em questões que, inicialmente possibilitavam pontos de convergência (como a experiência com a tecnologia do vídeo) e divergência (a relação com a condição de oficineiro, o envolvimento com movimentos sociais, a experiência com adolescentes).

$\mathrm{Na}$ análise dos registros, percebemos que as questões colocadas pelos dois oficineiros tinham pertinência com:

1. o próprio fazer, que aparece em forma de autonarrativa;

2. o espaço-intervenção que se produz ao oficinar;

3. a rede de instituições na qual a oficina se produz (escola, universidade, projeto e comunidade).

Essas questões guiaram a análise das trajetórias. Tomamos nessa análise a ideia de um processo enativo de subjetivação, ou seja, de que ser oficineiro resulta de um modo de viver como tal: falar-se, identificar-se, agir como se acredita que fala, que age um oficineiro em uma dinâmica conversacional —a oficina — que opera como uma rede de elementos interconectados capaz de sofrer alterações estruturais ao longo de uma história coletiva com uma certa permanência.

Nosso percurso será então mapear os diversos modos que nossos dois protagonistas “enatuam”, ou seja, os modos pelos quais sua ação produtiva, propositiva, faz emergir um mundo, mantendo vivo um modo de interação que denominam de oficina. Assim denominaremos os sujeitos da pesquisa, tomados aqui em análise, de "protagonistas”.

1. Como se faz oficineiro? - autonarrativas

O modo como nossos dois protagonistas (Vítor e Augusto) se apresentam ao grupo evidencia diferenças no sentido que atribuem ao fazer do oficineiro. Essa narrativa de si faz transparecer um modo de problematizar a própria experiência de oficineiro. 
Vítor, ao se apresentar, diz que trabalha nos correios e nas horas vagas com vídeo, se definindo como autodidata nesta área. Informa que colaborou na edição de um jornal numa escola da comunidade. Diz que não é oficineiro, mas se sente um. Tem experiências com jovens e vontade de ensinar. Está no projeto para se capacitar como oficineiro ${ }^{3}$.

Augusto trabalhou como ator e oficineiro de teatro, fotografia, rádio (já foi radialista da rádio comunitária). Também já trabalhou com massagem e atualmente trabalha com vídeo. Quer trabalhar com arte $e$ comunicação, promover mudança social, conhecer as pessoas, promover o desenvolvimento e o autoconhecimento.

A descrição inicial das trajetórias pode já trazer evidências de distintas posições e sentidos acerca do que é ser oficineiro a partir do modo como vivem essas experiências. Enquanto Vítor comenta que trabalha com algumas mídias, em específico vídeo e jornal, atuando junto ao público jovem nas horas livres, Augusto assume a atividade de oficineiro como sua ocupação principal. Estas diferenças demonstram que os sujeitos falam de um modo de viver como oficineiros e não somente como representam uma ideia ou uma noção de ser oficineiro.

As falas autorreferentes anteriores também estão articuladas a uma rede de conversações que remetem ao reconhecimento dessas atribuições pela própria comunidade, evidenciando que os processos de autoria de constituir-se a si mesmo se sustentam não somente com uma autorreferência, mas em uma referência a outras instituições.

Assim, para Vítor existe uma diferença entre "sentir-se" um oficineiro e ser reconhecido como tal. Diz que se sente oficineiro pelo desejo de ensinar aquilo que sabe. Mas o reconhecimento está em outra instância como a de uma capacitação. Para ser um oficineiro, é tão importante sentir-se como tal (ter o desejo de) como ser reconhecido

\footnotetext{
3 Todos os relatos de campo apresentados neste trabalho foram registros escritos tomados entre novembro de 2003 e julho de 2004 por diferentes integrantes do projeto. Estes registros estarão indicados em itálico.
} 
institucionalmente como tal. Já para Augusto, a sua própria experiência já se constitui fonte de reconhecimento. Mas, em sua concepção, não é qualquer experiência com oficina que constitui um sujeito como oficineiro. Uma distinção fundamental é a participação em movimentos sociais. Augusto diz: "temos muitos ativistas políticos na comunidade. $O$ oficineiro é ligado aos movimentos sociais, engajado no social". A militância e a dedicação que são definidoras de um oficineiro para Augusto contrastam com o altruísmo e a certificação para Vítor.

2. Oficinando

Assim como "ser oficineiro" é um modo de individuação, a oficina é um espaço-invenção que se produz no próprio exercício do oficinar. As questões e problemas que apontam nossos protagonistas permitem acompanhar sua processualidade.

Vítor diz que a oficina tem que contemplar o real (gesticula como quem manipula argila) para lidar tem que tocar as coisas. As ideias necessitam ser concretizadas através de ações ou operações práticas, essa característica é que distingue uma oficina de outra prática educativa.

Augusto faz outras distinções: a oficina é mais maleável que ensino formal: "educa o sentimento, tem linguagem mais acessível, abarca mais saberes, improvisa, aceita emoção. Tem apresentação, aquecimento, relaxamento e volta (reflexão)".

Na fala de Augusto, a oficina se produz em contraponto à educação formal. A comparação com os modos escolares de intervenção retorna em vários momentos, tanto na preparação e avaliação quanto na execução da própria oficina, produzindo assim uma marca identificatória pela busca de uma alteridade.

As falas revelam ênfases no que se distingue como oficina. Uma condição necessária é a atividade e, parece, uma atividade manual e material, não somente intelectual. A atividade e o conteúdo necessitam ter ligação. A técnica deve ser usada a favor do tema, e não só como técnica 
pela técnica. Não se trata, tampouco, de um empreendimento meramente cognitivo. A oficina contém uma estrutura: "faltou unidade, objetivo e fechamento" (Fala de Augusto, ao analisar elementos faltantes em uma experiência de oficina de outra colega).

Apesar das diferenças, ambos oficineiros afirmam a oficina muito mais como um modo de operar do que seus elementos constituintes. Uma forma de ação produtiva, enativa.

O lugar do objeto técnico também foi objeto de debate. O vídeo, meio de registro ou conteúdo de uma aprendizagem? Essa problematização é interessante, pois revela que existe uma tensão entre as relações de meios e fins, onde alguns objetos podem ocupar simultaneamente diferentes funções.

Para Vítor a proposta é que a aprendizagem do uso do vídeo ocorresse durante todo o tempo, priorizando o vídeo como conteúdo da aprendizagem, o que gerou um questionamento de Augusto: "nós não vamos avaliar o uso do vídeo, vamos avaliar a oficina através do vídeo”.

Para Augusto o foco não deveria ser a câmera, deveria ser outro tema e o vídeo ser usado a favor desse tema. $\mathrm{O}$ vídeo deve estar a serviço da oficina e não o contrário. O fim da oficina não é produzir expert em vídeo, mas o vídeo é um instrumento para se apropriar do tema.

A posição de Vítor, embora criticada por Augusto tanto pelo voluntarismo quanto pelo tecnicismo, foi que possibilitou o acesso dos jovens à câmera de vídeo. Vítor teve a iniciativa de apresentar a câmera ao grupo e em seguida devolvê-la ao grupo em questão, permitindo que este se experimentasse na posição de estar atrás das câmeras. O que pode revelar que um ativismo sem experimentação, domínio técnico, também torna-se inócuo.

A tensão do lugar da tecnologia durante as oficinas possibilitou a ampliação da experimentação de suas funções e usos. O vídeo pôde ser tomado como (1) um objeto de aprendizagem: como produzir vídeos, como filmar; (2) um outro ponto de vista de observação, uma vez que o que era filmado era exibido em uma TV presente na oficina, possibilitando aos 
participantes combinar sua perspectiva de observação com a perspectiva de quem que filmava e (3) um documento de registro da experiência capaz de atualizar o ponto de vista do operador da câmera distante do momento da oficina; (4) como um meio potencializador de reflexões sobre temas específicos. A ampliação dos usos não era algo pré-determinado. Aqui encontramos como a enação faz emergir um gradiente de possibilidades ainda não antecipado pelo grupo. Ou seja, a polêmica produzida por nossos protagonistas entre meio e fim, possibilitou a experimentação do vídeo abrindo possibilidades inusitadas de uso, como o ponto 2 e 3 acima referidos.

As diferentes experiências com o vídeo na oficina constituíram coletivamente outros usos aos dois previamente formulados por nossos dois protagonistas. O vídeo tornou-se um instrumento interessante de avaliação provocando o debate, a argumentação e a contra-argumentação. Certamente Vítor não previa que ao disponibilizar o vídeo para os oficinandos sua própria ação poderia ser tomada como objeto de análise, de debate, uma vez que as filmagens eram objeto de análise para o preparo das oficinas subsequentes.

Outro fator que merece destaque, e que já vínhamos mencionando, é a função do registro no trabalho. Diferentemente da experiência da maioria dos oficineiros, que organizava e desenvolvia oficinas individuais, o projeto incentivou o trabalho coletivo. Esse elemento desafiador tornou possível conversar sobre diferentes funções de um oficineiro em uma oficina, tema que não era muito problematizado quando cada oficineiro conduzia sozinho sua oficina. Como a experiência proposta consistia na organização de oficinas com mais oficineiros e os demais também participariam houve a necessidade de uma diferenciação de funções.

Vítor propõe um "rodízio" entre os oficineiros tanto na composição das oficinas como para a confecção das observações e dos relatos. Segundo ele, esse rodízio traria coesão ao grupo e suas práticas.

A situação inusitada de contar com vários oficineiros trabalhando em conjunto possibilitou também que a oficina de vídeo pudesse funcionar ao 
mesmo tempo como oficina e como registro do trabalho, transversalizando as demais oficinas.

\section{Fazendo redes}

O fazer-se oficineiro e a prática da oficina se constituem em uma tensão entre o fora da oficina: público-alvo, comunidade e universidade. Esse "fora” insiste nas próprias questões levantadas pela equipe, levando a diferentes posições e negociações.

Os jovens são uma das principais razões de existir o trabalho dos oficineiros. São jovens considerados “vulneráveis” ou “em situação de risco”, e as oficinas são frequentemente vistas (pelas políticas públicas e pelos próprios oficineiros) como formas de oferecer alternativas a este jovem, afastando-o das drogas, do crime, aumentando seu envolvimento com a comunidade, sua autoestima, estimulando a criatividade e a crítica social.

Nos momentos de preparação, onde a discussão do público emergiu, podemos detectar nuances de distintos pronunciamentos.

Augusto traz o seguinte questionamento: as oficinas é que vão se adaptar ao público ou o público é que vai se adaptar às oficinas?. Esta pergunta levanta uma questão importante para o delineamento da oficina. Quem são os jovens que serão convidados a participar das oficinas? De qual faixa etária? São jovens que frequentam a escola, ou não? E como chegar até esses últimos? Pelo Conselho Tutelar? Após o debate, a equipe decidiu contatar as escolas da comunidade, recomendando que as mesmas não privilegiassem nenhum "tipo” de aluno, formando um grupo heterogêneo. Apesar da solicitação, os jovens que participaram eram os que tinham relação mais próxima com os professores, os que normalmente se envolviam com as atividades extracurriculares.

Outra questão proposta por Vítor mostra uma falsa tensão. Vítor pergunta se os jovens que acorrem às oficinas de grafite o fazem porque querem aprender ou porque estariam já vivendo nesse contexto? A resposta dos oficineiros é interessante, pois apontam para Vítor que essa é uma falsa 
questão, pois não existe um desejo isolado de seu contexto de produção. $O$ grafiteiro Jackson explica que conhece um monte de gente diferente, até os normais que nem Vítor (explicou o normal: ter um emprego, ir na igreja, coisas assim...) dizendo que o caráter do grafitti não convida apenas um tipo de gent. O grafitti é uma forma de expressão, o sentimento do grafitti podendo ser compartilhado por qualquer um. Essa ideia é pois indica um laço entre o fazer e o pensar e não somente o desejo de aprender uma técnica. Cada técnica carrega consigo um mundo de sentidos, como já apontava Augusto em relação aos movimentos sociais.

Outro plano de tensão se configurou em torno da universidade. A relação do grupo de oficineiros com os universitários se mostrou, desde o início do trabalho, conflituosa. Primeiramente, por ser uma instituição de ensino formal em um contexto de questionamento deste tipo de ensino. Também pelo histórico de relação com a comunidade já eram conhecidas as pesquisas universitárias que iam ao bairro para coletar dados, sem nunca trazer projetos concretos que pudessem também devolver um pouco daquilo que se leva.

Augusto trouxe esta questão em alguns debates, relatando a desconfiança da comunidade em relação à universidade. A posição dos acadêmicos foi de produzir uma apropriação dos oficineiros na relação com a universidade, para que eles pudessem utilizar o espaço acadêmico público. Vítor e Augusto demonstraram interesse pelos laboratórios e equipamentos de vídeo da universidade, querendo conhecê-los (...). O grupo então organizou uma visita à universidade, onde foram feitos contatos que possibilitaram que a interação siga correndo em outros níveis ${ }^{4}$.

A relação com a comunidade é trazida de forma bastante diferente por Augusto e Vítor. O primeiro valoriza a militância comunitária e tem como objetivo promover mudança social, conhecer pessoas, promover o desenvolvimento, o autoconhecimento da comunidade. Vítor tem um

4 Em várias ocasiões os oficineiros foram convidados a participar de atividades na universidade. No evento Portas Abertas de 2004 desenvolveram uma oficina; no evento Convivências, em 2005, recepcionaram universitários na comunidade. Um dos oficineiros prestou vestibular e foi aprovado no curso de Filosofia da universidade. 
objetivo bastante diferente: diz que a comunidade não sabe o que é vídeo e que tem muita vontade de ensinar, transmitir o que sabe. Apesar dessa visão bastante instrutiva do ensino, ele traz desejo de emancipação: diz ter vontade de dar oportunidades a outras pessoas de acessar esse meio de controle, referindo-se ao vídeo e à televisão. Apesar de serem oficineiros da comunidade, ambos se colocam de modo distinto. Existe um nós e um eles. Nós, os oficineiros, participamos de domínios de saberes diferentes dos deles.

Havia no grupo de oficineiros uma grande tensão na relação com a escola: por um lado, é a grande instituição à qual eles se opõem, tentando apresentar novas práticas de ensino; por outro lado, as escolas do bairro são geralmente os lugares que eles possuem interlocução para fazer suas oficinas, e os jovens que participam das oficinas geralmente são encaminhados pelas escolas. Neste projeto não foi diferente.

\section{Saberes e práticas enatuadas}

A estratégia metodológica utilizada nessa análise: acompanhar as posições e o trabalho dos dois protagonistas no percurso do projeto revelou distintas maneiras de produzir questões, problemas e soluções. As questões emergentes em relação à própria condição de oficineiro, ao trabalho na oficina, aos recursos e materiais e às redes nas quais estão inseridos revelam a riqueza e os desafios desse tipo de trabalho. Ser oficineiro e trabalhar com oficinas são fazeres que se definem reciprocamente em uma contingência reticular que envolve os participantes, a comunidade, a escola.

Uma primeira reflexão refere a necessária conexão de práticas educativas não formais com a rede formal de educação e saúde. A riqueza da ação dos oficineiros pode ficar limitada ao voluntariado ou à militância, sem que suas ações impliquem movimentos e desafios aos projetos já instituídos de saúde e de educação. Percebe-se que existe uma interação com a escola, mas a mesma é ainda pouco potencializadora de mudança para todos os participantes. Educadores sociais e educadores com 
reconhecimento universitário podem ter muito a trocar, haja vista as importantes questões tratadas nesse pequeno recorte da experiência.

Outra reflexão importante referes-se à características postas em ação nas oficinas e que poderiam produzir possibilidades de construção coletiva ao transformar os tensionamentos em táticas na proposição de projetos educativos com jovens.

A heterogeneidade esteve presente em várias dimensões do projeto: heterogeneidade de participantes, de modalidades de interação, de objetos e temáticas da oficina e de posições de observador.

A condição heterogênea de composição do coletivo do projeto produziu tensões e gerou discussão, por isso possibilitou a construção de alternativas e o exercício de composições inusitadas, tal como a multiplicação da posição de observação e a ampliação do acoplamento tecnológico para além da dicotomia entre meios e fins.

O exercício da grupalidade é outro operador que merece destaque. A ênfase na realização de atividades em parceria produziu formas de gestão coletivas capazes de regular o desenvolvimento do projeto, dar conta dos imprevistos e resolver os problemas.

O encorajamento da criatividade e da autoexpressão foram efeitos de um modo de regular aquilo que era planejado e a possibilidade de um certo improviso. Tal composição trouxe flexibilidade para reconfigurações de percurso e incremento de soluções criativas. Uma das ações mais frequentes é a ideia da bricolagem, ou seja, um modo de organizar arranjos com os materiais, objetos, pessoas e condições que estão à disposição e não apenas lamentar que as condições ideais não estejam presentes.

A informalidade e a ludicidade da oficina contribuem para uma participação efetiva e curiosa, produzindo um certo encantamento, ou desejo de conhecer e experimentar.

Algumas outras características mereceriam aprofundamento de análise, tal como a precariedade e o não reconhecimento do trabalho do 
oficineiro. Talvez a primeira reflexão concernentes às redes de conexão entre educação formal e não formal possam dar pistas dessas dificuldades.

Referências bibliográficas

HUNING, S. Ordinário, Marche! A Constituição e o Governo de Crianças/Adolescentes pelo Risco-Diferença. Porto Alegre: Dissertação de Mestrado não publicada, Pontifícia Universidade Católica do Rio Grande do Sul, 2003.

IBGE - Instituto Brasileiro de Geografia e Estatística. Pesquisa nacional por amostra de domicílios. [CD-ROM]. Microdados: Rio de Janeiro, 1997.

MARASCHIN, C. Pesquisar e intervir. Psicologia \& sociedade v.16, n. 1, p. 98-107, 2004.

VARELA, F. Conhecer: as ciências cognitivas tendências e perspectivas. Lisboa: Instituto Jean Piaget, 1994.

, THOMPSON, E. \& ROSCH, E. A mente incorporada: ciências cognitivas e experiência humana. Porto Alegre: Artmed, 2003. 


\title{
ÉTICAS, VIOLÊNCIAS E DIREITOS HUMANOS
}

\author{
CAPÍTULO 6
}

TRANSCENDÊNCIA E VIOLÊNCIA

Jurandir Freire Costa

Universidade do Estado do Rio de Janeiro

Transcendência ética e violência ligam-se por laços de dependência e

1 oposição que, até hoje, vêm sendo investigados pelos estudiosos do tema. A primeira é tida como a única força capaz de fazer face à violência, enquanto a última é o que pode enfraquecer, desagregar ou eliminar a primeira.

Pode-se perguntar, então, por que apenas a transcendência pode se opor à violência tornando-se um pré-requisito da vida ética? Esta é a questão que penso em discutir neste trabalho. De início, tentarei precisar a noção de transcendência, e, no final do trabalho, a de violência. Espero que, o desenvolvimento do argumento, esclareça os motivos dessa ordem expositiva.

\section{Sobre a transcendência}

A palavra transcendência possui uma grande extensão semântica. Na acepção ética, contudo, podemos defini-la como o estado ou a condição de um princípio, entidade ou realidade postulados como fundamento das aspirações morais do sujeito. O transcendente ético, portanto, é o Outro cujas exigências condicionam nossa existência como pessoas responsáveis por decisões e ações orientadas pela distinção entre o Bem e o Mal.

Na visão de mundo pré-moderna, a realidade transcendente foi prática e teoricamente assimilada à ideia de Deus. Na Idade Média, Deus era o criador perfeito, eterno, necessário e onipotente, enquanto o sujeito era a criatura imperfeita, mortal contingente e finita. O transcendente 
causava o sujeito naquilo que ele era e deveria ser, e este último era convocado a se autogovernar no intuito de aproximar sua inerente imperfeição da plenitude ontológica do Outro divino.

A Modernidade político-filosófica revogou a maior parte destas crenças, dissociando a ideia de transcendência da ideia de Deus. No pensamento secular, o transcendente tornou-se um simples artefato cultural feito da matéria humana e com finalidades humanas. O sujeito, dizia-se, mediante o pleno uso da Razão, conheceria seus melhores interesses, e, ipso facto, seus mais nobres objetivos. A heteronomia ética chegara ao fim. A emancipação em relação ao Outro sobrenatural transformou o indivíduo das revoluções democrático-burguesas em ator e autor de suas aspirações ao Bem ou à felicidade.

Contudo, foi justamente neste momento teórico-histórico que a violência emergiu como um objeto de inquietações morais e intelectuais. $\mathrm{O}$ pivô da questão foi o debate sobre a legitimação racional da força da Lei. Isto é, se o Transcendente ético foi, sobretudo, imaginado como a Lei válida para todos, qual deveria ser a natureza da força que tornaria eficaz sua aplicação? A força da Razão ou a força bruta da violência? E se por acaso fosse a última, quais argumentos poderiam fundamentar racionalmente tal escolha?

\section{O repúdio secular à violência divina}

Desdobro o raciocínio. Uma das críticas recorrentes à religião feita pelo pensamento leigo concerniu à violência intrusiva da Lei divina nos negócios humanos. A intrusão foi denunciada em duas esferas da vida cultural: a político-social e a antropológica. No caso da primeira, afirmavase que a ordem sociopolítica do catolicismo medieval havia fracassado em seus objetivos, quais sejam, tornar a comunidade temporal dos crentes um espelho da cidade espiritual de Deus. Durante e após as Guerras Religiosas, que se iniciaram com a Reforma protestante - 1520, aproximadamente- e se prolongaram até a Paz de Vestfália —1648 - , muito se fez para mostrar que o ethos católico, em vez da paz, trouxera a opressão, o atraso social e a 
carnificina da guerra. A melhor prova era o imobilismo da nobreza, que reprimia a expansão das novas iniciativas socioeconômicas, e os intermináveis banhos de sangue entre as famílias reais governantes. A solução para o problema era substituir Deus pelo Estado democrático, único capaz de direcionar o viver coletivo rumo à concórdia e à segurança.

Os ideais de transcendência ética foram, por essa razão, empurrados da órbita da Lei divina para a das Leis humanas. O estado de direito democrático converteu-se no alicerce das finalidades pessoais e sociais, e sua base racional assentou-se nas concepções de História e do respeito às liberdades individuais. A valorização da História pretendia tornar o ideal de perfectibilidade humana um processo em aberto, e não uma busca pela ilusória perfeição perdida nos tempos pré-adâmicos, e a ideia de liberdade individual visava anular o peso da vontade divina, substituindo-o pela vontade humana. Deus, dizia-se, não havia criado o homem; o homem é que havia inventado Deus, por ignorar seu verdadeiro potencial criador. $\mathrm{Na}$ medida em que tomasse consciência de sua alienação, ele poderia elevar sua moralidade ao nível do governo autônomo de si.

No caso da segunda esfera, a antropológica, o dano teria sido outro. Os pensadores leigos afirmavam que Lei coextensiva ao Transcendente divino tinha-se mostrado exorbitante em seus requerimentos. Por considerar o sujeito como um ser marcado pela Queda, a religião não dava tréguas à pretensa malignidade escondida em sua alma. O Outro divino era implacável e a violência lhe era congenial. Ele não hesitava em castigar aqueles que não podiam amá-lo através do amor ao próximo, razão da culpa, do temor e da perda de liberdade sofridos pelos seus súditos fiéis.

O exemplo cabal da infantilização do indivíduo pelo medo era a moral do sacrifício. A ética sacrificial, para os fundadores do materialismo racionalista e ateísta, nutria-se do permanente sentimento de dívida e culpa, visto por eles como um atentado à dignidade do sujeito secular. $\mathrm{O}$ sujeito religioso, afirmava-se, fora moralmente coagido a sentir-se, ao mesmo tempo, portador de um Mal sem redenção mundana e devedor da própria 
vida, ou seja, a vida da qual fruía era uma dádiva amorosa recebida sem merecimento. Ao nascer, portanto, ele já chegaria ao mundo cabisbaixo, acusado de inadimplência ontológica, pois a dívida que fora obrigado a contrair era impagável. Viver equivalia a sentir-se culpado por gozar de um benefício ao qual não se fez jus e que poderia ser perdido se Deus decidisse privá-lo da bem-aventurança da vida eterna. Só havia um meio de atenuar essa culpa esmagadora: encená-la no ritual compulsivo do sacrifício. Nos ritos de reconhecimento da dívida, o indivíduo pagaria em pequenas parcelas o tributo devido ao Transcendente, desonerando-se do excesso de culpa, mas tornando-se, inevitavelmente, um animal triste. O caminho para restaurar a dignidade humana lesada pela mistificação religiosa era devolver ao sujeito a consciência de que ele era o próprio produtor de suas crenças.

\section{O núcleo violento da Lei humana}

Do prisma ético, entretanto, a deposição de Deus e a entronização do Estado democrático como guardião do Bem Comum revelou-se mais precária do que pensaram seus mentores. O objetivo da secularização era o de expurgar a violência do viver terreno, neutralizando a presença esmagadora e alienante de Deus. Tal objetivo, porém, malogrou. A violência expulsa pela porta da frente retornou pela de trás, e o motivo do retorno deveu-se ao modo pelo qual o Transcendente leigo foi concebido, ou seja, como Lei garantidora do poder do Estado liberal democrático.

Os ideólogos do pensamento secular - em especial, os porta-vozes do liberalismo filosófico político- desde pronto defrontaram-se com um sério obstáculo à pretensão de fundar uma ética em bases puramente racionais. O obstáculo pode ser sumarizado em duas interrogações: a primeira concerniu ao rumo da História; a segunda, ao valor conferido ao indivíduo como agente autônomo dos ideais éticos. No caso da História, a pergunta era: se os eventos históricos eram contingentes, e não pontos contínuos em uma linha teológica pré-traçada, como reconhecer neles indícios seguros do progresso ou do retrocesso moral? No que tange ao indivíduo, a pergunta era similar: sem o aval de um Deus onisciente e 
onipotente, como saber se os fins morais momentaneamente aprovados não se revelariam, posteriormente, como maus e destrutivos? Em síntese, como garantir a bondade do ideal ético perseguido apoiando-se na transitoriedade das opções morais assumidas?

A saída para o impasse consistiu em substituir a Vontade divina pelo assentimento de todos em obedecer à Vontade Geral. Esta, obtida pelo consenso racional sobre as verdadeiras finalidades da conduta humana, ofereceria o metro indubitável da retidão das atitudes e crenças morais. Entretanto, para ser eficiente, tinha que dispor do Estado legislador e repressor, sem a violência implícita no poder de reprimir os dissidentes, ela se tornaria um simulacro impotente de si mesma.

Os teóricos da secularização foram, por isso, levados a chamar de volta a violência atribuída ao Deus católico para colocá-la a serviço do legislador humano. Mas, para justificar o passo atrás, tiveram que revisar, para baixo, a idealização do indivíduo racional dos sonhos seculares. Ao contrário do que havia sido dito, a sensatez, a cortesia e a boa-vontade não mais seriam predicados espontâneos do sujeito racional liberado da superstição religiosa. O indivíduo, com ou sem a nódoa do pecado original, continuava resistente a curvar-se à lei racionalmente fundada, dada sua natureza originariamente violenta.

A inconsistência teórica-prática foi, assim, casuisticamente remendada com um adendo ad hoc, o mito da gênese violenta da cultura. O mito, em linhas gerais, consistiu em tratar uma suposição teórica com um dado empírico. Em um suposto estágio pré-civilizatório, dizia-se, bandos de criaturas humanas viviam em perene estado de guerra de todos contra todos. Finalmente, após um período de lutas fratricidas, as hordas concluíram um pacto que delegava a uma única instância simbólico-social o poder de matar ou de deixar viver. Essa instância assumiu várias feições, ao longo da história da civilização, até tomar a forma do Estado democrático da Modernidade. Seja como for, a ideia nodal do mito é a de que a Lei, o contrato social, seria o produto da violência assassina que habita em cada um de nós. 
Esse conto noir das origens da civilização foi, no entanto, asperamente criticado por autores das ciências humanas e da religião. As objeções levantadas ao argumento do homem lobo do homem foram de vários tipos. Cito, entre outras, duas que estão mais próximas de nosso interesse.

A primeira objeção dirigiu-se à alegada fidedignidade empírica da história narrada, e, em consequência, à sua plausibilidade teórica. Por que a versão do surgimento da cultura proposta pelo liberalismo seria menos mistificadora e mais racional do que a versão religiosa? - perguntam os críticos. Afinal, a lenda da guerra de todos contra todos não é nem mais nem menos gratuita e arbitrária do que a doutrina da criação amorosa de Deus!

A segunda, argumentam estudiosos como Milbank, Smith e Cavanaugh, o mito da violência original é uma mera manobra do pensamento liberal e secular para tornar suas crenças culturais aceitáveis (MILBANK, 1995; CAVANAUGH,2003; SMITH, 2004). Este mito cumpriria duas funções na estratégia de secularização das mentalidades: A primeira seria legitimar a ordem jurídica do liberalismo clássico, criando a ficção que antes do Estado liberal existia apenas o caos; a segunda seria a de projetar retrospectivamente o ethos individualista no fundamento da sociabilidade, visando desacreditar o regime da hierarquia participativa, solo ideológico do poder temporal do catolicismo romano medieval.

Na verdade, prosseguem eles, não temos provas antropológicas da fictícia condição anômica vivida pelos sujeitos na pré-história humana. Insinuar, portanto, que antes da visão de mundo individualista havia apenas destruição, opressão e privação de autonomia é um preconceito sujeito à impugnação. A participação regrada na vida comunal não é privilégio do liberalismo secular, que teria fabricado um relato sobre a fundação da sociabilidade adequada às suas premissas, e, em seguida, suprido os furos do enredo com um fantasioso medo de morrer comum aos membros da comunidade pré-legal. De fato, finalizam os críticos, se colocássemos o indivíduo competitivo e aquisitivo do liberalismo clássico em uma realidade onde não existisse lei e repressão legal, provavelmente teríamos que 
imaginar algo tão brutal quanto o assassinato mútuo para compreender como pactos de paz teriam podido surgir e manter-se.

Número três, os críticos sustentam que os ideólogos do secularismo e seus herdeiros modernos apenas deslocaram a violência de lugar, sem perceberem que estavam produzindo uma outra ética sacrificial. A culpa e a dívida atribuídas à moral religiosa foram rejeitadas, mas em favor da submissão ao poder do Outro secular, que deveria proteger o sujeito do desamparo diante da ameaça de morte pela mão dos iguais. No fim das contas, continuam eles, o sujeito liberal foi incentivado a abrir mão da autonomia por um motivo idêntico ao do sacrifício religioso. A diferença é que, desde então, o que havia sido descrito como mistificador e alienante passou a se apresentar como racionalmente justificável. No entanto, perguntam os opositores do mito liberal do nascimento da cultura, o que se ganha em racionalidade e desalienação trocando o sentimento de culpa e divida experimentado em face do Transcendente divino pela angústia do medo de morrer pela iniciativa de outros indivíduos?

Ora, é neste ponto que o segundo tipo de objeção feita ao mito da gênese violenta da cultura ganha importância. Os autores, aqui, não refutam apenas a credibilidade empírica da teoria; assinalam as incongruências internas do esquema interpretativo. Girard, por exemplo, sublinhou o fato de que "se os membros do grupo tivessem simplesmente medo uns dos outros terminariam todos, uma vez mais, por se matarem entre eles" (GIRARD, 1978:84 85). MacIntyre, por seu turno, apontou para a incoerência da tese com outros argumentos:

(...) o que falta aqui [no mito] é a explicação de como pode ter ocorrido a transição de um estado em que cada qual procura impor a própria vontade aos demais, para outro em que haja normas e instituições socialmente estabelecidas que, de uma maneira impessoal, regulem o comportamento humano (...) Um contrato só pode ser feito quando a instituição do prometer e as normas referentes ao cumprimento de promessas são estabelecidas. Logo, o alegado estado primordial não é, de modo algum, pré-institucional, nem pré-legal, nem pré-moral (MacINTYRE, 1973: 58:60). 
Para os dois, em resumo, o mito da violência originária em nada esclarece o surgimento do pacto social. O ciclo repetitivo do homicídio e da vingança é, do ponto de vista lógico, insuficiente para explicar o nascimento da Lei e da harmonia coletiva. A fábula inventada nem consegue convencer-nos de que a paz pode nascer diretamente do medo aterrador, nem que pode prescindir da noção da "instituição do prometer", noção que teria sido falaciosamente subtraída do argumento.

\section{O lado violento da Lei}

Dito de outro modo, se é a instituição da promessa e não o mútuo medo de morrer que explica o nascimento da Lei, como entender a gênese da primeira? Parte da resposta consiste em elucidar o significado do termo "instituição"? Se entendermos por "instituição" o aparato legislador, a Lei, faremos com que a questão retorne ao ponto zero, pois, nesse caso, a violência continuaria a ser ultima ratio da transcendência ética.

Explicito melhor o argumento. Ao falarmos de violência pensamos, de imediato, na ideia de abuso de poder que resulta em atentado à dignidade física ou moral do outro. A ideia é parcialmente correta. Resta saber, no entanto, como podemos reconhecer um certo ato de força como abuso. De modo usual, a primeira resposta dada à pergunta é a de que o abuso se configura quando uma norma moral costumeira ou legalmente instituída é infringida. Essa resposta, porém, já parte da premissa de que o critério para o reconhecimento de um ato violento é a transgressão à letra da Lei. Mas, se a Lei depende da violência para tornar-se efetiva, como pode funcionar como um padrão moral neutro para a condenação do abuso?

No fim das contas, a Lei usada para condenar a violência é, ela própria, fruto de uma violência primordial, que aparece recalcada no imaginário cultural. Em outras palavras, é isto que autores como Agamben parecem querer mostrar. Para Agamben, a lei, em sua vertente liberal e secular, oculta, sob o escudo da Razão, seu lado violento (AGAMBEN, 2004a; 2004b; 2004c.). Isto quer dizer que sempre que pensamos em Lei 
atentamos apenas para sua dimensão normativa, ou seja, para seu caráter de código. Não é verdade, entretanto, que a lei se manifeste, exclusivamente, dessa maneira. A lei, embora tenda a se estabilizar como código prescritivo, está, de forma permanente, referida à exceção. A exceção é criada quando a lei se desaplica ela mesma, tornando extralegal o que, até então, era legal. É o caso, por exemplo, do estado de sítio ou do toque de recolher, nos quais os direitos constitucionais, perfeitamente assegurados em períodos de normalidade social, são revogados por um ato legal.

O funcionamento rotineiro do dispositivo legal, portanto, esconde sua inevitável tendência a se autossuspender ou a incorporar, caso a caso, o que lhe é estranho. Dessa flexibilidade depende sua eficácia. A ordenação legal não é um evento ontologicamente distinto e anterior à mítica violência prélegal; é sua faceta normativa, a qual sempre cede a vez à violência crua quando a autoridade instituída é ameaçada em seu poder.

Em síntese, a Lei não apenas depende da violência manifesta para se afirmar como a inclui, de modo latente, no rol das condições necessárias a sua autopreservação. Lei e violência não são termos opostos, contrários ou contraditórios. A violência integra a Lei, que, sem ela, seria uma não Lei. Assim, fazer equivaler Lei e transcendência ética significa algemar esta última ao caráter violento da primeira.

\section{A transcendência da promessa e do perdão}

Voltando, então, a instituição do prometer, diríamos que se a “instituição” da promessa for reduzida à sua dimensão legal não há como fazê-la escapar da servidão da violência. O desafio teórico, assim, é o de fazer da promessa suporte da ética, sem torná-la um apêndice da Lei.

Antes de continuar o raciocínio, é importante retificar a tese de MacIntyre sobre a promessa em um ponto crucial. No mito da passagem da violência generalizada ao compromisso ético, a atitude de prometer implica, obrigatoriamente, a de perdoar. Isto é, interromper o circuito das retaliações passadas, recomeçando um tempo fundado na promessa de não matar. 
Prometer e perdoar são gestos e disposições simultâneos. Trata-se, deste modo, de saber se podemos compatibilizar a originalidade da promessa e do perdão com alguma imagem do sujeito verossímil, dos pontos de vista teórico e empírico.

Diria que sim, e sugiro três dessas hipóteses: uma oriunda da filosofia política e duas outras da psicanálise. Tomo o pensamento de Hannah Arendt como representante da filosofia política. De acordo com Arendt, o fundamento da promessa e do perdão pré-legais é correlato à concepção do ser humano como alguém capaz de iniciar algo novo, de forma indeterminada e imprevisível. A seu ver, não somos, de forma dominante, seres reativos, e ainda menos exclusivamente movidos pelo medo; somos originariamente destinados a agir de maneira livre. Em função disso, diz ela:

A imprevisibilidade, eliminada, pelo menos parcialmente, pelo ato de prometer, tem dupla origem: decorre ao mesmo tempo da treva do coração humano, ou seja, da inconfiabilidade fundamental dos homens, que jamais podem garantir hoje quem serão amanhã, e da impossibilidade de se prever as consequências de um ato numa comunidade de iguais, onde todos têm a mesma capacidade de agir. $\mathrm{O}$ fato de que o homem não pode contar consigo mesmo nem ter fé absoluta em si próprio (e as duas coisas são uma só) é o preço que os seres humanos pagam pela liberdade; e a impossibilidade de permanecerem senhores únicos do que fazem, de conhecerem as consequências de seus atos e de confiarem no futuro é o preço que pagam pela pluralidade e pela realidade, pela alegria de conviverem com outros num mundo cuja realidade é assegurada a cada uma pela presença de todos (ARENDT, 2001: 255-6).

Em suma, porque a "treva do coração" nos impede de ser "senhores únicos do que sentimos e fazemos" e porque não temos poder de prever as consequências de nossos atos somos impelidos a prometer e a cumprir o que prometemos. A instituição da promessa, desta maneira, dispensa a violência ou a Lei para se realizar. Seu único requisito é a confiança de que o outro possui igual capacidade de prometer, por reconhecermos nele um ser de ação idêntico a nós mesmos.

Quanto ao perdão, diz Arendt: 
Se não fôssemos perdoados, eximidos das consequências daquilo que fizemos, nossa capacidade de agir ficaria, por assim dizer, limitada a um único ato do qual jamais nos recuperaríamos; seríamos para sempre vítimas de suas consequências, à semelhança do aprendiz de feiticeiro que não dispunha da fórmula mágica para desfazer o feitiço (ibid. 249).

Em seguida, continua, dado que

... a ação estabelece constantemente novas relações numa teia de relações, precisa do perdão, da liberação, para que a vida possa continuar, desobrigando constantemente os homens daquilo que fizeram sem o saber. Somente através dessa mútua e constante desobrigação do que fazem, os homens podem ser agentes livres; somente com a constante disposição de mudar de ideia e recomeçar, pode-se-lhes confiar tão grande poder quanto o de consistir em algo novo (ibid. 252).

Sem perdão, sem a chance de nos desobrigarmos do que fizemos sem saber que estávamos fazendo, não poderíamos recomeçar e agir em liberdade. Aliás, a simples fantasia de que poderíamos permanecer presos pelo resto da vida às consequências do que um dia fizemos é o desenho mais cruel da danação religiosa! Portanto, não é preciso imaginar que somos seres angelicais, generosos e altruístas para entender porque perdoamos e esperamos que o outro nos perdoe. Perdoamos e prometemos porque somos seres livres, isto é, seres que não podem deixar de agir. E como o produto do agir humano é inelutavelmente irreversível e imprevisível, perdoamos para nos tornarmos responsáveis pela liberdade que exercemos no passado e prometemos para nos tornarmos responsáveis pela liberdade que venhamos a exercer no futuro.

No caso das teorias psicanalíticas, o eixo da explicação gira em torno do "sujeito afetivo ou pulsional". Como veremos, a psicanálise oferece, por assim dizer, uma espécie de suplemento psicológico ao que Arendt afirmou. Tomo Freud como primeiro exemplo. Costuma-se alinhar Freud à lista dos difusores do mito da gênese violenta da cultura. A imputação, a meu ver, não se sustenta. Freud, efetivamente, encampou parte desse mito em seu relato das origens do tabu do incesto e do parricídio. Mas, embora marcado pela antropologia funcionalista do século XIX e pelo ideário do liberalismo 
político, soube fugir do reducionismo intelectual das doutrinas que o influenciaram.

Recapitulemos, de modo breve, o mito freudiano do nascimento do tabu do incesto e do parricídio. Freud aceitou, inicialmente, as teses de Darwin sobre a horda primitiva e a proibição do acesso às mulheres, decretada pelo pai primordial. Entretanto, logo percebeu que a tese deixava inexplicada a transição da horda animal para a sociedade humana, pois, dizia ele,

Este estado primitivo da sociedade nunca foi observado em lugar nenhum. A organização mais primitiva que conhecemos e que existe ainda em certas tribos consiste em associações de homens gozando de direitos iguais e submetidas às limitações do sistema totêmico, inclusive a herança na linhagem materna (FREUD, 1968:162-3).

Em virtude disso, recorreu às ideias de Atkinsons sobre o parricídio e as lutas fratricidas, que vieram a colocá-lo junto aos pensadores seculares do liberalismo político-filosófico (ibid. 163). Ao contrário, porém, daqueles pensadores, Freud não se contentou com esta solução, pois, nem o parricídio nem as lutas fratricidas tornavam compreensível a transição da obediência a uma ordem externa e violenta para a obediência a uma lei invisível e interiorizada. O dilema foi solucionado pela introdução das ideias de ambivalência e culpa, e do curioso acréscimo de uma terceira, a de que os irmãos, por ocasião do banimento da horda pelo chefe, "criaram laços sentimentais entre eles” (FREUD, 1948:111), ou seja, a culpa pelo assassinato do pai odiado, mas também amado, e o desenvolvimento de laços sentimentais entre os irmãos estariam na base de

uma primeira forma de organização social, com a renúncia aos instintos, a aceitação de obrigações mútuas, o estabelecimento de certas instituições declaradas invioláveis, sagradas, em suma, o início da moral e do direito (ibid.:112).

Dito de outra maneira, o medo de morrer não disporia da força coercitiva necessária ao surgimento da cultura, como postula o liberalismo clássico. Sem ambivalência, culpa e vínculo sentimental, os irmãos nunca 
poderiam ter passado do estágio de lutas fratricidas para o de respeito a normas morais.

A mudança na grade interpretativa é evidente. Enquanto os sujeitos foram concebidos como mônadas narcísicas interessadas no próprio gozo, o medo da morte perpetuou o impasse do fratricídio. À medida que Freud os descreveu como seres ambivalentes, capazes de odiar e amar uma mesma pessoa, o impasse teve fim, pelo fato de sermos ambivalentes podemos perdoar e prometer.

Retomando, assim, o que observaram Girard e MacIntyre, diria que o nexo lógico entre o fratricídio e a Lei não pode ser inferido do medo de morrer, mas do poder de prometer e perdoar, que se atualiza na ambivalência de nossos laços afetivos com o Outro. A promessa e o perdão primordiais, portanto, não precisam ser "institucionalmente legalizadas" para funcionarem como trincheira contra o homicídio mútuo. Ao descrever a barbárie que teria precedido o advento da cultura, Freud quis ilustrar, fantasiosamente, o panorama macabro de um mundo despido da força transcendente da promessa e do perdão.

O segundo exemplo vindo da psicanálise, é a teoria winnicottiana. Winnicott também mostra o que nos dispõe afetivamente a confiar na promessa do Outro, e, por conseguinte, a tornar-nos promitentes aptos a cumprir promessas (COSTA, 2004). Sua tese articula, de certa forma, as afirmações de Arendt sobre o sujeito da ação livre e as de Freud sobre a fonte afetiva da promessa e do perdão. Mas o fundamento de seu ponto de vista é a ideia do sujeito originalmente espontâneo e confiante. A espontaneidade concerne á ação agressiva e criativa do sujeito no ambiente, que, no vocabulário do autor, recobre o que designamos como mundo cultural. Para Winnicott, todavia, cultura não é primordialmente uma engrenagem protetora contra a culpa ou a impotência diante de impulsos assassinos auto ou heterodirigidos; é o terreno privilegiado de manifestação da espontaneidade criadora. Por essa razão, o mito da gênese violenta da cultura lhe parece inaceitável. 
A recusa em ver na cultura uma montagem que defende os indivíduos de seus próprios impulsos violentos baseia-se em dois tipos de argumentos. O primeiro é de natureza epistemológica. Cultura, observa Winnicott, não é uma lente racional blindada que o sujeito fabrica para se abrigar da intrusão do Outro; é o fator indispensável à constituição da vida subjetiva. Enquadrar a cultura na moldura da culpa diante de uma dívida impagável ou do desamparo frente à ameaça de morte, se não é falso, é tendencioso. A cultura pode vir a adquirir essa função como pode abrir-se à multiplicidade imprevisível de outras funções, todas criadas retrospectivamente, tendo em vista outros possíveis horizontes de significação.

O segundo tipo de argumento é de ordem psicológica. Neste ponto, insere-se o conceito de confiança. A espontaneidade, relembro, refere-se a relação do sujeito com sua agressividade criadora; a confiança, em contrapartida, concerne à presença ativa do Outro. Mas, entenda-se bem, confiança, na metapsicologia do autor, não é um ideal moral conscientemente cultivado pelos homens de bem; é a condição sine qua non do desenvolvimento psíquico. Confiança é a disposição para atribuir gratuitamente ao Outro uma boa fé para conosco da qual não temos provas ou garantias. Embora não possamos justificar racionalmente esta disposição, sem ela a vida relacional seria impossível. Confiamos no Outro não por estarmos pressionados pelo medo de morrer —o que seria um contrassenso-, mas pelo fato de termos tido experiências contínuas e previsíveis de que, pelo menos, um Outro mostrou-se sensível aos desejos e necessidades que nos permitiram viver. $\mathrm{O}$ pressuposto da confiança, assim, precede a prova da confiabilidade, esta sim, uma habilidade emotivocognitiva adquirida ao longo da maturação psíquica.

Em suma, se sempre tivéssemos sido frustrados em nossas legítimas expectativas, nenhum medo da morte nos levaria a prometer o que quer que fosse ou a perdoar quem quer que fosse. Somos capazes de prometer e perdoar porque aprendemos, ao longo do tempo, que muitas promessas que nos foram feitas foram cumpridas, e que as eventuais falhas no cumprimento puderam ser reparadas ou perdoadas. Donde nossa atitude 
habitual de primeiro confiar, e, só depois de nos decepcionarmos, perder a confiança. Essa é uma constante psicológica dificilmente refutável. Suspeitar sistematicamente do Outro, imputando-lhe o desejo de nos fazer mal significaria lidar com um estado mental totalmente incompatível com o equilíbrio psíquico. Para Winnicott, então, no início não estava a culpa ou o medo de aniquilamento; estava um Outro que doa o necessário e o adequado ao exercício da criatividade. Sem isso, o sujeito ficaria paralisado no mundo interior de suas fantasias ou se esgotaria no trabalho inútil de vencer obstáculos humanamente intransponíveis.

Essa ideia aparentemente simples e prosaica suscitou críticas sarcásticas. Muitos viram nela um rousseauísmo angelical, pronto para o consumo das almas pias e "pré-pós-modernas". Winnicott, porém, não nega a existência da latência demoníaca do que Freud chamou pulsão de morte ou do que Lacan chamou de Real. Ele apenas argumenta, com base em Darwin, que se a teoria infernal da vida psíquica fosse consistente estaríamos todos loucos ou mortos! De sua perspectiva, portanto, violência é tudo que nos faz perder a confiança no outro, e, por conseguinte, nos impede de exercer o poder de prometer e perdoar. A disposição para confiar, certamente, não tem seguro contra riscos. Podemos enganar-nos quanto à boa vontade do Outro ou quanto a nossa própria boa vontade. Podemos, igualmente, desentender-nos quanto à natureza das finalidades morais que nos levam a prometer e a perdoar. Não podemos, entretanto, dispensar a premissa da confiança, se quisermos viver em coletividade.

O poder de prometer e perdoar, portanto, não é um ornamento das boas consciências; é a expressão compulsória do fato de sermos criaturas ativas e afetivas. Porque somos espontaneamente ativos, podemos prometer, e porque somos espontaneamente afetivos, podemos perdoar. A promessa e o perdão, assim, são a face visível da Transcendência ética. Transcendência que, aquém da Lei e além da violência, nos ensina que a vida vale a pena ser vivida. 
Referências bibliográficas

AGAMBEN, Giorgio. O poder soberano e a vida nua I. Belo Horizonte: Editora UFMG. 2004a. $1^{\text {a }}$ reimpressão.

. Le temps qui reste - Un commentaire de l’Épître aux Romains. Paris: Payot. 2004b.

. O estado de exceção. São Paulo: Boitempo Editorial. 2004c.

ARENDT, Hannah. A condição humana. Rio de Janeiro/São Paulo. Editora Forense Universitária. 2000. $10^{\mathrm{a}}$ ed.

CAVANAUGH, William T. The city - Beyond secular parodies. In: MILBANK, John, PICKSTOCK, Catherine and WARD, Graham (Eds). Radical Orthodox. London and New York: Routledge, $4^{\mathrm{a}}$ edição, 2003:182-200.

COSTA, Jurandir Freire. O vestígio e a aura - Corpo e consumismo na moral do espetáculo. Rio de Janeiro: Garamond. 2004.

FREUD, Sigmund. Totem et tabou. Paris: Payot. 1968. . Moïse et le onothéisme. Paris: Payot. 1948.

MacINTYRE, Alasdair. As ideias de Marcuse. São Paulo: Cultrix. 1973.

MILBANK, John. Teologia e teoria social. São Paulo: Edições Loyola. 1995.

SMITH, James K. Introducing Radical Orthodoxy - Mapping a Postsecular Theology. Grand Rapids, Michigan: Baker Academic. 2004. 


\section{JUVENTUDE, POLÍTICA E RELIGIÃO: UM PRETEXTO PARA DISCUTIR ÉTICA, VIOLÊNCIA E DIREITOS HUMANOS NA SOCIEDADE CONTEMPORÂNEA}

Luiz Alberto Oliveira Gonçalves*

Universidade Federal de Minas Gerais

\section{Introdução}

T as últimas décadas, parte significativa de nossa produção voltou-se 1 quase que exclusivamente para o estudo das formas urbanas de violência que atingiam, sobretudo, a população juvenil em contextos escolares. A partir desse estudo, podíamos verificar que, além da tão propalada violência simbólica já amplamente estudada nos anos de 1960 por Pierre Bourdieu e Jean-Claude Passeron, outros estudiosos, de diferentes matizes, detectavam, no final do século passado e início do século XXI, a existência de formas mais explícitas de violência que adentravam os estabelecimentos de ensino e se combinavam com as relações intra e extraescolares. A escola deixava de ser o santuário das boas maneiras e dos bons costumes. Tal como a família, a escola passava por questionamentos profundos. Sua condição de centro de controle social e de socialização do mundo moderno, como a definiam os sociólogos da cultura, se enfraquecia a olho nu. Não foi por acaso que parte da bibliografia sobre o tema retomou ao antigo debate acerca da relação entre cultura e natureza, levando-nos a refletir sobre os sentidos que teriam nos dias atuais o que Freud chamou, em sua época, de mal estar na civilização. $\mathrm{O}$ fato de a escola ter se transformado, em várias situações, em cenário de violência, de manifestação clara de desacordo com as normas sociais, e de adoção de comportamentos que nada tinham a

\footnotetext{
* Doutor em Sociologia pela École des Hautes Études en Sciences Sociales. Professor Associado do Departamento de Ciências Aplicadas 'a Educação da Universidade Federal de Minas Gerais.
} 
ver com os princípios do processo civilizador amplamente descrito por Norbert Elias, tudo isso nos fazia ver que algo turbulento se passava em nossas sociedades, que alguns, como veremos mais à frente, denominavam de “crise”, já outros, de "mutação".

Diante desse quadro, que não refletia apenas a situação brasileira, mas de várias outras nações, governos em diferentes partes do mundo desencadearam uma série de políticas voltadas para combater e prevenir manifestações de violência ou mesmo seus efeitos em meio escolar, consequentemente, no meio juvenil.

De lá para cá, assistiu-se a uma enxurrada de programas públicos estatais ou não, destinados aos jovens, sobretudo, aos oriundos de famílias de baixa renda, cujo objetivo era, e continua sendo, envolvê-los o máximo possível em ações denominadas de socioeducativas, por acreditarem que estas, por si sós, coibiriam a entrada desses jovens no mundo do crime, das drogas e da "morte anunciada". Cultura da Paz, Pró-Jovem, Protagonismo Juvenil, Capoeira na escola, Hip Hop e Afro-Reggae; essas (e outras) são tarjas com as quais, hoje no Brasil, rotula-se a juventude pobre, alvo privilegiado das políticas de inclusão (ARAÚJO, 2007, SPOSITO, SILVA e SOUZA, 2006).

Qualquer observador atento às iniciativas públicas, principalmente no campo social, não terá nenhuma dificuldade para perceber que, nos últimos cinco anos, há um grande volume de ações do poder público, seja esse municipal, estadual ou federal, competindo, no quotidiano, por parcelas de jovens de classes desfavorecidas, em torno de projetos que respondem, ou tentam responder, as necessidades imediatas, em geral vinculadas a questões de sobrevivência; respostas essas que aliviam, sem dúvida, os sofrimentos de ordem material, mas não avançam um só milímetro na emancipação desses sujeitos (ARAÚJO, op. cit.).

Coincidência ou não, o fato é que tais iniciativas são explicitamente disputadas, no cotidiano, por organizações não governamentais que se 
profissionalizaram na prestação de serviços assistenciais e, hoje, funcionam como executoras dessas políticas de inclusão juvenil (ARAÚJO, op. cit.).

Visto de um ângulo otimista, pode-se dizer que tudo isso que acabamos de relatar acima prova que a "ação concreta" suplantou discursos vazios, reflexões infindas e sem resultados palpáveis. O fazer é o que conta. O sujeito da vez é aquele que se identifica como "gente que faz". Aliás, no atual estágio em que se encontram as ditas políticas de inclusão dos jovens de famílias de baixa renda, tem-se a sensação de que o lema a ser seguido é "fazer, fazer e fazer". E assim tem sido. Resta saber se esse fazer que pouco ou nada compreende do que está acontecendo tem atingido o âmago do problema que acredita estar resolvendo.

Na sequência propomos analisar, com base nas observações acima, os três eixos que orientam o tema que nos foi proposto para essa mesa redonda, a saber: ética, violência e direitos humanos. O exemplo das políticas de inclusão dos jovens de famílias pobres foi, por nós, evocado apenas para fortalecer nosso argumento de que algo de turbulento está se passando nas sociedades contemporâneas que é preciso, antes de mais nada, compreender. O que está acontecendo com os jovens ocorre também, a nosso ver, com outros segmentos sociais que, em passado bem recente, ampliaram direitos duramente conquistados por seus movimentos sociais; que foram grandes defensores da universalização dos direitos humanos lutando para fortalecer a democracia no Brasil. Esses segmentos permanecem, mas seus movimentos estão cada vez mais escassos, alguns até desapareceram. A relação de conflito entre ação coletiva e instâncias de poder dominante vem dando espaço a políticas públicas que instauram novos mecanismos de controle e dominação; políticas essas que aparecem com a promessa de estarem dando aos jovens "oportunidades nunca tidas", embora se constituam, na maioria das vezes, em repasses irrisórios de recursos públicos para grupos focalizados (SPÓSITO e CORROCHANO, 2005).

Alguns estudos sobre essas políticas têm demonstrado que a característica básica desses programas governamentais ancorados por ONG 
(s) tem sido a sua focalização. Dito de outra forma, no lugar de se ampliarem políticas universais que fortaleçam o sentido republicano e de cidadania plena, ou então, políticas que propiciem, aos jovens, experiências em torno das quais possam desenvolver-se enquanto sujeitos éticos, as ações governamentais têm sido fragmentadas, no âmbito do atendimento à juventude. As consequências dessa fragmentação passam por novas formas de violência, ou mais precisamente, por novos estigmas (ARAÚJO, 2007, SPÓSITO e CORROCHANO, 2005).

Sem negar a relevância das políticas de inclusão em vigor em nossa sociedade, gostaríamos de trazer para o nosso debate as seguintes questões: é possível, com esse tipo de política, construir um sujeito ético? Estaríamos, de fato por meio delas, combatendo a violência ou estaríamos produzindo uma nova forma de violência? Cabe ainda perguntar, em que medida tais políticas contribuem na difusão e compreensão dos direitos humanos?

\section{Contextos em mutação}

Responder as questões acima exige, de nossa parte, um trabalho reflexivo acerca das atuais condições históricas nas quais ética, violência e direitos humanos se entrelaçam, se confirmam, se excluem mutuamente e se reinventam em múltiplas dimensões.

Pensando o atual contexto brasileiro, deparamo-nos com situações que nos deixam perplexos e que requerem muita reflexão. Diante de inúmeros eventos envolvendo corrupção e negligência com os cuidados relativos à vida humana e do planeta, demanda-se um "retorno à ética". Em razão de ações coletivas contra formas explícitas de dominação, evoca-se o caráter conciliador e cordial da sociedade brasileira, reconstituindo-se, cem anos depois, o mito de um Brasil nãoviolento, de um Brasil não racista. Face ao aumento das liberdades individuais, questionam-se duramente as conquistas advindas dos direitos humanos. A nosso ver, essas ações e contrarreações se imbricam e, por isso se explicam pelos mesmos condicionantes. 
Alguns autores argumentam que as situações acima citadas resultam de uma percepção de que estamos diante de uma "crise de valores". Outros, porém, reconhecem nessas situações, não uma crise e, sim, a existência de mutações que precisam ser compreendidas (WIEVIORKA, 2007). Como diferenciam crise da mutação, resta saber o que faz com que as duas interpretações coexistam para designar os mesmos problemas, em dado contexto comum. Comecemos, assim, falando do sentimento de crise que se expressa em muitos textos e debates públicos, evocando o "retorno à ética".

A esse respeito, nos diz Marilena de Souza Chauí, fala-se em "retorno ética" como se esta estivesse sempre pronta e disponível em algum lugar e como se nós a perdêssemos periodicamente, devendo, periodicamente, encontrá-la (p.2). Para a autora, nessa fala, a ética é vista como algo externo ao sujeito e não como uma ação intersubjetiva consciente e livre que se faz à medida que agimos e que existe somente por nossas ações e nelas (idem).

Na base desse apelo ao "retorno à ética", existem, para Chauí, poderosos fatores que o impulsionam. Na realidade, são fatores que afetam o mundo em sua globalidade e tiveram sua origem na modernidade capitalista ocidental, mas que se expandiram e envolveram as nações contemporâneas, suas economias e culturas, como um todo (CASTELLS, 1999).

Vale, contudo, destacar que esse sentimento de que valores básicos da vida humana estão em crise, pode ser encontrado em outros momentos da produção intelectual do mundo ocidental. Não se trata, assim, de uma nova percepção, embora, em outros momentos, essa crise tenha sido explicada por outros fatores que não os de agora, assim como o apelo ao "retorno à ética" tenha tido, também, significados muito diferentes dos que circulam, hoje, em nossos meios de comunicação. Para efeito de nossa apresentação, fixaremos dois momentos cruciais do mundo ocidental, nos quais, a nosso ver, configura-se uma situação de "crise”.

O primeiro deles, refere-se à passagem do século XIX para o século XX. Ali, construtores da sociologia registravam sinais dessa crise em 
termos dramáticos. Um exemplo deles é Georg Simmel ([1911] 1988). Vejamos algumas passagens de seu pensamento, pois, a nosso ver, ele ofereceu uma das reflexões mais fascinantes acerca da crise de valores no mundo ocidental em um período de profundas mutações. Nessas passagens, Simmel descreve o processo que faz com que sintamos que produtos culturais, embora produzidos pelos próprios sujeitos sejam por esses percebidos como algo acima deles, que lhes oprime. Dentre esses, está à ética conforme assinalada por Chauí, na passagem supracitada.

Para Simmel, a crise era resultante de uma tragédia que, segundo ele, era intrínseca à própria vida em sua expressão mais íntima. No dizer desse autor, o que havia de profundamente trágico na cultura era que a vida, para poder existir, devia converter-se, antes de qualquer outra coisa, em não vida. O que queria ele dizer com isso?

Em consonância com o espírito de sua época, Simmel defendia a ideia de que, com a inserção do indivíduo humano nos legados da natureza, instaurava-se o primeiro grande dualismo em torno do qual se desenvolveu a relação entre sujeito e objeto (SIMMEL, op. cit., p. 177). Já o segundo grande dualismo, diz ele, nasceu no íntimo de cada indivíduo humano. Sua gênese ocorre da seguinte maneira: tendo desenvolvido o pensamento, este engendra inúmeras produções (arte, agricultura, religião, direito, técnica, ciência, moral, normas sociais, família...). Estas, uma vez criadas, continuam a existir em sua autonomia específica, independentemente do pensamento que as criou, bem como de quem as acolhe ou de quem as rejeita (idem, p. 177).

Não se pode esquecer que Simmel formula seu pensamento no período em que proliferam os germes do industrialismo europeu. Na lógica da acumulação do capitalismo industrial, predominante naquela época, as produções do espírito e do trabalho humano, as quais o autor se referia, enquadravam-se, perfeitamente, nas imagens do "fetiche da mercadoria" denunciado por Karl Marx, ao analisar o processo de alienação dos reais produtores (os trabalhadores) em relação ao produto de seu trabalho (as 
mercadorias). Estas circulavam no mercado, como se fossem coisas autônomas, completamente divorciadas de seus reais produtores, como se elas tivessem vida própria.

Simmel estende esse processo de alienação aos produtos culturais. Estes, para nosso autor, nada mais eram do que o pensamento transformado em objeto e até mesmo em mercadoria. Assim, tendo assumido uma forma concreta e cristalizada, esses produtos culturais se opunham ao fluxo da vida e às diversas tensões do psiquismo subjetivo. É nesse formato que o pensamento, diz Simmel, conhece inúmeras tragédias nascidas dessa profunda contradição formal, entre a vida subjetiva e seus conteúdos (SIMMEL, idem). A vida subjetiva, no dizer de Simmel, não tem repouso, é inquieta, mas é limitada no tempo. Já os seus conteúdos, uma vez criados, adquirindo formas definidas, existem como se fossem imutáveis e intemporais. Nesse sentido, a cultura não era ameaçada, segundo nosso autor, do exterior, mas do íntimo de cada indivíduo, pelo fato de que este tem necessidade de que as formas culturais se tornem independentes para que ele possa orientar-se por elas. Forma-se, assim, um dualismo, no seio do qual, para esse construtor da sociologia, reside à ideia de civilização. As obras da cultura, como, por exemplo, a ética e as normas sociais, uma vez criadas pelos sujeitos, assumem, no contexto do capitalismo industrial, uma autonomia sem precedentes. Mas, mesmo reconhecendo esse caráter objetivo da produção cultural, Simmel (op. cit., p. 181) vai insistir que a referida produção só afeta o indivíduo porque aquilo que ela evoca ou manifesta já existe dentro dele, em seu íntimo.

Assim, ao falar da cultura, o autor explora a ideia original do próprio termo, a saber: para que se diga que um ser tem cultura é preciso que este ser seja cultivado. Entretanto, só se cultiva algo que já existe em germe na coisa ou no ser que será submetido ao cultivo. É assim que, para ele, a cultura não é outra coisa senão a evolução em direção a um fenômeno que existe na personalidade em germe, nela esboçada a título de projeto ideal (idem). Simmel antecipa de alguma forma, as comprovações experimentais que as neurociências vão trazer no final do século XX. Por exemplo, o bem 
estar que um indivíduo experimenta ao ser exposto a uma música ou uma obra de arte qualquer, esse bem estar só existe porque, ao sofrer a exposição, neurotransmissores foram liberados por seu cérebro. Essa condição subjetiva tem de existir a priori, caso contrário, a música não teria o efeito citado. Na perspectiva simmeliana, um ser humano só é considerado culto quando os conteúdos externos a ele (conhecimentos, virtuosidades, refinamentos possíveis) vierem desenvolver apenas aquilo que já existe em sua subjetividade enquanto sua mais profunda pulsão, enquanto prefiguração íntima de sua realização pessoal (SIMMEL, op. cit. p.181).

Visto dessa forma, o conceito de cultura em Simmel representa uma solução para a equação sujeito e objeto. Ele reconhece que existem objetivos supraindividuais, ou seja, ideais culturais, exteriores ao centro psíquico individual que o orientam de acordo com as exigências desses ideais. Dentre estes, figuram as instituições, os valores morais, a arte, a ética, as normas sociais, em suma, os princípios que orientam a vida coletiva. Ainda que tudo isso seja uma criação do próprio espírito humano, não é possível identificar, no conjunto da produção humana, quem seria o seu produtor específico. Por exemplo, não há como dizer quem foi o produtor da ética, da moral e das normas sociais. É, nessa separação entre o sujeito produtor e o objeto de sua produção, que Simmel descrevia, como vimos acima, a tragédia da cultura sendo o produto que adquire forma objetivada e independente, e muitas vezes se volta contra o seu próprio criador, contra a vida subjetiva dos indivíduos, oprimindo-o.

Voltando à questão inicial suscitada por Chaú acerca de uma dada percepção na qual a ética é vista como algo externo que se perdeu e é preciso que a ela se retorne para solucionar uma crise de valores, pode-se dizer, seguindo as reflexões de Simmel, que essa percepção teve sua raiz no pensamento ocidental que refletia o mal estar da civilização em uma das fases da acumulação capitalista, a saber: a sociedade industrial.

É daí, a nosso ver, que vem o tal sentimento referido acima por Chauí, de que a ética é algo externo ao qual temos de nos submeter E esse 
sentimento, por maior crítica que já tenha recebido, permanece em nosso cotidiano quase que inabalável. Não raro ouvimos pessoas próximas de nós, e até nós mesmos, reclamando da "tirania" de normas, de leis. E quando alguém nos pergunta, mas quem fez essas normas? Dificilmente nos reconhecemos como seus produtores. Na maioria ou totalidade das vezes não fomos, de fato, nós quem as produziu, mas nossos antepassados, ou contemporâneos que ocupam uma posição social que lhes outorga autoridade ou poder para fazê-lo. Mas é claro que aquela pergunta não é feita para identificar um indivíduo particular e, sim, para ressaltar que esses produtos não são obras de seres inumanos, deuses ou extraterrestres, mas de seres como nós, humanos.

Como se pode ver, o dualismo de Simmel não separa dois mundos -0 interno do externo, ao contrário, estabelece uma relação intrínseca entre os dois. O mundo externo, o das formas, é mais durável, transcende, enquanto o de dentro, o da vida subjetiva, é fluxo contínuo. Por isso, conflitam.

Em modo contínuo, a vida, para Simmel, é o valor supremo. É dela que deriva tanto o critério de verdade e do erro, quanto o critério do bem e do mal. Bergson e Nietzsche ${ }^{1}$ estão, sem dúvida, na base desse pensamento. Na obra de Simmel, a vida é representada em toda sua exigência fisiológica, ou seja, naquela em que a vida aspira mais e mais vida. Mas é representada também em suas exigências espirituais, isto é, naquela em que a vida almeja mais do que o simples viver. Nos seres humanos, essas duas exigências são intensificadas pela consciência. É esta que faz das exigências da vida um dever (moral). E como nos lembra Evaristo de Moraes Filho (1983), um grande estudioso da obra de Simmel, o dever moral na perspectiva vitalista simmeliana, reveste-se do caráter de uma "lei individual" (p. 26). Ainda que individual, ressalta Moares Filho, a lei da qual deriva o critério de verdade e de erro, de bem e de mal, não é, para Simmel, subjetiva. Isto ocorre porque ela é imposta pela própria vida. Assim, o a realizar-se a si

\footnotetext{
${ }^{1}$ Sobre a influência desses autores na obra de Simmel cf. FREUND, J. Introduction In: SIMMEL, G. Sociologie et épistemologie. Paris: PUF, 1981, p7-18.
} 
mesmo passa a ser um dever moral de cada indivíduo, e é apenas realizando tal dever que o indivíduo irá conseguir superar o conflito acima mencionado entre a vida e cultura.

Com essas observações, cremos que indicamos os principais aspectos que caracterizaram um dos momentos do mundo ocidental, final do século XIX e início do século XX, que se configurou como sendo crise de valores. Passemos, assim, para uma breve caracterização de um segundo momento, final do século passado e início do nosso milênio, para ver o que tem sido apontado como crise, em linhas gerais.

Podemos identificá-lo com as mudanças que tem origem na segunda metade do século XX, momento em que avança um modelo societário descrito como sociedade em rede na era informacional (CASTELLS, 1999).

A característica fundamental dessa era é dada, como nos diz Castells, pelos efeitos da revolução tecnológica, baseada na informática que conecta o mundo e os indivíduos em redes cada vez mais extensas, introduzindo uma nova subjetividade, na qual evoca a construção de si, o cuidado de si como os valores supremos da vida (MOLENAT, 2006)

Na era informacional, as ciências humanas se veem obrigadas a mudar o foco de análise que, no século XIX, sempre esteve ligado às questões da ordem, ou seja, da sociedade, na qual o indivíduo era subordinado e pela qual era moldada sua personalidade.

Com as transformações proporcionadas pela nova revolução tecnológica, há uma brusca inversão de foco. Da sociedade se passa ao indivíduo e este se torna o foco de muitas produções teóricas sob suas diferentes designações: sujeito, ator social, Eu, agente social, e assim por diante.

Em sua obra, o Retorno do Ator (1984), Alain Touraine analisa os problemas dessas polarizações que ora centra o indivíduo, ora, a sociedade, deixando de observar que ambos os polos se relacionam em conflito constante, e que é esse conflito que funda a modernidade em seu esplendor. 
Lembramos que Simmel, já em sua obra acima analisada, assinalava essa combinação. Para ele, o conceito da sociedade era fundado no relacional. A sociedade era, segundo ele, resultado de uma síntese mental que se realizava pela própria atividade de seus componentes. Em suma, ela era o resultado das ações e reações dos indivíduos entre si, isto é, por suas relações. Assim a sociedade resultava, no dizer de Simmel, de processos psíquicos, intermentais cujos suportes são os indivíduos, suas consciências, a totalidade de sua vida psíquica (SIMMEL, op. cit.).

Surge, assim, nesse contexto uma outra percepção dos produtos culturais. Esses continuam sendo percebidos como externos aos sujeitos, e autônomos, mas as ciências humanas começam a produzir uma outra imagem, na qual eles são descritos como resultado da intersubjetividade, das interações humanas.

Pensamos que é com essas duas configurações que teremos que ler os eixos propostos para essa mesa redonda. E assim o faremos.

\section{A difícil construção do sujeito ético}

Desde o momento que decidimos estudar as experiências religiosas e místicas na cultura urbana juvenil, tínhamos certeza de que tudo o que não queríamos era cair na armadilha da sociabilidade. Embora Simmel aponte esta como o objeto central da sociologia, alegando que os conteúdos da mesma seria objeto de outras áreas de estudo, decidimos enveredar por essas outras áreas.

Diante do aumento de jovens nas estatísticas populacionais integrando novas modalidades religiosas, estudos alertavam para: a) a importância dessas adesões apresentando-as como uma espécie de reação dos jovens em face de um mundo fragmentado que nada lhes oferecia, b) para os riscos em uma sociedade cujas mortes de jovens se constituíram em uma verdadeira tragédia. Outros estudos descreviam esse momento como resultado de um processo de secularização no qual as adesões religiosas se 
subordinavam muito mais à escolha autônoma e racional dos jovens do que à velha tradição que inclina os jovens à religião de seus pais.

Estaria havendo, de fato, alguma mudança? Estaria ali se desenhando um novo tipo de "sujeito ético"? Este, segundo Chauí, quando pensado dentro de uma ética que procura não a inculcação de padrões de conduta, mas sim, investigar as ações e as paixões em vista da felicidade, se define como um ser racional e consciente que sabe o que faz. Sobre essa definição diz a autora: $a$ ação ética é balizada pelas ideias de bom e mal, justo e injusto, virtude e vício, isto é, por valores que podem variar de uma sociedade para a outra ou na história de uma mesma sociedade, mas que propõe sempre uma diferença intrínseca entre condutas, segundo o bem, o justo e o virtuoso... a ação ética só é virtuosa se for livre e só será livre se for autônoma, isto é, se resultar de uma decisão interior ao próprio agente e não vier da obediência a uma ordem, a um comando ou a uma pressão externa.

De certa forma, Chauí propõe que pensemos a ética, no atual contexto, não como uma "reforma dos costumes" ou como uma restituição de valores, mas como uma análise das condições de uma ação ética.

Mas que condições seriam essas?

Como vimos anteriormente, desde a última década do século 20, não falamos mais no centralismo da sociedade industrial. Identificamos, ali, o momento em que a acumulação ampliada do capital se define pela "acumulação flexível" que enfraquece a ação coletiva pautada nas lutas sindicais. Instaura-se, assim, o reino da ação individual com base na ideologia da competência profissional. O resultado mais direto desse enfraquecimento foi a fragmentação e a dispersão na construção das identidades (CASTELLS, 1999a).

O enfraquecimento desse processo, na segunda metade do século XX, trouxe outra consequência também observável nesse início de milênio. Há um refluxo dos movimentos e das políticas de emancipação do gênero humano (CHAUÍ, op. cit.). Basta lembrar que a ideia que mais mobilizou o debate político e intelectual no Brasil, principalmente no final da década de 70 e 80 , 
girava em torno dos movimentos sociais tanto na consolidação da democracia, decretando o fim do regime militar, quanto no avanço de direitos de segmentos até aquele momento marginalizados dos processos políticos. Aos poucos, a face desses movimentos foi esmaecendo. Houve conquistas e mudanças. Mas por outro lado, houve um claro enfraquecimento desses movimentos. Muitas de suas reivindicações que, na época da efervescência democrática, eram tidas como utopias, foram se constituindo, como diria Simmel, em formas políticas bastante concretas. Exemplos disso, foi a criação da Secretaria Especial das Mulheres e da Secretaria Especial de Políticas de Igualdade Racial, ambas, com status de Ministério, ligadas à Presidência da República. Esse é o exemplo típico de uma demanda viva que se converte em establishment À medida que seus conteúdos foram cristalizando-se em estruturas políticas oficiais, criou-se um vazio. Pelo menos, não se tem mais o eco dos movimentos que sustentaram as reivindicações dos segmentos femininos e negros da sociedade brasileira. Se as observações de Simmel ainda se aplicam podemos esperar que o mundo da vida, representado por aqueles movimentos, estejam (quem sabe?) engendrando novas formas, que, ainda não conseguimos perceber.

Por fim situamos o aspecto que, talvez, mais tenha afetado a vida juvenil nesse início de milênio que é, também, resultado dessa fase da “acumulação flexível do capital”, representado pelo consumo. Este aumentou, de forma significativa, na sociedade dominada por uma mídia que, como bem assinala Chaú, engendra uma subjetividade de tipo novo: sujeito narcisista (idem). E ainda, promete tudo o que, dificilmente, a maioria dos nossos jovens conseguiram ter, a saber: satisfação imediata de seus desejos, juventude eterna, sucesso rápido e sem esforço.

De um lado, as ditas promessas acabam em frustrações e tragédias. Muitas acreditando nas possibilidades aventadas se lançam até no mundo do crime. Por outro lado, essas promessas e suas frustrações configuram um estado em que não é mais possível falar de ética no sentido universal. Esta se fragmenta, como nos diz Chauí, em particularismos. Hoje fala-se em ética na política, ética profissional, ética da pesquisa, ética familiar e assim 
por diante. No fundo, essa fragmentação acaba transformando a ética em competências específicas do especialista (as comissões de ética) que detêm o sentido das regras, normas, valores e julgam as ações dos demais segundo esses pequenos padrões localizados (idem).

É assim, por exemplo, que a noção de ética está funcionando no nível de várias instâncias. Basta lembrar a quantidade de julgamentos que temos, hoje, na esfera do Congresso Nacional, ambas as casas —-Senado e Câmara dos Deputados têm suas respectivas comissões de ética e, por vezes, julgam ações semelhantes com resultados completamente diferentes e contraditórios. O sistema judiciário, as corporações policiais, a pesquisa nas universidades, todos criam suas comissões de ética.

É um erro imaginar que a proliferação de comitês de ética localizados signifique um maior grau de democracia, ou de controle social. Ao contrário, essa proliferação revela, pelo menos, duas condições; A primeira, como atesta alguns estudos sobre o estágio das sociedades contemporâneas, revela que está cada vez mais difícil de se sustentar uma imagem unitária da sociedade (WIEVIORKA, 2007), tal como se tinha no final do século XIX e início do século XX. Cada vez mais, os indivíduos estão voltados para uma construção de si como resultado de sua ação social (TOURAINE, 1984). A segunda acentua que é preciso pensar o mais urgentemente possível que mediadores poderiam ajudar a estabelecer a ponte entre esses fragmentos éticos que tornam sempre mais difícil a convivência humana.

Dito isso, passemos aos eixos da violência e dos direitos humanos para ver em que sentido eles estão vinculados ao da ética. E como reatá-los de uma outra maneira, se é que isso é possível.

\section{Violência e direitos humanos}

Como dissemos anteriormente, o nosso ponto de partida da juventude foi a violência escolar, tema que mobilizou ou vem mobilizando vários setores da sociedade brasileira. 
Um dos problemas que nós, e a maioria dos pesquisadores que trataram do assunto, identificamos era a dificuldade de, no interior das escolas, definir o que cada ator entendia por violência. Em todo caso, o que assustava no cenário estudado era o fato de a escola estar sendo palco de atos de violação, de abuso físico e/ou psíquicos contra alguém, de transgressão, de tráfico de drogas e assim por diante (RIBEIRO 2002, ESPÍRITO SANTO 2002). A violência física passou a ter espaço na escola, o que exigiu reflexão dos pesquisadores da educação. Os fenômenos surpreendiam porque, como ressaltou Abramovay e Ruas (2003), ao longo de sua existência, as escolas acreditavam, assim como a sociedade da qual elas faziam parte, de que, no Brasil, a violência era uma variável isolada e controlável e não algo que fizesse parte da sua estrutura.

Como diz Chauí (op. cit.), no Brasil, o mito da não violência é muito poderoso. Apesar de todas as evidências e do aumento assustador de indicadores de homicídio, sobretudo, de jovens entre 14 e 17 anos, em nosso país, persiste a imagem de um povo generoso, alegre, sensual, solidário que desconhece o racismo, o sexismo, o machismo, que respeita as diferenças étnicas, religiosas e políticas, não discrimina as pessoas por suas escolhas sexuais etc. (CHAUÍ, op. cit.).

Um exemplo de como o mito da não violência sobrevive em meio à violência, pode ser visto no atual debate acerca das políticas de ação afirmativa para negros nas universidades. A crítica mais contundente vem dos próprios setores universitários, pesquisadores, com apoio, é claro, de uma mídia que sustenta, sem qualquer dificuldade, que políticas de cunho racial são aberrações porque quebram aquilo que é o "jeito de ser do brasileiro", a saber: um povo mestiço, mistura de inúmeras etnias. De um só golpe, reescreve-se em uma outra lógica a história das relações raciais no Brasil. Embora não haja espaço no presente artigo para desenvolver esse tema, gostaríamos, apenas de ressaltar que toda nova construção de um Brasil mestiço e cordial não apaga séculos de desigualdades (PAIXÃO e GOMES, 2006), não anula a política da elite branca no século XIX, tentando "embranquecer" o país por meio de intervenções que facilitavam a 
entrada maciça de imigrantes europeus no país (AZEVEDO, 1987), não sobrepõe, de forma alguma, a luta de movimentos negros que, ao longo do século $\mathrm{XX}$, não fez outra coisa senão denunciar a violência racial nas entranhas da nação (GONÇALVES e SILVA, 2000). Alguns estudos mostram que essa demonstração de violência, longe de ser um ato isolado, ou uma variável controlável, faz parte das instituições. O Brasil, há muito, desenvolve um racismo institucional (PAIXÃO, 2006).

Assim como acontece com a violência racial, todas as outras formas de violência institucional desapareceram, também, do olhar imediato. Ficam imperceptíveis. Ou quando são percebidas, passam a ser vistas como ações sem consequências políticas mais amplas. Dito de outra forma, a sociedade brasileira não é percebida como estruturalmente violenta (CHAUÍ, idem). Ainda no dizer dessa autora, isso ocorre porque a mitologia $e$ os instrumentos ideológicos fazem com que a violência que estrutura $e$ organiza as relações sociais brasileiras não possa ser percebida, e, por não ser percebida, é naturalizada e essa naturalização conserva a mitologia da não violência com a qual se brada pelo "retorno à ética" (idem).

O mais importante a ressaltar na citação acima refere-se à persistência da matriz mítica da não violência. Segundo Chauí, ela se conserva porque é periodicamente refeita com noções que correspondem ao presente histórico (op. cit.).

Tomando o caso racial como exemplo, o mito aparece inicialmente, entre outras, na obra de Gilberto Freyre ao defender o caráter pacífico do colonizador português em contraste com os anglo-saxões que teriam levado os Estados Unidos da América do Norte a um terrível sistema de segregação racial. A Escola de Sociologia de São Paulo na figura de Florestan Fernandes e Roger Bastide desconstruiu essa imagem mostrando as terríveis condições em que os negros viviam no início do século XX na cidade de São Paulo.

Na linha defendida por Freyre, o Brasil era um país miscigenado e isto era prova de que o branco colonizador não criou barreiras para a 
integração. Paralelamente à teoria da miscigenação, as elites promoviam, como bem assinalou Azevedo (op. cit.) um processo de entrada de imigrantes europeus que possibilitaria o embranquecimento do país.

No início dos anos de 1940, movimentos negros na cidade do Rio de Janeiro e na cidade de São Paulo, organizaram-se para denunciar a construção da identidade brasileira sob a égide do governo de Vargas (GONÇALVES e SILVA, op. cit.). Ocultando as desigualdades raciais , o mito da democracia racial reatualizava a ideologia da brasilidade. No atual contexto, ele reaparece sob o signo de um Brasil mestiço no qual é "impossível dizer quem é branco e quem é negro".

Mas esse mito, alerta Chauí, só consegue sobreviver porque ele tem base material real que se traduz no autoritarismo social. Este se reproduz no núcleo familiar, nas relações escolares, nas relações de trabalho, na indistinção entre público e privado, na naturalização das desigualdades e assim por diante.

Finalizando, destacamos o eixo dos direitos humanos. Estes ganham força com os movimentos sociais. Na realidade, foram esses atores sociais que introduziram na cena política temas que sequer imaginávamos que seriam discutidos na esfera pública. Foi por meio deles que conseguimos atingir direitos de cidadania para gays, para minorias religiosas e para segmentos marginalizados que não tinham nem voz nem espaço na sociedade dominante.

O refluxo desses movimentos nos últimos anos, proporcionado por políticas que os estabilizam e os esvaziam é preocupante, e merece, em outro texto, uma reflexão mais alongada.

\section{Conclusão}

Na realidade, no mundo juvenil que temos mergulhado para estudar as experiências religiosas e suas consequências na construção de um sujeito ético, acabamos encontrando situações que orientam os jovens em direções 
diferentes. As políticas de inclusão que cada vez mais fragmentam esses jovens nas suas escolhas acabam criando uma ética normativa porque acreditam que essa é a função das iniciativas do poder público, a saber: oferecer aos jovens alternativas de socialização para evitar sua entrada no mundo do crime. Aqui, a ética como algo externo e moralista aparece, como acentua Chauí, de forma clara e indiscutível. O controle sobre os jovens é reforçado por todos os lados, aliás para participar dos benefícios do programas os jovens devem se comprometer a construir seu comportamento na direção desejada pelo programa. Na realidade, tais programas são concebidos para combater a violência ou impedir que os jovens fiquem vulneráveis a ela. Entretanto, a violência é ainda construída como sendo um atributo do indivíduo e não uma consequência estrutural, como ressalta Chauí.

Como essas políticas não atingem o sujeito na sua vida subjetiva, permanecem vazios o que leva os jovens a buscar preenchê-los em suas experiências religiosas. Estas têm se orientado por éticas completamente diferentes. A novidade é a emergência dos movimentos neopentecostais que quebram bastante a antiga ética protestante centrada na salvação individual, que concebe o sujeito ético como alguém que decide racionalmente e se responsabiliza individualmente por sua salvação. Na nova leva, o aperfeiçoamento pessoal vem acompanhado com a promessa da prosperidade do sucesso, rápido e imediato, e da não subordinação dos indivíduos às estruturas. Entretanto, nessas experiências, violência e ética não são polos opostos, ao contrário, em muitas delas um justifica o outro. Esperamos poder aprofundar esses elementos em um próximo encontro. Obrigado!

Referências

ARAÚJO, M.C. de A. Políticas púbicas para a juventude de Belo Horizonte um estudo sobre os programas e o enfrentamento da violência em áreas definidas pela territorialidade e sua vulnerabilidade. São Paulo: Tese de Doutorado (Educação), Universidade de São Paulo, 2007.

AZEVEDO, C.M.M. de. Onda negra, medo branco: o negro no imaginário das elites-século XIX. Rio de Janeiro: Paz e Terra, 1987. 
CASTELLS, M. Sociedade em Rede, vol. I, Rio de Janeiro: Paz e Terra, 1999.

. O Poder da Identidade, vol. II, Rio de Janeiro: Paz e Terra, 1999a.

CHAUÍ, M. de S. Ética e violência. Teoria e Debate. São Paulo, Fundação Perseu Abramo. Disponível em:

http://www2.fpa.org.br/portal/modules/news/article.php?storyid=2305

Acesso em 3 de setembro de 2007.

ELIAS, N. O Processo civilizador, uma história dos costumes. v. I, 2 $2^{\mathrm{a}}$ ed, Rio de Janeiro: Zahar, 1994.

ESPÍRITO SANTO, S.S.R. do. O processo de constituição da violência nas relações juvenis de tensão na escola noturna.. Belo Horizonte: Dissertação de Mestrado (Educação). Universidade Federal de Minas Gerais, 2002.

GONÇALVES, L.A.O. e SILVA, P.B.G e. Movimento negro e Educação Rio de Janeiro, Revista Brasileira de Educação, v 15, n 6, p.134-158, 2000 .

MOLENAT, X. L'Individu contemporain, Paris: Ed Sciences Sociales, 2006. MORAES FILHO, E.(org.) Simmel. São Paulo: Ática, 1983.

PAIXÃO, M. O desenvolvimento econômico e o lema das relações raciais no Brasil. Revista Virtual de Gestão de Iniciativas Sociais. Rio de Janeiro, p.33-38, 2006.

e GOMES, F. dos S. Exclusão racial, uma questão política e moral. Teoria e Debate. São Paulo, ano 19, n68. p.30-36, 2006.

RIBEIRO, R. Droga, Juventude: os significados atribuídos ao consumo de drogas ilícitas por jovens alunos de escolas públicas. Belo Horizonte: Dissertação de Mestrado (Educação). Universidade Federal de Minas Gerais, 2002.

RUAS, M. das G. e ABRAMOVAY, M. Violência nas escolas. Brasília: UNESCO, 2003.

SPOSITO, M e CORROCHANO, M.C. A face oculta da transferência de renda para os jovens no Brasil. Revista Tempo Social. São Paulo. N.2, p.141-172, 2005. 
, SILVA. H.H. de C. e SILVA, N.A. da. Juventude e poder local; um balanço das iniciativas públicas voltadas para jovens em municípios de regiões metropolitanas. Revista Brasileira de Educação. São Paulo. V.11, n. 32, p.248-267, 2006.

SIMMEL, G. La tragédie de la culture et autres essais, Paris: Editions Rivages, 1988.

TOURAINE, A. Le retour de l'acteur, Paris: Fauyard, 1984.

WIEVIORKA, M (Org.) Les Sciences Sociales en Mutations, Paris: Ed Sciences Sociales, 2007. 


\title{
DIREITOS HUMANOS E RESPONSABILIDADE ÉTICA NO EXERCÍCIO DA PSICOLOGIA
}

\author{
Andrea Ferrero* \\ Universidad Nacional de San Luis, Argentina
}

\begin{abstract}
importância da ética em todo o tipo de intervenção no campo da 1 psicologia é, em nossos dias, um fato inquestionável, tendo ficado estabelecido que um bom desempenho científico e profissional irá apoiar-se em duas colunas: o grau de conhecimento adquirido e a posição ética desde onde este conhecimento é instrumentalizado, já que cada intervenção não tem explícita uma posição ética (CORTINA, 2003).
\end{abstract}

O aporte mais relevante nesse sentido tem sido sem dúvida a promulgação dos Direitos Humanos, já que toda prática eticamente correta deve respeitar, antes de tudo, o conjunto de declarações que fazem referência aos mesmos e põem em jogo determinado tipo de valores básicos afins (PEREIRA, RIBEIRO \& CARDOSO, 2004), mesmo que a base da ética da prática profissional seja o fato de ser exercida por e para cidadãs e cidadãos. No caso da psicologia, o compromisso com os Direitos Humanos tem adquirido um caráter particular, dado que é uma ciência e uma profissão com um elevado nível de compromisso e de responsabilidade social (FERRERO, 2000, 2003).

\footnotetext{
Doutora em Psicologia. Professora e pesquisadora, Ministério de Educação, Ciência y Tecnologia da Nação Argentina. Diretora do Projeto de Investigação “Aspectos deontológicos e éticos da graduação e da prática profissional da psicologia na Argentina. Estudo comparativo entre os países do Mercosul”, aprovado pela Secretaria de Ciência e Técnica da Universidade Nacional de San Luis, Argentina. Membro da Sociedade Argentina de Bioética. Coordenadora da Task Force de "Ética e deontologia Profissional" da Sociedade Interamericana de Psicologia. E-mail: aferrero@unsl.edu.ar
} 
As declarações de direitos humanos de caráter geral historicamente mais representativas são: a Declaração Universal dos Direitos Humanos (ORGANIZAÇÃO DAS NAÇÕES UNIDAS, 1948), a Declaração Americana dos direitos e deveres do homem (ORGANIZAÇÃO DOS ESTADOS AMERICANOS, 1948), o Pacto Internacional de Direitos Econômicos, Sociais e Culturais (ORGANIZAÇÃO DAS NAÇÕES UNIDAS, 1966), a Convenção Americana sobre Direitos Humanos (ORGANIZAÇÃO DOS ESTADOS AMERICANOS, 1969), e a Declaração de Viena (ORGANIZAÇÃO DAS NAÇÕES UNIDAS, 2003).

Embora todas estas declarações tenham alguma particularidade, todas elas incluem tanto artigos de caráter geral referidos à defesa da dignidade das pessoas, como artigos especificamente relacionados com o direito à saúde, ao processo social e a uma vida digna, em todos seus aspectos, reconhecendo também o direito de toda pessoa ao desfrute do mais alto nível possível da saúde física e mental.

Sobre os direitos fundamentais, que obviamente incluem a saúde física e mental, é necessário destacar a importância que adquiriram as declarações estabelecidas pela Convenção Internacional sobre a Eliminação de Todas as Formas de Discriminação Racial (ORGANIZAÇÃO DAS NAÇÕES UNIDAS, 1965) e pela Convenção sobre a Eliminação de Todas as Formas de Discriminação Contra as Mulheres (ORGANIZAÇÃO DAS NAÇÕES UNIDAS, 1979), as duas já ratificadas.

Dentro as declarações dos direitos referidas ao âmbito da saúde, relacionadas com os chamados direitos da segunda geração, os direitos sociais, econômicos e culturais, encontramos declarações vinculadas especificamente ao campo da saúde mental, sendo as mais tradicionais a Declaração de direitos de pessoas com atraso mental (ORGANIZAÇÃO DAS NAÇÕES UNIDAS, 1971), a Declaração de direitos de pessoas deficientes (ORGANIZAÇÃO DAS NAÇÕES UNIDAS, 1975), e os princípios para a Proteção de Pessoas Acometidas de Transtorno Mental e a Melhoria da Assistência à Saúde Mental (ORGANIZAÇÃO DAS 
NAÇÕES UNIDAS, 1991), cujos princípios têm sido atualizados e ampliados na Declaração de Quito em abril de 2003 (ORGANIZAÇÃO DAS NAÇÕES UNIDAS, 2003).

Todas estas declarações foram progressivamente ocupando diversos aspectos da vida dos seres humanos, e dando conta da necessidade de preservar direitos que anteriormente não eram considerados, como o direito à paz ou à solidariedade dos povos, chamados direitos de terceira geração. Inclusive, as novas tecnologias começaram a propiciar a necessidade de pensar-se em uma quarta geração de direitos humanos, como são os referidos ao campo da investigação biomédica e da comunicação.

Mesmo que todos os documentos citados constituam direitos iniludíveis de cidadãs e cidadãos, e impliquem deveres e obrigações em nível pessoal e social, fundamentalmente, por parte dos poderes públicos, estes deveres adquirem uma maior relevância se estão relacionados com o exercício de uma profissão que tem impacto diretamente na saúde da comunidade, como é o caso da psicologia (GOUVEIA, VASCONCELOS, QUEIROGA, FRANCA E OLIVEIRA, 2003; LINDSAY, 1996; LOLAS-STEPKE, 1995).

Ao mesmo tempo, a tarefa de investigação em saúde, especialmente em se tratando de investigação com os seres humanos, tem considerado particularmente o aporte da ética desde o campo dos direitos humanos, sendo cada vez mais específicas as normativas que regulam este tipo de práticas. Sem dúvida, o primeiro antecedente de defesa de direitos de participantes em uma investigação foi o Código de Nuremberg, sancionado pelo Tribunal Internacional do mesmo nome, em 1947 (INTERNATIONAL MILITARY TRIBUNAL AT NUREMBERG, 1949). O contexto deste Código foi dado pelas evidências surgidas nos julgamentos de Nuremberg com respeito aos experimentos realizados com seres humanos vítimas do regime nazista, atingindo todo tipo de direitos. Um dos aspectos determinantes das sentenças foi que os responsáveis pelas investigações não somente tinham causado sofrimentos excessivos aos participantes, como nunca tinham obtido o consentimento voluntário dos sujeitos envolvidos. O Código de Nuremberg 
assentou as bases da defesa dos direitos dos sujeitos participantes em investigações relacionadas com a saúde: o consentimento voluntário, a eliminação do sofrimento, o cálculo dos riscos e a prioridade de preservar o bem-estar do participante em relação aos interesses do experimento (INTERNATIONAL MILITARY TRIBUNAL AT NUREMBERG, 1949).

A partir desta declaração, foram gerados diversos tipos de regulamentos, como o Informe Belmont: Princípios éticos e guia para a proteção de sujeitos humanos de investigação (NATIONAL COMMISSION FOR THE PROTECTION OF HUMAN SUBJECTS OF BIOMEDICAL AND BEHAVIOURAL RESEARCH, 1979), as Pautas Éticas Internacionais para a Investigação e Experimentação Biomédica em Seres Humanos (COUNCIL FOR INTERNATIONAL ORGANIZATIONS OF MEDICAL SCIENCES e WORLD HEALTH ORGANIZATION, 2002), o Guia para a conduta em investigação que envolve sujeitos humanos (UNITED STATES DEPARTMENT OF HEALTH AND HUMAN SERVICES. NATIONAL INSTITUTES OF HEALTH, 1995), a Declaração de Helsinki: Princípios éticos para as investigações médicas em seres humanos (WORLD MEDICAL ASSOCIATION, 2004), e a Declaração Universal sobre Bioética e Direitos Humanos, adotada por aclamação em 19 de outubro de 2005 pela 33a Sessão da Conferência Geral da UNESCO (ORGANIZAÇÃO DAS NAÇÕES UNIDAS PARA A EDUCAÇÃO, CIÊNCIA E CULTURA, 2006).

A Declaração de Helsinki foi formulada pela Assembleia da Associação Médica Mundial, em Helsinki, em 1964, e ampliada e modificada ligeiramente em cinco sucessivas Assembleias da Associação Médica Mundial, a última das quais foi a de Edimburgo, em 2000, e duas inclusões aclamatórias a respeito de alguns conceitos chaves, em 2002 e 2004. A declaração de Helsinki é atualmente considerada a principal regulação ética destinada a preservar o bem-estar e a defender os direitos dos sujeitos envolvidos em investigações, especialmente no âmbito biomédico (WORLD MEDICAL ASSOCIATION, 2004). 
Em princípio é possível encontrar grandes diferenças entre estas declarações, já que algumas são de caráter mais geral e mencionam princípios éticos básicos, como o Informe Belmont, e outras têm um elevado nível de especificação desenvolvido ao longo de grande quantidade de artigos, com é o caso da Declaração de Helsinki. Sem embargo todas elas têm um objetivo comum, que é o de preservar o bem-estar físico, psicológico e social dos indivíduos e das comunidades que participam em tarefas de investigação, incluídas nas investigações psicológicas.

Dito bem-estar se centrará basicamente no respeito à decisão de indivíduos e comunidades de participar ou não das mesmas, de deixar de participar quando assim o decidam, de não ser submetidos a nenhuma classe de dano, maltrato ou desvalorização, e de jamais colocar a finalidade da investigação sobre o bem-estar dos participantes.

Ao mesmo tempo, estas regulações destinadas a proteger os direitos dos participantes de investigações se relacionam diretamente com os princípios básicos da bioética de beneficência (e não da "maleficência"), autonomia e justiça, os quais propiciam que cientistas e profissionais guiem a produção e aplicação dos seus conhecimentos a partir de um uso ético dos mesmos. Estes princípios básicos da bioética evidenciam a passagem de uma velha moral de caráter naturalista (o que acontece é assim porque está na mesma natureza do sujeito, inclusive porque assim quis Deus), a uma nova moral de ordem basicamente normativista, na qual é relevante a noção de indivíduo autônomo e ao mesmo tempo parte de uma comunidade, a qual gera suas próprias normas de convivência tendentes à preservação do bemcomum (DRANE, 2002; MAINETTI, 2000).

Junto a estes desenvolvimentos, referidos especialmente ao âmbito geral dos direitos humanos e ao da investigação com humanos, as profissões vinculadas à saúde também têm realizado um importante aporte desde o ponto de vista normativo, gerando ferramentas tendentes à regulação de todo tipo de prática em saúde, de acordo com os diversos campos profissionais psicologia, medicina, trabalho social, enfermagem etc. 
Estas normativas são, basicamente, os respectivos códigos deontológicos, habitualmente chamados códigos de ética profissional, onde se expressam os limites do exercício da profissão desde o ponto de vista ético, e se apresentam os princípios fundamentais expressos tanto nas declarações de direitos como nos princípios bioéticos mencionados. Se nos circunscrevermos às normativas que regulam o exercício da psicologia, é necessário destacar que atualmente todas as leis relativas ao exercício profissional apoiam que os direitos humanos formem parte dos princípios iniludíveis que devem guiar ou acionar o profissional (FERRERO, 2005).

Nesse mesmo sentido, os códigos de ética profissional da psicologia de maior impacto, como o da American Psychological Association, o da European Federation of Psychologist's Associations, o Protocolo de Acordo Marco de Princípios Éticos para o Exercício Profissional dos Psicólogos no Mercosul e Países Associados, e inclusive numerosos códigos nacionais de nossos países latinos americanos, contam entre os denominados princípios gerais o respeito pelos direitos e a dignidade das pessoas, seja de forma explícita ou implícita (American Psychological Association, 2002; EFPPA, 1995; Comité Coordinador de Psicólogos del Mercosur y Países Asociados, 1999). Atualmente, os princípios gerais destes códigos são praticamente idênticos, e, com pequenas diferenças, fazem referência aos mesmos aspectos (FERRERO, 2006; LEACH \& HARBIN, 1997).

Como exemplo, analisaremos o conteúdo dos princípios gerais do Protocolo de Acordo Marco de Princípios Éticos para o Exercício Profissional dos Psicólogos no Mercosul e Países Associados, do Comitê Coordenador de Psicólogos do Mercosul e Países Associados, formulado em 1997. Nele se faz evidente a presença dos direitos humanos. Para tanto, o primeiro dos seus pontos, denominado precisamente "Respeito pelos direitos e a dignidade das pessoas", aponta explicitamente para esta temática, e por isso o citamos de forma completa:

Os Psicólogos se comprometem a fazer próprios os princípios estabelecidos pela Declaração Universal dos Direitos Humanos. Assim sendo, guardarão respeito aos direitos fundamentais, à 
dignidade e ao valor de todas as pessoas, e não participarão em práticas discriminatórias. Respeitarão o direito dos indivíduos à privacidade, confidencialidade, autodeterminação e autonomia (COMITÉ COORDINADOR DE PSICÓLOGOS DEL MERCOSUR Y PAIISES ASOCIADOS, 1999, pp. 11) (Tradução nossa).

Além da referência explícita aos direitos humanos, neste ponto que inaugura o Protocolo, a mesma intenção se faz também presente nos outros itens do mesmo, referidos a diversos aspetos centrais da prática profissional. Vemos assim que no ponto $B$. Competência, se menciona que os psicólogos: "Terão em conta que as competências que se requerem na assistência, ensino e/ou estudos de grupos humanos, variam com a diversidade desses grupos”. No ponto $D$. Integridade, se esclarece que os psicólogos: "Se empenharão em ser sumamente prudentes frente às noções que degeneram em rotulações desvalorativas ou discriminatórias”. Finalmente, o ponto E. Responsabilidade social apoia que: “Os psicólogos exercem seu compromisso social através do estudo da realidade e promovem e/ou facilitam o desenvolvimento de leis e políticas sociais que indiquem, desde sua especialidade profissional, a criar condições que contribuam ao bem-estar, ao desenvolvimento do indivíduo e da comunidade" (COMITÉ COORDINADOR DE PSICÓLOGOS DEL MERCOSUR Y PAÍSES ASOCIADOS, 1999, pp. 12-13) (Tradução nossa).

Nestes princípios gerais vinculados à competência, à integridade e à responsabilidade social dos profissionais da psicologia, é possível reconhecer a necessidade de respeitar a diversidade individual e cultural, evitar qualquer prática discriminatória, e propiciar políticas sociais tendentes ao desenvolvimento individual e coletivo, aspectos todos vinculados aos direitos básicos das pessoas e das comunidades (COMITÉ COORDINADOR DE PSICÓLOGOS DEL MERCOSUR Y PAÍSES ASOCIADOS, 1999; FERRERO, no prelo).

Além destes princípios gerais, os códigos deontológicos de caráter vinculante da psicologia contam com artigos específicos que também se relacionam com os direitos humanos dos consultantes. Por exemplo, a 
obrigação de respeitar o segredo profissional a confidencialidade, se sustenta no respeito ao direito de privacidade, a necessidade de contar com o consentimento informado se relaciona com o respeito ao princípio de autonomia, e portanto com o direito à livre decisão. A responsabilidade nas relações profissionais aponta para a preservação dos direitos básicos dos consultantes frente à assimetria de papéis existentes. A responsabilidade com a comunidade estabelece especificamente a não discriminação em função de nacionalidade, religião, raça, ideologia ou preferências sexuais de seus consultantes. Inclusive, as pautas estabelecidas com respeito à publicidade que realizam os profissionais acerca de seus serviços, apontam ao direito à informação veraz por parte dos consultantes (FERRERO, 2000). É possível, então, advertir como as obrigações profissionais estipuladas nos códigos deontológicos da psicologia se articulam de modo indissolúvel com o respeito pelos direitos do indivíduo e da comunidade, sendo estes outros seus colegas, seus consultantes ou membros da comunidade em geral.

A partir do percurso realizado, verifica-se que tanto as regulações gerais vinculadas ao âmbito da saúde e da investigação com seres humanos, como as específicas do campo da psicologia levam em consideração os temas estabelecidos pelos direitos humanos, e portanto estão destinadas a defender os direitos dos consultantes e da comunidade, já que uma prática profissional e científica ética deverá estar sempre socialmente situada. Em virtude disso, podemos concluir que o exercício profissional da psicologia, em qualquer dos seus campos de aplicação, deverá sustentar-se não só em um desenvolvimento científico e técnico da maior qualificação possível, se não também em um iniludível compromisso ético, baseado no respeito irrestrito pelos direitos humanos.

Referências

AMERICAN PSYCHOLOGICAL ASSOCIATION. Ethical principles of Psychologists and Code of Conduct. American psychologist, Washington, v. 57, n. 12, p.1060-1073. dez/2002. 
COMITÉ CORDINADOR DE PSICÓLOGOS DEL MERCOSUR Y PAÍSES ASOCIADOS. Protocolo de acuerdo marco de principios éticos para el ejercicio profesional de los psicólogos en el Mercosur y Países Asociados. In: CONSELHO FEDERAL DE PSICOLOGIA. A psicologia no Mercosul (pp. 11-14). Brasilia: Autor, 1999.

CORTINA, A. Ética mínima. Introducción a la filosofía práctica. Madrid: Tecnos, 2003.

COUNCIL FOR INTERNATIONAL ORGANIZATIONS OF MEDICAL SCIENCES (CIOMS) e WORLD HEALTH ORGANIZATION. International Ethical Guidelines for Biomedical Research Involving Human Subjects. Geneve: Author, 2002

DRANE, J.F. What is bioethics? A history. In: LOLAS-STEPKE, F. \& AGAR-CORBINOS L (Eds.). Interfaces between bioethics and the empirical social sciences (pp. 15-31). Santiago de Chile: Regional Program on Bioethics OPS/OMS Publication Series, 2002.

EUROPEAN FEDERATION OF PROFESSIONAL PSYCHOLOGISTS ASSOCIATIONS - EFPPA. European metacode of ethics. Brussels: Author, 1995.

FERRERO, A. La ética en psicología y su relación con los derechos humanos. Fundamentos en Humanidades, San Luis (Argentina), v. 2, n.2, p. 21-42, dez. 2000.

- Consecuencias sociales y psicológicas de la globalización en Argentina. Una mirada desde la ética profesional. Revista Iberoamericana de Educación, Salud y Trabajo, Rosario (Argentina), n. 4, p. 253-264, jul. 2003.

. El surgimiento de la deontología profesional en el campo de la psicología. Fundamentos en Humanidades, San Luis (Argentina), v. 6, n. 11, p. 182-190, out. 2005.

. Human Rights and Psychology Ethics Codes in Argentina. In: COLUMBUS, A (Ed.), Advances in Psychology Research, (pp. 129135). New York: Nova Science Publishers, 2006. 
- Professional ethics in psychology facing disadvantaged social conditions in Argentina. Professional Ethics: A Multidisciplinary Journal, Gainesville, Florida, 25, no prelo.

GOUVEIA, V.; VASCONCELOS, T.; QUEIROGA, F.; FRANCA, M. e OLIVEIRA, S. A dimensão social da responsabilidade pessoal. Psicologia em Estudo, Maringá, v. 8, n. 2, p.123-131, jul.-dez/2003.

INTERNATIONAL MILITARY TRIBUNAL AT NUREMBERG. Nuremberg Code. In: Trials of War Criminals before the Nuremberg Military Tribunals under Control Council Law No. 10, Vol. 2 (pp 181-182). Nuremberg: Washington, DC: US Government Printing Office, 1949.

LEACH, M.M. \& HARBIN, J.J (1997). Psychological Ethics Code: a comparison of twenty-four countries. International Journal of Psychology, East Sussex, v. 32, n. 3, p.181-192, may-jun/1997.

LINDSAY, G. Psychology as an ethical discipline and profession. European Psychologist, Göttingen, v. 1, n. 2, p. 79-88, jun. 1996.

LOLAS-STEPKE, F. Apuntes para un ética del saber. In: ROVALETTI, M.L. (Ed.), Ética y psicoterapia (pp. 147-154). Buenos Aires: Biblos, 1995.

MAINETTI, J.A. Compendio bioético. La Plata: Editorial Quirón, 2000.

NATIONAL COMMISSION FOR THE PROTECTION OF HUMAN SUBJECTS OF BIOMEDICAL AND BEHAVIORAL RESEARCH. Belmont Report. Washington: Autor, 1979.

ORGANIZAÇÃO DAS NAÇÕES UNIDAS. Declaração Universal dos Direitos Humanos, 1948. In: Universidade de São Paulo. Comissão de Direitos Humanos, Biblioteca Virtual de Direitos Humanos. Disponível em:

www.direitoshumanos.usp.br/counter/declaracao/declaracao_univ.html Acesso em: 11 abr 07.

. Convenção Internacional sobre a Eliminação de Todas as Formas de Discriminação Racial, 1965. In: Universidade de São Paulo. Comissão de Direitos Humanos, Biblioteca Virtual de Direitos Humanos. Disponível em:

www.direitoshumanos.usp.br/counter/Onu/Minorias_discriminacao/text o/texto_1.html Acesso em: 10 abr 07. 
Pacto Internacional de Direitos Econômicos, Sociais e Culturais, 1966. In: Universidade de São Paulo. Comissão de Direitos Humanos, Biblioteca Virtual de Direitos Humanos . Disponível em:

www.direitoshumanos.usp.br/counter/Onu/Sist_glob_trat/texto/texto_2. html. Acesso em: 9 abr 07.

- Convenção sobre a Eliminação de Todas as Formas de Discriminação Contra as Mulheres, 1979. In: Universidade de São Paulo. Comissão de Direitos Humanos, Biblioteca Virtual de Direitos Humanos. Disponível em:

www.direitoshumanos.usp.br/counter/Onu/Mulher/texto/texto_3.html Acesso em: 12 abr 07.

- Declaração de Quito, 2003. Documento elaborado durante o Seminário e Oficina Regional das Américas sobre normas e padrões existentes em relação aos direitos das pessoas com deficiência (Tradução de Romeu Kazumi Sassaki). Disponível em:

ww2.prefeitura.sp.gov.br//arquivos/secretarias/saude/deficiencia/0008/De claracao_de_Quito.pdf

Acesso em: 11 abr 07.

. Declaração e Programa de Ação de Viena, 1993. In: Universidade de São Paulo. Comissão de Direitos Humanos, Biblioteca Virtual de Direitos Humanos. Disponível em:

www.direitoshumanos.usp.br/counter/Onu/Confere_cupula/texto/texto_ 3.html. Acesso em: 10 abr 07.

. Declaration on the Rights of Mentally Retarded Persons. New York: Author, 1971. [G.A. res. 2856 (XXVI), 26 U.N. GAOR Supp (No.29) at 93, U.N. Doc. A/8429].

. Declaration on the Rights of Disabled Persons. New York: Author, 1975. [G.A. res. 3447 (XXX), 30 U.N. GAOR Supp (No. 34) at 88, U.N. Doc. A/10034].

. Principles for the Protection of Persons with Mental Illnesses and the Improvement of Mental Health Care. New York: Author, 1991. [G.A. res. 46/119, 46 U.N. GAOR Supp (No. 49) at 189. U.N. Doc. A/46/49]. 
ORGANIZAÇÃO DAS NAÇÕES UNIDAS PARA A EDUCAÇÃO, CIÊNCIA E CULTURA (UNESCO). Declaração Universal sobre Bioética e Direitos Humanos [Adotada em 19 de outubro de 2005 pela 33a. Sessão da Conferência Geral da UNESCO]. Tradução pela Comissão Nacional da UNESCO - Portugal. Paris: Organização das Nações Unidas para a Educação, Ciência e Cultura. Divisão de Ética das Ciências e Tecnologias. Sector de Ciências Sociais e Humanas, 2006.

ORGANIZAÇÃO DOS ESTADOS AMERICANOS. Declaração Americana dos direitos e deveres do homem, 1948. Disponível em: www.cidh.oas.org/Basicos/Portugues/b.Declaracao_Americana.htm Acesso em: 25 abr 07.

. Convenção Americana sobre Direitos Humanos, 1969. Disponível em:

www.cidh.oas.org/Basicos/Portugues/c.Convencao_Americana.htm Acesso em: 25 abr 07.

PEREIRA, C.; RIBEIRO, A. \& CARDOSO, S. Envolvimento nos direitos humanos e sistemas de valores. Psicologia em Estudo. v. 9, n. 1, p. 55-65, jan-abr/2004.

UNITED STATES DEPARTMENT OF HEALTH AND HUMAN SERVICES. NATIONAL INSTITUTES OF HEALTH. Guidelines for the Conduct of Research Involving Human Subjects at the National Institutes of Health. Washington: Author, 1995.

WORLD MEDICAL ASSOCIATION. World Medical Association Declaration of Helsinki. Ethical Principles for Medical Research Involving Human Subjects. Tokyo: Author, 2004. 


\title{
GÊNERO E SEXUALIDADE: HISTÓRIA, CONDIÇÕES E LUGARES
}

CAPÍTULO 9

\author{
GÊNERO EM CONTEXTOS RURAIS: \\ A LIBERDADE DE IR E VIR E O CONTROLE DA \\ SEXUALIDADE DAS MULHERES NO SERTÃO DE \\ PERNAMBUCO ${ }^{1}$
}

Rosineide de L. M. Cordeiro

Universidade Federal de Pernambuco

\section{Apresentação}

— ste trabalho pretende compreender as restrições e os obstáculos de gênero à liberdade de ir e vir das lideranças e participantes do Movimento de Mulheres Trabalhadoras Rurais do Sertão Central de Pernambuco (MMTR), tendo como hipótese norteadora que na restrição ao ir e vir das mulheres também se consubstancia o controle da sexualidade feminina. Para isto, dialoga com as ideias de Foucault (2004) sobre moral e sexualidade, com as reflexões feministas sobre gênero (SCOTT, 1991) e o referencial das práticas discursivas e produção de sentidos no cotidiano (SPINK, 1999).

O texto está organizado em três partes: a primeira apresenta a discussão sobre as ordens morais de gênero e a fofoca como prática discursiva; a segunda aborda a participação das mulheres em movimentos como uma ameaça às ordens morais de gênero; e a última enfoca as

\footnotetext{
${ }^{1}$ Este trabalho é uma síntese de um capítulo da minha tese de doutorado em psicologia social (CORDEIRO, 2004). Uma parte destas reflexões foi publicada em Cordeiro (2006).
} 
restrições ao ir e vir das mulheres no Sertão Central. Utilizei as observações etnográficas realizadas para a minha pesquisa de tese de doutorado durante dois anos (2001 e 2003) no Sertão de Pernambuco e incluí, também, trechos de relatórios produzidos pelo movimento de mulheres e depoimentos presentes em dissertações, teses e artigos que de alguma forma fazem referência à temática.

\section{As ordens morais de gênero}

No texto 'Os usos dos prazeres e as técnicas de si', para responder à indagação de por que e sob qual forma a atividade sexual foi constituída como domínio moral, Foucault estabelece diferenças importantes entre código moral, moralidade dos costumes e o sujeito moral. Ele define código moral como o conjunto de valores e normas que são prescritas por meio de diversos aparelhos; a moralidade dos costumes se refere ao comportamento dos indivíduos em sua relação com as regras e os valores; e o sujeito moral é a maneira como é preciso conduzir-se e constituir a si mesmo como sujeito moral.

Foucault faz uma série de admoestações quanto à suposta aceitação irrestrita e sujeição dos indivíduos aos preceitos morais. Assinalarei três delas. A primeira diz respeito à transmissão e veiculação das normas e valores. O autor destaca que, longe de formar um conjunto alinhado e coerente, elas constituem “(...) um jogo complexo de elementos que se compensam, se corrigem, se anulam em certos pontos, permitindo dessa forma compromissos ou escapatórias” (2004, p. 211). A segunda enfoca a maneira pela qual, as pessoas aceitam, resistem, respeitam ou negligenciam um principio de conduta, uma interdição ou um conjunto de valores. Para Foucault, o estudo da moralidade dos comportamentos deve precisar de que modo e com que margem de variação ou de transgressão os indivíduos ou grupos se conduzem em referência a um sistema prescritivo numa dada cultura. A última se refere à variedade de modos de condução do sujeito moral. Para o autor, há muitas formas de ser fiel e obediente a um princípio 
moral, e isto não significa operar simplesmente como agente passivo, mas sim como sujeito moral da ação.

O autor destaca então que a moral inclui o código das condutas e as formas de subjetivação. "Toda ação moral implica uma relação com o real em que ela se realiza, e uma relação com o código a qual ela se refere; mas também implica uma certa relação consigo mesmo; esta não é simplesmente 'consciência de si', mas a constituição de si como 'sujeito moral' (...)" (FOUCAULT, 2004, p.214). Essas duas dimensões não devem ser dissociadas, contudo, eventualmente possuem certa autonomia. Em certas sociedades ou períodos históricos a ênfase é no código, em outras, nas formas de subjetivação e nas práticas de si.

Com base em Foucault, defino como ordens morais de gênero os valores e as normas pertencentes a uma dada matriz heterossexual que circunscrevem as maneiras pelas quais homens e mulheres devem se constituir e se conduzir num certo sistema prescritivo de gênero. Considero ainda que homens e mulheres, de acordo com as posições que assumem nas diferentes relações sociais, combinam formas variadas de adesão e ou rejeição às ordens morais de gênero. Há diferentes modos de burlar, transgredir e resistir aos valores e às normas que circulam num determinado contexto cultural linguisticamente pautado.

$\mathrm{Na}$ trama das relações interpessoais as transgressões e negligências não são isentas de sanções e coerções. Os burburinhos, disse me disse, anedotas, sussurros, rumores, mexericos que assolam o cotidiano tentam impor limites aos amores mal-ditos e a quem escapa para além do que é permitido, fazendo Deus sabe o quê. Falo da fofoca como prática discursiva.

É importante reiterar que para a compreensão da fofoca estou considerando uma das correntes voltadas ao estudo da linguagem que se aproxima da psicologia discursiva. O foco são as práticas discursivas, que são entendidas como práticas sociais e como linguagem em ação. Para Spink e Medrado (1999), elas constituem as diferentes maneiras a partir das quais as pessoas produzem sentido e se posicionam em relações cotidianas. 
Na versão de Davies e Harré (1996) são todas as formas por meio das quais as pessoas ativamente produzem realidades sociais e psicológicas.

Na análise da fofoca concentrar-me-ei nos conteúdos das práticas discursivas, ou seja, nos repertórios linguísticos. Na definição de Potter et al. (1990), os repertórios são agrupamentos de termos facilmente discerníveis, descrições, lugares-comuns e figuras de linguagens muitas vezes agrupadas em torno de metáforas ou imagens.

Potter lembra que a ideia de repertório é semelhante à do repertório do(a) bailarino(a), que escolhe determinados movimentos de acordo com o contexto imediato. A ênfase se volta para a flexibilidade do uso do repertório, ou seja, como é utilizado em contextos discursivos e interacionais específicos.

Catarina Tanaka (2003) aborda que a fofoca tem um aspecto paradoxal: ao mesmo tempo em que gera constrangimentos, favorece a interação e o entretenimento. Tem especial importância no campo da interação social e das práticas cotidianas. Para mim, a fofoca é uma forma de contar histórias sobre a vida dos outros que alimenta os vínculos e a cumplicidade entre os(as) participantes e o sentimento de pertença ao grupo ou comunidade. Pelo seu caráter ambíguo também é um dos recursos costumeiramente utilizados para o controle, a vigilância e a regulação das condutas num dado sistema prescritivo.

\section{A participação das mulheres em movimentos como ameaça às ordens morais de gênero}

As pesquisas sobre a agricultura familiar tendem a assinalar o padrão rígido e assimétrico das relações de gênero na área rural. Os(as) pesquisadores(as) ressaltam que as mulheres são confinadas ao espaço da casa, do roçado e da comunidade onde moram, defrontando-se com ordens morais de gênero que impõem duras restrições ao ir e vir.

Se o espaço socialmente atribuído às mulheres na área rural está circunscrito a casa, ao grupo familiar e à comunidade a que pertencem, cabe 
aos homens lidar com outros espaços sociais. Isso significa usufruir a liberdade de ir e vir e poder circular em outros lugares, comunidades vizinhas e cidades. Como compete aos homens a gestão da unidade familiar, a aquisição de equipamentos para o trabalho, a comercialização dos produtos e o comércio de terras, eles desfrutam de espaços e de relações inerentes a essas atividades — o comércio, a feira, as exposições, os bancos, órgãos públicos e programas governamentais. Além disso, homens jovens e adultos têm mais liberdade do que as mulheres para sair, beber com os amigos, ir às festas e jogos, não necessariamente acompanhados da família.

Essa análise se transformou quase num modelo ideal para pensar as relações de gênero na área rural e particularmente na agricultura familiar. Entretanto, ela deixa de fora os conflitos, as tensões, as fissuras, e como homens e mulheres negociam e barganham novas posições e lugares. Também não aborda a variedade de modos de organização familiar na área rural — que não corresponde ao modelo de pai, mãe, filhos e filhas - e as diferentes formas de organização da produção familiar.

Uma das formas que parece ameaçar as relações de gênero na agricultura familiar é a participação das mulheres em movimentos sociais. As ativistas ampliam as redes de relações para além dos sítios e comunidades e desenvolvem novos interesses e compromissos fora da família; deslocam-se de suas casas para participar de eventos promovidos pelos movimentos, ficam dias fora de casa e muitas vezes viajam para fora do município e do estado. Reorganizam o tempo e as suas atividades agrícolas e domésticas. Essas inflexões provocam tensões e conflitos nas famílias e não passam despercebidas dos(as) parentes, vizinhos(as) e comunidade.

\section{As restrições e os obstáculos ao ir e vir das mulheres}

Sair de casa para as mulheres ativistas aparece como um aprendizado e uma conquista. No rol das conquistas elas incluem trabalhar fora de casa e ter liberdade para viajar, participar de encontros e passear. 
Quando elas falam que aprenderam a sair de casa, geralmente ressaltam três aspectos: o primeiro é o desvencilhamento dos serviços e das responsabilidades domésticas — destacam que aprenderam a largar a casa para ir aos encontros; o segundo refere-se aos vínculos interpessoais fora da família e da comunidade - além de conhecer pessoas novas elas são reconhecidas e valorizadas fora do espaço da casa; o terceiro diz respeito à liberdade de forma mais ampla, que inclui andar sozinha e ser livre para sonhar, andar, falar, pensar e viajar.

Entretanto, mesmo que as mulheres reconheçam que aprenderam a sair de casa e transitar em outros espaços, elas ainda enfrentam muitas dificuldades. Poderíamos dizer que esta ainda não é uma conquista plenamente estabelecida para as participantes do MMTR, e muito menos para todas as mulheres. Nos depoimentos é possível identificar três tipos de obstáculos: a distância e o acesso a transporte; a falta de apoio da família; 'as críticas' dos parentes, vizinhos e da comunidade.

Para transitar além dos sítios e das comunidades as mulheres lidam com as distâncias e a dificuldade de acesso a transporte, além dos gastos financeiros com as viagens. Como não existe na área rural regularidade do sistema de transporte, as pessoas dependem dos proprietários de carros particulares para se locomover. Há escassez de transporte, intermitência na oferta de horário ou dias e veículos que não oferecem segurança aos(às) passageiros(as). As mulheres enfrentam uma verdadeira maratona para participar de um evento fora da comunidade onde moram.

Muitas mulheres se deparam com a franca oposição ou com a falta de apoio do companheiro/marido e/ou dos(as) filhos(as). Elas se queixam que não têm com quem deixar os(as) filhos(as), que há pouca ou nenhuma divisão dos serviços domésticos e das atividades que desenvolvem. Há sobrecarga de trabalhos e é difícil conciliar suas atividades em casa e no roçado com o ativismo político.

Um outro tipo de obstáculo está relacionado ao uso da fofoca pelos(as) vizinhos(as) e comunidades para delimitar e restringir o ir e vir 
das mulheres. Ao se deslocar para além do sistema prescritivo de gênero as mulheres são alvo de boatos e mexericos. É curioso observar que as participantes afirmam que as próprias 'mulheres da comunidade’ são as que tecem criticas e cuidam para que os limites à mobilidade feminina se mantenham. Para a análise, agrupei repertórios linguísticos que dão conta da mobilidade das mulheres em quatro eixos: danos à imagem da ativista; indagações sobre os resultados da ação política; acusação de infidelidade das casadas ou questionamento da sexualidade das solteiras; incapacidade dos pais e maridos de controlar as mulheres.

Para atingir a imagem da ativista as fofocas denunciam que ela não está cumprindo com as atribuições de gênero, especialmente o papel de esposa e mãe amorosa:

Nas comunidades tem 'crítica' quando a gente vai sair, dizem: 'oxem' menina, pra onde tu vai? Que tanta viagem é essa? Chama de vadia, desocupada, perdeu o amor dos filhos, do marido, de tudo, não é mais aquela mulher responsável que era antes, e as companheiras, algumas dizem: Ah! aquela não respeita mais o marido não nessas alturas (apud MMTR, 1994, p. 34).

Temos que enfrentar ainda nossos vizinhos, depois de quatro anos de caminhada as pessoas ainda nos chamam de mulheres desocupadas, dizem que lugar de mulher é no fogão cuidando das panelas. Chamam-nos de doidas, vadias, beatas, mulheres sem governo, que o marido perdeu o controle, vão para onde querem, são mulheres soltas no mundo (apud CRUZ, 1999, p. 61).

Além disso, pesam sobre as mulheres mais três acusações: são vadias, ou seja, não têm um comportamento moral adequado às normas de gênero, nas quais o recato feminino, a obediência aos pais e ao marido, a discrição dos afetos e da sexualidade e a conformação dos limites corporais e das condutas são traços importantes; são desocupadas, num contexto no qual homens e mulheres trazem as marcas do trabalho nos corpos, nas roupas cerzidas, no cuidado com a terra, com a lavoura e com os animais —os(as) agricultores(as) falam com orgulho que trabalham para que a família tenha as coisas, o que comer e o que vestir; por último, vivem sem controle e sem governo.As ativistas são repreendidas por escapar do controle da família e 
também dos parentes, vizinhos e da comunidade como um todo. Escolher $o$ próprio destino, ser dona da sua vida, provavelmente em um espaço de valoração dos projetos individuais isto seria considerado uma qualidade, porém, não na área rural, onde os vínculos familiares, de parentesco e de vizinhança são fundamentais para a reprodução das pessoas e dos grupos.

As interpelações sobre os resultados da ação política é uma estratégia discursiva utilizada tanto pela família como pelas demais pessoas. As ativistas se defrontam com uma visão mais 'pragmática' das outras mulheres. Indagações ( $O$ que vou ganhar com isso? Para que você sai, se não traz nada para casa?) e expectativas de ganhos materiais às quais o Movimento não consegue responder de forma imediata deixam as ativistas embaraçadas.

(...) a começar da minha família mesmo, algumas criticam dizendo que a gente não ganha nada, só quem não tem o que fazer... Não sabem elas que o conhecimento vale mais do que dinheiro (apud MMTR, 2004, p. 90).

Elas também relatam as aflições para manter o funcionamento dos grupos nos sítios e localidades. É difícil convencer as mulheres, enfrentar os preconceitos de que são alvo nas comunidades e conviver com a falta de apoio dos homens. Também é árduo encarar o machismo dos homens e das mulheres na comunidade e nas organizações mistas.

As acusações de que as mulheres aproveitam os encontros para namorar ou trair os maridos são muito corriqueiras. Uma vez, conversando com as mulheres numa reunião sobre esse assunto, quase todas tinham uma história para contar. As pessoas dizem que elas vão namorar, vão botar chifre no marido ou que não têm nada para fazer. Uma delas me disse: "Oxem, mulher! o povo diz que Zé não é filho do meu marido e sim do presidente do sindicato”.

Já as solteiras são questionadas a respeito do 'verdadeiro estado civil’:

(...) cobranças dos homens do meu convívio, de ser separada, ou casada, ou solteira (apud MMTR, 2004, p. 90).

(...) se não namoramos, somos questionadas; se choramos e falamos alto e muito, somos doidas e fracas; se somos solteiras, somos 
questionadas; se viajamos muito e recebemos alguns convites, somos turistas e amostradas, queremos aparecer (apud MMTR, 2004, p. 92).

As famílias das ativistas também são recriminadas por não serem capazes de 'controlar' o ir e vir das mulheres. Na dissertação de mestrado de Lindalva Cruz (1999) sobre o movimento de mulheres do Brejo paraibano, há vários depoimentos nos quais esse tema também aparece. Num deles uma trabalhadora afirma:

Na minha comunidade era triste, todo mundo dava conta da minha vida, pra onde eu ia sair e a hora que eu chegava... Chamavam meu pai de frouxo, porque deixava eu sair, minha mãe, chamavam de depravada porque não controlava a filha, eu fiquei discriminada na comunidade (apud CRUZ, 1999, p. 120-121).

No caso dos maridos/companheiros participarem de algum movimento social, eles também são recriminados por deixar as mulheres sozinhas em casa. Ouvi de um sindicalista que algumas pessoas da comunidade foram avisar que ele estava saindo muito de casa para ir às reuniões e que se não tivesse cuidado iria levar "chifre” da mulher.

Há muitas mulheres vivendo sozinhas na área rural, entretanto, existe uma vigilância para que elas, mesmo separadas, viúvas ou solteiras, não exerçam a sexualidade fora da união conjugal. No relatório do sétimo encontro do MMTR (1992), cujo tema foi a sexualidade, as mulheres fizeram uma lista de proibições existentes a esse respeito: mulher separada fazer sexo na sua casa com outro homem; mãe solteira; sexo sem casar entre outras. Ana Paula Portella, em pesquisa sobre corpo e saúde reprodutiva no Sertão de Pernambuco, mostra que há alterações demográficas acerca do número de filhos das famílias e um discurso favorável ao uso de contraceptivos, porém “qualquer mudança no significado de casamento e família parece ser dramática” (2002, p.17).

\section{Considerações finais}

As ativistas não enfrentam obstáculos quando saem de casa para resolver problemas relacionados à saúde, educação, trabalho ou qualquer 
outra questão relativa à família. Joana, por exemplo, diz que o marido não a deixa dormir fora de casa para participar de reuniões e encontros, mas não se importa quando ela viaja para 'pagar promessa' ou acompanhar alguém que está doente.

As dificuldades se instalam quando as mulheres transgridem os espaços delimitados socialmente para elas e assumem novas posições: não estão totalmente absorvidas com as suas atribuições como mãe e esposa; estabelecem novos vínculos interpessoais fora da família e da comunidade; desenvolvem novos interesses e posturas diante de suas vidas e do entorno à sua volta. Parece que as mulheres encontram um ambiente muito mais favorável, de respeito, valorização e estima nas redes de relações tecidas além dos sítios e comunidades onde vivem.

No que se refere à fofoca, ela parece ser um dos recursos amplamente utilizados em diferentes contextos rurais para dificultar, impedir as transgressões, desrespeitos ou negligências às ordens morais de gênero pertencentes a uma dada matriz heterossexual.

Apesar das transformações na área rural e da superação do debate sobre o mundo rural e o mundo urbano como instâncias isoladas, o controle e a regulação das condutas e dos corpos das mulheres constituem elementos importantes nas ordens morais de gênero. E a família, parentes, vizinhos(as) e a comunidade exercem vigilância para que assim continue. Ficar 'falada', ‘mal-falada', ser alvo dos ‘olhares’ ‘de alguém reparando’ são algumas das artimanhas a que homens e mulheres recorrem para impor sanções, coerções ou dificultar as escapadas e piscadelas das mulheres.

Referências bibliográficas

CORDEIRO, Rosineide. Além das secas e das chuvas: os usos da nomeação mulher trabalhadora rural no Sertão de Pernambuco. São Paulo: Tese de Doutorado (Psicologia Social). Pontifica Universidade Católica de São Paulo, 2004. 
. Empoderamento e mudança das relações de gênero: as lutas das trabalhadoras rurais no Sertão de Pernambuco. In: SCOTT, Parry; CORDEIRO, Rosineide (Orgs.). Agricultura familiar e gênero: práticas, movimentos e políticas públicas (NEAD Debate 10) Recife: Editora Universitária, 2006.

CRUZ, Lindalva Alves. A emergência da mulher como sujeito político e coletivo na história do MMT/PB. João Pessoa: Dissertação de Mestrado (Serviço Social). Universidade Federal da Paraíba, 1999.

DAVIES, B.; HARRÉ, R. Posicionando: a produção discursiva de selves. Journal for the Theory of Social Behavior, v. 20, n. 1, p. 43-63, 1990. Trad. Mary Jane P. Spink. São Paulo, 1996 (mimeo).

FOUCAULT, Michel. Os usos dos prazeres e as técnicas de si. In: FOUCAULT, Michel. Ética, sexualidade e política. Rio de Janeiro: Forense Universitária, 2004. p. 192-217 (Ditos e Escritos V).

MOVIMENTO DE MULHERES TRABALHADORAS RURAIS DO SERTÃO CENTRAL DE PERNAMBUCO (MMTR). Uma história de mulheres. Serra Talhada, 1994. . Uma história de mulheres. 2. ed. atual. Serra Talhada, 2004.

- Relatório do VII Encontro de Mulheres Trabalhadoras Rurais do Sertão Central (maio de 1992). Serra Talhada, s.d.

POTTER. J. et al. Discourse: noun, verb or social practice. Philosophical Psychology, v. 3, n. 2, p. 205-217, 1990.

PORTELLA, Ana Paula. Direitos sexuais e reprodutivos no contexto rural. Cadernos SOS CORPO. Recife, julho/2002.

SCOTT, Joan. Gênero: uma categoria útil para análise histórica. Recife: SOS CORPO, 1991.

SPINK, Mary Jane P (Org.) Práticas discursivas e produção de sentidos no cotidiano. São Paulo: Cortez , 1999.

SPINK, Mary Jane P.; MEDRADO, Benedito. Produção de sentidos no cotidiano: uma abordagem teórico-metodológica para análise das práticas discursivas. In: SPINK, Mary Jane P (Org.) Práticas discursivas e produção de sentidos no cotidiano. São Paulo: Cortez, 1999. p.41-61. 
TANAKA, Catarina. A psicologia social da fofoca. São Paulo: Tese de Doutorado (Psicologia Social). Pontifícia Universidade Católica de São Paulo, 2003. 


\title{
SEXUALIDADE, GÊNERO E GERAÇÕES: CONTINUANDO O DEBATE
}

\author{
Maria Juracy Filgueiras Toneli \\ Universidade Federal de Santa Catarina
}

As pessoas dizem: "o prazer passa, a juventude acaba. Que eles tenham prazer, afinal sabemos que isso não os levará muito longe. Pagarão bem caro por esse prazer, com sofrimento $e$ dor, com solidão, com rupturas, com disputas, com ódio ou com ciúme", em suma, sabe-se que o prazer é compensado e, por conseguinte, ele não incomoda. Mas a felicidade... A felicidade não é resgatada por nenhuma infelicidade fundamental... Então, as coisas se tornam intoleráveis.

FOUCAULT citado por ERIBON, 1994/1996, p.168.

proposta do tema deste simpósio parece-me demasiadamente
abrangente e desafiadora. A justaposição de três conceitos complexos e polêmicos, por si só, já representa um desafio hercúleo, na medida em que a própria definição dos termos caracteriza-se como polissêmica e polifônica, revelando seu caráter histórico. Torna-se necessário, portanto, nessa introdução, o esclarecimento do lugar teórico que elegi nesse momento, mesmo porque, parece-me que no campo da Psicologia (e não apenas nele), persistem confusões que merecem um pouco mais de atenção.

Com intuito de uma primeira aproximação que me possibilitaria adentrar ao tema, busquei referências junto à BVS (Biblioteca Virtual em Saúde) uma das mais consultadas pela área da Psicologia, que inclui, por exemplo, a Scielo (Biblioteca eletrônica que abrange uma coleção selecionada de periódicos científicos brasileiros), a LILACS (Literatura 
Latino-Americana e do Caribe em Ciências da Saúde) e a MEDLINE (Literatura Internacional em Ciências da Saúde). Com a palavra-chave gênero, acessei 2089 títulos na Scielo, 4947 na LILACS, e 14736 na MEDLINE. Filtrando esses indicadores para os títulos que estão agregados no Î́ndex Psi Periódicos Técnico-Científicos, encontrei 257 menções, 10 no Índex Psi Periódicos de Divulgação Científica, 90 Índex Psi Teses 83 no PEPsic Periódicos Eletrônicos em Psicologia.

Ainda que não tenha conseguido analisar todos os itens, dediquei-me um pouco mais à Scielo, buscando nos resumos disponibilizados na página brasileira (415), pistas que pudessem me auxiliar a entender quem, como e porque tem utilizado o termo gênero em seus trabalhos. É importante destacar que, ao pesquisar gênero e sexualidade, encontrei 35 títulos, e com as palavras-chave gênero e geração, apenas dois. Cruzando as três palavraschave, não encontrei nenhum trabalho.

Os trabalhos encontrados refletem, no meu entender, tanto a diversidade das definições possíveis para gênero e as tradições teóricas e metodológicas a ele associadas, quanto, correlatamente, a diversidade interna da própria área da Psicologia. Nesse caso, por exemplo, é possível encontrar trabalhos que se dedicam a algum gênero animal ou vegetal, literário e/ou do discurso, assim como aqueles que ainda utilizam gênero como sinônimo da variável sexo. Em contrapartida, as filiações teóricoepistemológicas apontam, também, para debates complexos que incluem as perspectivas pós-estruturalistas, o diálogo com a psicanálise e a discussão sobre as adequações metodológicas que o conceito exigiria. Destacam-se os trabalhos publicados em revistas acadêmicas dedicadas aos feminismos como a Revista Estudos Feministas (REF) e a Cadernos PAGU, assim como a revista Psicologia \& Sociedade da ABRAPSO, em um cenário que inclui revistas das mais diversas áreas, em especial as da Saúde e da Educação.

Nesse contexto diverso, penso ser necessária a recuperação da história do conceito, uma vez que as palavras, ideias e coisas que significam têm uma 
história e lutar por uma única definição ou sentido parece, de antemão, uma causa perdida (SCOTT, 1990). É de autoria da historiadora norte-americana Joan Scott o texto que marcou visivelmente a produção acadêmica que utiliza o conceito gênero, haja vista o número de trabalhos que o citam direta ou indiretamente. Cunhado pelo feminismo anglo-saxão, a partir da chamada "segunda onda" do movimento feminista e em oposição a sexo, gênero pressupunha a forma como cada grupo cultural "dramatiza” o binarismo sexual, rechaçando a fatalidade da natureza. Nesse texto datado, Scott define o conceito de forma a incorporar a assimetria atribuída aos sexos e ao gênero, e, portanto, a noção de que as relações de gênero são relações de poder. Analisa, ainda, as principais tradições teóricas que trabalhavam com o conceito, mostrando seus limites e possibilidades. Pode-se afirmar que, na época, o próprio conceito de gênero mantinha alguns binarismos que criticava como o de natureza-cultura, uma vez que o gênero seria socialmente construído e o sexo corresponderia ao que é biologicamente dado.

Os desdobramentos e debates teóricos, no entanto, permitiram pensar que o próprio binarismo sexual é uma produção cultural e o corpo deixa de ser uma constante para ser visto como uma variável. Tomas Lacquer (2001), por exemplo, recupera a história da noção de corpo, mostrando como, no pensamento ocidental a partir do século XVII, as características físicas passaram a ser vistas como a origem das distinções masculino/feminino, culminando na noção contemporânea do corpo bissexuado. A partir de então, as diferenças anatômicas passaram a ser pensadas em termos de descontinuidade e oposição e não mais como continuidade e hierarquia, tal qual no modelo do sexo único que pensava as diferenças como sendo de grau (COSTA, 1996; NICHOLSON, 2000; LACQUER, 2001). Essa operação que cunhou, inclusive, nomes diferentes para os órgãos sexuais, ou seja, linguisticamente os instituiu como distintos, permitiu a ideia da "identidade sexual” enraizada em um corpo diferenciado.

Esse binarismo aparece presente no feminismo da "segunda onda" o feminismo da diferença que, de certa maneira, apresentava um discurso que, por um lado, diferenciava essencialmente mulheres e homens, e, por outro 
lado, igualava as mulheres entre si, de forma a permitir a produção do sujeito político "mulheres". Ou seja, o retorno ao determinismo biológico do qual se quer escapar mantém-se presente nessa lógica (igualdade na diferença), dando a entender que há algo fixo e imutável que se aplicaria a todas as mulheres como uma verdade trans-histórica (SCOTT, 2002).

A desconstrução da oposição binária igualdade/diferença é defendida por Scott (1988), uma vez que oculta a interdependência dos dois termos (a diferença não impede a igualdade e esta, por sua vez, não significa a eliminação da diferença). A igualdade reside na diferença, para Scott, e o discurso da diferença macho-fêmea oculta as inúmeras diferenças entre as mulheres (e entre os homens). A autora defende, portanto, a tese da diferença múltipla ao invés da diferença binária, entendendo que mulheres entre si diferenciam-se quanto à origem de classe, raça/etnia, geração, comportamento, caráter, desejo, subjetividade, sexualidade, experiência histórica.

Na esteira do debate, posições diversas são encontradas. Dentre elas, destacam-se as de Linda Nicholson (2000) e Judith Butler (1990, 1993a) que problematizam a ideia de natureza como algo dado e comum a todos os grupos culturais. Ademais, defendem a tese de que o gênero não é algo como uma inscrição cultural (significação) sobre um sexo previamente dado. Antes, o corpo e o sexo são interpretados e instituídos pelo gênero, de sorte que em determinadas culturas africanas pessoas com a genitália feminina podem ser pensadas como maridos, ou em grupos indígenas americanos uma pessoa com genitália masculina pode ser entendida como meio-homem e meio-mulher (NICHOLSON, 2000). Ou seja, não se pode postular a diferença entre os sexos em termos de substância, mas sim como uma ação performativa sem status ontológico (BUTLER, 1993a e 1993b), produzida pelas práticas discursivas responsáveis pelas categorizações como homens e mulheres (LACLAU \& MOUFFE, 1985).

Nessa perspectiva o sexo é produzido pelo gênero. O gênero é performático e múltiplo, é ação e não identidade ou totalidade, e está 
associado a outros vetores de distinção como classe, etnia e geração. E finalmente, as diversidades intracategorias revelam tanto quanto aquelas entre categorias, o que politicamente leva às coalizões por afinidades e não por identidades, de forma a superar as matrizes identitárias totalizadoras (HARAWAY, 2000; BUTLER, 1990).

Dessa forma, pode-se afirmar com Butler (1990) que:

O gênero pode também ser designado como o verdadeiro aparato de produção através do qual os sexos são estabelecidos. Assim, o gênero não está para a cultura como o sexo para a natureza; o gênero é também o significado discursivo/cultural pelo qual a 'natureza sexuada' ou o 'sexo natural' é produzido e estabelecido como uma forma 'pré-discursiva' anterior à cultura, uma superfície politicamente neutra sobre a qual a cultura age (BUTLER, 1990, p. 7).

Simultaneamente, essas proposições permitem pensar a sexualidade como construções sociais e históricas que sempre implicam certo tipo de conexão com as relações de poder. Nos dizeres de Gayle Rubin (1998):

O âmbito da sexualidade (...) tem sua própria política interna, iniquidades e modos de opressão. Como acontece com outros aspectos do comportamento humano, as formas institucionais concretas da sexualidade humana, num espaço e num tempo determinados, são produtos da atividade humana. Elas são repletas de conflitos de interesse e manobra política, tanto de natureza proposital quanto circunstancial. Nesse sentido, sexo é sempre politizado. Há, porém, períodos históricos nos quais a sexualidade é mais contestada e abertamente politizada. Nesses períodos, o domínio da vida erótica é efetivamente renegociado (RUBIN, 1998, p. 100).

Tomo por base aqui as ideias de Michel Foucault, para quem a sexualidade foi inventada como um "instrumento-efeito na expansão do biopoder” (DREYFUS \& RABINOW, 1995, p. 185). Na passagem do século XVIII para o século XIX, houve uma mudança de uma sexualidade como aspecto indiferenciado da vida cotidiana e relativamente livre, para outra vigiada e controlada. O dispositivo da sexualidade (entendido como estratégias de força que suportam tipos de saber e vice-versa) permitiu ao biopoder estender suas redes ao sujeito individual. Com efeito, até o século 
XVIII, os principais códigos legais ocidentais centravam-se no dispositivo da aliança que articulava as obrigações religiosas ou legais do casamento com a transmissão da propriedade e dos laços de sangue, constituindo o sistema social. O dispositivo da "sexualidade" tem sua origem na separação do sexo do dispositivo da aliança.

A sexualidade é da ordem do indivíduo. Diz respeito aos prazeres e às fantasias ocultos, aos excessos perigosos para o corpo e passou a ser considerada como a essência do ser humano individual e núcleo da identidade pessoal. Para Foucault (1984, 1994, 1997), as formas de dominação ligadas à identidade sexual são características de nossas sociedades ocidentais e, por isso mesmo mais difíceis de serem identificadas por nós que preferimos acreditar que os movimentos de autoexpressão sexual são resistências às formas de poder em vigor. Foucault $(1984,1994,1997)$ não os vê como inerentemente livres ou opostos à dominação. A reformulação do discurso sobre a sexualidade em termos médicos demonstra bem sua articulação com uma forma poderosa de saber que conecta indivíduo, grupo, sentido e controle. As classificações das perversões, das sexualidades desviantes e "improdutivas", encontram-se associadas a uma "ortopedia" do sexo que incide sobre o corpo o lugar da sexualidade que passa a ser escrutinado nos menores detalhes em busca de todos os segredos biológicos e psíquicos.

Os dispositivos de saber e poder sobre o sexo se desenvolvem, desde o século XVIII, a partir de quatro grandes conjuntos estratégicos: (1) "Histerização do corpo da mulher": tríplice processo pelo qual o corpo da mulher foi analisado como corpo integralmente saturado de sexualidade, integrado ao campo das práticas médicas e posto em comunicação orgânica com o corpo social, com o espaço familiar e com a vida das crianças; (2) "Pedagogização do sexo da criança": pais, famílias, educadores, médicos e, mais tarde, psicólogos devem se encarregar continuamente do controle sexual destes pequenos seres em perigo; (3) "Socialização das condutas de procriação”: socializações econômica, política e médica, que visam incitar 
ou frear a fecundidade dos casais; (4) "Psiquiatrização do prazer perverso" (FOUCAULT, 1997, p. 99-100).

A nova tecnologia do sexo desenvolve-se, segundo Foucault (1997), ao longo de três eixos: o da pedagogia, tendo como objetivo a sexualidade específica da criança, o da medicina, com a fisiologia sexual própria das mulheres, e o da demografia, com o objetivo da regulação espontânea ou planejada dos nascimentos e das populações. Basicamente, ela vai se ordenar em torno da instituição médica, da exigência da normalidade e do problema da vida e da doença.

Ainda hoje, em nossa sociedade, vemos a articulação desses três campos — medicina, demografia e pedagogia — na administração da conduta sexual da população. Exemplos disso são os dados demográficos sustentando as argumentações de médicos e do governo sobre as necessidades de planejamento familiar, em geral voltado para as populações pobres. $\mathrm{O}$ acesso à informação aparece como elemento chave —ainda que não suficiente- para esse controle, o que pode ser constatado por meio das políticas públicas na área da Educação que propõem a educação sexual como uma das tarefas das escolas. As concepções médico-higienistas, que influenciaram profundamente a política educacional oficial no Brasil no século XIX, também exerceram influência na educação sexual no século $\mathrm{XX}$, que tinha como objetivo o combate à masturbação, às doenças venéreas e o preparo da mulher para 0 papel de esposa e mãe, procurando assegurar a saudável reprodução da espécie (BONATO, 1996). Hoje, apesar da força das concepções médico-higienistas não ser mais a mesma dos séculos XIX e XX, de uma forma ou de outra, elas ainda se mantêm presentes nos espaços escolares como forma de "prevenir" as DST/AIDS e a chamada "gravidez precoce".

Voltamos, então, à questão da produção dos corpos, incluindo seus atributos femininos e masculinos, num processo significativo que restitui, no discurso e na matéria, as representações valorativas que dão sentido às relações sociais. Assim, a sexualidade torna-se o eixo principal da identidade e do ser no mundo, fundamentando-se em valores institucionais 
tais como procriação, casamento e família, em um contexto de heteronormatividade. Essa complexa engrenagem compreende todo um sistema de representações e autorrepresentações codificadas em normas, regras, paradigmas morais e modelos corpóreos, constituindo o que Tereza de Lauretis (1987) chama de “sistema sexo gênero", que delimita os campos do aceitável, do dizível, do compreensível. Para Butler (1993a) trata-se do inteligível e do não inteligível, de forma a delimitar aquilo que é considerado humano, não humano e inumano. De Lauretis (1987, p. 19) aponta para "as tecnologias do gênero" que de maneira discursiva ou imagética “(...) têm o poder de controlar o campo do sentido social e então produzir, promover ou implantar as representações de gênero”.

Para Foucault (1997, p. 145-146) "é pelo sexo efetivamente, ponto imaginário fixado pelo dispositivo de sexualidade, que todos devem passar para ter acesso à sua própria inteligibilidade (...), à totalidade de seu corpo (...), à sua identidade”. Assim, como postula Butler, "não há identidade de gênero atrás da expressão de gênero; esta identidade é performativamente constituída pela expressão que deveria ser o seu resultado” (BUTLER, 1990, p. 25). O gênero, portanto, cria o sexo e não a evidência de seu contrário. Essa perspectiva, portanto, permite a desconstrução da ilusória evidência do sexo biológico como demarcador dos limites identitários.

Como articular, então, gênero e sexualidade com gerações? A categoria geração se insere nas redes sociais que comunicam as estruturas de poder na sociedade, e também demonstra com muita clareza, diferenças decorrentes da vivência de ciclos domésticos em pontos variados, e da passagem do tempo histórico. A geração então, com as suas diferenças e/ou semelhanças nos discursos sobre sexualidade aponta continuidades e mudanças na formação de redes sociais que evidenciam inserções particulares nas estruturas de poder.

As posições ocupadas por homens e mulheres, crianças e idosos, diferenciam-se conforme mudanças contextuais relativas ao tempo histórico, à classe, à etnia, dentre outros vetores. No entanto, os 
essencialismos parecem permanecer aqui, uma vez que a partir da instauração da capacidade biológica de gerar outro ser, a dependência incontornável da mulher em relação a seu corpo sexuado na incapacitação que resulta da TPM (tensão pré-menstrual) ou na universalização dos “males” da menopausa, reduz a multiplicidade da experiência à imagem da mulher fragilizada por uma natureza que justifica e reitera seu lugar subordinado (“a histérica”) (SWAIN, 2001). Por outro lado, aos homens, especialmente aos jovens, é atribuída uma incapacidade de controle dos “instintos sexuais” de forma a justificar uma série de comportamentos considerados essencialmente masculinos.

Embora o processo de transição à vida adulta tenha se alterado nas sociedades urbanas ocidentais contemporâneas, incluindo mudanças nas concepções de infância, nas organizações familiares e autoridade parental, bem como nas normas educativas, a matriz heteronormativa de gênero ainda parece pregnante com suas prescrições, produzindo corpos sexuados inteligíveis e não inteligíveis. Pode-se afirmar, também, que a regulação da sexualidade jovem está na ordem do dia, justificada e medicalizada por meio do debate sobre a gravidez, o aborto, a AIDS, a violência, entre outros “problemas de saúde pública”.

\section{O que dizem os jovens sobre o corpo: diferenças de sexo ou de gênero?}

Para ilustrar o que tentei desenvolver até aqui, trago resultados relativos ao campo de Florianópolis, de pesquisa multicêntrica que investigou as práticas sexuais e reprodutivas de jovens de 15 a 24 anos, de ambos os sexos, por meio de entrevistas e grupos focais ${ }^{1}$, nos quais foi utilizada uma pequena história de dois jovens (Camila e Tiago), como dispositivo disparador da discussão. A imagem corporal, para estes jovens, está associada a imagens e influências ditadas pela moda e pela mídia nacional. Corpos malhados significam corpos saudáveis. No entanto, apesar

\footnotetext{
${ }^{1}$ Exercício dos direitos sexuais e reprodutivos: caminhos para a construção de outros olhares sobre os adolescentes. Projeto multicêntrico contemplado com bolsas PQ e IC do CNPq e com verba do Ministério da Saúde, em parceria com o Instituto Papai/PE.
} 
de concordarem que devam ter um padrão estético que acople um corpo físico malhado, quase nenhum dos rapazes adere a academias e trabalhos físico-corporais. Há uma preocupação maior por parte das meninas em relação aos cuidados com o corpo, principalmente sobre a estética corporal. A imagem corporal tem uma dimensão estética muito pontual no relato das informantes e remete aos padrões de beleza socialmente legitimados, veiculados pela mídia e valorizados pelos pares.

Pergunta: Com relação ao seu corpo, você se cuida? Como?

"Eu faço regime porque eu acho legal, do meu corpo eu cuido para não engordar demais" (VIVIANE ${ }^{2}, 15$ anos)

"O que eu posso eu me cuido. Como bastante salada, bastante fruta, tô sempre correndo. Mas eu já fui mais magra (CÁTIA, 21 anos)

Modelos de camadas médias urbanas são apreendidos e visualizados nos/ pelos discursos dos jovens, mostrando que o corpo é produzido por meio de apetrechos (roupas, calçados e adornos) a partir de parâmetros contemporâneos que indicam, para os rapazes, uma cultura urbana hip hop divulgada, entre outros meios, pelas novelas da televisão. Alusões a grupos de rock que cantam a realidade dos morros também aparecem, e o funk carioca começa a se fazer presente na realidade desses grupos ${ }^{3}$.

Pergunta: Você acha que alguém ou alguma coisa pode influenciar a forma do jovem pensar? "A música influencia bastante, eu acho, os jovens, adolescentes da periferia. Televisão, muito. Até na formação né. Criança que vê muito filme e vive ligado na televisão, ela acaba absorvendo aquele tipo de vida que a televisão passa (...) Tipo, na minha comunidade e nas comunidades... Eu moro na periferia, eu sempre fiquei sacando tudo. Teve a minha fase também, a fase que tava vindo depois de mim e teve a antes de mim... Eu saquei tudo, porque o rap, ele passa pra ti a ideia de não fazer aquilo, retratando a realidade da favela e dizendo pra você não seguir o caminho errado (HUGO, 21 anos).

\footnotetext{
2 Todos os nomes são fictícios.

${ }^{3}$ Ver: SOARES, L. S., BILL, MV, ATHAYDE, C (2005). Cabeça de Porco. Rio de Janeiro: Ed. Objetiva.
} 
Há uma demanda explícita pela possibilidade de consumir mercadorias investidas de valores de camadas médias, veiculadas pela mídia e reforçadas pelas relações entre os pares. Tal demanda é muito frequentemente atendida e esses jovens, garotos e garotas, transitam pelos territórios socialmente reconhecidos como próprios de consumo de camadas médias, como os shopping centers, e circulam nestes espaços com adereços corporais, reproduzindo performances mediadas pelas relações de consumo. O trabalho aparece como um meio pelo qual essa demanda é atendida, sendo que um dos informantes relatou que a participação no tráfico foi uma mediação importante para possibilitar o acesso a tais bens.

Tal relação entre imagem corporal, acesso aos bens de consumo e à cultura do tráfico nos morros remete a uma discussão sobre a constituição das próprias subjetividades desses/as jovens e, portanto, de como eles/as se lançam no mundo e quais mediações são significativas no estabelecimento de relações entre os pares.

Entre os garotos, o padrão normativo de imagem corporal é enfatizado, valorizando o modelo heterossexual, branco e "sarado". A questão do corpo é tomada a partir de um tópico central, a saber, como eles se veem e lidam com seu corpo. A imagem corporal relaciona-se também a uma "identidade" ou subjetividade jovem.

Os meninos mais jovens demonstram-se mais desinibidos para falar da imagem corporal das meninas do que deles mesmos. Quando se referem ao corpo das garotas, apresentam descrições mais detalhadas, descrevendo partes do corpo; já quando solicitados a falar da imagem corporal de meninos, alguns se recusam a dizer, demonstrando traços homofóbicos, expressos por meio de comentários jocosos sobre a relação entre corpos de rapazes e algo que os aproxime, em alguma medida, a modelos femininos. Os garotos demonstram acreditar que as garotas de sua idade se sentem bem com seu corpo, pois este está se desenvolvendo, no entanto ressaltam que algumas esperam algo diferente, ou seja, esperam que seus corpos se modifiquem, adequando-se a um modelo de um corpo 
esbelto e esperado ("violão", gostoso aos olhos dos garotos). Com relação aos meninos da mesma idade, eles relacionam a satisfação com o próprio corpo à autoestima, relatando que se o garoto aborda a garota ele está se sentindo bem com seu corpo.

Nota-se, de modo geral entre os garotos, uma grande preocupação relacionada com a imagem, seguindo o padrão normativo percebido com frequência em praias badaladas de Florianópolis, como a Praia Mole, considerada reduto jovem. Preocupam-se em estar dentro de um perfil exigido pelos pares, ou seja, um corpo malhado de academia, com roupas e acessórios de marca famosa.

Pergunta: Vocês acham que os meninos fazem alguma coisa para cuidar do corpo?

I: "Provavelmente" (GF Meninos 20-24 anos)

Pergunta: Tipo o quê?

I: “(...) academia, regime, caminhada, natação, a rapaziada gosta de esporte".

I2: "Tem que ter um corpo legal para estar na moda, porque você olha as pessoas indo pra praia mole, ai você também vai querer ir, ai o que vai acontecer, ai entra na academia, vai malhar para também poder ir” (GF Meninos 20-24 anos)

Observa-se que estes garotos buscam alcançar um padrão ditado pela burguesia, afirmando que assim podem conquistar mais facilmente as garotas, independente da classe social.

Pergunta: O que mais chama a atenção das meninas nos meninos?

I: "Eu acho que é na bunda. Se o cara tira a camiseta e não tem um corpo legal, ninguém olha”.

I2.: "Ai eu vou discordar de ti cara, porque hoje em dia...".

I.: "Cara, mais a maioria é assim, se você tirar a camiseta e tiver um corpo legal você não precisa falar nada”.

I.: "Olha só, antes se você ia pegar uma guria de uma classe social mais alta, não tinha, não pegava se a guria estudasse no Energia, por exemplo. Hoje em dia, se você coloca uma camisa de marca, coloca uma corrente de prata e vai lá na X. Duvido que elas não cheguem” (GF Meninos 20-24 anos) 
A imagem corporal feminina que eles idealizam também está relacionada ao padrão de beleza colocado pela mídia: "Loira, olhos azuis, corpo perfeito, rosto de boneca...”. Ao mesmo tempo afirmam que muitas garotas de sua idade são gordas e a maioria, segundo eles, não está satisfeita com seu corpo:

Pergunta: E essa Camila, digamos que ela tenha 22 anos, vocês acham que ela está se sentindo bem com o corpo dela?

I.: "A mulher pode estar com 10, 20, 30, 50 anos, ela sempre vai achar algum defeito. Que nem roupa, ela vai se olhar no espelho e sempre vai achar alguma coisa errada, é sempre assim".

I2.: "A mulher com corpo bonito, ela já briga com o espelho todo dia, imagina se ela tiver com um pneuzinho a mais” (GF Meninos 20-24 anos)

Quanto às garotas, a imagem corporal reflete a heterogeneidade dos tipos físicos das participantes da pesquisa. Ou seja, que esta pode ser tanto alta quanto baixa, tanto magra quanto "gordinha", não havendo um padrão único de referência. O mesmo, porém, não ocorre quando descrevem o tipo físico de um menino da mesma faixa etária. Este parece seguir um padrão normativo de beleza. Esta visão que possuem dos meninos, leva-as a pensar que eles sentem-se sempre bem com o seu corpo. Um fator que contribui nesta direção, segundo as garotas, é o fato de que os meninos, diferentemente delas, não sofreriam pressão para estarem de acordo com este padrão. Elas, por sua vez, não parecem satisfeitas com os seus corpos, mostrando estarem aquém de um ideal de beleza aparentemente inatingível para si mesmas. É pertinente apontar que, apesar de ambos, garotos e garotas, sentirem-se pressionados a alcançar e manter um padrão de estética corporal, na concepção dos garotos, essa pressão não ocorreria com as meninas, enquanto que elas afirmam, inversamente, que isso não aconteceria com eles.

Quanto ao autocuidado, percebe-se uma interconexão com o descrito acima. Ou seja, os cuidados com o corpo vão buscar modelos dominantes de estética corporal. Com relação ao cuidado com a saúde e com o seu próprio corpo, percebe-se que os/as jovens dão mais ênfase à 
estética do que à promoção de saúde. Os garotos acreditam que atualmente cuidar do próprio corpo é algo relacionado a ambos os sexos e não somente imposto às mulheres.

Pergunta: E eles fazem alguma coisa pra cuidar do corpo? O Tiago ou a Camila?

I: "Ah, mas claro né".

I: "Se produzem, se embelezam".

I: "Que até o homem agora ta se produzindo, né. Não é só mulher. Isso aí já é coisa do passado, só mulher” (GF Meninos 15-19 anos).

Entretanto, os garotos não fazem referência a uma preocupação quanto aos cuidados para com o seu próprio corpo e aos cuidados em relação à(s) parceira(s) no âmbito da promoção de saúde, o que incide sobre um modelo de masculinidade que parece legitimar práticas de vulnerabilidade por meio de estratégias de reafirmação das posições que homens "devem” ocupar na dinâmica social e, atravessadas por concepções socialmente legitimadas a respeito das masculinidades ${ }^{4}$. Há também o uso de bebidas alcoólicas como parte de um lócus que relaciona valentia, força, disposição e coragem como elementos de investimento e de marca de um masculino exaltado pelos pares e pelas garotas também.

No que se refere às transformações corporais desta idade, os garotos remetem à atuação dos hormônios influenciando no surgimento da atração sexual e afirmam que ocorre uma intensificação do desejo sexual, da vontade de ter uma relação sexual; ou seja, uma relação entre prazer e

4 A esse respeito, ver dentre outros: NASCIMENTO, Pedro. 'Ser homem ou nada': Diversidade de experiências e estratégias de atualização do modelo hegemônico da masculinidade em Camaragibe/PE. Dissertação (Mestrado em Antropologia Cultural). Recife: UFPE, 1999; KIMMEL, Michael S. El desarrollo (de género) del subdesarrollo (de género): la producción simultánea de masculinidades hegemónicas y dependientes en Europa y Estados Unidos. In: VALDÉS, Teresa y OLAVARRÍA, José (eds.). Masculinidades y equidad de género en América Latina. Santiago: FLACSO, 1998, p. 207-217; CONNELL, R. W. La organización social de la masculinidad. In: VALDÉS, Tereza y OLAVARRÍA, José (Eds.) Masculinidades y equidad de género en América Latina. Santiago: FLACSO/ISIS Internacional, Ediciones de las Mujeres, 1997, p. 31-48; CONNELL, R. W. El imperialismo y el cuerpo de los hombres. In: VALDÉS, Teresa y OLAVARRÍA, José (Eds.) Masculinidades y equidad de género en América Latina. Santiago: FLACSO, 1998, p. 76-89. 
desejo masculino remetida à ordem do biológico. Eles comentam as transformações corporais da adolescência, como o início da 'malícia' entre os sexos e o surgimento do desejo sexual. Colocam também que nesta fase ocorre uma mudança na maturidade, ou seja, com o despertar da sexualidade e as mudanças corporais, o próprio jovem cresce, amadurece em direção à fase adulta.

As garotas demonstram estarem informadas sobre as transformações corporais decorrentes da passagem da infância para a adolescência, apontando que tais mudanças exigem outros cuidados, principalmente em relação às questões referentes à vida sexual, o que parece remeter a um reconhecimento de si em relação ao seu próprio corpo. Contudo, percebe-se que os cuidados com o corpo são muito mais enfatizados quanto a se manterem magras do que à promoção de saúde.

$\mathrm{Na}$ busca para atingir mais rapidamente o padrão de estética normativo, as garotas, principalmente as de 15 a 19 anos, recorrem a métodos mais rápidos de emagrecimento, como a bulimia. Desta maneira, o cuidado consigo mesmas está mais voltado à vaidade com os cabelos e com a higiene do que com exercícios físicos, o que as leva a utilizar o recurso da bulimia para emagrecerem. Para elas os garotos malham muito mais que as garotas e tomam "bomba" (anabolizantes) para atingir os seus objetivos físicos mais rapidamente. Esta utilização de recursos que proporcionam resultados mais rápidos demonstra o quanto o ideal estético estabelecido pela mídia e pelos seus pares, controla as atitudes destes/as jovens que não conseguem atingi-lo.

Ainda em relação ao autocuidado o uso de chás é citado pelas garotas como técnica usada para "fazer a menstruação descer" e para emagrecer. Elas não fazem referência ao uso de medicamentos ou de técnicas médicas para se manterem no padrão de beleza ou para cuidarem do que acontece no seu corpo, mas afirmam que usam a pílula como método contraceptivo.

Pergunta: Com relação ao seu corpo, você se cuida? Como? 
"No verão passado eu tomava chá de sene, tomava outros laxantes como lacto purga. Tô sempre me cuidando, faço exame de sangue, urina, uma fez por ano (...) Acho importante cuidar do corpo, claro, principalmente nos últimos anos. Imagina, se eu não arranjar marido pra mim agora!” (CÁTIA, 21 anos)

Pergunta: E já rolou alguma vez sem camisinha? E depois que acontece você faz alguma coisa para evitar a gravidez?

"Já (...) se eu tivesse transado sem camisinha e achasse que iria engravidar, antes da menstruação descer já tomo um chazinho e a menstruação desce normalmente. Tem um remedinho, que não é abortivo, mas é um remédio superforte. Um monte de menina aborta com isso. Mas eu acho um veneno. Eu sempre tomei chazinho, se é natural, não faz mal” (KEILA, 19 anos).

Como se pode evidenciar na análise de outras falas das garotas, como as que contemplam a discussão sobre o uso ou não uso de preservativo, os cuidados com o corpo também aparecem sob a ótica das preocupações em relação à gravidez, muito mais do que em relação às DST/AIDS. Mesmo que, muitas vezes, elas admitam que não sejam sempre tão cuidadosas quanto à prevenção, de modo geral as informantes demonstram estarem informadas quanto ao que pode se processar no seu corpo quando iniciam sua vida sexual.

O duplo padrão de moral sexual ainda mantém-se presente nos grupos investigados, assim como a exigência da atividade sexual por parte dos homens como forma de comprovação de sua virilidade/masculinidade. No entanto, a preocupação em torno da virilidade não encontra correspondência no que diz respeito à fertilidade, o que pode ser atestado pela maior negligência por parte dos jovens homens com relação aos cuidados contraceptivos. A vida reprodutiva é vista quase que exclusivamente como uma responsabilidade das mulheres. Ainda que alguns admitam que os cuidados contraceptivos e a responsabilidade pelos filhos são atribuições de ambos, homens e mulheres, o uso da camisinha de vênus é assistemático, sendo que outros métodos são pouco utilizados, e por meio da iniciativa das mulheres. Os filhos, quando existem, ficam sob os cuidados das mães, embora alguns jovens afirmem a divisão das responsabilidades nesse campo. No entanto, a própria iniciativa do aborto pode ser identificada, em alguns 
casos, como uma imposição do homem que ameaça a parceira com a quebra do vínculo. Já entre as jovens mulheres investigadas, a reprodução aparece como uma das consequências da vida sexual ativa e se torna uma preocupação maior do que para os homens. Ou seja, o corpo sexual nem sempre é visto como um corpo reprodutivo, especialmente entre os garotos.

As vivências corporais relativas à sexualidade e aos padrões de estética são muito mais discutidas entre seus pares do que com a família, ainda que algumas dessas informantes tenham relatado que estabelecem alguma forma de diálogo com mulheres da família (mãe, tia, avó, prima), onde conversam sobre mudanças corporais provenientes da adolescência e sobre cuidados com a saúde sexual reprodutiva.

Pergunta: Tu tens a preocupação com o teu corpo? Como tu cuida disso, com relação às DSTs?

"Eu sempre eu procuro me informar do que é isso, do que é aquilo. Porque é uma preocupação com o formato do corpo da gente, sempre procuro manter o contado com a minha mãe sobre dores menstruais" (SILVIA, 15 anos).

\section{Alinhavando os termos a título de uma conclusão sempre provisória}

A partir dos relatos, vemos jovens se constituindo como sujeitos ancorados "na experiência de um corpo construído entre o assujeitamento às imagens e valores do social e a sua crítica” (SWAIN, 2004, p. 185). A valorização do corpo juvenil nas sociedades contemporâneas, conforme afirma Valérie Daoust (2005) engendra um processo no qual a "constituição de si" corresponde a um "consumo de si”, de forma a expulsar de si tudo o que não se identifique com um ideal narcísico produzido de forma discursiva e imagética pelo social. Para Daoust (id.) a lógica discursiva que define a obsessão das sociedades contemporâneas pela juventude está ligada a uma concepção de sexualidade que faz referência à beleza e à atividade sexual. No entanto, a regulação das experimentações das sexualidades juvenis (tentativas de controle sobre a iniciação sexual e controle da gravidez, por exemplo) e as tutelas dos corpos e de suas estéticas de transformação (estilos de moda, 
corpos "sarados", cortes de cabelo e piercings, por exemplo) demonstram o olhar vigilante sobre esses corpos saturados de sexualidade e inundados de práticas normalizantes (POCAHY \& NARDI, 2007). As poucas possibilidades de (re)invenção desses corpos, no caso das travestis e dos homossexuais por exemplo, não escapam dessa lógica na medida em que ela mesma se sustenta pela produção do ininteligível, do não dizível, do não aceitável, sobre o qual recaem as adjetivações pejorativas e o medo daqueles que não querem com ele serem identificados.

Corpos jovens heterossexuais, brancos, magros e bonitos são desejáveis e desejados nessa arena marcada também pelos vetores de classe, que delimitam as condições de acesso aos bens culturais e suportes sociais na/da cidade. As estratégias modernas de assujeitamento consistem na manutenção das diferenciações de gênero, sexualidade, gerações, classe social, estilos de vida, nas relações com os outros e consigo mesmo, como se pode depreender das falas dos jovens entrevistados.

Portanto, embora conceitos distintos e justapostos como no título do presente trabalho, gênero, sexualidade e gerações constituem dispositivos identitários que engendram discursos de verdade imbricados nos processos de (auto)constituição dos sujeitos. Como problematizar a institucionalização das identidades e desconstruir o gênero (BUTLER, 2004) de maneira a permitir a emergência de novas formas de subjetivação e de experimentação da sexualidade, de uma "vida vivível” (BUTLER, idem)? Eis a questão.

Referências bibliográficas

BONATO, Nailda M. da C. Educação [sexual] e sexualidade: o velado e o aparente. Rio de Janeiro: UERJ, 1996. Dissertação (Mestrado em Educação). Universidade do Estado do Rio de Janeiro. Disponível: www.geocities.com/Athens/Ithaca/9565/tese/indicee.html Acesso em: 15 de julho de 2007.

BUTLER, Judith. Gender trouble. Feminism and the subversion of identity. New York: Routledge, 1990. 
.Bodies that matter: On the discursive limits of sex. New York \& London: Routledge, 1993a.

- Gender as Performance: An Interview with Judith Butler. Entrevista realizada por Peter Osborne e Lynne Segal. Londres, 1993b. Disponível em: www.theory.org.uk/but-int1.htm. Acesso em 19 de agosto de 2007.

. Undoing gender. London \& New York: Routledge, 2004.

CONNELL, Robert W. La organización social de la masculinidad. In: VALDÉS, Tereza y OLAVARRÍA, José (Eds.) Masculinidades y equidad de género en América Latina. Santiago: FLACSO/ISIS Internacional, Ediciones de las Mujeres, 1997. p. 31-48.

COSTA, Jurandir F. O referente da identidade homossexual. In: PARKER, Richard \& BARBOSA, Regina M (Orgs.) Sexualidades Brasileiras. Rio de Janeiro: Relume-Dumará, ABIA, IMS/UERJ, 1996.

DAOUST, Valérie. De la sexualité en démocratie. L'individu libre et ses espaces identitaires. Paris: PUF, 2005.

DE LAURETIS, Teresa. Technologies of Gender, Essays on Theory, Film and Fiction. Bloomington/Indiana: Indiana University Press, 1987.

DREYFUS, Hubert \& RABINOW, Paul. Michel Foucault: uma trajetória filosófica. Rio de Janeiro: Forense Universitária, 1995.

ERIBON, Didier. Michel Foucault e seus contemporâneos. Rio de Janeiro: Jorge Zahar, 1996.

FOUCAULT, Michel. História da Sexualidade O Uso dos Prazeres (Vol. 2). Rio de Janeiro : Graal, 1984.

. Dits et écrits (Vol. 4). Paris: Gallimard, 1994.

. História da Sexualidade A Vontade de Saber (Vol. 1). Rio de Janeiro: Graal, 1997.

HARAWAY, Donna. Manifesto ciborgue: ciência, tecnologia e feminismosocialista no final do século XX. In: SILVA, Tomaz T (Org.). Antropologia do ciborgue: as vertigens do pós-humano. Belo Horizonte: Autêntica, 2000. p. 37-129. 
KIMMEL, Michael S. El desarrollo (de género) del subdesarrollo (de género): la producción simultánea de masculinidades hegemónicas y dependientes en Europa y Estados Unidos. In: VALDÉS, Teresa y OLAVARRÍA, José (Eds.). Masculinidades y equidad de género en América Latina. Santiago: FLACSO, 1998. p. 207-217.

LACLAU, Ernesto \& MOUFFE, Chantal. Hegemonía y estrategia socialista. Madrid: Siglo XXI, 1985.

LACQUER, Tomas. Inventando o sexo: corpo e gênero dos gregos a Freud. Rio de Janeiro: Relume-Dumará, 2001.

NASCIMENTO, Pedro. 'Ser homem ou nada': Diversidade de experiências $e$ estratégias de atualização do modelo hegemônico da masculinidade em Camaragibe/PE. Recife: Dissertação de Mestrado (Antropologia Cultural). Universidade Federal de Pernambuco, 1999.

NICHOLSON, Linda. Interpretando o gênero. Estudos Feministas, v. 8, n. 2, 9-41, 2000.

POCAHY, Fernando A. \& NARDI, Henrique C. Saindo do armário e entrando em cena: juventudes, sexualidades e vulnerabilidade sexual. Estudos Feministas, v. 15, n. 1, 45-66, 2007.

RUBIN, Gayle. Thinking sex: notes for a radical theory of the politics of sexuality. In: NARDI, Peter M. \& SCHNEIDER, Beth E (Eds.). Social perspectives in lesbian and gay studies. London: Routledge, 1998.

SCOTT, Joan. Gender and the politics of history. New York: Columbia University Press, 1988.

- Gênero: uma categoria útil de análise histórica. Educação $e$ Realidade, 16(2), 5-22, 1990.

. Fantasy Echo - história e a construção da identidade. Labryz, estudos feministas, 1-2, julho/dezembro 2002. Disponível em:

http://www.unb.br/ih/ihs/gefem/labrys_2/scott1.html

Acesso em 20 de agosto de 2007.

SOARES, Luiz Eduardo, BILL, MV \& ATHAYDE, Celso. Cabeça de Porco. Rio de Janeiro: Ed. ObjetiVa, 2005. 
SWAIN, Tânia N. Feminismo e recortes do tempo presente: mulheres em revistas “femininas”. São Paulo Perspec., São Paulo, v. 15, n. 3, 2001. Disponível em:

http://www.scielo.br/scielo.php?script=sci_arttext\&pid=S0102-

$88392001000300010 \& \operatorname{lng}=$ en\&nrm=iso

Acesso em: 25 de agosto de 2007

. Feminismo, corpo e sexualidade. In: TONELI, Maria Juracy F. \& RIAL, Carmen S.M (Orgs.). Genealogias do silêncio: feminismo e gênero. Florianópolis: Editora Mulheres, 2004. 


\title{
HISTÓRIA E FORMAÇÃO DO PSICÓLOGO
}

\author{
CAPÍTULO 11
}

\section{A FORMAÇÃO DE PSICÓLOGOS NA ARGENTINA: A PSICOLOGIA SOCIAL DE PICHON-RIVIÈRE}

\author{
Hugo Klappenbach \\ Consejo Nacional de Investigaciones Científicas y Técnicas \\ Universidad Nacional de San Luis, Argentina
}

$\mathrm{D}$ esde a redemocratização em 1983, a formação de psicólogos na Argentina ganhou em diversidade e extensão. Até aquele momento era possível cursar estudos superiores de Psicologia em apenas sete universidades públicas e dez particulares. Segundo informações coletadas no Ministério de Educação em agosto de 2007, a oferta em universidades públicas não variou significativamente, uma vez que, agora, o curso de Psicologia é ministrado em nove institutos deste gênero; por outro lado, é possível escolher entre 31 universidades particulares, além de uma estadual (ver Tabelas 1 e 2). Se bem que a ampla oferta de cursos assegure uma diversidade em variados aspectos, é também possível identificar um núcleo constitutivo comum para esses quarenta e um programas em Psicologia (KLAPPENBACH, 2003a).

A análise histórica do ensino universitário da Psicologia na Argentina identifica alguns aspetos comuns no início da formação destes cursos no país, bem como uma série de aspetos divergentes (VILANOVA, 1993).

Como é conhecido, em nível internacional os primeiros estudos dedicados a verificar a situação dos programas de formação universitária em Psicologia foram produzidos nos Estados Unidos, especialmente nos anos próximos à Segunda Guerra Mundial. Lá, tais estudos foram produzidos no marco de análises das condições profissionais para o trabalho no campo 
clínico. Um dos primeiros relatórios foi elaborado por um Comitê designado pela Associação de Psicólogos de Michigan e consistiu na análise de um questionário em que se solicitava aos associados que descrevessem os cursos necessários para o trabalho em diagnóstico e tratamento, fora do âmbito dos cursos de graduação, mestrado ou doutorado (GREENE, 1938). Ainda quando as informações apresentavam bastante dispersão, as conclusões do estudo sublinham que $80 \%$ dos entrevistados coincidia no fato de que o treinamento para diagnóstico e tratamento exigia não menos de quinze cursos em psicologia, além de cinco em ciências sociais, três em medicina e outros cinco tanto em ciências como em língua estrangeira (GREENE, 1938). O contexto do estudo mostrava as exigências para ser aceito o campo do diagnóstico e tratamento em torno do qual, antes da Segunda Guerra Mundial, havia se iniciado a disputa —que amadureceria uma década depois - entre psicólogos e psiquiatras (BUCHANAN, 2003).

No contexto da década de 30, a formação e treinamento profissional constituíam ferramentas centrais no debate das reivindicações profissionais.

Training was in important means maintaining medical control over psychotherapy in this period. There was a paucity of graduate training programs for would be clinical psychologists before the war. Existing programs were master-level at best and tended to emphasize diagnostic (BUCHANAN, 2003, p. 227).

Nos Estados Unidos, as limitações na formação profissional do psicólogo vinham sendo assinaladas em vários estudos desde o começo da década de 1940. Um destes estudos, que se converteria em clássico, por exemplo, foi o levado a cabo por David Shakow (1942). É interessante destacar que Shakow atuava na universidade somente em âmbito hospitalar, no conhecido Worcester State Hospital. Shakow (1942) enquadrava seu relatório no marco da psicologia aplicada em geral, ainda que seu objetivo fosse o treinamento do psicólogo clínico. Sugeria que o treinamento em psicologia clínica fornecesse o fundamento para todo o trabalho profissional do psicólogo, mesmo quando reconhecia, numa nota de pé de página, que o programa de treinamento por ele sugerido era o resultado de sua experiência hospitalar. 
Ou seja, o campo profissional sobre o qual se recortava a formação em psicologia era explicitamente o da medicina, ao qual se acrescentava o do trabalho social. Contudo, o Relatório Shakow recomendava articular a formação acadêmica à profissional, insistindo que a formação deveria ser tão rigorosa e extensa como um doutorado, além de que a ela se deveria acrescentar um ano de internato (proposta já formulada anteriormente em Shakow, 1938). Nessa direção, o autor descrevia as três atividades básicas do treinamento em psicologia clínica: diagnóstico, investigação e terapia.

The question becomes one of determining the king of trained person who, at the present stage of development of the profession and with the present needs of the field, would most adequately represent and advance clinical psychology. Such a person would seem to be one who, besides meeting certain basic personality requirements and having a breadth of educational background, is competent to carry a triad of responsibilities: diagnosis, research, and therapy (SHAKOW, 1942, p.278).

Há muitas razões para analisar com cuidado o Relatório Shakow, como sua ênfase no nível da graduação (undergraduate), a ideia de que a especialização principal (major) deveria ser em ciências biológicas, sendo a secundária (minor) em ciências sociais. Assim mesmo, os estudos denominados de ciências médicas (anatomia, fisiologia, neuroanatomia, endocrinologia, medicina clínica, terapia) adquiririam importância no segundo nível de formação, tendente ao doutorado. Para a tradição argentina, é interessante a recomendação do autor do estudo de línguas como castelhano e russo, assim como suas considerações sobre a formação psicanalítica:

If psychoanalysis is accepted as part of the program special care will have to be taken to select analysts who are relatively free from doctrinarism and who have an interest in psychological theory as well as in therapy (SHAKOW, 1942, p.281).

Apenas um ano depois do Relatório Shakow, outro estudo reconhecia a necessidade de revisar a formação acadêmica clássica em psicologia, principalmente aquela dirigida à investigação. 
Psychologists report their greatest number of deficiencies both in themselves and others in psychology, particularly in the applied fields, this in spite of the fact that most of them have taken a great many psychology courses.

This condition suggests the desirability of making a study of the kind of psychology that is studied in the regular courses. It is possible that the traditional degree-program set up as training in research should be considerably overhauled to be suitable for professional psychological work (TROW \& SMART, 1943, p. 40).

Enquanto nos Estados Unidos, portanto, os primeiros estudos acerca da formação em psicologia apareceram nas décadas de 30 e 40, na Argentina, por seu turno, os estudos sobre o tema são todos posteriores à década de 1960, estando relacionados à implantação de cursos de psicologia na metade da década anterior (tabela 1 e 2).

Há uma quantidade significativa de estudos centralizados em um determinado curso ou programa de formação em psicologia, sendo os de La Plata pesquisados em Piacente, Compagnucci, Schwartz \& Talou (2000) e os de Tucumán por Lapur (1972).

Igualmente, não têm faltado estudos relacionados ao ensino de uma determinada matéria ou grupo de matérias em diferentes universidades (NAZUR, CORILI \& CASADO, 2001), estudos centralizados no treinamento de determinadas especialidades também em diferentes universidades (KLAPPENBACH, 2003b) e estudos focalizados na aquisição das habilidades por parte dos formados (CASTRO SOLANO, 2004).

De particular interesse, três trabalhos publicados nos primeiros anos de existência dos cursos de psicologia, entre 1961 e 1975, realizavam estudo comparativo sobre a formação do psicólogo em todas as universidades nacionais (BARRIONUEVO \& GARCIA MARCOS, 1975; CHAPARRO, 1969; HORAS, 1961). Destes trabalhos, em muitos aspectos divergentes entre si e respondendo a objetivos igualmente distintos, podemos extrair algumas conclusões gerais sobre a formação do psicólogo na Argentina e, em particular, em psicologia social. 
Por exemplo, o estudo de Chaparro (1969) revela que mais de um quarto das matérias era comum aos seis cursos das universidades públicas. As oito matérias comuns eram Psicologia Social, Neurobiologia, Estatística, Psicometria, Psicologia Evolutiva, Psicopatologia, Técnicas Projetivas ou Psicodiagnóstico e Psicologia do Trabalho. Juntas, estas oito matérias representavam $28 \%$ do número total de disciplinas cursadas em um programa mediano.

Ademais, outras quatro matérias eram comuns a cinco dos cursos analisados: Filosofia, Psicologia Geral, Psicologia Profunda e Psicologia da Personalidade. Essas matérias, somadas às anteriores, representavam $41 \%$ do número total de disciplinas em um programa mediano.

Por último, outras cinco matérias eram comuns em quatro dos cursos estudados: Introdução à Psicologia, Sociologia, Antropologia Cultural, Métodos e Técnicas de Investigação Psicológica e Psicologia Clínica de Crianças e Adultos. Somadas às anteriores, as disciplinas citadas correspondiam a $62 \%$ do número total de matérias cursadas em um programa mediano (CHAPARRO, 1969).

Em suma, quase dois terços das matérias eram comuns a pelo menos quatro dos seis cursos de psicologia nas universidades públicas. Entre estas matérias, é interessante indicar que a formação em psicologia social estava contemplada em todas as universidades públicas desde suas respectivas fundações, junto a outras matérias afins como Psicologia do Trabalho ou, ao menos em quatro universidades, a Sociologia.

Por sua vez, o estudo de Barrrionuevo \& García Marcos (1975) diferia do de Chaparro por sua ênfase em apontar as diferenças absolutas entre todos os planos de estudo. Não obstante, concordava que, nos dez cursos oferecidos em Buenos Aires, existiam três matérias comuns: Psicologia Geral, Psicologia Evolutiva e, novamente, Psicologia Social. Por fim, o relatório de Plácido Horas afirmava que "na universidade nacional a carreira de psicologia nas diversas faculdades carece de diferenças 
essenciais e seus planos se assemelham aos oferecidos pelas instituições de estudos superiores de outros países" (HORAS, 1961, p.346).

Nesse contexto, podemos perceber que a psicologia social não ocupava lugar secundário por dois motivos. Primeiro, porque era uma das poucas matérias comuns a praticamente todos os cursos de graduação em psicologia no país. Segundo, porque os cursos de psicologia apareceram na República com um interesse manifesto nos campos da educação e do trabalho, logo, era inevitável uma aproximação social. Durante os anos 60, em diferentes contextos intelectuais, começaram a serem sentidas mudanças significativas que enfatizavam o interesse em aproximações sociais dentro do campo psicológico (KLAPPENBACH, 2000; VEZZETTI, 2004).

Na segunda metade dos anos 60, a Argentina passava por eventos que impactariam a formação do psicólogo e em psicologia social em particular. Por um lado, desde a queda de Perón em 1955, a denominada "nova esquerda" começava a se distanciar do clássico antiperonismo de esquerda vinculado ao Partido Socialista ou ao Partido Comunista Argentino (TERÁN, 1993). Por outro lado, no domínio universitário, guiado pela concepção de que "a universidade somos nós”, os anos seguintes à queda de Perón foram caracterizados pelo protagonismo do movimento estudantil, especialmente na Universidade de Buenos Aires e em La Plata (SIGAL, 2002, p.43).

A literatura costuma considerar a década entre 1955 e 1966 como a "idade de ouro" da universidade argentina em razão de vários indicadores, como a absoluta economia das universidades, a renovação curricular e a crescente ênfase na pesquisa. Contudo, historiadores insuspeitos de simpatia com o regime que findou em 1955 observam que o dito período não foi menos arbitrário que o iniciado na universidade argentina na década anterior. O movimento estudantil, por exemplo, promoveu o ajuizamento dos docentes relacionados com o regime peronista (SIGAL, 2002). Mais ainda, um conhecido jurista expulso da Universidade de Buenos Aires em 1946 foi reincorporado em 1955; neste momento o interventor na Faculdade de Direito e Ciências Sociais da referida Universidade sustentava que era 
"preferível um professor honesto e de só mediana preparação a outro sapientíssimo, mas desonesto” (BUCHBINDER, 2005, p.171). Contudo, na medida em que a década avançava, os concursos para docentes enfatizavam, mais que a mera antiguidade no exercício da docência, a afirmação de recursos e as publicações internacionais (BUCHBINDER, 2005).

A década de afloramento do movimento estudantil foi bruscamente interrompida pelo golpe de estado cuja "primeira vítima foi a universidade, considerada como um foco de subversão ideológica e de corrupção moral" (HALPERIN DONGHI, 1998, p. 571), ainda que a crítica ao cientificismo e à recepção de fundos para a investigação de fontes externas (como, por exemplo, a Fundação Ford), tenham se iniciado na mesma comunidade universitária (BUCHBINDER, 2005; SIGAL, 2002; TERÁN, 1993).

À medida que os anos 60 avançavam e especialmente no imediato pós-66, começaram a adquirir importância as tendências revolucionárias que exerciam forte questionamento às posições reformistas, por considerálas liberais e comprometidas com o regime vigente. Em geral, no plano das ideias, já em 1963 a lista de best-sellers da revista Primera Plana, uma das impulsoras da modernização cultural argentina, incluía o livro de Juan José Hernández Arregui, Que è o ser nacional?, no qual assinalava o fim da hegemonia liberal (TERÁN, 1993). No terreno universitário, em 1971 a revista Panorama reproduzia declarações que testemunhavam um novo antagonismo na universidade: o do cientificismo contra a universidade combativa "em torno dos problemas nacionais e em busca de uma saída socialista” (SIGAL, 2002, p.54). Em outras palavras:

As opções de grande parte dos universitários, de um setor dos professores e, sobretudo, dos estudantes, foram, neste contexto fortemente radicalizado e adverso, privilegiar novamente o compromisso revolucionário. A situação universitária dependia, em última instância, da estrutura social e os males do país radicavam em sua situação dependente (BUCHBINDER, 2005, p. 195).

É esse o ambiente no qual situamos duas das principais características da psicologia social pichoniana. Primeiro de tudo, a ênfase 
na psicologia social "operativa e instrumental” buscando uma "mudança social planificada” (PICHON-RIVIÈRE, 1969, p. 9). Em segundo lugar, o forte questionamento à "psicologia social acadêmica que, preocupada somente com as problemáticas das técnicas ou dos tipos possíveis de mudança, se sente paralisada frente à sua responsabilidade de realizar uma síntese de teoria e prática” (PICHON-RIVIÈRE, 1969, p. 9). Como sustentava Germán Garcia: "Pichon-Rivière consuma (leva à total perfeição) o discurso que engendra as crises da universidade” (GARCIA, 1978, p.241).

A partir da análise histórica, a estrangeridade de Pichon-Rivière com o âmbito acadêmico vinha de muito antes: Pichon havia iniciado sua carreira docente numa escola de formação para responder às necessidades que lhe impunha a famosa experiência Rosário, organizada pelo Instituto Argentino de Estudos Sociais (IADES), instituição organizada pelo próprio Pichon-Rivière. Ele, mais Bleger, Liberman e Rolla (1960) denominara, aquela instituição Escola Particular de Psiquiatria mesmo um de seus filhos, Joaquim Pichon-Rivière, considerando que se tratava de uma Escola de Psiquiatria Dinâmica (PICHON-RIVIÈRE, 2005). Não somente a experiência Rosário adquiriu um escopo místico (ULLOA, 1995), como também o ano exato de fundação daquela Escola de psiquiatria ou psiquiatria dinâmica, antecedente da Escola de Psicologia Social, se confunde com o próprio mito. Como afirma Mariano Plotkin:

A vida de Pichon-Rivière ficou tão entrelaçada com o mito que resultou uma dificuldade de separar os fatos da ficção. Seu filho Marcelo disse: "Meu pai, como Borges, às vezes preferia uma frase feliz a uma frase verdadeira. Era uma de suas formas de sedução" (PLOTKIN, 2003, p.164).

Marcelo Pichon-Rivière iria mais longe ainda; sustentava que, ao modo de travessura, seu pai era um admirável mentiroso e era capaz de inventar histórias inacreditáveis com uma capacidade de persuasão assombrosa (PICHON-RIVIÈRE, 2003). Uma verdadeira hagiografia pichoniana possibilitou que suas lições no Hospital Psiquiátrico na década 
de 40 dessem a "sensação" das Conferências das Terças de Charcot na Salpêtrière, ou que a clínica que Pichon inaugurou na Rua Copérnico, no Bairro Norte da Cidade de Buenos Aires, fosse considerada a "pequena Menninger” em alusão à Menninger Clinic (Resnik, 2001).

Voltando ao início da Escola de Psiquiatria, os próprios textos pichonianos indicam sua origem em 1959; a página web da Primeira Escola Particular de Psicologia Social informa que esta surge em 1953 como formação de pós-graduação de psicoterapeutas (PRIMEIRA ESCOLA PARTICULAR DE PSICOLOGIA SOCIAL, 2007). Também sinaliza-se como antecedente na década de 1940 o trabalho grupal de enfermeiros psiquiátricos no Asilo de Torres (GARCIA \& WAISBROT, 1981) ou de trabalhos em grupos com pacientes chagásicos na mesma época (FABRIS, 1999). Roudinesco \& Plon (1998), por outro lado, destacam as diferentes formas de práticas grupais, desde os grupos operativos iniciados em 1947 até a fundação da Escola em 1959.

Para além das datas, Ana Quiroga enfatizou que, em sua origem na década de 40 , a ideia de grupo operativo não possuía finalidade educativa mas foi desenvolvida simultaneamente à assistência a pacientes psicóticos (KLAPPENBACH, 1987). Então, em algum momento da década de 50 (possivelmente depois da queda de Perón), Pichon formalizou uma formação em psiquiatria social que era paralela à formação psiquiátrica acadêmica, e que também se converteu em formação paralela àquela em psicologia social nos nascentes cursos de psicologia. Ademais, a psicologia social pichoniana era também adjacente ou paralela ao campo da psicanálise (García, 2005), embora Pichon-Rivière a considerasse como uma democratização da psicanálise (ZITO LEMA, 1993).

O questionamento à psicologia acadêmica pela formação em psicologia social pichoniana de modo algum era um argumento exclusivo deste psicólogo sendo, ao contrário, frequente entre os psicanalistas argentinos. Bleger, por exemplo, ao inaugurar a primeira cátedra de Psicanálise na Universidade do Litoral (antes desta tornar-se Universidade 
de La Plata), propunha "reconsiderar alguns problemas da psicologia acadêmica, como o da atenção, memória, juízo etc." (BLEGER, 1962, p.59). Desde já, a psicologia acadêmica era uma caracterização que cobria diferentes significados: psicologia como "conhecimento humanístico" ou desvinculado da prática (BLEGER, 1962); psicologia entendida como versão bibliográfica, informação teórica oposta à aplicação do conhecimento ou ao exercício de um ofício (BLEGER, 1964); como diferenciada de uma formação profissional (BALÁN, 1991). Em testemunho autobiográfico, Ricardo Avenburg (2003) lembra a oposição entre a formação psicanalítica e a universidade, enquanto Débora Fleischer (2003) argumenta que a presença de Bleger na Universidad de la Plata (junto às suas posições de esquerda), o impediu de ser candidato à Presidência da Associação Psicanalítica Argentina.

É possível afirmar que a psicologia social acadêmica questionada era aquela que tinha lugar em instituições públicas, e não aquela que tinha lugar em estabelecimentos particulares como o Instituto de Psicanálise ou a Escola de Psicologia Social. Entretanto, é interessante notar que as fontes do pensamento pichoniano formavam parte dos conteúdos da psicologia social nos cursos de psicologia; por exemplo, as obras de George Mead e de Kurt Lewin (MACCHIOLI, 2006; VEZZETTI, 2002) eram referências centrais não somente em psicologia social mas sobretudo no pensamento de algumas das personalidades mais importantes da psicologia acadêmica desde o início da década de 50.

Do mesmo modo, Luis Felipe de Garcia de Onrubia —acadêmico por antonomásia — assinalava a importância da teoria do campo de Kurt Lewin, pois possibilitava o estudo da conduta humana no "mais seguro instrumento conceptual de uma psicologia da estrutura” (GARCIA DE ONRUBIA, 1950, p.1371). Por seu lado, Plácido Horas, personalidade central da psicologia acadêmica na década de 50, presidente do Segundo Congresso Argentino reunido em San Luis em 65 e do Terceiro Congresso Argentino de Psicologia reunido em Rosário em 68 resgatava, em 1954, a teoria de campo de Lewin ao mesmo tempo que se mantinha crítico dos testes mentais e de uma psicologia que parecia avançar por caminhos paralelos 
sem cognição alguma (HORAS, 1955). Em direção convergente, também em 54 Oscar Oñativia assinalava o aporte de Kurt Lewin por aproximar conceitos da Gestalt e das psicanálises e as tentativas de Murray de articular a topologia de Lewin ao freudismo (OÑATIVIA, 1955).

Por outro lado, algumas cátedras de psicologia social ou institucional em universidades, públicas e particulares, incorporaram conteúdos pichonianos, havendo inclusive algumas que diretamente se centraram em um enfoque pichoniano. Caso paradigmático constitui a matéria de Psicologia Social na Universidade Nacional de Tucumán, que explicitamente declara sua moratória à obra de Pichon:

A teoria da Psicologia Social desde os trabalhos e investigações de Enrique Pichon-Rivière se inicia nos fins da década de 50 a partir especialmente do desenvolvimento das Psicanálises na Argentina (UNIVERSIDADE DE TUCUMÁN. FACULDADE DE PSICOLOGIA, 2005, p.1).

O caso de Tucumán não deve surpreender: Pichon-Rivière viajou reiteradamente por aquela província para praticar experiências com cultivadores de cana-de-açúcar e logo começou a ensinar grupos operativos. Seu filho Joaquin Pichon-Rivière destaca devermos

(...) ter em conta que praticamente a primeira escola de psicologia social, a particular, da última etapa, foi aberta primeiro em Tucumán e depois em Buenos Aires; quer dizer que esta experiência fundadora entre 1958 e 1960 deixa em Tucumán uma marca muito grande com os colaboradores; de fato ele nunca deixou de viajar para Tucumán e supervisar um grupo muito forte, hoje uma escola muito importante que, creio, inclusive já oferta pós-graduação em psicologia social em Tucumán” (CARMONA PARRA, 2007 s/p).

Além de Tucumán, há casos em que a influência de Pichon-Rivière sobre as universidades respondem a distintas variáveis, dentre as quais destacamos as pessoais. Em fins da década de 70, a cátedra de Psicologia Social na Universidade de Salvador esteve a cargo de Ana Quiroga, última esposa e seguidora do ensino de Pichon-Rivière, além dela mesma ser a diretora da primeira Escola Particular de Psicologia Social. Não só os 
conteúdos do programa eram nitidamente pichonianos, como também a didática enfatizava os grupos operativos, como eu mesmo pude comprovar enquanto estudante.

Ademais, foram constituídas cátedras operativas ou livres que explicitamente retomam os ensinos de Pichon, dentre as quais o Seminário eletivo "Desenvolvimentos clínicos baseados no pensamento do Doutor Enrique Pichon-Rivière: patologias atuais", na Universidade Nacional de Rosário (GALIÑANES, 2004).

De todas as maneiras, ainda que existam outras experiências, o ensino da psicologia social não tem privilegiado o enfoque pichoniano. Desde já, em todos os cursos de graduação em psicologia, tanto em universidades públicas como em particulares, há um número variável de disciplinas diretamente relacionadas ao campo da psicologia social (ver Tabelas 3 e 4). Paralelamente, o mais reconhecido curso de formação em psicologia social pichoniana tem tido um desenvolvimento externo a quaisquer universidades, baseando-se em Escolas ou Institutos terciários instituições não universitárias que conferem títulos não universitários, como “Operador em Psicologia Social” ou similar.

Dois exemplos paradigmáticos desta formação paralela à universitária constituem a primeira Escola Particular de Psicologia Social, dirigida por Ana Quiroga, e a Escola de Psicologia Social do Sul, dirigida por Gladys Adamson.

A primeira é a fundada por Pichon-Rivière em 1967, transformando a antiga Escola de Psiquiatria Social que perdeu seu caráter de pósgraduação. Com essa mudança,

a instituição e o curso de Psicologia Social se abrem a todos aqueles que, sejam qual fossem seus estudos e formação prévia, se interessem em realizar uma aprendizagem centrada na compreensão dos processos de interação e o na análise do processo social, particularmente ao que faz a relação entre estrutura social e subjetividade (PRIMEIRA ESCOLA DE PSICOLOGIA SOCIAL, 2007a, s/p). 
A oferta acadêmica da escola oferece diferentes titulações terciárias:

1) Técnico Superior em análise e intervenção, nos campos grupal, institucional e comunitário (Curso terciário de quatro anos com título oficial reconhecido). Com uma carga horária de 16 horas, ou seja, dentro da média semanal, com duas reuniões semanais e tarefas não presenciais;

2) Curso tradicional de Psicologia Social; curso terciário de quatro anos de duração - Título não oficial (Tabela 5).

Por seu turno, a Escola de Psicologia Social do Sul tem sido especialmente promotora do reconhecimento dos títulos terciários, oferecendo também diferentes títulos reconhecidos (Resolução 606/02 da Secretaria de Educação do Governo da Cidade de Buenos Aires):

1) Técnico em Comunicação e Psicologia Social (dois anos);

2) Operador em Psicologia Social (três anos) (tabela 6).

Iniciativas dessa natureza existem em todo o país e implicam uma formação terciária não universitária, embora o título de operador social e outros análogos comecem a ser reconhecidos em instituições públicas para o exercício de certas práticas. Ao mesmo tempo, foi constituída a Associação de Psicólogos Sociais da República com a argumentação de que representa aqueles que obtiveram seu título naquela escola terciária. Por outro lado, a Província de Buenos Aires, a maior do país, tem sob estudo, desde setembro de 2006, a sanção de uma lei relativa ao exercício profissional do Operador em Psicologia Social (Câmara de Deputados de Buenos Aires, 2006).

Ainda, a partir de 1999 a Universidade CAECE (anteriormente Universidade "Centro de Altos Estudos em Ciências Exatas" que, tornandose mais abrangente, passou a ser intitulada "Universidade CAECE") implantou a Licenciatura em Psicologia Social explicitamente com o objetivo de articular a formação desse profissional com as formações técnicas superiores em psicologia social de diferentes instituições terciárias 
(Tabela 7). Explicitamente, o curso destaca alguns dos títulos aceitados para essa articulação (UNIVERSIDADE CAECE, 2007a, s/p):

- “Operador em Psicologia Social” (Resolução 992/93 do Ministério de Cultura e Educação da Nação Argentina);

- "Operador em Psicologia Social (Resolução 679/94 da Direção Geral de Escolas e Cultura da Província de Buenos Aires)”;

- "Plano Alternativo do Curso de Formação de Operadores em Psicologia Social” (Resolução 14286/97 da Direção Geral de Cultura e Educação da Província de Buenos Aires);

- "Plano Alternativo do Curso de Formação de Operadores em Psicologia Social” (Resolução 4521/98 da Direção Geral de Cultura e Educação da Província de Buenos Aires).

- “Operador em Psicologia Social” (Resolução 401/99 da Secretaria de Educação do Governo da Cidade de Buenos Aires).

- "Técnico Superior em análise e intervenção nos campos grupal, institucional e comunitário" (Resolução 346/01 da Secretaria de Educação do Governo da Cidade de Buenos Aires).

- “Operador em Psicologia Social” (Resolução. 606/02 da Secretaria de Educação do Governo da Cidade de Buenos Aires).

O modelo da Universidade CAECE despertou várias críticas, fundamentadas no modelo latino-americano proposto na Conferencia Latinoamericana sobre treinamento do psicólogo, ocorrida em 1974 em Bogotá, que recomendava títulos gerais em nível de grau universitário (ARDILA, 1975). Em 2005 a mesma universidade estabeleceu a Licenciatura em Psicologia, apesar da Licenciatura em Psicologia Social não ter desaparecido. 
Em definitivo, os cursos de graduação em modelos pichonianos de intervenção em psicologia social na Argentina têm ficado a cargo de instituições terciárias, com exceção da Universidade CAECE. O crescimento de ditas escolas tem sido fenomenal, especialmente após a redemocratização. Por seu lado, os cursos universitários de psicologia iniciaram processo que tende a reconhecer seus cursos universitários, logo que os mesmos sejam declarados de interesse público, a partir de uma petição que foi compartilhada pela Associação de Psicologia (AUAPsi), instituição que reúne os cursos de psicologia das universidades nacionais, a Unidade de Vinculação Acadêmica de Psicologia (UVAPsi), que reúne os cursos de psicologia de universidades particulares e a Federação de Psicologia da República Argentina (FePRA) (REPÚBLICA ARGENTINA. MINISTERIO DE EDUCACIÓN, CIENCIA Y TECNOLOGÍA, 2005).

Nesse sentido, os títulos em psicologia e de operador ou técnico superior em psicologia social parece que seguirão por caminhos divergentes, não obstante algumas situações isoladas de aproximação.

Referências

ARDILA, R. The first latin-american conference on training in psychology. International Journal of Psychology, 7, 435-446, 1975.

AVENBURG, R.. Psicoanálisis, universidad, institución psicoanalítica. In: KRIEGER, E.A.; SABSAE FOKS, G.; IZAGUIRRE, M.; LEW, C.; SZWARC, N. \& TABACZNIK, M (Eds.), Fragmentos de la historia del psicoanálisis en la Argentina. Buenos Aires: JVE Ediciones, 2003.

BABOT, J.C. de, VENTURA, M., JORRAT, M. \& LUPIAÑEZ, G. Una historia vivida. La historia de la Facultad de Psicología en la Universidad Nacional de Tucumán. San Miguel de Tucumán: Universidad Nacional de Tucumán. Facultad de Psicologia, 2006.

BALÁN, J. Cuéntame tu vida. Una biografía colectiva del psicoanálisis argentino. Buenos Aires: Planeta, 1991. 
BARRIONUEVO, M.S. \& GARCÍA MARCOS, F. La carrera de psicología en las universidades argentinas. Psicología médica, 2 (1), p. 83-110, 1975.

BLEGER, J. Clase inaugural de la Cátedra de Psicoanálisis. Acta Psiquiátrica e Psicológica Argentina, 8 (1), p. 56-60, 1962.

(1964). Psicologia de la conducta (2a ${ }^{\mathrm{a}}$ ed.). Buenos Aires: EUDEBA.

BUCHANAN, R.D. Legislative warriors: American psychiatrists, psychologists, and competing claims over psychotherapy in the 1950s. Journal of History of the Behavioral Sciences, 39 (3), p. 225-249, 2003.

BUCHBINDER, P. Historia de las universidades argentinas. Buenos Aires: Sudamericana, 2005.

CÁMARA DE DIPUTADOS DE BUENOS AIRES. Señor Diputado Bonicatto, proyecto de ley, ejercicio profesional del Operador en Psicología Social. In: CÁMARA DE DIPUTADOS DE BUENOS AIRES, Período 134. Asuntos entrados en la Sesión del 27 de septiembre de 2006 (p. 81-88). La Plata: Autor, 2006.

CARMONA PARRA, J.A. Entrevista con Joaquín Pichon-Rivière. Poiesis, Revista electrónica de Psicologia social, 13, s/p, 2007. Disponível em: www.funAm.edu.co/poiesis/Edicion013/poiesis13.carmona.html Acesso em 15/9/2007.

CASTRO SOANO, A. Las competencias profesionales del psicologo y las necesidades de perfiles profesionales en los diferentes ambitos laborales. Interdisciplinaria. Revista de Psicología y Ciencias Afines, 21 (2), p. 117-152, 2004.

CHAPARRO, F.J. La carrera de psicología en las universidades nacionales. Revista Argentina de Psicología, 2, p. 147-154, 1969.

COMPAGNUCCI, E.R., CARDÓS, P. \& OJEDA, G. Acerca de las prácticas docentes y la enseñanza de la psicología. Revista de Teoría y Didáctica de las Ciencias Sociales, 7, p. 7-24, 2002.

ESCOLA DE PSICOLOGIA SOCIAL DO SUR. Carreras. Disponível em: www.psicosocialdosur.com.ar/, 2007a. 
. Contenidos. Disponível em www.psicosocialdosur.com.ar/, 2007b.

FABRIS, Fernando. Pichon-Rivière a comienzos de los años 30. Antecedentes lejanos del Pichon-Rivière fundador de una psicología definida como social. Acheronta, 10, s/p, 1999. Disponível em:

www.acheronta.org/acheronta10/pichon.htm

FLEISCHER, D. El psicoanálisis en la Universidad de Buenos Aires. In: KRIEGER, E.A.; SABSAE FOKS, G.; IZAGUIRRE, M.; LEW, C.; SZWARC, N. \& TABACZNIK, M (Eds.), Fragmentos de la historia del psicoanálisis en la Argentina. Buenos Aires: JVE Ediciones, 2003.

GALIÑANES, M.D. Programa del Seminario Electivo de Pre-grado de la Facultad de Psicología de la UNR. In: FABRIS, F. \& GALIÑANES, M.D. Psicología clínica pichoniana. Una perspectiva vincular, social y operadora de la subjetividad. Buenos Aires: Ediciones Cinco, 2004.

GARCÍA, G. La entrada del psicoanálisis en la Argentina. Obstáculos y perspectivas.. Buenos Aires: Altazor, 1978.

. El psicoanálisis y los debates culturales. Ejemplos argentinos. Buenos Aires: Paidós, 2005.

GARCÍA, M. \& WAISBROT, D. Pichon-Rivière. Una vuelta en espiral dialéctica. Buenos Aires: Centro Editor Argentino, 1981.

GARCÍA DE ONRUBIA, L.F. de. La crisis de la psicología y la teoría de la forma. In: Actas del Primer Congreso Nacional de Filosofía (Tomo II, p. 1367-1374). Mendoza: Universidad Nacional de Cuyo. 1950.

GREENE, E.B. What courses are essential for work in psychological diagnosis and treatment? Journal of Consulting Psychology, 2 (2), p. 43-45, 1938.

HALPERIN DONGHI, T. Historia contemporánea de América Latina (13 ed.). Madrid: A, 1998.

HORAS, P. El hombre total como motivo de la psicología contemporánea. In: Actas del Primer Congreso Argentino de Psicologia (vol. 1, p. 245-254). San Miguel de Tucumán: Universidad Nacional de Tucumán, 1955. 
La enseñanza de la Psicología en la universidad argentina y otros comentarios. Anales del Instituto de Investigaciones Psicopedagógicas, 6, p. 339-354, 1961.

KLAPPENBACH, H. Diálogo con Ana Quiroga. Pichon-Rivière entre la psicología social, el proceso de aprendizaje y Lacan. Actualidad Psicológica, 133, p. 6-7, 1987.

- El psicoanálisis en los debates sobre el rol del psicólogo. Argentina, 1960-1975. Revista Universitaria de Psicoanálisis (Universidad de Buenos Aires), 2, p. 191-227, 2000.

. La globalización y la enseñanza de la psicología en Argentina. Psicologia em Estudo, 8 (2), p. 3-18, 2003a

- La investigación en carreras de grado de psicología en universidades nacionales de Argentina. In: VILLEGAS, J.; MARASSI, P. \& TORO, J.P (Eds.), Problemas centrales para la Formación Académica y el Entrenamiento Profesional del Psicólogo en las Américas (tomo 3, p. 257-271). Santiago: Sociedad Interamericana de Psicologia, 2003b.

LAPUR, O. La psicología en Tucumán. Humanitas, 23, p. 239-243, 1972.

MACCHIOLI, F. Impacto de la psicología social norteamericana en Pichon-Rivière. In: UNIVERSIDAD DE BUENOS AIRES. FACULTAD DE PSICOLOGÍA, Memorias de las XIII Jornadas de Investigación y Segundo Encuentro de Investigadores en Psicología del Mercosur (p. 141-143). Buenos Aires: Autor, 2006.

NAZUR, M.A., CORILI, M.A., CASADO, J.C. Evaluación de la calidad educativa en cátedras de psicodiagnóstico. Revista Iberoamericana de Diagnostico y Evaluación Psicológica, 12 (2), p. 97-109, 2001.

OÑATIVIA, O. Psicologia, ciencia joven. In: Actas del Primer Congreso Argentino de Psicologia (vol. 1, p. 199-213). San Miguel de Tucumán: Universidad Nacional de Tucumán, 1955.

PIACENTE, T., COMPAGNUCCI, E., SCHWARTZ, L. \& TALOU, C. Aportes para un nuevo curriculum en psicología en la Universidad Nacional de La Plata. La Plata: Departamento de Psicologia de la Universidad Nacional de La Plata, 2000. 
PICHON-RIVIÈRE, E. Estructura de una escuela destinada a la formación de psicólogos sociales. Revista Argentina de Psicología, 2, p. 9-16, 1969.

. Lo legal y lo legítimo desde la Asociación de Psicólogos Sociales de la República Argentina. In: GRANDE, A. \& COBLIER, D (Eds.), Lo legal e lo legítimo. Rosario: Ediciones Sapiens, 2005.

. Imágenes de un padre. Y porqué no. La Revista del Centro de Psicoterapia y Técnicas Operativas, 2003. Disponível em:

www.Awebdocpo.com.ar/imagenes\%20deun\%20padreexqno\%20nro3.htm Acesso em 17/05/2005.

, BLEGER, J., LIBERMAN, D. \& ROLA, E. Técnica de los grupos operativos. Acta Neuropsiquiátrica Argentina, 6 (1), p. 32-39, 1960.

PLOTKIN, M. Freud en las pampas. Buenos Aires: Sudamericana, 2003.

PRIMERA ESCOLA PRIVADA DE PSICOLOGIA SOCIAL. ¿Cuál es la historia de esta escuela? 2007. Disponível em: www.psicologiasocial.esc.edu.ar/historia.html; Acesso em 15/06/2007.

. Carrera Tradicional de Psicologia Social., 2007b. Disponível em: http://www.psicologiasocial.esc.edu.ar/pAn_tradicional.htm

REPÚBLICA ARGENTINA. MINISTERIO DE EDUCACIÓN, CIENCIA E TECNOLOGÍA. Anexo VIII. Resolución 136/04. In: PUGLIESE, J.C. Informe diagnóstico sobre certificaciones em el sistema universitario argentino (p. 164-165). Buenos Aires: UNESCO IESALC, 2005.

REPÚBLICA ARGENTINA. MINISTERIO DE EDUCACIÓN, CIENCIA E TECNOLOGÍA. SECRETARÍA DE POLÍTICAS UNIVERSITARIAS. Títulos Universitarios con reconocimiento oficial. Psicologia, 2007. Disponível em: ses.siu.edu.ar; Acesso em 10/08/2007.

RESNIK, S.; PICHON-RIVIÈRE, Enrique. In: EGUÍA, R.D.M (Ed.), Grandes psicoanalistas argentinos. Buenos Aires: Lumen, 2001.

ROUDINESCO, E. \& PLON, M. Diccionario de Psicoanálisis. Buenos Aires: Paidós, 1998. 
SHAKOW, D. An Internship year for psychologists with special reference to Psychiatric Hospitals. Journal of Consulting Psychology, 2 (3), p. 73-76, 1938.

. The training of the clinical psychologist. Journal of Consulting Psychology, 6 (6), p. 277-288, 1942.

SIGAL, S. Intelectuales y poder en Argentina. La década del sesenta. Buenos Aires: Siglo XXI, 2002.

TERÁN, O. Nuestros años sesenta. A formación de A nueva izquierda intoectual argentina. 1956-1966 ( $3^{\mathrm{a}}$ ed.). Buenos Aires: El cielo por asalto, 1993.

TROW, W.C. \& SMART, M.S. Psychologists report their trainining needs. Journal of Consulting Psychology, 7 (1), p. 27-40, 1943.

ULLOA, F. Novela clínica psicoanalítica. Historial de una práctica. Buenos Aires: Paidós, 1995.

UNIVERSIDAD CAECE. Carreras de Grado. Licenciatura en Psicologia social. 2007. Disponível em www.caece.edu.ar/Grado/psicosocial.asp.

UNIVERSIDAD DE TUCUMÁN. FACULTAD DE PSICOLOGÍA. Psicologia Social, 2005. Disponível em:

www.psicologia.unt.edu.ar/programas05/psico_social2005.doc

Acesso em 25/10/2006.

VEZZETTI, H. Enrique Pichon-Rivière: el vínculo y la Gestalt. Anuario de Investigaciones, 10, p. 443-452, 2003 a.

. From the Psychiatric Hospitals to the streets: Enrique PichonRivière and the diffusion of Psychoanalysis in Argentina. In: PLOTKIN, M (Ed.), Argentina on the Couch: Psychiatry, State and Society, 1880 to the Present (p. 141-174). Albuquerque: University of New México Press, 2003b.

. Los comienzos de la psicología como disciplina universitaria y profesional: debates, herencias, proyecciones sobre la sociedad. In: NEIBURG, F. \& PLOTKIN, M (Eds.), Intelectuales y Expertos. La constitución del conocimiento social en la Argentina (p.293-326). Buenos Aires: Paidós, 2004. 
VILANOVA, A. La formación de psicólogos en Iberoamérica. Acta Psiquiátrica y Psicológica de América Latina, 39 (3), p. 193-205, 1993.

ZITO LEMA, V. Conversaciones con Pichon-Rivière sobre el arte y la locura. Buenos Aires: Ediciones Cinco, 1993. 


\begin{tabular}{|c|c|c|c|c|c|c|c|c|c|c|c|c|}
\hline \multirow{6}{*}{ 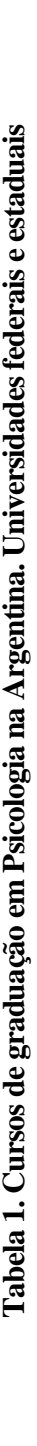 } & 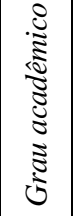 & 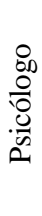 & 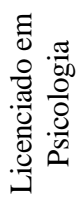 & 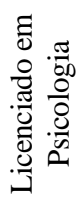 & 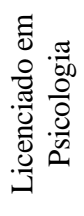 & 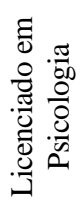 & $\begin{array}{l}0 \\
0 \\
0 \\
0 \\
0 \\
\frac{0}{2} \\
0\end{array}$ & 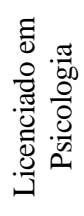 & 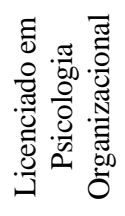 & 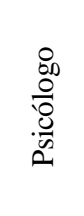 & 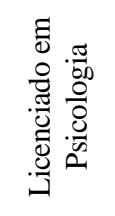 & \\
\hline & 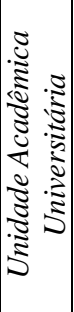 & 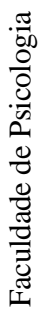 & 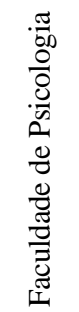 & 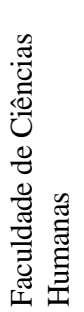 & 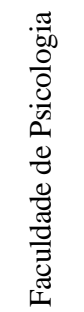 & 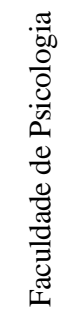 & 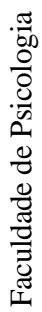 & 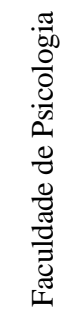 & 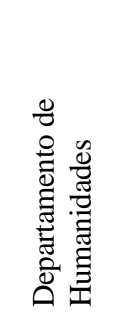 & 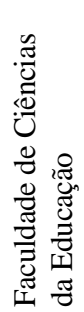 & 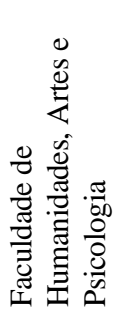 & \\
\hline & $\begin{array}{ll}8 & 0 \\
0 & 0 \\
\vdots & \vdots \\
\vdots & \vdots\end{array}$ & 0 & م & L & L & م & L & م & $\nabla$ & מ & $\frac{\nabla}{\omega}$ & \\
\hline & 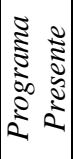 & 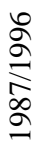 & 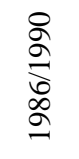 & 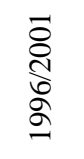 & 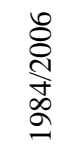 & $\begin{array}{l}\mathscr{\infty} \\
\text { O్ర }\end{array}$ & ๙ิ & $\begin{array}{l}\text { வ } \\
\text { ద }\end{array}$ & ঃ̊̊ి & 농 & ஜ̊ & \\
\hline & 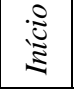 & 岁 & ڤึ & $\begin{array}{l}\infty \\
\stackrel{2}{\sim}\end{array}$ & 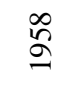 & $\begin{array}{l}\infty \\
\stackrel{\leftrightarrow}{\emptyset}\end{array}$ & 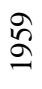 & ஜூ & ஓి & ㄴㅇㅇ & 옹 & \\
\hline & 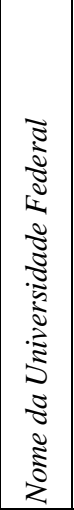 & 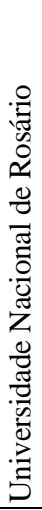 & 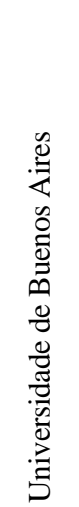 & 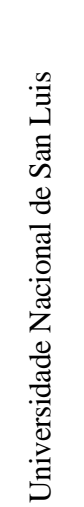 & 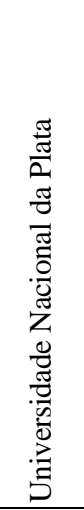 & 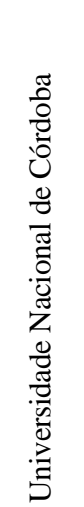 & 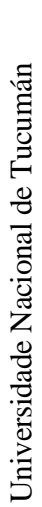 & 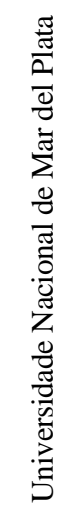 & 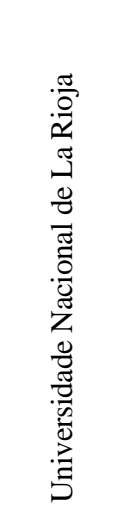 & 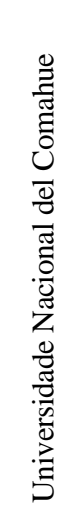 & 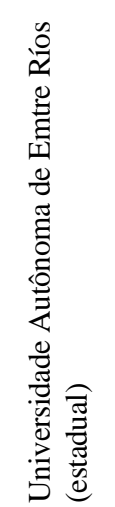 & 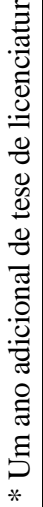 \\
\hline
\end{tabular}

Fonte: levantamento do autor em bases de dados das referidas universidades e na base: República Argentina. Ministério da Educação, Ciência e Tecnología. Secretaría de Políticas Universitárias (2007). Títulos Universitários com reconhecimento oficial. Psicologia. Disponível em: http://ses.siu.edu.ar; acesso em 10/8/2007 


\begin{tabular}{|c|c|c|c|c|c|c|c|c|c|c|c|c|}
\hline \multirow{6}{*}{ 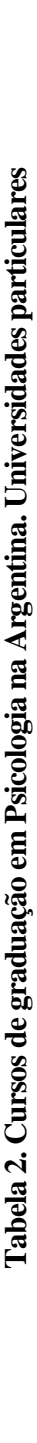 } & 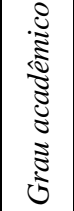 & 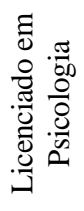 & 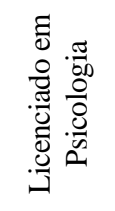 & 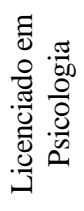 & 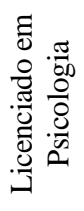 & 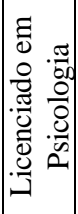 & 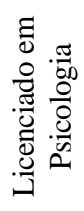 & 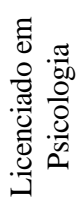 & 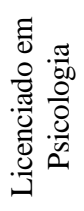 & 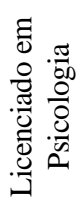 & 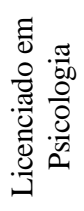 & 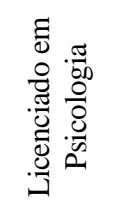 \\
\hline & 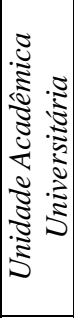 & 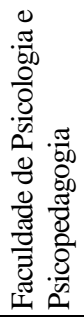 & 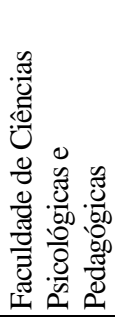 & 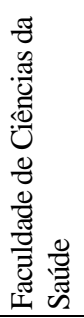 & 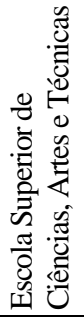 & 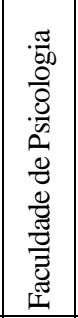 & 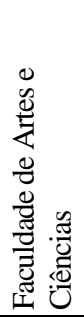 & 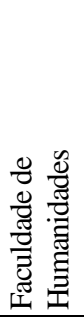 & 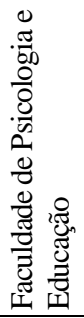 & 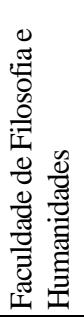 & 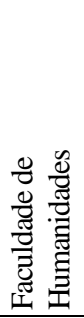 & 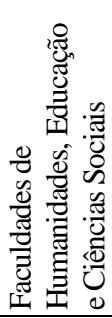 \\
\hline & 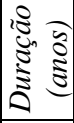 & م & $\nabla$ & מ & م & מ & م & $\nabla$ & \llcorner & L & \llcorner & L \\
\hline & 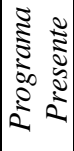 & ஜ̊ & 옹 & 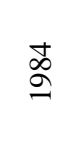 & ঠి & बి & 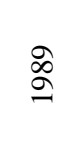 & ஓి & مิ & ষ̊ঠ & $\begin{array}{l}\vec{\infty} \\
\stackrel{\sigma}{\sigma}\end{array}$ & ஓి \\
\hline & : & 옴 & ซै & ֶి & 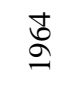 & 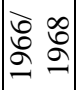 & ڤ̆ & ڤ્ڤ & ஜூ & ஜூ & $\begin{array}{l}\text { oీ } \\
\stackrel{2}{\longrightarrow}\end{array}$ & ஓ \\
\hline & 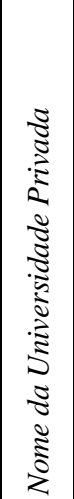 & 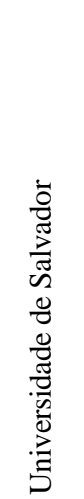 & 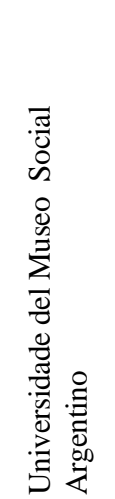 & 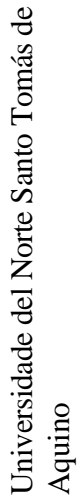 & 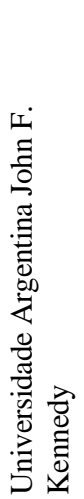 & 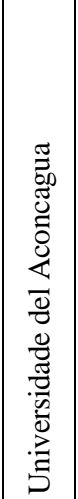 & 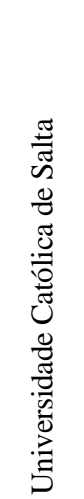 & 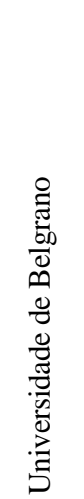 & 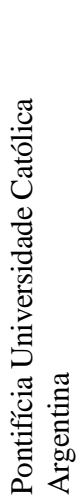 & 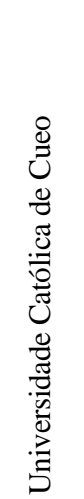 & 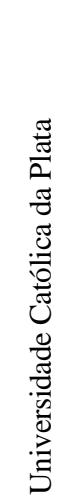 & 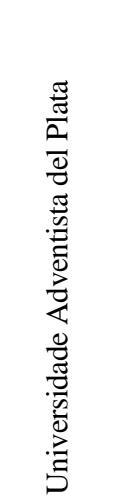 \\
\hline
\end{tabular}




\begin{tabular}{|c|c|c|c|c|c|c|c|c|c|c|c|c|}
\hline \multirow{6}{*}{ 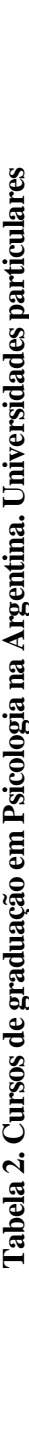 } & 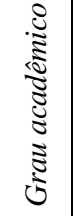 & 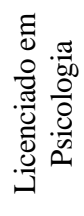 & 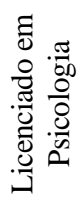 & 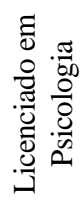 & 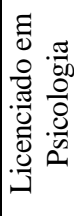 & 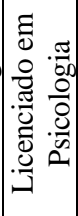 & 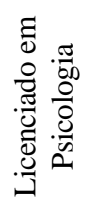 & 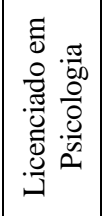 & 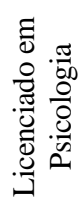 & 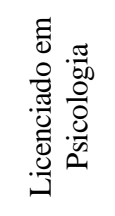 & 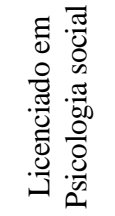 & 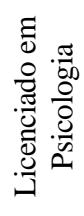 \\
\hline & 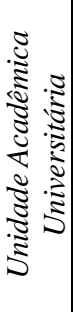 & 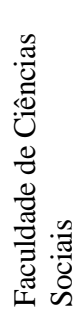 & 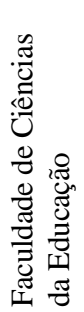 & 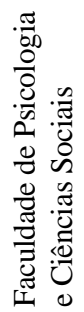 & 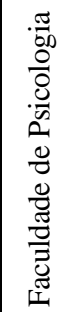 & 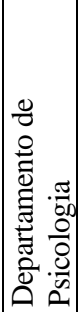 & 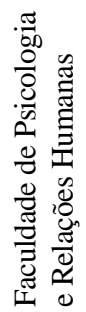 & 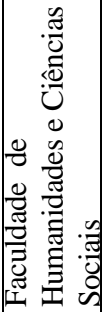 & 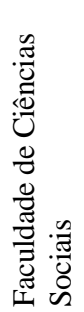 & 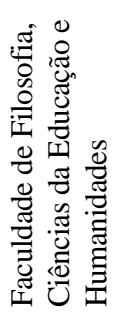 & 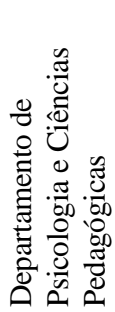 & 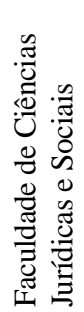 \\
\hline & 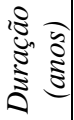 & $\nabla$ & 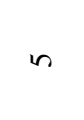 & $\nabla$ & ூㅗ & 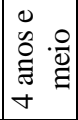 & เ & $\nabla$ & $\nabla$ & $\nabla$ & $\nabla$ & $\nabla$ \\
\hline & 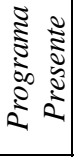 & ণి & ది & ஓి & 노 & 㟔 & Sิ & $\stackrel{\infty}{\circ}$ & ळ̊ & g. & g & ঠి \\
\hline & : & ন & 요 & 농 & 농 & Д & S) & 吕 & 吕 & ब & ஓి & ঠิ \\
\hline & 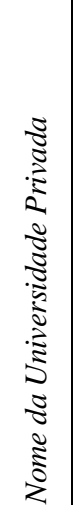 & 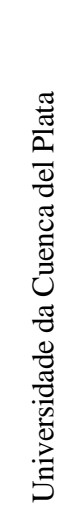 & 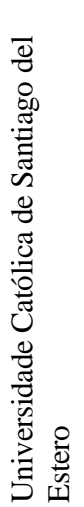 & 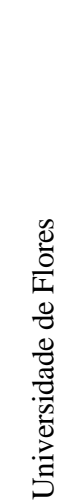 & 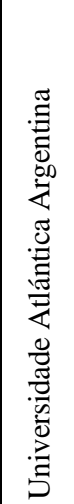 & 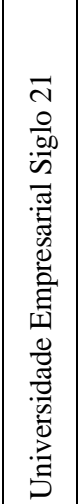 & 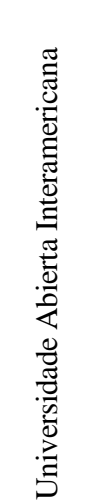 & 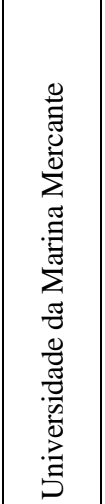 & 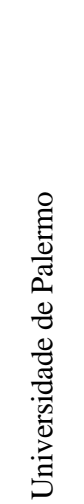 & 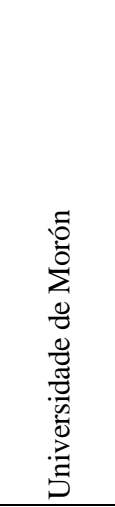 & 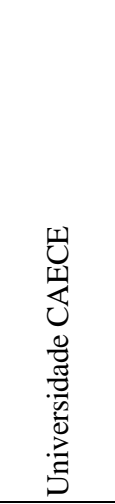 & 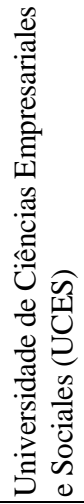 \\
\hline
\end{tabular}




\begin{tabular}{|c|c|c|c|c|c|c|c|c|c|c|c|c|c|}
\hline \multirow{6}{*}{ 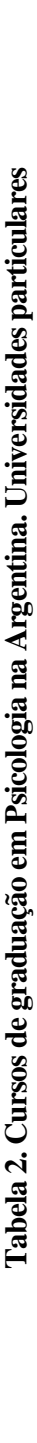 } & 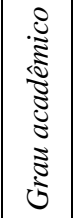 & 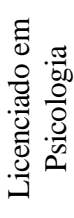 & 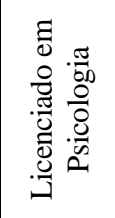 & 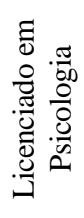 & 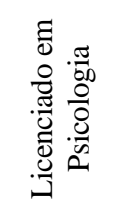 & 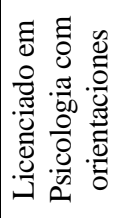 & 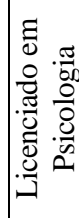 & 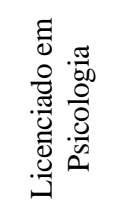 & 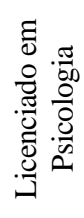 & 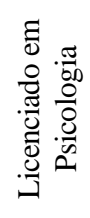 & 1 & 1 & I \\
\hline & 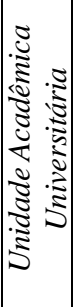 & 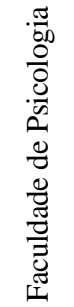 & 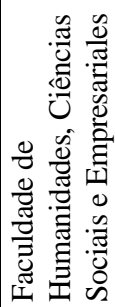 & 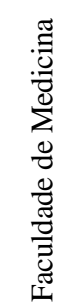 & 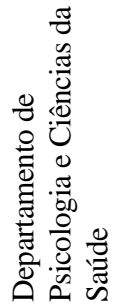 & 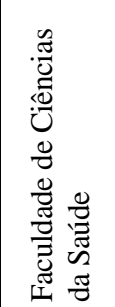 & 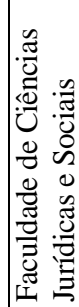 & 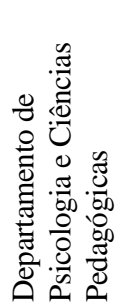 & 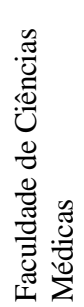 & 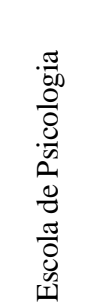 & 1 & 1 & 1 \\
\hline & 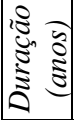 & $\begin{array}{l}\stackrel{0}{\square} \\
\Xi \\
0 \\
\forall\end{array}$ & $\nabla$ & & $\nabla$ & مו & $\nabla$ & $\nabla$ & $\nabla$ & L & 1 & 1 & 1 \\
\hline & 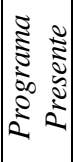 & ஓ̊요 & 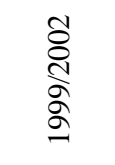 & ֻి & ֻి & ষ̊ঠ & ঠి & 농 & ஜ̊ & 옹 & $\begin{array}{l}\frac{\pi}{0} \\
\text { : }\end{array}$ & 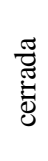 & 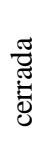 \\
\hline & : & 응 & $\begin{array}{l}\text { ̊ิ } \\
\text { ঠे }\end{array}$ & ֻి & ֻి & ঠঠ & ঠి & ํㅇㅇ & 仓ิ & ڤ્ఠ & 杏 & 疋 & హু \\
\hline & 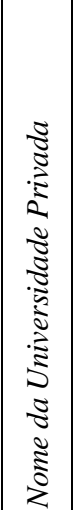 & 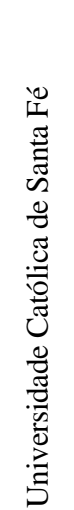 & 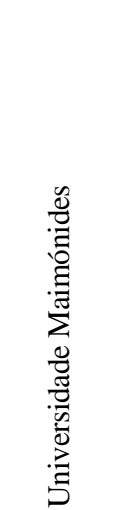 & 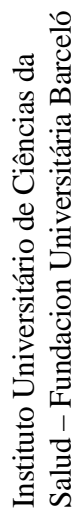 & 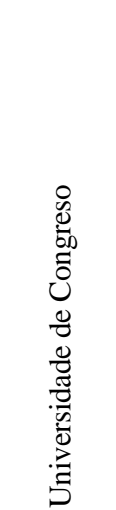 & 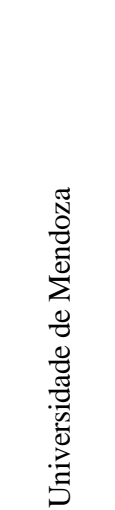 & 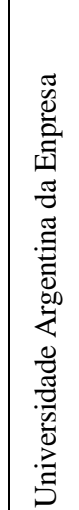 & 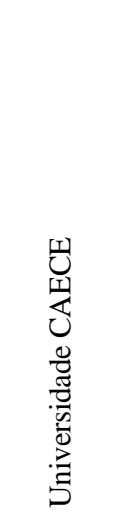 & 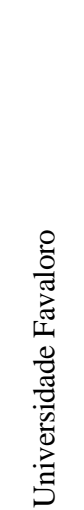 & 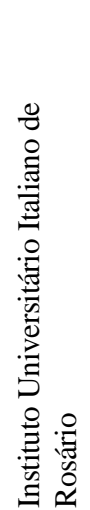 & 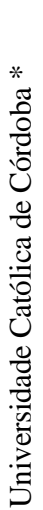 & 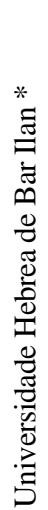 & 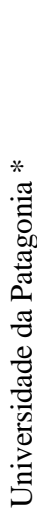 \\
\hline
\end{tabular}

Fonte: levantamento do autor em bases de dados das referidas universidades e na base: República Argentina. Ministério da Educação, Ciência e Tecnología. Secretaría de Políticas Universitárias (2007). Títulos Universitários com reconhecimento oficial. Psicologia. Disponível em: http://ses.siu.edu.ar; acesso em 10/8/2007 


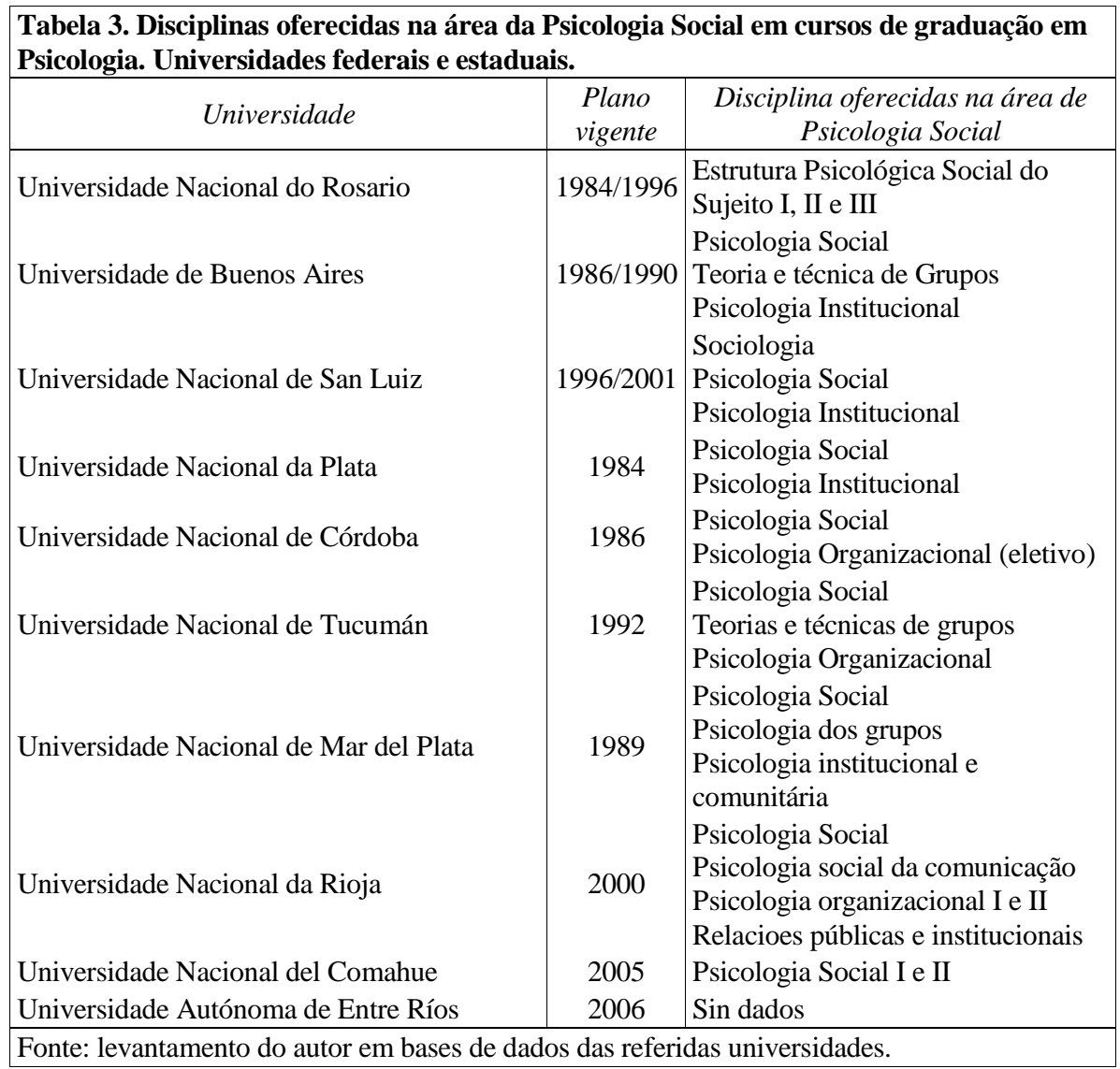




\begin{tabular}{|c|c|c|}
\hline \multicolumn{3}{|c|}{$\begin{array}{l}\text { Tabela 4. Disciplinas oferecidas na área da Psicologia Social em cursos de graduação em } \\
\text { Psicologia. Universidades particulares. }\end{array}$} \\
\hline \multicolumn{3}{|c|}{\begin{tabular}{l|c|c} 
Universidade & Plano & Disciplina oferecidas na área de \\
\end{tabular}} \\
\hline Universidade del Salvador & 2006 & $\begin{array}{l}\text {-Psicologia da Interação Social e dos } \\
\text { Pequenos Grupos } \\
\text {-Psicologia Institucional e } \\
\text { Organizacional } \\
\text {-Psicologia Comunitária } \\
\text {-Psicologia da Família }\end{array}$ \\
\hline $\begin{array}{l}\text { Universidade del Museo Social } \\
\text { Argentino }\end{array}$ & 2007 & $\begin{array}{l}\text {-Psicologia Social } \\
\text {-Teoria e técnica de grupos } \\
\text {-Mediação } \\
\text {-Psicologia das Instituições } \\
\text { Organizacionais e Empresas }\end{array}$ \\
\hline $\begin{array}{l}\text { Universidade del Norte Santo Tomás de } \\
\text { Aquino }\end{array}$ & 1984 & -Psicologia Social e Comunicacional \\
\hline Universidade Argentina John F. Kennedy & 2004 & $\begin{array}{l}\text {-Psicologia Social } \\
\text {-Dinâmica de grupo } \\
\text {-Psicologia Institucional e das } \\
\text { Organizacionais }\end{array}$ \\
\hline Universidade del Aconcagua & 1999 & $\begin{array}{l}\text {-Psicologia Social } \\
\text { - Teoria e técnica de grupos } \\
\text {-Psicossociología de grupos } \\
\text {-Psicologia comunitária }\end{array}$ \\
\hline Universidade Católica de Salta & 1989 & $\begin{array}{l}\text {-Psicologia Social } \\
\text {-Dinâmica de grupo } \\
\text {-Psicologia Organizacionais } \\
\text {-Psicologia da Marginalidade Social }\end{array}$ \\
\hline Universidade de Belgrano & 2000 & $\begin{array}{l}\text { - Teoria da comunicação humana } \\
\text {-Psicologia Social I e II } \\
\text {-Dinâmica de grupos } \\
\text {-Psicologia Organizacional } \\
\text {-Psicologia política (optativa) }\end{array}$ \\
\hline $\begin{array}{l}\text { Pontifícia Universidade Católica } \\
\text { Argentina }\end{array}$ & $1997 / 2005$ & $\begin{array}{l}\text {-Psicologia Social e Institucional } \\
\text { - Psicologia Organizacional } \\
\text { - Psicologia da família e da } \\
\text { comunidade }\end{array}$ \\
\hline Universidade Católica de Cueo & 2006 & -Psicologia Social \\
\hline Universidade Católica da Plata & 1981 & $\begin{array}{l}\text {-Psicologia Social } \\
\text {-Sociologia } \\
\text {-Psicologia Organizacional e Laboral }\end{array}$ \\
\hline
\end{tabular}




\begin{tabular}{|c|c|c|}
\hline Universidade Adventista del Plata & 1990 & $\begin{array}{l}\text {-Psicologia Social } \\
\text {-Teoria e técnica de grupos }\end{array}$ \\
\hline Universidade da Cuenca del Plata & 2002 & $\begin{array}{l}\text { - Teoria e técnica de grupos } \\
\text {-Psicologia Social, Família e } \\
\text { Sistemas } \\
\text {-Psicologia Institucional e } \\
\text { Comunitária }\end{array}$ \\
\hline $\begin{array}{l}\text { Universidade Católica de Santiago del } \\
\text { Estero }\end{array}$ & 1995 & $\begin{array}{l}\text {-Teoria e técnica de grupos } \\
\text {-Psicologia Social }\end{array}$ \\
\hline Universidade de Flores & 2000 & $\begin{array}{l}\text {-Psicologia Social } \\
\text {-Fundamentos de Sociologia } \\
\text {-Dinâmica de grupos } \\
\text {-Família e Sistemas sociais } \\
\text { - Negociação e manejos de conflitos }\end{array}$ \\
\hline Universidade Atlántida Argentina & 1995 & $\begin{array}{l}\text {-Fundamentos da sociologia } \\
\text {-Psicologia Social } \\
\text {-Teoria e técnica de grupos } \\
\text {-Psicologia Institucional } \\
\end{array}$ \\
\hline Universidade Empresarial Siglo 21 & 1995 & $\begin{array}{l}\text {-Psicologia Social } \\
\text {-Psicologia Organizacional } \\
\text {-Diagnóstico Organizacional } \\
\text {-Psicologia Institucional e } \\
\text { Psicohigiene }\end{array}$ \\
\hline Universidade Abierta Interamericana & 2005 & $\begin{array}{l}\text {-Teorias da Comunicação humana } \\
\text {-Problemáticas Sociológicas e } \\
\text { Antropológicas } \\
\text {-Teoria e técnica de grupos } \\
\text {-Psicologia Institucional } \\
\text {-Psicologia Social I e II }\end{array}$ \\
\hline Universidade da Marina Mercante & 1997 & $\begin{array}{l}\text {-Psicologia Organizacional } \\
\text {-Psicologia Social } \\
\text {-Fundamentos em Sociologia }\end{array}$ \\
\hline Universidade de Palermo & 2005 & $\begin{array}{l}\text {-Sociologia } \\
\text {-Psicologia Social } \\
\text {-Interação social e Dinâmica de } \\
\text { grupos } \\
\text {-Psicologia cultural e política } \\
\text { (optativa) }\end{array}$ \\
\hline Universidade de Morón & 2005 & $\begin{array}{l}\text {-Psicologia Social } \\
\text {-Dinâmica e técnica de grupos } \\
\text {-Psicologia Institucional } \\
\text {-Mediação }\end{array}$ \\
\hline
\end{tabular}




\begin{tabular}{|c|c|c|}
\hline Universidade CAECE & 1999 & -Ver tabela 7 \\
\hline $\begin{array}{l}\text { Universidade de Ciências Empresariales } \\
\text { e Sociales (UCES) }\end{array}$ & 1999 & $\begin{array}{l}\text {-Fundamentos da Sociologia } \\
\text { - Teoria e técnica de grupos } \\
\text {-Psicologia Institucional } \\
\text {-Psicologia Organizacional (opcional) } \\
\text {-Introdução à mediação de conflitos }\end{array}$ \\
\hline Universidade Católica de Santa Fé & 2001 & $\begin{array}{l}\text {-Sociologia } \\
\text {-Psicologia Social } \\
\text {-Psicologia Social de grupos e } \\
\text { comunidades } \\
\text {-Teoria Geral das Organizações }\end{array}$ \\
\hline Universidade Maimónides & $1999 / 2002$ & $\begin{array}{l}\text {-Sociologia } \\
\text {-Psicologia Social } \\
\text {-Dinâmica grupal } \\
\end{array}$ \\
\hline $\begin{array}{l}\text { Instituto Universitário de Ciências de } \\
\text { Salut - Fundación Universitária Barceló }\end{array}$ & 2003 & $\begin{array}{l}\text {-Fundamentos da Sociologia } \\
\text {-Psicologia Social } \\
\text { - Teoria e técnica de grupos } \\
\text {-Psicologia Institucional }\end{array}$ \\
\hline Universidade de Congreso & 2003 & $\begin{array}{l}\text {-Sociologia } \\
\text {-Psicologia Social } \\
\text {-Psicologia Organizacional }\end{array}$ \\
\hline Universidade de Mendoza & 2004 & -Sem dados \\
\hline Universidade Argentina da Empresa & 2004 & $\begin{array}{l}\text {-Pensamento crítico e comunicação } \\
\text {-Psicologia Social } \\
\text {-Psicologia Institucional } \\
\text {-Dinâmica de grupos } \\
\text {-Conflitos e mediação psicológica } \\
\text {-Análise organizacional }\end{array}$ \\
\hline Universidade CAECE & 2005 & $\begin{array}{l}\text {-Sociologia } \\
\text {-Psicologia Social } \\
\text {-Dinâmica de grupos } \\
\text {-Psicologia das Instituições e das } \\
\text { Organizações }\end{array}$ \\
\hline Universidade Favaloro & 2006 & $\begin{array}{l}\text {-Psicologia Social } \\
\text {-Teoria e técnica de grupos I e II }\end{array}$ \\
\hline Instituto Universitário Italiano de Rosario & 2007 & $\begin{array}{l}\text {-Seminário Problemática Social, } \\
\text { Institucional e Comunitário I e II }\end{array}$ \\
\hline
\end{tabular}




\section{Tabela 5. Primeira Escola Particular de Psicologia Social. \\ Curso tradicional de Psicologia Social. Título não oficial.}

Primer año

Introducción al campo de la Psicología Social: Objeto de la Psicología Social; análisis de la relación entre el orden histórico-social y la subjetividad.

Especificidad del análisis de la Psicología Social. Psicología Social y problemática del sujeto. Análisis crítico la cotidianeidad. La subjetividad en el fin del siglo. Subjetividad y crisis social. Vínculo: Concepto. Procesos de interacción. Estructura interaccional primaria. Sujeto, necesidades y vínculo. Vínculo como espacio de configuración del sujeto. Procesos de comunicación y aprendizaje en el vínculo. Mundo "interno" y mundo externo.

Conducta: Historicidad de la conducta. Multicausalidad. Necesidad, vínculo y conducta. Conducta y aprendizaje.

Grupo: Concepto. Organizadores internos de la estructura grupal. Grupo como proceso. Interjuego grupo externo y grupo interno. Concepto de portavoz. Concepto de emergente. Roles. Funciones de la grupalidad. Problemáticas de la grupalidad hoy. El grupo como forma organizativa de la vida social.

Institución y organización. Conceptos. Relación organización / institución. Institución y subjetividad. Sujeto, vínculo, organización. Grupo y organización.

La organización familiar: niveles de análisis de la organización familiar. La organización familiar mediadora entre el sujeto y el orden social. Organización familiar como grupo. Génesis de la subjetividad en la familia. Procesos identificatorios. Roles, comunicación. Cambios en la familia. Duelos familiares. Problemáticas actuales de la organización familiar. Legislación y familia. Familia y trabajo.

Institución educativa: Tareas, estructura, roles y funciones. El sujeto en la institución educativa. Crisis

cambio en la escuela, sus efectos en la subjetividad. Situaciones conflictivas. Violencia en la escuela. Introducción a algunas cuestiones de la vida social: Medios de comunicación de masas y su eficacia en la configuración de la subjetividad. Rol social de los medios. La violencia social.

El grupo como dispositivo de trabajo ( módulo de integración temática)

El grupo como instrumento de trábale. Las contradicciones del campo grupal. El grupo operativo como técnica.

Segundo año

Procesos de la constitución de la subjetividad en sus distintos ámbitos: La concepción de sujeto desde la Psicología Social. Sujeto del hacer, de la necesidad y del conocimiento.

Procesos de aprendizaje y de configuración de la subjetividad: El aprendizaje como proceso. Su especificidad Escenarios del aprender. Concepto de matriz de aprendizaje. Análisis de los modelos internos de aprendizaje y vínculo. Aprendizaje grupal, aprendizaje individual. Especificidades, diferencias y relaciones.

El proceso de trabajo en la constitución de la subjetividad: Características del proceso de trabajo. Aprendiza] y trabajo. Trabajo y grupo. Trabajo y comunicación. Las organizaciones del trabajo. El trabajo en la sociedad actual. Algunos abordajes de la problemática del trabajo en las organizaciones. 
La problemática de la salud y sus organizaciones: Salud como proceso. Distintas concepciones de salud, hombre y vida social. Distintas organizaciones de la salud. La institución salud y su relación con otras instituciones sociales.

Conducta: Fundamentos psicoanalíticos de la Teoría de la conducta. Concepto de inconsciente. Primera Tópico Concepto de conflicto psíquico. Formaciones del inconsciente ( lapsus, actos fallidos) Segunda Tópica. Yo, Superyó, Ello. Procesos de identificación. Angustia y mecanismos de defensa. Concepto de sexualidad en psicoanálisis. Conceptos de Melanie Klein: concepto de posición: depresiva, esquizoparanoide. Mecanismo de defensa.

Las organizaciones: estructura de la organización. Tarea. Roles. Comunicación y aprendizaje. El conflicto en organización. El grupo en las organizaciones. Sujeto y organización.

Tercer año

El análisis de lo vincular.

Mediación y Psicología Social.

Fundamento en la dialéctica del esquema conceptual referencial y operativo. Su método de análisis e intervención.

Transferencia y fantasía inconsciente. Especificidades y relaciones.

Operación psicológica-operación psicosocial-actitud psicológica

Actitud psicológica.

La investigación en Psicología Social.

La entrevista.

El ámbito comunitario.

Los grupos de discusión.

Seminarios.

Talleres.

Trabajo de entrevista.

Cuarto año

CURSO DE ESPECIALIZACION EN ANÁLISIS E INTERVENCIÓN EN EL CAMPO GRUPAL, SEGUN LA TÉCNICA DE GRUPO OPERATIVO.

Parte 1) La función de observación: su ejercicio y aprendizaje: La observación en Ciencias Sociales. La observación en Psicología Social, base del método de análisis e intervención. Observación y formación en Psicología Social. (Fundamentación. Objetivos. El proceso de aprendizaje del rol.)

Parte 2) El campo operacional, grupo-grupalidad, y técnica de grupo operativo: Concepto de grupo. Su relación con la concepción de sujeto en la Psicología social planteada por E. PichonRivière. Hipótesis acerca de la operatividad intrínseca a los grupos (EPR). El concepto de obstáculo su relación con las ansiedades básicas y la dramática subyacente al acontecer grupal.

Método. Técnica. Dispositivo. Antecedentes y fundamentación teórica de la técnica de grupo operativo. Elementos de esta técnica y su encuadre.

Parte 3) El campo operacional: Su análisis desde una perspectiva teórico técnica: el acontecer grupal y su análisis desde material de crónica referentes teóricos.

Segunda etapa

Según este disetio los alumnos continúan con el trabajo del rol observador, pero incluyen en el 
grupo operativo de 4to. año tareas de rol playing de coordinación, aproximaciones psicodramáticas a situaciones de coordinación.

Dialéctica de los procesos grupales. Principales contradicciones que configuran el proceso grupal." Análisis de las contradicciones que se dan en el texto y el contexto de la tarea y entre texto y contexto del proceso grupar (EPR) Especificidad del análisis desde la técnica del grupo operativo. (Relación de lo manifiesto y lo latente en función de la tarea explícita) su indagación y trabajo en el campo grupal como tarea del coordinador. Su análisis y elaboración como un aspecto de la tarea del grupo operativo. Complementariedad de tareas y roles. Operación y la actitud psicológica desde el rol coordinador.

Relación entre análisis e intervención como unidad dialéctica. Carácter dominantemente estratégico y logístico del análisis carácter táctico y técnico de la intervención. La intervención como operación logística.

Operación y la actitud psicológica desde el rol coordinador.

Relación entre análisis e intervención como unidad dialéctica. Carácter dominantemente estratégico y logístico del análisis carácter táctico y técnico de la intervención. La intervención como operación logística. Ti os de intervención. Estilos de coordinación.

Fonte: Reproduzido de Primera Escuela Privada de Psicología Social (2007b). Carrera Tradicional de Psicología Social. Disponível em: www.psicologiasocial.esc.edu.ar/plan_tradicional.htm

\section{Tabela 6. Escola de Psicologia Social do Sul. Curso de Operador em Psicologia Social.}

\section{Titulo oficial}

Primeiro Ano:

- Psicologia Social

- $\quad$ Teoria de los grupos

- Introdução a la Psicanálise

- Teoria da conduta

Segundo Ano:

- Teoria de la constituição da subjetividade

- Psicologia da Vida cotidiana

- $\quad$ Teoria da Técnica de Grupo Operativo Teoria das estruturas vingares

- Metodologia da Pesquisa Psicosocial

- Ética e Deontologia Profissional

- Intervenccão na Area Psicosocial

Terceiro Ano:

- $\quad$ Estrutura e dinámica del Rol Observador

- Práctica do Rol Observador de grupos

- $\quad$ Estrutura y análise dos fenómenos grupais

- Psicologia Social Aplicada

- $\quad$ Estrutura e dinámica do Rol Coordinador Grupal

- Técnicas de abordagem no campo da Psicologia Social Práctica da Coordinacão de Grupos

Fonte: Reproduzido de: Escuela de Psicologia Social del Sur (2007b). Contenidos. Disponível em www.psicosocialdelsur.com.ar/; acessado em 11/8/2007. 
Tabela 7. Universidade CAECE.

Licenciatura em Psicologia Social. Curso universitário aprovado oficialmente em 1999.

\begin{tabular}{|c|c|c|}
\hline Ano & Primeiro quadrimestre & Segundo quadrimestre \\
\hline 1 & $\begin{array}{ll}\text { - } & \text { Introdução a la Psicología Social } \\
\text { - } & \text { História da Psicología Social } \\
\text { - } & \text { Transformação Social I } \\
\text { - } & \text { Teoria dos Grupos }\end{array}$ & $\begin{array}{ll}- & \text { Constituição do Sujeito Social } \\
- & \text { Transformação Social II } \\
- & \text { Problemáticas } \\
& \text { Contemporâneas da } \\
& \text { Psicología Social } \\
- & \text { Metodologia da Pesquisa } \\
& \text { Psicossocial I } \\
\end{array}$ \\
\hline 2 & $\begin{array}{ll}- & \text { Teoria da Técnica Psicossocial } \\
- & \text { Teoria Psicoanalítica } \\
- & \text { Metodologia da Pesquisa } \\
& \text { Psicossocial II } \\
- & \text { Teoria e Técnica da } \\
& \text { Observación Psicossocial }\end{array}$ & $\begin{array}{ll}- & \text { Procesos Psicosociales e } \\
& \text { Fenómenos de Masa } \\
- & \text { Teoria Construcivista } \\
- & \text { Ambitos e Metodología de } \\
& \text { Abordagem } \\
-\quad & \text { Formação e Evaluação de } \\
\text { Projetos }\end{array}$ \\
\hline 3 & $\begin{array}{ll}- & \text { Métodos e Técnicas de } \\
& \text { Intervenção Grupal I } \\
- & \text { Epistemologia das Ciências } \\
& \text { Sociais } \\
-\quad & \text { Psicologia Social e } \\
& \text { Desenvolvimento Social } \\
-\quad & \text { Metodologia da Pesquisa } \\
& \text { Psicossocial III }\end{array}$ & $\begin{array}{ll}\text { - } & \text { Epistemologia da Psicologia } \\
& \text { Social } \\
\text { - } & \text { Métodos e Técnicas de } \\
& \text { Intervenção Grupal II } \\
- & \text { Agenda Internacional } \\
- & \text { Seminário de Pesquisa } \\
& \text { Psicossocial I }\end{array}$ \\
\hline 4 & $\begin{array}{ll}\text { - } & \text { Gerenciamiento da } \\
& \text { Organizaciones da Comunidad } \\
\text { - } & \text { Psicologia Social e Empresas } \\
\text { - } & \text { Sociopatias. Adição e Violência }\end{array}$ & $\begin{array}{ll}- & \text { Emergencias Psicossociales } \\
- & \text { Psicologia Social e a } \\
& \text { Problemática do gênero } \\
- & \text { Psicologia Social e Trabalho } \\
- & \text { Seminário de Pesquisa } \\
& \text { Psicossocial II }\end{array}$ \\
\hline
\end{tabular}




\title{
PALAVRA E SABERES PSICOLÓGICOS NA HISTÓRIA DA CULTURA BRASILEIRA
}

Marina Massimi

Universidade de São Paulo / Ribeirão Preto

\begin{abstract}
função terapêutica da palavra é um dos pilares da intervenção do A psicólogo e como tal constitui-se num aspecto muito importante de sua formação. Freud coloca no texto Tratamento psíquico (ou anímico) de 1905, que "tratamento psíquico quer dizer tratamento que parte da alma, pelos meios que atuam, em primeiro lugar e de maneira direta, sobre o que é anímico no ser humano. Um desses meios é, sobretudo a palavra, e as palavras são também a ferramenta essencial do tratamento anímico" (1905, p. 271).
\end{abstract}

A descoberta desta função da palavra assinalada claramente por Freud é, por sua vez, fruto de um processo histórico. Na concepção de filósofos e médicos da antiguidade clássica, a cura da alma pela filosofia acarretava a sua submissão à razão transmitida pelo discurso (em grego logos significa seja razão seja palavra). A cura da alma — concebida como formação interior da própria alma - implicava no uso da palavra num diálogo que poderia ser interior consigo mesmo, ou com um interlocutor externo. Com efeito, conforme Agostinho, "as palavras obtiveram entre os homens o principal lugar para a expressão de qualquer pensamento, sempre que alguém quer manifestá-lo" (1991, p. 96). Na Idade Moderna, a confiança no poder da palavra enquanto instrumento de persuasão e modificação dos comportamentos, baseava-se no conhecimento e na prática da arte retórica e de suas influências no dinamismo psíquico, proporcionados pela psicologia filosófica aristotélico-tomista. 


\section{A palavra na cultura indígena}

No contexto da cultura brasileira esta confiança foi sem dúvida reforçada pela importância assumida pela palavra e pelo discurso na tradição cultural dos índios brasileiros.

Uma das informações mais antigas acerca da importância do uso da palavra nas culturas indígenas aparece numa narrativa de 1593 do padre visitador da Companhia de Jesus, o português Fernão Cardim (1548-1625). $\mathrm{O}$ relato merece ser analisado por evidenciar as peculiaridades da retórica indígena e frisar a grande propensão dos nativos para a prática da palavra. Cardim relata que, na aldeia do Espírito Santo, após a recepção pelos "principais"', ele juntamente aos outros dois visitadores, o padre Cristóvão de Gouveia e o irmão Barnabé Telho, foram levados em procissão à Igreja pelos índios com danças e músicas de flautas. Citamos o relato mantendo seu estilo e escrita originária:

Feita a oração, lhes mandou o padre fazer uma falla na língua, de que ficaram muito consolados e satisfeitos; aquela noite os índios principais, grandes línguas, pregavam da vida do padre a seu modo, que é da maneira seguinte: começam a pregar de madrugada deitados na rede por espaço de meia hora, depois se levantam, e correm toda a âldea, pé ante pé muito devagar, e o pregar também é pausado, freimatico, e vagaroso; repetem muitas vezes as palavras por gravidade; contam nestas pregações todos os trabalhos, tempestades, perigos de morte que o padre padeceria, vindo de tão longe para os visitar, e consolar, e juntamente os iniciam a louvar a Deus pela mercê recebida, e que tragam seus presentes ao padre, em agradecimento. Era para os ver vir com suas cousas etc., patos, galinhas, leitões, farinha, beijús com algumas raízes e legumes da terra (1980, p. 146).

Os chefes da tribo, apropriando-se do discurso do missionário pregador, traduziam-no em sua própria linguagem para transmiti-lo à comunidade, legitimando assim a presença do padre e ao mesmo tempo

\footnotetext{
${ }^{1}$ Expressão utilizada nos relatos missionários da época para indicar as autoridades políticas das populações nativas.
} 
colocando-se como mediadores insubstituíveis entre este e o povo. No mesmo documento, Cardim fornece outras informações acerca do valor da arte do discurso junto aos índios: ao descrever as ocas indígenas e sua organização social, coloca que em cada "oca" morava um principal, cuja autoridade exercia-se principalmente pelo uso da palavra. Este os exortava ao trabalho, excitava-os à guerra e era muito respeitado por todos. Estas exortações inicialmente eram feitas dentro da oca, "por modo de pregação": o chefe começava sua fala de madrugada, deitado na rede, pelo espaço de uma meia hora; depois, ao amanhecer, ele se levantava e percorria toda a aldeia continuando sua pregação, "a qual faz em voz alta, mui pausada, repetindo muitas vezes as palavras" (ibidem). Cardim continua o relato, narrando que entre os índios principais e pregadores, "há alguns velhos antigos de grande nome e autoridade entre elles, que têm fama por todo o sertão, trezentas e quatrocentas léguas, e mais”. Afirma que os nativos estimam tanto "um bom língua que lhe chamam o senhor da fala. Em sua mão tem a morte e a vida, e os levará por onde quiser sem contradição". Quando eles querem testar se um indivíduo possui esta capacidade, "ajuntam-se muitos para ver se o podem cansar, falando toda noite em peso com ele, e ás vezes dois, três dias, sem se enfadarem” (idem, pp. 152-153).

A descrição de Cardim deixa transparecer a surpresa do religioso português diante da importância atribuída ao uso da palavra pelos índios brasileiros: inesperado ponto de convergência entre a cultura desconhecida destas populações e o imenso esforço de comunicação da cultura europeia daquela época, evidente na criação de novos instrumentos como a imprensa, na busca de contatos e conhecimentos de novos povos, novas culturas e novas línguas e como veremos neste livro, no grande desenvolvimento da arte retórica e das suas infinitas possibilidades enquanto meio pedagógico e doutrinário.

Na cultura brasileira, desde o século XVI, encontram-se várias formas de experimentação do poder da palavra —no que diz respeito à transmissão de saberes e práticas e à persuasão visando modificar crenças e 
comportamentos e atingir, portanto, tanto a pessoa quanto a sociedade. Dentre destas formas, destacam-se a pregação e o teatro.

\section{A palavra na pregação}

A pregação no contexto da sociedade colonial era uma atividade difusa e bastante valorizada pela população. Notícias e descrições acerca das atividades de pregação no meio social brasileiro são dadas em relatos e cartas de viajantes e missionários, desde os primeiros tempos da colonização. Esta prática assumiu uma função importantíssima de transmissão cultural de conceitos, práticas e crenças da tradição clássica, medieval e renascentista ocidental, visando à mudança dos hábitos e da mentalidade dos indivíduos e dos grupos sociais pela força da palavra. Realizada no Brasil num contínuo temporal que se estende desde o século XVI ao século XVIII, deve ser considerada como uma relação dinâmica de intercâmbio entre pregadores e destinatários, assumindo as características que podem ser definidas, conforme uma expressão de R. Chartier, como uma "prática partilhada que atravessa os horizontes sociais” (1988, p. 134) — prática de encontro entre a cultura popular e a letrada. Tal prática passa por diversos níveis de apropriação, que assinalam a intervenção da "invenção criadora no próprio cerne dos processos de recepção” (idem, p. 136). As possibilidades dos mesmos bens culturais, textos e ideias recebidos, serem submetidos a interpretações e empregos diversos, dependem da modalidade em que estes são recebidos pela comunidade dos ouvintes em seu conjunto ou pelos grupos diversificados que a compõem. Além da função de transmissão cultural, a pregação constitui-se em laboratório de experimentação do poder da palavra — numa perspectiva que num certo sentido remete à atual compreensão psicanalítica e psicológica da eficácia terapêutica da palavra, mas que, em se tratando da Idade Moderna, deve ser reconduzida principalmente à aplicação da arte da retórica. Pois, a palavra deve ser considerada seja no que diz respeito ao seu poder de transmissão cultural, seja no que diz respeito à sua capacidade evocativa de afetos. 
Nesta perspectiva, a palavra é remédio para a salvação, concebida nos termos do conceito global de saúde postulado pela Medicina da Alma: saúde do corpo animado e espiritual do indivíduo e saúde do corpo político e social. A palavra - entendida em suas dimensões doutrinária, persuasiva, evocativa e revelativa é, portanto, o verdadeiro pharmacon em poder do homem, para que aprenda a bem viver e a bem morrer. A insistência acerca do cuidado de si mesmo, assim concebido, é originária da filosofia socrática e herdada posteriormente pelo estoicismo e pelas filosofias cristãs (GILSON, 1995), sendo reconhecido como objeto de competência específica inicialmente de duas áreas de conhecimento, a filosofia e a medicina; e posteriormente ao advento do cristianismo, também de uma terceira área de competência, a teologia. Se, por um lado, o interesse indagador acerca da totalidade do objeto era próprio do método filosófico, por outro lado, na tradição clássica e medieval, o médico era aquele que conhecia o universo como um todo: a música, a astrologia, a meteorologia, as relações entre os deuses e os homens. Aplicando este enfoque global à visão do ser humano, evidenciava-se que cuidar dele implicava em considerar todas as dimensões de sua existência, segundo o ideal socrático ${ }^{2}$. Aristóteles, nesta mesma perspectiva, identificava a saúde ou salvação do homem com a realização da felicidade, sendo que " $a$ felicidade é uma certa atividade da alma conforme à excelência perfeita" ${ }^{3}$, que se alcança pela virtude da prudência. Esta baseia-se no reconhecimento e na escolha do "justo-meio", princípio que a ética aristotélica compartilha com a medicina hipocrática. A virtude, pois, é o justo-meio entre os vícios (defeito ou excesso), sendo que seu aprendizado se alcança através da prática. A definição de pessoa explicitada por Tomás de Aquino, retomando Boetius, implicara a consideração de que "esta alma, esta carne e estes ossos pertencem à razão deste homem”", acarreta, no plano terapêutico, a

\footnotetext{
2 “Outra coisa não faço senão andar por aí persuadindo-vos, moços e velhos, a não cuidar tão aferradamente do corpo e das riquezas, como de melhorar o mais possível a alma, dizendovos que dos haveres não vem a virtude para os homens, mas da virtude vem os haveres e todos os outros bens particulares e públicos” (Sócrates, Em Platão em Defesa de Sócrates, 1980, 29b, p. 15).

${ }^{3}$ Ética a Nicômacos, 1, 13, 1102a, p.82, trad. nossa.

4 Tomás, 2001, I, Q.29, Art.2, p. 527.
} 
importância do cuidado com o princípio individual, com cada indivíduo. A preservação e o restabelecimento da saúde, enfim a cura, implicam também na existência de um agente que cure e que acolha a pessoa, ou seja, pressupõem um relacionamento terapêutico, um lugar terapêutico.

O pregador reúne em si um leque de competências múltiplas, destinadas ao cuidado e à cura, atuantes de modo unitário, por serem sempre atentas à unidade do sujeito portador de saúde e da exigência de cuidado, de modo a abranger as dimensões do somático e do mental, da saúde física e da saúde mental. Não lida apenas com almas, mas também com corpos, entendidos no plano individual, social e cósmico. O que explica a dupla função que o modelo exemplar da oratória sagrada lusobrasileira, padre Antônio Vieira, atribui ao pregador.

Por um lado, no Sermão da Sexagésima pregado em 1655, na Capela Real, após regressar da missão em São Luís do Maranhão, Vieira define o pregador como um "médico das almas", pois o efeito do sermão não deve ser o deleite dos ouvintes, mas a cura deles:

A pregação que frutifica, a pregação que aproveita, não é aquela que dá gosto ao ouvinte: é aquela que lhe dá pena. Quando o ouvinte a cada palavra do pregador treme; quando cada palavra do pregador é um torcedor para o coração do ouvinte; quando o ouvinte vai do sermão para cada confuso e atônito, sem saber parte de si, então é a pregação qual convém, então, se pode esperar que faça fruto. (VIEIRA, 2001, p. 51).

Por outro lado, em sermão de 1669, proferido diante da Capela Real de Lisboa, na terceira quarta-feira da Quaresma, Vieira apresenta o pregador como o verdadeiro médico das chagas do corpo espiritual e também do corpo social e político:

E quem não houvesse até agora no púlpito, quem tomasse por assunto a consolação desta queixa, o alívio desta melancolia, o antídoto deste veneno, e a cura desta enfermidade? Muitos dos enfermos bem havia mister um hospital. Mas à obrigação desta cadeira (que é de medicina das almas) só lhe toca disputar a doença, 
e receitar o remédio. E se este for provado, e pouco custoso, será fácil de aplicar (idem, p. 101).

Em um sermão pregado na Terceira Quarta-Feira de Quaresma de 1669, na Capela Real, Antônio Vieira estabelece uma analogia entre as crises do Estado, entendido como corpo político e social, e as patologias do corpo humano. Outra analogia entre a condição da vida política e o estado de saúde do corpo é colocada por Vieira no Sermão da Visitação de Nossa Senhora de 1640. Assinalando que a "origem" e a "causa original das doenças do Brasil” são o roubo, a cobiça, os interesses de ganhos e conveniências particulares, que impedem o respeito da justiça e determinam a perdição do Estado, o jesuíta exclama: "Perde-se o Brasil, senhor, porque alguns ministros de Sua Majestade não vêm cá buscar nosso bem, vêm cá buscar nossos bens” (VIEIRA, 1993, p. 1230). A terapia por ele recomendada então é moldada em analogia com as terapias de medicina do corpo:

Assim, como a medicina, diz Filo Hebreu, não só atende a purgar os humores nocivos, senão a alentar e alimentar o sujeito debilitado: assim a um exercito e republica não lhe basta aquela parte da justiça, que com o vigor do castigo a alimpa dos vícios, como de perniciosos humores, senão que é também necessária a outra parte, que com prêmios proporcionados ao merecimento esforce, sustente e anime a esperança dos homens (idem, p. 1222).

É neste sentido então, que a palavra do pregador é concebida como o "farmaco" eficaz e definitivo para o bem dos corpos individuais animados pela alma racional bem como dos corpos sociais animados pelo vida do espírito de Deus - que ao mesmo tempo cria a comunidade eclesial (o corpo místico) e a comunidade política (a Res-pública: corpo do Rei e corpo do povo).

\section{A palavra no teatro}

Como é sabido, ao jesuíta José de Anchieta deve-se a composição e a realização no Brasil, das primeiras peças teatrais construídas nos moldes do teatro praticado na Europa da Idade Moderna. De sua autoria é um conjunto considerável de peças: Auto da Pregação Universal, 1570; Diálogo do Pe. 
Pero Dias Mártir, 1571; Na Festa de Natal ou Pregação, 1577; Na Aldeia de Guapimirim, 1580; Excerto do Auto de S. Sebastião, 1584; Auto da Visitação de Sta. Isabel, 1597, a última composta praticamente já no leito de morte em 1597 (em Reritiba, Espírito Santo). Esta produção é explicável se lembrarmos os tempos da formação universitária de Anchieta em Coimbra e seu contato com a obra teatral dos grandes autores de sua época (como Gil Vicente, Tirso de Molina, Calderón de la Barca) e ao mesmo tempo se considerarmos o seu olhar agudo em perceber a disposição à expressão teatral inerente à cultura indígena. Com efeito, em Coimbra, Anchieta tinha realizado os estudos da arte retórica e de suas diferentes aplicações, especialmente na poesia, na oratória e no teatro. Ao observar que os índios eram muito interessados nas representações teatrais e nas cenografias realizadas pelos colonos na ocasião de algumas festividades, cria peças teatrais onde adapta os preceitos da retórica do teatro humanista português e espanhol aos gostos e às formas rituais próprias da cultura dos nativos, como por exemplo o cerimonial indígena de recebimento dos hóspedes. A construção retórica básica do teatro vicentino, a luta entre o bem e o mal, é retomada e relida à luz da cultura indígena, sendo introduzidas personagens deste contexto, mas conservando o mesmo objetivo moralizador da batalha e da vitória final do bem. Neste esquema cenográfica, a luta entre o bem e o mal trava-se entre anjos e demônios, com batalha e vitória final de Cristo, através da intercessão de Nossa Senhora e dos Santos. O espetáculo apresenta uma linguagem fácil, didática e tem fortes apelos sensoriais. Inspirado nos Exercícios Espirituais, este teatro forma imagens, sugeridas através das representações. Os autos escritos por Anchieta valeram-se do plurilinguismo como forma de aculturação. Era comum o uso das três línguas num mesmo auto. De 1564 até a sua morte, Anchieta escreveu aproximadamente 20 autos, o que corresponde à quase totalidade das peças jesuíticas do período, e escrevendo para os nativos ou para os colonos que já entendiam a língua geral da costa, o missionário adotava quase sempre o idioma tupi.

$\mathrm{O}$ teatro apresenta-se assim como um espaço destinado à evidenciação e à persuasão: nele o gesto é unido à palavra visando 
amplificar sua eficácia e proporcionar uma cena onde o envolvimento entre ouvinte (destinatário) e locutor (ator) seja favorecido. Nele, a própria coreografia e a representação tornam-se um discurso 'mudo', uma 'palavra' capaz de comunicar pelos gestos, imagens etc... para além das diferenças de idiomas e de formação cultural.

\section{Raízes psicológicas da retórica, na perspectiva dos jesuítas}

A palavra dessa maneira teatralizada e pregada é produto de um longo processo de experimentação e de molde proporcionado pela tradição da arte do discurso condensada na Retórica. No Brasil, onde a maioria da população é iletrada, o recurso à palavra oral, como veículo transmissor de ideias e como meio "terapêutico", é prioritário. Além do mais, vimos que este recurso fora amplamente valorizado em sua conotação de cura, no âmbito da tradição cultural indígena, pois, desde o século XVI, nos relatos e cartas dos viajantes e missionários, ressalta a função taumatúrgica atribuída à palavra, pelos nativos. Na Idade Moderna, o exercício da arte retórica constituiu-se como lugar de experimentação das potencialidades da palavra, sendo este processo um pressuposto indispensável para o uso da mesma com função terapêutica. Pois, naquela época, "diante dos efeitos das dúvidas e da fragmentação do saber, são enfatizadas não tanto as coisas a serem comunicadas, quanto as maneiras de torna-las persuasivas" (BATTISTINI, 2000, pp. 40-41). A palavra eloquente não apenas veicula a coisa, mas induz também comportamentos diante dela, associando a razão à verdade e à moralidade e chamando em causa a liberdade como condição de tal associação.

Cabe também ressaltar que neste contexto, a aprendizagem e o exercício das funções comunicativas, persuasivas e terapêuticas da palavra passavam por um amplo e cuidadoso processo formativo.

Com efeito, a proposta da retórica jesuítica inseria-se no trabalho de assimilação da cultura humanista, realizado pela filosofia escolástica do século XVI. Em Salamanca e depois em Coimbra, acontecera um encontro fecundo entre o Humanismo e a herança medieval, encontro do qual os 
manuais do Curso Conimbricense representam uma das expressões mais significativas. O empenho em unir a retórica clássica com a eloquência cristã, é um exemplo desta vontade de conciliar fé e razão, antigos e modernos. Neste terreno, aparece a vitalidade e genialidade da cultura jesuítica ao responder ao desafio da modernidade, construindo um edifício novo com tijolos antigos.

O compêndio mais utilizado nos colégios jesuítas é o elaborado pelo jesuíta português Cipriano Soares ${ }^{5}$ : o De arte rhetorica libri tres (Coimbra, 1560). Inácio, nutrido por uma sólida cultura clássica, proclama diretrizes que previam a leitura direta dos grandes textos da retórica clássica, alinhavada segundo os cânones da cultura humanista. Por isto, o primeiro manual de retórica oficialmente adotado nas escolas da Companhia, escrito por volta de 1560, por Soares, é uma espécie de resumo de passos derivados de Aristóteles, Cícero, e Quintiliano. O pequeno compêndio, devido ao seu caráter sintético, teve centenas de reedições, alcançando uma ampla difusão na Europa (consta nos currículos de colégios jesuítas italianos, portugueses, espanhóis, flamengos, alemães). Neste manual, o ensino da retórica é realizado em chave pedagógica: não se trata de técnica em quanto tal, mas de um “instrumento de formação no qual a palavra com sua potencialidade de comunicação podia alcançar o ser humano colocando nele sementes de transformação e de civilização" (ZANLONGHI, 2002, p. 199), baseando-se na concepção ciceroniana da língua, enquanto forma transmitida na qual é preservado o conteúdo herdado da civilização. A palavra colocada a serviço da verdade, seja no nível gnoseológico, seja no nível moral, fundamenta um projeto da oratória sagrada rumo à tradição iniciada por Agostinho no De doctrina christiana e apoiado na tradição patrística e humanista.

A arte retórica — segundo Soares - estrutura-se em cinco partes: inventio, dispositio, elocutio, memória, actio. A elocutio assume grande importância não mais apenas como enfeite e sim também como o que

${ }^{5}$ SOARES, CIPRIANO, De arte retorica libri III, ex Aristotele, Cicerone et Quintiliano precipue deprompti, nunc ab eodem recogniti et multis in locis locupletis, Roma, F. Zanettum, 1580. 
confere cor, e em geral dimensão sensorial, à linguagem, no sentido de propiciar a inteligibilidade e a intencionalidade da palavra, através da valorização da componente sensorial do significante. Com efeito, grande importância é atribuída à esfera do sensível, do corporal, e do preconceitual, ou seja, da faculdade imaginativa como lugar interior no qual razão e afetividade se unem. Neste projeto retórico espelha-se assim a unidade da pessoa irredutível numa única dimensão: a palavra é análoga à alma, e a imagem ao corpo do discurso. Na verdade, a antropologia filosófica aristotélica unitária, contrária ao dualismo entre forma e substância, comportava uma psicologia atenta a descrever e reconhecer as múltiplas interações entre o intelecto e a paixão, entre a racionalidade e a afetividade. As frequentes metáforas corpóreas utilizadas na esfera da linguagem atestam este fundamento (ZANLONGHI, 2002).

No manual de Soares, no proêmio, encontra-se a afirmação de que "oratio est quasi imago rationis quaedam": declara-se, portanto, o nexo estreitíssimo entre ratio e oratio, a partir da etimologia comum das duas palavras na língua grega. Como a língua latina utiliza os termos oratio e ratio, Soares, coerente com a tradição, define a oratio como rationis imago. Pois a imagem é o nexo analógico que une conceito e palavra. A oratio leva à luz o conceito: verbum mentis.

Esta doutrina implica numa concepção universalista e ecumênica da palavra, a qual espelhando a razão torna-se portadora de verdades. Tal visão da palavra, por sua vez, depende da concepção da inteligência humana própria da filosofia escolástica, segundo a qual, a inteligência conhece num duplo plano: o das espécies sensíveis e o das espécies inteligíveis. Por sua vez, estas se dividem em espécies impressas e espécies expressas. Neste dinamismo psíquico, a transformação da coisa para a palavra acontece segundo certa ordem: o objeto suscita, na inteligência do sujeito humano, a espécie sensível impressa; esta origina a espécie sensível expressa, ou seja a imagem, ou fantasma da coisa. Tal reprodução representativa do objeto, por sua vez, cria a espécie inteligível impressa, ou seja, proporciona a assimilação intelectual do objeto pela ação do intelecto agente, a saber o seu 
reconhecimento pelo intelecto. Finalmente, este reconhecimento produz a espécie inteligível expressa, ou seja, à formulação do conceito, verbum mentis: a palavra. O verbum mentis humano necessita sempre de um veículo sensível: a imagem. Portanto, a retórica enfatiza a função de sinal que a imagem tem, utilizando-se de processos analógicos e imaginativos.

A palavra encarnada na elocução penetra os ânimos e atinge o plano moral, tornando-se assim ética. Desse modo, Soares revela a função moral da mesma e demonstra que, enxertando-se na tradição cristã, a retórica pode ser pensada numa perspectiva humanista, unida à sabedoria civil e moral. A palavra eloquente não apenas veicula a coisa, mas sugere também comportamentos diante dela. A retórica, portanto, associa a razão à verdade e à moralidade, chamando em causa a liberdade como condição de tal associação.

Segundo Quintiliano e Cícero, voz e gesto são importantes canais de comunicação. À voz é reconhecida a capacidade de movere. Tal relação entre eloquência e comportamento funda-se no pressuposto de uma continuidade entre a interioridade e os gestos exteriores, numa antropologia que, como vimos, pressupõe uma unidade entre a alma e o corpo, pela qual a educação de um envolve também a outra, sendo possível assim a teatralização da interioridade.

Soares utiliza-se também da tradição retórica de uso da memória como acervo de recursos para a elaboração do discurso: trata-se de fixar, no pensamento, lugares imaginários onde colocar aquilo que deve ser lembrado, de modo que a ordem dos lugares guarde a ordem das coisas, a partir da ordem das imagens em seu acervo. Se estabelece, assim, uma correspondência entre coisa, lugar e imagem. A noção de ordem faz com que a memória não seja entendida apenas como mero armazém passivo, mas seja reconhecida como faculdade ativa, dotada de função ordenadora, agindo assim em sintonia com a intencionalidade da mente humana.

A antropologia que fundamenta o projeto retórico dos jesuítas tem como alicerce a metafísica do conhecimento de Tomás, segundo a qual o homem só pode conhecer a partir dos dados sensíveis, obtidos pelos sentidos 
externos. Este percepto, por sua vez, é processado pelos sentidos internos (fantasia, potência cogitativa, memória, senso comum) como fantasma. A potência cogitativa é ratio particularis, uma espécie de continuação do espírito na sensibilidade, pois manifesta nesta, o universal. Assim, mesmo que ela pertença ao âmbito do pré-racional, apresenta-se já orientada para o todo, de modo que a sensibilidade é ela também plasmada pelo espírito. $\mathrm{Na}$ continuidade entre sensibilidade e intelecto, a potência cogitativa é o meio onde o espírito e a sensibilidade unem-se, para formar um único conhecimento humano. $\mathrm{O}$ ato de pensar requer a presença de imagens e simulacros fantásticos depositados na memória, onde as espécies repousam prontas para despertar novamente diante da solicitação da imaginação. Segundo os Conimbricences, ${ }^{6}$ a vontade pressupõe o conhecimento, mas também depende do apetite sensitivo o qual, por sua vez, segue a fantasia. Soares indica o processo que une a vontade, a razão, a potência cogitativa e os apetites, evidenciando assim as raízes psicológicas da persuasão e da retórica: atuando sobre os sentidos internos, a palavra eloquente suscita o interesse da imaginação. Ao tornar bela a própria verdade, através do aprazível, estimula o apetite e solicita a adesão. Assim, a retórica através do governo das paixões, estimula a adesão aos preceitos propostos. Trata-se, portanto, de um projeto retórico unitário, sustentado por uma “atenção finíssima à psicologia” (ZANLONGHI, 2002, p. 220). A pedagogia da palavra no âmbito da Companhia, enraíza-se na valorização das artes clássicas da palavra bem como nos Exercícios espirituais onde a força da palavra não é construída apenas na base da argumentação lógica, mas também nas da imaginação, da memória, das paixões, dos sentidos e do corpo.

\section{Experimentação das possibilidades da palavra}

Em consonância com esta tradição, a prática do uso da palavra no teatro e na pregação constitui-se, no Brasil colonial, num fecundo terreno de experimentação do poder da palavra, seja no que diz respeito ao conteúdo

\footnotetext{
${ }^{6}$ Idem, cap. 13, q.1, ${ }^{\text {a3.n.3. }}$
} 
veiculado, seja no que diz respeito à forma de transmissão. Experimentação, cuja importância foi enorme, inclusive ao considerarmos que, no universo da cultura brasileira, muitos foram os caminhos abertos e inspirados por esta "arte da palavra", não apenas no âmbito da pregação religiosa, mas também nas atividades pedagógicas, na poesia, na prosa e no teatro, no campo da oratória política (primoroso no século XIX) e na ciência médica, que no século XIX cria a área da "terapia moral" destinada a cuidar das "moléstias do espírito" (MASSIMI, 1990), por meio de remédios farmacológicos, mas também pelo diálogo e pelo bom uso da palavra.

Com efeito, um dos aspectos do saber psicológico na Idade Moderna é a articulação de uma forma de conhecimento de si funcional ao controle sobre as próprias ações, que se fundamenta na possibilidade do sujeito de representar sua experiência interior através do discurso: pressupõe-se a existência de uma relação de determinação entre os fenômenos psíquicos e as palavras, como frisa o pregador Mateus da Encarnação Pinna, o qual concebe afetos e paixões do coração humano como as fontes de onde brotam as palavras. Pois, é através "das palavras que o entendimento interpreta o que se passa no coração" (PINNA, 1730, p. 319; citado por MASSIMI, 1990, p. 19).

Por sua vez, a possibilidade do discurso depende da existência do interlocutor "se há de falar a quem deseja ouvir" (Pereira, vol.1, p. 26). O outro é um termo essencial para o conhecimento de si mesmo, sendo que a escuta que ele oferece ao sujeito, permite a este uma melhor articulação de sua comunicação verbal e a libertação do afeto penoso vivenciado através da exteriorização da fala, como esclarece Siqueira: "o dar parte da pena é diminuir e aliviar a pena” (1754; citado por MASSIMI, 1990, p. 19).

Segundo o médico filósofo baiano Eduardo Ferreira França (18091857), pela linguagem "os nossos pensamentos são traduzidos por sinais, assim como os sinais são interpretados e indicam os pensamentos" (1973, p. 467), a palavra evidenciando assim a "duplicidade" do ser humano, dado que os sinais pertencem ao corpo (matéria) e os pensamentos indicados ao espírito. 
Desse modo, no terreno fértil da cultura moderna, abriram-se caminhos significativos para o uso terapêutico da palavra que serão percorridos pela ciência médica do século XIX (terapia moral) e pela psicologia moderna.

Referências bibliográficas

AGOSTINHO, A Doutrina Cristã, tradução: Assis Oliveira, São Paulo: Edições Paulinas, 1991.

ARISTÓTELES, Etica Nicomachea. Tradução italiana com texto grego. Organizado por: C. Mazzarelli. Milano: Rusconi, 1994. (1, 13, 1102a, p.82, trad. nossa).

BATTISTINI, A, Il Barocco, Roma, Editrice Salerno, 2000.

CARDIM, F. Tratado da Terra e Gente do Brasil. Edição moderna organizada por Garcia, R. São Paulo Belo Horizonte: Editora da Universidade de São Paulo e Editora Itatiaia, Coleção Reconquista do Brasil, n. 131980 (Original: 1593).

CHARTIER, R., História Cultural, (edição e tradução portuguesa realizada por M.M. Galhardo). Lisboa, Difel: Memória e Sociedade, 1988.

FERREIRA FRANÇA, E. Investigações de psicologia 1854, São Paulo: EDUSP, 1973.

FREUD, S. Tratamento psíquico (ou anímico). In: Freud, S. Edição Standard das Obras completas de Sigmund Freud. Vol. VII. Rio de Janeiro: Imago, 1996.

GILSON, E. A filosofia na Idade Média. Edição brasileira. São Paulo: Martins Fontes. (Original: 1986) 1995.

MASSIMI, M., História da Psicologia brasileira. São Paulo: Editora Pedagógica Universitária, 1990. . Palavras, almas e corpos no Brasil colonial. São Paulo: Edições Loyola, 2005.

PEREIRA, N.M. Compêndio narrativo do Peregrino de América. 1718. Rio de Janeiro, Publicações da Academia brasileira, 1939. 
VIEIRA, A., Sermões, Tomo I e II, (organizados por Pecora, Al.) São Paulo: Hedra, 2000; 2001.

ZANLONGHI, G. Teatri di formação, Actio, parola e immagine nella scena gesuitica del Sei/settecento a Milano, Milano, Vita e Pensiero, 2002. 


\title{
POR UMA EPISTEMOLOGIA HISTORICAMENTE ORIENTADA DA PSICOLOGIA
}

\author{
Iray Carone \\ Universidade Paulista
}

D retendemos, neste artigo, discutir um pouco a epistemologia historicamente orientada de Thomas Kuhn (1922-1996). Inicialmente, mostraremos que a recepção das ideias desse autor no domínio da Psicologia sofreu algumas distorções por causa de uma apropriação retórica de seu conceito de paradigma. Em seguida, daremos uma visão mais completa das modificações sofridas pela sua teoria da ciência dos anos 60 aos anos 90, com a finalidade de recolocar a questão da Psicologia e da importância de se reconstruir a sua história seguindo o seu modelo historiográfico.

A lição mais proveitosa da obra de Thomas Kuhn, no que tange à epistemologia da Psicologia, é a de apontar como o caminho certo para descobrir a natureza do conhecimento por ela produzido, o acompanhamento das contingências de seu desenvolvimento histórico. No entanto, durante décadas e décadas, os psicólogos entraram por uma via equivocada na recepção das ideias de Kuhn, tentando descobrir “paradigmas" e "revoluções científicas” na sua ciência, como se paradigmas e revoluções fossem um verdadeiro imperativo categórico para a Psicologia adquirir estatuto científico e um lugar honroso no rol das ciências. E o pior de tudo: buscaram paradigmas e revoluções na Psicologia através de uma leitura superficial e incompleta de um autor eleito como campeão ou paladino da defesa de uma ciência vetada pelo positivismo no século XIX e por outras epistemologias normativas que se lhe seguiram. Dessa maneira, tentaram superar os anátemas que perseguiram historicamente a Psicologia ou negaram a sua cientificidade, por meio do 
artifício meramente retórico de demonstrar a existência de seus "múltiplos paradigmas coexistentes”.

Uma simples leitura da obra de Kuhn, no entanto, destrói e mina a base desse artifício — não há nada que legitime essa pretensão. O próprio autor lamentou essa vulgarização do conceito de "paradigma", ou seja, o relaxamento semântico do conceito e a perda de controle sobre o seu uso. Nas suas últimas obras, da década de 90, Thomas Kuhn foi abandonando o conceito de paradigma exatamente por causa das imprecisões que surgiram no processo de sua apropriação ou recepção, tendo preferido utilizar outro conceito baseado na análise das linguagens científicas: o de léxico taxonômico.

Essa busca por paradigmas, embora infrutífera, pode ter criado um efeito inesperado, muito semelhante à estória de um senhor de um vinhedo abandonado que iludiu seus herdeiros ao dizer que ali se encontrava um tesouro enterrado. Logo depois de sua morte, os herdeiros cavaram o solo endurecido, em busca do tesouro. Não se sabe durante quantos meses ou anos, até desistirem da empreitada. A terra revolvida pelas intensas escavações, entretanto, se tornou fértil novamente e o vinhedo começou a crescer. Pouco tempo depois, os herdeiros puderam contar com o renascimento de uvas de qualidade e com elas, se enriqueceram. A ilusão da riqueza passou a ser realidade.

A história da Psicologia, não buscada diretamente pelos primeiros escavadores de paradigmas e revoluções científicas, é a verdadeira fonte alimentadora da epistemologia da psicologia. Mas qual história ou pelo menos, qual é o modelo historiográfico que deve ser seguido dentro dessa empreitada?

Na verdade, o estado presente da Psicologia é o de uma multiplicidade de teorias conflitantes e coexistentes, advinda de tradições ou matrizes ontológica e epistemologicamente diferentes. Qualquer estudioso da Psicologia logo reconhece que elas divergem até nas suas nomenclaturas e maneiras de construir os objetos; a mais notória divergência diz respeito aos termos mentais. Umas usam termos mentais, outras negam a necessidade ou mesmo a validade de se recorrer a eles, por serem metafóricos ou por 
designarem entidades e processos não observáveis e mensuráveis. Umas investigam o psiquismo humano como causa dos comportamentos; outras investigam as determinações externas e ambientais desses mesmos comportamentos. Outras buscam por determinações externas e determinações internas do comportamento individual, a partir do primado do social e histórico sobre o subjetivo e o individual.

Até o momento, o que se pode dizer é que essas tradições divergentes coexistem paralelamente, sem a hegemonia de uma sobre a outra - de modo que não há paradigma vencedor que tenha resultado de uma revolução científica a desbancar alguma teoria paradigmática que lhe seja anterior. Mesmo que os adeptos de uma teoria possam julgar que a teoria que elegeram seja paradigmática, essa convicção não tem fundamento histórico algum (CARONE, 2003).

Thomas Kuhn disse, em A estrutura das revoluções científicas (KUHN, 1975, original de 1962) que após ter feito um estágio no Centro para Estudos Avançados nas Ciências Comportamentais, de 1958 a 1959, que esse contato o impressionou, enquanto cientista advindo das comunidades de cientistas da natureza, por causa do "número e da extensão dos desacordos expressos existentes entre os cientistas sociais no que diz respeito à natureza dos métodos e problemas científicos legítimos" e as "controvérsias que parecem endêmicas entre, por exemplo, os psicólogos ou sociólogos" (p.12-13). Mais adiante, disse: "permanece em aberto a questão a respeito de que áreas da ciência social já adquiriram tais paradigmas. A História sugere que a estrada para um consenso estável é extraordinariamente árdua" (р.35). Ou seja, as ciências sociais e a psicologia se encontram ainda num estágio pré-paradigmático indicado pela própria multiplicidade de escolas em competição, cujo progresso se dá apenas no interior de cada uma delas (p.205).

O que se deve discutir, de fato, é a própria teoria ou metateoria dos paradigmas de Thomas Kuhn. Ela tem sido sujeita a inúmeros questionamentos, sobretudo por estar baseada nas ciências que Kuhn teve 
como objeto de sua investigação: a Astronomia, a Física teórica, a Química e a Biologia. Por ter formação em Física, Kuhn se dedicou ao estudo da história ou desenvolvimento histórico da Física e das ciências a ela aparentadas.

Vejamos um exemplo de definição de paradigma tal como surgiu numa obra denominada A tensão essencial (KUHN, 1989, original de 1977), na qual propôs dar um novo nome ao paradigma: o de matriz disciplinar. Com esse novo nome pretendeu não só dar mais precisão ao conceito "estragado" de paradigma contido em A estrutura, como também restaurar a ligação física e lógica do paradigma com a comunidade científica. É por meio de um paradigma, de uma teoria paradigmática ou de um conjunto de paradigmas que se é introduzido numa comunidade científica.

Paradigma é, então, uma matriz disciplinar de uma comunidade científica. Matriz porque se compõe de elementos ordenados de vários gêneros, tais como generalizações simbólicas, os modelos e os exemplos padronizados de resolução de problemas. Ter domínio de uma matriz disciplinar é pertencer a uma comunidade científica, pois isso significa adquirir o seu aparato cognitivo.

Essa matriz é disciplinar porque é a possessão comum dos praticantes de uma disciplina profissional. Uma comunidade científica é, portanto, o conjunto dos praticantes de uma especialidade científica, unidos pelos elementos comuns da respectiva educação e aprendizagem, caracterizada pela abundância de comunicação dentro do grupo e pela relativa unanimidade do juízo grupal em matérias profissionais (p.356).

A matriz fornece aos futuros praticantes uma série de generalizações simbólicas na forma de equações ou de sentenças gerais que ninguém põe em dúvida ou exige justificação. O poder de uma ciência aumenta muito de acordo com o número de generalizações simbólicas disponíveis aos praticantes, que servem, sobretudo, para funcionar como esquemas de generalizações num sistema matemático puro. Com essa formalização, os esquemas podem ser aplicados com sucesso a inúmeros objetos diferentes, versatilizando a teoria da qual fazem parte. 
Os modelos, por sua vez, fornecem analogias com grande valor heurístico, como por exemplo, um circuito elétrico entendido por analogia como um sistema hidrodinâmico em estado estacionário ou um gás como uma coleção de bolas de bilhar microscópicas em movimento aleatório.

Os exemplos constituem o terceiro elemento da matriz e são aqueles que fornecem não modelos, mas exemplos concretos de resolução de problemas ou quebra-cabeças. O sentido original da palavra "paradigma” é "exemplo" que serve para mostrar alguma coisa e não, para demonstrar alguma coisa a partir de outras pela via dedutiva (apodeixis). Contém o elemento dêitico, um indicador tal como este, isto, aquilo, lá, cá, eu, tu, ele, nós etc. O paradigma não demonstra, mas mostra, exemplifica, indica o caminho. É a via principal de aprendizado das ciências: não basta conhecer a teoria paradigmática; é preciso de exemplos que mostrem ao educando como resolver problemas com base na teoria.

Por esses elementos do paradigma, podemos claramente perceber que Thomas Kuhn está se referindo a algumas ciências e não, a todas as ciências! Como ter generalizações simbólicas, equações, modelos e exemplos numa ciência como a História? Por aí se vê que nem todas as ciências têm paradigmas ou precisam ter paradigmas para serem científicas! O próprio autor se referiu a esse uso equivocado do conceito de paradigma, num debate em Atenas em 1997:

Paradigma era uma palavra perfeitamente boa até que eu a estraguei (...) A primeira vez que o termo foi utilizado, foi introduzido em um trabalho por mim publicado num artigo chamado A tensão essencial (1959), que li numa conferencia. E lá eu o uso corretamente.Mas eu tinha procurado descrever o que os cientistas, a maneira pela qual uma tradição trabalhava em termos de consenso. E acerca de que existia consenso?Havia consenso acerca de modelos, mas também com respeito a várias outras coisas que não são modelos. E eu prossegui usando o termo para tudo, para todas as coisas, o que levou a que fosse muito fácil ter uma ideia completamente errada do que eu achava ser minha posição, e simplesmente fazer disso a tradição toda, que é a maneira pela qual tem sido usada desde então (KUHN, 2003, p.360). 
No livro A tensão essencial (1989), publicado pela primeira vez em 1977, Kuhn deu ênfase à necessidade de se recorrer à história das ciências no trabalho de reconstrução racional e filosófica do desenvolvimento científico, embora enfatize também qual é o modelo historiográfico compatível com essa tarefa. Novamente observa que as ciências sociais e humanas não têm se preocupado com essa questão, apresentando pouco desenvolvimento historiográfico e consequente rarefação no campo epistemológico: "até agora a nova historiografia não aflorou as ciências sociais. Nestes campos, a literatura histórica, quando existe, tem sido produzida inteiramente por praticantes da própria ciência. A History of Experimental Psychology de Boring talvez seja o exemplo marcante. Tal como as mais antigas histórias das ciências físicas, esta literatura é muitas vezes indispensável, mas como história, comparte suas limitações" (KUHN, 1989, p.151).

Então, qual é a nova historiografia de que falou Kuhn em 1977?

É mais fácil dizer o que ela não deva ser pelos exemplos por ele arrolados no capítulo 5 da referida obra. Em primeiro lugar, ela não deve ser presentista e celebrativa, ou seja, representar o estágio atual como o ponto mais alto do desenvolvimento científico, do qual a história representa apenas sua paleontologia, ou seja, aquilo que já foi superado pelo estágio recente. Esse modelo supõe a existência de um desenvolvimento linear e cumulativo da ciência. Esse ponto de vista sugere que o desenvolvimento científico seja uma marcha quase mecânica e triunfante do intelecto impondo a sujeição sucessiva dos segredos da natureza aos métodos sólidos criados pelos cientistas ao longo da linha do tempo.

A mudança desse modelo se deveu em parte à influência da história da filosofia, que sempre recomendou como atitude correta diante dos filósofos antigos, nem a reverência nem o desprezo, mas uma simpatia hipotética que permita saber o que é acreditar nas suas teorias (BERTRAND RUSSELL, apud KUHN, 1989, p.146). 
Assim, não é por meio de juízos de valores, com base no que já sabemos de um ponto de vista moderno, que devemos olhar para um texto antigo. Kuhn se reporta à sua primeira leitura da Física de Aristóteles em 1947, quando a julgou errada e absurda em face da noção moderna de movimento como mudança no espaço ou mudança de posição de um corpo no espaço da Física de Newton, ou seja, a sua não apreensão e resgate do sentido aristotélico do movimento como mudança qualitativa.

Atribuiu essa leitura errônea à falta de um elemento que se tornou essencial ao novo modelo historiográfico, a verdadeira chave interpretativa de uma leitura dos antigos: a incomensurabilidade. A incomensurabilidade é uma noção que surgiu de suas tentativas de compreender passagens aparentemente sem sentido, encontradas em velhos textos científicos. De modo geral, essas passagens foram consideradas como evidências de crenças confusas ou equivocadas do autor antigo. No entanto, suas experiências levaram-no a sugerir, em vez disso, que essas passagens estavam sendo erroneamente interpretadas: a aparência de absurdo poderia ser removida pelo resgate de significados mais antigos para alguns dos termos envolvidos, significados diferentes daqueles subsequentemente correntes (KUHN, 2003, p.23-24).

O que Kuhn quis dizer sobre a sua má leitura inicial da Física de Aristóteles é que não percebeu o hiato entre a Física moderna que aprendera e a outra que deveria aprender como uma nova língua, uma língua desconhecida. Deste modo, entre uma e outra, não havia adição de conhecimento ou mera correção de erros. Nesse sentido, esse mergulho histórico na língua antiga correspondia a uma espécie de hermenêutica do sentido perdido pelo hiato entre uma e outra.

Em segundo lugar, a história das ciências não pode ser uma narrativa em cima de outras narrativas já construídas, sem a busca de fontes primárias documentos, memorandos, cartas, interlocuções entre cientistas contemporâneos, discussão de resultados em academias científicas, arquivos das antigas sociedades científicas, revistas das sociedades 
científicas existentes na época etc. que poderão até desmontar as narrativas consagradas. Essa história é denominada história interna da ciência.

Em terceiro, não pode ser semelhante àquelas histórias gerais, meramente especulativas e doutrinárias como a de Auguste Comte, a respeito dos estágios teológico, metafísico e positivo do saber humano. Dentro dessa ótica doutrinária, por exemplo, a Psicologia foi vítima de uma condenação: a de não ser capaz de atingir o estatuto de ciência positiva porque seu objeto —os fenômenos cognitivos e afetivos- não seria acessível à observação científica ou externa. O positivismo, nesse sentido, é uma epistemologia normativa e não historicamente orientada.

Em quarto, a história da ciência não deve ser confundida com as sociologias das ciências que antes de examinar a sua história interna, buscam determinantes externos não cognitivos e extracientíficos para explicar as ideias prevalecentes na matriz disciplinar, ou seja, embora haja elementos sociológicos no desenvolvimento científico, eles não são os únicos a serem levados em consideração na historiografia científica. Nos seus últimos escritos, Kuhn estava particularmente preocupado com as tendências sociologistas da história da ciência, que acabaram criando uma visão distorcida do conhecimento científico como a simples crença dos vencedores, sobretudo pela incapacidade demonstrada em estudar a história interna da ciência, os pressupostos, conceitos teóricos e detalhes técnicos das teorias científicas.

A ênfase de Kuhn, nessas obras, foi a de investigar a história da ciência como método de trabalho para dar consistência à investigação epistemológica, livrando-a de dogmas e normas. No entanto, a partir dos anos 90, a sua teoria sofreu uma inflexão — a chamada virada linguística ou linguistic turn. Nesta inflexão, podemos notar uma exploração mais detida da incomensurabilidade como um traço peculiar e necessário das revoluções científicas e das porções do léxico taxonômico da ciência que revelam a mudança revolucionária. A análise das linguagens científicas 
tomou, paulatinamente, o lugar antes consagrado aos estudos históricos do desenvolvimento científico.

Essa virada representou, antes de tudo, em uma retomada e exploração de algo que já havia sido apontado de passagem em A Estrutura: a árvore evolucionária do saber científico. Numa série de artigos e conferências sob o título "O caminho desde A Estrutura" (2003/ original de 1990), Kuhn esboçou os temas daquele que seria seu último livro, que não chegou a completar, mostrando os pontos em que se distanciava de sua proposta original e ao mesmo tempo, resgatando algumas intuições nela presentes. Disse, então, que caracterizava uma revolução científica que seria a mudança em várias categorias taxonômicas nas descrições do mundo e suas generalizações científicas.

Para entender a revolução científica como mudança taxonômica, tomemos a categoria "planeta" da Astronomia de Ptolomeu. Ela inclui o Sol e a Lua, mas não a Terra. Na Astronomia de Copérnico, a categoria "planeta" inclui a Terra, Marte, Júpiter, mas não o Sol; a Lua, por sua vez, passou a ser classificada por uma nova categoria, uma nova espécie de corpo: a categoria "satélite". Logo, a mudança taxonômica foi evidente, pois implicou na mudança dos objetos ou conjunto de objetos entre as categorias e a introdução de novas categorias como "satélite". Houve, pois reclassificação das entidades, pois aquelas que eram vistas como diferentes - a Terra e outros planetas - passaram a ser vistas como membros da mesma categoria (planetas). O Sol mudou de categoria, ou seja, foi deslocado da categoria planeta para a categoria estrela. As funções astronômicas antes atribuídas à Terra foram transferidas ao Sol: a de ser o centro dos movimentos planetários.

Em outras palavras: as mudanças operadas não foram meras correções de erros ou adições à Astronomia de Ptolomeu, mas sim, alteração radical no modo de ver o mundo celeste. A diferença de método de trabalho na epistemologia de Kuhn significou, antes de tudo, em prestar 
atenção ao léxico taxonômico das duas astronomias, ou melhor, em porções locais desse léxico: estrela, planeta e satélite.

Assim, dizer: "No sistema ptolomaico, os planetas giravam em torno da Terra; no sistema copernicano, os planetas giram em torno do Sol", é não prestar atenção na falta de univocidade do termo "planeta", pois o termo não tem o mesmo sentido e a mesma referência nas duas linguagens. Logo, há um hiato ou incomensurabilidade entre elas que só pode ser superado pelo trabalho da interpretação e não, pela mera tradução das palavras. Hoje, já pensamos com as categorias copernicanas e não, com as ptolomaicas.

Os nossos céus são diferentes dos céus dos gregos antigos, pois dividimos a população dos céus de maneira diferente em diferentes categorias de coisas. Eles viam os céus repartidos em três categorias: planetas, estrelas e meteoros. Mas colocavam o Sol, a Lua, Júpiter, Marte, Mercúrio, Saturno e Vênus na mesma categoria planeta. Viam a Via Láctea, para nós, constituída de estrelas, na mesma categoria que arco-íris, anéis ao redor da Lua, estrelas cadentes e outros meteoros. Seriam meras crenças a respeito de objetos, e não, céus diferentes? Há um hiato entre os céus dos gregos e os nossos céus, e a dificuldade para descrever os céus deles no nosso vocabulário conceitual, é um exemplo de incomensurabilidade.

A Astronomia de Ptolomeu estava numa situação escandalosa antes dos trabalhos de Copérnico, por causa das complicações introduzidas para salvá-la e que a transformaram num verdadeiro monstro. Assim, para uma pessoa da Renascença, antes de Copérnico, o mundo cósmico era finito, com a Terra imóvel ao centro. O céu, a morada de Deus, ficava além da esfera das estrelas fixas, marcando o fim do espaço. Após Copérnico, Galileu e Kepler, nas primeiras décadas do século XVII, o Sol passou para o centro do cosmo e a Terra, a ser um mero planeta. Como diz Marcelo Gleiser (GLEISER, 2007,15/04/2007): o que era verdade em 1520, não era verdade para alguém em 1650; o universo de hoje, gigantesco, com centenas de bilhões de galáxias se afastando umas das outras, é completamente diferente de uma pessoa de 1650. E daqui a algumas centenas de anos? Ou 
daqui a 1000 anos (se ainda houver vida na Terra) quem poderá prever as reviravoltas científicas nas teorias cosmológicas?

O termo flogisto da Química antiga, por exemplo, não corresponde mais a nada na linguagem da Química moderna. Sem dúvida, é um termo obsoleto que só tem sentido na linguagem de origem, ou seja, na Química do século XVIII, a qual temos de aprender como uma língua desconhecida se quisermos superar o hiato produzido entre as duas linguagens químicas. Podemos substituir a maioria das palavras dessa química, mas não um subgrupo de termos que desapareceram da Química moderna e perderam toda a sua significação para nós: flogisto, ar flogisticado, princípio metalizante etc. Mas a palavra "elemento", por exemplo, permaneceu central no vocabulário da Química moderna. A interpretação dos termos incomensuráveis, entretanto, tenta recuperar os seus usos referenciais, como, por exemplo: flogisto é uma substância liberada na combustão como um princípio químico, o mesmo que torna o ar impróprio para respirar e que, quando extraído de um material apropriado, deixa um resíduo ácido.

Por que, então, de modo geral os cientistas não têm a experiência de revoluções científicas ou de grandes mudanças paradigmáticas na sua ciência, seja na Astronomia ou na Química, da mesma maneira que um historiador da ciência? A resposta de Kuhn é simples: quando uma reconceituação ocorre em um campo científico, os conceitos desalojados desaparecem rapidamente do cenário profissional e, sobretudo dos manuais de ensino da ciência. As ciências se desvinculam de seu passado, substituindo-o por uma reconstrução sistemática e são poucos os cientistas que vão ler trabalhos científicos do passado nas bibliotecas. É interessante observar que isso não acontece na crítica literária, onde a própria formação do crítico se faz recorrendo às obras do passado.

Como já foi dito anteriormente, Kuhn foi abandonando o termo "paradigma” por outros: no fim da década de 70, por "matriz disciplinar"; na década de 90, com a virada linguística e sua análise das linguagens científicas para detectar mudanças taxonômicas, por "léxico taxonômico". 
Poderíamos dizer, então, que há pelo menos três versões da teoria da ciência de Kuhn, contadas a partir de A estrutura das revoluções científicas.

O léxico taxonômico corresponde, em termos linguísticos, ao vocabulário de termos taxonômicos de uma teoria, ou seja, os termos para espécies naturais, artificiais e sociais. São termos próprios e não traduzíveis de um léxico, que devem ter duas características essenciais: 1) são rotulados como termos para espécies em virtude de características lexicais tais como admitir o artigo indefinido; 2) não podem ser superpostos quanto aos seus referentes quando são categorias disjuntas, a menos que estejam relacionados entre si como uma espécie a um gênero ou de uma categoria inclusa na outra.

Duas teorias são incomensuráveis quando estão enunciadas em léxicos taxonômicos mutuamente intraduzíveis um pelo outro. No entanto, a incomensurabilidade é local ou restrita, ou seja, atinge apenas uma porção ou subconjunto dos termos de duas teorias —os kind terms pois a maior parte de seus termos é comum e pode ser traduzida por causa da preservação de seus significados. São os subconjuntos de termos para espécies que causam os hiatos entre elas e a intradutibilidade desses termos; no entanto, no interior da mesma teoria, eles são usualmente interdefinidos por meio das sentenças que os contém. Por outro lado, são os termos comuns, que preservaram os seus significados ao longo de uma mudança de teoria, fornecem uma base suficiente para a discussão das diferenças e para as comparações relevantes para a escolha de teorias. Eles fornecem até mesmo uma base de onde podem ser explorados os significados dos termos incomensuráveis (KUHN, 2003, p. 49-51)

Revolução científica é, portanto, mudança taxonômica local de um léxico taxonômico anterior! Os desenvolvimentos científicos que não alteram o léxico taxonômico e simplesmente fazem acréscimos ao conhecimento não são revolucionários e sim, apenas cumulativos — correspondem à fase paradigmática de uma teoria. Desenvolvimentos científicos que requerem o 
abandono de parte daquilo em que se acreditava e que exigem mudança taxonômica local, são revolucionários (KUHN, 2003, p.125).

Quando surge uma nova especialidade científica como, por exemplos, a Bioquímica, a Microbiologia, a Físicoquímica etc., ocorrem, de modo geral, mudanças taxonômicas locais em relação às ciências que aparentemente foram unificadas num só corpo. Na verdade, surgem novas linguagens com seus kind terms, como espécies diferentes ou novos brotos da árvore evolucionária.

Essa é a razão pela qual Kuhn aproximou, nos seus últimos escritos, o desenvolvimento científico do desenvolvimento biológico no sentido darwiniano: "Até esse ponto, tentei firmar e estender o paralelo entre o desenvolvimento científico e o desenvolvimento biológico sugerido ao final da primeira edição de A Estrutura: o desenvolvimento científico deve ser visto como um processo empurrado por trás e não puxado para frente como evolução a partir de algo, e não como evolução em direção a algo" (KUHN, 2003, p. 125)

Embora os últimos escritos de Kuhn não sejam completos, eles ainda assim assinalaram a necessidade de olhar para trás, para o passado da ciência, no lugar de supor uma teleologia do saber científico. A evolução, nesse sentido, não é um caminho deliberado e racional, mas antes de tudo, a imprevisibilidade ou a contingência da história.

Por essas razões, perguntamos agora: qual é o estatuto epistemológico da Psicologia? Temos necessidade de paradigmas, nos três sentidos apontados por Thomas Kuhn ao longo de sua obra (paradigma, matriz disciplinar e léxico taxonômico) para considerá-la científica? É bem verdade que a vantagem da epistemologia de Thomas Kuhn é que ela não impôs vetos ou critérios ou normas que atingissem o cerne da Psicologia (como o fizeram as epistemologias clássicas normativas), mas tampouco a tomou como objeto de suas investigações históricas e de suas análises das linguagens científicas. 
Há algumas indicações que ele deixou, entretanto, para os psicólogos e demais especialistas das ciências humanas, nos seus últimos escritos e falas. Num artigo sobre "As ciências naturais e as ciências humanas" de 1989, diz que leu, na década de 40, alguns ensaios metodológicos de Max Weber e capítulos do Ensaio sobre o homem de Ernest Cassirer: "Fiquei entusiasmado e encorajado pelo que neles encontrei. Esses autores eminentes estavam descrevendo as ciências sociais de modo estreitamente paralelo ao tipo de descrição que eu esperava fornecer para as ciências físicas" (KUHN, 2003, p. 265).

No entanto, continua, o seu entusiasmo foi logo arrefecido quando eles diziam que suas análises se aplicavam apenas às ciências sociais, considerando as ciências naturais inteiramente diferentes destas, ao descrevê-las à maneira dos empiristas e positivistas. As ciências humanas seriam interpretativas, porque tratam de fenômenos dotados de intencionalidade (sociais, políticos, psicológicos etc.) e as ciências naturais, não interpretativas. Os céus seriam os mesmos para todas as culturas, para os gregos, para os japoneses e para nós. Se eles têm significado, esse significado é o mesmo para todos e não há lugar para a interpretação quando o objeto é um fenômeno natural.

O argumento de Kuhn é que os céus não têm o mesmo significado, quer para os gregos quer para nós: os conceitos ou categorias sobre o mundo natural e sobre o mundo social são propriedades de comunidades, compartilhados e passando de geração para geração. Não existe nas ciências naturais e nas humanas um conjunto de categorias que seja neutro, independente da cultura e no qual a população seja de objetos seja de ações humanas — possa ser descrita (KUHN, 2003, p. 270).

A diferença entre as ciências naturais e as humanas é que as primeiras ao estabelecerem paradigmas, conseguiram alcançar a fase normal por meio de uma interpretação que se revelou útil para a solução dos quebra-cabeças, até que outra interpretação venha a se tornar necessária para as gerações seguintes ou sucessoras. Em suma, todas as ciências são 
interpretativas e adéquam o mundo social ou natural, à sua linguagem e às categorias por ela criadas.

Não seria possível, pergunta Kuhn, que com o passar do tempo, um número crescente de especialidades encontrasse paradigmas que viabilizassem as pesquisas normais solucionadoras de quebra-cabeças? Não poderá isso já estar ocorrendo em algumas especialidades atuais das ciências humanas? Conclui: "Minha impressão é a de que em partes da economia e da psicologia isso já possa ter ocorrido” (KUHN, 2003, p. 273).

Contudo, não deixa de observar que a necessidade de contínuas reinterpretações possa ser requerida nas ciências humanas, ou seja, maiores dificuldades a serem enfrentadas para estabelecer a uniformidade de uma interpretação. Nesse sentido e apenas nesse, as ciências humanas são mais interpretativas que as ciências naturais.

Referências bibliográficas

CARONE, I. A psicologia tem paradigmas? São Paulo: Casa do Psicólogo/ FAPESP, 2003.

GLEISER, M. Sobre a verdade. In: Folha de São Paulo (Caderno Mais!), São Paulo, 15/04/2007, p. 09, 2007.

KUHN, Th.S. A estrutura das revoluções científicas. São Paulo: Ed. Perspectiva, 1975 [1962]. . A tensão essencial. Lisboa: Edições 70, 1989 [1977].

. O caminho desde a estrutura. São Paulo: Editora UNESP, 2003 [2000]. 


\title{
INFÂNCIAS, ADOLESCÊNCIAS E FAMÍLIAS
}

\author{
CAPÍTULO 14
}

\section{A CRIANÇA NEGRA NO BRASIL}

Mary Del Priore*

Universidade Salgado de Oliveira

A s crianças brasileiras estão em toda parte. Nas ruas, na saída das Há aquelas que estudam, as que trabalham, as que cheiram cola, as que brincam, as que roubam. Há aquelas que são amadas e outras, simplesmente usadas. Seus rostinhos mulatos, negros, mestiços enfim, desfilam na televisão, nos anúncios da mídia, nos rótulos dos mais variados gêneros de consumo. Não é a toa que o comércio e a indústria de produtos infantis vêm aumentando progressivamente sua participação na economia nacional, assim como a educação primária tanto quanto o combate à mortalidade infantil são permanentes temas da política nacional.. O bem-estar e o aprimoramento das relações pais \& filhos são assunto constante de psicólogos, sociólogos, psicanalistas, enfim, de especialistas que além de trazer uma contribuição inédita para a melhor inserção da criança na sociedade do ano 2000, reproduzem seus conhecimentos em revistas e teses, propondo uma nova ética para a infância.

No mundo atual, essas mesmas crianças passaram de reis a ditadores. Muitas de suas atitudes parecem-nos incompreensíveis, quase hostis. Uma angústia sincera transborda das interrogações que muitos de nós se faz

\footnotetext{
* Professora do Departamento de História da FFLCH/USP, mas, por ocasião deste artigo, lecionando como professora convidada no Departamento de História da Universo/Salgado de Oliveira. Agradeço a FAPERJ a bolsa de estudos que permitiu este intercâmbio.
} 
sobre o que seja a infância ou a adolescência. É como se as tradicionais cadeias de socialização tivessem, hoje, se rompido. Socialização na qual os laços de obediência, de respeito e de dependência do mundo adulto, acabaram sendo trocadas por uma barulhenta autonomia. Influência da televisão? Falta de autoridade dos pais? Pobreza e exclusão social de uma imensa parcela de brasileiros? Mas, e se tudo isso secretasse, nas margens da sociedade, uma brutal delinquência juvenil, ou, mesmo se entre as famílias mais equilibradas nas quais a presença dos pais e o excesso de amor substituem a educação, gerando um profundo mal estar feito de incompreensão e brigas?

Ora essa quase onipresença infantil nos obriga, pois, a algumas questões. Terá sido sempre assim? O lugar da criança negra na sociedade brasileira terá sido sempre o mesmo? Como terá ela passado do anonimato para a condição de cidadã, com direitos e deveres aparentemente reconhecidos? Numa sociedade desigual e vincada por transformações culturais, teremos, ao longo dos tempos, recepcionado nossas crianças da mesma forma? Sempre choramos, do mesmo jeito, a sua perda? Que marcas trazem as crianças de hoje, daquelas que as antecederam no passado? Mas há, também, questões mais contundentes tais como, por que somos insensíveis às crianças negras que mendigam nos sinais? Por que as altas taxas de mortalidade infantil, agora, começando a decrescer, pouco nos interessam? Essas respostas, entre tantas outras, só a história pode dar. Não será a primeira vez que o saudável exercício de "olhar para traz” irá ajudar a iluminar os caminhos que agora percorremos, entendendo melhor o porquê de certas escolhas feitas por nossa sociedade.

Para começar, a história sobre a criança feita no Brasil, assim como no resto do mundo vem mostrando que existe uma enorme distância entre o mundo infantil descrito pelas organizações internacionais, por organizações não governamentais ou autoridades, e aquele no qual a criança encontra-se quotidianamente imersa. O mundo do que a "criança deveria ser" ou "ter" é diferente daquele onde ela vive, ou no mais das vezes sobrevive. O primeiro é feito de expressões como “a criança precisa”, "ela deve”, "seria oportuno 
que", "vamos nos engajar em que” etc. até o irônico "vamos torcer para". No segundo, as crianças são enfaticamente orientadas para o trabalho, o ensino, o adestramento físico e moral, sobrando-lhes pouco tempo para a imagem que normalmente se lhe está associada: aquela do riso e da brincadeira.

No primeiro, habita a imagem ideal da criança feliz, carregando todos os artefatos possíveis capazes de identificá-la, numa sociedade de consumo: brinquedos eletrônicos e passagem para a Disneylândia. No segundo, o real, vemos acumular-se informações sobre a barbárie constantemente perpetrada contra a criança, materializadas nos números sobre o trabalho infantil, naqueles sobre a exploração sexual de crianças de ambos os sexos, no uso imundo que faz o tráfico de drogas de menores carentes, entre outros. Privilégio do Brasil? Não! Na Colômbia, os pequenos trabalham em minas de carvão; na Índia, são vendidos aos cinco ou seis anos para a indústria de tecelagem. Na Tailândia cerca de 200.000 são roubados anualmente às suas famílias e servem à clientela doentia dos pedófilos. Na Inglaterra, os subúrbios miseráveis de Liverpool, produzem os "baby killers", crianças que matam crianças. Na África, $40 \%$ das crianças entre 7 e 14 anos trabalham. Esses mundos opostos se contrapõem em imagens radicais de saciedade versus exploração. Como se não bastasse, a mudança pelas quais passa o mundo real fazem elas também suas tenras vítimas: a crescente fragilização dos laços conjugais, a explosão urbana com todos os problemas decorrentes de viver em grandes cidades, a globalização cultural, a crise do ensino face aos avanços cibernéticos, tudo isso tem modificado, de forma radical, as relações entre pais e filhos, entre crianças e adultos.

Pensar tais questões, assim como seus antecedentes históricos, vem sendo uma preocupação geral, para especialistas ou não. O estudo das representações ou das práticas infantis é considerado tão importante, que a historiografia internacional já acumulou consideráveis informações sobre a criança e seu passado. Na Europa, por exemplo, há trinta anos a demografia histórica ajudava a detectar a expectativa de vida, o papel da criança nas estruturas familiares, os números do abandono infantil ou da contracepção. Em 1948, o pioneiro francês Philippe Ariès lançava os primeiros estudos 
sobre a questão. O seu História das populações francesas e de suas atitudes face à vida desde o século XVIII trazia, então, um capítulo completo sobre a criança e a família. A seguir, o clássico A criança e a família no Antigo Regime, datado de 1960 apresentava duas teses que revolucionariam o tema: a escolarização, iniciada, na Europa, no século XVI, levada a cabo por educadores e padres, católicos e protestantes, provocou uma metamorfose na formação moral e espiritual da criança, em oposição a educação medieval feita apenas pelo aprendizado de técnicas e saberes tradicionais, no mais das vezes, ensinado pelos adultos da comunidade. A Idade Moderna passa a preparar, nas escolas, o futuro adulto. Ou seja, a criança, esse potencial motor da História, é vista como o adulto em gestação. Paralelamente a essa mudança, a família sofria, também, uma profunda transformação com a emergência da vida privada e uma grande valorização do foro íntimo. A chegada destas duas novidades teria acelerado, no entender de Ariès, a supervalorização da criança. Apesar de todas as críticas que essas teses receberam, sobretudo quanto à percepção de um certo “evolucionismo” na condição histórica da criança — essa, na Idade Média não significaria muito para seus pais, passando a condição de "reizinho do lar” com a evolução da sociedade burguesa—, as teses de Ariès instigam o historiador brasileiro a procurar suas próprias respostas. E por quê?

Em primeiro lugar, entre nós, tanto a escolarização quanto a emergência da vida privada chegaram com grande atraso. Comparado aos países ocidentais, onde o capitalismo instalou-se no alvorecer da Idade Moderna, o Brasil, país pobre, apoiado inicialmente no Antigo Sistema Colonial e posteriormente, numa tardia industrialização, deixou sobrar pouco espaço para tais questões. Sem a presença de um sistema econômico que exigisse a adequação física e mental dos indivíduos a uma nova forma de trabalho, os instrumentos que permitiriam tal adaptação não foram implementados com a mesma eficácia ${ }^{1}$.

\footnotetext{
${ }^{1}$ Aproveitei, nestes primeiros parágrafos algumas teses que já havia discutido no prefácio de História das Crianças no Brasil, (Org.) Mary Del Priore, São Paulo, Contexto, 1999.
} 
Desde o início da colonização, as escolas jesuítas eram poucas e, sobretudo, para poucos. Se as crianças indígenas tiveram acesso a elas, o mesmo não podemos dizer das crianças negras, embora saibamos que alguns escravos aprendiam a ler e escrever com os padres ${ }^{2}$. O ensino público só foi instalado, e ainda assim, mesmo de forma precária, durante o governo do marquês de Pombal, na segunda metade do século XVIII. Nessa época, a preocupação com a evasão escolar aparece precocemente no parágrafo que regulamentava a entrada das crianças na escola, como vemos, por exemplo, no Estatuto elaborado pelo Morgado de Mateus: "Que todos os meninos que admitirem será com despacho do mesmo General (Morgado de Mateus) e não poderão passar a outra escola sem proceder o mesmo despacho, e isto para que os mestres os possam castigar livremente sem receio de que seus pais os tirem por esse motivo, ou, por outros frívolos, que comumente se praticam". Os cuidados com a evasão, com o ensino da religião cristã, das "obrigações civis" ou dos chamados "Estudos Maiores" não cobriam, contudo, as necessidades de uma parcela importante da população: aquela constituída por filhos de forros ${ }^{3}$. Nos documentos, nem uma palavra sobre a educação de crianças negras ou de filhos de escravos, salvo a religiosa que, segundo o jesuíta Antonil, era obrigatória. Esta obrigatoriedade acabou empurrando o catolicismo para dentro dos rituais de candomblé afro-banto: "O kêrêkêrê relampejou! Pelo Cálice e pela Hóstia! (...) Noé, Noé, Sua barca é-vem! Évem cheia de caboclo, completa ou sozinha sem mais ninguém!”

No século XIX, a saída para os filhos dos pobres não seria a educação, mas a sua transformação em cidadãos úteis e produtivos na lavoura, enquanto os filhos de uma pequena elite, eram ensinados por professores particulares. Reclamada, desde 1824 e criada em 1856, para

\footnotetext{
${ }^{2}$ Ver, por exemplo, meu artigo "Ritos da Vida Privada” in História da vida privada no Brasil, cotidiano e vida privada na América portuguesa, (dir.) Fernando Novais, (org.) Laura de Mello e Souza, São Paulo, Companhia das Letras, 1998, vol.1 pp. 276-330.

${ }^{3}$ Ver Marco Antônio Cabral dos Santos et al., Luzes e sombras sobre a Colônia - educação e casamento na São Paulo do século XVIII, São Paulo, Humanitas/EDUSP, 1998, "O início da reforma”, pp.50-78.

4 Edison Carneiro, Religiões negras - Negros Bantos, Rio de Janeiro, Civilização Brasileira, 1991, pp.193-194.
} 
atender as necessidades de uma população livre e vacinada, a escola pública proibia seus assentos às crianças escravas. Às pobres, provavelmente mulatas e negras, reservava espaço quando se tratavam daquelas que demonstravam "acentuada distinção e capacidade". Examinando relatórios de mestres, lecionando em Jacarepaguá e no Rio de Janeiro, no final do século passado, Alessandra Martinez de Schuler ${ }^{5}$ demonstra que segundo esses, uma parcela diminuta de alunos era constituída por libertos "pretos", além de um "número pequeno de cor parda". A desigualdade social e racial inscrevia-se, portanto, nas origens do ensino público que não era para todos. Mas, para alguns.

Para as crianças libertas com a lei do Ventre Livre (28/09/1871) sobrou a perspectiva do ensino profissionalizante. Institutos privados, na sua maior parte, de origem religiosa como o do Sagrado Coração de Jesus ou o abrigo Santa Maria, em São Paulo, recolhiam crianças pobres e davam-lhes um mínimo de preparo prático para ofícios manuais ${ }^{6}$. Schueler lembra ainda que, num dos seus artigos, a mesma lei, previa a educação dos "ingênuos" (termo que designava crianças de até 5 anos) que fossem entregues ao governo pelos senhores. A instrução primária e o encaminhamento dos filhos livres das escravas para os ofícios manuais foram projetadas no texto legal. Instituições como o Asilo de Meninos Desvalidos, no Rio de Janeiro, visavam não apenas atender os meninos que vagavam pelas ruas das cidades, mas também encontrar soluções para disciplinar os libertos. Muitos proprietários de escravos solicitaram, de fato, matrículas de "ingênuos" no Asilo, como forma de indenização pelos gastos com alimentação e cuidados com as crianças libertas pela lei. No Asilo, atual Instituto João Alfredo, as crianças negras aprendiam leitura, escrita, aritmética, mas aprendiam, sobretudo, o trabalho manual capaz de reproduzir, por si só, a desigualdade social na qual estavam mergulhadas. Quando das grandes reformas urbanas que atingiram as capitais

\footnotetext{
${ }^{5}$ Ver o artigo de Alessandra F. Martinez de Schueler, "Criança e escolas na passagem do Império para a República” in Revista Brasileira de História, n 37, Infância e Adolescência, vol.19, 1999, pp.59-84.

${ }^{6}$ Ver Marco Antônio Cabral dos Santos, “Criança e criminalidade no início do século”, in História das crianças no Brasil, (org.) Mary Del Priore, São Paulo, Contexto, 1999, pp. 210230.
} 
dos estados, no final do século XIX, vozes como as de Cândido Motta, Moncorvo Filho e Bush Varella, juristas e médicos, imprecavam contra a presença crescente de crianças nas ruas -as negras eram maioriasexigindo solução para estancar a circulação destes "desgraçados, sem teto, sem lar, sem educação, sem instrução e sem ordem”. Na República, recém proclamada e que ostentava na bandeira o lema "Ordem e Progresso", a infância negra prometia desordem e atraso. Na capital, Rio de Janeiro, pequenos mendigos, indigentes e vadios faziam da Praça XV, do Arco do Telles e das portas de igrejas, o seu ponto de apoio ${ }^{7}$. Quarenta anos depois, o Estado Novo criava, em 1941, o Serviço de Atendimento ao Menor, (SAM), sistema que ajudou a criminalizar definitivamente o menor de rua ${ }^{8}$. No primeiro quartel do século $\mathrm{XX}$, a população de crianças carentes tinha que se defrontar com um binômio imposto pela sociedade burguesa: lazer versus trabalho e honestidade versus crime. Normalmente foram associadas ao trabalho e, na ausência deste, crime. Os rostos de crianças negras são os mais frequentes nas imagens mostradas sobre a FEBEM.

No final deste mesmo século, o trabalho infantil continua, contudo, sendo visto pelas camadas subalternas, como "a melhor escola". Pais pobres, com renda inferior a meio salário mínimo, exigem que seus filhos trabalhem para incrementar os rendimentos do grupo familiar. "O trabalho —explica uma mãe pobre- é uma distração para a criança. Se não estiverem trabalhando vão inventar moda, fazer o que não presta. A criança deve trabalhar cedo". E pior, hoje, afogados pelo trabalho, quase $60 \%$ desses pequenos trabalhadores, no Nordeste, são analfabetos e entre eles a taxa de evasão escolar chega a $24 \%$. No sul do país o cenário não é muito diferente. Trabalhando em lavouras domésticas ou na monocultura, as crianças interrompem seus estudos na época da colheita, demonstrando que estar inscrito numa escola primária, não significa poder frequentá-la plenamente. Assim, o trabalho, como forma de complementação salarial para famílias

\footnotetext{
${ }^{7}$ Ver Schueler, op.cit., idem, ibidem.

${ }^{8}$ Edson Passeti, “Crianças carentes e políticas públicas”, in História das crianças no Brasil, op.cit., pp.345-375.
} 
pobres ou miseráveis, sempre foi priorizado em detrimento da formação escolar. Neste quadro, a criança negra e analfabeta, tornava-se uma espécie de testemunha muda, silenciosa, de seu tempo ${ }^{9}$.

Quanto à evolução da intimidade, sabemos o quanto ela sempre foi precária, entre nós. Os lares monoparentais, a mestiçagem, a pobreza material e arquitetônica que se traduzia em espaços onde se misturavam indistintamente crianças e adultos de todas as condições, a presença de escravos, forros e libertos, a forte migração interna capaz de alterar os equilíbrios familiares, a proliferação de cortiços, no século XIX e de favelas, no XX, são fatores que alteravam a noção que se pudesse ter no Brasil, até bem recentemente, de privacidade tal como ela foi concebida pela Europa urbana, burguesa e iluminista. A noção de privacidade para escravos é ainda mais complexa de ser pensada. Ela não passa pela constituição de espaços de intimidade. Passa, sim, por seu corpo. Seu território privado é o “eu”, espécie de bolha irregular e protetora, mais ou menos desenvolvida de acordo com a sua condição na sociedade. Na busca de interação ou em atitudes de rejeição, o território do eu permitia marcar certo espaço ou violar o dos outros. A intimidade de mães e filhos, por exemplo, elaborava-se, não em casa, mas na rua. Nos relatos de viajantes, demonstra Kátia Q. Mattoso, ${ }^{10}$ crioulinhos e pardinhos acompanham suas mães nas tarefas do cotidiano. Quando muito novos para correrem pelos caminhos e vias públicas, iam arrimados nas costas de suas mães, envolvidos por panos coloridos. Teresa da Bavieira pintou em 1888 uma negra baiana em todo o seu esplendor; negra que carregava na cabeça um imenso tabuleiro, repleto de bananas, levando nas costas um menino de mais ou menos dois anos de idade, cuja ponta do pé balança-se alegremente fora de sua cadeira de pano. A proximidade com $o$ seio materno, com o dialeto, no qual as mulheres se comunicavam os adornos de coral e os balangandãs que usavam contra forças maléficas e até a forma

\footnotetext{
${ }^{9}$ Ver o artigo de Irma Rizzini, “Pequenos trabalhadores do Brasil”, in História das crianças no Brasil, op.cit., pp.376-406.

10 _’O filho da escrava”, in A criança na História do Brasil, (Org.) Mary Del Priore, São Paulo, Contexto, 1991, pp.76-97.
} 
como penteavam seus cabelos e o de suas crias, fazia parte deste território do eu, dividido, no aconchego do colo, entre mãe e filho. A passagem da alimentação mista para a semissólida operava-se com infinita precaução, não percebida, todavia, pelos viajantes estrangeiros. A técnica de pré-digestão de alimentos embebidos na saliva materna significava muito mais um cuidado, do que falta de higiene. Na tradição africana, era comum a mastigação de sólidos e a passagem destes, em forma de bolo cremoso, para a boquinha dos pequenos. Ernest Abel, viajante austríaco de passagem pelo Brasil em 1824, escandalizara-se com escravas que alimentavam seus filhos ou outras crianças, "com mingau de tapioca que elas lhes levavam à boca, servindo-se para isso dos dedos”. Era habitual, também, dar de comer aos pequenos, pirão de leite ou farinha seca com açúcar bruto, de manhã, leite com jerimum ou escaldado de carne no almoço. O prato de resistência era o feijão cozido servido com farinha ou machucado à mão. Leite de cabra era considerado fortificante. Para se comunicar, as mães negras criaram uma linguagem que em muito colaborou para enternecer as relações entre o mundo infantil e o mundo adulto. Reduplicando as sílabas tônicas, pronunciavam com especial encanto: dodói, cacá, pipi, bumbum, tentem, dindinho, bimbinha. Para adormecê-los contavam-lhes estórias de negros velhos africanos, papa-figos, boitatá e cabras-cabriolas. A cultura africana inundou o imaginário infantil, com assombrações como o mão-de-cabelo, o quibungo, o xibamba, criaturas, que segundo, Gilberto Freyre, rondavam casas grandes e senzalas aterrorizando criança mal-criada:

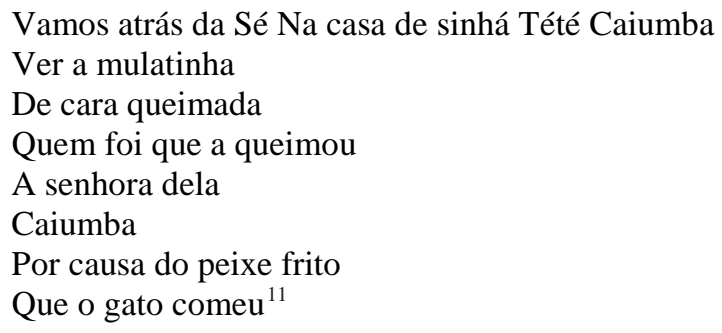

Vamos atrás da Sé Na casa de sinhá Tété Caiumba

Ver a mulatinha

De cara queimada

Quem foi que a queimou

A senhora dela

Caiumba

Por causa do peixe frito

Que o gato comeu ${ }^{11}$

\footnotetext{
11 Apud Gilberto Freyre, Mary Del Priore, O quotidiano da criança livre no Brasil entre a Colônia e o Império, in História das Crianças no Brasil, op.cit., p. 95.
} 
Não poderíamos tampouco incorporar as teses de um epígono americano de Ariès, Lloyd de Mause, para quem a história dos pequenos seria apenas um catálogo de barbáries, maus tratos e horrores. No diz respeito à história do Brasil encontramos, de fato, passagens de terrível sofrimento e violência. Mas não só. Os testamentos feitos por jovens mães, negras livres, escravas ou forras, no século XVIII não escondem a preocupação com o destino de seus "filhinhos do coração". Os viajantes estrangeiros não cessaram de descrever o demasiado zelo com que, numa sociedade pobre e escravista, os adultos tratavam as crianças. As cartas desesperadas de mães, mesmo as escravas analfabetas, tentando impedir que seus rebentos partissem para a guerra do Paraguai, como grumetes, sublinham a dependência e os sentimentos que se estabeleciam, entre umas e outros:

Prisciliana, de nação cassange, africana livre que tendo um filho de menor idade de nome Justino Pedro Barrozo, o qual se achava na corporação dos menores artesãos da Casa de Correção da Corte, o qual se acha na fortaleza da Boa Viagem por ser para ali mandado à disposição da Marinha. A suplicant , Imperial Senhor, é o único filho que tem e que lhe faz falta para o amparo na sua velhice e, além disso lhe deseja dar uma educação regular...recorre à clemência de Vossa Majestade Imperial para que seu filho lhe seja entregue em atenção de ser o único que tem e em quem confia as esperanças de amparo para o futuro ${ }^{12}$.

Prisciliana não era a única a cuidar e a contar com seu pequeno. As listas nominativas do período colonial trazem centenas de exemplos de mães, vivendo sós, em companhia de seus filhos ao lado de quem constituíam lares e famílias, e cujo trabalho coletivo garantia a todos a sobrevivência, a união, a solidariedade ${ }^{13}$. Em São Paulo, no século XVII, por exemplo, a mulata Maria de Oliveira subsistia do jornal de um filho carpinteiro e do soldo de outro, "tambor de milícias; um com vinte e outro

\footnotetext{
${ }^{12}$ Apud Renato Pinto Venâncio, “Os aprendizes da guerra” in História das crianças no Brasil, op.cit., p. 205.

${ }^{13}$ Mary Del Priore, Ao sul do corpo - condição feminina, maternidades e mentalidades na Colônia. Rio de Janeiro, José Olympio, 1993, especialmente o capítulo "Mães e filhos: pontos e nós”, p.56 e passim.
} 
com dez anos”. A preta Maria Monteiro, por sua vez, mantinha-se “de suas quitandas e do jornal dos filhos”, um sapateiro e outro alfaiate. Eram, sem dúvida, alianças contra a pobreza e a solidão, num mundo onde o escravismo e o preconceito racial os tratavam sem piedade.

Nos dias de hoje, educadores e psicólogos perguntam-se, atônitos, de onde vem o excesso de mimos e a "falta de limites" da criança brasileira já definida, segundo os resmungos de um europeu de passagem pelo Brasil em 1886, como “pior do que um mosquito hostil”. O excesso de mimos não era fortuito. Sabemos, graças aos estudos de antropólogos, que a recepção de uma criança na sociedade africana era fonte de imensa satisfação. Muitos dos ritos que cercavam o nascimento foram transpostos para o Brasil. Ao nascer, os pequenos de origem nagô eram untados com óleos e imersos em banhos de folhas com finalidade de proteção. Entre os cassanges, toda a comunidade participava do parto, não trabalhando no campo, nem tocando em instrumentos cortantes. Tão logo a criança nascia, tinha o narizinho apertado e a cabeça massageada para adquirir uma forma, que parecia às mães de origem africana, mais estética. Os umbigos eram curados com pimenta do reino em pó ${ }^{14}$. Aos finais do século XVIII, o médico francês, Jean Marie Imbert ${ }^{15}$, autor de um Tratado doméstico das enfermidades dos negros, registrou, entre atônito e chocado, a bulha festiva de comadres, parteiras e amigas em torno da africana que estivesse dando a luz. Nenhum gesto era destituído do mais profundo simbolismo.

O batismo, obrigatório nas senzalas, consistia num rito de purificação e de promessa de fidelidade ao credo católico, mas significava também uma forma de dar solenidade à entrada das crianças nas estruturas familiares e sociais. No caso dos filhos de escravos e libertos, os laços estabelecidos graças ao sacramento do batismo, eram também étnicos e culturais. Os registros paroquiais de localidades como Inhaúma e Jacarepaguá, no estado

\footnotetext{
${ }^{14}$ Mary Del Priore, “A maternidade da mulher escrava”, in Cadernos do Cedhal, CEDHAL/ USP, $n^{\circ} 4,1989$.

15 IMBERT, J.B.A, Manual do fazendeiro ou tratado doméstico para curar as enfermidades dos negros, Rio de Janeiro, Tipografia Nacional, 1839.
} 
do Rio de Janeiro, no início do século XIX, revelam que entre 5\% e 6\% dos escravos batizados, tomavam os nomes de seus padrinhos e madrinhas escravos, numa forma de ampliar sua rede de parentela. Em 1842, informam Góis e Florentino, na freguesia de Inhaúma haviam sido registrados 1,6 mil batizados. Os escravos foram padrinhos em $67 \%$ das cerimônias, os libertos em $24 \%$ e as pessoas livres em menos de $10 \%$. Na maioria dos plantéis de escravos, $75 \%$ dos padrinhos eram escravos, demonstrando o empenho escravo em constituir redes e laços familiares ${ }^{16}$.

A amamentação durava dois anos e a dentição era acompanhada com cuidado. O primeiro dentinho era festejado com farinha e caulim, símbolo da prosperidade. O lugar mesmo dos pequenos dentro da sociedade era de ordem ontológica. A criança era uma porta entre o presente e o passado, personificado nos ancestrais. Muitas recebiam, para além de um nome cristão, aquele de um animal e de um orixá. Ao nascer, seus pais plantavam uma árvore, símbolo de seu futuro vigor e força. A passagem para o mundo adulto realizava-se através da circuncisão de meninos aos 12 ou 13 anos. No Brasil, tais ritos eram festejados nas festas de Quicumbi, nas quais, os "mometos", circuncidados com taquaras, bailavam e dançavam antes de passar, com os convivas, a um banquete ${ }^{17}$. Se morriam pequenas, as crianças negras eram carregados num tabuleiro recoberto por uma toalha de renda, e suas mães alugavam flores artificiais e coroas para cumprir o dever de enterrar condignamente seus rebentos ${ }^{18}$.

Como se vê, a historiografia internacional pode servir de inspiração, mas não de bússola. As lições devem começar em casa: mestre Gilberto Freyre, em 1921, manifestava seu desejo de "escrever uma história do menino — da sua vida, dos seus brinquedos, dos seus vícios - brasileiro, desde os tempos coloniais até hoje. Já comecei a tomar notas na biblioteca

\footnotetext{
${ }^{16}$ Ver o capítulo de José Roberto Góis e Manolo Florentino, “Crianças escravas, crianças de escravos”, in História das Crianças no Brasil, op.cit., pp.177-191.

${ }^{17}$ Ver o meu Festas e utopias no Brasil colonial, São Paulo, Brasiliense, 1994, onde há um capítulo sobre crianças na festa.

${ }^{18}$ Ver meu artigo já mencionado, “O cotidiano da criança livre...”, op.cit., p. 93.
} 
de Oliveira Lima —anotava, ele-: nos cronistas coloniais, nos viajantes, nas cartas dos jesuítas. Sobre meninos de engenho, meninos do interior, da cidade. Os órfãos dos colégios dos jesuítas, os alunos dos padres, os meninos mestiços. De crias da casa grande. De afilhados de senhores de engenhos, de vigários, de homens ricos, educados como se fossem filhos por esses senhores. É um grande assunto. E creio que só por uma história deste tipo -história sociológica, psicológica, antropológica e não cronológica - será possível chegar-se à uma ideia sobre a personalidade do brasileiro. É o menino que revela o homem". Ora, os historiadores brasileiros têm que partir de constatações bem concretas, tiradas, na maior parte das vezes, das fontes documentais com as quais trabalham e da sua observação crítica da realidade para contar sua própria história.

A primeira dessas constatações aponta para uma sociedade, certamente injusta na distribuição de suas riquezas, avara, no que diz respeito ao acesso à educação para todos, vincada pelas marcas do escravismo. Como fazer uma criança obedecer a um adulto, como queria a professora alemã que vai, na segunda metade do século XIX, às fazendas do vale do Paraíba, ensinar os filhos dos fazendeiros de café, quando esses distribuem ordens e gritos entre os seus escravos? E não são apenas as crianças brancas que possuem escravos. As mulatas ou negras forras, uma vez seus pais integrados ao movimento de mobilidade social que teve lugar em Minas Gerais, na primeira metade do século XVIII, tiveram eles também seus escravos. Muitas vezes, seus próprios parentes ou até meios irmãos! Na sociedade escravista ao contrário do que supunha a professora alemã, criança, branca ou negra mandava e o adulto escravo, obedecia. Por vezes, em circunstâncias dramáticas. Retrato em preto e branco desta situação nos apresentou Kátia Q. Mattoso. Ouçamo-la:

Em 1872 falecera, em Salvador, Diogo Correia da Rocha, de seu estado viúvo, sem filhos, originário de Pernambuco e, segundo tudo indica, pequeno feirante na praça de Pernambuco. Ao falecer, Diogo deixou quatro escravos e a seguinte situação: uma moça africana nagô chamada Joaquina, já liberta, mãe de Inês, mulatinha que Diogo reconhece como sua filha legítima e universal herdeira. Contudo, por 
parte da mãe, Inês tem três meios irmãos que são escravos de seu pai. No seu testamento, Diogo dá liberdade gratuita à meia-irmã, a crioula Leopoldina, mas obriga os dois outros meios-irmãos de sua filha, os crioulos Felis e Cosme, ambos oficiais de pedreiro, a trabalharem para a irmã Inês, dando-lhes 320 réis por dia até que esta complete seus quinze anos, após o que os dois crioulos ficam livres. Quanto ao quarto escravo, o crioulo Benedito, oficial de calafate, este poderá ficar livre se no prazo de dois anos pagar à herdeira Inês a quantia de $400 \$ 000$ réis. Infelizmente o documento não dá nem a idade de Inês, nem a de sua mãe, nem as de seus meios irmãos, mas nos põe perante uma situação extremamente pungente, na qual as obrigações decorrentes da situação escravista sobrepõem-se e dominam as que naturalmente brotariam no bojo das solidariedades familiares. Não tentemos, porém, nem sequer imaginar o que essa situação podia representar na mente daqueles cuja matriz biológica era comum, mas que se achavam do lado de cá, ou do lado de lá, da divisão livre/escravo. Desta maneira, a criança escrava, não somente convivia com irmãos de cores diferentes, como também convivia com irmãos de status diferentes, que legalmente podiam tornar-se seus senhores ${ }^{19}$.

A dicotomia dessa sociedade, dividida entre senhores e escravos, gerou outras impressionantes distorções, até hoje presentes. Tomemos o tão discutido exemplo do trabalho infantil. Dos escravos desembarcados no mercado do Valongo, no Rio de Janeiro do início do século XIX, 4\% eram crianças. Destas, apenas $1 / 3$ sobrevivia até os 10 anos. A partir dos 4 anos, muitas delas já trabalhava com os pais ou sozinhas, pois perder-se de seus genitores era coisa comum. Aos 12 anos, o valor de mercado das crianças já tinha dobrado. E por quê? Considerava-se que seu adestramento já estava concluído e nas listas dos inventários já aparecem com sua designação estabelecida: Chico “roça”, João “pastor”, Ana "mucama”, transformados em pequenas e precoces máquinas de trabalho ${ }^{20}$.

Tais máquinas compravam-se a preço baixo e tinham a vantagem de prometer vida longa em funcionamento. Gilberto Freyre, criticando o “ensardinhamento" em que viajavam os africanos, no auge do tráfico,

\footnotetext{
${ }^{19}$ Kátia Queirós Mattoso, op.cit., p. 88.

${ }^{20}$ Apud José Roberto Góes e Manolo Florentino, Crianças escravas, crianças dos escravos, História das crianças no Brasil, op.cit., pp.177-191.
} 
refere-se a "meninos e adolescentes que sob os nomes técnicos de molequinhos, moleques, crias e molecões", encontram-se, tantas vezes nas faturas de carregamentos de escravos e nos anúncios de vendas e fugas.

Das faturas de escravos destaque-se este caso típico: de quarenta negros mandados buscar em 1812, por Bento José da Costa, o mais poderoso escravocrata pernambucano de seu tempo, e que constam de um livro manuscrito do outrora engenho do Salgado (...) só dois eram 'negros barbados'; os mais eram moleques, molequinhos, crias e molecões. Dezesseis moleconas ${ }^{21}$.

Alguns anos mais tarde, o reverendo Walsh interessou-se por uma menina “de ar e pensativo e doce” que viu no mercado do Rio. A uma chicotada forte do traficante cigano, levantou-se. "Walsh viu-a, então, nua, de pé, diz ele que toda acanhada. O cigano quis fazê-la tomar atitudes interessantes. Mas, o padre inglês não consentiu e a negrinha dissolveu-se tímida, medrosa, entre outros negros” ${ }^{22}$. A menina lhe parecera tão discreta, pudica e delicada que nenhum inglês bem formado - diz Freyreduvidaria por um instante de que era dotada da mesma natureza e sentimento, de suas próprias filhas ${ }^{23}$.

Trabalho ao longo da infância, sem tempo para a ideia que comumente associamos à infância, a da brincadeira e do riso, era o lema perverso da escravidão. Contudo, a mesma resistência que se lhe opunham os adultos foi transmitida à criança. Não foram poucas as que contrariaram a obrigação do eito e a exploração, pela fuga. Freyre os acompanhou através de anúncios publicados em jornais pernambucanos e cariocas no século XIX. Eram procurados e caçados, como seus ancestrais:

Também deve ter sido criado em casa e com muito mimo, em pequeno ninado no colo das iaiás e posto para engatinhar pelos tapetes de lã inglesa da sala de visitas, o mulatinho cor-de-rosa e talvez de sangue ilustre que desapareceu de uma casa do Recife, em

${ }^{21}$ O escravo nos anúncios de jornais brasileiros do século XIX, São Paulo/Recife, Editora Nacional, Instituto Joaquim Nabuco, 1979, p.22.

${ }^{22}$ Apud Gilberto Freyre, op.cit., p.21.

${ }^{23}$ Idem, ibidem. 
1865; "estatura alta, bem alvo e bonito, seco de corpo, braços compridos, dedos finos e grandes, sendo os dois mínimos dos pés bastante curtos e finos; tem dezoito (18) anos de idade, cabelos corridos e pretos levando eles rentes... mãos e pés bem feitos e cavados, olhos pardos e bonitos, sobrancelhas pretas e grossas, não buça, levou calça de brim branco e já usada e camisa de chita com flores roxas”. Já a mulatinha puxando a sarará, de nome Joana, de 14 anos prováveis, fugida de um engenho do Cabo, seria, com suas pernas e mãos muito finas, "uma verdadeira flor do pecado", cor alvacenta, cabelo carapinho e russo, corpo regular, com todos os dentes, mas com "vestígios antigos de chicote no corpo... a fala às vezes viciosa... padecendo de bouba nas partes ocultas ${ }^{24}$.

Quando da abolição da escravidão, as crianças e adolescentes moradores de antigas senzalas, continuaram a trabalhar nas fazendas de cana de Pernambuco. Tinham a mesma idade de seus avós, quando esses começaram: entre 7 e 14 anos e até hoje, ainda cortando cana, continuam despossuídas das condições básicas de alimentação, moradia, saúde, educação e garantias trabalhistas. Como no passado, o trabalho doméstico entre as meninas, também é constante, constituindo-se num "outro" turno, suplementar ao que se realiza no campo. Como se não bastasse a ação de fatores econômicos a interferir na situação da criança, a ausência de uma política do Estado voltada para a formação escolar da criança pobre e desvalida só acentuou seu miserabilismo. Ora, ao longo de todo esse período, a República seguiu empurrando a criança para fora da escola, na direção do trabalho na lavoura, alegando que ela era "o melhor imigrante”.

No início do século, com a explosão do crescimento urbano em cidades como São Paulo, esses jovens dejetos do que fora o fim do escravismo encheram as ruas. Passaram a ser denominados "vagabundos". Novidade? Mais uma vez, não. A história do Brasil tem fenômenos de longa duração. Os primeiros "vagabundos” conhecidos eram crianças brancas recrutados pelos portos de Portugal, para trabalhar como intermediários entre os jesuítas e as crianças indígenas, ou como grumetes nas embarcações que cruzavam o Atlântico. No século XVIII, terminada a

\footnotetext{
${ }^{24}$ Idem, p.31.
} 
euforia da mineração, crianças vindas de lares mantidos por mulheres livres e forras, perambulavam pelas ruas, vivendo de expedientes muitas vezes escusos, —os nossos atuais "bicos"- e de esmolas. As primeiras estatísticas criminais elaboradas em 1900 já revelam que esses filhos da rua, chamados durante a Belle Époque de “pivettes”, eram responsáveis por furtos, "gatunagem", vadiagem e ferimentos, tendo na malícia e na esperteza as principais armas de sobrevivência. Hoje, quando interrogados pelo serviço social do Estado, dizem com suas palavras, o que já sabemos desde o início do século: a rua é um meio de vida!

Como se vê, a pobreza e a falta de escolarização da criança brasileira, ao longo de sua história, tornam as teses europeias absolutamente inadequadas face às realidades de uma sociedade onde, como explica "uma menina de rua”, “sonhos não enchem a barriga”! A divisão da sociedade, velha divisão dos tempos da escravidão, entre os que possuem e os que nada têm só fizeram agravar a situação dos nossos pequenos.

Outra característica desse trabalho é que diferentemente da história da criança feita no estrangeiro, a nossa não se distingue daquela dos adultos. Ela é feita, pelo contrário, à sombra daquela dos adultos. No Brasil, foi entre pais, mestres, senhores e patrões, que pequenos corpos dobraramse à violência, às humilhações, à força quanto foram amparados pela ternura os sentimentos familiares os mais afetuosos. Instituições como as escolas, a Igreja, os asilos e posteriores FEBENS e FUNABENS, a legislação ou o próprio sistema econômico fez com que milhares de crianças se transformassem, precocemente, em gente grande. Mas não só. Foi a voz dos adultos que registrou ou calou, sobre a existência dos pequenos, possibilitando ao historiador escrutar esse passado através de seus registros e entonações: seja através das cartas jesuíticas relatando o esforço de catequese e normalização de crianças indígenas, ou a correspondência das autoridades coloniais sobre a vida nas ruas, pano de fundo para as crianças mulatas e escravas. Seja através das narrativas dos viajantes estrangeiros, dos textos de sanitaristas e de educadores, os Códigos de Menores, os jornais anarquistas, os censos do IBGE etc. 
$\mathrm{O}$ que restou da voz pequenos? O desenho das fardas com que lutaram contra o inimigo carregando pólvora para as canhoneiras brasileiras, na guerra do Paraguai; as fotografias tiradas por um "photographo" como Christiano Jr, que as capturou nas costas de suas mães, envoltos em panos da Costa, ajudando-as com seus tabuleiros de frutas, aprendendo a jogar capoeira; as fugas da FEBEM. Não há, contudo, dúvida que foi, muitas vezes, o "não registrado" mal estar das crianças frente aos adultos que obrigou os últimos, a repensar suas relações de responsabilidade para com a infância, dando origem a uma nova consciência frente aos pequenos, que se não é, hoje, generalizada, já mobiliza grandes parcelas da população brasileira.

A tarefa do historiador é, então, a de resgatar a história da criança negra não apenas enfrentando um passado e um presente cheio de tragédias anônimas como a venda de crianças escravas, a sobrevida nas instituições, as violências sexuais, a exploração de sua mão de obra, mas tentando também perceber, para além do lado escuro, a história da criança simplesmente criança, as formas de sua existência quotidiana, as mutações de suas ligações sociais e afetivas, a sua aprendizagem da vida através de uma história que, no mais das vezes, não nos é contada diretamente por ela.

Resgatar esse passado significa, primeiramente, dar voz aos documentos históricos, perquirindo-os nas suas menores marcas, exumando-os nas suas informações mais concretas ou mais modestas, iluminando as lembranças mais apagadas. E pela voz de médicos, professores, padres, educadores, legisladores que obtemos Informações sobre a infância, no passado; essa fala obriga, contudo, o historiador a uma crítica e a uma interpretação de como o adulto retrata o estereótipo da criança ideal, aquela saudável, obediente, sem vícios, a criança que é uma promessa de virtudes. Mas face a essas vozes adultas é preciso colocar-se algumas questões: será que, numa sociedade historicamente pobre e vincada tanto pela mestiçagem quanto pela mobilidade social, conseguimos construir tal modelo de criança? Médicos e legisladores do início do século acreditavam que sim. Eis porque acabaram por criar, a fim de transformá-la, 
instituições de confinamento onde ao invés de encontrar mecanismos de integração, a criança "não ideal", achou os estigmas definitivos de sua exclusão. Ela passou de "menor da rua" para "menor de rua" com todas as consequências nefastas implícitas nesse rótulo. Se no passado esse sinal de Caim significou sofrimentos de todos os tipos de perseguição policial, elas reagem, hoje, pela afirmação cada vez maior a sua exclusão.

Outro problema para o estudioso da história da criança negra: para cruzar com tais representações teríamos restos do que foi a infância no passado? Será que o clima dos trópicos deixou sobreviver os restos materiais destas pequenas vidas, tais como berços, brinquedos, roupas, ou essas ausências apenas confirmam o quão fugaz é a passagem entre o tempo da infância e aquele do mundo adulto? Diferentemente de europeus ou americanos cujas culturas produziram, desde as épocas mais tardias, imagens, objetos e representações que nos contam sobre a infância, no Brasil temos que estar alertas a outro tipo de fonte para responder a essas questões. São, todavia sensíveis memorialistas como Pedro Nava, capazes de fazer reviver em seus textos, as cores, sons e cheiros do passado, que sugerem ao historiador um programa de pesquisas capaz de orientá-lo na busca do que tenha sido, para muitas crianças anônimas, ser simplesmente criança num país marcado por diferenças raciais e diferenças de condição social, mas vincado, igualmente, por uma identidade dada pela pobreza material que atingia ricos e pobres, escravos e livres. Ouçamos o que ele nos diz:

O fumo e a bosta de cavalo postos na ferida umbilical foram os mesmos para todos ; os que escaparam e os que morreram do mal de sete dias. A boneca de pano velho e marmelada foi chupada por todos os meninos de Minas. Conhecidos ou não (...) íntimos ou sem costume, uns com os outros - somos queijo do mesmo leite, milho da mesma espiga, fubá da mesma saca. Todos usamos o mesmo cagadoiro pênsil sobre o chiqueiro onde os porcos roncam (...) Os mesmos oratórios de três faces com o calvário encima e o presépio em baixo. Os mesmos registros de santos enchendo as paredes para impedir os mesmos demônios e os mesmos avantesmas das noites de Minas. (...) Eram amigos como irmãos. 
Assim, os cuidados com o corpo, a alimentação, o brinquedo, as formas de religiosidade, os laços familiares se constituem em grandes linhas de pesquisa que atravessariam, de um lado a outro, a sociedade brasileira, guardadas, certamente, as proporções e as especificidades dos diferentes grupos raciais, sociais e regionais. Através de temas presentes na memória e na recordação associados à coleta de documentos capazes de nos aproximar da vida da criança no passado, podemos tentar reconstituir o seu quotidiano. Da técnica de pré-digestão de alimentos, embebidos na saliva dos adultos, à tradição da culinária africana, do pirão de leite com farinha seca e açúcar bruto; das brincadeiras entre os pés de cana e de café, a chupar fruta sob as árvores; do simbolismo dos ritos de batismo, primeiro entre escravos e livres, aos atuais “ungimentos” ou batismos em casa; também de outros simbolismos, aqueles em torno dos enterros: os nas biqueiras da casa, para criança pagã ou o cortejo dos anjos carregando pequenos caixões ataviados de papel prateado até as fotografias dos mortos nos colos de suas mães; dos banhos de rio, em Recife, aos banhos de mar, no Rio de Janeiro; de um mundo entrelaçado ao dos adultos e aos familiares, onde desfilavam os rostos dos avós, de tios e primos, de vizinhos e onde o levar e trazer recados, bem como a conversa eram nas recordações de um memorialista, “imprescindíveis como a água, a farinha e o amor”.

Por fim, parece-nos evidente que querer conhecer mais sobre a trajetória histórica dos comportamentos, das formas de ser e de pensar em relação às nossas crianças negras, é também uma forma de amá-las, todas e indistintamente, melhor.

Referências bibliográficas

CARNEIRO, Edison. Religiões negras - Negros Bantos. Rio de Janeiro: Civilização Brasileira, 1991.

DEL PRIORE, Mary. A maternidade da mulher escrava. In: Cadernos do Cedhal, CEDHAL/USP, n.4, 1989. 
. Mães e filhos: pontos e nós. In: DEL PRIORE, Mary. Ao sul do corpo - condição feminina, maternidades e mentalidades na Colônia. Rio de Janeiro: José Olympio, 1993.

. Festas e utopias no Brasil colonial. São Paulo: Brasiliense, 1994.

. Ritos da Vida Privada. In: NOVAIS, Fernando (dir.); SOUZA, Laura de Mello e. História da vida privada no Brasil, cotidiano e vida privada na América portuguesa. São Paulo: Companhia das Letras, 1998.

. (Org.) História das Crianças no Brasil. São Paulo: Contexto, 1999.

FREYRE, Gilberto. O escravo nos anúncios de jornais brasileiros do século XIX. São Paulo/ Recife: Editora Nacional, Instituto Joaquim Nabuco, 1979.

\& DEL PRIORE, Mary. O quotidiano da criança livre no Brasil entre a Colônia e o Império. In: DEL PRIORE, Mary. (Org.) História das Crianças no Brasil. São Paulo: Contexto, 1999.

GÓIS, José Roberto \& FLORENTINO, Manolo. Crianças escravas, crianças de escravos. In: DEL PRIORE, Mary. (Org.) História das Crianças no Brasil. São Paulo: Contexto, 1999.

IMBERT, J.B.A, Manual do fazendeiro ou tratado doméstico para curar as enfermidades dos negros. Rio de Janeiro: Tipografia Nacional, 1839.

MATTOSO, Kátia Q. O filho da escrava. In: DEL PRIORE, Mary (Org.) História das Crianças no Brasil. São Paulo: Contexto, 1999.

PASSETI, Edson. Crianças carentes e políticas públicas. In: DEL PRIORE, Mary (Org.) História das Crianças no Brasil. São Paulo: Contexto, 1999.

RIZZINI, Irmã. Pequenos trabalhadores do Brasil. In: DEL PRIORE, Mary (Org.) História das Crianças no Brasil. São Paulo: Contexto, 1999.

SANTOS, Marco Antônio Cabral dos; et al. Luzes e sombras sobre a Colônia - educação e casamento na São Paulo do século XVIII. São Paulo: Humanitas/EDUSP, 1998. 
. Criança e criminalidade no início do século. In: DEL PRIORE, Mary (Org.) História das Crianças no Brasil. São Paulo: Contexto, 1999.

SCHUELER, Alessandra F. Martinez de. Criança e escolas na passagem do Império para a República. In: Revista Brasileira de História, $\mathrm{n}^{\circ}$ 37, Infância e Adolescência, vol.19, pp.59-84, 1999.

VENÂNCIO, Renato Pinto Venâncio. Os aprendizes da guerra. In: DEL PRIORE, Mary (Org.) História das Crianças no Brasil. São Paulo: Contexto, 1999. 


\title{
INFÂNCIA, ADOLESCÊNCIA E A FAMÍLIA: PRÁTICAS PSI, SOCIEDADE CONTEMPORÂNEA E PRODUÇÃO DE SUBJETIVIDADE*
}

\author{
Neuza Guareschi* \\ Pontifícia Universidade Católica do Rio Grande do Sul
}

$\mathbf{W}_{\text {produção da subjetividade sem nos debruçarmos contemporânea e }}^{\text {ão }}$ perspectivas de tempo e espaço tencionadas pelo avanço, quase que frenético, da ciência, da tecnologia e da mídia. Em um processo mundial denominado globalização, rearranjos de ordem cultural, política, econômica e social provocam sensíveis modificações nos modos de ser e habitar o mundo em transformação. Esse processo constitui experiências de velocidade, aceleração, fragmentação, turbulência, efemeridade, e nos provoca a pensar a vida cotidiana a partir, de pelo menos, duas problematizações centrais: Quais as formas de subjetividade que podemos experimentar a partir de outros olhares para as práticas psi na contemporaneidade? Que sujeito se produz na contemporaneidade mediante essas formas de subjetivação? Se pararmos para observar e pensar algumas imagens que nos são lançadas no turbilhão do cotidiano, ficamos perplexos com os paradoxos das múltiplas realidades discrepantes que convivem ao mesmo tempo, pois se vislumbra um período de descompasso entre as fortes e constantes transformações técnico-científicas e as condições de

\footnotetext{
* Este texto parte de reflexões sobre temas que são foco de discussão de teses e dissertações, concluídas e em andamento, e que foram desenvolvidas no grupo de pesquisa "Estudos Culturais e Modos de Subjetivação” sob minha orientação. Sou muito grata a Anita Bernardes, Betina Hillesheim, Lilian Cruz, Simone Huning, Patricia Medeiros, Marcos Azambuja e Zuleika Gonzales por me possibilitarem a oportunidade de realizar estas problematizações sobre a produção do conhecimento em Psicologia.

** Professora/Pesquisadora do PPGP —Faculdade de Psicologia — PUCRS. Coordenadora do grupo de Pesquisa “Estudos Culturais e Modos de Subjetivação”.
} 
vida: "a percepção vertiginosa de que estamos por um fio, a descoberta penosa de ver-se reduzido a quase nada, a suspeita crescente de que esse pouco talvez não baste para prosseguir. Ao lado da certeza esvaída, a vida depauperada, o abismo escancarado, a quebra irremissível no fio do tempo e no contorno da alma" (PELBART, 2000, p.7), ou seja, a segurança que as instituições nos davam agora é por elas mesmas desmontada. Mas o paradoxo reside, justamente, na tentativa de produção de um lado de multiplicação e provisoriedade das formas de subjetividades e, por outro da busca perene de marcadores identitários que tornariam essas subjetividades essencializadas e permanentes como a infância e a adolescência.

Ao seguirmos a primeira interrogação sobre as formas de subjetividade, não poderíamos deixar de nos perguntar sobre as possibilidades que emergem a partir dessas transformações, já que a subjetividade, na discussão que é feita aqui, é produzida por agenciamentos coletivos e, portanto, visível em território ético-político tanto como evidência quanto como problema, ou seja, com interpretações múltiplas e divergentes. Por exemplo, as relações entre os corpos e os modos de viver ganham outras matizes na articulação entre vida e sistemas de informação/comunicação. Bauman (2004) nos diz que neste mundo em rede e de relacionamentos virtuais, tudo é mais fluido e líquido e nossas relações estão funcionando mais na ordem da impermanência, nas quais podemos nos conectar e desconectar no instante em que desejamos. Isso pressuporia uma experiência de maior liberdade, mas o que ocorre é que essas novas formas de subjetividade estariam amarradas cada uma delas a uma identidade, constituídas por novas formas de governo da vida. Dessa forma, a experiência contemporânea não está mais presa a noção de um espaçotempo fechado, mas sim a uma identidade circunscrita que se movimenta em um espaço-tempo cibernético/virtual (AZAMBUJA, 2006).

A modernidade entende as experiências concretas e imediatas como sendo particulares, mas inseridas em espaços gerais, abstratos, infinitos e ideais. O que se pode chamar de lugar é o espaço vivido e definido pelo sensorial, pelo imediato e, ao mesmo tempo, ideal. Nesses termos, conta muito 
mais a capacidade de criar novos "lugares no espaço e de trocar de lugar para lugar, ou seja, de mobilização” (VEIGA-NETTO, 2002), em contraposição à lógica medieval, em que as práticas diárias dependiam de um espaço físico concreto, onde a dominação dependia da posse de um espaço físico.

Já na lógica espaço-tempo estabelecida no contemporâneo, importa cada vez mais o produto dessa relação —a velocidade—, que toma a frente nas formas de subjetivação, valorizando sempre mais a mobilidade, a velocidade de acesso a todas as coisas, com efeitos de "hiper consumo", descartadas pelas práticas econômicas e políticas. Outra condição presente neste mesmo cenário é o que Veiga-Netto (2002) aponta como sendo a volatilidade nas experiências vividas no cotidiano, um estado de sempre mudança sentido na sua inconstância. Bauman (2001), como foi apontado no início desta apresentação, refere-se a um estado de leveza e fluidez em contraponto ao sólido presente numa lógica espacial e temporal com mais durabilidade e com limites bem definidos presentes na modernidade. Com a mobilidade e o volátil demarcando posições no campo subjetivo, o que se mostrava de longo prazo, com grande durabilidade, definitivo, apresenta-se com um caráter cada vez mais transitório, supondo "uma crescente aceleração no ritmo de se relacionar com as coisas e com as pessoas, transformando o cotidiano num caleidoscópio de apelos, exigências e possibilidades” (JOBIM E SOUZA, 2005, p. 101).

Pensar a subjetividade desta maneira implica olhá-la como um tipo de experiência forjada por relações entre verdade e poder. As relações de poder não devem ser entendidas somente enquanto algo instituído, mas também como um poder periférico que atravessa as relações no microtecido social. O poder é algo que se exerce, que se efetua, é uma ação sobre outra ação possível (FOUCAULT, 1995). Estas ações não se restringem somente ao plano de uma economia política, mas também, ao de uma economia subjetiva.

A relação entre economia política e economia subjetiva é algo forjado na modernidade. Se tomarmos a vida na polís grega, por exemplo, a esfera pública (ARENDT, 1989) dizia respeito à aparência ligada à 
existência quando vista e ouvida por outros, de modo que o público era o contrário do privado, a existência de uma desindividualização, de um vivido não em um espaço de dentro, mas de um vivido no coletivo, o público voltava-se para o comum, para um espaço onde o humano se dava a conhecer de forma igual. Era visto e ouvido aquele ou aquilo que tinha uma existência pública. Em contrapartida, a esfera privada apresentava como característica uma existência que se privava de algo, ou seja, o privado estava relacionado à privação. Privação em termos de participação, de pertencimento ao comum, "quem quer que vivesse unicamente uma vida privada —o homem que, como o escravo, não podia participar da esfera pública ou que, como bárbaro, não se desse ao trabalho de estabelecer tal esfera - não era inteiramente humano" (ARENDT, 1989, p. 48). Essa divisão entre público e privado começa a ser borrada na medida em que a formação dos Estados- Nação, e não mais cidades-estados ou feudos, têm como estratégia de governo uma economia política, ou seja, não se trata mais de uma economia doméstica no sentido de como o homem-livre ou o homo faber na pólis grega deveria administrar o seu lar para poder participar da vida pública e do mercado de trocas, mas de uma forma de governo da população, de uma arte de governar a vida.

Para Foucault (1995, p. 278) o nascimento da economia política está relacionado à problemática de governo, ou seja, "Como se governar, como ser governado, por quem, até que ponto, com qual objetivo, com que método etc." Para este autor o significado moderno de economia somente é possível a partir da percepção dos problemas da população, depois da sociedade soberana e a partir da seguinte questão: “(...) como introduzir a economia —isto é, a maneira correta de gerir corretamente os indivíduos, os bens, as riquezas no interior da família- no nível da gestão de um Estado?” Assim, é nas relações que se estabelecem entre a população e a riqueza que passam a se produzir os saberes que sustentam a economia política como ciência do governo e que o Estado passa a ter a família como instrumento para exercer parte das funções de manutenção da vida até então exclusivas destas. Trata-se de um gerenciamento sobre as formas de viver: 
uma economia política que forja uma economia subjetiva. Isso assume uma importância central para os saberes que buscam a regulação dos comportamentos nas instituições sociais, pois fica caracterizado “(...) a entrada da vida na história — isto é, a entrada dos fenômenos próprios à vida da espécie humana na ordem do saber e do poder-, no campo das técnicas políticas” (FOUCAULT, 2003, p. 133).

É neste plano do conhecimento que a Psicologia começa a engendrarse na direção da produção de um sujeito dotado de um "mundo interno", de um "mundo de representações”, de uma identidade, que forjam a figura do sujeito privado. Este sujeito privado difere do sujeito privado da economia política, pois não se trata de localizar essa experiência do privado, em um primeiro momento, no âmbito da economia doméstica, no âmbito do lar, e sim de localizá-lo em um espaço interior, um espaço dentro do sujeito não específico da atividade cerebral, do organismo do ser vivo, mas específico da condição humana, de sua relação com o passado e com o futuro (BERNARDES, 2006). Trata-se de examinar o humano naquilo que o difere das noções de natureza: a experiência de interioridade, pois segundo Foucault (2002, p. 138), o evolucionismo

mostra que o fato psicológico não tem sentido senão com relação a um futuro e a um passado, que seu conteúdo atual assenta-se sobre um fundo silencioso de estruturas anteriores que o carregam de toda uma história, mas que ele implica, ao mesmo tempo, um horizonte aberto sobre o eventual.

São os fenômenos de adoecimento que empurram a Psicologia para uma ciência humana e não natural. Os fenômenos de adoecimento serão considerados na sua articulação com um plano de representações e significações mentais que formulam, de um lado, a estrutura do sujeito psicológico, figuras neuróticas, psicóticas, perversas; de outro lado, a relação dessa estrutura com aquilo que é exterior à interioridade do sujeito, a família. Essa problemática da interioridade para o campo psicológico irá intensificar as formas de governo das vidas, ou seja, na medida em que a interioridade cria descaminhos pelas relações que estabelece com a família 
que a constitui de modo a tornar a psicopatologia uma forma de objetivação das formas de viver, abre-se um espaço de investimento governamental sobre a interioridade e a família bem como a necessidade de conformar categorias identitárias nesse plano de subjetivação (BERNARDES, 2006).

As formas de governo da interioridade e da família tornam-se possíveis, pois, aliam-se aos ideais modernos da saúde como uma questão de polícia (FOUCAULT, 1995). A Psicologia apresenta-se como uma possibilidade de salvaguardar individualidades, na medida em que é nessa figura que investe, é a possibilidade de objetivação do indivíduo que dá à Psicologia um status, um regime de verdades.

As práticas de governos "psi" forjam o privado e o justificam como uma forma de proteção do conjunto da população. A maneira da Psicologia subsidiar os jogos políticos, diz respeito à intensificação da privatividade do indivíduo por meio de práticas e procedimentos que o tornam não apenas responsável pelos processos de adoecimento, mas o mantém "responsabilizável”. Essa manutenção do "responsabilizável” torna-se um dos mecanismos biopolíticos da Psicologia (BERNARDES, 2006).

Esse mecanismo será articulado no interior do espaço doméstico, daquilo que se estabelece como família nuclear, que é a via pela qual se torna possível objetivar uma economia psíquica. É por meio do governo (práticas de exame e confissão, tribunal de condutas, condicionamentos) da economia psíquica que a Psicologia começa a tornar-se uma estratégia de controle das populações. A economia psíquica é a forma pela qual às práticas psicológicas inscrevem o "eu" individualizado e interiorizado como a base de uma narrativa histórica. Isso implica voltar-se para os efeitos dessa economia no que tange à problemática da conduta do sujeito sobre si mesmo ou sobre os outros. A inteligibilidade e a visibilidade que as práticas psicológicas produzem possibilitam tanto a necessidade de administração da economia psíquica quanto à forma personalizada como será administrada. A economia psíquica torna-se uma estratégia da economia política e, portanto, uma forma de economia subjetiva. 
As práticas psicológicas permitem criar uma fronteira entre o público e o privado, objetivando o primeiro como população/pobreza/Estado organizados em comunidades periféricas e o segundo como o "eu interior" envelopado pela pele. As práticas psicológicas começam a entrar no cotidiano das comunidades mediante tecnologias de bem-estar social. $\mathrm{O}$ foco não é propriamente o interior do sujeito, mas a forma de manifestação desse interior em termos de comportamento, de conduta, de hábitos diários, um território no qual o indivíduo torna-se inteligível e praticável segundo um modelo de equilíbrio social.

A tutela passa a ser um dos campos de aplicação das práticas psicológicas para o sujeito privado que nunca está livre, é uma subjetividade que carece dos ideais da economia psíquica: pai alcoolista e desempregado; mãe prostituta e empregada doméstica; pais e mães ausentes; pais violentos e mães submissas; mães que se tornam pais e pais que desaparecem; famílias desestruturadas. A tutela permite que esse indivíduo privado seja governável para compreender que sua história repetirá a história de seus pais, portanto deve responsabilizar-se em controlar essas faltas internas para modificar a sua história. As figuras formuladas por essas práticas são os indivíduos que não cessam de aparecer nas populações: as crianças e os jovens, os "psicopatológicos", os "criminosos" e suas vítimas, os "subversivos", os operários. É o que poderíamos nomear, em termos de práticas "psi” de reformatórios psíquicos e ressocializações psíquicas que investem no indivíduo privado. Neste sentido, são práticas de privação que vêm ao encontro dessa figura indivíduo para reforçá-la e responsabilizá-la. O privado torna-se uma condição para salvaguardar o público, para este não ser contaminado (BERNARDES, 2006), ou seja, entramos aqui na segunda interrogação que apresentei no início da minha fala: que sujeitos são produzidos a partir de certas formas de subjetivação.

Desta forma, as biopolíticas desenvolvem mecanismos de sujeição da subjetividade no interior de uma combinação complexa de técnicas políticas de individualização e de procedimentos de totalização nas formas de 
governamento da vida. Porém, o exercício de poder deve ser entendido junto com as possibilidades de resistência que constituem os processos de subjetivação. É nesse jogo que a família passa a ser objetivada em relação à infância e a adolescência. Essas duas objetivações no interior da família aparecem tanto como foco de investimentos biopolíticos quanto como formas de resistência à quilo que as configuram em termos de campo de saber. A infância e a adolescência são formas do poder se estender e se multiplicar — de família nuclear passa-se a investir nos elementos constitutivos dessa instituição. São figuras-existências que ao serem forjadas adquirem utilidade e rentabilidade política nas formas de governo da família. Isso porque a família nuclear é antropologicamente desconstruída na contemporaneidade, porém criam-se novas formas de experiência de família da qual emergem novos objetos: infância e adolescência entre outros. Porém, é importante que também apontemos que a resposta diante disso é que a produção de subjetividades mostra-se capaz e disposta a correr riscos, a lidar com o provisório e a criar alternativas que se propõem a lidar com as inquietudes e as descontinuidades e, a gerar, a partir delas, as possibilidades de outros modos de vida à convivência familiar, de educar a infância e de entender a adolescência.

Assim, a discussão sobre família, infância e adolescência e as práticas psi remete-nos ao que chamou Foucault (1999) de "corpo político", ou seja, considerar a produção de conhecimentos sobre essas categorias é pensar em um "conjunto de elementos materiais e de técnicas que servem de armas, de reforço, de vias de comunicação e de pontos de apoio para as relações de poder e de saber que investem nos corpos humanos e os submetem a uma condição de objetos de saber” (FOUCAULT, 1999, p.27). Analisar o investimento político-estratégico sobre isso a partir de um campo de saber e de relações de poder é pressupor que existe uma implicação mútua entre "sujeito que conhece, os objetos a conhecer e as modalidades de conhecimentos" e que esses "são outros tantos efeitos dessas implicações fundamentais do poder-saber e de suas transformações históricas" (FOUCAULT, 1999, p. 29). É nesses termos que discutimos a implicação 
das práticas psicológicas como ferramentas conceituais e de intervenção no investimento em termos de disciplinarização e controle de corposexistências na perspectiva de que esses se tornem bem adaptados, sadios e integrados à ordem social.

É, também, nesse percurso que o instrumental da Psicologia foi e é de grande valia para o esquadrinhamento e classificação de condutas. Como diz Rose, "a psicologia, como um corpo de discursos e práticas profissionais, como uma gama de técnicas e sistemas de julgamento e como um componente de ética, têm uma importância particular em relação aos agenciamentos contemporâneos de subjetivação" (1999 p. 146). Assim, exerce também o papel de definir as características e os critérios balizadores para a classificação das populações.

A produção de conhecimento sobre a vida, demarcada, sobretudo, pelas Ciências Naturais, no século XIX, pretendia "desvendar" as leis naturais que regeriam, especialmente, o corpo, a mente e a sociedade. Tal como na prática da biologia evolucionista, emergem práticas psicológicas destinadas ao controle dos sujeitos por meio da disciplina ou pela valorização da busca de um suposto indivíduo autônomo, remetendo-o a uma ordem do natural (GONZALES, 2007).

Com a modernidade ocidental, surge, então, uma rígida cronologização do curso da vida individual, com vistas à obtenção de um critério objetivista e naturalista para a determinação da idade de cada indivíduo, o que gerou uma profusão de saberes científicos, jurídicos sobre estágios da vida (GROPPO, 2000). Por exemplo, a modernidade propiciou uma concepção relativa à juventude como uma fase de transição, composta por um conjunto de etapas normatizadoras que conduziriam progressivamente em direção ao mundo adulto em uma sequência linear em que a sucessão e a ordem das etapas a serem percorridas estariam ligadas à certeza do projeto dessa modernidade. Já, no contemporâneo, a possibilidade de entender a juventude como um encadeamento contínuo e necessário em relação às experiências dos jovens, articula-se às exigências 
do mundo das instituições sociais e políticas, dissolve-se perante as transformações e mudanças ocorridas neste tempo. A primeira dessas transformações é a própria impossibilidade de se ter continuidade e certeza sobre a noção de tempo e espaço gerando ao mesmo tempo diferentes experiências espaço-temporais (GONZALES, 2007).

A noção de idade, no entanto, na perspectiva discursiva que assumimos aqui, pode ser tomada como uma marca que nos posiciona no mundo, marcadores identitários que se inscrevem como símbolos culturais que diferenciam, agrupam, classificam e ordenam as pessoas conforme marcas inscritas na cultura —-sobretudo, na cultura do corpo, “cujos significados nem são estáveis nem têm a mesma importância ou penetração relativa, combinam-se e recombinam-se permanentemente entre si” (VEIGA-NETO, 2000, p. 215).

Com essa noção relativa às idades, questionamos a visão instituída por um pensamento psicológico desenvolvimentista que estabelece características inerentes para cada uma das etapas da vida. Da mesma forma, a constituição e objetivação da vida cronologizada em etapas a serem percorridas é fruto desta vertente "psi” de cunho evolutivo, porém, não somente, mas também de vertentes médicas, sociológicas. Se, por um lado, é na modernidade que se produz as concepções de infância, de juventude e de família como a conhecemos hoje, por outro, a própria constituição da sociedade moderna, com instituições como a escola, o Estado, o direito e o trabalho industrial, assentou-se "no reconhecimento das faixas etárias e na institucionalização do curso da vida”, mostrando-nos um mútuo engendramento de mudanças e institucionalizações na rede social no período moderno, o que se configurou também como um solo fértil para a objetivação das idades (GROPPO, 2000).

Nesse processo, a psicologia duplica conceitos empíricos para legitimar seus próprios conceitos em uma função transcendental, instituindo bases fundamentais para a compreensão da natureza humana e do desenrolar evolutivo das idades — da infância à idade adulta, gerando saberes e práticas 
em torno desse homem-indivíduo. Cada indivíduo, segundo essa lógica, passaria a ter certeza de que, em determinado momento, o sinal da natureza iria despertar em si transformações bio, psico e sociais pré-diagnosticadas pelas ciências médicas e psicológicas (GONZALES, 2007).

É, nesse sentido ainda, que as disciplinas psi, como diz Rose (1999 p. 147), "estabeleceram uma variedade de 'racionalidades práticas', envolvendose na multiplicação de novas tecnologias e em sua proliferação ao longo de toda a textura da vida cotidiana: normas e dispositivos de acordo com os quais as capacidades e a conduta dos humanos têm se tornado inteligíveis e julgáveis”. É ancorada, principalmente, nessa lógica desenvolvimentista em que se preconiza um progresso contínuo da humanidade no qual o indivíduo, a partir de seus “estágios iniciais” vai se desenvolvendo em etapas predefinidas, cada vez mais, rumo à maturidade do adulto, que a psicologia vem prescrevendo e legitimando concepções acerca da infância e juventude, ordenando-as e objetivando-as em uma ordem social entre as fases de transição da infância e a maturidade do período adulto.

Foi com a crença na transição dos indivíduos para uma maturidade que as ciências humanas e sociais, do século XIX ao século XX, produziram instituições preocupadas em proteger e diagnosticar os indivíduos considerados ainda não maduros e diagnosticados como portadores de fragilidades, e instituições interessadas na possibilidade de intervir na potencialização das capacidades desses indivíduos. É sob essa visão que, na construção de uma infância dita 'normal' em oposição a uma infância de risco e tantas outras que aparecem como opostas à primeira, se entrelaça uma noção de uma essência infantil, vista como natural e, portanto, fixa e imutável. A pretensão de igualar infâncias desiguais é formulada dentro de princípios científicos que historicamente caracterizam as crianças a partir de um modelo hegemônico, integrando-se aos valores defendidos pelo liberalismo (CRUZ; HILLESHEIM; GUARESCHI, 2005).

Já, a adolescência passa a ser considerada como um estágio que pode ser perigoso ou frágil, propício para contrair toda espécie de males. Tal 
concepção contribuiu para a vigilância e regulação social desses indivíduos neste período. É nesse processo de cerceamento político, moral, policial, empírico e científico do indivíduo, próprio da modernidade, que a psicologia buscou "uma definição exaustiva, detalhada e objetiva das fases de maturação do indivíduo, bem como propôs métodos de acompanhamento apropriados a cada fase dessa evolução do indivíduo à maturidade ou idade adulta” (GROPPO, 2000, p. 59).

Dentro desse processo de definição objetiva e naturalizante das pessoas, estas categorias passaram a carregar em si, do ponto de vista das ciências modernas, a função social de "maturação" dos indivíduos, pressupondo a tarefa emergente de socialização, com vistas a torná-los “indivíduos autênticos e integrados à sociedade moderna” (GROPPO, 2000, p. 60). Dessa forma, define-se o desenvolvimento humano por elementos que, de forma naturalizada, são constitutivos da vida infantil mas que devem amadurecer durante o período da adolescência e juventude, pois não são tolerados na vida adulta. Formar família, entrar no mercado de trabalho e ser pai e mãe são passos homogêneos e hegemonicamente reconhecidos como sendo aqueles que produzem e definem a vida humana.

Como invenção do pensamento moderno, a finitude humana é aquilo que possibilita esclarecer o seu aparecimento, sua constituição e os movimentos presentes para visibilizar momentos futuros. Esse controle sobre a natureza humana coloca-a na ordem do pensável para diferentes campos do conhecimento. Porém, para a Psicologia, esta concepção se configurará no ponto de apoio para os diversos diagnósticos que elencarão as constantes e renováveis patologias e para a divulgação de um arcabouço de padrões de normalidade (HUNING e GUARESCHI, 2005). Assim, a emergência de um discurso de valorização do cuidado e do controle sobre a infância e a juventude por parte das instituições públicas ou privadas, são legitimadoras e reguladoras dos modos de ser e viver de crianças e de jovens na sociedade, remete-nos às produções das práticas sociais e institucionais também impostas pela ordem dos processos econômicos, culturais e políticos que vêm sendo construídos em diferentes momentos 
históricos. Dessa maneira, conforma-se um espaço de privatividade do indivíduo a partir de marcas identitárias e uma forma de controle pública dessas interioridades:

a sociedade de controle suprimiu essa dialética entre fechado e aberto, entre dentro e fora, pois aboliu a própria exterioridade, realização maior do capitalismo em seu estágio atual (...) Ele abomina o dentro e o fora, é inclusivo e prospera precisamente incorporando em sua esfera efetivos cada vez maiores e domínios da vida cada vez mais variados (PELBART, 2000, p.30).

A esta conformação presente nas relações atuais — também com relação à infância e adolescência - desponta com vigor o caráter efêmero e mutante do que vem a ser consumido, sejam coisas, ideias, 'atitudes' ou comportamentos, entrecruzados com o mesmo vigor que se desenvolvem as tecnologias que operam na produção e sustentação deste cenário atual. Ou seja, infância e adolescência são formas de consumo, uma economia subjetiva em que bens materiais e formas de vida equalizam-se a capitais de consumo.

Nesta perspectiva, o que queremos enfatizar, é que diferentes práticas engendram objetos sempre diversos, sendo necessário desnaturalizar quaisquer noções totalizantes sobre a infância, adolescência e família que se pretendam permanentes e universais, provocando-se, assim, um contínuo questionamento sobre as relações entre poder e verdade. E isso deveria estar no centro das atenções da psicologia.

Referências

ARENDT, Hannah. A condição humana. Rio de Janeiro: Forense, 1989.

AZAMBUJA, Marcos, A. Espaço Tempo em Educação a Distância e a Produção de Subjetividade. Porto Alegre: Dissertação de Mestrado (Psicologia). Pontifícia Universidade Católica do Rio Grande do Sul, 2006.

BAUMAN, Z. Modernidade líquida. Rio de Janeiro: Jorge Zahar, 2001. - Amor Líquido: sobre a fragilidade dos laços humanos. Rio de Janeiro: Jorge Zahar, 2004. 
BERNARDES, Anita G. Políticas da Existência no Campo da Saúde: o Público como um Dispositivo. Tese de Doutorado (Psicologia). Pontifícia Universidade Católica do Rio Grande do Sul, 2006.

CRUZ, L.; HILLESHEIM, B.; GUARESCHI, N.M.F. Infância e políticas públicas: um olhar sobre as práticas psi. Psicologia \& Sociedade, set/dez, v.17, n.3, p.42-49, 2005.

FOUCAULT, Michel. Microfísica do Poder. Rio de Janeiro: Graal, 1995.

. Vigiar e Punir: história da violência nas prisões. 21. ed. Petrópolis: Vozes, 1999.

. História da sexualidade I: a vontade de saber. Rio de Janeiro: Graal. 1999.

. A Psicologia de 1850 a 1950. In. FOUCAULT, Michel. Ditos $e$ escritos I. Rio de Janeiro: Forense Universitária, 2002.

- Arrancados por intervenções enérgicas de nossa permanência eufórica na história, pomos as "categorias lógicas" a trabalhar. In. FOUCAULT, Michel. Ditos e escritos IV. Rio de Janeiro: Forense Universitária, 2003.

GONZALES, Zuleika. Protagonismo: Formas de Governo da População Juvenil. Dissertação de Mestrado (Psicologia). Pontifícia Universidade Católica do Rio Grande do Sul, 2007.

GROPPO, L.A. Juventude: Ensaios sobre Sociologia e História das Juventudes Modernas.Rio de Janeiro: Difel, 2000.

HUNING, S.M.; GUARESCHI, N.M.F. Efeito Foucault: desacomodar a psicologia. In: GUARESCHI, N.M.F.; HUNING, S.M. (Orgs). Foucault e a Psicologia. Porto Alegre: ABRAPSO Sul, 2005, p. 107127.

PAL PELBART, Peter. A vertigem por um fio. São Paulo: Iluminuras, 2000.

ROSE, N. Inventando nossos eus. In: SILVA, T.T. (Org.). Nunca fomos humanos - nos rastros do sujeito. Belo Horizonte: Autêntica, 1999, p. 139-204. 
VEIGA-NETO, A. As idades do corpo: (material)idades, (divers)idades, (corporal)idades, (ident)idades... Em: AZEVEDO, J.C.; GENTILI, P.; KRUG, A.; SIMON, C. (Orgs). Utopia e democracia na educação cidadã. Porto Alegre: Ed. Universidade/UFRGS/SMED, 2000.

. De geometria, currículo e diferenças. Educ. Soc. Campinas, 2002, v.23, n.79. p. 163-186. Disponível em: www.scielo.br/scielo. 


\title{
A PRODUÇÃO DAS INFÂNCIAS E ADOLESCÊNCIAS PELO DIREITO
}

\author{
Edinete Maria Rosa \\ Universidade Federal do Espírito Santo \\ Eda Terezinha de Oliveira Tassara \\ Universidade de São Paulo
}

ecisivamente, no Estatuto da Criança e do Adolescente - ECRIAD ${ }^{1}$ (1990) - o Direito ${ }^{2}$ reconhece que a criança e o adolescente são pessoas em condição especial de desenvolvimento, muito embora, as análises das práticas jurídicas e das práticas sociais apontem para um recorrente desrespeito a essa condição.

O Direito produz sentidos para determinados tipos de infâncias e adolescências e essa produção pode ser percebida, principalmente, quando questões de conflitos, envolvendo crianças e adolescentes, chegam às instâncias máximas do sistema de justiça ou quando essas questões requerem uma ação interventiva do Estado por meio de programas sociais.

${ }^{1}$ O Estatuto da Criança e do Adolescente (Lei Federal 9069/90) ficou popularmente conhecido como ECA, desde a sua criação em 1990 até por volta de 10 anos após sua criação. Um movimento de defensores desta lei buscou substituir essa sigla por ECRIAD, porque entendiam que a nomenclatura ECA se tornara pejorativa. Apesar de sermos sensíveis também àqueles que consideram "ECA" uma forma carinhosa de se referir ao Estatuto da Criança e do Adolescente, como a professora Silvia Leser de Mello, optamos por adotar, neste trabalho, "ECRIAD" como sigla do Estatuto.

${ }^{2}$ Apesar de haver várias definições do Direito, achamos pertinente registrar as ideias de Santos (1988) para quem o direito é "o conjunto de processos regularizados e de princípios normativos, considerados justiciáveis num dado grupo, que contribuem para a criação e prevenção de litígios e para a resolução destes através de um discurso argumentativo, de amplitude variável, apoiado ou não pela força organizada”. 
Pretendemos desenvolver este tema abordando dois pontos: no primeiro momento, iremos discutir os avanços e as limitações dos direitos das crianças e dos adolescentes no Brasil apontando que o "legal” e o "social" caminham juntos. No segundo momento, apresentaremos uma pesquisa em que analisamos a atuação da justiça, em casos que envolvem conflitos com crianças e seus familiares, demonstrando assim o aspecto ideológico dos discursos jurídicos sobre esses sujeitos.

\section{O atual direito da criança e do adolescente: avanços e limites}

“O ECA não foi uma dádiva do Estado, mas uma vitória da sociedade civil"

(SILVA, 2005, p. 36)

A epígrafe utilizada nesse tópico já apresenta o foco sobre o qual queremos tecer algumas reflexões a respeito do ECRIAD anunciando, pelo discurso, que se trata de uma análise política do direito.

Bobbio (1992) em sua obra clássica “A era dos direitos” nos diz que ao buscar o fundamento de um direito há de diferenciar-se, caso se trate de um “direito que se tem ou de um direito que se quer” (p.15).

No primeiro caso, explica o autor, há de ver se há uma norma válida que o reconheça e, no segundo caso, há de se buscar "boas razões para defender a legitimidade do direito em questão e para convencer o maior número de pessoas a reconhecê-lo” (p.15).

Em se tratando especificamente do Direito da Criança e do Adolescente, creio que caberia reconhecer a necessidade de buscar esses dois fundamentos para tal direito: a norma e a legitimidade da norma. Isso porque mesmo o tendo reconhecido Direito da Criança e do Adolescente expresso em Leis- a legitimidade desse muitas vezes é posta em questão, principalmente nessa época em que se fortalece, por meio de divulgação midiática, uma percepção de ineficácia principalmente no combate a violência juvenil. 
No primeiro caso, a norma válida está expressa na lei 8.069/90 intitulada Estatuto da Criança e do Adolescente e no segundo, temos uma série de trabalhos científicos além de experiências cotidianas de grupos populares que nos fazem crer, cada vez mais, que este direito é necessário para se construir uma sociedade mais igualitária e, portanto, mais favorável ao desenvolvimento saudável e integral de todas as crianças e adolescentes.

Mas, Bobbio talvez defenderia que, em se tratando dos direitos das crianças e dos adolescentes, o problema maior de nosso tempo seria o de protegê-lo e não o de fundamentá-lo. Porque como diz o autor a respeito dos direitos do homem "o problema que temos diante de nós não é mais filosófico, mas jurídico e, num sentido mais amplo, político” (p.25). Assim não se trata mais de convencer a comunidade em geral da necessidade de proteção de nossas crianças para viverem e crescerem em condições favoráveis às suas plenas potencialidades enquanto seres humanos; assim como não se trata mais de convencer que a educação, formal e/ou informal é importante porque ela pode ser um meio de aprendizagem e exercício da cidadania; que a saúde, o lazer e a convivência familiar e comunitária, quando de qualidades, trazem condições mais favoráveis para o crescimento integral das pessoas. Trata-se agora, de garantir todos esses direitos, impedindo que "apesar das solenes declarações, eles sejam continuamente violados” (p.25).

Os direitos sociais -e localiza-se aqui a maioria dos direitos da criança e do adolescente elencados no ECRIAD—, são aqueles que surgem no século XX como consequência do entendimento que a felicidade humana não seria garantida somente com a proteção dos homens contra o Estado (direitos do homem), mas também com a proteção dada pelo próprio Estado (VELLOSO, 2003).

Neste sentido, a Constituição Federal Brasileira de 1988 — CF/88dispõe que são direitos sociais e, portanto, dever do Estado: a educação, a saúde, o trabalho, a moradia, o lazer, a segurança, a previdência social, a proteção à maternidade e a infância e a assistência aos desamparados (Artigo $6^{\circ}$ da $\mathrm{CF} / 88$ ). Esses direitos se desdobram em outros tantos como, 
por exemplo, no que se refere ao direito ao trabalho, o direito à organização sindical e o direito à greve dentre outros.

Ainda no que se refere aos direitos sociais, a Lei Orgânica de Assistência Social —LOAS - traz como um dos princípios a sua universalização mesmo que fundamentalmente, os direitos sociais seriam para aqueles que estão em condições sociais desiguais em relação aos demais.

Nesse âmbito o Estatuto da Criança e do Adolescente rompeu com uma tradicional forma de entender e realizar a assistência à infância e juventude ${ }^{3}$ no Brasil, principalmente, ao assegurar a universalização desses direitos, colocando todos aqueles que estão abaixo da idade de 18 anos sob a mesma condição jurídica.

Na verdade, assegura Mendonça (2002) que foi já a partir dos anos 80 do século passado que a política de assistência social se reordenou, estabelecendo novos parâmetros para as intervenções públicas com crianças e adolescentes "a partir da adoção de princípios como descentralização, participação social e universalização da atenção, visando reduzir a exclusão social e garantir a equidade no plano dos direitos" (p. 115). Nos lembra ainda Silva (2005) serem esses marcos os quais possibilitaram emergir a grande mobilização nacional, com repercussão internacional, em prol da construção de novos direitos para crianças e adolescentes brasileiros a partir das críticas à mentalidade social e às práticas jurídicas fundamentadas no Código de Menores de 1979.

Com isso decorre uma reflexão inovadora do conceito de criança/adolescente em oposição ao conceito de "menor", adotando a partir deste marco, no plano legal e social a primeira forma de nomeação em detrimento da segunda, "buscando desfazer estereótipos criados a partir da associação entre menor, crime e delinquência” (MIRAGLIA, 2005, p. 84),

\footnotetext{
${ }^{3} \mathrm{O}$ termo juventude é utilizado de forma diferenciada do termo adolescência por vários autores. Porém neste texto iremos considerá-los como simular considerando todas aqueles sujeitos que se encontram na faixa etária de 12 a 18 anos, como estabelece o Estatuto da Criança e do Adolescente. Para maiores esclarecimentos consultar Rosa, Ribeiro Júnior e Rangel (2007).
} 
assim como romper com a tradicional forma de tratamento dispensado às crianças e aos adolescentes pobres, antes colocado na condição de irregularidade e, portanto, “merecedores” da intervenção estatal sociojurídica (RIZZINI, 1995).

A principal inovação do ECRIAD é que ele expressa o paradigma da proteção integral, incorporando o reconhecimento de que as pessoas com idade inferior a 18 anos estão em estado especial de desenvolvimento e transforma os anseios populares em proposições mais explícitas e mais articuladas para as práticas tanto jurídicas quanto sociais com a parcela infanto-juvenil.

Sendo assim, os principais pontos do Estatuto, destacados como inovadores, se relacionam ao reconhecimento do estado especial de desenvolvimento humano em que se encontram as crianças e os adolescentes, rompendo, por um lado com o paradigma da pobreza como norteador das ações assistenciais em prol da infância e, por outro, diferenciando o direito destes em relação aos direitos dos adultos. O que vale agora é a consideração que é devido ao seu estado de desenvolvimento e das necessidades que decorrem deste estado que crianças e adolescentes devem ser tratados de forma distinta e prioritária. Assim, seu direito é afirmado pela positividade de seu valor e não pela falta ou carência de sua condição.

De acordo com vários autores, destacamos como positivos os seguintes pontos do ECRIAD: a) A defesa de uma educação voltada para o pleno exercício da cidadania e da qualificação para o trabalho, assegurando igualdade de condições para o acesso e a permanência na escola, bem como a garantia da participação da criança, do adolescente e da família na vida escolar (LEAL, 2004); b) O reconhecimento da necessidade de ter uma família e uma comunidade de pertença, combatendo a institucionalização de crianças e adolescentes e, ajudando a promover as famílias em condições básicas de acolhimento para criarem seus filhos (RIZZINI, et al., 2006); c) A amplitude no reconhecimento dos direitos individuais como o direito à liberdade, ao respeito e à dignidade que possibilitam o reconhecimento do valor de si e o 
valor do outro, fundamentando a construção de relações de alteridade (MELLO, 1999); d) O combate ao trabalho infantil —em qualquer hipótese e a busca da compreensão de que o trabalho para jovens só pode ser reconhecido quando este trouxer ganhos para a formação integral desse jovem- em concordância com os estudos e comprovações científicas que mostram os impactos danosos do trabalho infanto-juvenil para o desenvolvimento dos mesmos, afetando, principalmente, sua saúde, seu processo de escolarização e de formação de identidade (CAMPOS e FRANCISCHINI, 2003) além dos benefícios socioeconômicos advindos do investimento na busca da erradicação do trabalho infanto-juvenil no Brasil (KASSOUF, DORMAN e ALMEIDA, 2005); e) A promoção da democratização da coisa pública institucionalizando a participação popular por meio dos Conselhos Tutelares e Conselhos de Direitos (SILVA, 2005), para citar apenas alguns.

Se, por um lado, temos várias referências gloriosas à nova lei, por outro, alguns autores tecem críticas e apontam suas limitações, apesar de também reconhecerem seus méritos. Destacaremos duas críticas importantes: a) No campo da participação o Estatuto não conseguiu garantir o direito de todos aqueles que agora são considerados "sujeitos de direitos". Essa limitação se estabelece, paradoxalmente, também pelo reconhecimento do estado de desenvolvimento em que se encontram esses sujeitos. Assim questiona Sales (2004, p. 220): "Como falar de política a propósito de um segmento social ainda em desenvolvimento?” lembrando que todas as ações de defesa da criança são protagonizadas por adultos ${ }^{4}$; b) No que se refere ao direito dos jovens em conflito com a lei, há limitações intrínsecas no Estatuto, principalmente, referente às garantias processuais penais, que uma vez não reconhecidas como necessárias, acabam por potencializar formas de punição severas sob a pretensa ação educativa coercitiva (GUINDANI, 2005; MIRAGLIA, 2005). Disso decorre que o número de adolescentes que recebem medidas privativas de liberdade é grande e desproporcional aos

\footnotetext{
${ }^{4}$ A autora ressalta que, em raros casos o protagonismo dos movimentos sociais em prol dos direitos das crianças e dos adolescentes são compartilhados com crianças e adolescentes como, por exemplo, no Movimento Nacional de Meninos e Meninas de Rua.
} 
que recebem outras medidas, sendo que, se analisarmos as motivações para a aplicação da medida de internação, veremos que, pela gravidade das ações, muitos adolescentes poderiam estar cumprindo outra medida menos drástica para sua vida (ROSA, RIBEIRO JÚNIOR E RANGEL, 2007). Além disto, são constantes as interpretações errôneas sobre as medidas socioeducativas, gerando o mito da impunidade (VOLPI, 2001). Mas há de se destacar, como a mais contundente crítica ao ECRIAD (na nossa avaliação), aquela elaborada por Silva (2005): as mudanças e reformas incorporadas pelo ECRIAD, na verdade, fazem parte "do jogo pelo poder e acompanham as reconfigurações societais” nas sociedades de capitalismo avançado. Sendo assim, são “inerentes às reformas institucionais legais e burocráticas, que na fase da mundialização do capital se revestem de discursos democráticos para continuar operando na reprodução do sistema de dominação” (p.45).

Acreditamos que essas duas críticas indicam os principais desafios que temos que enfrentar na luta pela efetivação do direito da criança e do adolescente. Por isso mesmo esse debate do direito da criança e do adolescente tem que prosseguir, tendo como parâmetros os ideais emancipatórios, por um lado, e as configurações sociais, econômicas e políticas atuais, por outro, para continuarem vivas as tensões que estiveram presentes em sua proposição e preservar sua história sem desvios.

\section{Uma aplicação do Direito: analisando o discurso jurídico}

"O mapa, o poema e o direito, embora por diferentes razões, distorcem as realidades sociais, as tradições ou os territórios, e todos os fazem segundo certas regras".

(SANTOS, 2005, p. 198)

Em 2003 concluímos uma pesquisa, desenvolvida no doutorado, cujo objetivo consistiu em compreender o discurso jurídico a respeito da violência de pais contra filhos — crianças ou adolescente- (ROSA, 2004). Para tal, analisamos os argumentos adotados para emissão de juízos 
presentes nas sentenças de nove processos configurados no artigo 136 do Código Penal Brasileiro:

Expor a perigo a vida ou a saúde de pessoa sob sua autoridade, guarda ou vigilância, para fim de educação, ensino, tratamento ou custódia, quer privando-a de alimentação ou cuidados indispensáveis, quer sujeitando-a a trabalho excessivo ou inadequado, quer abusando de meios de correção ou disciplina:

Pena - detenção de 2 (dois) meses a 1 (um) ano, ou multa.

$\S 1^{\circ}$ Se do fato resulta lesão corporal de natureza grave:

Pena - reclusão, de 1 (um) a 4 (quatro) anos.

$\S 2^{\circ}$ Se resulta a morte:

Pena - reclusão, de 4 (quatro) a 12 (doze) anos.

$\S 3^{\circ}$ Aumenta-se a pena de $1 / 3$ (um terço), se o crime é praticado contra pessoa menor de 14 (quatorze) anos.

Os nove processos abrangiam todo o universo de processos conclusos, no período de janeiro de 1995 a dezembro de 2000, e existentes nas três varas criminais de um município da região metropolitana de Vitória/ES. O município comparecia como um dos mais recorrentes nos registros da Delegacia de Proteção à Criança e ao Adolescente (DPCA) de Vitória que é a única delegacia especializada em crimes contra crianças e adolescentes no Estado.

O material da pesquisa consistiu nas sentenças judiciais ${ }^{5}$ e a análise dos dados foi realizada à luz da lógica (ARAÚJO, 2001) e dos sistemas de significação (PIAGET, 1989).

Piaget (1989) distingue dois tipos de sistemas de significação: o lógico e o não lógico que dão visibilidade à lógica do pensamento humano, tanto na forma como um tal pensamento se estrutura, quanto nos conteúdos e valores pessoais e/ou sociais que estão presentes nos discursos.

Os sistemas de significação lógicos e os sistemas de significação não lógicos dependem de implicações significantes e, consequentemente, das inferências. A diferença é que nos sistemas lógicos as implicações são

\footnotetext{
${ }^{5}$ Outras análises foram feitas dos processos, porém, neste texto, iremos tratar exclusivamente das sentenças.
} 
lógico-matemáticas; já nos sistemas de significações não lógicos, as implicações são individuais, construídas com as experiências que se têm ao longo da vida.

A lógica é definida por Kant (1992) como "a ciência das leis necessárias do entendimento e da razão em geral ou (...) da mera forma do pensamento em geral” (p.30). Copi (1978), por sua vez, a define como “o estudo dos métodos e princípios usados para distinguir o raciocínio correto do incorreto" (p.19).

Ao reconhecermos a máxima, segundo a qual, "o direito é a arte da argumentação”, consideramos que o discurso jurídico é composto em sua maioria de argumentos, visto que, "além de diversos outros fatores, tais como emocionais, psicológicos, utilitários e outros, um dos principais fatores envolvidos no convencimento de um interlocutor é um raciocínio bem articulado" (ARAÚJO, 2001, p. 4).

Os resultados do nosso estudo apontaram uma produção maciça de raciocínio falacioso, produzindo sentidos para a violência, a família, a autoridade dos pais e para a infância ${ }^{6}$.

No que se refere à violência observamos o uso excessivo de paráfrases que serviram, em todos os processos, para aliviar a gravidade dos fatos, sendo utilizadas, quase sempre, com omissões de elementos discursivos que qualificavam a gravidade dos casos. Nos nove processos analisados, por exemplo, a palavra "violência" não constou uma vez sequer no discurso dos juízes.

A tortura é outra qualidade de crime que parece não existir para crimes contra crianças, é o que podemos inferir dos nossos dados. Apesar de os crimes terem sido narrados de maneira a demonstrar um tal caráter, nenhum juiz admitiu essa tipificação nos seus discursos.

\footnotetext{
${ }^{6}$ Apesar de termos iniciado o estudo com a intenção de estudarmos os crimes cometidos contra crianças e adolescentes, todos os processos, por nós analisados, eram referentes às crianças.
} 
(...) o G. passou a dar vários tapas na filha R. e em ato contínuo pegou a criança por um braço e uma perna, sentido horizontal, socando-a contra o chão por várias vezes, só parando quando a criança virou os olhos e ficou toda mole parecendo estar morta, que o G. não atendeu aos pedidos de clemência da depoente a qual implorava que ele parasse de espancar a criança indefesa (...) (Depoimento de uma testemunha - Caso 1)

(...) quando sua mãe chegou do trabalho e deu pela falta da carne e dos perfumes, deu uma surra de fio na informante e em sua irmã P., que conseguiu fugir; que após apanhar a informante ficou chorando, tendo sua mãe esquentado uma colher e passado em seu rosto, enquanto as primas A. e N. e as vizinhas J. e P. a seguravam para que não fugisse(...) (Depoimento da criança - Caso 7)

A família e a autoridade dos pais foram conteúdos subjacentes na maioria dos discursos. A falta de argumentação constatada nos processos permitiu, que os fatos concretos constituídos pelos crimes se transformassem como em uma forma "mágica”, no decorrer de todo o processo, e acabassem sendo resumidos numa versão bem distante da que deu origem ao inquérito. Em última análise, através do seu discurso, o sistema jurídico produz uma imagem de sociedade tolerante aos castigos aplicados pelos pais, na qual os interesses pela manutenção da família sobressaem em relação aos interesses da prática da justiça. Isso pode ser demonstrado nas análises dos enunciados a seguir.

É de salientar que em virtude da pobreza da família e do estado que a acusada se mantinha, junto com seu companheiro, grande parte do dia embriagados, tal providência era melhor para a menor F., que não teve os problemas de seu outro irmão que vivia na rua a ponto de não mais retornar para casa. Aparentemente ela não corria nenhum perigo no trabalho que executava. (Discurso do juiz - Caso 2)

Este enunciado foi emitido por um juiz ao sentenciar sobre o caso em que a mãe "consentiu" que sua filha, de 10 anos, trabalhasse na casa de um senhor —realizando os trabalhos domésticos e cuidando de uma criança de cinco anos (filho desse senhor), além disso foi forçada a manter relações sexuais com este senhor por vários anos - todas essas práticas eram de conhecimento da mãe. 
O raciocínio do juiz adota como premissas: a) A família vive em grande pobreza; b) A mãe e seu companheiro mantêm-se, grande parte do dia, embriagados; e como conclusão: É melhor para a criança ficar em companhia do acusado e prestar todos os serviços.

(...) Dada a palavra ao MP, este assim se manifestou: 'tendo em vista que com a oitiva da criança e seus genitores nesta audiência ter ficado provado que a surra dada pela mãe da criança na mesma foi com o intuito de corrigir na sua educação, não tendo trazido nenhum dano à criança, opino pelo arquivamento do presente procedimento'. (Discurso do MP presente na sentença - Caso 8)

Esse segundo enunciado trata do discurso do MP, em um caso em que a criança foi surrada, com um fio, porque não havia feito os serviços domésticos, conforme o gosto da mãe. Nele podemos depreender as seguintes premissas: a) O castigo aplicado pela acusada à vítima teve intuito educacional; b) A surra dada pela mãe não trouxe nenhum dano à criança; e a conclusão: o processo deve ser arquivado.

Esses raciocínios, além de exporem a fragilidade da imposição de limites jurídicos nos casos de violência contra crianças, reforçam uma ideologia em que os ideais de família e os valores sociais (principalmente do trabalho e da obediência aos pais) contribuem para lastrear declarações como "isso é violência" ou "isso não é violência".

Todas essas considerações já denunciam a forma como as crianças eram consideradas, principalmente, nos discursos jurídicos. Silenciadas nos processos, as vítimas ficaram à mercê dos operadores do direito. Dos nove processos, somente em, três, as vítimas tiveram voz nos inquéritos policiais. Daí por diante seu depoimento só comparecia fragmentado nos discursos dos operadores do direito ou do Juiz.

A despeito das idades das crianças, no momento da instauração dos inquéritos, que variaram entre recém-nascidos e 12 anos $^{7}$ (sete crianças

\footnotetext{
7 Apesar do ECA estabelecer o limite de 11 anos para criança, analisaremos o caso, considerando esse sujeito também como criança, visto que, quando foi vítima ela tinha 11 anos.
} 
estavam acima da idade de sete anos), descumpria-se a prerrogativa estatutária de serem consideradas e respeitadas como sujeitos de direitos. Além disso, à época da sentença, elas já estavam bem mais crescidas visto que, em média, o tempo decorrido entre a instalação do inquérito e a sentença era de 2 anos. A criança recém-nascida, por exemplo, tinha quatro anos quando a sua mãe foi julgada.

Depreendeu-se dos discursos que a infância não possuía características e peculiaridades que as tornassem merecedoras de cuidados especiais e proteção integral. Esse discurso foi corroborado em todos os processos, independente das características do crime que haviam sofrido.

Essa imagem da infância esteve ancorada na descrição de uma certa pobreza que imprime aos sujeitos, condições concretas de vida tomadas como naturais à sua condição, como no discurso do juiz no caso dois, descrito acima. Dessa forma, no decorrer dos processos se sublima a infração e os fatos passam a serem justificados por condições naturalizadas.

Dos nove processos, somente, em um foi dado uma sentença condenatória do réu. Neste o réu foi pego em flagrante e só se manteve apreendido porque não teve $\mathrm{R} \$ 80,00$ reais para pagar a fiança. Dada a sentença condenatória o tempo de apreensão, imposto pelo juiz, foi menor do que o tempo que já havia passado na prisão (quatro meses), sendo então isento das custas processuais como forma de "reparar" esse tempo cumprido a mais.

Em outros estudos realizados no judiciário foram encontrados resultados semelhantes ao nosso, no que se refere, ao reconhecimento de uma certa tendência, em se utilizar uma forma distorcida do Estatuto, ou simplesmente de negligenciá-lo (MIRAGLIA, 2005; COSTA, 2005; TOMAZELLI, 2007).

Miraglia (2005), ao acompanhar as audiências de julgamento de jovens, pôde constatar que, além de serem conduzidas com uma certa informalidade, houve também, pouca preocupação com as garantias processuais conquistadas com o ECRIAD. Outra constatação da autora foi 
que, as sentenças tinham o caráter de lição, entendida pelos juízes como uma atitude pedagógica por parte deles. No entanto essas "lições" compreendiam gritar com os jovens, fazer seus familiares chorar, fazer comparações e ameaças etc.

Costa (2005) concluiu, em sua pesquisa, que existe uma face punitiva em todas as medidas socioeducativas e como Miraglia, que o desrespeito às garantias processuais, associado às características do cumprimento das medidas, são os principais indícios da negação de direitos especiais aos adolescentes. Os resultados encontrados por Tomazelli (2007) não se distanciam destes outros. A autora analisou processos referentes a adolescentes autores de ato infracional, concluindo que as questões jurídicas processuais se sobrepõem às questões de ordem psicossocial e, os processos acabam sendo formalidades, por meio das quais, se impõem um discurso jurídico acrítico e individualizante quando se analisam os acontecimentos qualificados como infrações. Neles, se observa também que, a defesa da sociedade excluiu a defesa do adolescente, demonstrando um claro viés jurídico de culpabilização dos jovens. Neste estudo, a autora, mostrou que nenhum outro discurso questiona o discurso competente do juiz.

\section{A título de conclusão}

Percebemos nesta exposição que a produção das infâncias e adolescências pelo direito perpassam caminhos diversos. Por um lado, a histórica conquista jurídica, em prol das crianças e adolescentes, tem um importante marco em 1990, com a promulgação do ECRIAD. Porém, se, por um lado, essa lei instrumentalizou e potencializou mais as lutas populares pelos direitos das crianças e adolescentes, por outro, permitiu dar maior visibilidade às injustiças e aos desrespeitos constantes existentes no Brasil.

É fato que, no cenário mundial, o Brasil possui uma das melhores leis de defesa dos direitos da criança e do adolescente, embora isso não garanta sua aplicação, quando da sua violação e, da necessidade de implementação de políticas públicas. Da mesma forma, o sistema de justiça não consegue 
garantir o cumprimento do Estatuto ao lidar com casos particulares porque, entre outras razões, o que rege as decisões judiciais são os valores e interesses daqueles que regulam a sociedade.

O descumprimento da lei, no aspecto da falta de reconhecimento da violência nas relações familiares, reproduz a ordem violenta que permeia as relações dos homens em todas as suas instâncias.

Ao agir dessa forma, o sistema jurídico fortalece o espaço doméstico, legitimando o seu mecanismo de poder, ao passo que alivia os mecanismos de poder do espaço da cidadania, fortalecendo a família e o parentesco e, enfraquecendo o Estado, enquanto espaço de domínio do público, ou do bem comum (SANTOS, 1999).

\section{Referências}

ARAÚJO, R.C. Lógica e teoria da argumentação. Vitória: 2001. Inédito.

BOBBIO, N. A era dos direitos. 8 ed. Rio de Janeiro: Campus, 1992.

BRASIL, Lei Orgânica da Assistência Social _LOAS— Lei 8742, de 07/12/1993.

. Constituição (1988). Constituição da República Federativa do Brasil: Constituição do Brasil: promulgada em 5 de outubro de 1988. Brasília: Centro Gráfico do Senado Federal, 1988.

CAMPOS, Herculano Ricardo; FRANCISCHINI, Rosângela. Trabalho infantil produtivo e desenvolvimento humano. Psicologia em Estudo. Maringá, v. 8, n. 1, 2003.

COPI, I.M. Introdução à lógica. 2a ed. São Paulo: Mestre Jou, 1978.

COSTA, A.P.M. As garantias processuais e o direito penal juvenil como limite na aplicação da medida socioeducativa de internação. Porto Alegre: Ed. E Livraria do Advogado, 2005.

GUINDANI, M. A face punitiva do ECA. Serviço Social e Sociedade. Especial Criança e Adolescente. no 83, ano 16. São Paulo: Cortez, 2005.

KANT, I. Lógica. Rio de Janeiro: Tempo Brasileiro, 1992. 
KASSOUF, A.L., DORMAN, P. e ALMEIDA, A.N. de. Costs and benefits of eliminating child labour in Brazil. Econ. Apl., jul./set. 2005, vol.9, no.3, p.343-368.

LEAL, M.C. O estatuto da criança e do adolescente e a lei de diretrizes e bases da educação como marcos inovadores de políticas sociais. In SALES, M.A.; MATOS, M.C e LEAL, M.C. (org.) Política social, família e juventude: uma questão de direitos. São Paulo: Cortez, 2004.

MELLO, S.L. de. Estatuto da criança e do adolescente: é possível torná-lo uma realidade psicológica? Psicologia USP. Vol. 10, n. 2, 1999. pp. 139-151.

MENDONÇA, M.H.M. O desafio da política de atendimento à infância e à adolescência na construção de políticas públicas equitativas. Cadernos de Saúde Pública. Rio de Janeiro, n.18 (Suplemento), p.113-120, 2002.

MINISTÉRIO PÚBLICO DO ESTADO DO ESPÍRITO SANTO. Estatuto da criança e do adolescente e legislação congênere. Vitória: ARTGRAF, 2002.

MIRAGLIA, P. Aprendendo a lição: uma etnografia das varas especiais da infância e da juventude. Novos Estudos. n. 72, julho de 2005, p. 79-98.

PIAGET, J e GARCIA, R. Hacia una logica de significaciones. México: Gedisa Editorial, 1989.

RIZZINI, I. (coord.). Acolhendo crianças e adolescentes: experiências de promoção de direito à convivência familiar e comunitária no Brasil. São Paulo: Cortez; Brasília: UNICEF; CIESPI; Rio de Janeiro: PUCRIO, 2006.

- (Org.) A arte de governar crianças: a história das políticas sociais, da legislação e da assistência à infância no Brasil. Rio de Janeiro: Instituto Interamericano Del Niño, Editora Universitária Santa Úrsula/Amais Livraria e Editora, 1995.

ROSA, E.M. ; RIBEIRO JÚNIOR, H. e RANGEL, P. $O$ adolescente, a lei $e$ $o$ ato infracional. Vitória: EDUFES, 2007 (no prelo). 
- Radiografia de um processo social: um estudo sobre o discurso jurídico a respeito da violência contra crianças. São Paulo: Casa do Psicólogo, 2004.

SALES, M.A. Política e direitos das crianças e adolescentes: entre o litígio e a tentação do consenso. In SALES, M.A.; MATOS, M.C e LEAL, M.C. (org.) Política social, família e juventude: uma questão de direitos. São Paulo: Cortez, 2004.

SANTOS, B. de S. O discurso e o poder: ensaio sobre a sociologia da retórica jurídica. Porto Alegre, Sergio Fabris, 1988.

. Pela mão de Alice: o social e o político na pós-modernidade. 6.ed. São Paulo: Cortez, 1999.

. Para um novo senso comum: a ciência, o direito e a política na transição paradigmática. $5^{\mathrm{a}}$ ed. São Paulo: Cortez, 2005.

SILVA, M.L. de O. e. O estatuto da criança e do adolescente e o código de menores: descontinuidades e continuidades. Serviço Social $e$ Sociedade. Especial Criança e Adolescente. $n^{\circ}$ 83, ano 16. São Paulo: Cortez, 2005.

TOMAZELLI, A. Análise dos processos jurídicos referentes a adolescentes em autoria de ato infracional. Dissertação de Mestrado. Programa de Pós-Graduação em Política Social da Universidade Federal do Espírito Santo, Vitória, 2007.

VELLOSO, C.M. da S. Dos direitos sociais na Constituição do Brasil. Disponível em www.anamatra.org.br/hotsite/3congresso/docs/dos_direitos_sociais.pdf Acesso em: 12/07/2007.

VOLPI, M. Sem liberdade, sem direitos. São Paulo, Cortez, 2001. 


\title{
MÍDIA, PODER E SUBJETIVIDADE
}

\section{CAPÍTULO 17}

\section{INFÂNCIA NA MÍDIA BRASILEIRA E IDEOLOGIA}

\author{
Fúlvia Rosemberg * \\ Fundação Carlos Chagas \\ Marcelo P. de Andrade \\ Universidade Federal de São João del Rey
}

\begin{abstract}
s últimas décadas têm assistido a uma mobilização mundial e nacional 1 visando ao reconhecimento e cumprimento de direitos à infância e adolescência que lhes assegurem o pleno exercício da cidadania. A publicização de condições degradantes, materiais e morais, em que vivem muitas crianças e adolescentes de países ricos e pobres, tem suscitado a indignação e a busca de soluções entre aqueles(as) que defendem a construção de uma Terra onde os direitos humanos sejam extensivos a todos(as) seus habitantes ${ }^{1}$.
\end{abstract}

Apesar de estudos em perspectiva histórica evidenciarem que manifestações de violência adulta contra crianças não são prerrogativa das sociedades contemporâneas (MÉLLO, 2006), diferentes instituições sociais contemporâneas — governamentais, não governamentais, empresariais ou

\footnotetext{
* Fúlvia Rosemberg é professora titular de Psicologia Social da PUC-SP e pesquisadora da Fundação Carlos Chagas, onde coordena o Programa Internacional de Bolsas de PósGraduação da Fundação Ford (www.programabolsa.org.br). Marcelo Andrade é professor Adjunto I da Universidade Federal de São João del Rei. Ambos integram o NEGRI (Núcleo de Estudos de Gênero, Raça e Idade) do Programa de Estudos Pós-graduados em Psicologia Social da PUC-SP. Fúlvia Rosemberg agradece à FAPESP o apoio recebido para seu estágio pós-doutoral no CERLIS (Centre de recherche sur les liens sociaux), onde pôde aprofundar questões tratadas nesta comunicação.

${ }^{1}$ A partir desta frase, abandonaremos a fórmula o(a) e passaremos a adotar o genérico masculino.
} 
sem fins lucrativos, internacionais e intergovernamentais- têm se empenhado em denunciar a intensidade e a extensão de situações degradantes em que vivem crianças e adolescentes, geralmente associadas a manifestações de violência adulta, coletiva ou individual, concreta ou simbólica, direta ou indireta. Os problemas sociais então demarcados têm provocado investigações, estímulo à solidariedade nacional e internacional, bandeira para campanhas de mídia e meta de políticas sociais.

Porém, este esforço de sensibilizar a opinião pública quanto as condições sociais degradantes de crianças e adolescentes pobres, gerou a delimitação de problemas sociais publicizados por meio de uma retórica específica, que vem percorrendo o mundo, e que, no seu esforço de convencimento, muitas vezes, estigmatiza famílias, crianças e adolescentes pobres.

Assim, nas últimas décadas, vários "problemas sociais" associados à infância pobre entraram na agenda das políticas sociais brasileiras, rotulando e fragmentando a pobreza. Iniciamos, então, no NEGRI (Núcleo de Estudos de Gênero, Raça e Idade) do Programa de Estudos Pós-graduados em Psicologia Social da PUC-SP, uma linha de pesquisa que tem como objetivo problematizar a construção da agenda de políticas sociais para a infância brasileira contemporânea. Para tanto, um dos projetos focaliza mídia e infância, a partir do qual nos propomos a apreender o tratamento dado pela mídia escrita, especialmente pelo jornal Folha de S.Paulo - considerado o veículo impresso brasileiro que mais atenção dá ao tema infância (ANDI, 2002) - a temas que passaram a ocupar a posição de "problemas sociais" na agenda de políticas públicas brasileira das últimas décadas do século XX: "prostituição infanto-juvenil" (ANDRADE, 2001), "gravidez adolescente" (NAZARETH, 2004), "trabalho infantil" (FREITAS, 2004) e "meninos de rua” (ANDRADE, 2005). Nesta comunicação focalizaremos o tratamento dado ao tema "meninos de rua" em matérias publicadas pelo jornal impresso Folha de S.Paulo entre 1980 e 2001. Esta comunicação busca articular dois campos teóricos — construção de problemas sociais e ideologia — sobre os quais apresentamos, a seguir, uma síntese. 


\section{A construção de problemas sociais}

Adotamos a perspectiva interacionista na compreensão da definição de problemas sociais, seguindo caminhos abertos e percorridos por Joel Best (1987), Joseph Gusfield (1984), Bernard Lahire (2005), entre outros. Tais autores, analisam a construção de problemas sociais não como um espelho das condições objetivas, mas como eles são definidos e concebidos pela sociedade enquanto projeção de "sentimentos coletivos" (HILGARTNER e BOSK, 1988: 60). Este primeiro enfoque, que problematiza a própria construção de problemas sociais, apela por uma parada, pois tem sido pouco tratado na literatura brasileira, apesar de frequentar a literatura anglo-saxônica desde os anos 1970 (BLUMER, 1970; SPECTOR e KITSUSE, 1973) ${ }^{2}$.

Por que a questão das crianças e dos adolescentes em situação de rua passou a ocupar a arena de negociação das políticas sociais, tendo sido alçada à condição de problema social brasileiro, disputando atenção, recursos e ações públicas específicas? Uma resposta "objetivista" diria: porque é um problema grave, real, que atinge inúmeras crianças e adolescentes brasileiros. Portanto, a extensão real e a gravidade seriam suficientes para que fosse definido como problema social. Mas pode-se argumentar: por que o déficit de vagas em creche, por exemplo, que tem efeitos devastadores e que atinge um número expressivo de crianças não ocupa esta prioridade na agenda de políticas sociais? Isto é, extensão e gravidade como indicadores objetivos são insuficientes para delimitar e hierarquizar uma questão como problema social. É necessário que a questão incite a atenção pública a partir da mobilização de atores (ou arenas) sociais que abracem a causa da resolução deste problema social. Conforme a frase lapidar de Best (1955: 4), "Problemas sociais são o que as pessoas consideram ser problemas sociais”.

\footnotetext{
2 Uma síntese do papel da mídia na América Latina no processo de elaboração de políticas públicas pode ser encontrado no manuscrito de Sallie Hughes (2005). Ver também BID (2006).
} 
No campo da Sociologia e das Ciências Políticas, já se observara certa abertura a partir dos anos 1960/1970, quando passou-se a abordar os problemas sociais focalizando seu “ciclo vital” (OSZLAK e O'DONNELL, 1976), desde sua delimitação e incorporação na agenda, até sua resolução. Mas o que seria a "resolução" de um problema social? A eliminação do problema ou sua saída da agenda? Percebe-se que várias questões entram e saem da agenda de políticas sociais, sem que tenham sido resolvidos os sofrimentos ou as necessidades humanas. Que se pense, por exemplo, o lugar que ocupa a "mortalidade infantil” na histórica agenda de políticas sociais brasileiras. Neste sentido, o que passa a ter interesse é a própria definição e delimitação do problema social. Em outras palavras, passa a interessar ao pesquisador a transformação de uma questão em problema social. Por isto, no NEGRI, desenvolvemos esta linha de pesquisa que se interroga sobre a entrada, na agenda das políticas para a infância, de temas associados à pobreza. Portanto, do "ciclo vital" de um problema social, focalizamos uma etapa — sua definição e delimitação— e uma das arenas em que ocorre sua construção: a mídia. Nossa questão não é como a sociedade constrói crianças e adolescentes em situação de rua, mas como a sociedade constrói ou fabrica a categoria "meninos de rua" e a incorpora como tema de relevo na agenda das políticas para a infância. Portanto, não estamos procurando causas e consequências do fenômeno crianças e adolescentes em situação de rua, mas procuramos desconstruir o que parece uma evidência: a construção da categoria "criança de rua" e sua assunção como problema social. Como se configura esta etiqueta, este rótulo, esta categoria? Como a mídia participa de sua construção?

Hilgartner e Bosk (1988) oferecem um ponto de partida promissor para se apreender o "processo coletivo de definição" e delimitação de um problema social: a competição entre diferentes questões sociais que podem se converter em problema social, para se transformarem em "tópico dominante do discurso social e político" (p. 16). Isto é, da infinidade de questões sociais que podem incitar a atenção social algumas se transformam 
em "celebridade", outras mobilizam apenas setores sociais restritos e outras, ainda, são ignoradas. Processa-se a uma hierarquização das questões.

Isto nos leva a vislumbrar um "mercado de problemas sociais" nas sociedades ocidentais contemporâneas, no qual apreendem-se múltiplas competições: qual a questão que deve incitar a atenção: mortalidade infantil ou "engruvinhamento" da pista do aeroporto de Congonhas? Qual a versão legítima da "realidade" na definição do problema social: "menino de rua" significa abandono? Quais os arautos que participam da construção e sustentação do problema social na agenda de políticas sociais? A construção de problemas sociais não significa apenas sua delimitação e reconhecimento como tal. Os "construtores" de problemas sociais (em inglês a expressão consagrada é claims makers) —governo, ONGs, sindicatos, movimentos sociais, grupos de pressão, organizações multilaterais e internacionais, partidos políticos, fundações, mídia etc.também os formatam conforme "sua própria definição social e do contexto social no qual os situam. Enfim, definir o 'problema' de um modo ou de outro tem consequências sobre a maneira pela qual se pretende remediá-lo e solucioná-lo" (LAHIRE, 2005: 35). Por exemplo, enquadrar a mortalidade infantil como sendo decorrente de inadequação de práticas maternas ou como decorrente de inadequação de saneamento básico tem implicações muito diversas não só, mas também, para as políticas sociais.

A nosso ver, o mercado dos problemas sociais é mais do que uma metáfora, pois a definição de um problema pode dinamizar os mercados de trabalho e de consumo, via produção de mercadorias, de serviços e de bens simbólicos: o reconhecimento de uma questão como problema social depende de sua publicização que, por sua vez, demanda a ação de "operadores", ativistas ou profissionais, que lançam mão de diferentes recursos e estratégias e jogam no mercado diferentes produtos e serviços ${ }^{3}$.

\footnotetext{
${ }^{3}$ São “operadores”, e não apenas ativistas, porque os objetivos que perseguem são variados, desde a mobilização por mudança ou estagnação social, passando pela disputa eleitoral, até
} 
Uma das arenas de competição para definição dos problemas sociais, nas sociedades modernas, são as mídias: "cobertura da mídia, especialmente uma cobertura simpática, pode fazer com que milhões de pessoas tomem conhecimento de um problema social. Ativistas necessitam da mídia para prover tal cobertura, do mesmo modo que a mídia depende de ativistas e outras fontes para publicar notícias” (BEST, 2001: 15). Aqui, a competição para ocupar uma posição privilegiada na hierarquia dos problemas sociais é alta, pois a disponibilidade de espaço (na mídia impressa) e tempo (na mídia audiovisual) é restrita e determinada, entre outras, por razões mercadológicas, políticas, posições institucionais, rotinas, competências e repertórios discursivos (HILGARTNER e BOSK, 1988).

Estudiosos do tema têm evidenciado uma retórica prevalente na construção de certos problemas sociais e que se fazem onipresentes nas múltiplas arenas ${ }^{4}$. Lahire (2005), ao fazer uma análise transversal dos discursos sobre a "invenção do iletrismo" na França contemporânea, menciona um "fundo discursivo comum" construído por lugares comuns "que podem ser reencontrados na boca ou na escrita de um ministro socialista, de um deputado $\mathrm{UDF}^{5}$, de um universitário linguista ou psicólogo, de um educador, jornalista, responsável por uma associação, homem de igreja, etc.” (p. 18-19)6.

Para capturar a atenção pública, as arenas em que se constroem os problemas sociais desenvolvem uma retórica específica que associa a credibilidade de fatos a uma dimensão dramática, e que vem sendo

\footnotetext{
“ganhar dinheiro”: “para alguns, os problemas sociais nada mais são que um dia a mais de trabalho” (HILGARTNER e BOSK, 1988: 18).

${ }^{4}$ Best (1995) é um dos pesquisadores que mais atenção vem dando à retórica na construção de problemas sociais, merecendo destaque tanto a coletânea que organizou (Images of issues: typifying contemporary social problems, 1995), quanto seus estudos sobre o desaparecimento de crianças nos EUA (Rhetoric in claims making: constructing the missing children problem, 1987).

${ }^{5}$ UDF é a sigla do partido União para a Democracia Francesa.

${ }^{6} \mathrm{O}$ mesmo fundo comum foi observado quanto aos discursos sobre "meninos de rua”, como uma de nós havia percebido a partir da análise transversal de discursos brasileiros dos anos 1980 e 1990 (ROSEMBERG, 1995).
} 
desconstruída por diferentes autores em diferentes contextos (ANDRADE, 2001; BEST, 1998; GUSFIELD, 1981; LAHIRE, 2005; ROSEMBERG, 1995, entre outros)”.O drama é a fonte de energia que dá vida ao problema social e sustenta seu desenvolvimento. Ao criar [narrativa] dramática, o operador que apresenta problemas sociais usa alguns dos tropos do teatro clássico" (HILGARTNER e BOSK, 1988: 60).

Um dos componentes centrais da retórica é, pois, a dramatização do problema focalizado. A dramatização do problema social é necessária para chamar a atenção e revesti-lo da urgência da mobilização e indignação social na competição com outros problemas. São vários os recursos retóricos para operar esta dramatização: um deles é a associação com crianças. Os dramas sociais constituem uma das vias régias da visibilidade de crianças no espaço público. Aqui se opera uma simbiose com os hábitos discursivos da grande imprensa: conforme a literatura vem mostrando (ARFUCH, 1997; PONTE, 2005), infância é notícia quando associada à violência, enquanto vítima ou algoz.

A desconstrução desses tropos, dessa retórica, especialmente do processo de rotulação de pessoas e grupos sociais, tem levado alguns(as) pesquisadores(as) a questionar o qualificativo de "subjetivista" atribuído a esta forma de lidar com os problemas sociais. O termo "subjetivista” “(...) situa a 'realidade' e o 'discurso', entre o 'real' e as 'representações', quando, de fato, estamos lidando com uma realidade perfeitamente objetivável, aquela da construção social do problema, que não se confunde com a realidade social do problema social evocado pelo discurso" (LAHIRE, 2005: 35).

Neste sentido, esta dramatização não é inoperante do ponto de vista de impactos sociais nos segmentos sociais dramaticamente rotulados (ROSEMBERG, 1993; ANDRADE, 2004; LAHIRE, 2005). Constata-se, em alguns casos, uma produção discursiva estigmatizadora contra esses mesmos grupos sociais a favor dos quais a demarcação do problema social se propõe defender. É o que temos denominado de armadilhas desse tipo de retórica (ROSEMBERG e ANDRADE, 1999; ANDRADE, 2004; LAHIRE, 2005). 
Daí o interesse acadêmico de se desconstruírem categorias nativas ou rótulos que passam a demarcar segmentos sociais, de se "dessevidenciar” discursos não problematizados, conforme Lahire (2005: 23). "Que podemos fazer se não explicitar o implícito, avançar consequências lógicas e sociais não pensadas dos discursos, tentarem avançar efeitos inesperados possíveis?”

Em nossos estudos vamos além, pois apreendemos efeitos inesperados da prática de produção discursiva jornalística sobre os sujeitos crianças e adolescentes usados como fonte para as matérias. Com efeito, conforme mostraram L. Andrade (2004), M. P. Andrade (2005), Freitas (2004) e Nazareth (2004), frequentemente peças jornalísticas referentes a problemas sociais associados à infância pobre brasileira desvelam a identidade civil de crianças e adolescentes, como discutiremos adiante.

É neste contexto de reflexões que foram construídos os argumentos que orientam este estudo: a mídia, nas sociedades contemporâneas, assume posição de destaque na construção de problemas sociais; o tratamento dado pela mídia a crianças e adolescentes pobres estando, ou não, em situação de rua estigmatiza a pobreza, configurando-se, então, como uma produção ideológica.

\section{Conceito e teoria de ideologia}

A sequência dos argumentos enunciados aponta para o segundo campo teórico que nos tem alimentado: os estudos sobre ideologia propostos por John B. Thompson (1995). Como Thompson, entendemos ideologia como a produção, circulação e recepção de formas simbólicas que sustentam e reproduzem relações de dominação, entendendo relações dominação como relações de poder sistematicamente assimétricas.

Um dos aportes do NEGRI, para a análise de discursos midiáticos no contexto de sua interpretação ideológica, tem sido a inclusão do estigma como uma das estratégias de produção ideológica (ANDRADE, 2004). Com efeito, recorrendo ao conceito de estigma proposto por Goffman (1982) “a desapropriação de indivíduo(s) ou grupo(s) do exercício pleno de sua humanidade pela valorização de uma deficiência ou corrupção de alguma 
condição física, moral ou social”-, Andrade (2004) postula a estigmatização como uma das estratégias do modo de operação da fragmentação, diferenciando-a de outras estratégias e modos de operação na produção ideológica em decorrência de sua configuração retórica” (...) A estigmatização pode ser construída para um indivíduo ou grupo e utilizada na permanência das relações de dominação através de formas simbólicas que classificam indivíduos ou grupos estigmatizados como desprovidos de autonomia, discernimento, autodeterminação, sugerindo, muitas vezes, com pesar e desculpas, uma subumanidade a ser guiada, corrigida ou salva” (ANDRADE, 2004: 99).

Esta busca de integração do conceito de estigma à proposta teórica de Thompson e o estudo da mídia na construção de problemas sociais têm nos ajudado a enfrentar um dos óbices no uso dessa teoria de ideologia para apoiar projetos de pesquisa realizados em contexto acadêmico. Como se sabe, projetos individuais de pesquisa em contexto acadêmico são de curta duração: 30 ou 40 meses, tempo insuficiente para se dar conta da análise das condições de produção, circulação e recepção das formas simbólicas sob investigação. Na maior parte das vezes, os projetos se centram na análise da produção, estabelecendo apenas inferências sobre circulação e recepção. Ora, o estatuto heurístico do conceito de estigma a partir de Goffman, o situa entre a produção (a construção do estigma) e a recepção (pessoa/grupo estigmatizados), o que confere maior segurança às inferências sugeridas quanto à recepção.

Além disso, quando focalizamos a mídia como uma das arenas de construção de problemas sociais, ampliamos a compreensão de quem sejam os receptores das formas simbólicas sob análise. Uma visão, talvez ingênua, tem sido a de confundir os receptores com as pessoas comuns leitoras de jornal, ou de modo mais restritivo ainda, confundi-los com aquelas pessoas concernidas pelo problema social sob análise (no caso desta comunicação, crianças e adolescentes em situação de rua). Ora, no caso da mídia no contexto da construção de problemas sociais, os receptores são os “fazedores de opinião” (os claims makers), as pessoas que ocupam posições institucionais capazes de ser ouvidas, influenciar na elaboração de 
orçamento, negociar com legisladores, pautar uma questão, quem sabe, no Jornal Nacional ou na Folha de S.Paulo.

\section{“Meninos de rua” na Folha de S.Paulo}

A partir desses enquadres teóricos, apresentaremos, a seguir, uma síntese da pesquisa de Marcelo P. de Andrade (2005) sobre os discursos sobre a categoria "meninos de rua” apreendidos na análise de 449 unidades de informação (UI) extraídas do jornal Folha de S.Paulo (versão impressa) no período de 1980 a $2001^{7}$.

A categoria "meninos de rua” foi entrando no jornal nos anos 1980, para se instalar a partir da passagem de 1989 para 1990 (o primeiro pico no gráfico 1). O jornalista Gilberto Dimenstein, em 1990, teve sua investigação jornalística sobre assassinatos de criança no Brasil publicada com destaque em uma longa matéria intitulada "Marcados para morrer" (UI 104, 18/03/1990), que resultou no livro Guerra dos meninos, resenhado pelo jurista Hélio Bicudo e publicado na Folha (UI 106, 07/04/1990). O jornal foi dando mais destaque à questão o que se observa por vários indicadores: escreveram sobre "meninos de rua” colunistas fixos renomados; o tema foi tratado em sete editoriais, em artigos na sessão Opinião, em pesquisa realizada pelo DataFolha, em matérias na Folhateen e Folhinha; o tema mereceu resenhas de livros e informações sobre teses. Em média, a Folha publicou 20 matérias por ano sobre a questão.

As matérias foram predominantemente do tipo reportagem, produzidas pela redação ou equipe de reportagem, por profissionais tendo como vínculo institucional o próprio jornal. Ou seja, as matérias, mesmo quando não ocuparam a sessão de editorial, refletem, predominantemente, a posição do jornal sobre o tema. Nas matérias analisadas, foram identificados 117 autorias individuais, entre as quais se destacam jornalistas da Folha de S.Paulo (André Lozano, Gilberto Dimenstein e a parceria Lalo

\footnotetext{
${ }^{7}$ Reportar-se a Marcelo P. de Andrade (2005) para uma descrição completa dos procedimentos de análise.
} 
de Almeida e Rogério Wassermann). Isto sugere que as tendências prevalentes identificadas nesta pesquisa não resultam de idiossincrasias pessoais, pois foram compartilhadas por diferentes autores.

Várias personalidades estiveram associadas ao tema "meninos de rua" nas páginas do jornal, acarretando o que Thompson denomina de "valorização cruzada": o tema valoriza a personalidade pública que, por sua vez, ganha visibilidade por se associar ao tema. Dom Helder Câmara, Dom Luciano Mendes de Almeida, Fernando Collor de Mello, Fernando Henrique Cardoso, Luiz Inácio Lula da Silva, Mario Covas, Leonel Brizolla, Augusto Boal, Paulo Freire, Sérgio Adorno, Pelé, Lady Diana e Hilary Clinton foram alguns dos representantes do establishment nacional e internacional que tiveram seus nomes associados a matérias sobre "meninos de rua” na Folha de S.Paulo.

Notamos, então, uma simbiose entre o tema "meninos de rua" e personalidades. A associação de celebridades com a questão de crianças e adolescentes em situação de rua vira notícia, abre-lhes o jornal; a associação do tema "meninos de rua" com celebridades abre o jornal ao tema "meninos de rua": Primeira dama dos EUA visitará escola de menor de rua de Brasília (04/10/1995). Situações de contraste, de inusitado são também notificadas pelo jornal: meninos de rua do Rio conhecem Monet (UI 462, 22/03/1997). Encontrar "meninos de rua", quando programa constando da agenda de diversas personalidades, vira objeto de notícia: um grupo de nove alemães da cidade de Grabenstatt (foto) esteve ontem na Praça da Sé para saber como vivem os meninos de rua (UI 255, 28/07/1993). Como o fluxo de personalidades é constante, noticiar tais visitas mantém o tema na pauta; como crianças e adolescentes em situação de rua estão disponíveis, pauta-se a visita.

Crianças e adolescentes em situação de rua por si sós não dão destaque às matérias: não são autores de UI, não constituem a principal fonte nas peças jornalísticas. Constituem o objeto da UI, especialmente quando associados à violência. Assim, a violência é a via real de acesso do tema no jornal. Uma síntese dos títulos que associam violência a "meninos 
de rua" (38,9\%) permite apreender o quadro: "crianças", "meninos", "menores", "em bando", ou não: a) furtam, roubam caminhão, assaltam no semáforo, fazem arrastão, roubam para comer, precisam de coragem para roubar, organizam quadrilha, põem fogo em mendigo, assustam moradores, compõem um exército, transformam a Sé em campo de batalha, brigam na praça da Sé; b) usam crack logo pela manhã, cola de sapateiro, traficam droga, são microtraficantes caçados pela polícia; c) discutem violência, organizam dossiê sobre esquadrão da morte, sofrem violência policial, são chutados, agredidos, molestados, mortos por tiro, levam tiro na cabeça, no rosto, são achados feridos, esfaqueados, assassinados, enterrados em cemitério clandestino, são exterminados, massacrados, perseguidos por blitz, morrem de AIDS, sofrem violência doméstica, pagam para não serem molestados; d) têm medo, são mais violentos, são infratores, presos; a violência está fora de controle, são mais violentos.

Como outros jornais contemporâneos que não mais abrigam uma sessão policial, a Folha de S.Paulo semeia manchetes (ou títulos) que sugerem um tratamento de tipo "notícia policial" no caderno cotidiano, conferindo ao tema "meninos de rua" um estilo sensacionalista, associado à violência. A metáfora da guerra é evocada em várias peças jornalísticas: exército paralelo (UI 104, 18/03/1990); limpeza étnica, o brutal mecanismo que os sérvios aplicam na Bósnia, capacetes azuis (UI 3432, 01/08/1995); campo de batalha entre soldados da PM e meninos de rua (UI 132, 11/05/1991), marco zero da praça de São Paulo vira a praça da guerra dos meninos (UI 153, 10/08/1991).

A literatura sobre a construção de problemas sociais aponta a rotulação ou categorização como um dos eixos fundamentais para apreender-se a retórica. Assinala-se a frouxidão conceitual, o uso de categorias "saco de gatos" (catch-all) sob um rótulo comum (BEST, 1998; LAHIRE, 2005; ANDRADE, 2004). Foi a análise da delimitação, conceituação, nomeação e explicação do problema social "meninos de rua" que nos permitiu apreender uma das vias de produção do estigma. 


\section{Um rótulo que estigmatiza}

No conjunto de manchetes e títulos das 442 UI que compõem o corpus, foram encontradas 27 expressões e termos para se referir a crianças e adolescentes em situação de rua, sendo as mais frequentes as variações em torno da expressão "meninos de rua": menores de rua, crianças de rua, adolescentes de rua, crianças que vivem nas ruas, ex-garoto de rua, exmenino de rua, garoto da Praça, meninos da Sé, garotos da Candelária. Porém, tais expressões cobrem uma conceituação flexível que incorpora "pivete", "trombadinha", interno e ex-interno da FEBEM, indigente, crianças e adolescentes pobres, que trabalham (nas ruas ou não), que frequentam ou não, a escola, que vivem, ou não, com suas famílias, também em suas casas.

A conceituação "meninos de rua" adotada pelo jornal transparece, também, no uso que faz das estimativas que circularam no período. Assim, várias UI do corpus fazem referência a estimativas sobre o número de "meninos de rua": 54 UI (12,8\%) citam tais estimativas, dentre as quais $39,2 \%$ usam como fonte as pesquisas realizadas no Brasil (censos e contagens) e as demais (60,8\%) ou utilizam fontes indiretas ou não mencionam fontes: estimativas, via de regra, sem explicitação de procedimentos, número redondos bombásticos (ANDRADE, 2004), de fácil memorização e que circulam desde 1979 (ROSEMBERG, 1993). Assim, o jornal passou a ser fonte de estimativas sem fontes. Uma das principais fontes referenciadas é o UNICEF, importante circulador de estimativas sobre "meninos de rua", "prostituição infanto-juvenil", "trabalho infantil" nas últimas décadas (ROSEMBERG, 1993).

O uso de estatísticas no mercado de problemas sociais é recorrente: "pessoas debatendo problemas sociais escolhem estatísticas seletivamente e apresentam-nas para apoiar seus pontos de vista (...) lembrar que a mídia gosta de citar estatísticas porque números parecem ser factuais, fatias de verdade (BEST, 2001: 18-19). Constituem "efeitos do real", como o depoimento coletado ao vivo. Grandes número operacionalizam (e 
sustentam) o drama, "advertem-nos que o problema é comum, incitam nossa atenção, envolvimento e ação” (BEST, 2001: 17).

Vejamos como a Folha de S.Paulo trata as estatísticas sobre "meninos de rua".

Existiram no Brasil: 36 milhões de carentes (UI 64, 27/09/1985 e 82, 04/03/1987) ou abandonados (UI 88, 07/07/1988); 30 milhões de crianças carentes, carentes marginalizados, abandonados; 25 a 30 milhões de menores carentes (UI 25, 14/10/1982); 28 milhões de menores carentes (UI 30, 08/07/1983); 25 milhões de abandonados (UI 88, 07/07/1988); 20 milhões de meninos e meninas de rua (UI 361, 06/10/1995); 20 milhões em estado de miséria e abandono (UI 553, 28/10/1999); 15 milhões de crianças e adolescentes indigentes (UI 350, 11/09/1995); 6 milhões de abandonados (UI 82, 04/03/1987); milhões de crianças marginalizadas (UI 38, 25/08/1984); milhões de menores abandonados (UI 81, 11/10/1986); milhões e milhões de jovens carentes e abandonados (UI 82, 04/03/1987); 1,2 milhão de crianças de rua (UI 172, 07/11/1991); poucos milhões de meninos e meninas de rua (UI 510, 02/08/1998); 800 mil meninos de rua (UI 114, 25/10;1990); 200 mil crianças de rua (UI 588, 24/12/ 2000); milhares de crianças jogadas na rua (UI 510, 02/08/1998). A expressão “dança dos números”, que vem sendo usada por Rosemberg (1993) e Andrade (2001), ajusta-se à perfeição ao corpus aqui analisado.

Estimativas tão diversas, que podem conviver em uma única UI (por exemplo a UI 82), sustentam a frouxidão conceitual que embasa as peças jornalísticas: "meninos de rua” com aspas ou sem aspas, em sentido estreito ou lato podem tanto se referir a crianças, adolescentes e homens adultos moradores de rua que frequentam a praça da Sé ou a Candelária, a crianças e adolescentes trabalhadores (na rua, no campo ou em empresas), a crianças e adolescentes que frequentam ou não escolas e à "ponta do iceberg” de

\footnotetext{
8 Joel Best (2001; 2003) tem se dedicado a debater o uso das estatísticas na construção de problemas sociais, questão que provocou um cisma entre "construcionais radicais" e "críticos” (ou contextuais). Concordando que toda e qualquer estatística é criada, que constitui uma simplificação da realidade social, que envolve escolhas, Best (2001: 161) pondera, porém, que podem-se criar boas e más estatísticas, e incita-nos não a seu abandono, mas a uma postura crítica frente a elas.
} 
crianças e adolescentes pobres ou indigentes, teoria adotada pelo jornal para explicar o fenômeno "meninos de rua".

A análise dos editoriais publicados sobre o tema permitiu que apreendêssemos, de modo mais preciso, a teoria do jornal sobre a produção de "meninos de rua". Sinteticamente, associam uma explicação estruturalfuncionalista ("'meninos de rua' são produto da pobreza brasileira que leva as famílias a abandonarem seus filhos") à metáfora do iceberg: "meninos de rua" são a ponta do iceberg da pobreza brasileira. Ou seja, apreendemos a retórica do tropo, do emblema, da tipificação enunciada por outros pesquisadores: a complexidade da desigualdade social brasileira é tipificada na personagem "menino de rua", cujo núcleo central parte do abandono e violência, mas que se expande para as crianças pobres do Brasil. Vejamos alguns exemplos.

O editorial Os meninos da Sé (UI 60, 08/04/1985) se refere a 50 crianças que moram nesse local, onde pedem esmolas, fogem de policiais, cheiram cola de sapateiro (...) e dão seus primeiros passos na criminalidade. Porém, continua o texto, "Muitos mais existem em São Paulo". O editorial salta para as estimativas sobre carentes no Brasil (32 milhões), dos quais $47,7 \%$ estariam fora da escola e, mencionando o UNICEF como fonte, informa que entre 10 e 20 milhões é o número de crianças e adolescentes desassistidos no Brasil, dos quais $700 \mathrm{mil}$ residiriam na cidade de São Paulo.

O editorial De boné no Planalto (UI 366, 09/10/1995) retoma notícia da semana anterior, quando o presidente FHC havia recebido representantes do Movimento Nacional de Meninos e Meninas de Rua (MNMMR) e vestido seu boné. $\mathrm{O}$ texto menciona reivindicações e promessas, denuncia o ato como bom marketing político e prossegue: Desmontados os palcos (...) 7 milhões de crianças e adolescentes brasileiros voltarão ao trabalho para ajudar na renda familiar. Novamente, o processo de redução ocorre: $a$ maioria [dos trabalhadores infantis] estará abandonando a escola antes da quinta série. Os noticiários registrarão diariamente os novos episódios em que se meteram: prostituição, tráfico de drogas, trabalho escravo, 
pequenos delitos e grandes crimes, na roda-vida do cotidiano desafortunado (Grifos nossos).

O estigma da rua (UI 471, 30/05/1997) foi um editorial que iniciou uma série de três em que o tema do estigma parece central, partindo da discussão da expressão "menino de rua", desta feita usada entre aspas pelo jornal. Informa que a expressão veio substituir o termo menor, mas (...) parte do sentido de que ambos remetem à imagem de crianças a um universo de marginalidade. E termina, mais uma vez, afirmando que $A$ pesquisa do SOS criança [que mostrou que "meninos de rua" têm família, dormem em casa e estudam] indica que os meninos de rua, sem aspas, e seu comportamento são na verdade um traço indicador da miséria que afeta milhares de outras crianças (...). Ou seja, no enfrentamento da complexidade reflexiva apontada pela pesquisa do SOS, o editorial volta à teoria do iceberg: os "meninos de rua" constituiriam apenas a ponta do iceberg da pobreza brasileira.

Uma síntese dos três últimos editoriais é retomada em As crianças de rua e FHC (UI 510, 02/08/1998), que usa como gancho a distinção do então presidente FHC entre "menino de rua e menino na rua". A mesma argumentação e conclusão: os "meninos de rua" (...) são uma amostra escandalosa de como vivem 20 milhões de crianças brasileiras.

Talvez seja a UI (11/09/1995) que melhor sintetize a concepção do jornal sobre "meninos de rua" inserida em contexto de uma teoria (nativa) do iceberg, que se associa ao paradigma estrutural-funcionalista de reprodução da pobreza e abandono familiar. A manchete Brasil tem $32 \mathrm{mil}$ indigentes (UI 350) anuncia a pesquisa do IPEA (Instituto de Pesquisa Econômica Aplicada) referente ao mapa da fome. O texto informa que são 32 milhões de brasileiros indigentes, o que corresponde a 9 milhões de famílias (...) cuja renda mensal garante, na melhor das hipóteses, apenas a aquisição de uma cesta básica de alimentos (...) Praticamente a metade do total de indigentes brasileiros é formado por crianças e adolescentes, segundo outro estudo (...) o Brasil tem 15 milhões de crianças $e$ 
adolescentes indigentes (...) Os dados do estudo do IPEA mostram que os índices de indigência diminuem conforme aumenta a idade das crianças. É o caso de $X, 15$, que desde os 11 anos morava na rua e podia ser incluída nas estatísticas de indigente (...) (UI 350, 11/09/1995, grifos nossos).

Em síntese, a análise do corpus sugere que o jornal Folha de S.Paulo participou da construção de uma categoria nativa "meninos de rua", com o apoio de jornalistas, acadêmicos, religiosos, especialistas, ativistas, funcionários de organizações multilaterais, celebridades, políticos e polícia, cujo núcleo central é constituído por crianças e adolescentes tipificados enquanto associados à violência, ao delito, ao abandono, mas que alcança uma multidão de crianças e adolescentes não apenas em situação de rua, mas para além delas: as crianças e os adolescentes pobres do Brasil.

\section{Personagens e depoentes}

Para aprofundar a análise (descrição e interpretação), passaremos a focalizar o tratamento dados aos personagens/depoentes encontrados nas UI da amostra. A análise da configuração da categoria "meninos de rua" permitiu-nos apreender quatro tipos de personagens: os genéricos ou coletivos (meninos de rua do Brasil, os meninos da Candelária), os individuais ( $A C$ vive na Praça da Sé) que podem ser depoentes quando têm sua identidade civil desvelada; "ex-meninos de rua”, algumas vezes adultos bem sucedidos.

Para todos os tipos de personagens/depoentes, a construção textual é frouxa, acarretando uma composição fluída: não se dispõe de informações sobre sua cor-raça, escolaridade, procedência, vínculos familiares e institucionais. Portanto, via construção desses personagens/ depoentes, a categoria "meninos de rua" constitui uma abstração que apresenta, porém, três atributos enfatizados: o que fazem, onde estão e com querem interagem. Predominantemente são descritos como envolvidos em atos ilícitos, mesmo nos casos em que depoentes têm sua identidade civil 
desvelada; são predominantemente descritos "perambulando" nas ruas, em interação com seus pares, polícia e funcionários.

A família de crianças e adolescentes em situação de rua, sejam eles depoentes ou não, é raramente consultada, ouvida, mencionada. Isto acarreta a associação do personagem/depoente "menino de rua" à ideia de abandono. Mesmo que os sentidos do termo abandono tenham se expandido a partir da década 1970 (GREGORI, 2000: p. 64-65) —-"a ideia do abandono moral foi substituída pela noção do abandono provocado pela situação estrutural de marginalidade, pelo fosso criado por uma condição de permanente desigualdade social"-, mesmo que o editorial da Folha (UI 471, 30;05;1997) afirme que "meninos de rua" convivem com famílias, a construção do personagem/depoente pelo jornal, ao eliminar a família de seu horizonte, cria o abandono familiar do "menino de rua". A exceção aberta pela Folha de S.Paulo é quando notícia uma fatalidade9 .

Analisaremos, a seguir, o tratamento dado aos depoentes, crianças e adolescentes tratados pelo jornal como "meninos de rua" e que tiveram sua identidade civil desvelada. Dentre os 86 personagens/depoentes, 43 (50,0\%) tiveram sua identidade civil desvelada, dentre os quais $19(44,2 \%)$ tiveram seu nome completo revelado, sendo que a identificação dos demais ocorre por meio de prenome, sobrenome ou abreviatura associados a outros indicadores (localização, instituição, fotos, entre outros) que permitiriam identificá-los. Dentre os depoentes, 29 foram descritos em alguma atividade, sendo que dentre esses, sete foram descritos em atividade ilícita (uso de drogas,prostituição). Exemplo: D11 [nome e sobrenome completos fornecidos pelo jornal] tem apenas 13 anos e, há dois anos, é menina de rua em Manaus. Como as demais crianças em sua situação, tem medo de represálias. Ela já foi obrigada a servir a policiais. Amedrontada, não dá nomes, nem dia, e até nega que isso tenha acontecido. D11 só tinha a mãe

\footnotetext{
${ }^{9}$ Njaine e Minayoi (2002) também identificaram nos jornais fluminenses a ausência da voz dos pais de adolescentes internados em instituições correcionais, é como se eles não tivessem raízes. O silêncio dos pais somente é quebrado quando ocorrem casos de tragédias gravíssimas e fatais, momento em que as famílias são ouvidas.
} 
que, há três, morreu de câncer. Mora na rua com sua irmã (...) (UI 199, 06/03/1992).

Apesar de terem sua identidade revelada, indicando tratamento desrespeitoso à lei, sua voz raramente é expressa nas UI. Assim, os depoentes, ao entrarem nas páginas da Folha, raramente são tratados como atores sociais, pois o jornal quase nunca publica sua opinião sobre os pontos que os afetam. Eles são apenas a prova viva, a personificação do "menino de rua”, o efeito de verdade. A maioria deles (72,1\%) não é consultada para explicar porque estão na rua, quais as consequências desse fato $(100,0 \%)$ e qual seu prognóstico de vida (93,0\%). Na grande maioria das UI que transcrevem alguma fala, têm direito à palavra coadjuvantes adultos (funcionários do governo ou de ONGs, acadêmicos/especialistas, religiosos ou jornalistas): nós adultos do establishment sobre eles "meninos de rua”.

\section{À guisa de conclusão}

a) A categoria "meninos de rua" reproduzida, produzida e veiculada pelo jornal que apreendemos se organiza em torno de um núcleo impregnado pelo delito e pela violência, mas que se expande para outros grupos de crianças e adolescentes pobres, mesmo para aqueles que não estejam em situação de rua.

b) Para o jornal, "meninos de rua" são produzidos pela situação de desigualdade, econômica e social do país que, por sua vez, gera famílias que abandonam seus filhos, processos que, associados, determinam o desvio de "meninos de rua" e a inexorabilidade de seu destino como marginais, que produzirão novos "meninos de rua". Assim, propomos uma radicalização na definição da categoria: segundo nossa proposta interpretativa, a categoria mais se aproximaria da denominação "filhos da rua”, onde a palavra menino parece assumir a conotação de filho ${ }^{10}$.

\footnotetext{
${ }^{10}$ Esta interpretação vem sendo aprofundada por Rosemberg (2007) na análise transversal de vários gêneros discursivos em português, francês e inglês sobre a categoria "meninos de rua”. Rosemberg (2007) vem buscando apreender diferenciações nos sentidos associados ao
} 
c) O jornal abre as páginas para que diversas pessoas do establishment (inclusive trabalhando para o próprio jornal) explorem o tema ganhando "noticialidade”. Vozes de crianças e adolescentes em situação de rua, bem como as de seus familiares, raramente são publicadas. Entretanto, inúmeras vezes, o jornal desvela a identidade civil de crianças e adolescentes depoentes, em desrespeito aos direitos socialmente construídos dessas pessoas.

Apreendemos, então, dois processos de estigmatização complementares no tratamento que a Folha de S.Paulo dá à categoria "meninos de rua": o primeiro corresponde à generalização do atributo "desvio de caráter" a todas as categorias sociais que o jornal associa à expressão "meninos de rua”, transformando-as em desacreditáveis; o segundo corresponde ao tratamento sub-humano que o jornal confere a crianças e adolescentes, considerados, ou não, como estando em situação de rua ou não, que fotografa e identifica pois, ao desvelar sua identidade, confere-lhes a condição de estarem aquém de ter seus direitos respeitados. Neste caso, o jornal, a empresa e seus colaboradores transfiguram os desacreditáveis em desacreditados. O próprio jornal revela a impunidade do procedimento, não só porque o pratica, mas porque o pratica publicamente e o divulga em suas páginas. Trata-se, a nosso ver, de caso exemplar de legitimização de relação de dominação. Uma ação ilegal e injusta, publicamente praticada, além de não ser criticada ou punida, é revestida, enquanto forma simbólica (a peça jornalística), da auréola benfeitora. Isto nos levou a alterar a denominação “crianças e adolescentes vulneráveis” para crianças e adolescentes vulneráveis à estigmatização e propor um código de ética que tratem-nos enquanto atores sociais na produção e circulação de matérias a seu respeito (ROSEMBERG e ANDRADE, 2004).

termo criança conforme o idioma disponha de palavras específicas para a condição de puer e filius (como dispomos em português, criança e filho) ou não disponha (como em inglês children e em francês enfant). 


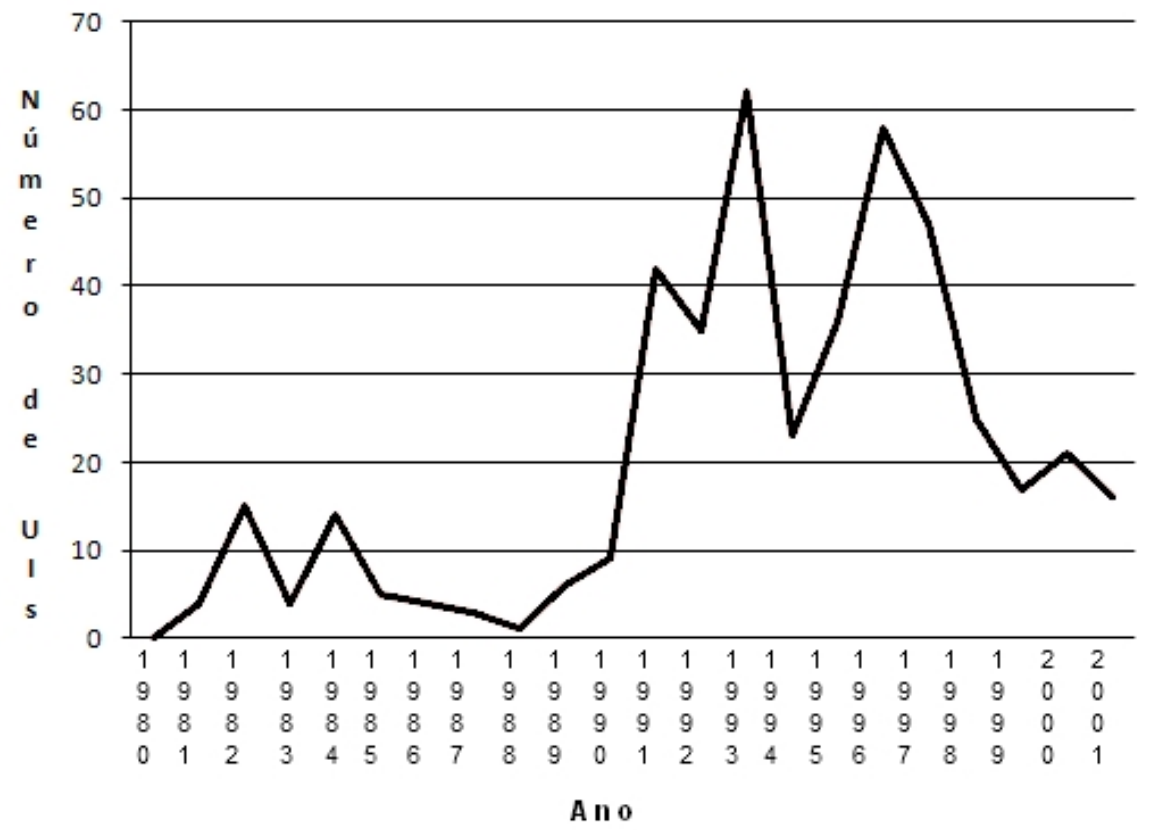

Fonte: Andrade (2005).

Referências

ANDI; IAS. Infância na mídia: síntese de resultados do segundo semestre de 1997. Pesquisa ANDI. Disponível em:

www.andi.org.br/pesqinf/pesqinf1.html. Acesso em: 09 dez. 2002.

ANDRADE, Leandro Feitosa. Prostituição infanto-juvenil na mídia: estigmatização e ideologia. São Paulo: EDUC; FAPESP, 2004.

ANDRADE, Marcelo P. de. A Categoria “meninos de rua” na mídia: uma interpretação ideológica. São Paulo: Tese de Doutorado (Psicologia Social). Pontifícia Universidade Católica de São Paulo, 2005.

ARFUCH, Leonor. Crimines y pecados: de los jóvenes en la crónica policial. Cuadernos del Unicef, Buenos Aires, 1997. 
BID. A Política das políticas públicas: progresso econômico e social na América Latina; relatório 2006. Rio de Janeiro: Elsevier; Washington, DC: BID, 2007.

BEST, J. Damned lies and statistics. University of California Press. Berkeley, 2001.

. Rhetoric in claims-making: constructing the missing children problem. Social Problems, v. 34, nº 2, p.101-121, April 1987.

(ed), Images of issues: Typifying Contemporary Social Problems. New York: Aldine de Gruyter, 1995.

BLUMER H. Social problems as collective Behavior. Social Problems, v.18, nº3, p.298-306,1971.

FREITAS, Rosangela F. de. O Tema trabalho infanto-juvenil na mídia: uma interpretação ideológica. São Paulo, 2004. Tese (Dout.) Psicologia Social, PUC-SP.

GOFFMAN, Erving. Estigma: notas sobre a manipulação da identidade deteriorada. 4 ed. Rio de Janeiro: Livros Técnicos e Científicos, 1988.

GREGORY, Maria Filomena. Meninos nas ruas: a experiência da viração. São Paulo: Tese de Doutorado (Antropologia Social). Universidade de São Paulo, 1977.

GUSFIELD J., The Culture of public problems: drinking-driving and the symbolic order. Chicago: The University of Chicago Press, 1981.

HILGARTNER S.; BOSK, C.S., The Rise and fall of social problems: a public arena model. American Journal of Sociology, n.94, p. 53-78, juillet 1988.

HUGHES S., The Role of the news media on the policymaking process. Washington, DC: Inter-American Development Bank., Feb. 28March 2, 2005.

JOHNSON J.M. Horror stories and the construction of child abuse. In: BEST, J. (ed.), Images of issues: typifying contemporary social problems. New York: Aldine de Gruyter, 1995. p.17-31.

LAHIRE, Bernard. L'invention de l'<illettrisme> rhétorique publique éthique et stigmates. Paris: La Découverte/Poche, 2005. 
NAZARETH, Leila. O Discurso da mídia sobre a adolescente grávida: uma análise da ideologia. São Paulo, 2004. Dissert. (Mestr.) Psicologia Social, PUC-SP.

NJAINE, Kathie; MINAYO, Maria Cecília de Souza. Análise do discurso da imprensa sobre religiões de jovens infratores em regime de privação de liberdade. Ciência Saúde Coletiva, v.7, n.2, p. 285-297, 2002. Disponível em:

www.scielo.br/scielo.php?script=sci_arttex\&pid=S1413-

81232002000200009\&Ing=pt\&nrm=isso

Acesso em: 10 de out. 2004.

MÉLLO, Ricardo Pimentel. A Construção da noção de abuso sexual infantil. Belém: EDUFPA, 2006.

OSZLAK, Oscar; O’DONNELL, Guilhermo. Estado y políticas estatales en América Latina: hacia una estrategia de investigación. Buenos Aires: Clacso, n. 4, 52 p., mar. 1976. (mimeo).

PONTE, Cristina. Crianças em notícia: a construção da infância pelo discurso jornalístico (1970-2000). Lisboa: ICS, 2005.

ROSEMBERG, Fúlvia. A Retórica sobre criança de rua na década de 80. Cadernos de Pesquisa, no 87, p. 71-81, nov. 1993.

; ANDRADE, Leandro F. (1999). Ruthless rhetoric: child and youth prostitution in the Brazil. Childhood: a global journal of child research, v. 6, n. 1, p. 113-131, febr. 1999

SPECTOR M.; KITSUSE J.I., Social problems: a re-formulation. Social Problems vol. 21, nº 2, p. 145-159, 1973

THOMPSON, John B. Ideologia e cultura moderna: teoria social crítica na era dos meios de comunicação de massa. RJ: Vozes, 1995. 


\title{
CAPÍTULO 18
}

\section{EMOÇÕES E MÍDIA}

\author{
Ronald João Jacques Arendt \\ Universidade do Estado do Rio de Janeiro
}

\section{Cenas cariocas}

\section{Cena I}

Um grupo de assaltantes cerca um carro num subúrbio do Rio de Janeiro, próximo a uma favela, obriga os ocupantes a sair e arranca em alta velocidade. Os pais de um dos ocupantes, um menino, João Hélio, não conseguem desvencilhar a tempo o cinto de segurança no qual ele está preso e a criança é arrastada por quilômetros morrendo de forma terrível.

\section{Cena II}

Um rapaz recém saído de uma boate na Zona Sul atropela em alta velocidade uma jovem e foge sem prestar socorro. A polícia vai até o endereço fornecido por um taxista que ao presenciar a cena havia seguido o carro do rapaz. Ele foge uma segunda vez e se apresenta, dias depois, numa delegacia, acompanhado de um advogado.

\section{Cena III}

Cinco jovens de classe média alta espancam de madrugada uma moça num ponto de ônibus. A moça, uma doméstica, na Barra da Tijuca denuncia a agressão na delegacia, mais uma vez ajudada por um taxista que presencia a cena.

Presos e inquiridos quanto ao motivo que os teria levado a cometer tal agressão, os jovens delinquentes justificam-se dizendo que haviam confundido a doméstica com uma prostituta. Nos dias subsequentes à 
agressão o leitor dos jornais fica sabendo perplexo que não se tratava de um caso isolado: os chamados "pittboys" agrediam sistematicamente prostitutas que por medo não os denunciavam.

\section{A teoria das emoções predominante no Ocidente}

Estes episódios são alguns exemplos de violência ocorridos no decorrer de 2007, infelizmente banais na cidade do Rio de Janeiro. Estes episódios recebem da imprensa, um tratamento que merece ser analisado pela psicologia. Em todos os casos a descrição dos delitos efetuada pelos jornais inclui um viés emocional que de forma implícita ou explícita atenua o delito cometido. Assim, na primeira cena os assaltantes favelados são avaliados como monstros, indivíduos doentes sem valores morais que deveriam ter sido fornecidos por famílias constituídas (embora se tenha constatado depois que um dos integrantes do grupo era de classe média e de família evangélica); o advogado do segundo caso (mesmo considerando as inúmeras infrações cometidas pelo rapaz) traz um documento no qual um especialista atesta ter o seu cliente passado por um “choque psíquico-emocional”; no terceiro caso, em que pese o comportamento inaceitável dos jovens delinquentes, o parente de um deles se apressa em dizer que ele sofria de TDAH (Transtorno do Déficit da Atenção e Hiperatividade) e tomava remédios, enquanto o pai de outro dizia que não era justo este "menino" ir para a cadeia — afinal ele era de família constituída e cursava universidade. É curioso o argumento invertido: quando o jovem delinquente é favelado lhe falta uma família. Quando ele é de classe média, por ser de família, ele não pode ser delinquente. Comportamentos sociais extremamente graves são reduzidos a doenças, transtornos afetivos ou questões individuais e familiares envolvendo dificuldades de desenvolvimento, aprendizagem ou atenção. O tema desta palestra é analisar a teoria das emoções subjacente a estas falas acolhidas sem muita discussão pelos jornais de grande circulação. Parto da hipótese que esta é a teoria dominante das emoções no mundo ocidental —daí a quase obviedade de sua utilização pela mídia. Como funciona esta teoria? Ela funciona efetuando uma divisão opondo razão e emoção. $\mathrm{O}$ argumento segue 
mais ou menos da seguinte forma: há indivíduos razoáveis, centrados, controlados, formados por sólidos valores morais. Quando estes controles falham ou faltam (por conta da ausência da família ou de um desenvolvimento precário de qualquer ordem) emerge o sujeito irracional, o monstro doentio. O jovem atropelador e os jovens agressores seriam cidadãos sérios e cumpridores dos seus deveres, estudantes universitários, bons meninos, não fora o lamentável desvio do seu caminho responsável causado por choques psíquico-emocionais ou síndromes de deficiência da atenção. Enquanto os sistemas racionais seriam ativos e externos, os sistemas emocionais seriam internos, íntimos, escapando frequentemente ao controle dos sistemas racionais.

Em seu texto "Estas emoções que nos fabricam” a psicóloga belga Vinciane Despret (1999) detalhará esta concepção das emoções enquanto interiores ao corpo humano, instâncias íntimas, pessoais, autênticas, associadas, em nossa sociedade, ao frágil, ao feminino, em contraste com a razão enquanto exterior ao corpo, masculina, típica do homem de atitudes firmes e decididas, concepção presente em inúmeras abordagens contemporâneas da psicologia social e da psicanálise. As origens deste modelo devem ser buscadas na filosofia antiga dos gregos, segundo Despret. Detenhamo-nos por algum tempo no pensamento grego. O linguista francês Alban Cornillet (2005), em sua tese "O discurso da emoção” nos lembra como para os gregos a experiência da paixão sempre foi algo misterioso e perturbador, algo que chega bruscamente produzindo dor e sofrimento, algo que possui passivamente o indivíduo. Frente às paixões o indivíduo não é ativo —está sujeito a elas. Assim os gregos irão julgar as paixões de forma negativa. Será Platão um dos primeiros pensadores a sistematizar o discurso sobre as emoções. "Platão elabora um modelo tripartite da alma: três funções são repartidas em três locais do corpo. Uma parte racional situada na cabeça deve dirigir. Situados no abdômen (à distância da cabeça) os desejos formam a parte concupiscível da alma. Entre os dois, para proteger a razão da desordem, das paixões e dos desejos concupiscentes, para fazer uma barragem e domá-los, Platão 
coloca uma parte irascível da alma no coração” (p. 30). Observa o autor que este modelo será retomado por Aristóteles, pelas teorias antropológicas e morais cristãs desde Santo Agostinho até os tempos modernos, com Descartes. Trata-se de um projeto político centrado em torno da ideia do domínio que, por sua vez, é subjacente à abordagem platônica da alma. Assim, "Platão postula que no homem a autoridade deve poder ser exercida pela alma quando ela é sensata e que a arma mais eficaz para combater os desejos é o domínio de si, a continência” (p.32). As paixões devem, portanto, ser objeto de vigilância e controle. Há que se ter desconfiança das paixões mantendo-as à distância, pois elas podem trazer a desgraça se interferirem sobre a parte que comanda a alma.

É importante que nos demos conta de nossa "herança platônica". Despret (op. cit.) nos mostra como esta influência vai da teoria psicanalítica - a autora consagra todo um capítulo de seu livro para detalhar a forma como Freud construiu a psicanálise a partir do controle das paixões, à neurobiologia. Assim, por exemplo, ela cita o biólogo J. D. Vincent que, num texto recente, sublinha a tendência recorrente da neurobiologia a "descobrir para cada função do corpo e do espírito, o lugar do cérebro centro— de onde emanam a lei e a ordem” (p.192).

\section{Emoções e publicidade}

Uma tese recentemente defendida no PPGPS da UERJ (Pinheiro, 2007) permite confirmar a hipótese acima formulada. Pesquisando em anúncios publicados em revistas de circulação nacional (Veja, Playboy e Marie Claire) a autora busca conceituar e descrever as estratégias emocionais utilizadas na persuasão publicitária. Partindo de autores como Cristopher Lasch, Gilles Lipovetsky, ou Zygmunt Bauman (que configuram o que os teóricos chamam de hipermodernidade) a autora identifica as estratégias do hedonismo imaginativo e as estratégias repressoras. A primeira estratégia reporta ao "modo como as pessoas na contemporaneidade buscam prazer através de devaneios sobre suas vidas e assim consomem tudo aquilo que estimule este sonhar acordado” (p.72). A 
segunda ao "apelo (do anúncio) ao medo e à ansiedade com imagens ou palavras que mostrassem o perigo da não utilização da mercadoria” (p.73). Para dar conta dos conceitos que emergem destas estratégias como a "busca do prazer" ou o "medo e a ansiedade com imagens ou palavras" a autora, seguindo as propostas do referencial conceitual escolhido, termina por introduzir um olhar psicanalítico em sua análise. O consumidor, frente à experiência da frustração vivida na realidade, teria sua satisfação preenchida por meio da alucinação propiciada pelos anúncios que disparariam o seu narcisismo. Em síntese o universo dos anúncios investigados apresentaria "um discurso infantil e regressivo associado às fantasias de poder e ausência de limites” (p. 97).

Ora, em pleno discurso hipermoderno, não deixa de ser surpreendente a referência da autora a uma obra de Pringle \& Thompson (publicada em 2000), para os quais haveria duas “ondas” principais na construção de uma marca ao público e a sua apresentação através da propaganda: a onda racional e a onda emocional. Na onda racional "os anunciantes demonstravam, em geral, o que os serviços faziam, os atributos, o desempenho e a funcionalidade do produto e, às vezes como ele era fabricado, numa comunicação muito direta com o público” (p. 50). A abordagem racional, entretanto "não capta diretamente seus clientes, isto é, não atrai sua atenção, principalmente na TV, quando, em geral, buscam entretenimento, a menos que eles estejam de antemão interessados na informação sobre determinado bem de consumo e disposto a comprá-lo. Caso contrário, é uma informação desnecessária” (p.51). Surge então a onda emocional. "O grande interesse dos profissionais de marketing passou a ser o entendimento das motivações de compra, principalmente dos impulsos inconscientes, buscando assim estreitar o relacionamento entre consumidor e marca. A escola emocional entendeu que os receptores das mensagens comerciais têm autopercepção diferenciada, como também selecionam a mensagem pela marca e mídia utilizada” (p. 54) conclui a autora.

Ora, se combinarmos as duas estratégias presentes na persuasão publicitária com o descarte da onda racional, chegamos a uma situação 
intrigante: a sociedade capitalista contemporânea incentiva a produção de consumidores narcisistas, apoia posturas regressivas na sua falta de limites e seus comportamentos infantis. Desta análise emerge uma estranha convergência com os casos de delinquência descritos na primeira seção: nos casos de violência dos jovens a emoção vinha à tona na falta da razão, do controle sobre si mesmo do agressor (questiona-se aqui a irracionalidade dos atores), na publicidade se busca a falta da razão e do controle do consumidor para que a "onda emocional" atinja toda sua plenitude (questiona-se aqui a racionalidade dos atores). De um modo, ou de outro, permanecemos na divisão platônica que contrapõe razão e emoção. Em ambos os casos a emoção é uma força que desarruma a razão, para o mal ou para o bem.

\section{Uma pequena digressão filosófica}

Na próxima seção deste artigo vou procurar expor um modelo de emoções elaborado numa tradição filosófica alternativa ao platonismo - o empirismo radical de William James ou o "segundo empirismo" como o intitula Latour (2007). Convém determo-nos muito brevemente sobre esta noção. O primeiro empirismo, diz Latour, não considerava senão dados elementares dos sentidos. "Era necessário então, para fazer a síntese destes dados, que interviesse um espírito humano suposto de criar as relações que a experiência inicial não podia dar de saída. Encontramo-nos aqui numa natureza tão 'bifurcada' que tudo o que é dado na experiência deve, se podemos assim dizê-lo, escolher seu campo, e se situar seja do lado da coisa a conhecer seja do lado do espírito conhecedor" (p. 9). Vale observar que "natureza bifurcada" é uma expressão que Latour toma do filósofo inglês Alfred Norman Whitehead para o qual a natureza "bifurca" quando se assume uma posição dualista na qual existiríamos nós "aqui” e o mundo "lá". Para Whitehead (assim como para James) isto seria inconcebível. A originalidade do segundo empirismo, ressalta Latour, será se insurgir contra tal situação, procurando dar conta não apenas da experiência, mas das relações que a experiência estabelece com o mundo. No mesmo sentido, Cornillet (op. cit.) se insurge contra a teoria tradicional das emoções ao 
comentar uma afirmação (de Catherine Kerbrat-Orecchioni) para quem a reflexão sobre as emoções sofreria por não problematizar de forma suficiente as inter-relações entre os níveis psicológico, cognitivo e linguístico. Observa ele que o problema não seria o de uma purificação incompleta destes níveis (esta purificação devendo mais é ser contestada). Segundo ele o princípio mesmo da distinção entre "psicológico", “cognitivo" e "linguístico" seria inadequado, como o seria a construção histórica da noção de indivíduo e do funcionamento representacional da linguagem. Nesta o cognitivo ou a representação são entendidos como um duplo do real, a duplicação sendo a colocação à distância do mundo pelo indivíduo —ou a separação deste último enquanto entidade distinta do mundo. Assumir o funcionamento representacional da linguagem seria assumi-lo enquanto instrumento deste distanciamento ou duplicação (p.9).

\section{Uma outra versão da teoria das emoções}

O comentário de Cornillet configura um exemplo claro de bifurcação da natureza no âmbito da teoria das emoções. Seria possível propor uma outra versão da teoria das emoções não platônica e não bifurcada? Seria possível elaborar uma ciência das emoções que possibilitasse, como diz Despret (op. cit.) novos acessos para pensá-las, para inventá-las, “para suscitar, a partir delas, novas formas de experiência” (p. 247)? Despret irá expor esta versão alternativa a partir da proposta das emoções elaborada por William James. “A teoria das emoções de James é antes de tudo uma proposta de experiência que, por fazer existir um certo tipo de saber sobre a emoção, faz existir uma nova relação consigo e com o mundo. Ao propor uma outra forma de ler as emoções, James induz uma nova experiência destas, isto é, uma nova experiência com relação a elas e assim uma nova experiência emocional com relação ao mundo, uma outra maneira de afetar e ser afetado” (p. 259). A emoção, neste sentido, “não é apenas o que é sentido, é o que faz sentir”. A emoção “não é apenas o que nos faz acolher o mundo, é também a maneira que pedimos ao mundo de nos acolher” (p. 270). Esta ênfase na indeterminação da relação do corpo com o mundo que 
acompanha a experiência emocional torna-se indeterminação do corpo. O corpo pode ser o mundo que afeta a consciência, a consciência em relação com o mundo ou a consciência produzindo um corpo (p. 257). A relação na qual não há como decidir entre "o que é produto da emoção, entre o que nós fabricamos como emoção e a maneira como ela nos fabrica” (p. 258), nos permite considerar o fato de que emoções não são instâncias internas ao corpo. Elas "podem ser criadas, [podem] propor novas definições de si próprias, podem transgredir e resistir, mas principalmente podem ser negociadas singularmente e coletivamente e participar então ativamente da criação do social” (p. 246). Estamos longe do platonismo: “ (...) rimos porque a piada é engraçada ou ela é engraçada porque rimos; estamos aterrorizados ou tornamos o mundo terrificante? É esta paisagem que me torna triste ou é minha tristeza que se imprime sobre a paisagem? É o vinho que torna os pensamentos alegres ou é nosso corpo que torna o vinho alegre? Será que o mundo me surpreende ou é minha surpresa que torna o mundo surpreendente? Podemos afirmar ambos os casos, diz James, porque estas experiências estão ao mesmo tempo no mundo, no corpo e na consciência. E não é este corpo é, na experiência emocional, mundo, consciência, articulação?” pergunta Despret. “Nosso corpo nos produz emocionados, mas nós podemos da mesma forma produzir um corpo emocionado; é isto afinal o que os atores nos ensinam”, responde ela (p. 263).

\section{Uma experiência de pensamento}

As propostas da última seção permitem traçar em grandes linhas uma concepção não platônica das emoções. Embora eu não tenha espaço neste pequeno ensaio para desenvolver adequadamente esta linha de reflexão, ressalto a compatibilidade da última citação a com a sociologia do ator-rede proposta pelo sociólogo Bruno Latour (2006). Para esta sociologia, quando se trata de descrever os atores numa situação social não caberia estabelecer de antemão um modelo teórico que para interpretar suas ações. Latour sugere que "sigamos os atores". Vale observar que nesta abordagem o ator não age simplesmente. Ele é levado a agir tendo em vista a rede de relações 
em que está envolvido, sem ser agido por ela. Isto é mais um exemplo da indeterminação acima discutida agora ao nível da relação entre um ator e a rede de inter-relações que tece o social. Esta a rede diz Latour "faz-fazer”. Como diria ainda o filósofo Étienne Souriau o ator instaura um modo de ser tendo em vista a rede. Com este referencial em mente, proponho que façamos uma experiência de pensamento: se, como procurei argumentar, a mídia se funda prioritariamente num modelo tradicional das emoções para dar conta dos fenômenos do quotidiano ou da persuasão do consumidor, como seria seu proceder frente a uma versão alternativa não platônica ou bifurcada, como a que busquei descrever? Responderia a esta questão seguindo duas linhas de argumentação.

Por um lado, se as emoções podem "participar ativamente da criação do social”, penso que à mídia deveria incentivar um jornalismo investigativo no qual o leitor ou espectador pudesse acompanhar o processo de construção dos fenômenos que redundaram nos fatos relatados pelos meios de comunicação. Assim, não avança muito para o leitor caracterizar os delinquentes favelados como "monstros" ou os delinquentes de classe média como sujeitos acometidos por "choques psíquicos": isto o faz permanecer infantil, regressivo. Há que analisar a fabricação das emoções para além da descrição psicológica. Há que adentrar em campos sociológicos e antropológicos Então, nos exemplos considerados há que formular outras perguntas: como surgiram as favelas cariocas, porque elas se tornaram um espaço que propiciou a disseminação da criminalidade envolvida com o tráfico de armas e de drogas? Qual a relação da violência com a oferta de condições adequadas e qualidade de vida (educação, saúde, moradia, segurança) e assim por diante. No caso dos delinquentes de classe média e alta, como emergiu no Rio de Janeiro esta cultura dos pittboys? Em termos conceituais, haveria que descrever a rede de articulações que "fez fazer” estes acontecimentos e produziu o quadro emocional indevidamente reduzido a causas internas. No âmbito da indeterminação ou da ambiguidade de James, os delinquentes são o mundo do qual fazem parte, e que os afeta. Eles fabricam este mundo e são fabricados por ele. Suas 
experiências "estão ao mesmo tempo no mundo, no corpo e na consciência”. Penso que a mídia deveria seguir estes atores e não se fixar neles. Outro exemplo de grande repercussão na mídia em que um grande número de atores está envolvido: a recente crise aérea brasileira. Latour (2001) já observou há tempos que quem voa é a companhia aérea. Fica claro depois dos graves acidentes que ocorreram recentemente que quem voa é o avião, os pilotos, os controladores de voo, a burocracia aérea (Ministério da Defesa, a Infraero, a ANAC, entre outras entidades), os aeroportos, as companhias aéreas e seus usuários sem contar com os interesses econômicos e políticos envolvidos e tudo isso gerido segundo os princípios de gestão brasileiros, que contrastam com os padrões americanos ou europeus. Como vimos, há que descrever esta rede de articulações. Entretanto, deveríamos ter claro que a própria mídia fabrica emoções e frequentemente faz um uso perverso desta fabricação. Assim, ela deveria menos mostrar o choro da mãe de João Hélio ou os gritos de dor desesperados dos parentes das vítimas dos acidentes aéreos e mais descrever a rede de implicações destes complicadíssimos acontecimentos que produziram esta dor. Cenas chocantes paralisam o público na forma tradicional da emoção e são um dispositivo de manipulação da opinião pública que perde a oportunidade de refletir sobre o processo que geraram tais acontecimentos.

Por outro lado, fica patente que a propaganda e publicidade fundadas na abordagem tradicional das emoções constroem consumidores passivos, meramente reativos. Na linguagem da teoria do ator-rede a relação tradicional é assimétrica. Praticamente todas as coordenadas são dadas pelo publicitário que organiza uma campanha publicitária deixando para o consumidor uma margem de manobra mínima. Vou me valer de alguns parâmetros da prática de pesquisa de campo para melhor caracterizar esta assimetria. Ao descrever o trabalho desenvolvido por pesquisadores da emoção em culturas não ocidentais, Despret (op.cit.) relata que na tentativa de compreendê-las ocorrem mal-entendidos. Estes mal entendidos ganham um sentido "promissor” se eles permitirem a reavaliação da estratégia interpretativa da investigação. Para a autora estabelecer uma relação com o outro envolve uma atitude de respeito 
pelas práticas deste outro e entrar em contatos com ele de forma simétrica constituiria o que ela chama de "polidez do travar conhecimento". No mesmo sentido, Stengers (2006), ao comentar a questão da prática do pesquisador, observa se impõe aqui a questão de como "bem tratar" os sujeitos de pesquisa, "sem separá-los do que os faz sentir e pensar" (p. 141). Há que se ter o risco enquanto pesquisadores de sermos inquiridos pelos nossos sujeitos de pesquisa quanto à formulação de nossas perguntas. O que está em jogo nestas análises é a formulação de perguntas interessantes que permitam um melhor domínio da relação com o outro e propiciem uma descrição adequada do coletivo pesquisado, propiciando por sua vez a ampliação do campo de pesquisa. Ora, os profissionais da propaganda e da publicidade visualizados a partir destes parâmetros definitivamente não tratam bem o seu público. Eles não são polidos, não se colocam em risco, não estão preocupados com mal-entendidos, não formulam questões interessantes. Esta série de negativas — que configura sua assimetria frente ao público constituído por suas campanhas publicitárias. Haveria como pensar uma outra forma de participação do consumidor? Haveria um outro público? Ou melhor, não estaria em curso um processo de transformação desse público na contemporaneidade? Sim, responde Bruno Latour numa entrevista concedida ao jornal francês Le Figaro em 31 de agosto de 2004. As colocações de Latour são do maior interesse para os argumentos deste trabalho. Suas proposições deixam claro como as emoções emergem no encadeamento de processos sociais e políticos. Acompanhemos estas proposições. As controvérsias científicas teriam há muito ultrapassado o muro dos laboratórios e estaríamos confrontados diariamente com problemáticas científicas. O entrevistador deseja que Latour esclareça porque, segundo ele, o cidadão comum participaria de programas de pesquisa, até mesmo de políticas de pesquisa. Consideremos um consumidor, pondera Latour. Ele quer comprar um veículo de tração $4 \mathrm{X} 4$. Ainda que indiretamente ele se envolva com a política de energia e com o aquecimento global. Devem as mulheres consumir suplementos hormonais para tratar das alterações da menopausa? Estamos no cerne de uma disputa envolvendo milhares de mulheres. Devemos ou não comprar organismos geneticamente modificados no supermercado? Estamos no meio de disputas que vão da geopolítica mundial ao futuro da agronomia 
passando pela biologia molecular forçando o indivíduo a tomar posição frente a tais problemas. Se as ciências sempre estiveram entremeadas de forma íntima à vida pública, o que se teria transformado seria a nossa percepção da situação. Há trinta anos atrás, no âmbito da modernização triunfante, no que Ulrich Beck chamou de primeira modernidade, ninguém dava atenção a tais problemas. Hoje, segue Latour, entramos no que Beck chama "a segunda modernização". A primeira modernização foi pensada no modo da emancipação e da desvinculação. O progresso consistia em liberar pressões. Latour pondera que isto foi um formidável progresso e uma imensa esperança, mas este modelo começa a “fazer água” em toda parte, pois para se emancipar era também necessário rejeitar multidões de fenômenos como a poluição, o lixo nuclear, as religiões. A segunda modernidade exige que muito mais variáveis sejam levadas em consideração. "Entre num supermercado e veja tudo o que você precisa levar em conta para comprar apenas um pacote de café. No futuro as instruções, precauções, atenções, serão cada vez mais numerosas. Não é o fim do progresso, mas o fim da despreocupação quanto ao progresso, sim, da enorme importância do princípio de precaução”. Frente à pergunta do entrevistador se hoje haveria boas razões de ser otimista ou pessimista, Latour responde que não há nunca boas razões de ser otimista, mas há boas razões de buscar pensar de outra forma o futuro e a política. Uma das formas seria incluir nas paixões e interesses públicos as apostas, as preocupações, os objetos das controvérsias, o que em inglês se chama issues, temas de discussão que estão em todos os lugares e permitem repensar a vida pública. (Diria que às issues corresponderiam as perguntas interessantes de que falam Stengers e Despret).

Penso que a mídia teria que incorporar as questões da segunda modernidade e trazer estas controvérsias apaixonadas para o debate público. Diria, a partir da fala de Latour que a prática dos publicitários descrita por Pinheiro, embora compreendida pelos teóricos que ela utilizou como "hipermoderna” trata os consumidores como se o público permanecesse na primeira modernização. No contexto da segunda modernização o público teria que sair de sua passividade reativa, e a própria mídia seria levada a 
agir em função de acontecimentos. Tomemos o exemplo de uma issue particularmente pertinente ao argumento deste artigo. Refiro-me às controvérsias introduzidas pelo filósofo australiano Peter Singer.

Como relata a jornalista Roslyn Guy (2007), por conta de campanhas que remontam aos anos 90 a cadeia de lojas fast food McDonald's modificou os ingredientes dos seus cardápios após se haver constatado a partir de uma auditoria que um dos abatedouros que fornecia carne para a fabricação de seus hambúrgueres desmembrava os animais ainda conscientes e esta situação se tornou pública. Ou seja: a maior responsabilidade da cadeia de produtos fast food não ocorreu por que ela decidiu ser responsável, mas ela foi forçada a ser mais responsável em consequência de um movimento no qual um consumidor não infantilizado se recusou a consumir um produto cujos ingredientes não provinham de uma fonte confiável. Ao debater não apenas o direito dos animais no que tange ao abate, mas as consequências dos hábitos alimentares na destruição do meio ambiente (por exemplo, o uso de imensas áreas para criação de gado ou o transporte de alimentos em veículos movidos a combustível poluente), Singer é realista quanto às poucas chances do mundo rejeitar tão cedo o consumo de carne, embora ele confie que o debate público das mudanças climáticas possa levar as pessoas a repensar suas escolhas alimentares. Singer não espera que todos aceitem estas propostas, mas colocá-las em discussão é um passo no sentido de propiciar decisões que tenham menor impacto destruidor no meio ambiente e nos animais. Esse passo configuraria uma mídia não platônica ou bifurcada.

À guisa de conclusão, cabe observar que esta maneira de conceituar as emoções - como fruto de um processo social, cultural e político, abre perspectivas completamente novas para pensar a psicologia e a psicologia social (ARENDT, 2006). A sociologia do ator-rede que Latour desenvolve em um de seus últimos trabalhos (LATOUR, 2006) sistematiza a ideia de que o social não antecede e constitui nossas práticas. O social estaria sempre sendo tecido e re-tecido na rede heterogênea de articulações em que estamos atuando. Nesse sentido, uma determinada instância, no caso a 
sociologia, dependeria de inúmeros fatores não sociológicos. Na tradução que busco efetuar da teoria do ator-rede para nossa disciplina, o mesmo valeria para a psicologia e para a psicologia social: categorias como: a emoção e a cognição, não estariam localizadas no indivíduo, e emergiriam da articulação de instâncias não obrigatoriamente psicológicas (no linguajar de Latour, na articulação de humanos com não humanos), através da prática dos atores nos coletivos em que estivessem atuando. Tomemos, por exemplo, as emoções produzidas pela arte, pelo cinema ou pelos esportes. Isto, porém é tema de outro trabalho.

Referências

ARENDT, R.J.J. Psicologia e Construtivismo: esboço de uma psicologia não moderna. Rio de Janeiro: Projeto para o programa Prociência, UERJ/FAPERJ, 2006.

CORNILLET, A. Discours de l'émotion, du contrôle au management, 2005. Disponível em www.revue-texto.net/marges/marges/Documents\%20Site\%203/ the0023_cornillet_a/the0023.pdf Acesso em 24/04/07.

DESPRET, V. Ces emotions qui nous fabriquent. Ethnopsychologie del'authenticité. Paris : Les Empêcheurs de tourner en rond, 1999.

GUY, R. To pig out on burgers is bad, but the professor says it's up to you, 2007. Diponível em

www.theage.com.au/news/national/to-pig-out-on-burgers-is-bad-butthe-professor-says-its-up-to-you/2007/02/16/1171405442629.html Acesso em 02/08/07.

LATOUR, B. Sur um livre d'Etienne Souriau: Les Différents modes d' existence, 2007. Disponível em www.bruno-latour.fr/articles/article/98-SOURIAU.pdf Acesso em 03/07/07.

- Changer de société - Refaire de la sociologie. Paris : La Découverte, 2006. LATOUR, B. C'est la fin de l'insouciance du progrès. Entrevista concedida ao jornal francês Le Figaro, em 31/08/2004. 
A Esperança de Pandora. Bauru, SP: EDUSC, 2001.

PINHEIRO, M.C.T. Publicidade emocional: a sensibilidade a serviço do consumo. Rio de Janeiro: Tese de Doutorado. (Psicologia Social) Universidade do Estado do Rio de Janeiro, 2007.

STENGERS, I. La vierge et le neutrino. Les scientifiques dans la tourmente. Paris : Les Empêcheurs de tourner en rond, 2006. 


\section{VIOLÊNCIA E POLÍTICA: A DEMOCRACIA E AS REORDENAÇÕES DO POLÍTICO NO BRASIL CONTEMPORÂNEO}

CAPÍTULO 19

\section{SOCIEDADE CIVIL VERSUS VIOLÊNCIA (HIPÓTESES BRASILEIRAS)}

Céli Regina Jardim Pinto* Universidade Federal do Rio Grande do Sul

T a atual discussão sobre a violência no Brasil, há uma constante presença 1 da sociedade civil, ora como vítima ora como ator, capaz de ações de protestos ou de promoção de projetos na direção da minimização do problema. A sociedade civil tem se colocado, desde as últimas décadas do século XX, como ator capaz de solucionar problemas antes restritos a intervenção da esfera estatal, e isto traz para discussão um número importante de questões tanto no nível teórico como no da prática política e social.

No que concerne à violência, no atual contexto brasileiro pode-se destacar três ações muito características da sociedade civil: ações de protesto contra uma violência difusa que atinge principalmente a classe média; projetos sociais implementados por ONGs visando à luta contra a violência nos locais onde ela é gerada, em bairros pobres e favelas; campanhas promovidas, também por ONGs no combate à violência doméstica contra crianças, mulheres e idosos e a outros grupos expostos a preconceitos de raça e opção sexual. Estas não são as únicas expressões de violência no país, mas para a análise que focarei aqui elas sintetizam

Doutora em Ciência Política pela Universidade de Essex/Inglaterra; Professora do Departamento de Ciência Política do IFCH da UFRGS. 
algumas das formas mais presentes de violência, principalmente, nos grandes centros urbanos brasileiros.

$\mathrm{O}$ século $\mathrm{XX}$ foi por excelência, do primado do Estado, tanto no que concerne aos cenários da política dos países ocidentais, como nos projetos e utopias das militâncias políticas; o novo século inaugura-se sob a égide da sociedade civil, analistas e militantes, agora veem este espaço com grande privilégio na arena pública. As crises do socialismo real e da social democracia dos países desenvolvidos do hemisfério norte, ambos fortemente estadistas, provocam uma nova onda, na qual a sociedade civil aparece como ator central. Por um lado, a reação à forte presença do Estado aposta no neoliberalismo, com uma sociedade civil desempenhando o papel fundamental de substituí-lo com vantagens. Essa sociedade torna-se para o social, o que o mercado tornou-se para o econômico, ambos como reação a grande presença do Estado no século anterior. Por outro lado, em uma perspectiva progressista, a sociedade civil aparece como protagonista de um pacto a ser construído, que permitiria a superação de uma democracia puramente representativa, onde a participação em canais alternativos aos processos eleitorais convencionais seria um forte elemento constitutivo de uma proposta de maior igualdade e justiça social.

A centralidade da sociedade civil é um forte contraponto a um sempre presente discurso do fracasso do Estado em dar conta das tarefas a que se propôs, tanto em sua versão autoritária e conservadora concretizada nos regimes militares autoritários ao redor do mundo, como em sua versão de condutor do socialismo real ou ainda em sua versão suavemente progressista das democracias do estado de bem estar do hemisfério norte.

O presente ensaio busca identificar modelos de sociedade civil e indagar como esses se expressam no Brasil e se relacionam com o problema da violência nas suas diversas manifestações.

Antes de avançar na discussão se faz necessário estabelecer algumas premissas que elegemos como fundamentais para entender o conceito de sociedade civil. A primeira é a de que a existência desta não garante valores 
morais, posturas éticas nem regimes políticos, ou seja, a sociedade civil não é virtuosa por natureza; a segunda é a de que o caminho possível para o aprimoramento da democracia representativa passa pelo acoplamento a modos de democracia participativa, o que implica na presença de uma sociedade civil robusta. A existência de democracias que se mantiveram sem elas durante o século $\mathrm{XX}$, não justifica a possibilidade de sua permanência no cenário atual e vindouro. Elas se mantiveram exatamente pela possibilidade de um Estado forte e provedor que se mostra, agora, esgotado pelo menos na forma até então engendrado; a terceira premissa é de que a sociedade civil, para existir, necessita preencher um conjunto de condições e, é a sociedade organizada a partir destas condições, que estabelece relações com as demais dimensões do público e do privado em uma dada comunidade, região ou país.

\section{I}

Cohen e Arato examinando um conjunto de autores responsáveis pelo que chamam de "revival” da sociedade civil na teoria social, concluem que

todos concordam que a sociedade civil representa uma esfera diferente ou mesmo oposta ao Estado, todos incluem, quase sempre de forma não sistemática, alguma combinação de redes de proteção legal, associações voluntárias e formas independentes de expressão (COHEN e ARATO, 1993 p. 74) ${ }^{1}$.

Ao longo de sua volumosa obra os autores desenvolvem o conceito de sociedade civil enfatizando uma série de importantes características, a primeira e mais fundamental é a diferenciação da sociedade civil do estado e do mercado, principalmente, a independência em relação ao segundo. Para os autores, o modelo que eles denominam “modelo de três partes” permite pensar um projeto político que se afaste tanto do conservadorismo neoliberal (fundamentalismo econômico) como do intervencionismo estatal do estado de bem estar (COHEN e ARATO, 1993, p. 464).

\footnotetext{
1 Tradução minha, desta e de todas as citações do presente ensaio.
} 
A importância da autonomia está diretamente relacionada ao perigo da colonização da sociedade civil pelo mercado e pelo poder político, noção desenvolvida por Habermas quando trata de relação entre o sistema e o mundo da vida e a retomada pelos autores em tela, na discussão sobre a sociedade civil. Afirmar a autonomia da sociedade civil em relação ao mercado e ao Estado, não envolve afirmar que eles não estejam interligados e que não sofram uma forte influência mútua. Há casos em que a sociedade civil e o Estado estão bastante próximos, sendo difícil identificar até onde a primeira está agindo como sociedade ou como parte do próprio Estado ${ }^{2}$. O problema, no entanto, está em outro plano: se o analista não for capaz de identificar em certo momento uma sociedade autônoma, esta sociedade não existe. Mesmo Gramsci, quando afirma que a hegemonia deve acontecer primeiro na sociedade, e não a partir do Estado, está reconhecendo um momento de autonomia ${ }^{3}$.

Duas outras características do conceito de sociedade civil são especialmente importantes na sua configuração, a primeira delas é o que os autores denominam de utopia autolimitada, por sua impossibilidade de ser revolucionária, de tomar o poder. As organizações da sociedade civil por natureza não se propõem a tomada do poder, pretensão legítima dos partidos políticos. Textualmente Cohen e Arato afirmam: "O aspecto auto limitado da utopia refere-se à restrição da coordenação da ação comunicativa no coração institucional da sociedade civil, no lugar de impor este princípio organizacional a toda sociedade" (COHEN e ARATO, 1993, p.456).

A utopia autolimitada para sua realização, para os autores, envolve a segunda característica, isto é, a sua condição de mediadora, pois a mediação

2 Tal característica é bastante presente no Estado brasileiro atual, principalmente nos Conselhos, Conferências Nacionais e assessorias de ministérios.

${ }^{3}$ Discutindo as funções dos intelectuais no processo de dominação burguesa, Gramsci deixa explicito a separação entre o Estado e a Sociedade Civil: “ two super structural "levels”: the one that can be called civil society, that is the ensemble of organisms commonly called "privite”, and that of political society or State”. Segundo Gramsci os intelectuais dos grupos dominantes exercem sobre a sociedade civil hegemonia, espontaneamente aceita, enquanto o Estado exerce coerção (GRAMSCI, 1971, p.12). 
necessita ser feita com instituições que estabelecem relações verticais (entre indivíduos e grupos, entre grupos e instituições sociais, entre instituições sociais e a política global e presumivelmente econômica), o que as diferenciam do mundo da vida caracterizado por relações horizontais (solidariedade). O caráter de mediador assume importância particular quando se trata de pensar a presença da sociedade civil, como protagonista de um espaço na democracia, diferente da representação. A questão da autolimitação e da mediação é muito bem tratada na obra de Íris Young, principalmente em seu livro "Inclusion and Democracy" quando atenta para a diferença entre autodeterminação e autodesenvolvimento, mostrando que a sociedade é muito mais preparada para dar conta do primeiro (lutando contra a dominação) do que do segundo, que se constitui em uma luta que envolve processos econômicos os quais necessitam da intervenção do Estado (YOUNG, 2000, 156).

Habermas, comentando Arato e Cohen enfatiza outra característica fundamental da sociedade civil, qual seja, a necessidade de uma vida privada intacta, pois é de cidadãos privados que a sociedade civil é formada. "Habermas detalha esta condição da seguinte forma:

(...) as associações só podem afirmar sua autonomia e conservar sua espontaneidade na medida em que puderem apoiar-se num pluralismo de formas de vida, subculturas e credos religiosos. A proteção da "privacidade" através de direitos fundamentais serve à incolumidade de domínios vitais privados, direitos da personalidade, liberdades de crença e de consciência, liberalidade, sigilo de correspondência e telefone, inviolabilidade da residência, bem como da proteção da família caracterizam uma zona inviolável da integridade pessoal e da formação do juízo e da consciência autônoma (HABERMAS, 2003, p.101).

Garantidas todas as qualidades apontadas por Cohen, Arato e Habermas cabe chamar a atenção para uma última característica da sociedade civil bastante enfatizada nas obras de Young (2000) e Fraser (1997), trata-se da diversidade no interior da sociedade civil, onde classes, interesses, posições de poder, gênero e etnias colocam os cidadãos em posições de poder e de atuação 
distintas e a transformam em espaço onde as relações se constituem através do exercício do poder, do diálogo, do conflito e do consenso.

Em suma, o que se descreveu até aqui é um ideal tipo minimalista de uma sociedade civil moderna que destarte suas diversidades e relações de poder, têm autonomia, é autolimitada e protegida por um conjunto de direitos, que garante uma vida privada intacta aos cidadãos que a formam. Esta sociedade civil tem lugar mais aproximado do modelo em sociedades, onde a democracia representativa tem funcionado de forma mais satisfatória, malgrado suas crises mais recentes, a saber nos países desenvolvidos ocidentais. Nestes países, como chamam a atenção os teóricos elitistas, a presença ou não da sociedade civil pouco tem pesado para o funcionamento das instituições democráticas, entretanto, são neles que se criaram as condições ótimas para o aprofundamento do regime em direção à participação. Todavia, a questão da participação da sociedade civil coloca-se de forma mais concreta em democracias novas, com instituições mais frágeis. É neste cenário, onde o Estado tem recursos escassos e menos eficiência, que a sociedade civil tende a ocupar mais espaços, tanto como prestadora de serviço e como porta voz das demandas da população. O Brasil é um exemplo bastante complexo desta situação, onde organizações da sociedade civil cada vez mais tendem a tomar posições antes do Estado e a gerar ações substitutiva de políticas públicas ${ }^{4}$. No caso específico da violência não foge o padrão geral, a questão é indagar sobre a eficácia de tais ações.

\section{II}

Nas próximas páginas indicarei três expressões da sociedade civil com características bastante distintas do ideal tipo de sociedade moderna traçado anteriormente, trata-se da sociedade civil: militante, tradicional e profissional. A descrição destes cenários pretende trazer subsídios para entender melhor a importância do conceito e a potencialidade das situações concretas, no que

\footnotetext{
${ }^{4}$ Em outra oportunidade discuti está questão, ver Céli Regina Jardim Pinto. A sociedade Civil e a Luta contra a Fome (2005).
} 
concerne a questão da atuação da sociedade civil em uma questão específica. Nenhum destes tipos somados à sociedade civil moderna apresenta-se em estado puro, o que se está buscando é delinear tendências.

O que chamamos de sociedade civil militante tende a estruturar-se em países que viveram ou estão vivendo experiências totalitárias ou autoritárias; ou mesmo em jovens democracias com grandes problemas sociais. São sociedades colonizadas pela política, por projetos políticos e por isto expressam-se frequentemente como movimentos sociais, agindo muitas vezes como contra público ${ }^{5}$ (FRASER, 1997). Diferencia-se basicamente da sociedade civil moderna por não ser auto limitada, pretende um novo pacto ou mesmo a tomada do poder. Este tipo de organização da sociedade, por sua natureza, é na maioria das vezes passageira e corresponde a momentos de crise de regimes autoritários ou grande mobilização política. Exemplo disto são os movimentos pela anistia nos países de regime militar na América Latina; movimentos pela democratização nos países do leste europeu; movimentos ambientalistas; feminista principalmente da década de 80; movimento negro. Quando estes movimentos estão muito próximos de uma luta contra o Estado eles podem perder sua possibilidade manter-se como sociedade civil. Arato, analisando o caso da Polônia durante a queda do regime comunista, aponta para o desaparecimento da sociedade civil quando da chegada do grupo Solidariedade ao poder (2000). Entretanto, a sociedade militante não dirigida à tomada de poder pode deitar raízes na sociedade dos princípios de participação, propiciando o aparecimento de experiências de modelo de democracia participativa como exemplos temos a presença dos movimentos: negro, de mulheres, feministas em diversas instâncias de participação pública e política no Brasil.

Comparando a sociedade civil militante com o tipo ideal de sociedade civil moderna algumas diferenças são muito marcantes, a mais importante

\footnotetext{
${ }^{5}$ Fraser entende como contra público aquele que se forma em condições de dominação e subalternidade. Para ela o exemplo mais marcante é do feminismo que conseguiu dar publicidade a violência doméstica o a sociedade dominada pelos homens (1197; 80).
} 
delas é que surgidas em cenários muito distintos, a moderna sociedade tende a ser mais difusa e alargada, isto é, incluir um maior número de habitantes de uma dada comunidade. A sociedade civil militante, por suas características, exige um envolvimento maior e mais comprometimento com princípios ideológicos e políticos sendo por isto menos capaz de agregar um grande número de pessoas. Como veremos no final deste ensaio, estas duas formas de organização resultam em ações muito distintas no enfrentamento de problemas como, por exemplo, o da violência.

O segundo tipo de sociedade civil é a chamada por vários autores de tradicional. Estudiosos (OBADARE, 2004; LEWIS, 2004; DORJ, 2004; FREIZER, 2004), ao examinarem as sociedades africana, asiáticas e mesmo algumas sociedades latino-americanas chamam a atenção para um alto nível de sociabilidade em comunidades rurais e tribais, onde as elites econômicas e políticas locais, as famílias, os clãs, as tribos, os grupos geracionais e étnicos tomam a si a administração das comunidades, provendo-as com os serviços básicos e mesmo com princípios de organização política. Trata-se de organizações hierárquicas, excludentes que detém poder político, econômico e/ou simbólico. Se comparadas com o modelo, mesmo que simplificado de sociedade moderna que desenhamos acima, não parece que esta última encontra qualquer identidade, mesmo se comparada com o que designamos de sociedade civil militante.

O conceito neste cenário teria o valor de possibilitar a busca neste tipo de sociabilidade, de raízes possíveis para a construção de uma sociedade civil, entretanto, ao contrário da sociedade militante, que pode chegar a uma sociedade civil participativa, o que se verifica é que a sociedade civil quando aparece nestes locais está em oposição a dominação tradicional, não se valendo da experiência anterior. Este fenômeno é próprio de sociedades africanas e de alguns exemplos asiáticos, nos quais o Estado é frágil e não chega às regiões do interior dos países. Uma questão que permanece aqui, e que merece ser mencionada, é até onde estes movimentos podem oferecer uma espécie de cultura solidária e uma garantia de privacidade pessoal como uma matéria prima para uma possível sociedade civil? 
O primeiro problema a se enfrentar é a presença de uma elite que se apropria das funções do Estado e exerce uma espécie de poder privado. O conceito usado desta forma é problemático pelas seguintes razões: 1) revela uma situação comum das elites em estados pobres e incapazes de governar. A privatização das funções do Estado por elites não pode ser indicativo da presença de sociedade civil. Se assim fosse o coronelismo, o caudilhismo, o cacequismo e tantos outros fenômenos semelhantes que têm constituído a política Latino-Americana teriam cores de sociedade civil. Tomando Cohen e Arato, e antes deles Hegel e Gramsci todos concordam que a sociedade civil existe na medida em que o Estado existe, em contraposição a ele ou mesmo como parte integrante dele, ora a fragilidade do Estado e a tomada do poder por elites privadas vai na direção inversa da sociedade civil; 2) uma segunda razão que deve ser tomada em consideração é o não afastamento do conceito de sociedade civil do de cidadania, ou seja de igualdade de direitos ou, em um primeiro momento, de luta por igualdade de direitos, o que não se apresenta nestas chamadas sociedades civis prémodernas ou tradicionais; 3) de outra forma, se é possível fazer um paralelo entre estas manifestações pré-modernas e a moderna sociedade civil ele acontece no momento que esta última assume o caráter de Terceiro Setor, onde as questões de igualdade e cidadania não têm lugar como problemática. Em ambos os casos setores privilegiados da sociedade tomam a si funções que deveriam estar nas mãos do Estado, em ambos os casos se está frente a uma espécie de privatização do próprio Estado.

Em relação a esta questão da sociedade civil tradicional no que concerne a questão da violência cabe chamar atenção para os guetos de solidariedade e troca de favores que se constituem nas favelas e bairros periféricos, muitas vezes liderados por contraventores, ou seja, pelos próprios agentes da violência.

O terceiro tipo de sociedade civil é a que denominamos de sociedade civil profissional, que corresponde a sociedades dominadas por organizações não governamentais, as chamadas ONGs. Estas organizações proliferaram nas últimas décadas do século $\mathrm{XX}$ ao redor do mundo, principalmente, nas 
regiões mais pobres, menos democráticas e menos providas de tradição associativa. Originárias, na maior parte das vezes dos países do hemisfério norte, estas organizações têm grande presença no atendimento das populações pobres não protegidas pelo Estado e na defesa de direitos humanos.

A presença das ONGs na sociedade civil ou como sinônimo de sociedade civil é uma questão bastante complexa assim como a simples identificação destas organizações com projetos do neoliberalismo do norte, para os países pobres do sul de forma alguma esgota a questão, no que pese ser parte dela. As ONGs também surgiram em desenvolvimento ou em países que experimentaram momentos de sociedade civil militante. Na América Latina e, particularmente, no Brasil são inúmeros os exemplos de movimentos sociais que se institucionalizaram através de ONGs, como os movimentos pelos direitos humanos, feministas e os movimentos étnico-raciais., entre outros. Portanto, identificam-se, pelo menos, duas formas diversas de profissionalização: a primeira encontra-se em regiões onde não existe nenhum tipo de organização local e é formada na maioria das vezes por um conjunto de ONGs internacionais, com pouco ou nenhum laço com a sociedade, são meramente prestadoras de serviço a populações carentes. O segundo tipo de profissionalização da sociedade civil é resultado da "onguinização" dos movimentos sociais, quando a militância cede lugar para profissionais, na maioria das vezes, oriundos desta própria militância. Este é um processo bastante presente no movimento feminista e mesmo no movimento negro no Brasil. Neste tipo de cenário também é possível surgir uma sociedade de tipo participativa que tanto pode servir de apoio para expansão da participação da sociedade civil, como pode evoluir para uma espécie de novo poder monopolizado pelas próprias ONGs em espaços participativos do Estado. Esta situação revela um dos nós mais difíceis de serem desatados, na teoria da democracia participativa e na experiência prática.

\section{III}

Os modelos indicados acima não aparecem nos cenários históricos de forma pura. Em sociedades complexas e desiguais, com realidades muito 
distintas convivendo no mesmo espaço urbano e no mesmo tempo histórico, é bastante provável que se encontrem todos os perfis de sociedade civil e muitas hibridizadas. No entanto, acreditamos que os modelos indicados acima são bastante promissores para pensarmos a questão das formas de participação da sociedade civil. A partir destes modelos levantarei quatro hipóteses para a discussão sobre a relação entre sociedade civil e violência no Brasil:

1. A sociedade civil moderna é formada no Brasil, primordialmente, por uma classe média urbana, formadora de opinião pública que se relaciona com a violência se autorreconhecendo como sua principal vítima e se organizando de forma pouco orgânica, em manifestações contra o Estado pedindo mais segurança. Para este grupo a solução para a violência se esgota na segurança.

2. Há no Brasil uma sociedade civil profissionalizada, dentro de ONGs que é oriunda da militância de movimentos sociais ou do próprio ambiente de alto risco de violência e marginalização. A relação desta parcela da sociedade civil com a violência é a de tratá-la como questão social e atuar através de projetos no sentido de construir alternativas para a população jovem moradora das periferias e exposta ao comércio de drogas ilícitas.

3. A sociedade civil brasileira em relação à violência é fortemente permeada por sua condição de classe, onde as classes médias se organizam como vítimas do Estado que não lhes garante segurança, enquanto os setores populares e militantes enfrentam a questão como um problema social buscando solução para evitar a marginalização dos jovens pobres.

4. Há uma terceira forma de intervenção da sociedade civil, também através de ONGs que se dirige ao Estado, mas de forma diferenciada em relação a primeira hipótese. E também diferenciada em relação às duas primeiras, quanto a sua pertença classista, pois está recortada por questões de identidade e de grupos específicos. São as ONGs e movimentos que lutam contra a violência doméstica, por exemplo, em relação às crianças, as mulheres e os idosos. 
Referências

ARATO, A. \& COHEN, J. Civil Society and Political Theory. Cambridge: MIT Press, 1993.

FRASER, N. Justice Interrupts Critical Reflections on the "Possocialists" condition. New York: Routlede,1997.

FREIZER, S. Central Asian fragmented civil society: communal and neoliberal forms in Tajikistan and Uzbekistan. In: GLASIUS, M \& LEWIS, D. \& SECKINELGIN, H. Exploring Civil Society Political and Cultural Contexts London: Routledge, 2004.

SORJ, Bernardo. Sociedades Civis e Relações Norte-Sul: ONGs e Dependência. Working paper, 1 de novembro de 2005.

Disponível em: www.centroedelstein.org.br

Acesso em: 20 de novembro de 2006.

GRAMSCI, A. Selections from Prison Notebooks. London: Lawrence and Wishart, 1971

KOWELL, J \& PIEARCE, J. Civil Society and Development. A critical Exploration London: Lynne Rienner, 2001.

LEWIS, D. "Old” and "new” civil societies in Bangaladesh. In: GLASIUS, M \& LEWIS, D. \& SECKINELGIN, H. Exploring Civil Society Political and Cultural Contexts London: Routledge, 2004.

OBADARE, E. Civil Society in West Africa: between discourse and reality In: GLASIUS, M. \& LEWIS, D. \& SECKINELGIN, H. Exploring Civil Society Political and Cultural Contexts London: Routledge, 2004.

PINTO, Céli R.J. A Sociedade Civil Luta contra a Fome no Brasil. In: Soceidade e Estado, vol 20 n. jan/abr 2005.

YOUNG, Iris. Inclusion and Democracy. New York: Oxford University Press, 2000. 


\title{
PROCESSOS ORGANIZATIVOS, COMUNIDADES E PRÁTICAS SOCIAIS
}

CAPÍTULO 20

\section{A DEMOCRACIA E A ORGANIZAÇÃO SOCIAL DE BASE}

\author{
Aécio Gomes de Matos \\ Universidade Federal de Pernambuco
}

D ara o discurso formalista, a democracia seria uma consequência direta de instituições consolidadas na letra da lei e os direitos de cidadania estariam assegurados justamente pela legislação e pelos compromissos das autoridades assumidos em suas declarações políticas. Ledo engano que nos deixa com cara de bobos, a esperar que os direitos e a justiça social se estabeleçam como um passe de mágica, só porque esses são direitos universais; só porque somos todos iguais perante a lei; só porque vivemos em um país democrático.

Ora, tudo isso parece mistificação quando percebemos que, de fato, as pessoas não são iguais perante a lei. As de renda mais alta parecem ter mais influência sobre as políticas públicas, inclusive sobre aquelas políticas que interferem na distribuição de renda, do que as de baixa renda. (WEAKLIEM, ANDERSEN \& HEATH 2005). O próprio Banco Mundial, sempre muito genérico em relação ao conceito de democracia, revela em seu relatório sobre Desigualdade na América Latina e no Caribe "Rompendo com a História" (2003: 13) que o acesso a serviços de qualidade em educação, bastante desigual em países como o Brasil, é determinante para as assimetrias quanto à influência e ao poder dos segmentos sociais na defesa dos seus direitos da cidadania. 
Os conceitos de liberdade e igualdade que aparecem como fundadores das democracias ocidentais e da Declaração dos Direitos Humanos das Nações Unidas não resistem aos números que apontam quase a metade da população mundial vivendo abaixo da linha de pobreza definida pelas agências de cooperação para o desenvolvimento. Enquanto isso, uma população de privilegiados que vive nos países mais ricos e que não representa mais que um sexto de 6,2 bilhões de habitantes da terra usufruem de padrões de consumo exorbitantes que estão exaurindo as condições de vida sobre o planeta.

Se na diferença entre os níveis de consumo das nações se encontram as causas dos desequilíbrios ambientais que estão degradando as condições de vida de toda a terra, são as desigualdades sociais nos países periféricos onde o discurso genérico sobre a democracia aparece de maneira mais crua. De fato, como pode a democracia resistir ao desequilíbrio do poder econômico quando os 10\% mais ricos na América Latina acumulam quase a metade da renda total e os $10 \%$ mais pobres ficam com menos de $2 \%$. Os episódios frequentes de corrupção na classe política, de manipulação eleitoral, do autoritarismo dos governantes diante da fragilidade das instituições do Estado, não conseguem esconder as incongruências entre desigualdades sociais e democracia. Para Marx, a penúria é, em si, uma condição suficiente da alienação e, portanto, de negação da democracia.

No Brasil, onde se supõe que a democracia tenha sido instalada pelo restabelecimento do estado de direito no período pós-ditadura militar, as enormes dimensões das desigualdades sociais só refletem o paradoxo entre os direitos institucionais e a cidadania. Como conclui o Relatório de Desenvolvimento Humano, de 2006, do Banco Mundial "Equidade Desenvolvimento", as raízes da alienação dos mais pobres estariam correlacionadas às histórias de assimetrias sociais em cada País. Nessa perspectiva, a democracia política e institucional não se instala de fato sem equidade social. 
A democracia representativa com eleições regulares e até mesmo com relativa alternância de poder, mesmo superando os limites das classes sociais, como ocorreu no Brasil com a ascensão do Partido dos Trabalhadores à presidência da República e a de muitos governos estaduais, não conseguiu superar a correlação perversa entre poder econômico e poder político. O processo eleitoral e o exorbitante custo das campanhas justificam mecanismos de acumulação incompatíveis com o poder aquisitivo dos mais pobres e levam as alianças, nem sempre pautadas pela ética, com as mesmas elites dominantes que se perpetuam no poder e terminam por determinar as políticas responsáveis pela manutenção do mesmo modelo concentrador.

No caso brasileiro tivemos a ilusão de que os conselhos da sociedade civil seria um caminho mais direto para a democracia e os colocamos na Constituição de 1988, reforçando seu papel como formuladores e como controle social sobre as políticas públicas. Para Hannah Arendt (apud $\mathrm{GOHN}^{1}$ ), os conselhos consistiriam na única forma política para o exercício de um governo que tenha como princípio a participação e a cidadania.

De fato, mesmo reconhecendo os avanços dos conselhos como expressão da militância política na área de saúde, Cortes (2002) concorda pelo menos parcialmente com Grindle e Thomas (1991) sobre as dificuldades das classes populares na América Latina para constituírem mecanismos de representação devido à fragilidade da sociedade organizada para contrabalançar os interesses das elites que dominam a burocracia estatal. Nossas recentes pesquisas sobre "Redes Sociais em Saúde" (MARTINS et al., 2007) confirmam esse caráter pouco representativo com relação aos conselhos de saúde do Programa de Saúde da Família.

\footnotetext{
${ }^{1}$ GOHN, Maria Gloria. O papel dos conselhos gestores na gestão urbana. Disponível em: http://www//168.96.200.17/ar/libros/urbano/gohn.pdf.
} 


\section{As esferas de organização da democracia}

Essa controvérsia sobre a participação dos segmentos sociais mais pobres nos processos políticos da democracia brasileira, justifica um amplo questionamento sobre a dinâmica da sociedade civil e, em particular dos movimentos sociais, sua capacidade de articulação nas bases populares e, em última instância, seu poder político mudar o Estado, como pretende Gramsci.

Em um texto anterior (MATOS, 2002), procurei analisar esse processo fazendo a distinção entre três níveis complementares de organização, articulando as dimensões macro e micro da organização social sem escamotear as diferenças e contradições dialéticas entre a sociedade como um todo e as sua instâncias: a organização de massas, a organização política e institucional e a organização de base. Organização de massas, onde se inscrevem as grandes mobilizações (eleições, manifestações, contestações públicas), cuja aparente racionalidade dos argumentos e palavras de ordem não conseguem esconder o clima emocional que os fundamenta e que, segundo Pagès $(1998)^{2}$ é indispensável para o engajamento político dos grandes contingentes sociais que representam sua força. A organização institucional se define no plano normativo dos contratos sociais, da divisão instituída dos poderes republicanos, dos direitos e deveres que regulam as relações sociais tornando-se, como diz Lourau (1975: 39), "evidente, intocável e sagrado o que é apenas contingência política, (...) e legitimando no plano ideológico o que só é justificado pela força" (LOURAU, 1975: 39). Finalmente, a organização de base que se diferencia das duas anteriores por ser o espaço onde podem se constituir sujeitos coletivos conscientes de suas identidades em contraposição à impessoalidade das massas e à universalidade das instituições. A organização social de base é um espaço onde se pode

\footnotetext{
${ }^{2}$ Ver Max Pagès (1998) e sua análise do envolvimento emocional das massas no fenômeno revolucionário, como uma regressão criativa caracterizada entre suas diversas fases, por um movimento de contestação do poder instituído. Para esse autor, a contestação se expressa em forma de utopias de mudanças radicais e absolutas, sem que isso represente formas ordenadas de projetos racionais.
} 
construir a práxis pela reflexão crítica das experiências individuais e coletivas, onde se constituem coletivos autônomos que se expressam politicamente nas relações com outros coletivos, com as autoridades instituídas, com outros segmentos da sociedade.

Na minha perspectiva, não se pode pensar em democracia sem a articulação dessas três formas de organização. Uma reflexão sobre a realidade brasileira segundo essas três instâncias permitiria concluir que, embora já tenhamos avançado muito com relação às duas primeiras, a organização de massas e a organização institucional, pouco se avançou com relação à organização de base. Afirmo isso, mesmo considerando que os movimentos sociais estão bastante consolidados no plano local, tanto no campo como nas cidades. O que avançou pouco foi a autonomia desses segmentos locais, conforme voltarei a argumentar mais adiante.

É justamente nessa deficiência de organização social de base onde se concentram as nossas maiores fragilidades políticas e, segundo penso, repousam as maiores expectativas de aperfeiçoamento do processo democrático. E não é por falta de base: o Brasil nunca teve tantas organizações formadas na base. Em 2002 o IBGE (2002) ${ }^{3}$ registrava quase 300 mil entidades sem fins lucrativos, 47 mil das quais estariam comprometidas com lutas sociais em defesa do aperfeiçoamento da democracia.

Do ponto de vista metodológico, a construção desse processo democrático a partir da base chama-se de comunicação reflexiva em Habermas, de práxis em Gramsci, de autonomia em Castoriadis, de política sexual em Reich. O que esses autores colocam em destaque é o processo que permite a formação de uma consciência de si, socialmente inserida, uma articulação estratégica a partir dessa consciência, uma ação coletiva politicamente situada.

É nessa mesma perspectiva que utilizo o conceito de organizador social, colocando o foco nos dispositivos e processos que contribuem para a

\footnotetext{
${ }^{3}$ IBGE. As Fundações Privadas e Associações sem Fins Lucrativos no Brasil 2002 — Rio de Janeiro 2004.
} 
constituição de sujeitos coletivos, como uma unidade autorregulada, se exprimindo pelo reconhecimento recíproco e por sentimento de inclusão, que se caracterizam pelo uso da primeira pessoa do plural, "nós”. Segundo BARUS-MICHEL (1987 p.27),

(...) ao contrário do sujeito individual, o sujeito social (coletivo) não se define a partir de um substrato orgânico que lhe garantiria a integridade. É apenas uma organização, uma unidade postulada, construída, que pretende se garantir a si mesma, para estabelecer a lei que especifica o social.

A importância da base no desenvolvimento da democracia justifica, sim, aprofundar a análise desses processos de construção de sujeitos coletivos, fundamentais ao desenvolvimento da democracia. Por isso mesmo procurei orientar minhas pesquisas tendo como referência o conceito de organizador social, trabalhado por Anzieu (1993:179), numa perspectiva psicanalítica, para designar o que ele chamou organizadores psíquicos inconscientes dos grupos sociais, considerando que existe:

um roteiro imaginário que se representa entre várias pessoas, o sujeito estando geralmente presente no palco a título de espectadores não de ator. Resulta disso... uma representação grupal interna. Em sua conduta, em seus sintomas, em seus sonhos noturnos o sujeito tenta realizar esse roteiro.

Partindo dessa referência, o trabalho empírico com comunidades rurais e depois com comunidades urbanas conseguiu identificar outros tipos de organizadores com referenciais sociológicos, cuja ocorrência já havia sido sugerida pelo próprio Anzieu na mesma obra (pág. 97): “Nem tudo se reduz à psicologia, e há organizadores econômicos, sociológicos, históricos”.

Na prática, a análise do material empírico apontou um conjunto bastante amplo de organizadores sociais que aparecem de uma maneira mais ou menos generalizada na história das comunidades estudadas. Conseguimos ordenar três tipos diferenciados de organizadores:

- Organizadores instrumentais, com a predominância da racionalidade instrumental e da razão técnica. 
- Organizadores simbólicos, respaldando sentimentos de pertencimento, estabelecendo os limites do interno e do externo ao coletivo.

- Organizadores imaginários, que operam fundamentalmente com o imaginário grupal e com os processos inconscientes de identificação.

Cada um desses organizadores parecia ter uma função diferente e um momento preciso de utilidade. Ao mesmo tempo eles coexistiam simultaneamente se reforçando ou se contrapondo, traduzindo estratégias úteis à evolução da organização comunitária, das relações com as instituições públicas, com os proprietários de imóveis e com a sociedade civil.

Do ponto de vista científico, é razoável considerar que o conceito de "organizador social" e sua aplicação à análise sociológica demonstraram não apenas consistência teórica, mas garantiram a formulação de um conjunto de reflexões e sínteses coerentes com a interpretação da realidade social envolvida, podendo servir de base para aprofundamentos posteriores envolvendo outros contextos sociais.

Uma apresentação mais detalhada desses organizadores se justifica aqui como uma referência para aprofundar a reflexão sobre a organização social de base, analisando a maneira como são mobilizados, sua utilidade para a organização das comunidades, sua consistência, eficiência e sustentabilidade no curto, médio e longo prazo.

\section{Organizadores instrumentais}

A organização dos movimentos sociais e sindicais no Brasil nunca foi tão racional. As mobilizações são planejadas com objetivos precisos; as ocupações de terras no campo e de terrenos e prédios nas grandes cidades são organizadas com meses de antecedência; a pressão política é articulada com os prazos da mídia para garantir repercussão social. A organização da comunidade assume o caráter de um dispositivo voltado para resultados 
práticos e objetivos. Esta racionalidade caracteriza a organização dos coletivos de sem terras e sem teto como instrumento útil para que cada um dos seus participantes possa atingir seus próprios objetivos à medida que os objetivos coletivos sejam atingidos. O que motiva a participação é justamente uma razão instrumental que articula os objetivos de cada participante e o esforço de integração para atingi-los.

Entre os organizadores instrumentais, destaco os organizadores políticos que respondem pelas motivações de participação em mobilizações comunitárias e as grandes mobilizações regionais e nacionais que se traduzem como poder de pressão e de ação coletiva. Esses organizadores se fortalecem à medida que aparecem sob forma de reconhecimento da expressão política dos movimentos nas negociações com agências governamentais; na representação política das comunidades junto aos movimentos sociais e partidos políticos; na capacidade de coordenação das manifestações de rua; na hierarquia de decisão e controle social pela hierarquia dos movimentos. São expressões que dão segurança às pessoas e garantia de que a ação coletiva tem mais força política de que o esforço isolado de cada um: $O$ MST, ele é um movimento assim de força, quando tem uma coisa assim, eles conseguem $(2,3)^{4}$.

Os movimentos sociais aparecem assim como dispositivos libertadores, éticos e identificados com as populações pobres (desde o fundamento, até hoje, nós tamos aqui através do Movimento. - 41, 3); uma opção alternativa de organização política objetiva, numa estratégia de confrontação na luta por uma vida digna para suas famílias; confrontação com "o patrão e seus capangas", com "o governo e sua polícia", com riscos calculados e uma chance elevada de sucesso.

\footnotetext{
4 Os textos em itálico são extratos do material empírico recolhido em entrevistas nos assentamentos da reforma agrária, com base nos quais foram elaboradas as análises das pesquisas. Guardamos a numeração no final de cada extrato de frase que informa o número de ordem da entrevista e ao número da página da entrevista de onde foi retirado. As entrevistas da pesquisa de saúde não foram aqui reportadas diante dos limites do tamanho do texto.
} 
Ao contrário do que ocorre com as tramas políticas mais complexas, a luta pela terra e pela moradia tem objetivos bastante claros e o engajamento no movimento social acena com possibilidades concretas de sucesso, justificando o engajamento e os riscos: Aí o pessoal do sindicato passou anunciando num carro de som aí eu fui lá pra reunião e ingressei no movimento $(54 ; 1)$.

Esses organizadores políticos podem funcionar em duplo sentido, como uma força para enfrentar patrões e governo, mas também como poder disciplinador do próprio movimento, inibindo a explicitação das contradições e discordâncias em contraposição aos grupos hegemônicos. ... ou a gente aceitava a cooperativa, ou quando a terra fosse desapropriada, nós ia pra outra área. Aí, nós, bestinha, aí teve a obrigação de aceitar a cooperativa- $(36,3)$.

Um outro tipo de organizador instrumental com grande significado para as comunidades organizadas são os organizadores econômicos, mobilizando para o engajamento em atividades relacionadas que impliquem os meios de subsistência e a melhoria da qualidade de vida sob o pressuposto de que a união em torno dos movimentos sociais torna os trabalhadores pobres mais fortes: Eu vivia, nas periferias da cidade, desempregado, até passando fome e vim pra terra através do Movimento - $(18,6)$.

No caso das lutas empreendidas pelas populações mais pobres, os organizadores econômicos assumem, da mesma maneira que os organizadores políticos, um caráter instrumental. Sua força resulta de uma ponderação entre a falta de alternativas econômicas e do reduzido custo de oportunidade da aplicação do tempo dos desempregados, em contrapartida a possibilidades reais de acesso às políticas públicas que acenam com financiamento para as populações organizadas.

Nós, através da associação, vamos buscar os projetos, já trouxemos pra cá, já conseguimos o fomento, o alimento, já está em andamento o investimento pra plantação de inhame, coco, banana, também um custeio de mandioca, já está tudo no projeto feito - $(63,3)$. 
Observamos ainda, com menos importância nas comunidades, a existência de Organizadores Gerenciais fortalecendo a capacidade de articulação de comunidades que pretendem obter ganhos de sinergia pela ação associativa nos grupos de produção e comercialização, utilizando processos sistemáticos de planejamento e gestão das atividades coletivas. Esses organizadores aparecem mais raramente justamente porque, diferentemente dos organizadores políticos, a maioria não compreende os processos envolvidos.

Aqui quando a gente vai fazer uma coisa, umas querem horta, outras querem uma criação de galinha, outras querem negócio de queijo, outras já querem pra fazer rede, aí não decide, nunca chegam num acordo certo, cada qual quer uma coisa... $(1,5)$

Observamos ainda outros organizadores instrumentais como o uso de tecnologias coletivas, a exploração de recursos naturais de domínio comum etc. De uma maneira geral, pode-se concluir que os organizadores instrumentais dependem do nível de informação e racionalidade das comunidades envolvidas; quanto mais claros e compreensíveis forem os objetivos perseguidos; quanto mais exequíveis pareça ser o sucesso do empreendimento, mais esses organizadores têm força de mobilização, articulação e organização das populações envolvidas.

\section{Organizadores simbólicos}

A lógica de formação das identidades sociais depende das trocas simbólicas que ocorrem em um determinado grupo social. Ao mesmo tempo é possível observar, por exemplo, que o nível de cooperação em uma comunidade tem uma correlação direta com as identidades associadas às origens históricas e a referências comuns nos planos ideológico, cultural e religioso, dando maior coesão e articulação coletiva para definir e atingir objetivos comuns ou complementares.

Entre esses organizadores simbólicos remarcamos a existência de Organizadores Históricos que se constituem como uma das principais referências da formação e sustentabilidade dos grupos e subgrupos 
comunitários, com sentimentos de inclusão social. Relações de parentescos, compadrio e vizinhança, envolvendo famílias com muitos anos de conhecimento, interesses comuns, solidariedade e canais privilegiados de comunicação.

O reconhecimento desses organizadores tem levado os movimentos sociais a utilizar símbolos que possam representar identidades coletivas como bandeiras, palavras de ordem, histórias das lutas. O objetivo maior é constituir uma identidade comum que consolide a organização.

Eu vivia isoladamente num canto sem ser representado por ninguém, cada um por si e Deus por todos e aqui eu acho que mudou porque aqui é todos por um e um por todos, então isso dá muita força, muita força de vontade e lutar de um lado e de outro, a gente unido sempre consegue as coisa $(31,2)$.

Existem ainda Organizadores Ideológicos cuja função simbólica consiste em definir um pensamento comum que sirva para regular as relações sociais de maneira coerente. As pesquisas empíricas constatam a presença nas falas das comunidades com referências a valores éticos e programáticos dos movimentos sociais, divulgados em documentos. O próprio exemplo estoico do comportamento da militância ideologicamente identificada com os movimentos sociais e comprometida com a luta dos trabalhadores.

Aqui, como em outras situações, é preciso considerar que nem sempre a presença desses organizadores ocorre de maneira a reforçar a hegemonia dos movimentos sociais. No caso dos assentamentos da reforma agrária, por exemplo, observamos que, embora reconheçam e aceitem os valores programáticos dos movimentos sociais, sobretudo no que diz respeito à luta dos pobres por justiça social, subsistem referências ideológicas mais ligadas à religião e ao senso comum. Muitas das famílias assentadas têm ideologias conservadoras subsidiárias do pensamento das classes dominantes. Essa contradição entre as ideologias dos movimentos sociais e as posições mais conservadoras das famílias rurais é mediada na fase da luta pela terra, pela adesão incondicional motivada pelos organizadores instrumentais. À medida que se consolidam a posse da terra e 
os créditos que dependem do poder de pressão da organização coletiva, começam a surgir resistências a maiores integrações com os movimentos.

Os Organizadores Religiosos assim como os Organizadores Culturais, têm grande importância para as posturas coletivas das comunidades porque são referências historicamente consolidadas. Nas populações rurais, a tradição da ligação atávica com a terra, com o trabalho no campo. Entre os jovens a modernidade da vida cotidiana nas cidades, o lazer, os esportes, a relação com o tráfico são forças de congraçamento e identificação.

Observam-se ainda nas comunidades estudadas a existência de Organizadores Institucionais que aparecem na constituição de associações e outras entidades coletivas, muitas das quais exigidas pelos órgãos públicos como condição de acesso a recursos. Mesmo induzidas de fora, essas associações tem certa importância estratégica para o desenvolvimento dos projetos da comunidade: Disseram: "não, se vocês quiserem esse projeto, tem que fazer uma associação". Aí fomos atrás, juntemos todo mundo, quem quer, quem não quer $(1,9)$.

\section{Organizadores imaginários}

Depois dos organizadores instrumentais que se estruturam racionalmente em busca de objetivos de curto prazo e dos organizadores simbólicos, que operam na formação de referências coletivas de inclusão social, localizamos ainda um outro tipo de organizador diferenciado dos dois primeiros, particularmente por operar com base nas instâncias imaginárias, ou seja, no plano do inconsciente. Na análise do material empírico trabalhado identificamos três tipos de organizadores imaginários que respondiam a posturas coletivas de grande significado para a vida das comunidades.

Em primeiro lugar, surgem os Organizadores da Liderança mobilizando as projeções inconscientes dos membros da comunidade sobre um líder através da qual se constituem articulações coletivas. Os líderes são pessoas de dentro ou de fora da comunidade (de ONGs, dos movimentos 
sociais) com carisma e interlocução com os movimentos sociais e com as autoridades governamentais.

Ele [líder] trabalha bem, ele traz as coisas, corre atrás de projeto. Ele não pode saber de uma coisa que é boa pra gente que ele vai atrás, ele quer trazer, ele quer ver a coisa correr $(54 ; 3)$.

O reconhecimento do poder do líder, por ser uma pessoa diferenciada na comunidade, representa a projeção das fragilidades de cada um sobre essa figura poderosa (do líder). Constata-se assim uma identidade coletiva constituída a partir de mecanismos inconscientes que se caracterizam pela ambivalência em relação à liderança; ambivalência expressa em posturas e sentimentos de identificação, mas também de negação da identidade própria.

[líder] sempre tá lá, que ele é a pessoa que é mais desenrolada, tem mais estudo de que a gente e é uma pessoa bem educada, sabe? Pessoa que conhece mais do ... da área $(21 ; 4)$.

O medo da gente, é isso, é dele pegar o dinheiro, dar o golpe e desaparecer, não vir mais aqui $(58,3)$.

Essa ambiguidade já é sinal de um outro organizador recorrente nas comunidades que é a luta contra o líder, um movimento inconsciente que resulta de uma forma de organização natural do coletivo para enfrentar o poder do líder. A organização da horda, sem o concurso das lideranças, contra as figuras de poder e autoridade, representa um movimento que parte do inconsciente e se expressa na ruptura com a ordem instituída e na busca de uma organização alternativa. Na linguagem psicanalítica que interpreta as expressões do inconsciente, esse movimento de ruptura caracteriza o enfretamento do complexo de Édipo e a organização da horda objetiva a morte simbólica do Pai.

Esse tipo de reação contra as figuras de autoridades (patrões, governo, lideranças) revela uma evolução na organização da comunidade, as pessoas tentando se entender como sujeitos, rompendo a dependência.

De qualquer maneira aqui era feito escravo. Dia de domingo, ia cortar cana, embola cana no cacete, ajeita a cana, encostava o carro e 
ia. Hoje, o cara vai se quiser, a gente trabalha 2 dias, 3 dias se quiser $(60,7)$.

(Falando do movimento social) Eles não davam valor ao nosso tipo de coisa, como era o nosso projeto, aí resolveram fundar uma outra associação e hoje tem as duas $(1,9)$.

Essa busca de autonomia nem sempre é entendida pelos líderes como um estágio de desenvolvimento da comunidade, gerando reações negativas e tentativas de isolamento dos resistentes: Tem movimento que não quer que a associação seja autônoma, quer que seja submissa a ele porque (risos) pode manipular alguém $(63 ; 3)$.

Considere-se que na maioria das vezes, por conta dessas reações, a luta pela autonomia se expressa de maneira caótica, oscilando entre a autonomia e a ruptura.

As pessoas têm o costume de querer as coisas de mão beijada, elas assim se viciaram em ter as coisas tudo na mão deles, assim eles não costumam dizer não ao presidente da associação; então ele tem que resolver todos os problemas $(30,6)$.

Finalmente, o nível mais evoluído de organização das comunidades se expressa por organizadores imaginários que representam a constituição dos sujeitos coletivos, designados como Organizadores Grupais. A comunidade supera sua fase edipiana de contestação passando a uma forma de organização mais centrada sobre o coletivo, como uma autorreferência, que assume o controle e se apropria de sua história.

Embora se tenham poucos registros dessa fase de organização autônoma nas comunidades pesquisadas, pude constatar que em maior ou menor ênfase existem indicadores da emergência desse tipo de organizador. É o caso das rendeiras, dos tapeceiros, dos produtores e feirantes de produtos orgânicos, assim como dos grupos de jovens com referências culturais e esportivas. A autoimagem comunitária é positiva, o associativismo é diferenciado da média, a autonomia das informações e das iniciativas internas é marcante. 
Infelizmente, a pressão do tempo na luta contra a exclusão social e a miséria leva os movimentos sociais a privilegiar métodos de mobilização mais efetivos no curto prazo. A ênfase em metodologias diretivas e pregações doutrinárias se faz em detrimento da constituição de uma práxis que permita desenvolver uma consciência de si e um espírito crítico mais aguçado. Nessa lógica pode-se entender que quanto maiores e mais presentes são os movimentos sociais, maiores são as chances de sucesso de suas lutas, mas contraditoriamente menos autonomia terão as comunidades locais por eles coordenadas.

Temos discutido muito com as pessoas que nós não precisamos de líder, nós precisamos de grupo, se tiver um grupo organizado que sabe o que quer nós conseguimos ir bastante pra frente, se nós tiver um líder que vai querer ser um líder messiânico ou seja um líder político aí nós não conseguimos muita coisa $(30,6)$.

Apesar da desconfiança generalizada nas histórias e experiências associativas nas comunidades pesquisadas, foram observadas, em estágio latente, tendências à organização autônoma de pequenos grupos no interior dos assentamentos que, se apoiadas de maneira adequada, por metodologias não diretivas, poderiam frutificar em benefício do fortalecimento da organização dos assentamentos.

Aqui ninguém tem chefe, ninguém que manda aqui, nem aqui... 0 problema aqui é um por todos e todos por um $(26 ; 4)$.

Como me referi, no início deste texto, é essa evolução que tira o ser humano e os grupos sociais da alienação para um estágio avançado de autonomia e que se conclui com a constituição e o desenvolvimento de sujeitos coletivos; é o elo que une Habermas, Gramsci, Castoriadis e Reich. É uma luta que vale a pena lutar nessa companhia.

Referências bibliográficas

BARUS-MICHEL, Jacqueline. Le Sujet Social. Étude de Psychologie Sociale Clinique. Paris, Dunod, 1987. 209p. 
CASTORIADIS, Cornélius. L'Institution Imaginaire de la Société. Paris, Éditions du Seuil.1975. 498p.

CORTES, Soraya M.V. Construindo a possibilidade da participação dos usuários: conselhos e conferências no Sistema Único de Saúde Sociologias n.7, Porto Alegre jan./ jun. 2002. ISSN 1517-4522

ENRIQUEZ, Eugene. Organização em análise. Petrópolis. Vozes, 1997.

GODBOUT, Jacques. Pas de représentation sans représentativité. Revue du MAUSS $\mathrm{N}^{\circ}$ 26, Second semestre 2005 (p.90-104). Paris, La Découverte, 2005.

GOHN, Maria Gloria. O papel dos conselhos gestores na gestão urbana. 168.96.200.17/ar/libros/urbano/gohn.pdf

GRINDLE, Merilee S. e THOMAS, John W. Public choices and policy change: The political economy of reform in developing countries. London: The Jonhs Hopkins University Press,1991.

IBGE. As Fundações Privadas e Associações sem Fins Lucrativos no Brasil 2002 - Rio de Janeiro 2004

LEVY, André. Sciences Cliniques et Organisations Sociales: Sens et Crise du Sens. Paris. Presses Universitaires. 1997.

LOBATO, Ana Lúcia Martins. Para além da transferência de renda. Primeira Leitura $\mathrm{n}^{\circ} 1357$ (19/01/2005). Disponível em e-agora.org.br

LOURAU, René. Análise Institucional. Trad. Mariano Pereira. Petrópolis, Vozes, 1975.

MARTINS, Paulo Henrique; FONTES, Breno e MATOS, Aécio Gomes de. "Redes Sociais em Saúde" Relatório de pesquisa encaminhado ao CNPq em agosto de 2007.

MATOS, Aécio Gomes de. A Democracia da Miséria. Cronos, Natal RN, v. 5 e 6, n. 2004/2005, 2006.

- Organizadores sociais: algumas referências conceituais para análise das organizações sociais. Estudos de sociologia, Recife, v. 10, p. 123-154, 2004. 
- Organização social de base: reflexões sobre significados $e$ métodos. Editorial Aboré, 2003

- A Dialética de Formação e Apropriação do Capital Social nos Assentamentos da Reforma Agrária. Brasília, Relatório Final de Pesquisa. IICA-NEAD, 2000.

PAGES, Max. Le phénomène révolutionnaire: une régression créatrice. Paris, Desclée de Brouwer, 1998.

RIBEIRO, José Mendes. Conselhos de saúde, comissões intergestores e grupos de interesses no Sistema Único de Saúde (SUS). Cadernos de Saúde Pública, v.13 n.1, Rio de Janeiro jan./mar., 1997.

WEAKLIEM, David; ANDERSEN, Robert; HEATH, Anthony. Poder direcionador? Um estudo comparativo de opinião pública e distribuição de renda. Opinião Pública, ISSN 0104-6276, v.11 n.2, Campinas, out/2005.

WORNS, Jean-Pierre. Crise de légitimité des élites gouvernementales et politiques françaises, et conditions de refondation de la république. Revue du MAUSS No 26, Second semestre 2005, p.90-104). Paris, 2005. 


\title{
CAPÍTULO 21
}

\section{PROCESSOS ORGANIZATIVOS E AÇÃO PÚBLICA: AS POSSIBILIDADES EMANCIPATÓRIAS DO LUGAR}

\author{
Peter Kevin Spink \\ Fundação Getulio Vargas — São Paulo
}

\section{Os desafios do diálogo}

$\mathrm{O}$ s indicadores sociais e econômicos de grande parte da população e do território brasileiro atestam à situação calamitosa que o país enfrenta; situação esta que foi bem sintetizada por um colega ao usar a expressão "uma catástrofe em câmara lenta”. Mesmo com avanços significativos na provisão de certos serviços básicos, a distancia entre a fraca rede incompleta de apoios mínimos e as metas almejadas na constituição de 1988 continuam grandes.

Exemplo claro deste drama foi fornecido recentemente pelo estudo do Perfil das Famílias Beneficiárias do Programa Bolsa Família divulgado pelo Ministério do Desenvolvimento Social e Combate à Fome em agosto 2007. Comparando as informações do cadastro utilizado pela Bolsa Família com os dados sobre as famílias mais pobres do país identificadas pela Pesquisa Nacional por Amostra de Domicílios (PNAD), o estudo demonstra uma clara convergência nos resultados dos dois levantamentos e comprova que o Bolsa Família está chegando onde precisa chegar. São ao todo 45,8 milhões de pessoas atendidas com a transferência de benefícios que varia de \$18,00 a R \$ 112,00 e, sem dúvida, sua consolidação institucional enquanto política pública de reconhecida importância nacional é uma marca de sucesso do Governo atual. Por outro lado, o fato que é necessário fornecer uma garantia mínima de apoio a pelo menos $25 \%$ da população do país e 
que em muitos dos lugares onde o Bolsa Família está presente, esta é uma das poucas opções de renda disponível, demonstrando o tamanho da catástrofe silenciosa que está se configurando. Torna-se urgente, conforme também apontou a Secretaria Nacional de Renda de Cidadania do Ministério no anúncio do relatório, de "integrar o Bolsa Família a outras políticas públicas”.

Os dados indicam que dos responsáveis legais pelo Programa do governo, 92\% são mulheres; uma escolha consciente recomendada pelo Ministério porque "as mulheres são mais seletivas no gasto e privilegiam as demandas de toda a família”. Sem dúvida, tal decisão tem contribuído para melhorias na autoestima e na posição das mulheres, mas por outro lado também demonstra a fragilidade das relações de gênero nas situações agudas de pobreza. Nas regiões Norte e Nordeste quase 8\% dos, ou melhor, “das” responsáveis tem entre 16-24 anos, em contraste com as regiões Sudeste e Sul onde a porcentagem é cerca de $5 \%$. Na faixa etária oposta, a porcentagem de responsáveis com mais de 55 anos é entre 9\% e 12\% nas regiões Norte e Nordeste, em contraste de 7\%, e 8\% nas regiões Sul e Sudeste.

Como se esperaria de um benefício vinculado com a renda familiar, a inserção no trabalho é precária, sem carteira ou previdência social, entretanto os dados do estudo também demonstram o perigo de assumir de maneira simples que educação é geradora de renda. Enquanto no país como um todo, $16 \%$ dos responsáveis legais se declararam analfabetos e mais de $40 \%$ somente completaram entre a 1-4 série do ensino fundamental (na prática equivalente ao analfabetismo funcional), um outro $25 \%$ das responsáveis legais cursaram entre a $5^{\mathrm{a}}$ e $8^{\mathrm{a}}$ série completa do Ensino Fundamental e mais $12 \%$ entre a $1^{\mathrm{a}}$ e a $3^{\mathrm{a}}$ série do Ensino Médio (há também $0,3 \%$ com ensino superior).

A probabilidade que uma parte significativa da população permaneceria nesta situação é grande, a não ser que se repense o nosso modelo de desenvolvimento de maneira radical. Porque mesmo os efeitos positivos que o pacote de transferências produziu nos indicadores de 
desigualdade econômica, foram longe de ser suficientes para alterar uma situação onde, para citar um estudo analítico sobre a queda recente organizado pelo IPEA, "a concentração de renda brasileira ainda é extremamente alta, encontrando-se o Brasil entre os países com os mais elevados níveis de desigualdade" (PAES DE BARROS, FOGUEL \& ULYSSEA, 2006). Em linguagem direta e clara, vivemos num país onde a diferença entre o salário de um trabalhador urbano qualificado com escolaridade media e o salário de um executivo ou um juiz é de 2,500 \% (25 vezes); ou 5,000\% (50 vezes) em relação ao salário mínimo.

Talvez seja por causa da permanência desta situação geral, que Programas como o Bolsa Família são rotulados de assistencialistas. Porque diante do tamanho do desafio e da situação calamitosa de ausência de trabalho digno ou de uma renda cidadã digna (SUPLICY, 2006), até os efeitos criados pela circulação adicional de R\$ 819,7 milhões por mês no comércio local do país é incapaz de gerar um impacto mais estrutural e alterar significativamente a situação.

Há diversas razões que poderiam ser listadas como justificativa para esta situação, iniciando sem dúvida com anos de políticas econômicas negativamente redistributivas e do contingenciamento constante de investimentos no campo social. Levanta-se também a suspeita de que a naturalização da desigualdade brasileira no campo econômico-social, recortada por questões de gênero e raça, já se consolidou no imaginário social de uma parcela significativa das elites econômicas, sociais, intelectuais e políticas, a tal ponto de transformar-se em práticas ativas cujas consequências são um processo crescente de "apartheid social", conforme a frase de Cristovam Buarque (1994). Ao contrário daquelas que inocentemente ou não, argumentam em favor de nossa democracia racial e nossa igualdade e liberdade, a nossa história aponta para processos de embranquecimento e de um recusa absoluta a reconhecer as obrigações morais em relação a milhares de pessoas e suas descendentes que aqui foram trazidas, contra a sua vontade e forçadas a trabalhar como escravos. Sem repetir os dados, nem todas as 
pessoas em situação de pobreza são afrodescendentes, mas a grande maioria de afrodescendentes continua sendo pobres.

Melhorar o alcance e a efetividade dos diferentes serviços, políticas e programas públicos em qualquer país com indicadores sociais econômicos parecidos com o Brasil, já seria uma tarefa difícil. Fazê-lo numa situação também marcada pelo apartheid social é um desafio de tamanho assustador; porque adiciona à busca da igualdade, a necessidade da equidade. Exige reconhecer que ao falar da inclusão estamos também falando da exclusão e dos múltiplos bloqueios e desvios, das portas fechadas e paredes de vidro blindado que impedem acesso e ascensão.

\section{Canais de acesso, oportunidades, bloqueios e poderes}

Na década de 1940, foi solicitado a Kurt Lewin que elaborasse um estudo para entender melhor porque as pessoas comem o que comem; estudo este que poderia ajudar a direcionar informações sobre hábitos saudáveis e alternativas numa época de escassez. Lewin respondeu basicamente dizendo que não era necessário fazer estudo nenhum para responder a esta pergunta. A resposta era simples: pessoas comem o que comem porque está na mesa. O problema é outro, descobrir como a comida chega à mesa. Com este exemplo, Lewin abriu uma discussão importantíssima sobre os caminhos e os bloqueios, o que chega e não chega, e sobre os posicionamentos diversos sobre o que é válido comer e quando, sobre as diferentes formas de processar ingredientes e de sua disponibilidade e acesso.

Entretanto, os argumentos de Lewin se referiam não somente à construção social da mesa (com ou sem comida ou com ou sem mesa) mas de qualquer acontecimento territorializado num lugar (LEWIN, 1943). Podemos usar, como exemplo, este encontro. ABRAPSO é uma associação bastante democrática, mas porque que eu estou aqui sentado e não em pé ao lado de um pôster tentando atrair atenção àquilo que quero dizer? Um encontro é um acontecimento complexo com tipos diferentes de 
apresentações; por quê? Parece natural distinguir entre simpósio, mesas, pôsteres etc., mas por quê?

No caso específico do aqui e agora neste auditório, um dos canais é construído pelas discussões interorganizacionais sobre agendas entre os membros das comissões e a inevitável negociação de tópicos acadêmicos; e um outro leva à minha presença como alguém que pode assumir o tópico. Mas eu também, enquanto ator social sou produto de uma cadeia de ações e atividades. Vocês também estão aqui por várias razões e para chegar até aqui tiveram que utilizar recursos diferentes, fornecidos ora por vocês ora por outros (por exemplo, tempo, alojamento, transporte). De maneira similar, para "fazer" o encontro era necessário mobilizar salas de aula, equipamento, transporte, comida e equipes de apoio. Os caminhos envolvidos em cada um são muito diferentes. Podemos pensar sobre eles como cadeias ou canais de fluxos de ações e atividades que são, na sua microcausalidade, multidirecionais em caráter. Às vezes um evento estimula um outro, empurra questões e ideias para frente e às vezes é o contrário; as opções são restritas pelas exigências do momento. Às vezes uma atividade para, bloqueada por outras ações, para depois desaparecer ou até ser resgatada.

Em todos estes canais e em diversos momentos, pessoas, agrupamentos, organizações, frentes e redes avocatórias podem intervir e de fato intervém, abrindo e fechando portas para abrir e fechar opções e acessos, permitindo que certos fluxos continuem e fazendo com que outros parem. Cadeias ou canais de atividades e eventos, ações de porteiros, o fluxo do cotidiano - este é o terreno do qual fazemos parte e dentro do qual agimos. Voltando à mesa do Kurt Lewin, quantas práticas e ingredientes culinários desapareceram do cotidiano, só para voltar de maneira mais exclusiva. Um ovo descrito como caipira, que nada mais é do que um ovo produzido por uma galinha permitida de assumir suas atividades normais de ciscar, catar milho, minhocas e outras coisas que encontra pela frente, hoje custa mais do que o dobro de um ovo industrializado e mais ainda se é batizado com um selo orgânico. Antes era o ovo do fundo do quintal, de qualquer um. Assim também é construído o terreno da pobreza e da desigualdade. 
Vamos usar um exemplo do campo da educação. Para ter 100\% das crianças em idade escolar dentro do sistema educativo é necessário, simplificando, trabalhar em pelo menos duas cadeias de atividades ou canais de ação. Um canal leva a educação para as crianças, construindo escolas e outros equipamentos, treinando e contratando professores e auxiliares, organizando currículos, garantindo materiais, livros e merendas. O outro leva as criança para a educação e é composto de leis, mecanismos de transporte, conceitos — como o da pedagogia da alternância usado na área rural— e práticas que retiram outras restrições ao acesso como, por exemplo, a necessidade de trabalhar ou pedir esmola para suplementar a renda familiar. Na sua origem, o Programa Bolsa Escola foi concebido como um instrumento de intervenção nesta cadeia de atividades; para ajudar a abrir portas e reduzir bloqueios num canal de ação que levaria as crianças para a educação. Outros instrumentos também estão presentes, como, por exemplo, os programas de erradicação do trabalho infantil, ou a educação contextualizada sendo elaborada pela Articulação do Semiárido (ASA). Ao olhar para a construção da educação desta maneira, começa-se a compreender melhor a complexidade e a sutileza dos processos de desigualdade cotidianos, porque na prática são muitos os canais diferentes que abrem e fecham as possibilidades de maneira desigual em lugares diferentes para diferentes partes da população. Suas sociabilidades e materialidades são produzidas e reproduzidas por e em conversas-em-ação, muitas conversas e muitas ações. Em cada área de atuação e de interesse público, o cenário se repete, permeado por que Charles Tilly chamou de Desigualdades Duráveis (TILLY, 1999); aquelas desigualdades sistemáticas presentes nas oportunidades de vida que distinguem os membros de diferentes categorias de pessoas socialmente definidas e agrupadas, que perduram ao longo do tempo, sendo reconstruídas nas diversas interações sociais.

Uma boa parte dos sentidos que circulam nas conversas sobre a pobreza, focalizam a pobreza e a desigualdade exclusivamente sob a ótica monetária e individual. Infelizmente, esta categorização acaba sendo reproduzida por programas como o Bolsa Família quando estes são 
apresentados como sendo a solução para eliminar a pobreza. Sendo ações monetárias, vão ao encontro de noções que tem como pano de fundo a ideia de que a pobreza remete à condição de ser “pobre” e "quem é pobre é quem está sem renda”. Ao criticar esta posição, Amartya Sen (1992, 2000) enfatizou a importância de pensar primeiro não em nível de renda mas em sua adequação individual para uma vida digna, onde as pessoas podem ser bem nutridas, ter roupas, abrigo adequado, evitar doenças que podem ser prevenidas e assumir um papel na comunidade de cabeça erguida. Nas nossas sociedades mediadas por dinheiro, renda têm um papel crucial, entretanto, em muitos casos não é a renda que garante acesso a uma vida digna; porque, como Sen argumentou, certos grupos e segmentos da população podem ter dificuldades em converter renda em efetividade por causa de circunstâncias específicas, de inserção, e de discriminação — as desigualdades duráveis. Igualmente, num ambiente cada vez mais urbanizado, certos bens e direitos sociais são considerados como responsabilidade de provisão coletiva; não há como entendê-los a partir da renda porque não há renda que pode supri-los e, de novo, sua distribuição desigual gera, por sua vez, a própria desigualdade. Diferenças na distribuição de transporte, acesso a água potável, esgoto, eletricidade, habitação segura, policiamento, abastecimento, saúde, educação, documentos e informação não somente restringe o exercício pleno da cidadania mas contribuem para criar situações de exclusão parcial, ou de quase exclusão (CASTEL,1997).

Apesar da aparente amplitude da conceituação da pobreza enquanto exclusão parcial e desigualdade social e econômica, muitas vezes assimilada pelas ausências — de dinheiro, educação, saúde, alimentação, integração, liberdade e dignidade- ela contempla realidades extremamente diversas, às vezes mensuráveis, às vezes não, e está diretamente ligada às questões fundamentais da cidadania, da solidariedade coletiva e da democratização da sociedade. John Friedmann após uma longa experiência na América Latina, apontou oito vertentes a partir das quais o processo de inclusão precisa ser compreendido, começando pela base territorial do lar e 
da vizinhança segura —o que ele chamou de um ambiente amigável, que apoia a vida cotidiana. Suas outras vertentes de análise foram: tempo disponível adicional ao necessário para a subsistência; acesso a conhecimentos e habilidades; informação que é relevante, clara, honesta e de confiança sobre métodos, práticas e oportunidades; organização social; redes sociais; instrumentos de trabalho e de vida diária e recursos financeiros diretos ou em forma de crédito. Em cada uma destas vertentes, de lugar para lugar, de território para território, há cadeias de atividade, canais de acesso, jogos de poder, de oportunidades e bloqueios que abrem e que fecham possibilidades e que constroem constantemente este lugar que habitamos.

\section{Participação, empoderamento e emancipação}

Alguns anos atrás recebi de um colega uma foto tirada em La Paz, Bolívia, de uma casa com o ditado do Lênin "si no es parte de la solución es parte del problema” escrito em tinta aerossol. Guardo na minha mesa de trabalho para me lembrar de uma outra expressão, esta vez formulado por uma pessoa anônima e escrito em tinta aerossol num vagão do metrô em Nova Iorque: "if you are part of the solution you are part of the problem". Prefiro o segundo ao primeiro, mas também gosto da contradição que os dois ditados criam entre si.

Há, obviamente, muitas questões a serem levantadas para a psicologia social e não pretendo —e nem tenho a competência— de responder a elas. O pontapé oferecido por Kurt Lewin é um convite de levar mais a sério as questões do lugar e da constante produção e reprodução de socialidades e materialidades (SPINK 2001; LAW \& HASSARD, 1999; LAW \& MOL, 1995). Por exemplo, em São Paulo e algumas grandes cidades, a luta para a possibilidade de usar o espaço da calçada como oportunidade de venda de produtos é uma batalha (às vezes literalmente uma batalha) entre vendedores e fiscais; em outras cidades, se aceita que o pequeno comerciante, ou agricultor, a pessoa que cria seu próprio produto, que corta lenha para vender, estacione sua carroça na rua e venda seu produto. Quais os processos aqui presentes, quais os canais a partir dos 
quais certas ações são consideradas válidas ou inválidas, não por esta ou aquela administração, mas "pelo matrix" de atores sociais implicados na construção social do cotidiano e da naturalização das desigualdades (SPINK \& SPINK, 2006). Afinal —a quem pertence o espaço público? Quando falamos que o lugar é o lugar da gente, ou que tem a cara da gente, de que gente falamos?

O pontapé do Lewin é um convite de levantar um pouco a cabeça e olhar para o horizonte do dia a dia, não como lugar local, mas como lugar onde o local e o global se coincidem e colidem. Quero propor, no tempo que tenho, concentrarmos a nossa atenção sobre três palavras: participação, empoderamento e emancipação. Elas trazem, cada uma, ideias e noções de posicionamento, de inserção e de ação no sentido bem definido por Anthony Giddens "o fluxo de intervenções causais reais ou contempladas de pessoas no processo contínuo de eventos no mundo” e da observação chave na sua teoria de estruturação: em cada momento podemos "continuar ou não continuar”.

Estas três palavras criam expectativas diferentes e vem de lugares e processos diferentes. Pergunto, quais delas melhor se adéqua aos questionamentos que levantamos acerca das desigualdades duradouras brasileiras. É um problema de falta de participação, de falta de empoderamento, ou de emancipação.

O problema com a participação e o empoderamento é que muitas vezes a ênfase tem sido colocada no sujeito ou ator social em foco; a pessoa que terá a possibilidade de participar e será empoderado. Ausente, ou presente somente na penumbra das sutilezas, é o outro; que negou a parte e que negou o exercício do poder. $\mathrm{O}$ empoderamento das mulheres não é um problema das mulheres — por causa de uma imaginária divisão biológica ou natural de trabalho ou qualquer outra razão facilmente contra-argumentada —mas é um problema dos homens e das mulheres inseridos e inseridas numa luta histórica de definição e redefinição de relações de gênero. 
Empoderamento, se retornamos à aula do Lewin, não é a falta de poder de alguém que só precisa receber uma injeção de ânimo para ir para frente, mas ao contrário é produto das circunstâncias e dos posicionamentos apreendidos. Não adianta tentar ir "para frente" se as portas continuam fechadas; enquanto para passar por portas abertas é necessário apenas saber que estas estão abertas. Friedmann na sua análise dos processos de redução da pobreza, fez questão de enfatizar que empoderamento é um processo duplo; tanto a partir das comunidades como também a partir do Estado e é um processo de renegociação de relações. As pessoas em situações de pobreza, mesmo com restrições imensas, estão ativamente engajadas na produção e sustentação de suas vidas. Sem dúvida, o reconhecimento de suas organizações próprias é um passo importante na aceitação de sua presença, mas igualmente presente são as ações do Estado que pode agir para manter, reduzir ou aumentar os bloqueios e as restrições de acesso. Uma clássica definição da política pública, dada por Dye (1981), é útil aqui: "política pública é o que os governos escolhem fazer e escolhem não fazer”.

Talvez seja aqui que podemos reconhecer a contribuição potencial de nossa terceira palavra, emancipação. Ela é explicita em relação ao poder. Uma criança é emancipada quando o pátrio poder não mais têm efeito, um escravo é emancipado quando suas amarras são desfeitas e é livre para escolher o que quer fazer, um povo é emancipado quando se livra de um opressor e para os anarquistas, a emancipação é a liberdade que destrói as amarras dogmáticas, metafísicas e jurídicas e instala a solidariedade coletiva. Usar a palavra emancipação é no mesmo momento agressivo e libertador; é uma indicação das circunstâncias nas quais as pessoas se encontram e também de um movimento de mudança. Não presume a incompetência do outro e muito menos a sua falta de ânimo; ao contrário aponta claramente para a sua situação. Podemos lembrar a expressão bíblica atribuída a Moisés diante o Faraó de Egito, que Martin Luther King evocou no seu pronunciamento Nobel, em Oslo, em 1964: "Let my people go".

O lugar dos processos emancipatórios é o lugar do horizonte diário, da reconstrução de relações possíveis; não é o lugar do céu e dos grandes 
espaços e muito menos do chão imediato; por uma razão muito simples. Estes espaços não existem —o que existe é o lugar. Olhe para a direita, e olhe para a esquerda; pense das múltiplas conexões entre lugares que formam o seu horizonte de ação. É só isso —nada mais. Em termos analíticos podemos falar dos espaços mezaninos e de médio alcance, mas basicamente estamos falando do lugar onde o local e o global se conectam numa pororoca nada confortável, o lugar que habitamos e as suas possibilidades emancipatórias (CEDEÑO 2006; SOUSA SANTOS, 2007); porque é só isso que temos — nada mais.

Boaventura de Sousa Santos enfatizou (2007) a importância da emancipação social a partir de experiências bem-sucedidas em áreas como produção alternativa e democracia participativa, como também em relação ao reconhecimento dos sistemas de conhecimentos distintos dentro de uma ecologia de saberes. O trabalho do Programa Gestão Pública e Cidadania tende a confirmar estas possibilidades de renegociação e de uma pragmática potencialmente emancipatória, entretanto em muitos casos estamos somente no início.

No trabalho do Núcleo de Organização e Ação Social da PUC-SP, tivemos a oportunidade de acompanhar alguns destes processos de médio alcance em maiores detalhes, incluindo atividades dentro do campo da economia solidária, das cooperativas e dos assentamentos urbano-rurais, como também vendedores ambulantes e movimentos explicitamente emancipatórios em outros países. (BICHARA, 2003; IDE, 2006; GOMES, 2005; OLIVEIRA, 2005; CEDEÑO, 2006; NOBREGA, 2006; ZAZULA, 2007).

Entre os diferentes ensinamentos trazidos por estes estudos destacamse, talvez três. Primeiro a falta de conexão frequente entre as pessoas ativamente buscando soluções para sua sustentação econômica e aquelas buscando com toda seriedade apoiá-las. Não são poucas as vezes que as bem intencionadas conversas e argumentos teóricos sobre a solidariedade, a economia alternativa, o verdadeiro ou falso cooperativismo se perde numa retórica emancipatória que ao criar estranheza e a falta de compreensão no 
outro, acaba gerando resultados inversos dos esperados incluindo uma hierarquização dos saberes e um retorno ao conhecimento de regulação (SOUSA SANTOS, 2007). A ausência da horizontalidade dialógica e a negação da ecologia de saberes é um dos elementos constitutivos das desigualdades duráveis.

O segundo é de não tratar de maneira leviana o tremendo e assustador poder que o Estado democrático tem para manter o controle do espaço urbano, como por exemplo, o uso aleatório de instrumentos de repressão contra pessoas que construíram pequenos pontos de comercialização com suas freguesias e que de repente, de um momento para o outro são varridos das ruas, calçadas e praças como se fossem dejetos a serem lavados por jatos de água. A mesma se aplica aos assentamentos, vilas e outras formas de moradia às vezes temporária mas negada a possibilidade de uma inserção formal e respeitável.

O terceiro remonta a tese de Boaventura de Sousa Santos que movimentos emancipatórios são mesmo possíveis. Seus sucessos são e serão sempre parciais, porque são processos de construção de espaços contra-hegemônicos em cenários hegemônicos, seus limites são os limites da tensão entre as possibilidades quando não há luta direta, porque são como Alejandra Cedeño bem resume, iniciativas igualitárias em sociedades de controle (CEDEÑO, 2006). Mas aqui retomamos o argumento crucial de Henri Lefebvre (1991) sobre a produção de espaço, seus sucessos vêm justamente do reconhecimento de que o processo de emancipação é um processo que se expressa pelas materialidades e socialidades de lugares, onde nada é gratuito e onde espaços construídos e conquistados podem ser facilmente retomados.

É neste contexto que os sinais, mesmo ainda fracos, de um Estado que começa a reconhecer as implicações de sua presença como ator constitutivo de lugares precisam ser reconhecidos como positivo, mesmo que com cautela. Construir uma outra relação, especialmente uma que assume a responsabilidade de agir em relação às desigualdades duráveis não 
será fácil. É aqui que entra uma discussão bastante recente, sobre a ação pública, como ponto de interseção entre a política pública e a ação social.

\section{O caminho da ação pública — uma possibilidade intermediária}

Durante uma boa parte da década de 1980, no Brasil, a área pública andou —-mesmo quando preocupada com o social— com muita cautela no campo da participação popular e do engajamento com os movimentos e comunidades. Circulava a ideia de que um bom governo, além de ser eleito diretamente e democraticamente é aquele que administra bem. Havia sim, governos progressistas e voltados a ações bastante inovadoras, mas a ideia de que o bom governo também implicava um diálogo constante com a população, seja diretamente ou via conselhos representativos, ainda não fazia parte do imaginário governamental e menos a ideia da cogestão.

Em contraste, e vindos a partir da base da sociedade, havia movimentos sociais fortes em diversas áreas de atuação pública: movimentos reivindicatórios, movimentos propositivos, movimentos temáticos e de base territorial. A década de 1980 foi considerada a década dos novos movimentos sociais e da redescoberta da sociedade civil enquanto fonte de pressões para mudanças significativas e uma demanda para maior participação no delineamento das políticas públicas.

A constituição de 1988 corrigiu parte deste relativo imbalanço ao obrigar —em certas áreas - e recomendar —em outras - um maior entrosamento direto entre gestores e população em geral a partir de conselhos e fóruns tanto consultivos como deliberativos de diversos tipos. O imaginário do Brasil do "quem manda aqui sou eu" lentamente foi se transformando, especialmente a partir da metade da década de 1990, para o Brasil dos fóruns, dos debates e das inversões de prioridades. Juntou-se aos espaços institucionais abertos pela Constituição, uma nova geração de gestores e técnicos com interesse em agir no nível estadual e, especialmente, no âmbito municipal; produto tanto da renovação universitária, quanto dos movimentos profissionais nos campos sociais 
como, por exemplo, nas áreas da saúde, habitação urbana, serviço social, meio ambiente e segurança alimentar, dentre outras. Pouco a pouco, e às vezes de maneira distinta, os governos subnacionais - especialmente os locais - começaram a reconhecer e a aceitar a importância da presença cidadã na discussão e implementação de políticas públicas. Enquanto por sua vez, a mobilização cidadã começou a ir além da pressão e entrar no espaço da proposta, planejamento e implementação da ação.

$\mathrm{O}$ resultado, mesmo que ainda parcial, foi à mudança em direção a um Estado mais eficaz e disposto a discutir e responder aos anseios apresentados por uma cidadania mais ativa e engajada na busca de soluções. As preocupações e motivações eram de várias naturezas: técnicas —como ser mais eficaz; sociais - como lidar com os desafios atuais; e políticas como fazer isso de modo a ampliar e aprofundar a democracia. Na América Latina, começou-se a utilizar a expressão ação pública para descrever este movimento duplo do Estado para a sociedade civil e da sociedade civil para o Estado, sempre com ênfase nas instituições públicas no âmbito local, especialmente os municípios e outras formas de governo local onde as mudanças têm sido mais significativas. Ação pública (uma fusão feliz de política pública e ação social) pode ser entendida no sentido amplo para compreender as ações das diferentes instituições públicas e também qualquer outra atividade que está sendo articulada na esfera pública e em referência a um bem comum. Inclui atividades vinculadas diretamente ao exercício do poder e aquelas que resultam das atividades de cidadãos quando estão demonstrando sua preocupação ativa com a vida coletiva.

Nos estudos feitos pelo Programa Gestão Pública e Cidadania, tivemos oportunidade de focalizar melhor este processo do lado dos atores do setor público e os resultados, se não amplos, sugerem otimismo. Criado em 1996 como uma iniciativa conjunta da Fundação Getulio Vargas de São Paulo e da Fundação Ford, seu objetivo é identificar, analisar e disseminar práticas inovadoras que emergem nos governos subnacionais brasileiros (estados, municípios e povos indígenas, incluindo o Executivo, Legislativo e Judiciário) para o fortalecimento da cidadania e a melhoria da qualidade 
de vida coletiva. Focaliza experiências — políticas, programas, projetos ou atividades que têm impacto positivo no fornecimento de serviços públicos, que podem ser reproduzidas em outras localidades, que utilizam recursos e oportunidades de maneira responsável e ampliam o diálogo entre a sociedade civil e os agentes públicos. A estratégia utilizada combina uma metodologia de pesquisa pouco convencional na busca de informações (um ciclo de premiação anual aberto a todas as organizações públicas subnacionais, inclusive as de caráter intermunicipal, interestadual ou regional) com um mecanismo coletivo de análise, discussão e retorno das informações colhidas. Reúne assim, elementos dos observatórios de políticas públicas com aspectos de uma postura de pesquisa-ação.

Nos seus dez anos de trabalho, o programa já identificou e registrou mais de 8.000 experiências inovadoras localizadas em mais de 890 municípios de todos os tamanhos -incluindo um número significativo de municípios com menos de 20.000 habitantes - distribuídos por todos os estados brasileiros, além de um número significativo de experiências estaduais e dos povos indígenas. Em termos de áreas de atuação, as mais frequentes, por ordem, são: educação; criança e adolescente; saúde; assistência social; formação de mão de obra e geração de emprego e renda; cultura, patrimônio histórico e artístico; e desenvolvimento local em base sustentável. São, como se esperaria, as áreas de políticas públicas que formam o dia a dia das pessoas e que foram também foco de diversas das ações e propostas constitucionais em termos de descentralização.

Uma das características marcantes na grande maioria de experiências submetidas é a presença constante de alianças e vínculos interorganizacionais com outros atores tanto do setor público quanto de outros setores da sociedade. Ao todo, cerca de $66 \%$ de todos os programas, projetos e atividades inscritos reportam vínculos de trabalho com outros departamentos e agências públicas da mesma ou diferentes jurisdições, $60 \%$ mencionam alianças com 0 que podemos chamar de organizações de base comunitária, empresas e entidades de comércio local e outras associações presentes no lugar. Em $46 \%$ tais vínculos e alianças envolveram tanto outras organizações do setor 
público quanto da sociedade civil e em somente $20 \%$ dos casos não havia menção de outras organizações presentes na atividade inscrita. Em termos gerais, tais dados sugerem que há mesmo sinais de uma nova teoria de gestão emergindo da pragmática do agir consciente e comprometida, a que assume como necessário o engajamento do outro na busca de soluções e, consequentemente, que aceita a presença do outro no controle e no monitoramento dos impactos das mesmas. Ao analisar as razões dadas explicitamente pelos responsáveis das experiências sobre por que as mesmas eram inovadoras, cerca de $20 \%$ responderam que era porque se buscou envolver ativamente a comunidade na identificação e na cogestão da solução.

A disposição de buscar ativamente a presença da comunidade na identificação e na cogestão de soluções pode não representar uma revolução, mas pelo menos é um movimento em direção ao outro, um espaço novo que está sendo construído, uma janela de oportunidade que se abre. Cada vez mais os psicólogos estão saindo de suas inserções tradicionais e atuando na implementação das políticas públicas diretamente nos horizontes do dia a dia. O desafio não é mais de buscar a possibilidade de uma atuação mais ampla, estes canais foram abertos; o desafio agora é de lembrar a aula do Lewin, de ser atento para as ações que produzem e reproduzem as desigualdades; de usar a escuta psicológica para ouvir e reconhecer os sujeitos coletivos e as vozes dos processos emancipatórios; de não ter medo do enfrentamento e começar a ser parte da solução.

Referências

BICHARA, Tatiana Alves Cordara. Exclusão e informalidade: um estudo sobre o lugar social dos vendedores ambulantes de Quito Ecuador. São Paulo: Dissertação de Mestrado, PUC-SP, 2003.

BUARQUE, Cristovam. A revolução nas prioridades: da modernidade técnica à modernidade ética. São Paulo: Paz e Terra, 1994.

CASTEL, Robert. As armadilhas da exclusão. Em: CASTEL, Robert, WANDERLEY, Luiz Eduardo W. \& BELFIORE-WANDERLEY, 
Mariangela (orgs.). Desigualdade e a Questão Social. São Paulo: Editora EDUC, 1997.

CEDEÑO, Alejandra Astrid Leon. Emancipação no cotidiano: iniciativas igualitárias em sociedades de controle. São Paulo: Tese de Doutorado (Psicologia Social). Pontifícia Universidade Católica de São Paulo, 2006.

DYE, Thomas R. Understanding Public Policy. Englewood Cliffs, NJ: Prentice Hall, 1981.

GIDDENS, Anthony. Central Problems in Social Theory. London: Macmillan, 1979.

GOMES, José Agnaldo. A Comuna da Terra: utopia e alternativa. QuitoEcuador: Ediciones ABYA-YALA, 2005.

IDE, Roberto Minoru. Sobre as possibilidades de efetivação das cooperativas no cotidiano: uma aproximação construcionista. Cadernos de Psicologia Social do Trabalho. v.9, n. 2, p. 1-14, 2006.

LAW, John \& HASSARD, John. (orgs.) . Actor Network Theory and After. Oxford: Blackwell, 1999.

LAW, John \& MOL, Annemarie. Notes on materiality and sociality. The Sociological Review. V. 43, n. 2, p. 274-294, 1995.

LEFEBVRE, Henri. The Production of Space. Oxford: Blackwell, 1991.

LEWIN, Kurt. Psychological Ecology, 1943. In: CARTWRIGHT, D. ed: Field Theory in Social Science - selected theoretical papers by Kurt Lewin. London: Tavistock Publications, 1952.

NOBREGA, Juliana da Silva. As possibilidades de uma ecologia de saberes: a negociação de sentidos no processo de incubação. Dissertação de Mestrado, PUC-SP, 2006.

OLIVEIRA, Fabio de. Relações de Trabalho e Sentidos do Cooperativismo. São Paulo: Tese de Doutorado, Pontifícia Universidade Católica de São Paulo, 2005.

PAES DE BARROS, Ricardo, FOGUEL, Miguel Nathan \& ULYSSEA, Gabriel. (orgs.) Desigualdade de Renda no Brasil: uma análise da queda recente. Brasilia: IPEA, 2006. 
SEN, Amartya. Inequality Re-examined. New York: Russell Sage Foundation, 1992.

. Desenvolvimento como Liberdade. São Paulo: Companhia das Letras, 2000.

SOUSA SANTOS, Boaventura de. Renovar a Teoria Crítica e Reinventar a Emancipação Social. São Paulo: Boitempo Editorial, 2007.

SPINK, Mary Jane \& SPINK, Peter. 2006 (orgs.) Práticas Cotidianas e a Naturalização da Desigualdade: uma semana de notícias nos jornais. São Paulo: Editora Cortez, 2006.

SPINK, Peter. O Lugar do Lugar na Análise Organizacional. Revista de Administração Contemporânea, V. 5, Edição Especial, n. 5, p. 11-34, 2001.

SUPLICY, Eduardo Matarazzo. Renda Básica de Cidadania. Porto Alegre: L\&PM Editores, 2006.

TILLY, Charles. Durable Inequality. Berkeley. CA.: University of California Press, 1999.

ZAZULA, Marilene. Os sentidos da economia solidária: os caminhos da construção da autonomia coletiva e organizativa. São Paulo: Tese de Doutorado, Pontifícia Universidade Católica de São Paulo, 2007. 


\section{CAPÍTULO 22}

\section{INTERVENÇÃO PSICOSSOCIAL E COMPROMISSO: DESAFIOS ÀS POLÍTICAS PÚBLICAS}

Maria de Fátima Quintal de Freitas

Universidade Federal do Paraná

\section{Que Psicologia (Social) Comunitária?}

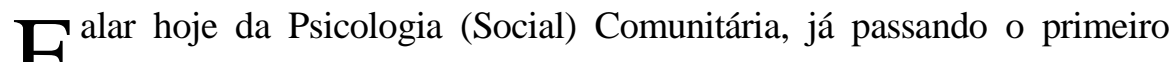
F lustro do século XXI, não tem o mesmo sentido, significado e abrangência como quando falávamos nos idos dos anos 80 ou 90 do século passado, ou mesmo quando do nascedouro desta área na América Latina, por volta dos anos 1960 e 1970, em diferentes países do continente latinoamericano.

Para aqueles que hoje deparam-se, já de início em seus cursos de formação em Psicologia com diferentes disciplinas — por exemplo, denominadas de Psicologia (Social) Comunitária; Psicologia Política; Psicologia e Políticas Públicas; Intervenção Psicossocial em Comunidade; Psicologia, Cidadania e Problemas do Mundo Contemporâneo, entre tantos outros nomes, todos buscando contemplar a realidade concreta atual de nossa sociedade-, torna-se importante assinalar que a Psicologia (Social) Comunitária não ocupou um lugar de destaque nas grades curriculares dos cursos de Psicologia, desde o seu início. Este é um fenômeno recente, seja no Brasil, seja na maioria dos países da América Latina, sem se falar no fato de que ainda em alguns países ela se inicia em sua tímida trajetória de consolidação.

Mesmo que possamos falar, hoje, de uma Psicologia (Social) Comunitária, na verdade, esta teve distintos desenvolvimentos, que 
aconteceram em momentos diferentes, devido às condições e forças hegemônicas dentro da psicologia que estavam mais ou menos atuantes naquele dado momento histórico e social. Poder-se-ia dizer, também, que hoje a existência de variadas formas, denominadas de Psicologia (Social) Comunitária, não necessariamente indica que se tratam de modos de ação e de intervenção comuns, similares e com bases epistemológicas idênticas.

Muitas vezes, no Brasil, por exemplo, nos idos dos anos 60 e 70 do século passado, quando tal disciplina incluía-se no processo de formação dos futuros psicólogos, isto acontecia muito mais por decisões pessoais e opções políticas de alguns professores e psicólogos que defendiam uma formação que fosse, de fato, comprometida com a transformação social, menos elitista e mais conhecedora da realidade social que nos cercava. Entre estes formadores, encontramos importantes psicólogos sociais e comunitários que dedicaram suas vidas e histórias à Psicologia e, em especial, à Psicologia Social Comunitária, Brasileira e Latino-Americanas. Entre eles podemos falar de Sílvia Tatiana Maurer Lane, da PUC-SP, e Ignácio Martín-Baró, da Universidad Centroamericana de El Salvador que, infelizmente, não convivem mais em nosso meio: ela falecida em abril de 2006, em São Paulo, Brasil, e ele barbaramente assassinado em novembro de 1989, em El Salvador. Ambos construíram campos de atuação e consolidaram propostas de intervenção psicossocial em comunidade. Com Sílvia Lane, na PUC, de São Paulo, a Psicologia Comunitária começou a adquirir espaço e visibilidade no Brasil, ainda em pleno regime militar. Iniciam-se com ela os primeiros trabalhos de estudantes de psicologia junto às favelas e bairros da periferia, na cidade de São Paulo, na busca de uma aproximação e desenvolvimento de trabalhos comunitários próconscientização e transformação. Com Martín-Baró, a Psicologia Social Comunitária e a Psicologia Política incorporam-se a vários outros trabalhos sociais no cenário salvadorenho, em pleno período de guerra civil, atuando junto à população na direção da transformação de suas condições precárias de vida. Ambos formaram gerações de pesquisadores e trabalhadores psicossociais que, hoje, atuam e trabalham seja em projetos comunitários, 
em políticas públicas, seja dentro das universidades na preparação e formação de novas gerações de psicólogos sociais e comunitários. Sílvia Lane e Martín-Baró constituem-se em dois importantes marcos na construção do Campo da Psicologia Social Comunitária no Brasil e na América Latina, que se distingue, histórica e politicamente, do campo correlato nos EUA e na Europa.

\section{Marcos na consolidação do campo da Psicologia Social Comunitária}

Alguns aspectos parecem-nos relevantes de serem destacados nesse percurso histórico, em especial para aqueles que hoje, ao chegarem, nas universidades e nos diversos campos de atuação já se deparam com esta denominação, podendo ter uma ideia incorreta de que esta área já seria comum e estaria integrando a psicologia desde os seus primórdios (FREITAS, 1998, 2000a, 2000b; MONTERO, 1994, 2003). Em verdade, a Psicologia Social Comunitária (PSC) passa a compor, efetivamente, os currículos de formação de modo constante e obrigatório, a partir da década de 1990. Ou seja, no Brasil, quase 30 anos após a criação dos cursos de psicologia é que a disciplina —psicologia comunitária ou psicologia social comunitária - sai do ostracismo e marginalidade, passando a integrar oficialmente o processo formativo dos futuros psicólogos.

O fato de, felizmente, estar havendo hoje uma ampla divulgação e expansão das práticas psicossociais em comunidade — envolvendo diversos setores e segmentos da sociedade civil, e podendo ser realizados em espaços variados e inusitados de atuação - não significa que haja uma similitude ou consenso — teórico, metodológico e epistemológico- entre elas. Trata-se, de um debate a respeito das orientações teórico-filosóficas que norteiam o desenvolvimento dos trabalhos em comunidade, de tal modo que a escolha ou opção por determinadas ferramentas para a compreensão do que venha a ser 'o fenômeno psicológico na dinâmica comunitária', nada mais faz do que revelar os graus de coerência em relação aos princípios ontológicos e filosóficos adotados (FREITAS, 2003b). 
O conhecimento e a detecção das dificuldades enfrentadas na construção de campos de ação em Psicologia — como foi o caso da Psicologia Social Comunitária - permitem identificar e compreender as bases teórico-conceituais que, hoje, fazem parte e orientam diversos trabalhos dentro desta perspectiva. Assim, dependendo das problemáticas locais críticas, da natureza das instituições e da formação teórico-política dos pesquisadores e profissionais envolvidos, quando da realização e construção destas práticas comunitárias, pode-se dizer que diferentes campos da psicologia estão tendo prevalência em relação a outros, de tal modo que podemos nos deparar com distintas psicologias, com distintos desenvolvimentos teórico-metodológicos, realizados em diferentes lugares e instituições. Desta maneira, os acontecimentos históricos — de nosso país, continente e em nossa profissão- mostram que as áreas da Psicologia que conhecemos não foram todas implementadas e desenvolvidas, ao mesmo tempo, da mesma maneira e com os mesmos referenciais epistemológicos. Revelam, ainda, que essa implementação não aconteceu com o mesmo conteúdo, expansão e sistematização. E, nos dizem ainda, que as áreas psicológicas nem sempre tiveram as mesmas características e apontaram na mesma direção em termos de resultados teórico-metodológicos e impactos profissionais, independentemente da semelhança dos quadros teóricos que foram utilizados. Estes são aspectos que nos parecem relevantes e mereceriam uma discussão mais aprofundada se quisermos, por exemplo, discutir o processo e as condições de formação de novos quadros para os campos da prática da psicologia.

Na trajetória de construção e consolidação do campo da Psicologia Social Comunitária encontramos alguns acontecimentos e marcos, nas décadas de 1960 a 1990, que desempenharam um papel importante. Podem ser indicados seis deles:

A] A meados dos século XX, os chamados "trabalhos comunitários", no Brasil e na América Latina, eram dirigidos aos setores populares e aos grandes contingentes de migrantes, tendo o intuito de adaptá-los, inseri-los ou adequá-los às novas condições de moradia, trabalho e convivência 
urbanas. Eram trabalhos desenvolvidos pelos profissionais do Serviço Social, Educação, Saúde e Ciências Sociais (FREITAS, 1998, 2000a), em sua maioria dentro de uma visão, ainda, de ciência neutra e pretensamente isenta de ideologias.

B] Os projetos políticos oficiais desta época buscavam a participação de profissionais com a finalidade de que desenvolvessem projetos comunitários voltados para a neutralização das reivindicações dos novos moradores e/ou trabalhadores. Este período - conhecido como de 'desenvolvimentismo' nos trabalhos comunitários, dos projetos de educação básica/alfabetização, e dos planos governamentais de casas populares (Freitas, 2000b) - reúne ações comunitárias e educativas, tuteladas pelo Estado, que primaram pelo assistencialismo e paternalismo.

C] Mesmo durante a ditadura militar no Brasil e em outros países da América Latina (anos 1960 a 1980), são desenvolvidos trabalhos claramente comprometidos com os setores populares e tendo a participação de psicólogos (FREITAS, 1998; MONTERO, 1994, 2003; SÁNCHEZ, 2000). Embora ainda tímidas e poucas, estas práticas ganham mais visibilidade e compõem propostas de ação nos projetos de investigação/extensão nas universidades. E, já ao início dos anos 1970, integram parte de uma disciplina oficial, nos currículos de psicologia, denominada de Psicologia Comunitária (FREITAS, 2000b).

D] Aparece a Educação assumindo um papel de compromisso com a transformação social (FREITAS, 1998; MONTERO, 1994), expresso na proposta político-pedagógica de Paulo Freire através da alfabetização, e na Educação Conscientizadora e Libertadora (BARREIRO, 1985; FREIRE, 1973, 1976). São os trabalhos de Educação Popular e da Educação de Adultos, realizados no Nordeste do Brasil, nos anos da década de 1960, estendendo-se para América Latina e África.

E] Internacionalmente, presenciam-se inúmeras reivindicações contra a fome, miséria, desemprego, analfabetismo e doenças, destacando-se: 1) as "barricadas de Paris" com a participação de Simone de Beauvoir, Jean Paul 
Sartre, Marcuse, Habermas, que denunciam a omissão das universidades na realidade social, caracterizando a chamada "Crise" do Modelo das Ciências Humanas e Sociais; 2) os movimentos acadêmico-científicos e comunitáriosociais de envolvimento da ciência com a sociedade, como nas propostas de David Laing, Basaglia, Berlinguer, Thomas Szasz, entre outros; 3) a denúncia do preconceito e racismo presentes no Apartheid na África e populações indígenas; 4) a fome denunciada nas figuras esqueléticas e sub-humanas dos habitantes da região do Biafra, Somália e tantos outros; 5) as várias tentativas de participação democrática dos latino-americanos contra as ditaduras militares em países como Argentina, Chile, Peru, Paraguai, Brasil; 6) a singular presença da Igreja Católica, neste período, declarando-se a favor dos pobres e oprimidos, através dos trabalhos das CEBs (Comunidades Eclesiais de Base), na perspectiva da Teologia da Libertação; e, 7) a luta dos camponeses por melhores condições de vida, juntamente com os trabalhos de participação e Investigação-AçãoParticipante (IAP), como os desenvolvidos por Orlando Fals Borda.

F] A criação oficial da Associação Brasileira de Psicologia Social (ABRAPSO), em 1980, que fortalece a aproximação e comprometimento da psicologia e, em especial da Psicologia Social Comunitária, para com a realidade concreta das pessoas, no Brasil e no continente latino-americano (FREITAS, 1998, 2000b, 2003).

Pode-se dizer que as práticas comunitárias, ao longo destas quatro décadas, revelam um 'fazer' diferente da psicologia em comunidade, destacando-se quatro aspectos: todas eram práticas orientadas por um tipo de Psicologia Social, Nacional e Latino-Americana, que buscava conhecer a realidade concreta das pessoas; eram trabalhos que explicitavam algum tipo de compromisso político em favor dos setores populares; defendiam uma ligação necessária com outras áreas do conhecimento; e criticavam as teorias psicológicas que fossem a históricas e reducionistas e que, infelizmente, predominavam na formação dos futuros psicólogos. 


\section{Desafios contemporâneos e temas presentes nas práticas psicossociais}

A partir de meados da década de 1990, começamos a presenciar importantes mudanças no campo da prática da psicologia em comunidade (FREITAS, 2005). Temos o aparecimento de diferentes instituições e entidades da sociedade civil, que se comprometem e se preocupam com os direitos básicos das pessoas e com a garantia de uma vida social digna. Assistimos à procura de diferentes segmentos e instituições da sociedade por atuações dos psicólogos que sejam 'diferentes das tradicionais' ou atuações novas, dirigidas aos problemas vividos pelas pessoas em suas vidas. São demandas associadas à saúde pública e coletiva, à violência cotidiana e doméstica, às formas de intolerância e preconceito para com as minorias sociais, às diferentes redes de relacionamento social e interpessoal. Neste cenário, ampliam-se as ONGs, cria-se o chamado Terceiro Setor, fortificam-se os trabalhos de caráter assistencialista e curativo, ao lado ainda de alguns trabalhos comunitários que se mantém na perspectiva de buscar uma participação ativa da população como autora de sua própria história.

Deparamo-nos, na atualidade, com inúmeros grupos e entidades cujos trabalhos comunitários defendem necessariamente alguma intervenção independentemente do caráter ser transformador ou mantenedor - que esteja dirigida (seja numa perspectiva curativa e pontual, ou preventiva e educativa) aos mais 'pobres, oprimidos, explorados', aos que estão 'excluídos da sua condição de cidadãos' (FREITAS, 2005, 2006; GOHN, 2000; MARTÍN-BARÓ, 1987, 1989; SCHERER-WARREN, 1999; WATTS, GRIFFITH \& ABDUL-ADIL,1999). Observa-se, também, um deslocamento do foco das análises psicossociais, saindo de uma visão totalizadora e histórica para uma ênfase em temas ou situações pontuais e focais, circunscrevendo a análise a fragmentos ou parcelas dos acontecimentos.

Diante deste quadro, poder-se-ia dizer, também, que estaria havendo uma espécie de substituição dos paradigmas de ação coletiva dos movimentos sociais, que existiam nas décadas de 60 e 70 (FREITAS, 2002, 2005; GOHN, 
2000) por uma espécie de paradigmas da “individualidade” e ações imediatas. Poder-se-ia, num primeiro momento pensar, à semelhança de Montero (1994; 2003) que estaria havendo uma convivência de paradigmas. Entretanto, parece-nos que há um “algo” a mais, na atualidade das relações globalizadas e bombardeadas por quantidades de informação, que não permitem um aprofundamento qualitativo das mesmas. Assim, estaria havendo uma espécie de substituição do Paradigma da Ação Coletiva (GOHN, 2000) por uma espécie de um Paradigma da "Presentificação da Vida Cotidiana” (FREITAS, 2005, prelo) em que se instauraria certa "luta (ou competição) polida e velada” em que presenciamos o renascimento de propostas e modelos antigos, agora à luz do mote, politicamente correto, da "defesa do social” como sendo uma condição sine qua non para dizer que os trabalhos são 'mais' comprometidos (FREITAS, 2005, prelo).

Nesta linha de reflexão, no quadro atual, pode-se dizer, então, que nos deparamos com inúmeros projetos de intervenção e ação comunitária, que apresentam algumas incoerências e paradoxos. Embora tais trabalhos defendam uma melhora na vida das pessoas e manifestem uma preocupação com as condições sociais delas, os projetos políticos e os seus compromissos efetivos são secundarizados, sobressaindo uma forte preocupação para com a quantidade e eficiência das ações pró-cidadania e pró-inclusão, como se os resultados e os números pudessem substituir os processos de formação, conscientização e participação. Ou seja, como se tais resultados ‘eficientes’ pudessem, por si só, ser sinônimos de projetos e compromissos políticos, em longo prazo, para a construção de uma sociedade mais justa e melhor.

Que fotografia, então, podemos fazer sobre os trabalhos comunitários que têm sido realizados e divulgados em diferentes eventos científicoprofissionais? Que temáticas e preocupações têm guiado a realização destas intervenções psicossociais?

Tendo como referência os trabalhos e práticas em comunidade, independentemente de quais sejam suas vertentes teórico-metodológicas, 
verifica-se que inúmeros cursos (rápidos ou longos, de formação ou não) têm sido realizados abordando as seguintes temáticas (LIVRO DE PROGRAMAS, II CONGRESSO BRASILEIRO PSICOLOGIA: CIÊNCIA E PROFISSÃO, 2006): a) Infância, Juventude e Violência sexual e social; Tipos de Ações, Penas e Medidas Socioeducativas; Varas da Infância e Juventude, Conselhos Tutelares e Políticas Afirmativas e de Cidadania; b) relações no campo da saúde; o SUS, os Conselhos Gestores e as Formas de Gestão em Saúde; c) diferentes formas de intervenção psicossocial, participação e a gestão participativa em: instituições, comunidades, terceiro setor e ONGs; e d) a economia solidária, a Terra e as condições/relações de trabalho.

Já do ponto de vista da prática de intervenção, observa-se uma expansão das fronteiras de atuação, assim como uma variedade de temas e possibilidades de parceria investigativa/intervenção nos trabalhos desenvolvidos. Isto mostra alianças teórico-metodológicas pouco comuns nos primórdios da Psicologia e que, hoje, estão tendo uma maior visibilidade, aceitação e, principalmente, compreensão da sua necessária interconexão. Entre estes temas encontram-se: a) as relações entre Comunidade, Escola e Família enfocando; b) as relações entre Envelhecimento, Família, Trabalho e qualidade de vida; c) os efeitos da precarização das relações de trabalho; d) interfaces entre aspectos psicossociais ligados à criança, juventude e família; e) mulher, gênero, sexualidade e novas formações familiares; f) relações e impactos da saúdedoença; g) diferentes formas de violência e discriminações sociais.

Apesar da amplitude destes temas, que têm sido objeto nos diversos trabalhos comunitários, pode-se dizer que surgem três aspectos importantes a respeito destas práticas, quais sejam: 1] indicam possibilidades e situações para o desenvolvimento do trabalho da psicologia, algumas mais novas e incomuns do que outras; 2] estas situações revelam necessidades prementes, vividas por diferentes setores da sociedade civil que têm solicitado uma participação da psicologia; e 3] indicam os desafios a serem enfrentados quanto "ao quê fazer”, seja no encontro de soluções adequadas aos problemas 
da realidade, seja na formação que deve dirigir-se a estas demandas, ultrapassando os modelos tradicionais de formação em psicologia.

\section{Práticas realizadas e desafios enfrentados}

Em que grandes áreas ou campos de trabalho a ação da psicologia poderia estaria acontecendo? Pode-se dizer que os diferentes trabalhos seja de um modo pontual e localizado, dirigido à resolução imediata dos problemas, seja numa perspectiva mais ampla de buscar planejamentos político-comunitários visando a resolução a longo prazo desses problemas - abordam e questionam aspectos relativos à Cidadania, aos processos de Inclusão e Exclusão, e a uma busca de melhoria na qualidade de vida das pessoas.

E o que estas diversas práticas nos revelam? Num primeiro momento, poder-se-ia pensar não haver diferenças significativas entre tais práticas. Entretanto, existem sim distinções, seja quanto à maneira distinta de encaminhar as ações, seja quanto à forma de explicar os determinantes das problemáticas vividas pelas pessoas.

Assim, ao longo da trajetória da Psicologia Social Comunitária, algumas categorias conceituais tornaram-se decisivas para as propostas de ação e intervenção comunitárias, como: a) a rede de relações dentro da comunidade; b) as lideranças autóctones e os processos psicossociais de formação; c) as formas de opressão, discriminação, competição e preconceito existentes na rede comunitária e cotidiana; d) as crenças e valores em relação a si mesmo, aos outros e às possibilidades de enfrentamento das adversidades; e) as formas de coesão, cooperação e conscientização entre os diferentes participantes; e f) as diferentes formas de ação (individual e coletiva) e as possibilidades de politização da consciência na rede comunitária.

Pode-se, então, dizer que a Psicologia Social Comunitária se diferenciaria em relação às outras práticas em comunidade destacando-se três aspectos. Num primeiro, em coerência à sua proposta de transformação social, a Psicologia Social Comunitária assume, também, uma ação 
pedagógico-formativa, já que deve ter um caráter preventivo na perspectiva de implementar projetos políticos que resultem em mudanças na vida cotidiana das pessoas. Quando os problemas já estão localizados, deve também desenvolver ações pontuais e específicas, sem contudo perder a perspectiva das possibilidades históricas presentes em um projeto político de sociedade. E, por fim, trata-se de um trabalho que necessita ser realizado em equipe, inclusive com outros psicólogos que atuam de modo mais específico e pontual. Desta forma, pode-se dizer que os trabalhos da Psicologia Social Comunitária devem ser dirigidos aos processos de conscientização e participação construídos na rede da vida cotidiana e comunitária (FREITAS, 2002, 2003b, 2005, prelo). Em cada etapa dos trabalhos comunitários, constitui-se como objetivo buscar os liames que se estabelecem entre estes processos e a rede de relações na vida cotidiana, de tal modo que possam ser fortalecidos os suportes sociais e maximizadas as redes de solidariedade, orientados por uma perspectiva mais coletiva de existência (FREITAS, 2006).

Observando-se a ampliação na realização dos trabalhos comunitários, em especial a partir dos anos 90, verifica-se que as práticas psicossociais em comunidade podem ser agrupadas em três blocos, revelando finalidades que as diferenciam: 1) referem-se a programas comunitários novos ou já em andamento em um dado lugar, objetivando o fortalecimento da equipe de trabalho e/ou possibilidades de intervenção psicossocial naquele espaço; 2) referem-se a problemáticas enfrentadas por diferentes setores/grupos, desde as ligadas ao suporte e estrutura/equipamentos institucionais (condições de moradia, saneamento, transporte, áreas de lazer); passando por questões ligadas à violência, desemprego e saúde comunitária; até problemas mais pontuais mas com impacto na dinâmica comunitária (alcoolismo, relacionamentos, processos psicossociais de solidão e envelhecimento, entre outros); e/ou 3) atendem demandas específicas de entidades (sindicais, profissionais, gremiais e comunitárias) para problemas pontuais e individuais, ou desafios das dinâmicas comunitárias (como as repercussões psicossociais da aposentadoria, desemprego, mercado informal, entre outros). 
Indagar sobre o 'papel social e profissional dos psicólogos sociais comunitários e sobre os compromissos que deveriam assumir', continuam sendo desafios importantes às intervenções psicossociais em comunidade. Estes desafios referem-se a quatro dimensões: à percepção sobre a realidade; a o quê fazer no dia a dia do trabalho comunitário; às relações estabelecidas e aos impactos produzidos. $\mathrm{O}$ primeiro deles refere-se àquilo que o profissional consegue detectar em sua prática, que critério utiliza e que elemento possui para saber se no caminho mais adequado das propostas de ação. Os desafios relativos a 'o quê fazer' indicam a necessidade de serem explicitadas as dimensões psicossociais presentes nos processos de submissão e conformismo, no dia a dia das relações comunitárias. O terceiro desafio refere-se ao tipo de relação que se dá entre profissional e comunidade e como isto pode afetar a continuidade das práticas comunitárias. E, finalmente, os impactos do trabalho e o compromisso assumido quando de sua realização constituem-se em desafios constantemente renovados e que, inclusive, colaboram para o fortalecimento ou enfraquecimento do trabalho comunitário.

\section{Legado e dívidas da Psicologia Social Comunitária}

Poderíamos, neste momento, pensar em grandes questões que se apresentam às práticas em comunidade, dentre as quais ressaltam-se as referentes ao tipo de dívidas que nos foram deixadas, e como poderíamos saldar os débitos sociopolíticos e epistemológico-éticos durante a realização de nossas práticas comunitárias. Isto significa pensar no que os séculos passados, e, em especial, o século XX nos deixou de legado.

Então, que aspectos positivos e que aspectos negativos este legado revela? De positivo, temos duas tarefas que constatamos ter nos países do Terceiro Mundo. A primeira é que os trabalhos comunitários e a busca de soluções dignas só têm sentido se fortalecerem as dinâmicas comunitárias dentro de uma perspectiva de libertação e transformação social. A segunda tarefa refere-se a "o quê fazer" para voltarmos a construir e fortalecer valores fundamentais de convivência humana, numa dimensão digna e 
solidária, evitando a perda de valores de humanidade, perda esta vista como 'natural' no mundo atual. De negativo, identificam-se armadilhas presentes em análises fragmentadas e a históricas sobre as condições reais de vida da população, contribuindo para visões naturalizantes sobre as mesmas.

Diante disto, poder-se-ia dizer que um desafio central colocado, hoje, aos trabalhos comunitários, localiza-se em um patamar anterior à própria organização e mobilização comunitárias e ao fazer psicossocial. Isto estaria indicado na indagação: de acordo com que princípios e valores as pessoas agem, se mobilizam e se organizam, para buscarem benefícios coletivos e justos a todos em seu cotidiano comunitário?

Além disto, cabe ressaltar que os trabalhos e práticas comunitárias também são trabalhos e programas educativos. Podem adotar desde a concepção de uma Educação Crítica e Conscientizadora, como a de Paulo Freire e as propostas de politização da consciência, até utilizar aspectos instrumentais visando a formação de pessoas para lidarem em seu cotidiano, adequadamente, com tarefas simples e complexas.

Responder a estas considerações e desafios, constitui-se em identificar uma grande dívida de nossa prática e profissão para com a nossa sociedade e para com a vida. Dentro das dívidas que temos - seja para com a pobreza, o desemprego, a precarização das relações e as diferentes formas de miserabilidade e violência na vida; seja no enfrentamento das sutis e variadas formas de desumanização e rompimento das bases de solidariedade- podese indagar: Em relação a que dívidas podemos — como psicólogos(as) comunitários(as) - ter uma ação, de fato, efetiva e comprometida? Em outras palavras, qual seria a "nossa parte” frente a estas dívidas e o que poderíamos fazer em nossas práticas de intervenção em comunidade?

Traduzem-se aqui, estes questionamentos em cinco grandes desafios que são colocados à Psicologia Social Comunitária Latino-Americana e que se referem às ações e intervenções comunitárias, quais sejam: 1] Como recuperar e reconstruir redes de convivência mais humanas e solidárias entre as pessoas?; 2] Como fazer com que as pessoas voltem a ter um 
projeto coletivo, em que o "outro social" deixe de ser um potencial inimigo?; 3] Como (re)criar um projeto de vida que seja, de fato, comunitário nas relações cotidianas?; 4] Como ter projetos que também formem e eduquem dentro das diferentes políticas públicas?; e 5] Como garantir uma perspectiva de transformação social e politização da consciência, quando os projetos e programas estão dirigidos a problemáticas fragmentadas da realidade social?

Hoje, presenciamos uma mudança na expressão das contradições e dificuldades que os setores populares vivem, ao lado de um grande movimento da sociedade que se mostra preocupada em ajudar.

Em vários momentos, isto cria a falsa ideia de que melhoraram as condições perversas de marginalidade e exploração, já que aumentaram os grupos e segmentos da sociedade civil que se envolvem em algum tipo de ação pró-cidadania. Infelizmente, não é o fato de haver este aumento da "vontade de ajudar" que gera uma diminuição dos problemas concretos, eliminando os determinantes dessas situações de opressão e exploração.

Tendo por base esta exposição, defende-se que o foco — para o qual a Psicologia Social Comunitária deve se voltar- refere-se a aspectos psicossociais, presentes nas relações cotidianas, que hoje aparecem de modo mais sutil e velado, constituindo-se em entraves para os processos de participação e conscientização dos atores sociais envolvidos em propostas comunitárias.

Finalizando, poderíamos indicar cinco aspectos relativos às contribuições da Psicologia Social Comunitária no cenário dos trabalhos comunitários, ao longo de sua trajetória no Brasil e na América Latina, quais sejam:

1] A Psicologia Social Comunitária continua aglutinando trabalhos e experiências de campos disciplinares diferentes, como os da Educação Popular, os trabalhos da Investigação-Ação-Participante (IAP) com os setores do campo e das periferias das grandes cidades (FREITAS, 2002, 
2003b, 2005, prelo). Com isto, redimensiona seu papel, também, como um trabalho Educativo e Pedagógico.

2] A Psicologia Social Comunitária dirige-se, fundamentalmente, à retomada dos processos psicossociais — conscientização e participaçãoassim como a conceitos como exclusão-inclusão-participação enfocandoos como categorias dialéticas histórico-socialmente construídas (FREITAS, 2005, 2006). Reforça-se, assim, a importância das análises macro e microssociais para a compreensão dialética da totalidade histórica da vida cotidiana.

3] A Psicologia Social Comunitária dá lugar central à Comunidade como foco nas relações e ações comunitárias. Encontramos, pela primeira vez, neste campo a Comunidade como categoria central de análise e de possibilidades de ação concreta (FREITAS, 2003b, 2005).

4] Nos trabalhos da Psicologia Social Comunitária, a vida cotidiana constitui-se em matéria prima para análise dos processos de conscientização e participação. Isto se refere a algumas das proposições em que se vem trabalhando, em que há uma preocupação em articular a Vida Cotidiana com as diferentes Estratégias de Sobrevivência e Resistência Psicossocial (FREITAS, 2003b, 2005, prelo), como forma de compreender as possibilidades de avanço e recuo dos trabalhos comunitários.

5] A Psicologia Social Comunitária defende o fortalecimento de redes de solidariedade, para que possa ser construído um projeto de sociedade digna e justa (FREITAS, 2005, 2006, prelo). Revela-se, então, a faceta da Educação Cidadã e Comunitária nos trabalhos de intervenção, em que a participação guia-se pelo sentimento de indignação diante da injustiça.

Desta forma, tendo em vista estas preocupações e compromissos apontados como inerentes à trajetória da Psicologia Social Comunitária, talvez possamos começar a diminuir o legado de dívidas que também, foi deixado à nossa profissão. 
Referências bibliográficas

BARREIRO, Julio. Educación Popular y Proceso de Concientización. Madrid: Siglo Veintiuno Editores, 1985.

FREIRE, Paulo. Concientización. Buenos Aires, Editorial Búsqueda, 1973. . Educación y Cambio. Buenos Aires, editorial Búsqueda, 1976.

FREITAS, M.F.Q. Novas Práticas e Velhos Olhares em Psicologia Comunitária. Uma Conciliação Possível? In SOUZA, L.; FREITAS, M.F.Q. \& RODRIGUES, M.M.P. (orgs.) Psicologia: reflexões (im)pertinentes. São Paulo, Casa do Psicólogo, 1998.

. O Movimento da Lente Focal na História Recente da Psicologia Social Latino-americana. In GUARESCHI, P.A. \& CAMPOS, R.H.F. (orgs.) Novos Paradigmas da Psicologia Social Latino-americana. Vozes, Petrópolis, 2000a.

. Voices From The Soul: The Construction of Brazilian Community Social Psychology. Journal of Community and Applied Social Psychology. Wiley Eds., Londres, 10: 315-326, 2000b.

. Intersecciones entre sentido de comunidad y vida cotidiana. In PIPER,

I. (comp.) Políticas, Sujetos y Resistencias - Debates y Críticas en Psicología Social. Santiago de Chile. Editorial ARCIS, 2002.

. Psychosocial Practices and Community Dynamics. Meanings and possibilities of advance from the perspective of the engaged social actors. The International Journal of Critical Psychology. MONTERO, M. and CHRISTLIEBB, P.F. (eds). 9, 107-124, London. Lawrence \&Wishart, 2003a.

. Práxis e Ética na Psicologia Social Comunitária: possibilidades de transformação social na vida cotidiana. In PLONER, K.S.; MICHELS, L.R.F; SCHLINDWEIN, L.M. \& GUARESCHI, P.A. (orgs.), Ética e Paradigmas na Psicologia Social. Porto Alegre: ABRAPSOSUL, 2003b.

- (In)Coerências entre práticas psicossociais em comunidade e projetos de transformação social: aproximações entre as psicologias 
sociais da libertação e comunitária. PSICO, Porto Alegre, PUCRS, v.36, n.1, pp. 47-54, 2005.

. Dimensões da Exclusão e da Participação na Vida Cotidiana: Perspectiva da psicologia Social Comunitária Latino-Americana. In SCHMIDT, M.A. \& STOLTZ, T. (orgs.) Educação,Cidadania $e$ Inclusão Social.. Curitiba: Aos Quatro Ventos, 2006.

- (prelo) Strategies of Community Action and the Myths of Participation: coming-together and coming-apart in everyday life. In: MONTERO, M. (ed).London:Lawrence \& Wishart.

GOHN, M.G. Mídia, Terceiro Setor e MST. (1ª Ed.). Petrópolis. Vozes, 2000.

MARTÍN-BARÓ, Ignácio. El latino indolente. Caráter ideológico del fatalismo latinoamericano. In MONTERO, M. (coord.) Psicología Política Latinoamericana. Caracas: Editorial Panapo, 1987.

. Sistema, Grupo y Poder - Psicología Social desde Centroamérica II. San Salvador: UCA Editores, 1989.

MONTERO, Maritza. Un Paradigma para la Psicología Social. Reflexiones desde el quehacer en America Latina. In MONTERO, Maritza (org.) Construcción y Crítica de la Psicología Social. Barcelona: Editorial Anthropos, 1994a.

- Teoria y Práctica de la Psicología Comunitária. Argentina: Paidós, 2003. SÁNCHEZ, E. Todos com la "Esperanza". Continuidad de la participación comunitária.Universidad Central de Venezuela, Caracas, 2000.

SCHERER-WARREN, Ilse. Cidadania sem Fronteiras. Ações coletivas na era da globalização. São Paulo: Ed. Hucitec, 1999.

WATTS, R.J., GRIFFITH, D.M. \& ABDUL-ADIL, J. Sociopolitical Development as an Antidote for Oppression - Theory and Action. American Journal of Community Psychology,v.27, n.2, p. 255-271, 1999. 


\title{
QUESTÕES CANDENTES NO DIÁLOGO DA PSICOLOGIA COM A SAÚDE COLETIVA
}

CAPÍTULO 23

\author{
SOBRE A PROMOÇÃO DA SAÚDE: \\ TENSÕES ENTRE O RISCO NA MODALIDADE DA \\ AVENTURA \\ E AS ESTRATÉGIAS CONTEMPORÂNEAS DE \\ BIOCONTROLE *
}

\author{
Mary Jane P. Spink ${ }^{* *}$ \\ Pontifícia Universidade Católica de São Paulo
}

$\mathrm{O}$

conceito de risco, na Saúde Coletiva, constitui estratégia fundamental de biocontrole que se atualiza em discursos sobre promoção da saúde. Trata-se de tema recorrente, na perspectiva prescritiva ou na vertente crítica, de denúncia do crescente uso da linguagem, dos riscos como governamentalidade, mas que sempre toma o risco como perda, como algo a ser evitado. Nosso olhar, nesta reflexão, volta-se ao risco que traz consigo possibilidades de ganho: o risco positivado na perspectiva da aventura ${ }^{1}$. Baseamo-nos, para isso, na classificação de jogos proposta por Roger Caillois, que situa o risco-aventura entre as atividades associadas ao ilinx, as quais podem assumir formas culturais (como os esportes que exaltam a vertigem), formas institucionais (no caso das profissões de risco) e formas corrompidas (em que a razão é obliterada, por exemplo, pelo uso de drogas

\footnotetext{
* XIV Encontro Nacional da ABRAPSO - 31 de outubro a 3 de novembro de 2007, UERJ, Rio de Janeiro. Simpósio: Questões candentes no diálogo da Psicologia com a Saúde Coletiva Coordenação: Maria Elizabeth Barros.

*** Endereço para contato: mjspink@pucsp.br.

${ }^{1}$ Esta temática vem sendo por nós trabalhada em uma série de pesquisas realizadas com o apoio do CNPq.
} 
psicotrópicas, sejam elas lícitas ou ilícitas). O desafio, nesta apresentação é pensar a promoção da saúde nos casos em que há opção de correr riscos, tendo por pano de fundo a tensão que se estabelece entre direitos (a correr riscos, no caso) e estratégias contemporâneas de biocontrole.

\section{Breve introdução sobre as modernas concepções de promoção da saúde}

Os discursos sobre prevenção da doença e promoção da saúde têm focos específicos e histórias distintas, quer na perspectiva dos cuidados individuais, quer no enquadre da Saúde Pública. Com base nas análises de Buss (2001), Czeresnia (2001), Westphal (2006), entre outros, acatamos a proposição de que a promoção da saúde é um movimento mais recente e bastante imbricado com a postura ideológica da Medicina Social e, no caso brasileiro, da Saúde Coletiva. Trata-se de movimento que tem seus fundamentos na década de 1970, com marcos como o Relatório Lalonde ${ }^{2}$ de 1974, e a Conferência de Alma Ata, realizada em 1978. Essas e as propostas que as sucederam procuraram romper com a visão biomédica e/ou comportamental de prevenção da saúde, uma centrada nos determinantes biológicos e fisiológicos da doença e a outra focalizada nos estilos de vida considerados inadequados para a saúde.

Márcia Westphal (2006) dá a essa ruptura o rótulo de "abordagem socioambiental" e a contrapõe às abordagens de prevenção de doenças e promoção da saúde derivadas da tipologia proposta por Leavell e Clark, em 1965, que não consideram a dimensão histórico-social do processo saúdedoença e não estimulam, nas coletividades, práticas políticas emancipatórias. Essa nova abordagem de promoção da saúde vem sendo fortalecida nas Conferências Internacionais de Promoção da Saúde, apoiadas pela Organização Mundial de Saúde, realizadas em Ottawa, Canadá, em 1986; em Adelaide, Austrália, em 1988; em Sundsval, Suécia,

\footnotetext{
2 Ministro canadense que propôs a ampliação das dimensões a serem abarcadas pelas políticas de saúde, incluindo o ambiente, a biologia humana, os estilos de vida das pessoas e o sistema de Saúde.
} 
em 1991; em Jacarta, Indonésia, em 1998; no México, em 2000 e em Bancoc, Tailândia, em 2005.

A moderna concepção de promoção da saúde, segundo Westphal (2006), tem por base cinco princípios: (1) uma concepção holística de saúde, voltada à multicausalidade do processo saúde-doença; (2) a equidade como forma de enfrentar as desigualdades estruturais, relacionada, portanto, à distribuição desigual dos determinantes da saúde na população; (3) a intersetorialidade como estratégia para dar conta da complexidade da realidade; (4) a participação social na definição das políticas, no controle social e na avaliação das ações e serviços e (5) a sustentabilidade como forma de garantir ações duradouras.

Obviamente, a moderna concepção de promoção da saúde é postura politicamente correta que adota uma concepção de saúde holística, multideterminada, processual e essencialmente voltada ao fortalecimento dos direitos básicos de cidadania. Todavia, há críticas a essa abordagem. Os críticos “(...) afirmam que esta é uma prática altamente prescritiva e tem sido bastante utilizada para configurar conhecimentos e práticas na perspectiva neoliberal e conservadora, estimulando a livre escolha a partir de uma lógica de mercado" (WESTPHAL, 2006, p.652)³. Nessa linha de pensamento, a responsabilidade individual é reforçada e a do Estado, diminuída e, para alguns, a Promoção da Saúde pode assumir conotações moralistas, ao impor estilos de vida considerados saudáveis. Ao acatarmos essas preocupações, havemos de indagar: quem define o que conta como saúde quando procuramos escapar da cilada de pensá-la apenas como ausência da doença? Quem define o que são estilos de vida compatíveis com a saúde?

\footnotetext{
${ }^{3}$ Márcia Westphal, contrapondo-se a essas críticas, afirma que a presença explícita dos cinco componentes listados acima não dá respaldo aos argumentos daqueles que têm dúvidas sobre a moderna concepção de promoção da saúde.
} 


\section{Quem define o que é saúde: anotações sobre a epidemiologia dos riscos}

Se tomarmos as definições correntes de saúde, verificaremos que tem havido tentativas de superar o modelo biomédico e defini-la para além das causas biológicas e físicas do adoecimento. De acordo com a definição adotada pela Organização Mundial de Saúde, por ocasião de sua fundação em 1946, a saúde é um estado de completo bem-estar físico, mental e social e não apenas a ausência de doença ou enfermidade ${ }^{4}$. No Brasil, por influência do movimento sanitário, além dessa definição abrangente, a saúde é também associada aos determinantes sociais do processo saúde e doença. Desse modo, no Tema 1 do Relatório Final da VIII Conferência de Saúde, realizada em março de 1986, que trata do direito à saúde, consta que:

Em seu sentido mais abrangente, saúde é a resultante das condições de alimentação, habitação, renda, meio ambiente, trabalho, transporte, emprego, lazer, liberdade, acesso e posse da terra, e acesso a serviços de saúde. É assim, antes de tudo, o resultado das formas de organização social da produção, as quais podem gerar grandes desigualdades nos níveis de vida.

Entretanto, para fins administrativos e tomada de decisão sobre investimentos na área da Saúde, o norte são as estatísticas de mortalidade e morbidade, um sistema complexo que extrapola fronteiras territoriais e busca casar o sistema internacional de classificação de doenças (o CID, atualmente em sua $10^{\mathrm{a}}$ edição) com as necessidades pontuais, nacionais e regionais (o sistema de classificação do Ministério da Saúde).

Esses sistemas, como qualquer outra estratégia de classificação, são formas poderosas de construção de fatos sociais. Por exemplo, Judith Green (1997) tomou como fio condutor de sua pesquisa a pergunta: quando se tornou possível falar de acidentes no contexto das estatísticas de morbidade e mortalidade? Para responder, ela analisa a classificação de doenças do

\footnotetext{
4 Preâmbulo da Constituição da Organização Mundial de Saúde adotada durante a Conferência Internacional de Saúde, realizada em Nova Iorque, de 19 a 22 de julho de 1946, assinada pelos representantes de 61 países (Official Records of the World Health Organization, no. 2, p. 100). Esta definição não foi modificada desde 1948.
} 
Registro Geral inglês, que teve início em 1839. A partir da análise desse sistema de classificação, Green traçou o longo processo que leva do acidente como categoria residual à sua inclusão no Registro como causa de mortalidade e morbidade.

A autora argumenta que esse processo é paralelo ao que Ian Hacking denomina de "domação da chance" que envolve o paulatino desenvolvimento da teoria da probabilidade, da estatística e da Epidemiologia, e que possibilita uma forma muito específica de gerenciamento de riscos na área da Saúde: a análise dos fatores de risco. Não surpreende que o domínio dos "acidentes" tenha sido central a essa estratégia, pois eles são provas cabais de que certos riscos não foram adequadamente gerenciados e, paralelamente, constituem o teste último do gerenciamento de riscos como estratégia de governo de populações.

Robert Castel (1991) também reflete sobre essa transição para um sistema de vigilância em saúde, que se fundamenta na análise de fatores de risco, mais compatível com as necessidades da sociedade de capitalismo avançado. Segundo o autor, essas estratégias dissolveram a noção de sujeito (ou de indivíduos concretos), substituindo-a por uma combinação de fatores (os fatores de risco); uma transição, portanto, da clínica do sujeito para uma clínica epidemiológica —um sistema de expertise multifatorial que suplanta a antiga relação entre paciente e médico. Um modelo que substitui a vigilância individualizada do panapticon foucaultiano pelo sistema de vigilância informatizada que propicia a detecção precoce sistemática dos problemas de saúde e doença que assolam a população.

Certamente essa transição só foi possível em razão do desenvolvimento técnico-teórico da Epidemiologia, campo que, como tantos outros domínios de saber, tem uma história externa e outra interna. A história externa tem suas raízes nos primeiros esforços de sistematização das estatísticas de morbidade e mortalidade que deram origem à abordagem epidemiológica associada com o movimento sanitário do final do século XVIII e início do século XIX. Já a história interna tem por foco a emergência da 
representação matemática de risco, corporificada no conceito emergente de taxas (ratios).

Essa história interna foi objeto do estudo de José Ricardo Ayres, publicado no livro Sobre o Risco (1997). Com esse objetivo, Ayres analisou os artigos publicados no American Journal of Hygiene (AJH), desde sua criação em 1921 até a década de 1960. O AJH havia sido criado como veículo oficial da Escola de Higiene e Saúde Pública da Universidade John Hopkins, durante o segundo período abordado por Ayres, e representava o pensamento mais avançado da Epidemiologia norte-americana. Com base nesse estudo, Ayres desenvolveu uma cronologia da formalização da noção epidemiológica de risco que abarca três etapas: da epidemiologia da constituição (período de 1872 a 1929), passando pela epidemiologia da exposição (1930-1945), até a epidemiologia do risco (1946-1965).

A Epidemiologia da constituição, ainda enraizada nas estatísticas sanitárias, tinha por foco as regularidades dos fenômenos epidêmicos tomados como expressão dos determinantes sociais e geográficos da insalubridade. A primeira referência a risco, como conceito autônomo, apareceu já no primeiro volume do AJH, em 1921. Todavia, este era apenas um pronto conceito, visto que a noção tinha um papel periférico e era quantificada apenas indiretamente por meio da noção de "taxas” (rates).

O segundo período diz respeito à Epidemiologia da exposição, formatada no período de 1930 a 1945. Nesse período, a Epidemiologia assumiu uma posição mais próxima à das ciências biomédicas, ocupando posição intermediária entre as ciências voltadas aos processos patológicos, no nível orgânico, e aquelas que focalizavam os aspectos coletivos dos fenômenos da saúde e doença: “a bacteriologia falava a respeito dos agentes, a epidemiologia deveria falar da dinâmica de sua distribuição populacional” (AYRES et al., 2006, p.282). O risco torna-se um conceito analítico, focalizado nas suscetibilidades individuais tomadas como determinantes do curso epidêmico de doenças infecciosas, e deixa de ser referido a uma condição que se dá no nível da população, passando a 
indicar uma relação entre fenômenos individuais e coletivos: "O objeto epidemiológico passou a ser delimitado como uma relação entre infectados/suscetíveis, que se define como oportunidade de exposição ao agente causal de uma doença" (AYRES et al., 2006, p.383). Há uma aceleração do processo de formalização do conceito, que passa a ser expresso na linguagem matemática das probabilidades.

Porém, o risco não era ainda uma "quantidade". O próximo passo no processo de formalização teve lugar no período seguinte, quando tomou forma a Epidemiologia do risco (1946-1965). Essa nova configuração da Epidemiologia tem como marco a Segunda Guerra Mundial. Vários fatores que se fizeram presentes nas sociedades ocidentais no período pós-guerra, reforçaram esses novos desenvolvimentos na teoria e métodos da Epidemiologia, entre eles: o impacto das ideologias preventivistas e securitárias no período logo após a guerra; a aceleração do quantitativismo em todas as ciências e a emergência das doenças crônicas como principal causa de morbidade e mortalidade.

O conceito de risco, neste período, "passa a designar chances probabilísticas de susceptibilidade atribuíveis a um indivíduo qualquer de grupos populacionais particularizados, delimitados em função da exposibilidade a agentes (agressores ou protetores) de interesse técnico ou científico" (1997:294). Nesse processo, a expressão "estar em risco", típica das noções de susceptibilidade das técnicas de gerenciamento da população no século XIX, perde seu sentido. Essa construção linguística desapareceu vagarosamente da literatura epidemiológica, embora tenha sido incorporada no vocabulário de outras disciplinas, entre elas a Psicologia. Em seu lugar, a expressão dominante passa a ser "dado $\mathrm{x}$, o risco é $\mathrm{y}$, ou mais sinteticamente, "o risco de x é y". O risco deixa de ser um indicador de infortúnio e torna-se “(...) uma expressão formal e probabilística do comportamento de frequências de determinados eventos de saúde quando inquiridos a respeito de associações particulares” (AYRES 1997, p. 282); daí a possibilidade de falar de "riscos relativos". 
O caminho fica aberto, assim, para a emergência do enquadre dos fatores de risco e das intervenções baseadas na "Abordagem dos Riscos”. A “Abordagem dos Riscos” teve por finalidade a organização seletiva de serviços de saúde e foi introduzida pela Organização Mundial da Saúde no final da década de 1970, no contexto do seu Programa de Atenção MaternoInfantil. Sua lógica é, aparentemente, inatacável (unassailable):

Sabemos por experiência que algumas pessoas, mais que outras, são mais suscetíveis a, ou são mais frequentemente afetadas por morbidades específicas do que outras. Pessoas com características comuns às daquelas que experienciam a morbidade de interesse são consideradas como estando em maior risco do que as que não possuem tais características. Tais características são denominadas fatores ou marcadores de risco (HAYES, 1991, p. 55).

Obviamente, foi necessário desenvolver um sistema de escores de modo a classificar as pessoas quanto às características de interesse. Esse sistema de classificação deveria, então, orientar tanto a provisão de serviços como as estratégias preventivas.

As classificações quanto ao risco passaram a ser fenômenos prototípicos das biografias na modernidade tardia. Esse potencial de geração de biografias transformaria a avalanche de indicadores numéricos, do início do século XVII a meados do século XIX, em instrumentos fundamentais para um novo tipo de gerenciamento de populações: o biopoder, noção utilizada por Foucault para designar formas de poder exercidas sobre pessoas como membros de uma população, nas quais questões de conduta sexual e reprodutiva de indivíduos se interconectam com questões de políticas e poder nacional.

Institui-se, nesse percurso, uma tensão entre o enfoque coletivo da Epidemiologia e da Saúde Pública e aquele voltado às suscetibilidades individuais que é próprio da clínica. Vale retomar, como propõem Ayres e colaboradores (2006), que a Epidemiologia se sustenta na tríade discursiva: “controle técnico — comportamento coletivo— variação quantitativa”. Ou seja, risco, nessa perspectiva, "está situado no âmbito da população 
produzido nos (ou atribuído aos) coletivos humanos. Risco é enfim uma propriedade das populações e a sua referência legítima será exclusivamente coletiva” (ALMEIDA FILHO, 1992). Mas ao migrar para a clínica sofre uma "tradução"; integra-se como solução técnica para as incertezas no processo de tomada de decisões, possibilitando reduzir os elementos subjetivos do raciocínio clínico. "Porém, na transplantação do conceito, a clínica interpreta o risco como aplicável a seu objeto técnico, que não tem caráter coletivo, que não se refere a populações (a não ser remotamente) e sim ao indivíduo no singular” (ALMEIDA FILHO, 1992:138).

Nessa migração, ocorreu uma fusão entre fator de risco e o risco propriamente dito, de modo que ser portador de um fator de risco, ou pertencer a um grupo de risco, passou a ter "o mesmo efeito de qualquer sinal clínico na prática propedêutica” Em outras palavras, "pertencer a (ser oriundo de) certos segmentos da população, ou ser portador de certas diferenças, idiossincrasias ou heterogeneidades, transformam aqueles predicados do paciente em potencial em sinais de interesse diagnóstico ou prognóstico" (ALMEIDA FILHO, 1992:141).

Essa noção transmigrada de risco teve papel central na configuração dos contornos da epidemia de AIDS e foi nesse contexto que emergiu uma nova frente de crítica aos usos do conceito na definição de políticas e práticas de prevenção. Diante do caráter urgente que esta síndrome assumia -levando à total falência do sistema imunológico e à morte rápida de pessoas jovens- e, sobretudo, na ausência de um agente etiológico identificável, os modelos explicativos centraram-se primeiramente nos grupos nos quais havia maior prevalência da doença, ou seja, nos grupos de risco (homossexuais, hemofílicos, haitianos, num primeiro momento). Diante do potencial de geração de preconceito, amplamente apontado pelos ativistas da AIDS, pressionou-se para que a expressão fosse abandonada em favor dos comportamentos de risco. Mais recentemente, diante da tendência à excessiva individualização da responsabilidade pela infecção, houve mais uma mudança, centrando-se a preferência na expressão práticas de risco. 
Movimento similar ocorreu na Epidemiologia, disciplina na qual a noção de risco tem papel central, buscando-se aí uma progressiva socialização do conceito com a adoção preferencial da noção de vulnerabilidade proposta por Jonathan Mann. Conforme apontam Ayres e colaboradores (2006):

De forma geral, a noção de vulnerabilidade busca responder à percepção de que a chance de exposição das pessoas ao HIV e ao adoecimento pela AIDS não é resultante de um conjunto de aspectos apenas individuais, mas também coletivos, contextuais, que acarretam maior susceptibilidade à infecção e ao adoecimento, e, de modo inseparável, maior ou menor disponibilidade de recursos de todas as ordens para se proteger de ambos (AYRES et al., 2006, p. 396).

As análises de vulnerabilidade, nesse enquadre, buscam integrar três dimensões: a individual, referida ao acesso à informação, capacidade de processá-la e de utilizá-la para fins de prevenção; a social, incluindo aí as relações raciais e de gênero, os aspectos estruturais da desigualdade e a estrutura jurídica-política dos países; e a programática (ou institucional) referente às maneiras como as instituições atuam para reproduzir condições sociais de vulnerabilidade. As análises de vulnerabilidade, portanto, complementam as análises de risco, até porque, cada qual funciona com base em uma racionalidade singular as do risco, "trabalham com uma racionalidade analítica na qual os fenômenos em estudo precisam ser partidos, isolados, discriminados”. Em contraste, as análises de vulnerabilidades "trabalham com uma racionalidade sintética, na qual se privilegia a construção de significados, a agregação de elementos diversos que contribuam para que os fenômenos em estudos sejam compreendidos como uma totalidade dinâmica e complexa” (AYRES et al., 2006, p. 399).

Contudo, se o foco é a promoção da saúde, a incorporação das informações no rol de preocupações cotidianas e a transformação dessas preocupações em práticas de prevenção, seja no enquadre da vulnerabilidade ou da Epidemiologia do risco aplicada à clínica, o que está em pauta é o estilo de vida. 


\section{Que são estilos de vida saudáveis? É hora de retomar Mary Douglas}

Conforme afirmam Luis David Castiel e Paulo Roberto Vasconcellos-Silva "Um estilo de vida pode ser entendido como um conjunto relativamente integrado de práticas individuais que tanto estão voltadas para necessidades utilitárias como, ao mesmo tempo, conformam narrativas identitárias próprias. Além de 'como agir' referem-se a 'quem ser”'(2006, p. 82). São certamente "hábitos” que, na modernidade tardia (ou na sociedade de risco), estão cada vez mais descolados de padrões de comportamento associados a grupos e/ou a classes sociais.

Essa transformação de habitus (BOURDIEU, 1983) em estilos de vida pessoais (saudáveis ou arriscados) está intrinsecamente relacionada às principais características da sociedade de risco, conforme teorizações de Ulrich Beck (1992): a globalização —que se refere, sobretudo, ao entrelaçamento de eventos e relações sociais que estão à distância de contextos locais; à individualização, que para Beck concerne à destradicionalização; e à reflexividade, ou seja, à suscetibilidade da maior parte dos aspectos da atividade social, à revisão crônica à luz de novas informações ou conhecimentos.

As conotações atuais de "estilo de vida" estão associadas, principalmente, aos processos de individualização decorrentes do rompimento da estrutura de classes, consequência das transformações dos modos de inserção na vida econômica (como o desemprego e a predominância do emprego informal) que leva à destradicionalização que, por sua vez, substitui biografias pautadas pela inserção em classe, por biografias reflexivas que dependem das decisões do ator. Essa individualização da existência pressupõe diversidade de estilos de vida que se opõem, assim, à estrutura de classes, típica da sociedade industrial. Isto gera a contradição de estarmos continuamente confrontados com um capitalismo sem classes, mas que mantém desigualdades sociais com todos os problemas sociais e políticos a elas associados. Com o colapso das classes e da família como unidade estável da sociedade, os indivíduos se 
tornam agentes de sua subsistência, sendo responsáveis por seu planejamento e organização. Portanto, as biografias tornam-se reflexivas.

Este é, pois, o contexto social e político do moderno conceito de estilos de vida que podem ser tomados como "padrões de consumo, manipulados pela chamada cultura de consumo de massa” (CASTIEL \& VASCONCELLOS-SILVA, 2006, p.83) com efeitos biográficos-identitários. Porém, na perspectiva da promoção da saúde, o que está em pauta quando se fala em estilos de vida, são "as escolhas e comportamentos com repercussões nos respectivos padrões e adoecimento das pessoas”. Voltamos, assim, à Epidemiologia do risco ou mais corretamente, como propõem esses autores, à noção de ‘estilos de vida arriscados’: estilos de vida como uma pré-patologia.

É nesse enquadre que são realizadas as enquetes, são definidos os escores e os parâmetros que orientam políticas públicas e esforços de promoção da saúde e que acabam por reforçar dois aspectos interrelacionados: (1) a moralização dos 'estilos de vida arriscados'; e (2) a responsabilização individual. Em 1992, a antropóloga inglesa Mary Douglas publicou um livro que teve influência considerável: Risco e culpabilização. Ela parte da premissa que a culpabilização e os sistema de justiça são sintomas da maneira como uma determinada sociedade está organizada. Adotando uma postura radical, Douglas associa culpabilização com modelos cognitivos individuais e propõe que toda cognição é arma de dominação ideológica. Considera, ainda, que as sociedades contemporâneas, sob a força da globalização, desenvolveram novos sistemas de prevenção e compensação que tem o risco como foco. “A ideia de risco poderia ter sido feita sob encomenda. Sua terminologia universalizante, seu nível de abstração, seu poder de condensação, sua cientificidade, sua conexão com análise objetiva, tornam-na perfeita” (1992, p.15). Em suma, a palavra risco serve admiravelmente bem às necessidades forenses da nova cultura global.

Historicamente, o risco, em sua acepção probabilística, referia-se à possibilidade de ganhos ou perdas. Atualmente, risco perdeu a conotação 
positiva: "A linguagem dos riscos é reservada ao registro léxico especializado para o discurso político sobre efeitos (outcomes) negativos” (1992, p. 24). Assim, nas sociedades modernas, risco substitui o efeito forense do "pecado", embora com diferenças substantivas decorrentes do crescente individualismo: enquanto a retórica do pecado ou do tabu era usada para a proteção da comunidade por sua vulnerabilidade diante da má conduta de indivíduos (misbehavior), a retórica do risco protege o indivíduo, por ser ele vulnerável à má conduta da comunidade.

Como outros autores que se debruçam sobre as peculiaridades da modernidade tardia, ou "sociedade de risco" como a denomina Ulrich Beck (1993), não é o "risco objetivo" que está em pauta: os riscos manufaturados contemporâneos são muito presentes e bastante horrível em suas consequências imponderáveis. O que Douglas busca fazer é chamar atenção para a maneira como esses riscos se politizaram: “(...) como vêm sendo usados para dar legitimidade automática e validada à lei e ordem vigente”. Em suma, sua função como estratégia de governamentalidade (FOUCAULT, 1995; SPINK, 2001).

\section{Há lugar para o risco como aventura?}

Diante da crescente tendência a moralizar o risco, especialmente aqueles incorridos propositadamente, cabe perguntar se há lugar para o risco como aventura. Sob o enfoque da promoção da saúde e dos estilos de vida saudáveis, a resposta mais imediata seria: não! Contudo, a aventura tem sido incorporada como estratégia de educação em vários contextos, incluindo a educação física, o escotismo e os esportes mais radicais. Tem, também, lugar de destaque como ousadia na tomada de decisão nas teorias de Administração ou no enquadre dos jogos, seja na aplicação de recursos em fundos de investimento, seja no pôquer, roleta e demais “jogos de azar”.

Por isso, a compreensão do papel do risco como aventura passa necessariamente por entendê-lo no contexto da teoria de jogos tal como proposta por Roger Caillois (1958). Este autor baseia seu modelo de jogos 
na intersecção de duas dimensões: as diferentes modalidades de jogos e o grau de disciplinarização dos jogos (Quadro 1). Propõe, dessa forma, quatro modalidades básicas: agôn, jogos de competição; alea, jogos de chance; mimicry, jogos de simulacro, e ilinx, jogos de vertigem. As quatro modalidades aparecem em duas formas: uma, mais espontânea (ou primitiva) — a paidia - e a outra, mais regrada —o ludus. Podemos pensálas na perspectiva da sociogênese, ou seja, a paidia como uma forma menos socializada dos jogos, típica, por exemplo, da infância e o ludus como a forma disciplinada, socializada e presa a regras de comportamento.

\begin{tabular}{|c|c|c|c|c|}
\hline $\begin{array}{l}\text { Modalidade } \\
\text { Disciplinarização }\end{array}$ & $\begin{array}{c}\text { AGÔN } \\
\text { Competição }\end{array}$ & $\begin{array}{l}\text { ALEA } \\
\text { Chance }\end{array}$ & $\begin{array}{c}\text { MIMICRY } \\
\text { Simulacro }\end{array}$ & $\begin{array}{c}\text { ILINX } \\
\text { Vertigem }\end{array}$ \\
\hline $\begin{array}{l}\text { PAIDIA } \\
\text { Algazarra, alarido, tumulto, } \\
\text { agitação, riso solto }\end{array}$ & $\begin{array}{c}\text { Corridas } \\
\text { Lutas }\end{array}$ & $\begin{array}{c}\text { Tesoura, } \\
\text { papel, pedra } \\
\text { Cara ou } \\
\text { coroa } \\
\end{array}$ & $\begin{array}{c}\text { Jogos de } \\
\text { ilusão } \\
\text { Máscaras } \\
\text { Fantasias } \\
\end{array}$ & $\begin{array}{c}\text { Carrossel } \\
\text { Dança }\end{array}$ \\
\hline $\begin{array}{c}\text { LUDUS } \\
\text { Esportes com regras, } \\
\text { Técnicas e equipamentos }\end{array}$ & $\begin{array}{c}\text { Box, } \\
\text { esgrima, } \\
\text { futebol } \\
\text { Bilhar, } \\
\text { damas, } \\
\text { xadrez }\end{array}$ & $\begin{array}{l}\text { Apostas } \\
\text { Roleta } \\
\text { Loterias }\end{array}$ & $\begin{array}{l}\text { Teatro } \\
\text { Circo }\end{array}$ & $\begin{array}{c}\text { Ski } \\
\text { Alpinismo } \\
\text { Bungee jump }\end{array}$ \\
\hline
\end{tabular}

Fonte: adaptado de Roger Caillois, 1958

Um dos fenômenos mais surpreendentes da época atual é o crescimento dos jogos de vertigem (ilinx) e é nesse contexto que situamos o risco-aventura. Faz parte desse movimento de expansão a emergência das diversas novas formas de esportes de aventura: as regatas oceânicas, com início em 1973; as disputas de veículos off-the-road, como o Rali ParisDakar, iniciado em 1979, e o Camel Trophy, realizado em lugares inóspitos, em diferentes países, a partir de 1980; e os ralis humanos, iniciados na década de 1990 que têm como ingredientes principais o trabalho em equipe, a resistência e o espírito de aventura mesclados com a consciência ecológica que se manifesta não só no respeito absoluto à natureza, como também na ação ambiental efetiva apoiando iniciativas locais. 
Porém, o ilinx não se apresenta apenas nessas formas disciplinadas de jogos de vertigem, características do ludus. Para entender a multiplicidade de modalidades de risco-aventura é conveniente recorrer mais uma vez à proposta de Caillois de que o ludus pode ter formas culturais e institucionais, assim como formas corrompidas. As formas culturais englobam todas as modalidades de esportes que exaltam a velocidade, a adrenalina, a obliteração da razão pela concentração total na ação. Por exemplo, o esqui, o alpinismo, o surfe e as diversas modalidades de esportes que envolvem desafio, sobrevivência e vertigem.

As formas institucionais se fazem presentes, sobretudo, nas profissões que exigem o domínio da vertigem. Inserem-se aqui as tradicionais profissões de risco, como os guias de montanha, os bombeiros e os detetives, entre outros. Mas inserem-se também as novas profissões que emergem em consequência dos riscos manufaturados. Ericson e Haggerty definem essas novas profissões do risco como "um grupo ocupacional que reivindica para si um conhecimento abstrato e exclusivo sobre como lidar com riscos específicos assim como a habilidade de prover serviços especializados para gerenciar esses riscos" (1997:102). Incluem-se aqui os gerentes de risco em bancos de investimento, os responsáveis pela segurança de tecnologias capazes de gerar desastres em larga escala, como a energia nuclear, e os responsáveis pela segurança das novas tecnologias associadas à engenharia genética.

Caillois propõe ainda que há formas corrompidas dos jogos de vertigem em que a razão é obliterada, por exemplo, pelo uso de drogas psicotrópicas, sejam elas lícitas ou ilícitas. Essa é a forma de risco que David Le Breton (1996) chama de blancheur. Trata-se do inverso da vertigem e do desafio "em que o risco é ativamente buscado" com a atração direcionada para o menos e não para o mais: um doce abandono à morte por meio do álcool, da droga, da fuga ou da vagabundagem.

São essas dimensões do risco que vêm sendo foco de reflexão de tantos autores. Alguns buscam entender a onipresença das formas culturais 
do risco-aventura, como no turismo de aventura, como forma de expansão dos processos de disciplinarização para além de suas formas institucionais. A aventura, nessa interpretação, passa a ser incorporada ao cotidiano como estratégia de edificação. Nesse enquadre, o que se verifica é a ampliação paulatina das estratégias de segurança. Na perspectiva da população, essas estratégias se traduzem em formas governamentais de administração de risco, como é o caso da legislação para proteção ao consumidor de pacotes de aventura. Na perspectiva individual, elas assumem o formato de triangulação entre informação, treinamento técnico e uso de equipamento de proteção (SPINK, GALINDO, CAÑAS E SOUZA, 2004).

Outros autores focalizam as formas corrompidas e buscam entendêlas na perspectiva dos processos de destradicionalização próprios da sociedade globalizada e do capitalismo informacional. Insere-se nessa vertente a instigante reflexão de Le Breton (1996), que analisa os ilinx modernos na perspectiva do ordálio: a busca de significado para a vida no enfrentamento da morte, dando chances iguais de dela escapar. Em suma,

quando o sentido da vida escapa, quando tudo é indiferente, o ordálio é uma solução. É a única estrutura antropológica que pode dar uma segunda chance. Ela metaforiza a morte por meio de uma troca simbólica em que o ator aceita que, para poder tudo ganhar, arrisca tudo perder (1996, p. 58).

Seja qual for a modalidade de risco-aventura, a pergunta candente é se haverá espaço para esses “estilos de vida arriscados” nas abordagens de proteção da saúde. Seria possível, por exemplo, pensá-los na perspectiva da redução de danos?

\section{Estilos de vida arriscados: cabe falar em redução de danos?}

A redução de danos é uma estratégia de Saúde Pública que parte da premissa de que algumas pessoas optam por estilos de vida ou práticas associadas a riscos, como uso de drogas, sexo casual, prostituição. O objetivo principal dessa estratégia é mitigar o risco para a pessoa ou o dano 
decorrente da proibição dessas práticas, como a morte materna associada ao aborto $^{5}$ ou o mercado ilegal de drogas.

A redução de danos tornou-se bastante conhecida no Brasil, no contexto da epidemia de AIDS, sobretudo no que diz respeito ao programa de troca de seringas para usuários de drogas intravenosas. O primeiro ensaio sobre o uso da estratégia de redução de danos no país ocorreu em Santos, em 1989, medida que, segundo Fabio Mesquita (1994), gerou intensa polêmica e acabou enquadrada como crime pelo Ministério Público de Santos. Foi apenas em 1992, sob a égide do acordo com o Banco Mundial, que a proposta voltou a ser discutida. A partir de 1993, foram dados os primeiros passos para sua efetivação.

Diversas avaliações da eficácia dos programas de troca de seringas e agulhas indicam redução nos comportamentos de risco quanto ao uso de agulhas e à transmissão do HIV. Além disso, eles têm servido como pontos de contato entre usuários de drogas e prestadores de serviços, dentre eles, aqueles voltados ao tratamento de abuso de drogas. Os benefícios desses programas aumentam consideravelmente, quando vão além da troca de seringas e incluem educação quanto à AIDS, aconselhamento e encaminhamento para uma variedade de opções de tratamento.

Essas medidas foram fortalecidas pela aprovação, em 1998, da Declaração dos Princípios da Redução de Demanda de Drogas, na Assembleia Geral das Nações Unidas $\longrightarrow$ primeiro instrumento internacional voltado exclusivamente para o problema do abuso de drogas. De acordo com o texto dessa Declaração, os programas de redução de demanda de drogas devem abranger todas as áreas de prevenção, desde o desencorajamento do uso inicial até a redução das consequências adversas

\footnotetext{
${ }^{5}$ Em entrevista concedida à Folha de S. Paulo em 4/6/2007, Carmen Barroso, diretora da Federação Internacional de Planejamento Familiar, defendeu a "redução de danos" como estratégia para diminuição da mortalidade associada ao aborto. Fazem parte do pacote: o atendimento precoce, a informação sobre riscos da interrupção da gravidez, sobre a possibilidade de entregar o filho para adoção e sobre o uso do Citotec, embora o medicamento não seja fornecido pelo serviço de saúde.
} 
do abuso de drogas para a saúde do indivíduo e para a sociedade, ou seja, da redução de danos.

Mais recentemente, a estratégia de redução de danos vem sendo empregada também no contexto do uso de tabaco. Em artigo publicado no British Medical Journal, em 2004, Ann McNeill lista uma série de estratégias de redução de danos para fumantes que não querem ou não conseguem parar de fumar. Contrapõe formas mais eficientes, como a redução no número de cigarros, a terapia de reposição da nicotina e os produtos orais do tabaco não fumígeno —o snus sueco, por exemplo— com as que têm menor impacto na redução de danos, como os cigarros de baixo teor de nicotina, os alternativos ou o uso de charutos e cachimbos.

Todavia, essas medidas são vistas com suspeita, pois, muitas vezes, são promovidas pela indústria de tabaco. No final do artigo de McNeill, por exemplo, os editores acrescentam uma nota sobre interesses conflituosos, informando que ela havia recebido financiamento e hospitalidade de diferentes indústrias de tabaco.

As estratégias de redução de danos certamente suscitam questões controversas por proporem a inevitabilidade dos estilos de vida arriscados. Em um mundo ideal, o imperativo moral seria o das práticas saudáveis. Seríamos todos bem informados sobre riscos e fatores de risco; teríamos o respaldo de instituições jurídicas, educacionais e de saúde para acesso a essas informações; teríamos motivação para a vida, longe das iniquidades sociais, do desemprego, da solidão, da pobreza. E nos satisfaríamos com as rotinas cotidianas, sem buscar a emoção do ilinx —ou se o desejarmos, nos atendo a suas formas culturais.

Entretanto, vários motivos nos impelem a correr riscos: o prazer, os benefícios associados à ousadia; a desterritorização decorrente das formas de sociabilidade do capitalismo avançado; a oferta de posições de pessoa associadas ao risco como aventura e até mesmo a imponderabilidade das pesquisas científicas que levam à contínua alteração dos indicadores dos riscos. Enfim, como forma de resistir aos excessos de moralização, 
potencialmente associados à abordagem da promoção da saúde e dos estilos de vida saudáveis, propomos que é importante refletir sobre diferentes e criativas maneiras de reduzir os danos.

Referências bibliográficas:

ALMEIDA FILHO, N. Des-construindo o conceito de risco. In:

(Org.). A clinica e a epidemiologia. Salvador/ Rio de Janeiro: APCE/ABRASCO, 1992.

AYRES, J.R.C.M. Sobre o risco: para compreender a epidemiologia. São Paulo: Hucitec, 1997.

; CALAZANS, G.J. ; SALETTI FO., H.C. e FRANÇA-JÚNIOR, I. Risco, vulnerabilidade e práticas de prevenção e promoção da saúde. In: CAMPOS, G.W. de S.; MINAYO, M.C. de S.; AKERMAN, M; DRUMOND JR. M. e CARVALHO, Y.M., (Orgs.). Tratado de Saúde Coletiva. São Paulo: Hucitec; Rio de Janeiro: Fiocruz, 2006.

BECK, U. Risk society: towards a new modernity. London: Sage, 1993.

BOURDIEU, P. Questões de Sociologia. Rio de Janeiro: Marco Zero, 1983.

BUSS, P.M. Uma introdução ao conceito de promoção da saúde. In: CZERESNIA, D. e MACHADO, C.E., (Orgs.). Promoção da saúde: conceitos, reflexões, tendências. Rio de Janeiro: Editora Fiocruz, 2003, p.15-38.

CAILLOIS, R. Les Jeux et les Hommes. Paris: Gallimard, 1958.

CASTEL, R. From dangerousness to risk. In: BURCHELL, G., GORDON, C. e MILLER, P., (Orgs.). The Foucault effect: studies in governmentality. Chicago: The University of Chicago Press, 1991, p.281-298.

CASTIEL, L.D. e VASCONCELLOS-SILVA, P.R. A noção 'estilo de vida' em promoção da saúde: um exercício crítico de sensibilidade epistemológica. In: BAGRICHEVSKY, M., et al., (Orgs.). A saúde em debate na educação física. Blumenau: Nova Letra, v.2, 2006, p.67-92.

CZERESNIA, D. O conceito de saúde e a diferença entre prevenção e promoção. In: CZERESNIA, D. e FREITAS, C.E.M., (Orgs.). 
Promoção da saúde: conceitos, reflexões, tendências. Rio de Janeiro: Editora Fiocruz, 2003, p.39-54.

DOUGLAS, M. Risk and blame: essays in cultural theory. London: Routledge, 1992. ERICSON, R. e HAGGERTY, K.D. Policing the risk society. New York: Oxford University Press, 1997.

FOUCAULT, M. Governamentalidade. In: MACHADO, R., (Org.). Microfísica do Poder. Apresentado no Curso do Collège de France em 1 de fevereiro de 1978. Rio de Janeiro: Ed. Graal, 1995, p.277-293.

GREEN, J. Risk and misfortune: the social construction of accidents. London: UCL Press, 1997.

HAYES, M.V. The risk approach: unassailable logic? Social Science and Medicine, v.33, n.1, p.55-70, 1991.

LE BRETON, D. Passions du risque. Paris: Éditions Métailié, 1996.

McNEILL, A. The ABC of smoking cessation: harm reduction. BMJ v. 328, p. 885-887, 2004.

MESQUITA, F. Perspectivas das estratégias de redução de danos no Brasil. In: MESQUITA, F. e BASTOS, F.I. (Orgs). Drogas e aids: estratégias de redução de danos. São Paulo: Fucitec, 1994. Pp. 169-180.

SPINK, M.J.P. Trópicos do discurso sobre o risco: risco-aventura como metáfora na modernidade tardia. Cadernos de Saúde Pública, v.17, n.6, p.1277-1311, 2001.

. A saúde na encruzilhada entre biopolítica e bioeconomia: reflexões sobre os paradoxos da "era dos direitos" na globalização hegemônica. In: RIBEIRO, M.A.T.R.; BERNARDES, J. de S. e LANG, C.E. (Orgs). A produção na diversidade: compromissos éticos e políticos em Psicologia. São Paulo: Casa do Psicólogo, 2007, p. 55-74.

; GALINDO, D.; CAÑAS, A \& SOUZA, D. Onde está o risco? Os seguros no contexto do turismo de aventura. Psicologia e Sociedade, Vol 16 (2): 81-89, 2004

WESTPHAL, M. Promoção da saúde e prevenção da doença. In: CAMPOS, G.W. de S.; MINAYO, M.C. de S.; AKERMAN, M; DRUMOND JR. 
M. e CARVALHO, Y.M., (Orgs.). Tratado de Saúde Coletiva. São Paulo: Hucitec; Rio de Janeiro: Fiocruz, 2006, p.635-667. 


\title{
A PSICOLOGIA E OS DESAFIOS CONTEMPORÂNEOS DA REFORMA PSIQUIÁTRICA
}

\author{
Maria Cristina Campello Lavrador
}

Universidade Federal do Espírito Santo

tema: A psicologia e os desafios contemporâneos da reforma psiquiátrica nos convidam a pensar sobre as estratégias de resistência que problematizam os saberes, os fazeres, os dizeres e os poderes que contornam as mais diferentes experiências da vida. Este é um dos recortes circunstanciais de uma experiência mais ampla de criação de si que implica variação nos modos de vida. Criação de si como "uma certa relação a si; essa não é simplesmente 'consciência de si', mas constituição de si" (FOUCAULT, 1985, p.28) que implica um exercício ético no qual o homem "problematiza o que ele é, e o mundo no qual ele vive" (p. 14).

Traçar múltiplos caminhos e compartilhar as incertezas são alguns dos desafios que se impõem a todos que estão implicados, de um modo ou de outro, com a invenção de novas possibilidades de/na vida em todos os dinamismos espaço-temporais.

Ao nos referimos à variação nos modos de vida, somos interpelados sobre qual a nossa potência de diferir, de quais processos de subjetivação queremos ser partícipes, como podemos pensar e agir diferentemente? E, ao mesmo tempo, em que medida se é levado às sujeições e/ou às cumplicidades com os "estados de dominação" que tanto denunciamos? Perguntas que exigem problematizações sobre a atualidade e que também nos inclui. Um entrelaçamento do que estamos fazendo da vida, do mundo, do outro e de nós mesmos, “(...) um ethos filosófico consistente em uma crítica do que dizemos, pensamos e fazemos, através de uma ontologia histórica de nós mesmos” (FOUCAULT, 2000, p. 347). Uma política, de 
uma estética e de uma ética da existência. Tarefa cotidiana e infinita de “uma vida”. Uma potência... Um cansaço... Mas, mesmo quando estamos exaustos, não conseguimos mais desacreditar na potência de possível, não conseguimos mais viver, pensar, sentir, fazer e dizer sem ter esse possível. Experiência limite, experimentações que exigem de cada um de nós uma paciência histórica, um perseverar na existência com suavidade, “(...) o trabalho crítico (...) sempre implica, penso, o trabalho sobre nossos limites, ou seja, um trabalho paciente que dá forma à impaciência da liberdade” (FOUCAULT, 2000, p. 351).

Por tudo isso, continua insistindo em nós essa disposição de um combate aos desejos de manicômios (Lavrador; Machado, 2002) de todo tipo, que se espraiam pelo mundo e que nos espreitam. Estes se exprimem através de um desejo em nós de dominar, de subjugar, de classificar, de hierarquizar, de oprimir e de controlar, que se fazem presentes em toda e qualquer forma de expressão que se sustente numa racionalidade carcerária, explicativa e, muitas vezes, despótica. Apontam para um endurecimento que aprisiona as experiências da vida ao obstruir a nossa potência de agir.

Especificamente com relação à experiência da loucura, nossa preocupação é de que esses desejos de manicômios ainda se façam presentes, algumas vezes, nos novos serviços de saúde mental e no encontro com a loucura. Que os mesmos se atualizem em práticas/discursos de exacerbada medicalização, de interpretações violentas, de posturas rígidas e despóticas. Pois a lógica manicomial em lugar de possibilitar outros modos de vida, produz submissão, infantilização e culpa, mesmo que sob uma nova roupagem. O que poderíamos caracterizar como sendo uma forma de controle contínuo no qual o outro pode ser dissimuladamente tutelado e controlado ao longo dos dias e a cada instante.

Ao se eleger e valorizar os valores transcendentes que depreciam a vida enreda-se nas teias do controle normalizador que busca sempre incidir sobre o singular para torná-lo homogêneo, para lembrá-lo que há um Modelo transcendente e arbitrário a ser seguido. Por exemplo, a loucura nos 
incomoda porque desvia e nos mostra que é possível desviar, porque nos aponta que essa verdade transcendente sobre o mundo é uma ilusão, porque ousa misturar numa mesma vida a multiplicidade, ou melhor, porque nos indica que "uma vida" se faz na multiplicidade.

E aí somos interpelados: como pensar, fazer, dizer, sentir e viver diferentemente? Como conseguir rachar 'as coisas e as palavras', que se grudaram nos valores transcendentes para deixar advir uma 'gagueira na própria língua’, como uma linha quebrada que aproveita as bifurcações e cria desvios?

Os regimes de controle contemporâneos tentam calar e capturar os movimentos instituintes, propagando uma pretensa hegemonia. O que nos impõe o desafio de criar estratégias de resistência ativa em todos os dinamismos espaço-temporais. Entendemos que esses são os desafios contemporâneos candentes da Reforma Psiquiátrica.

\section{A vida não cabe em si}

Por que é necessária uma linha divisória entre doença, saúde e normalidade? Qual o significado da partição entre doentes e sãos? O que esse mecanismo binarizador faz funcionar?

Nietzsche rompe com a ideia de que a saúde é algo individual, privado. Para ele, nem a saúde nem a doença são entidades, as diferentes dicotomias são apenas jogos de superfície. Entre doença e saúde há continuidade, diz Nietzsche, a doença é um desvio interior à própria vida, não há fato patológico em si (BARROS, 2003, p. 155).

As variações nos modos de vida nos incitam a afirmar a Diferença como pura multiplicidade e esta afirmação delineia variações nos modos de viver. Entretanto, em determinadas condições institucionais e históricas a Diferença é silenciada como se não fizesse parte da vida, como se não fosse constitutiva de sua multiplicidade.

A medicina classificatória concebia a vida como saúde e a opunha à doença Foucault (1987). Saúde e doença eram consideradas manifestações 
independentes umas das outras, sem nenhuma relação entre si. Uma concepção binária que trata os termos por oposição, ou seja, se há doença não há saúde e não há vida, e, ao contrário, se há saúde não há doença.

A doença não era considerada como uma alteração ou um desvio da normalidade. A distinção entre saúde e doença se fazia a partir de critérios de ausência ou de presença de determinadas qualidades, como: vigor, fluidez e flexibilidade que deveriam ser restabelecidas. A saúde se remetia à Natureza, concebida como harmonia ou equilíbrio, e a doença à Contra-natureza. Nessa perspectiva, não se colocava a possibilidade de aproximação ou de mistura, enfim, a possibilidade de variações nos modos de vida.

Posteriormente, saúde e doença passam a compor um mesmo campo. A doença faz parte da vida, mas como um acidente, um desvio da 'normalidade', uma alteração dos processos vitais que caracterizam a "vida patológica”, uma “forma patológica de vida”. Os estados mórbidos seriam variações, gradações - por excesso ou por carência - de um padrão considerado normal: "quando os órgãos funcionam com toda regularidade e uniformidade de que são capazes” (BÉGIN apud CANGUILHEM, 1978, p.36). O normal e o patológico diferiam apenas por graus de intensidade.

Canguilhem vê nessa definição uma tendência de se considerar a normalidade como um ideal de perfeição. A saúde seria uma espécie de essência ideal e a normalidade a forma ideal de vida. Nesse sentido, a vida não seria concebida como multiplicidade, não havendo espaço para diferenças.

Seguindo uma outra perspectiva, Canguilhem definiu de forma distinta os termos anomalia, anormal e patológico. Anomalia está ligada às variabilidades da vida, se refere ao que é desigual e irregular, e isto não implica obrigatoriamente sofrimento/impotência. "Não existe fato que seja normal ou patológico em si. A anomalia e a mutação não são, em si mesmas, patológicas. Elas exprimem outras normas de vida possíveis” (CANGUILHEM, 1978, p. 113).

A anomalia é singular, se manifesta na multiplicidade, na relação com o outro, "o portador de uma anomalia não pode, portanto, ser 
comparado a si mesmo” (CANGUILHEM, 1978, p. 108). Já a doença se manifesta numa sequência cronológica que é interrompida por uma enfermidade que pode levar a uma incapacidade de instituir novas normas de vida por acreditar que só existe uma única norma de vida. "O doente é doente por só admitir uma norma” (CANGUILHEM, 1978, p. 148). Dessa forma, pode-se dizer que anomalia não é doença, ou seja, a multiplicidade não é doença.

(...) no nível mais fundamental da vida, os jogos do código e da codificação abrem lugar para um acaso que, antes de ser doença, déficit ou monstruosidade, é alguma coisa como uma perturbação no sistema informativo, algo como um 'equívoco’ (FOUCAULT, 2000, p. 364).

Por sua vez, o termo "anormal implica referência a um valor, é um termo apreciativo, normativo” (CANGUILHEM, 1978, p. 101), ou seja, implica um valor normativo instituído pela vida e é aquilo que está fora das regras normativas. "Anormal quer dizer, precisamente, inexistente e inobservável” (CANGUILHEM, 1978, p. 107). E também não implica necessariamente sofrimento e impotência. Enfim, patológico "implica em pathos, sentimento direto e concreto de sofrimento e de impotência, sentimento de vida contrariada” (CANGUILHEM, 1978, p. 106). O estado patológico exprime uma paralisação da vida, uma restrição à criação de novas normas, à expansão do viver, mas não é uma ausência de normas. Entendendo que não há uma sinonímia universal e a histórica entre loucura e doença e sim uma sobreposição datada historicamente, pode-se dizer que a experiência da loucura não pertence necessariamente ao campo da doença. Assim, poderíamos pensá-la como estando próxima da noção de anomalia ou como uma manifestação da multiplicidade da vida?

Segundo Canguilhem (1978), “uma vida” institui suas normas para se preservar e lutar contra os perigos que a ameaçam. Mas, ao mesmo tempo, também tende a expandir-se ao encarar os riscos e arriscar a própria vida. A concepção de saúde não tem nada a ver com a de estabilidade e nem tampouco com um assujeitamento às normas. Faz parte da saúde abusar da própria saúde, criando novas normas de vida que permitam que ela se 
expanda. "Viver é, mesmo para uma ameba, preferir e excluir" (CANGUILHEM, 1978, p. 105). Quem é levado a diminuir as normas de vida, na busca da estabilidade, e quem não consegue se abrir para as novas condições de vida é aquele que não tolera o desvio, o porvir e não busca instituir novas normas para viver.

Canguilhem parece simpatizar com [a] perspectiva nietzschiana ao postular que saúde e doença se implicam num confronto e superação permanentes das tendências mórbidas. (...) Ou seja, busca afirmar a vida no seu aspecto de criação e expansão permanentes (BARROS, 2003, p. 159).

Os termos anomalia, anormal, patológico, e doença foram historicamente carregados de negatividade. E o termo saúde carregado de idealizações. É por isso que Canguilhem nos provoca e nos faz pensar: estaríamos hoje diante de um paradoxo com relação à saúde, pois em nome desta, procura-se extirpar da vida tudo o que a desassossega, tudo o que a desvia, tudo o que a faz diferir, tudo o que nos traz desassossego. Cada vez mais se busca e se propaga um ideal de perfeição: uma perfeita saúde, uma perfeita alimentação, um perfeito corpo, um perfeito amor, um perfeito trabalho etc. "Em certo sentido, pode-se dizer que uma saúde perfeita contínua é um fato anormal” (CANGUILHEM, 1978, p. 106). Ou melhor, a perfeição, em se tratando da vida, não existe, em suma, é um ideal. "Uma vida” é multiplicidade, é errância, é falha, é processo.

As classificações repartem, esquadrinham, separam. Assim, reduzemse as variações nos modos de vida a uma única forma de vida. Uma forma de vida padronizada, modelada, restrita, amedrontada, ou seja, uma negação e uma depreciação da vida. Uma vontade de verdade calcada em ideais de perfeição, na qual o erro, ou melhor, a errância tende a ser descartada para poder se dizer o que é o verdadeiro.

Mas, a verdade é uma mentira muitas vezes repetida, como nos diz Oswald de Andrade, ou a verdade é a mais profunda mentira, como nos diz Nietzsche. E no que diz respeito ao erro-errância, Foucault nos diz que "no limite, a vida — daí seu caráter radical— é o que é capaz de erro” (2000, p. 
364). A errância, a estranheza é constituinte de uma vida e, paradoxalmente, tenta-se esmaecer exatamente esse "caráter radical" da vida, ao se considerar o erro-errância como algo negativo e que precisa ser extirpado ou, ao menos, controlado.

Os mecanismos de regulamentação da vida promovem processos de expropriação da liberdade e da criação, diminuindo nossa potência de agir. No entanto, algo sempre irá escapar a todo poder-controle: linhas de resistência que nos instigam a experimentar outros dinamismos de espaço-tempo, heterocronias, multiplicidades rítmicas, enfim, variações nos modos de vida.

\section{Modulações do controle sobre a vida}

Foucault, em seus últimos escritos, acrescenta explicitamente, os modos de subjetivação na sua análise sobre os modos de objetivação da loucura pelas práticas médicas através do poder psiquiátrico.

O poder psiquiátrico se incumbiu de produzir a verdade da doença e a doença como verdade no espaço hospitalar. Ao mesmo tempo, poder e verdade estavam mutuamente implicados. Sem dúvida se tratava de um jogo de verdade que envolvia relações estratégicas de exercício do poder, “(...) é preciso distinguir as relações de poder como jogos estratégicos entre liberdades (...) e os estados de dominação, que são o que geralmente se chama de poder" (FOUCAULT, 2004, p. 285). Mas será que foi um jogo de poder aberto, será que se jogava "com um mínimo possível de dominação"? (FOUCAULT, 2004, p. 284). Nos "estados de dominação" as práticas de liberdade são um fio excessivamente reduzido e situado em um único lado. Ou será que foi um jogo pesado e cerrado frente às práticas violentas das duchas e, depois, dos eletrochoques? Em que medida se tratava de "jogos estratégicos entre liberdades" com possibilidades de inversão, de reversibilidade, e em que medida se tratava de "estados de dominação", de violência ilimitada e por isso sem possibilidades de inversão? Talvez uma mistura de ambos. Por um lado, menos possibilidades de inversões visíveis no sentido de que o poder médico-psiquiátrico se impôs pela coerção física 
e moral, e por outro, possibilidades de inversões invisíveis no sentido de que gotas d'água ainda possibilitavam alguns suspiros do exercício de liberdade. "Mesmo quando a relação de poder é completamente desequilibrada, (...) um poder só pode se exercer sobre o outro à medida que ainda reste a esse último [alguma] possibilidade” (FOUCAULT, 2004, p. 277). Em outras palavras, a loucura tentava resistir de algum modo, mesmo que fosse pelo silêncio. O poder psiquiátrico não controlava e não controla tudo, alguma coisa escapava e continua escapando. Os espaços de liberdade, mesmo que minúsculos e invisíveis, não subsumiram da vida social. Entretanto, é imprescindível um esforço de criar linhas de resistência em todos os âmbitos de nossa vida.

O asilo, ao mesmo tempo, foi a face visível e indispensável da estratégia psiquiátrica com suas práticas de reclusão asilar que conjurava e sequestrava, o que desestabilizava uma determinada ordem social. Diríamos que o asilo ainda é simbolicamente — com isso não estamos desprezando ou minimizando os indicadores de 56.582 leitos psiquiátricos no Brasil—umas das faces visíveis do disparate de uma sociedade, mas não é mais indispensável, pois o asilo "tem a proporção de uma cidade; não existem mais os muros do asilo. Eles explodiram, eles englobaram a cidade" (HASSOUN, 1999, p. 270). Supervalorizar essa face visível do asilo, como um lugar específico, pode desviar o nosso olhar do grande sonho e da ampla pretensão da psiquiatria: fortalecer e juntar-se a um modelo-projeto social global.

O projeto psiquiátrico, desde o início, foi muito além do asilo e do 'tratamento' aos doentes mentais "a medicina não tem somente como objeto estudar ou curar as doenças; ela tem relações íntimas com a organização social” (FOUCAULT, 1999, p. 295). Pode-se dizer que se ocupou menos do objeto doença do que de seu projeto global de controle social ou que intervir sobre a doença é antes de tudo intervir sobre a ordenação da vida. A ordem psiquiátrica se une à ordem mundial ou a nova ordem mundial contra todos os 'perigos' que rondam e ameaçam desestabilizá-la. Ambas se serpenteiam, se tornam maleáveis e palatáveis ao sabor das ondulações do capital, da mega indústria dos psicofármacos, para manter a sua 
onipresença, onisciência e onipotência assegurando certa regularidade, ordem e controle sobre a variação nos modos de vida.

A partir do século XIX, todos nos tornamos psiquiatrizáveis; a mais técnica, a mais racionalizante das sociedades colocou-se sob o signo, valorizado e temido, de uma loucura possível. A psiquiatrização não é alguma coisa que aconteça aos mais estranhos, aos mais excêntricos dentre nós; ela pode nos surpreender a todos e por toda parte, nas relações familiares, pedagógicas, profissionais (FOUCAULT, 1999, p. 296).

Essa afirmação continua cada vez mais atual, pois o aparato psiquiátrico hoje procura incidir sobre as nossas tristezas transformado-as em depressão, sobre os nossos medos transformando-os em pânico, sobre as nossas inquietações transformando-as em ansiedade, sobre as nossas alegrias transformando-as em euforia. Enfim, incide sobre o que difere, sobre o que desvia, sobre o que se apresenta como variação em nossos modos de vida. Entretanto, talvez hoje, os exercícios do poder psiquiátrico podem estar mais próximos desses “jogos estratégicos entre liberdades”, pois designamos à psiquiatria a tarefa de solucionar todos os nossos desconfortos, endossamos a medicalização e a patologização do cotidiano. Muitas vezes, trata-se da 'liberdade' como livre-arbítrio, a partir da qual as escolhas se dão por adesões cegas, sem uma prática refletida sobre a liberdade, sem um exercício de problematização sobre “que estamos ajudando a fazer de nós mesmos?”. O problema da liberdade e o seu avesso, os estados de dominação, bem como as condições do nosso tempo que afunilam as possibilidades de práticas de liberdade continuam nos provocando a pensar.

O valor de verdade da psiquiatria ainda se mantém através do poder/saber/fazer que quer controlar, dominar e subjugar o que difere. Esse querer se encontra com outros quereres moralizantes que não suportam o estranhamento das variações nos modos de vida. Pois quando não se 'compreende', moraliza-se e destila-se o imperativo de um dever encegueirado que constitui a "vontade de verdade". 
Entretanto, não basta somente desmontar o aparato psiquiátrico, é preciso, antes de tudo, desmontar essa "vontade de verdade". Interpelarmos porque ainda fazemos parte dessa engrenagem, porque ainda nos submetemos aos 'seus podres poderes'. "O que somos nesse tempo que é o nosso? (...) ‘O que somos hoje?’” (FOUCAULT, 2004, p. 301).

Acreditar no mundo significa principalmente suscitar acontecimentos, mesmo pequenos, que escapem ao controle, ou engendrar novos espaços-tempos, mesmo de superfície ou volume reduzidos. É ao nível de cada tentativa que se avaliam a capacidade de resistência ou, ao contrário, a submissão a um controle. Necessita-se ao mesmo tempo de criação e povo (DELEUZE, 1992, p. 218).

Muitas vezes, deixamos escapar por entre os dedos essa potência de acreditar/agir. Entretanto, é possível inventar — via contágio, contaminação, epidemia e não por decreto ou conscientização— outras formas de lidar com a loucura, acolhendo sua alteridade, abrindo portas em todos os sentidos e desobstruindo a potência de invenção de possíveis. Desobstruir a potência de possíveis implica um combate às práticas-intervenções-discursos reificadas, que produzem subjetividades mortificadas e entorpecidas.

As resistências e os combates à lógica manicomial passam pela luta, pelo fim dos desejos de manicômios que nos habitam, e pelo 'direito' a desrazão que nos perturba, que nos traz desassossego e também, vida, um sopro de vida, oxigênio em meio ao ar rarefeito, marolas em meio ao marasmo.

O direito a desrazão significa poder pensar loucamente, significa poder levar o delírio à praça pública, significa fazer do Acaso um campo de invenção efetiva, significa liberar a subjetividade das amarras da Verdade, chame-se ela identidade ou estrutura, significa devolver um direito de cidadania pública ao invisível, ao indizível e até mesmo, por que não, ao impensável (PELBART, 1993, p. 108).

Estamos nos referindo, ao mesmo tempo, aos desafios que se impõem ao movimento da Reforma Psiquiátrica e a todas as experiências de vida. Todos nós estamos um pouco entorpecidos e mortificados. Todos nós precisamos, um pouco, poder pensar 'loucamente'. Todos nós precisamos de um pouco de oceano indomável. Os chamados loucos e não loucos. 
Não haverá sempre um incontrolável a todo e qualquer dispositivo de controle? Não haverá sempre algo que escapa?

Referências bibliográficas

BARROS, Maria Elizabeth Barros de. A vida, como ela é? In: Revista Psicologia Clínica. Rio de Janeiro. Pontifícia Universidade Católica do Rio de Janeiro. Departamento de Psicologia. v. 15, nº 1, p. 153-166, 2003..

CANGUILHEM, Georges. O Normal e o Patológico. Rio de Janeiro: Ed. Forense Universitária, 1978.

DELEUZE, Gilles. Conversações. Rio de Janeiro: Editora 34, 1992.

FOUCAULT, Michel. História da Sexualidade II: O uso dos prazeres. 3. ed. Rio de Janeiro: Ed. Graal, 1985.

. O Nascimento da Clínica. 3. ed. Rio de Janeiro: Ed. ForenseUniversitária, 1987.

. O Asilo Ilimitado. In: Problematização do Sujeito - Psicologia, Psiquiatria e Psicanálise. São Paulo: Ed. Forense Universitária, Ditos e Escritos I, 1999.

. O que são as Luzes? In: Arqueologia das ciências e histórias dos sistemas de pensamento. Rio de Janeiro: Forense Universitária, Coleção Ditos \& Escritos II, 2000.

- A Vida: a experiência e a ciência. In: Arqueologia das ciências e histórias dos sistemas de pensamento. Rio de Janeiro: Forense Universitária, Coleção Ditos \& Escritos II, 2000.

. A Ética do Cuidado de Si como Prática de Liberdade. In: Ética, Sexualidade, Política. Rio de Janeiro: Forense Universitária, Coleção Ditos \& Escritos V, 2004.

. Verdade, Poder e Si Mesmo. In: Ética, Sexualidade, Política. Rio de Janeiro: Forense Universitária, Coleção Ditos \& Escritos V, 2004.

. A Tecnologia Política dos Indivíduos. In: Ética, Sexualidade, Política. Rio de Janeiro: Forense Universitária, Coleção Ditos \& Escritos V, 2004. 
LAVRADOR, Cristina; MACHADO, Leila. Loucura e Subjetividade. In: LAVRADOR, M.C.C.; MACHADO, L.D.; BARROS, M.E.B. (Org.). Texturas da Psicologia: políticas da subjetividade no contemporâneo. São Paulo: Casa do Psicólogo, 2002.

PELBART, Peter Pál. A Nau do Tempo-Rei. Rio de Janeiro: Imago, 1993. 


\title{
MÉDICOS, MULHERES E CESÁREAS: A CONSTRUÇÃO DO PARTO NORMAL COM "UM RISCO” E A MEDICALIZAÇÃO DO PARTO NO BRASIL
}

\author{
Alessandra Sampaio Chacham* \\ Pontifícia Universidade Católica de Minas Gerais
}

\section{Resumo}

T este trabalho exploramos alguns dos fatores que levam médicos a indicarem um número excessivo de cesáreas desnecessárias e um grande número de mulheres que desejam parto normais a aceitarem cesáreas. A partir do conceito de medicalização, analisamos como a abordagem biomédica dominante legitima a crescente intervenção médica nos processos de gravidez e no parto, quando passa a estabelecer os parâmetros que definem o que é normal e patológico nestes processos. Entrevistas com 18 médicos ginecologistas-obstetras e 60 mulheres que haviam tido filho recentemente, sendo 30 usuárias dos serviços privados de saúde e 30 usuárias do serviço público de saúde, usando de questionários com questões abertas com as quais procuramos apreender as percepções e as preferências das mulheres e dos médicos sobre os diferentes tipos de parto. Os resultados sugerem que a percepção do parto normal como potencialmente arriscado para o bebê e da cesárea como um procedimento isento de riscos, percepção esta que pode ser atribuída ao processo de medicalização do parto, parece exercer contribuição fundamental para que muitos médicos indiquem e as pacientes aceitem uma cesárea, especialmente no setor privado.

\footnotetext{
* Professora adjunta do Departamento de Ciências Sociais da Pontifícia Universidade Católica de Minas Gerais.
} 


\section{Introdução}

É um fato bem estabelecido que o Brasil tem taxas muito altas de cesáreas desnecessárias, entre as mais altas do mundo (MELO, 1976; BARROS, 1991, RATTNER, 1996). Há um consenso na literatura internacional e nacional de que o aumento da prática da cesárea não pode ser justificado somente por indicações estritamente médicas, posto que, a diferença no grau de intervenção médica no parto varia grandemente entre países e em regiões dentro do mesmo país, mesmo entre populações de características semelhantes, sem corresponder, frequentemente, a melhores índices de mortalidade materna e fetal. Se aceita, então, que diversos fatores sociais, econômicos e institucionais estão relacionados a esta questão (SAKALA, 1993). No caso do Brasil, especificamente, há diversos trabalhos que indicam uma maior incidência de cesáreas entre mulheres de nível socioeconômico mais elevado, que tem menor risco obstétrico, o que sugere que outros fatores que não razões médicas sejam condicionantes importantes da situação (FAÚNDES, CECATTI, 1991; BERQUÓ, 1993, 1994; RATTNER, 1996).

Em 1991, Faúndes e Cecatti observaram que fatores relacionados tanto à oferta quanto à demanda pelo procedimento seriam responsáveis pelo aumento da sua incidência no Brasil. Entre os principais estariam: questões sociais e culturais que gerariam uma demanda das mulheres pela cesárea, a possibilidade de esterilizar a mulher durante a cesárea e interesses diversos dos médicos no procedimento, interesses que estariam associados ao modelo de assistência obstétrica brasileiro. Apesar de não existirem com pesquisas feitas com mulheres sobre o tema (os autores basearam-se nas opiniões de médicos), a preferência das mulheres pela cesárea tem sido aceita como um fato.

Contudo, os resultados de pesquisas recentes realizadas com mulheres em diversas partes do país ${ }^{1}$ levantaram sérias dúvidas quanto a

\footnotetext{
${ }^{1}$ Carranza (1994); Hopkins (1998); Perpétuo, Bessa e Fonseca (1998). Todas estas autoras entrevistaram mulheres que tinham tido filho recentemente, em diversos estados do país e os resultados encontrados foram muito semelhantes entre si.
} 
realidade dessa demanda das mulheres pela cesárea. Todas estas pesquisas documentam que a maioria das mulheres entrevistadas, tanto as que têm partos no serviço público (com taxas mais baixas de cesárea), quanto no serviço privado (com taxas altas de cesárea), preferiam ter tido um parto normal. A indicação da cesárea teria partido do médico e seria aceita passivamente pelas mulheres. Estes resultados sugerem que os médicos seriam os principais responsáveis pela prática abusiva da cesárea, mas pouco esclarece sobre as motivações dos médicos para indicarem um grande número de cesáreas desnecessárias. Interesses financeiros diretos dos médicos na cesárea tem sido a principal explicação apresentada, embora, não haja comprovação empírica deste argumento, à semelhança do que acontece com a demanda das mulheres pela cesárea. A partir de uma perspectiva internacional, Sakala (1993) alerta que não há evidência suficiente para aceitar ou refutar esta suposição, pois diversos outros fatores podem estar envolvidos. Da mesma forma que os pressupostos sobre a demanda feminina não se verificaram, os pressupostos sobre os condicionantes do ponto de vista do médico também parecem inadequados para explicar a complexidade dessa situação. Algumas evidências sugerem que fatores relacionados à organização da assistência obstétrica no país teriam uma relação significativa com a prática da cesárea. É o que mostra, por exemplo, uma análise de 41.404 nascimentos ocorridos no ano de 1994 em Belo Horizonte, na qual o tipo de hospital onde a mulher teve seu parto (se privado, privado filiado ao SUS ou público) era o fator que mais influenciava a probabilidade de ter ou não uma cesárea ${ }^{2}$.

Estas considerações nos sugerem que, para elucidar como interagem os mecanismos responsáveis pela elevação e manutenção dos altos índices de cesárea no Brasil, necessitamos investigar com maior profundidade três questões:

\footnotetext{
2 Análise dos dados do SINASC (Sistema de informação sobre nascidos vivos) de Belo Horizonte para o ano de 1994, apresentada por Chacham e Pérpetuo (1996, 1998).
} 
1) Existem diferenças no modelo de assistência obstétrica de cada tipo de hospital que podem justificar os diferenciais da taxa de cesárea por tipo de hospital?

2) Quais são os fatores que levariam os médicos a indicarem um número excessivo de cesáreas desnecessárias?

3) Quais são os fatores que levariam um grande número de mulheres que desejam um parto normal a aceitarem passivamente uma cesárea?

Neste trabalho buscamos responder a estas perguntas com base em um arcabouço teórico que considera que o excessivo número de cesáreas praticadas no Brasil como parte da tendência mundial à medicalização do parto, a qual estimularia o uso crescente de tecnologia médica para administrar e controlar o processo do nascimento. Esta tendência estaria inserida em um processo muito mais abrangente de medicalização do corpo e tecnologização, presente em todas as sociedades industrializadas. Medicalização é o processo pelo qual se redefinem diversas condições de saúde, de status social e comportamentos como pertencendo ao âmbito médico, submetendo-os ao sistema de saúde para serem curados ou administrados (BECKER, NACHTIGALL, 1992). Este processo estabelece assim a homogenia e a afirmação da autoridade e do controle médico sobre a população (FARIA, 1989). A partir do conceito de medicalização, analisamos aqui como a abordagem biomédica dominante legítima a intervenção crescente do obstetra na gravidez e no parto e fornece os parâmetros para sua atuação. O modelo de conhecimento médico passaria, então, a permear uma percepção de corpo, gravidez e parto, compartilhada por médicos e pacientes. O conceito de risco foi instrumental nesse processo de redefinição do que é "aceitável” ou não em um trabalho de parto, colaborando para justificar a intervenção médica. É importante frisar que a progressiva medicalização do parto foi parte do processo de institucionalização da obstetrícia como especialidade médica legítima ${ }^{3}$. E isto só tornou possível pela

\footnotetext{
${ }^{3}$ Ver Oakley (1997) para uma discussão mais ampla sobre o processo de redefinição do parto como um processo potencialmente patológico e a obtenção do controle médico sobre o atendimento ao parto.
} 
transformação da percepção do parto de um fenômeno natural para uma percepção na qual este é visto como um processo potencialmente patológico, que requer o controle e intervenção médica. Como Arney (1982) coloca:

Enquanto que no século dezenove os obstetras se preocupavam somente com partos 'problemáticos', através do século vinte, todos os partos foram redefinidos como sendo potencialmente problemáticos. Eles assim o foram determinados através do uso rotineiro de procedimentos de monitoração (como monitores fetais eletrônicos). Depois que monitorizarão enquanto prática ficou firmemente estabelecida, a obstetrícia não se confinou mais ao parto anormal potencialmente patológico; todos os partos foram submetidos ao seu controle (p.100).

Neste trabalho, procuramos explorar as implicações do crescente processo de medicalização do parto sobre a prática médica e crenças e preferências das mulheres sobre o parto. Nas seções seguintes são apresentados os resultados de entrevistas com 18 médicos e 60 mulheres que tinham tido filhos recentemente e discutimos como o conceito de risco dentro do discurso médico impacta tanto na prática obstétrica quanto nas preferências das mulheres por um tipo de parto ou sua aceitação de um tipo de parto que não desejavam.

\section{A pesquisa com os médicos}

Para fundamentar nossa discussão, realizamos uma pesquisa com 18 médicos ginecologistas-obstetras. $\mathrm{O}$ instrumento de coleta de dados utilizado na pesquisa com os médicos foram entrevistas, nas quais um questionário (apresentado no anexo um) era aplicado. Este era composto majoritariamente por questões abertas, para permitir que os médicos entrevistados expressassem livremente suas opiniões e discutissem suas práticas. O questionário foi desenvolvido após longas conversas com obstetras com diferentes tipos de práticas (particular e em hospital público) e foi pré-testado e revisado algumas vezes antes de ser aplicado.

No total, 18 médicos ginecologistas-obstetras foram entrevistados entre o período de novembro de 1996 e maio de 1997. Na seleção dos médicos 
a serem entrevistados não buscávamos representatividade ou significância estatística, mas alguns critérios foram usados na escolha dos que foram entrevistados. Os médicos selecionados tinham basicamente uma ou mais das seguintes características: um longo tempo de prática médica, de preferência com mais de 30 anos de exercício de profissão e/ou atuação conhecida como sendo de referência para outros médicos na cidade. Alguns deles também ocupavam cargos de direção em escolas de medicina e em dois casos já tinham escrito tese ou artigo sobre o tema desta pesquisa. A partir da experiência destes profissionais, buscamos traçar as transformações no modelo de assistência obstétrica dentro das instituições e nas práticas dos médicos individualmente, do modo como foram percebidas por eles.

Os médicos entrevistados formam um grupo predominantemente masculino, com apenas 4 mulheres e 14 homens, sendo que entre os acima de cinquenta anos de idade há somente uma mulher. Em relação à idade, o médico mais novo entrevistado tinha 31 anos e o mais velho estava com 72 anos. Quatro entrevistados tinham até 39 anos, sete estavam entre 40 e 54 anos, e outros sete médicos tinham mais de 55 anos. A maioria era branca, só dois se descreveram como pardos. Em relação a formação profissional, todos os entrevistados eram especializados em ginecologia e obstetrícia. Quatorze estudaram na Faculdade de Medicina da UFMG, três estudaram na Faculdade de Ciências Médicas e um na UNB. Doze entrevistados fizeram residência nos Hospital das Clínicas da UFMG, dois em hospitais privados e quatro em outros hospitais públicos (uma médica também tinha feito residência no exterior). Entre os médicos entrevistados, seis tinham 30 ou mais anos de formados, quatro tinham de 20 a 29 anos de formados, sete tinham entre 10 e 20 anos, e somente um tinha menos de 10 anos de formado. Praticamente todos os médicos entrevistados possuíam experiência profissional tanto no setor privado quanto no setor público de atendimento à saúde. 


\section{Os médicos, o parto e o conceito de "risco"}

A primeira parte da entrevista compunha-se de questões sobre as preferências e opiniões dos entrevistados a respeito dos tipos de parto, assim como algumas perguntas sobre suas práticas obstétricas. Através destas, nos foi possível perceber, não apenas as opiniões dos médicos sobre o parto normal e cesárea, mas também como suas representações sobre os mesmos afetavam suas práticas obstétricas, de maneira às vezes contraditória com suas declarações. Ao captar as disjunções entre o discurso e a prática dos entrevistados (todos declaradamente favoráveis ao parto normal), a análise de suas possíveis causas nos possibilitou ilustrar alguns aspectos das relações entre práticas médicas e o aumento dos índices de cesárea.

Os entrevistados, embora todos professassem preferir, a princípio, o parto normal para suas pacientes, formavam dois grupos distintos em relação ao seu tipo de prática obstétrica. O grupo majoritário, composto pelos sete médicos com mais de 55 anos e por seis dos mais novos, era caracterizado por uma prática obstétrica mais intervencionista, no sentido de que recorriam mais rotineiramente a intervenções médicas, como o uso do fórceps, episiotomia e anestesias, durante o parto normal. Para eles, a defesa do parto normal não estava associada a uma abordagem mais naturalista do mesmo, típica do segundo grupo. Este era formado por cinco médicos, entre os mais jovens, que defendiam uma concepção menos "médica” do parto e um atendimento mais humanizado ao parto normal. Eles também recorriam a práticas mais “alternativas” como o parto de cócoras e a homeopatia. A maioria dos entrevistados, então, embora declarasse uma prática diferenciada em relação ao uso da cesárea, seria razoavelmente convencional em outros aspectos, não podendo deste modo ser considerados como uma “minoria radical” em relação a outros obstetras.

Nos dois grupos, a maioria absoluta dos médicos atribuiu sua preferência pelo parto normal ao caráter fisiológico deste, o que significaria, na opinião deles, um parto mais saudável e seguro para a mulher. Seus argumentos, em geral, seguiam o seguinte raciocínio: “o parto 
fisiologicamente deve acontecer pela via vaginal”. Alguns médicos, principalmente aqueles considerados mais "naturalistas", colocaram esta preferência até como uma questão filosófica para eles, parte do seus princípios de vida:

Prefiro o natural, que pode exigir corte do períneo, ou uso do fórceps, a natureza não é perfeita, mas na maioria das vezes está certa, é uma questão filosófica (médica, 40 anos).

Na opinião da maioria deles, os benefícios trazidos pelo parto normal para a mãe iriam além dos puramente físicos, envolvendo também alguns aspectos psicológicos que seriam favorecidos pelo parto normal. O parto normal foi colocado por alguns como um direito da mulher:

“A preferência é pelo parto normal, porque apesar da cesárea ser segura, antes de tudo é um direito da mulher, o parto normal é mais vivenciado, mais participativo, mais gratificante, para a mãe, para o neném e mesmo para o médico, apesar do estresse do parto normal, da insegurança, todos se beneficiam” (médico, 38 anos).

"[Prefiro] parto normal, em tese a chance de ser um parto normal é maior, o pós-operatório é muito mais leve, tudo é muito mais leve. E a mulher gosta de ter um parto normal, um parto normal resolve um monte de problema na cabeça dela. A cesárea é uma alternativa e não uma opção" (médico, 45 anos).

"Acho o envolvimento da mãe com o recém-nascido é maior, o entusiasmo da mãe é maior. Esse prazer de ter o filho as mulheres estão perdendo. A cesárea é muito impessoal, no parto normal o médico só assiste. Quem tem o parto normal tem o prazer de ter tido o filho" (médica, 53 anos).

Duas observações podem ser feitas a partir da análise desses depoimentos. A primeira se relaciona ao forte reconhecimento que os médicos fazem do significado emocional do parto normal para a mulher. A segunda seria a grande importância que atribuiriam à participação da mulher no parto e o impacto que percebiam desta participação na interação entre mãe e filho no pós-parto. Praticamente todos os médicos entrevistados mencionaram estes pontos, o que sugere que seja razoavelmente comum aos médicos terem certa consciência da importância dos aspectos psicológicos relacionados ao parto normal para as mulheres. Esta consciência, aparentemente obtida através da 
observação em suas práticas, contrasta como o pouco incentivo que estes mesmos médicos dão para suas pacientes se prepararem para o trabalho de parto. Eles, ao mesmo tempo em que reconhecem a importância da preparação psicológica da mulher para o parto, admitem que esta não ocupe muito tempo durante as consultas, e que se limita muitas vezes em enumerar as vantagens do parto normal, quando a paciente traz o assunto à tona. Alguns deles afirmaram que é "muito cansativo" convencer uma mulher que quer ter cesárea, a tentar um parto normal.

Aparentemente, embora os médicos percebam o aspecto emocional do parto como fundamental, este conhecimento não é traduzido em uma atenção maior a este durante o pré-natal, nem em uma discussão mais ampla de todas as vantagens, além das puramente físicas que os médicos veem no parto normal. Isto sugere uma falha na formação destes profissionais neste sentido, provavelmente devido à pouca importância que o lado psíquico ocupa dentro do próprio paradigma biomédico, no qual são caracterizadas como irrelevantes as interpretações subjetivas dos eventos ditos médicos.

Contudo, o que mais chama a atenção nas descrições dos entrevistados a respeito das vantagens do parto normal foi a perceptível ambiguidade que apresentam em relação a este. A princípio, o parto normal é definido por seus aspectos positivos: por ser fisiológico é o mais saudável, e, além disso, emocionalmente satisfatório para a mulher, sendo assim o parto ideal. Entretanto, frequentemente estes mesmos médicos deixam transparecer em algumas falas, uma percepção do parto normal na qual este aparece como imprevisível e estressante para o médico, e mesmo arriscado. O parto normal é o melhor, apesar de "estressante para o médico, da insegurança". Vários médicos se referiram a essa insegurança e imprevisibilidade que sentem com o parto normal, curiosamente utilizando-se das mesmas frases: "no parto normal nunca se sabe o que pode acontecer" ou "no parto normal, quando complica, complica mesmo" e que "nunca se arrependeu por ter indicado uma cesárea, mas com o parto normal sempre pode se arrepender". Estas observações foram feitas por quase todos os entrevistados, independente da idade, e do tipo de prática (se mais intervencionista ou naturalista). 
Em contraposição à esta insegurança atribuída ao parto normal, no qual "nunca se sabe", a cesárea é apresentada no discurso médico, como segura e previsível: "(na cesárea) todo mundo já sabe o que fazer”. Esta seria um procedimento mais fácil e tranquilo para o médico, e dentro do seu controle. Esta argumentação transforma o parto normal naquilo que a cesárea deveria ser: um procedimento de exceção, a ser usado em alguns casos. Na inversão do raciocínio, o médico se sente correndo riscos com o parto normal, que poderiam ser evitados por uma cesárea. A fala de um médico expõe muito bem este tipo de argumento: "atualmente faço mais cesáreas, porque, mexendo com a fertilização in-vitro, não posso me arriscar, não dá para ser muito acadêmico. A cesárea se torna inócua. Não se corre o risco do parto normal, faz-se a cesárea” (médico, 60 anos). A percepção da inocuidade da cesárea, ao mesmo tempo que se afirma o caráter imprevisível e arriscado do parto normal justificaria assim, o recurso frequente a esta. Como uma médica discute:

Na visão do médico, a cesárea é um procedimento muito simples, muito seguro, o que é um problema muito sério. O tempo que o médico gasta com o procedimento é muito menor, só 40 minutos, e depois dele entregar a criança para o pediatra ele não se sente mais responsável. A responsabilidade dele se mãe e filho saem vivos acabou, se tem complicação depois é fácil arrumar desculpas: se foi infecção foi o hospital, se foi hemorragia foi o banco de sangue.... $\mathrm{O}$ tempo de contato "pele a pele” é muito menor (médica, 37 anos).

É visível o impacto deste discurso do "parto normal como exceção" sobre a prática dos entrevistados, favorecendo um uso mais liberal da cesárea. Embora a maior parte destes médicos alegue ter uma prática privada diferenciada da maioria dos médicos em relação ao número de cesáreas que fazem. Quando perguntados sobre a proporção de cesáreas que fazem dentro do total de partos que atendem, a maioria deles disse ter índices em torno de $35 \%$ do total de partos que realizaram. Este número, sem dúvida, é significativamente mais baixo do que seria o encontrado nas práticas privadas da maioria dos obstetras. Nestas, a proporção de cesáreas provavelmente deve girar em torno dos $70 \%$, para corresponder ao número 
de cesáreas encontrado nos hospitais privados. Os médicos com mais de 55 anos foram os que declararam praticar os menores índices de cesárea, em torno dos $25 \%$. Eles mencionaram que praticam mais cesarianas agora do que antigamente, e justificam estes índices dizendo que atualmente eles têm muitas pacientes com cesárea anterior. Todos os médicos mais novos (que atendem a uma clientela particular) declararam praticar um número maior de cesáreas do que o assumido pelos mais velhos. Eles assumiram ter índices em torno de $35 \%$ a $40 \%$, até mesmo de 50\% de cesárea do total de partos que fazem. Mesmo os médicos conhecidos pela sua filosofia naturalista declararam ter índices acima de 35\% de cesáreas.

Quando fizemos esta pergunta, obviamente não esperávamos que os médicos respondessem com exatidão, nem tomar como a resposta como uma declaração verdadeira. Provavelmente, nem mesmo os médicos sabem com certeza a proporção de cesáreas da sua prática, a menos que já tenham feito algum levantamento ${ }^{4}$. O que buscávamos saber é a quantidade que eles admitiam praticar, e os números obtidos nos forneceram informações interessantes a respeito de sua prática: mesmo entre o que poderia se considerar uma espécie de "elite" de uma prática obstétrica menos intervencionista, ainda temos um número de cesáreas excessivamente alto, e medicamente injustificável. Injustificável, porque se considerarmos que a clientela desses médicos (de acordo com suas próprias declarações) é composta de mulheres de classe média com bom acesso aos serviços de saúde, bom estado geral de saúde e nutrição e de baixo risco obstétrico, estes índices parecem injustificáveis quando a Organização Mundial de Saúde admite para toda a população um índice de até $15 \%$.

A justificativa apresentada por eles (e todos justificaram espontaneamente seus números, mostrando ter consciência de que são

\footnotetext{
${ }^{4}$ Apenas um dos entrevistados declarou que alguma vez já tinha feito o levantamento da proporção de cesáreas na sua prática. Essa falta de controle dos médicos sobre sua prática é em si um fato muito interessante por indicar a ausência de qualquer tipo de controle e regulação em relação a prática médica. Os médicos, basicamente, não têm de prestar contas a ninguém a respeito do número de cesáreas que fazem.
} 
índices altos) é de que não seria possível abaixar estes números por uma questão de segurança. A preocupação com a segurança da paciente e do feto, reforçada pelo medo de processos judiciais, estimularia a prática da cesárea, segundo vários entrevistados. A pouca segurança para acompanhar o trabalho de parto devido à falta de aparelhos de monitoramento e, muitas vezes, de aparelhos de ultrassom, nas maternidades, geraria insegurança nos médicos. Estes, na dúvida, optariam por uma cesárea. Entretanto, deve ser lembrado que o uso do monitoramento fetal durante o parto elevou o número de cesáreas em todo o mundo e não teve efeito comprovado na diminuição da morbi-mortalidade fetal (McCUSKER et al., 1988, NELSON et al., 1996). Na base destes argumentos, que envolvem a questão de "segurança", poderíamos identificar novamente a representação do parto normal como arriscado e imprevisível, e da cesárea como opção segura.

A acentuação dos índices de cesáreas nos últimos anos, também não deixou de afetar a prática dos entrevistados: a maioria dos médicos entrevistados admite que houve uma diminuição do número de horas que eles esperam para um trabalho de parto evoluir, na ausência de complicações. Este fenômeno ocorreu mundialmente e é considerado um resultado do aumento do nível de intervenção no parto (LoCICERO, 1993). Alguns dos médicos mais velhos comentaram que antes esperavam até 18 horas por um parto, principalmente para primeiro filho. Um mencionou que antes era comum fazer indução seriada (começar uma indução de parto em um dia e, se o parto não progredir, parar com a indução e recomeçar novamente no dia seguinte), prática que ainda é rotineira no exterior. Hoje em dia, entretanto, eles normalmente esperariam somente entre 8 ou 12 horas por um parto. Esta média também foi mencionada por médicos mais jovens, apesar de alguns médicos, entre os que defendem uma prática menos intervencionista, terem declarado que acontece de esperarem até 15 horas por um parto. Aparentemente, os médicos consideram estressante esperar longas horas por um parto: a espera parece estar associada a risco.

Outro aspecto em que podemos observar como é crescente a tendência à maior medicalização do parto, é a diminuição do número de 
médicas e esposas de médicos que têm partos normais. Os médicos entrevistados foram perguntados sobre o tipo de parto que suas esposas tiveram e suas respostas foram marcadamente divididas pela faixa etária: entre os sete médicos cujas esposas tiveram partos normais, seis tinham mais de 55 anos. Uma única médica teve parto normal, e ela também tinha mais de 55 anos. Somente um médico entre aqueles cujas esposas tiveram partos normais tinha 44 anos; mesmo assim, deve ser observado que sua esposa já tinha tido dois partos normais em um casamento anterior, antes de se tornar "mulher de médico". Os próprios médicos observaram que não seria comum parto normal em médicas (e como vimos possivelmente nem entre mulheres de médicos): “elas ficam muito ansiosas, porque para nós é muita pressão, na cesárea tira logo a criança”.

Consideramos estas informações relevantes por sugerirem que a preferência pela cesárea não derivaria exclusivamente de puro interesse econômico no procedimento. Se, na opinião dos médicos, a cesárea fosse apenas mais vantajosa financeiramente em relação ao parto normal, mas, muito inferior a esse em termos de segurança e outras vantagens para mãe e filho, se esperaria que houvesse um número maior de partos normais entre as esposas dos médicos, mas não foi essa a situação encontrada, mesmo entre estes médicos que se consideram defensores do parto normal. Certamente, todos eles declararam que preferiam um parto normal para suas esposas, mas sempre alegavam, mostrando até certo constrangimento, que alguma indicação médica levou à cesárea. Um médico chegou a observar que "com mulher de médico sempre complica”. Mas deve-se observar que estas complicações ocorreram somente com as esposas dos médicos mais jovens e com nenhuma esposa dos médicos mais velhos. Isso parece indicar, mais provavelmente, que "complicação no parto" tem sido redefinida em termos mais amplos do que costumava ser a tempo atrás, especialmente no caso de esposas de outros médicos.

Parece meio óbvio afirmar que valores de cunho médico afetem os médicos primeiro e mais intensamente que ao resto da população. Contudo, provavelmente esta é a razão das contradições encontradas no discurso dos 
médicos entrevistados a respeito do parto normal. Nas falas da maioria deles, por mais que se considerem como defensores do parto normal, a cesárea aparece quase sempre como sendo segura, mais fácil e menos estressante, para o médico, enquanto que o parto normal é definido como arriscado. Ao mesmo tempo, deve ser lembrado que a redefinição do parto como evento médico depende da afirmação do caráter potencialmente problemático do parto, e é o que justifica a intervenção médica no parto. Como Davis-Floyd lembra, a cesárea é conceitualmente útil para a obstetrícia: "ao transformar o nascimento em um procedimento cirúrgico de rotina, legitima-se a obstetrícia enquanto ato médico, pois se incorpora à sua prática um elemento central da medicina moderna e uma das formas mais elaboradas de manipulação do corpo-máquina humano — a cirurgia” (1992:152).

A reafirmação constante do parto normal como imprevisível, seria coerente, assim, com o modelo de conhecimento médico e a prática médica. A crença no valor dos recursos tecnológicos da biomedicina para lidar com as possíveis complicações do parto normal, seria, então, igualmente compartilhada por médicos e pacientes. Estas observações, também nos levam a sugerir que a prática médica é afetada por muito mais do que interesses econômicos na cesárea. Pelo que pudemos observar, o discurso intervencionista afeta de maneira intensa mesmo médicos que por princípio se opõem a ele, e de variadas formas: no número de cesáreas que fazem; no número de horas que esperam por um parto; na falta de preparação da paciente para o parto durante o pré-natal; e mesmo nos partos de suas esposas. Só podemos especular a respeito do impacto provavelmente ainda mais significativo entre médicos que não têm um discurso tão cristalizado a favor do parto normal e que veem seus interesses como melhor servidos por uma prática mais intervencionista.

Quando perguntados sobre como seria possível diminuir os índices de cesárea, a maioria absoluta se mostrou pessimista em relação à esta possibilidade. Muitos apontaram que o modelo de assistência ao parto centrado na figura do médico é um dos grandes responsáveis pelo alto índice de cesáreas: para o médico é muito cansativo e financeiramente 
desvantajoso atender por longas horas o trabalho de parto de pacientes particulares. Entretanto, foram poucos, e somente aqueles com algum tipo de experiência direta com enfermeiras obstétricas, que levantaram a possibilidade de sua inclusão no atendimento e reformulações na organização do sistema como forma de se aumentar a viabilidade do parto normal. Os poucos que fizeram sugestões neste sentido admitiam que interesses corporativos dos médicos seriam contrariados pela reinstalação de parteiras hospitalares.

A análise das entrevistas com obstetras sugere que diversos fatores parecem estar relacionados a um tipo de prática obstétrica mais intervencionista, caracterizada pelo recurso frequente a cesáreas. Decerto há vários interesses da parte dos médicos envolvidos nesta questão, mas é importante frisar que estes não se restringem a interesses financeiros. Como vimos o menor tempo despendido com a cesárea não teria apenas implicações econômicas para os médicos. A espera pela finalização normal de um parto parece gerar considerável tensão e ansiedade entre os obstetras. Já a cesárea, por sua vez, proporcionaria ao médico a sensação de controle total sobre o processo de nascimento, e por isso é percebida como segura. O próprio modo que o parto normal é compreendido pelo do modelo de conhecimento médico parece estar associado a essas percepções. É inquestionável que os obstetras têm de lidar com uma ambiguidade: administram um processo fisiológico que, na maioria dos casos, eles mesmos reconhecem, acabaria bem, independentemente da sua presença. $\mathrm{O}$ recurso ao conceito de risco, justifica a presença do médico na assistência ao parto, mas também condiciona sua conduta, favorecendo a intervenção.

\section{A pesquisa com as mulheres}

Sessenta mulheres foram entrevistadas para esta pesquisa. Nas entrevistas com as mulheres procuramos observar o grau de influência de valores médicos sobre as crenças e preferências das mulheres de diferentes níveis socioeconômicos a respeito dos tipos de parto e estas se relacionam com o desejo pela cesárea e/ou sua aceitação. As entrevistas foram feitas 
com 30 usuárias dos serviços privados de saúde e com 30 usuárias do serviço público de saúde. Do mesmo modo que na pesquisa feita com os médicos, um questionário com questões abertas foi o instrumento utilizado para a coleta de dados. Esta técnica foi considerada como a mais adequada para captar o aspecto subjetivo da experiência de um número razoável de mulheres de diferentes classes sociais com o parto. Recentemente, tanto em hospitais privados como em um hospital que atende pelo sistema público de saúde, o questionário foi pré-testado com algumas mulheres que tiveram filhos em hospital privado e outras que foram pacientes no Hospital Sofia Feldman (que atende pelo SUS), sendo revisado algumas vezes antes de atingirmos a versão definitiva.

Esse critério foi escolhido porque, mais do qualquer outra característica da mulher, como idade, nível de educação ou número de filhos, o tipo de hospital onde a mulher teve seu filho é, individualmente, o fator com mais influência na probabilidade de a mulher ter, ou não, uma cesárea em Belo Horizonte (CHACHAM; PERPÉTUO, 1996, 1998).

A seleção das mulheres entrevistadas foi aleatória, sem ter como objetivo alcançar representatividade e significância estatística. O número total de entrevistadas não foi pré-determinado. O critério utilizado para determinar este número foi o da saturação. Ou seja, as entrevistas foram sendo feitas até obtermos respostas repetidas em número suficiente para garantir que os objetivos da pesquisa fossem cumpridos adequadamente. No final, foram entrevistadas 30 mulheres em hospitais privados e 30 mulheres no Sofia Feldman. As entrevistas foram feitas entre o segundo semestre de 1996 e no início do ano de 1997.

O Sofia Feldman é um hospital localizado no bairro Tupi, periferia da região norte de Belo Horizonte. É um hospital privado, mas de caráter filantrópico que atende pelo SUS. Este hospital é caracterizado por ter uma filosofia de atendimento obstétrico diferenciada de outras maternidades da cidade. Lá, eles procuram atender às mulheres dentro dos princípios de humanização do atendimento ao parto, usando de pouca tecnologia e 
procedimentos menos invasivos, respeitando a fisiologia do processo de nascimento. O hospital busca incentivar o parto natural, de cócoras, e também usa de enfermeiras-obstétricas para fazerem o atendimento ao parto e ao pré-natal de baixo risco ( $75 \%$ dos partos normais foram assistidos por enfermeiras em 1996). Como resultado desta filosofia, o hospital mantém a taxa de cesárea mais baixa da cidade ${ }^{5}$. No período que a pesquisa foi realizada (final de 1996 e princípio de 1997), a taxa de cesárea do hospital foi de $18,4 \%$, de acordo com os registros hospitalares. A proporção de partos onde fórceps foi usado não passou de 2,4\% do total, indicando que uma tecnologia invasiva não está sendo substituída por outra.

Três critérios determinaram a escolha deste hospital como local para a realização das entrevistas: o fato de ter o índice de cesáreas mais baixo da cidade, o modelo de assistência obstétrica diferenciado adotado e o grande número de mulheres que são atendidas neste hospital. No Sofia Feldman, como já foi dito, no caso de partos normais, sem complicações, as enfermeiras são responsáveis pelo atendimento e pelas decisões relativas a este, consultando os médicos sempre que consideram necessário. Em todos os outros hospitais da cidade, sejam públicos ou privados, o atendimento ao parto é centrado na figura do médico, seja o plantonista, no caso dos hospitais públicos e privados que atendem pelo SUS, ou o médico particular da paciente, no caso dos hospitais privados, é o médico que acompanha todo o parto, desde o estágio inicial até a fase final, e toma todas as decisões relativas a este. Essa diferença na forma de organização do atendimento é altamente significativa para entendermos a variação nas taxas de cesáreas entre instituições, pois a evidência encontrada na literatura (PEL et al., 1995; SAKALA; 1993b) indica que mulheres atendidas por médicos, consistentemente, têm taxas de cesáreas mais altas que as atendidas por uma equipe onde estão presentes também outros tipos de provedores de cuidados obstétricos como enfermeiras e parteiras, mesmo quando atendem a populações com características semelhantes.

\footnotetext{
${ }^{5}$ De acordo com os dados do SINASC de 1994 (CHACHAM; PERPÉTUO, 1996).
} 
Por outro lado, ao mesmo tempo em que o modelo de atendimento obstétrico é atípico, a clientela atendida por este é completamente típica dos hospitais que atendem pelo SUS. De acordo com o SINASC de 1994, mais de $90 \%$ das mulheres atendidas na instituição hospitalar vinham de bairros populares, onde a renda média é inferior a 5 salários mínimos. Deste modo, dentro do hospital tivemos fácil acesso a um grande número de mulheres moradoras de vários bairros populares da periferia de Belo Horizonte. Como o hospital também funciona como serviço de referência regional, ele recebe pacientes de diversas maternidades públicas de outras partes da cidade devido à falta de vagas. Deste modo, são atendidas mulheres de bairros bem distantes da maternidade e mesmo de outras cidades da região metropolitana.

Somente $30 \%$ das pacientes atendidas pelo hospital fizeram o prénatal no próprio hospital, tendo a maioria sido encaminhada para lá pelo posto de saúde onde foi feito o pré-natal ou por outro hospital. Portanto, o contato da maioria delas com o hospital é pequeno, pois só o procuram no momento do parto, e nele permanecem apenas dois dias em média. Mesmo levando isso em conta, pensamos que seria relevante observar o impacto da filosofia de atendimento do hospital sobre um grupo de mulheres vindas das camadas menos privilegiadas, mulheres que poderiam ser atendidas em qualquer outro hospital filiado ao SUS. Reconhecemos que é difícil dimensionar esse impacto sobre as representações e preferências das mulheres sobre o parto, mas acreditamos que este mereça ser explorado.

Ao selecionarmos, tanto mulheres que tiveram filhos em hospitais privados quanto as que tiveram filho no Hospital Sofia Feldman, nós entrevistamos mulheres que estão em polos opostos do atendimento obstétrico: umas em um serviço com financiamento estatal, que tem a taxa mais baixa de cesárea da cidade, e outras em serviços privados, com alta incidência de cesárea (em torno de 70\%). Esse acesso diferenciado aos serviços médicos reflete também as desigualdades socioeconômicas entre os dois grupos de mulheres entrevistadas. Apesar da diversidade entre elas, dentro dos grupos, as entrevistadas tendem a ter características bem semelhantes entre si, constituindo grupos razoavelmente homogêneos. As 
mulheres que foram entrevistadas no Sofia Feldman eram, na sua maioria, mulheres pobres, jovens, primíparas, com baixo nível de instrução, e sem atividade remunerada. Muitas eram mães adolescentes e a maioria era parda ou negra. Já as mulheres que tiveram filhos em hospitais privados constituíam um grupo bem mais velho, com nível mais alto de renda e de educação. A maioria era branca e pertencia aos estratos sociais mais privilegiados.

\section{Mulheres, partos normais e cesáreas: desejos e temores}

Nesta seção apresentamos uma síntese de nossos resultados das entrevistas com as mulheres e de nossas principais conclusões sobre estes, na forma de quatro grupos, nos quais as mulheres foram divididas pela sua experiência em relação ao tipo de parto desejado antes da sua entrada no hospital e pelo tipo de parto que tiveram. São estes: mulheres que desejavam ter parto normal e tiveram parto normal; mulheres que queriam ter parto normal e tiveram parto cesárea; mulheres que queriam ter cesárea e tiveram parto cesárea e mulheres que queriam cesárea e tiveram parto normal. Descrevemos aqui os principais aspectos encontrados em cada situação, para ilustrar diferenças e similaridades por classe social na preferência por tipo de parto em relação ao obtido e as possíveis causas da discrepância entre desejo e parto efetivamente obtido em cada grupo.

\section{Mulheres que desejavam um parto normal e tiveram parto normal}

Este grupo é composto em sua maior parte, por mulheres entrevistadas no Sofia Feldman, dado que, tanto a preferência pelo parto normal, quanto a ocorrência do mesmo são mais comuns entre mulheres de nível socioeconômico mais baixo, que tiveram seus partos pagos pelo SUS. As razões apresentadas para a preferência pelo parto normal variavam muito de acordo com o estrato social ao qual a mulher pertencia. As mulheres das camadas médias entrevistadas declararam preferir o parto normal principalmente por ser "natural” e o melhor para mãe e o bebê. Entre as mulheres dos estratos populares, o parto normal era preferível à cesárea por não ser uma cirurgia, trazer menos riscos para a mulher, e ter 
melhor recuperação. Há uma distinção importante aqui: enquanto as mulheres de classe média percebiam o parto normal como um valor em si mesmo, as mulheres no Sofia Feldman o preferiam por exclusão, por o considerarem “menos pior” que a cesárea.

Valores relacionados a uma filosofia mais "holística" de vida e da medicina, que buscam opções consideradas mais naturais e saudáveis, parecem influenciar a mulheres de classe média na sua opção pelo parto normal. Ao mesmo tempo, a aceitação e absorção do discurso e valores relacionados à percepção biomédica do parto, trazem uma ambiguidade ao discurso destas mulheres, no qual o parto normal é representado frequentemente como sendo o que denominamos de um "procedimento de exceção”. O caráter fisiológico do parto normal, ao mesmo tempo em que é ressaltado como positivo, é interpretado também como significando imprevisibilidade e risco. O parto normal é o ideal, mas somente se for fácil e rápido. Um parto mais longo é interpretado como um sofrimento desnecessário para a mulher e risco para o feto. O conceito de risco, inerente ao discurso médico, parece ser fundamental para que as mulheres aceitem uma cesárea à menor indicação de possibilidade de complicações. Parece claro também que as mulheres absorvem esta ideia, não exclusivamente, mas principalmente à partir do discurso de seus médicos. As diferenças entre mulheres dos dois grupos parecem ser fundamentais neste aspecto. A maioria das mulheres com médicos particulares declarou ter uma excelente relação com seu médico, de estreita confiança. O médico aparece como a principal referência da mulher sobre os assuntos de gravidez e parto, sendo suas recomendações em geral acatadas. Entre as mulheres que fizeram seu pré-natal com médicos do SUS a relação é bem mais impessoal e distante e elas demonstraram tanto certa desconfiança, quanto desconhecimento da opinião destes.

Essa percepção do parto normal como "procedimento de exceção" parece ter contribuído para que somente partos normais fáceis e rápidos ocorressem em hospitais privados. As mulheres que tiveram partos normais em hospital privado, de acordo com seus depoimentos, em geral tiveram 
partos fáceis, rápidos e sem intercorrências. A percepção do parto foi positiva, embora muitas tenham expressado uma sensação de alienação, distanciamento de todo o processo, conduzido pelo médico. As mulheres no Sofia tiveram partos de todos os tipos, demoraram mais, algumas tiveram intercorrências. De modo geral consideraram o parto como doloroso. Por outro lado, elas pareciam aceitar mais naturalmente o parto e participarem mais ativamente nele do que as mulheres que tiveram filho em hospitais privados. O tipo de assistência obstétrica que cada grupo de mulher recebeu pareceu ser determinante da probabilidade de a mulher ter um parto normal.

\section{Mulheres que desejavam um parto normal e tiveram cesáreas}

É a experiência mais provável de ocorrer para um grande número de mulheres das camadas médias. A maioria delas desejava um parto normal (mesmo as com cesárea anterior) e tiveram cesáreas. As razões da preferência pelo parto normal são as mesmas apresentadas no item anterior. Em geral, a decisão por um parto cesárea foi feita com antecedência, devido a alguma indicação apresentada pelo médico. Embora preferissem o parto normal, nenhuma mulher discutiu a indicação de uma cesárea ou questionaram a necessidade da cirurgia. Tampouco procuram uma segunda opinião. Algumas poucas mulheres se sentiram efetivamente pressionadas pelo médico, e uma pelo marido, a aceitar uma cesárea. Não foi o caso da maioria, que declarou ter sido incentivada, apesar de não preparada, para o parto normal, pelos médicos.

A representação do parto normal como um "procedimento de exceção” parece influir nessa aceitação razoavelmente tranquila da cesárea pelas mulheres. Mesmo não aceitando que o parto normal seja perigoso, a visão do parto normal como potencialmente arriscado (enquanto os riscos da cesárea são minimizados) predispõe a mulher aceitar a cesárea. Esta geralmente não é vista de modo negativo pelas entrevistadas, mas como um recurso sempre à mão. O fato de elas estarem cercadas por um grande número de amigas e parentas que também "falharam” ao tentar um parto normal, parece influenciar nesta aceitação sem culpas da cesárea, ao 
contrário do que descreve a literatura internacional (MUTRYN, 1993). Deste modo, a cesárea é uma experiência próxima e geralmente não é avaliada negativamente, embora algumas mulheres lamentem a experiência que perderam ao não terem tido um parto normal.

Já as mulheres que tiveram filho no Sofia Feldman, através de cesáreas, em geral passaram por um longo trabalho de parto antes da cirurgia. Diferentemente das mulheres de classe média, elas teriam maior probabilidade de terem uma percepção negativa da cesárea e de descreverem em termos negativos suas experiências. Elas queixaram-se principalmente de dificuldades na recuperação após a cesárea. A recuperação, que foi descrita como tendo sido fácil e rápida pelas as mulheres que tiveram filho em hospital privado, foi considerada difícil e dolorosa pelas mulheres atendidas pelo SUS.

\section{Mulheres que desejavam uma cesárea e tiveram cesáreas}

Entre as mulheres deste grupo, as das camadas médias são a maioria. Entre elas, quando uma mulher quer uma cesárea, normalmente ela a obtém. Já entre as mulheres atendidas pelo SUS, mesmo quando estas desejavam uma cesárea, elas só a conseguiam quando existia uma forte indicação médica para o procedimento.

A razão da preferência pela cesárea, diferentemente do que ocorre com a preferência pelo parto normal, não é diferenciada por classe social. O medo da dor do parto normal é apontado por quase todas as mulheres como sendo a principal motivação para preferir-se uma cesárea. Para as mulheres do Sofia Feldman esta foi à única razão apresentada, mas, entre as mulheres de classe média, outra razão apareceu ligada ao desejo por uma cesárea: a necessidade de controle sobre o parto. Para algumas poucas, a cesárea significava, especificamente, uma maior segurança para o bebê, por ser previsível, "ter os fatores controlados". No entanto, para a maioria das mulheres, a necessidade de controle sobre o processo do nascimento pareceu ser satisfeita ao marcarem o dia e hora da cesárea. Aparentemente, na medida em que o 
médico tem o controle do parto, elas se sentem em controle e seguras. Elas parecem aceitar o que Davis-Floyd (1992, 1994) define como o modelo tecnocrático de parto que valoriza o controle médico sobre o parto. Neste modelo, o natural é associado com insegurança e imprevisibilidade.

Embora quase todas as mulheres das camadas médias que queriam uma cesárea tenham obtido seu desejo, muitos dos seus médicos relutaram a princípio em indicar a cesárea. Para a maioria, somente ao final da gravidez o médico concordou com a cesárea, mas sempre apresentando alguma indicação médica, por mais discutível que fosse para tal. Deste modo, os médicos retiveram o controle sobre a decisão. A cesárea foi marcada com antecedência, na maioria das vezes, para as mulheres em hospitais privados. Já no Sofia Feldman a decisão pela cesárea foi tomada durante o parto. As primíparas que tiveram filho em hospital privado, e que queriam uma cesárea, declararam ter ficado extremamente assustadas antes da cirurgia, embora posteriormente tenham considerado a experiência positiva. Novamente, todas as mulheres de classe média consideraram sua experiência com a cesárea positiva e a recuperação fácil, ao contrário das mulheres do Sofia Feldman.

\section{Mulheres que desejavam uma cesárea e tiveram parto normal}

Um número pequeno de mulheres se encontrava nesta situação, mais comum entre mulheres do Sofia Feldman do que entre mulheres de hospitais privados. Quando a mulher é atendida pelo SUS, geralmente nem há oportunidade para a mulher expressar sua preferência, se houver a possibilidade de um parto normal. No privado, geralmente é o médico quem convence a pelo menos tentar um parto normal, ou permite a mulher a tentar, no caso das mulheres com cesárea anterior. Apesar de a razão mais comum para a mulher desejar uma cesárea ser o medo da dor, neste grupo apareceram algumas exceções. Algumas mulheres queriam a cesárea por que pensavam ter uma indicação para esta. Nesta situação, estavam duas mulheres que tinham cesárea anterior e tiveram partos normais desta vez e duas primíparas. Em geral, elas gostaram de seus partos, os quais, no caso 
das mulheres de hospital privado, do mesmo modo que o encontrado no primeiro grupo foram rápidos e fáceis.

As experiências das mulheres em relação ao parto e como vimos anteriormente, da gravidez e pré-natal, no relacionamento com o médico, e as razões de suas preferências podem ser divididas por estrato social e o tipo de atendimento obstétrico ao quais elas têm acesso.

\begin{tabular}{|c|c|c|}
\hline \multicolumn{3}{|c|}{ Uma síntese da experiência de pré-natal e parto das mulheres entrevistadas divididas por grupo } \\
\hline Caracterização & Camadas médias & Camadas populares \\
\hline Atendimento médico & Personalizado & Anônimo \\
\hline Interação médico-paciente & Afável ou plena & Mínima \\
\hline Treinamento para o parto & $\begin{array}{l}\text { Pouco, por iniciativa da } \\
\text { gestante }\end{array}$ & Inexistente \\
\hline $\begin{array}{l}\text { Transferência de informação } \\
\text { médico-paciente }\end{array}$ & Razoável & Mínima \\
\hline Confiança no médico & Irrestrita & Parcial \\
\hline $\begin{array}{c}\text { Reconhecimento do médico } \\
\text { como único expert em gravidez } \\
\text { e parto }\end{array}$ & Total & Parcial \\
\hline Deferência às decisões médicas & Total & Parcial, às vezes relutante \\
\hline Absorção do discurso médico & Significativa & Mínima \\
\hline $\begin{array}{c}\text { Razões da preferência pelo } \\
\text { parto normal }\end{array}$ & $\begin{array}{c}\text { Por ser "natural” } \\
\text { Melhor para a mãe e o bebê }\end{array}$ & Melhor recuperação \\
\hline $\begin{array}{c}\text { Razões da preferência pela } \\
\text { cesárea }\end{array}$ & $\begin{array}{c}\text { Medo da dor } \\
\text { Sensação de controle } \\
\text { Sobre o parto ou/e dia e hora }\end{array}$ & Medo da dor \\
\hline $\begin{array}{c}\text { Percepção da experiência do } \\
\text { parto normal }\end{array}$ & $\begin{array}{c}\text { Experiência positiva } \\
\text { Tranquilo }\end{array}$ & $\begin{array}{l}\text { Doloroso } \\
\text { "Menos pior" }\end{array}$ \\
\hline $\begin{array}{l}\text { Percepção da experiência do } \\
\text { parto cesárea }\end{array}$ & $\begin{array}{c}\text { Positivo } \\
\text { Tranquilo, rápido }\end{array}$ & Negativa \\
\hline Participação no parto normal & Pouca, dirigida pelo médico & Ativa, "trabalho duro" \\
\hline Descrição do parto cesárea & Mínima & Nenhuma \\
\hline Recuperação do parto normal & Mais difícil que esperava & Fácil \\
\hline Recuperação do parto cesárea & Rápida & Difícil e dolorosa \\
\hline
\end{tabular}


Nossos resultados indicam que a alta aceitação da cesárea por parte das mulheres pode ser atribuída, em parte, a alguns elementos presentes na relação entre as mulheres das camadas médias e seus médicos. Seriam estes: a aceitação da legitimidade da intervenção médica no parto e a absorção do modelo de conhecimento médico sobre o parto pelas mulheres. Embora não ocorra de forma linear, completa ou acrítica, esta aceitação e absorção do discurso médico pode explicar porque muitas mulheres que desejavam ter um parto normal aceitassem, sem relutância, a indicação da cesárea. Mesmo reconhecendo que há abuso na prática da cesárea, as mulheres geralmente submetem-se à decisão do médico, sem questionar sua validade.

Entre as possíveis razões para explicar a submissão ao discurso médico, apontamos primeiramente a hegemonia do modelo médico de conhecimento. Essas mulheres e seus médicos, em geral oriundos das camadas mais privilegiadas da população, compartilham a mesma linguagem e a crença na validade do enfoque biomédico na atenção à gravidez e ao parto $^{6}$. A legitimidade desse modelo seria também ainda mais forte nos setores com melhor acesso aos serviços de saúde. Se muitas vezes este enfoque parece ser conflitante com outra linha de valores mais "naturalistas", predomina a aceitação pelas mulheres do uso rotineiro da intervenção médica, e, em suas falas, as mulheres das camadas médias frequentemente reproduzem o discurso médico no qual o parto normal é sempre caracterizado como um "risco".

A submissão do paciente à autoridade médica pode ser, em parte, atribuída ao crescimento tecnológico e à crescente especialização da medicina. O uso de linguagem e conceitos técnicos diminui consideravelmente a capacidade das mulheres de tomar decisões informadas sobre a gravidez e o parto. No caso de mulheres, a submissão à autoridade médica seria reforçada por significar geralmente submissão a uma figura de autoridade masculina, ou mesmo a outra mulher desempenhando um papel que é percebido como tipicamente masculino. Contudo, a medicalização do

\footnotetext{
${ }^{6}$ Fenômeno também descrito por Martin (1984, 1987).
} 
corpo e do parto certamente não é uma especificidade brasileira. Em vários outros países, a medicalização da sociedade e o controle médico sobre a gravidez e o parto são até mais extenso e intensivo que no Brasil, mesmo que a assistência pré-natal e ao parto não seja feita por médicos e sim por outros profissionais de saúde.

No entanto, no Brasil nunca houve o estabelecimento de uma proposta alternativa ao modelo de assistência obstétrica centrado no médico, como ocorreu em outros países. Nestes, a figura da parteira foi incorporada ao sistema oficial de saúde e isso parece ter sido fundamental para manter baixas as taxas de cesárea, mesmo dentro de um contexto de intensiva medicalização da gravidez e do parto. Já nos Estados Unidos, certamente uma sociedade muito mais medicalizada que o Brasil, há um sistema de atendimento similar ao brasileiro e as taxas de cesáreas mais altas, entre os países desenvolvidos, ainda sendo menores que as nossas. Provavelmente, a força do movimento de consumidores nos EUA e o maior poder de regulação e vigilância da sociedade civil americana sobre a atividade médica, juntamente com a existência de expressivos movimentos feministas, são fatores que impedem um crescimento ainda maior das taxas de cesáreas americanas. A existência de um movimento organizado em defesa do parto natural, o "natural childbirth movement”, também contribuiu para coibir alguns excessos na prática da cesárea, assim como favorecer a criação de opções de atendimento ao parto alternativo às oficiais, como as casas de partos (SAKALA, 1993b). No Brasil, a substituição do modelo antigo, de partos domiciliares com parteiras tradicionais, pelo atual, centrado na figura do médico e muito intervencionista, não veio acompanhada por nenhum modelo alternativo de assistência ao parto acessível a um número mais expressivo de mulheres. A luta por um atendimento obstétrico mais humanizado depende assim das ações isoladas de médicos e pacientes e alguns poucos serviços de saúde.

\section{Comentários finais}

Nesse estudo encontramos quase um consenso entre as mulheres e os médicos entrevistados na preferência pelo parto normal. Que fatores 
conduziram então à alta incidência de cesáreas, especialmente entre mulheres que têm filhos em hospitais privados? A demanda por parte das mulheres e os interesses econômicos diretos dos médicos na cesárea, embora não possam ser completamente desconsiderados (principalmente o último), não explicam satisfatoriamente as situações encontradas nesta pesquisa. Nossos resultados indicam que o modelo de assistência obstétrica, tal como está organizado no Brasil, tem um papel determinante na elevação e manutenção dos altos índices de cesárea. Esse modelo está calcado em um paradigma de atendimento obstétrico que favorece e valoriza o uso de condutas profundamente intervencionistas na atenção ao parto.

No nível institucional da organização da assistência ao parto, se delega ao médico, e somente a ele, a responsabilidade de realizar partos. Como o médico é o único responsável pelo atendimento à mulher durante o trabalho de parto, e no parto a finalização normal ficaria exclusivamente na dependência dos interesses e habilidades do médico assistente. O médico, por sua vez, muitas vezes não tem disponibilidade para acompanhar um trabalho de parto, que dura em média 10-12 horas, sendo a cesárea com hora marcada a solução encontrada por muitos. Mesmo quando os médicos se dispõem a acompanhar o trabalho de parto, em um contexto no qual o parto normal é percebido como incorrendo em riscos evitáveis por uma cesárea, eles estão muito propensos a fazerem uma cesárea ao menor sinal de complicação e suas pacientes a aceitarem sem relutância esta indicação. As razões para o aumento das taxas de cesáreas podem ser assim diretamente relacionadas ao processo de medicalização do parto na forma que este ocorreu no Brasil e ao paradigma biomédico hegemônico na medicina ocidental moderna.

No modelo de conhecimento médico o normal é deduzido à partir do patológico em função da manifestação maior ou menor de sintomas, que são considerados desvios patológicos de um padrão normativo. Dentro dessa abordagem, o caráter fisiológico do parto normal, apesar de ser ressaltado como positivo nos discursos dos médicos e das mulheres de classe média, não é realmente levado em consideração na hora de se avaliar o trabalho de parto, quando quaisquer desvios do padrão pré-estabelecido podem ser interpretados 
como potencialmente problemático. Deste modo, se ignoram as peculiaridades de cada mulher, o tempo de cada uma, suas condições físicas e, principalmente, os aspectos psicológicos envolvidos no parto. A variedade, característica de um processo fisiológico, é reinterpretada como imprevisibilidade dentro do discurso médico, o que implica falta de controle para os médicos, gerando grande ansiedade para ambos os lados. Com o parto normal, não se sabe o dia e a hora do nascimento, o tempo que vai demorar a criança para nascer, o que se tornou inaceitável para muitos. O parto normal passa a ser julgado pelos padrões da cesárea, que se torna a norma. Os riscos envolvidos na cirurgia são subestimados e a cesárea se transforma em garantia de segurança e controle absolutos. Pode-se mesmo falar que na medida em que a medicalização cresce o parto normal “encolhe”: se restringe a definição do que é normal ocorrer em um parto, diminui o tempo em que se espera sua resolução normal e o número de situações nas quais se tenta um parto normal.

A percepção do parto normal como um "procedimento de exceção", adequado somente em circunstâncias favoráveis, estava presente tanto no discurso do obstetra quanto das mulheres das camadas médias entrevistadas. O relacionamento próximo e muito afável com os médicos e a confiança irrestrita que estas mulheres depositam neles parece contribuir significativamente para que elas aceitem e reproduzam o discurso médico em relação ao parto. A crença na validade da abordagem biomédica na atenção à saúde, e a avidez que as camadas mais privilegiadas no Brasil absorvem novas tecnologias em todas as áreas da vida, tornam os corpos das mulheres dessas camadas ainda mais susceptíveis a intervenção e manipulação médica. Embora experiências e projetos de vida considerados mais “naturais” sejam valorizados no discurso de boa parcela das mulheres mais privilegiadas, o controle do processo do nascimento pela medicina é visto como indispensável para garantir bons resultados. Para algumas mulheres, fica claro que só a cesárea oferece controle total, seja da dor, seja dos riscos que veem no parto normal. A cesárea se torna assim o instrumento pelo qual controlam seus corpos e partos. 
Neste trabalho, buscamos ressaltar o papel do modelo de conhecimento médico e da organização da assistência obstétrica no Brasil, no favorecimento da prática indiscriminada da cesárea, nos possibilita também superar as limitações de uma abordagem na qual os médicos podem ser facilmente caracterizados como vilões e as mulheres como vítimas de interesses escusos da parte dos médicos, ou, ao contrário, os médicos seriam pressionados por mulheres, “desesperadas” por uma cesárea. Ao contrário, o aumento da cesárea parece refletir a própria lógica do atendimento médico ao parto e sob este prisma, constituí-se um problema mais insidioso e difícil de contornar. Assim, parece ser essencial o desenvolvimento de formas alternativas de atendimento ao parto no Brasil, para dar condições efetivas às mulheres de terem um parto normal. A diminuição das taxas de cesárea dependeria, então, mais do que de campanhas de conscientização de mulheres e médicos, de uma reorganização da assistência obstétrica. De modo que outros profissionais capacitados possam realizar partos normais, cabendo ao médico resolver os partos em que a intervenção cirúrgica faz-se de fato necessária.

É importante frisar, contudo, que a questão que se coloca não é puramente a de diminuir os números de partos cesáreas. Também consideramos fundamental buscar uma assistência humanizada ao nascimento e ao parto. Uma assistência que respeite a autonomia e o controle da mulher sobre o processo de nascimento e possibilite ao bebê um começo de vida em boas condições físicas e emocionais. Para que isso se torne possível, pensamos que a mulher deva ter acesso a um tipo de atendimento obstétrico que proporcione as condições adequadas para um parto humanizado e seguro. A maternidade segura é um princípio básico dos direitos reprodutivos, assim como o direito da mulher de tomar as decisões bem informadas em relação ao seu corpo, sua saúde, sexualidade e reprodução.

Referências bibliográficas

ARNEY, W.R. Power and the Profession of Obstetrics. London: University of Chicago Press. 1982. 
BARROS, F.C., et al. Epidemic of Caesarean sections in Brazil. The Lancet. V. 338, n.20, p.167-169, July/1991.

BECKER, G., NACHTIGALL, R.D. Eager for medicalisation: the social production of infertility as a disease. Sociology of health \& Illness. V.14, no.4.,1992.

BERQUÓ, E. Esterilização e raça em São Paulo. Revista Brasileira de Estudos de População. V.11, no.1, p:19-27, 1994.

. Brasil, um caso exemplar - anticoncepção e parto cirúrgico - à espera de uma ação exemplar. Estudos feministas. v.1, no.2, p. 366382, 1993.

CARRANZA, Maria. De Cesáreas, Mulheres e Médicos: Uma Aproximação Médico-Antropológica Ao Parto Cesáreo no Brasil. Dissertação de Mestrado. UNB/Departamento de Antropologia Social. 1994.

CHACHAM, Alessandra S., PERPÉTUO, Ignez H.O. Determinantes SócioEconômicos da Incidência de Partos Cirúrgicos em Belo Horizonte". In: ENCONTRO NACIONAL DE ESTUDOS POPULACIONAIS, Anais do $X$ Encontro Nacional de Estudos Populacionais.10, Caxambu, 1996. Belo Horizonte: ABEP, v. 4, p.2587-2610, 1996.

. Incidence of Caesarean Delivery in Belo Horizonte, Brazil: Social and Economic Determinants. Reproductive Health Matters. v. 6, no.11, p.115-121, May/1998.

CONRAD. P. Types of medical social control. Sociology of Health and Illness. Vol.1, no.1, 1978.

DAVIS-FLOYD, Robbie E. Birth as an American Rite of Passage. Berkeley: University of California Press.1992.

. The Technocratic Body: American Childbirth As Cultural expression. Social Science and Medicine. v.38, no.8, p.1125-1140, 1994.

FARIA, Vilmar E. Políticas de Governo e Regulação da Fecundidade: Consequências não antecipadas e efeitos perversos. In: Ciências Sociais Hoje, ANPOCS, São Paulo, 1989. 
FAÚNDES, Aníbal, CECATTI, José Guilherme. A Operação Cesárea no Brasil. Incidência, Tendências, Causas, Consequências e Propostas de Ação. Cadernos de Saúde Pública, RJ, vol. 7, n.2: p.150-173, abr./jun., 1991.

HOPKINS, Kristine. Are Brazilian Women Really Begging For Cesareans? In: ENCONTRO NACIONAL DE ESTUDOS POPULACIONAIS, 11, 1998, Caxambu. Anais do XI Encontro da Associação Brasileira de Estudos Populacionais, Belo Horizonte: ABEP, 1998, v. 4, p.945-969.

MARTIN, Emily. Pregnancy, Labor and Body Image in the United States. Social Science and Medicine, v.19, p.1201-1206, 1984.

. Woman in the Body. Boston: Beacon Press. 1987.

MELO, Carlos G. Saúde e Assistência Médica no Brasil. Rio de Janeiro: Cebes-Hucitec.1977.

MUTRYN, Cynthia S. Psychosocial Impact of Cesarean Section on the Family: A Literature Review. Social Science and Medicine. V. 37, n. 10, p.1271-1281, 1993.

OAKLEY, Anne. Beyond the yellow wallpaper. Reproductive Health Matters. n.10, p.29-39, November, 1997.

PEL, Maria et al. Provider-associated factors in obstetric interventions. Obstetric \& Gynecology. V. 61, p.129-134, 1995.

PERPÉTUO, I.H O, BESSA, G.H., FONSECA, M.C. Parto Cesáreo: Uma análise da Perspectiva das mulheres de Belo Horizonte. In: ENCONTRO BRASILEIRO DE ESTUDOS POPULACIONAIS, 11, 1998, Caxambu. Anais do XI Encontro Nacional de Estudos Populacionais. Belo Horizonte: ABEP, 1998, V. 1. p. 95-119.

RATTNER, Daphne. Sobre a hipótese de estabilização das taxas de cesárea do Estado de São Paulo, Brasil. Revista de Saúde Pública, 30 (1): 1933, 1996.

SAKALA, Carol. Medically Unnecessary Cesarean Section Births: Introduction to a Symposium. Social Science and Medicine. V. 37, no. 10, p.1177-1198, 1993. 
. Midwifery Care and Out-of-Hospital Birth Settings: How do they reduce unnecessary cesarean section births? Social Science and Medicine. V.37, No. 10, p.1233-1250, 1993b. 


\title{
VISADAS SOBRE O TRABALHO CONTEMPORÂNEO
}

\author{
CAPÍTULO 26 \\ TRABALHO, ORGANIZAÇÕES E INSTITUIÇÕES
}

\author{
José Newton Garcia de Araújo \\ Pontifícia Universidade Católica de Minas Gerais
}

\begin{abstract}
p parte que me coube, neste simpósio, diz respeito ao olhar da A Psicossociologia sobre o mundo do trabalho. Em primeiro lugar, seria conveniente assinalar que esta disciplina não tem uma abordagem única, em suas investigações teóricas e em suas práticas de intervenção. Vou então restringir-me a alguns de seus enfoques, deixando de lado outros, tão relevantes quanto os que aqui vou abordar.
\end{abstract}

Meu ponto de partida não será o trabalho, entendido como o desempenho de uma atividade, suas condições ou sua organização —ritmo, pressão, repetitividade, relações autoritárias - ou ainda os impactos destes fatores na vida psíquica e social do trabalhador. Eu diria que vou abordar a moldura do quadro, ou seja, as instâncias que sustentam qualquer tipo de atividade humana, qualquer trabalho. Refiro-me às noções de organização e de instituição, das quais tentarei ressaltar alguns aspectos. Mas antes de situar cada uma destas noções, que guardam entre si diferenças essenciais, vale lembrar que elas são intimamente entrelaçadas, sendo difícil tratar de uma sem evocar a outra. E é com base nessa articulação entre elas que vamos levantar aqui alguns elementos que as constituem.

\section{A organização}

O termo organização tem tantas abordagens quantas são as ideologias que presidem à sua formulação. Ele não se esgota, portanto, em uma 
definição simples, podendo referir-se a um leque incontável de empreendimentos, de unidades sociológicas, de agrupamentos formais ou informais, visando aos mais diferentes fins. Basta começar a enumerar que não paramos: fábrica, hospital, igreja, clube esportivo, universidade, secretaria de estado, seitas políticas ou religiosas, centros de pesquisa científica, ONGs, máfias, cartéis da droga, grupos paramilitares, bancos, asilos, movimentos populares, assim por diante.

Levantemos agora uma constatação óbvia: toda organização tem de ser desejada, idealizada e concebida, abstratamente, por um indivíduo ou um grupo, antes de existir concretamente. Não foi a natureza nem um poder sobrenatural que fizeram nascer igrejas, partidos políticos ou redes de televisão. Essas organizações surgiram em determinadas condições históricas, fruto de demandas explícitas ou latentes, no campo social, político, religioso, estético, esportivo, gastronômico etc. Pensarmos, por exemplo: no Brasil-Colônia, não havia lugar, como no modelo neoliberal de nossos atuais governos, para a criação de quatro a cinco cursos superiores, por dia. Não vamos discutir aqui as raízes da proliferação dessas organizações do puro lucro. Mas sabemos que sua criação não está, forçosamente, atrelada à transmissão do saber ou à formação de cidadãos. Uma escola equipada com tecnologia ou uma burocracia "de Primeiro Mundo" pode ter um ensino de péssima qualidade. Assim, a racionalidade dos meios não visa, necessariamente, a objetivos éticos, embora os discursos que justificam a existência da escola sempre evoquem princípios sagrados, como ética, cidadania, saber etc. Podemos dizer o mesmo dos campos de concentração nazistas, da prisão de Guantánamo, em Cuba, ou de Abu Ghraib, no Iraque: elas podem ser ótimas organizações, do ponto de vista funcional, para a prática de torturas e extermínios.

O que se pode falar sobre o funcionamento de uma organização? À primeira vista, ele poderia parecer simples. Lévy (2001) define a organização como:

(...) uma unidade sociológica orientada para a produção coletiva de bens, de ideias ou de serviços, portanto um conjunto concreto de 
pessoas e de grupos, mas também de meios técnicos ou materiais, de conhecimentos e de experiências associadas para que se possa chegar a objetivos comuns, o que supõe a gestão e o tratamento de problemas de ação (LÉVY, 2001, p. 129).

Tal definição supõe uma série de recursos materiais (local, máquinas, insumos, dinheiro) e de "recursos humanos", isto é, trabalhadores que executam funções e tarefas, não importa o lugar hierárquico que eles ocupem, submetidos a uma gestão burocrática, a uma hierarquia mais ou menos rígida, com regulamentos, horários, definição de cargos e salários, e assim por diante.

A gestão e o tratamento dos problemas organizacionais, acima evocados, supõem a ocorrência de conflitos, crises, mudanças movidas por fatores internos e externos. Exemplos: conflitos entre dirigentes e dirigidos, má qualidade de produtos e serviços (medicamentos, brinquedos, atendimento hospitalar), assim como as condições e a organização do trabalho, que desembocam, se tomarmos exemplos explorados pela mídia, em acidentes de avião, rompimento de barragens de mineradoras, mortes na construção civil. Essa gestão de problemas leva ainda em conta fatores como recessão econômica, queda das bolsas, mudança de hábitos da população, mudança de crenças, de valores. Ela está na origem do chamado planejamento estratégico, atualmente adotado por governos, bancos, igrejas, partidos políticos, grupos armados, ONGs e tantas outras organizações.

Volto atrás, um pouco, para retomar a expressão "recursos humanos”, evocada acima. Sabemos que todo trabalhador, em qualquer organização, não é mais que isso, um recurso, tanto quanto a máquina ou a matéria-prima. Ele está ali para fazer funcionar a engrenagem e só não será descartado enquanto e apenas enquanto for útil, funcional. Além disso, pouco importa, do ponto de vista das práticas gerenciais, se o exercício de uma tarefa torna o trabalhador infeliz, se o adoece, mutila ou mata. E não estou falando de casos raros. Basta vermos os seguintes dados: a Organização Internacional do Trabalho (OIT, 2005) estima que a cada ano ocorrem no mundo cerca de 450 milhões de acidentes e doenças do trabalho. Na América Latina, também anualmente, 
acontecem entre 20 a 27 milhões de acidentes. Destes, 90 mil são fatais, o que significa que 250 pessoas morrem por dia. No Brasil, entre 1999 e 2003, ocorreram 1.875.190 acidentes de trabalho, com 15.293 mortes e 72.020 casos de incapacitação permanente. A média deste período daria, então, a cada ano: 468.797 acidentes, 3.823 mortes e 18.000 casos de incapacitação (MTE, FUNDACENTRO, 2007). A esses milhões de casos de exploração, mutilação e morte dos trabalhadores, ajuntemos o chamado trabalho escravo de crianças e adultos, o assédio moral e sexual, a síndrome de burnout, o stress e os inúmeros casos de doenças psicossomáticas, como úlceras, hipertensão, enfarto, além dos comportamentos aditivos, ligados ao desgaste físico e psíquico.

Um elemento essencial, do ponto de vista funcional ou gerencial, é que a organização está ancorada numa racionalidade técnica, puramente instrumental, geralmente movida pelos interesses do capital, como a eficácia econômica e o lucro. Essa racionalidade separa trabalho e vida, passando por cima da ética, da sensibilidade ao sofrimento do outro. Tratase aqui da apropriação mais ou menos violenta do trabalhador, presente na fórmula hobbesiana homo homini lupus, que Freud (1974) retomou em $O$ mal-estar da civilização:

Em resultado disso, o seu próximo é, para eles, não apenas um ajudante potencial, ou um objeto sexual, mas também alguém que os tenta a satisfazer sobre ele a sua agressividade, a explorar sua capacidade de trabalho sem compensação, utilizá-lo sexualmente, sem o seu consentimento, apoderar-se de suas posses, humilhá-lo, causar-lhe sofrimento, torturá-lo e matá-lo (FREUD, 1974, p.133).

Esse quadro trágico que Freud pintava, refletindo o conjunto das relações sociais, Marx já havia denunciado insistentemente em sua análise do capitalismo. Tomemos uma passagem dos Manuscritos:

O trabalho produz maravilhas para os ricos, mas produz desnudez para o trabalhador. Produz palácios, mas cavernas para o trabalhador. Produz beleza, mas mutilação para o trabalhador. Substitui o trabalho por máquinas, mas joga uma parte dos trabalhadores de volta a um 
trabalho bárbaro e faz da outra parte máquinas. Produz espírito, mas produz idiotia, cretinismo para o trabalhador (MARX, 1983., p. 152).

Araújo e Cianalli (2006) lembram que Marx falava da irracionalidade da economia moderna, enquanto Weber entendia que o capitalismo não é irracional, pois suas instituições seriam a materialização mesma da racionalidade. No entanto, tais pontos de vista supõem convergências, uma vez que o progresso técnico racional, avesso ao desenvolvimento da vida humana, seria a pura expressão da irracionalidade.

As consequências de um progresso técnico racional a favor das forças produtivas e avessas ao desenvolvimento da vida humana seriam provas suficientes de que não se trata de uma racionalidade, mas de uma irracionalidade, ao não considerar os efeitos sobre o mundo vivido e seus produtores, os homens (ARAÚJO e CIANALLI, 2006, p. 291).

Digamos que essa (ir)racionalidade é minuciosamente planejada, fazendo parte dela, no plano das estratégias empresariais, a indiferença aos milhões de acidentes, mutilações e mortes dos trabalhadores, ao seu adoecimento físico e mental; e no plano das estratégias governamentais, a indiferença à promoção de guerras, às populações dizimadas pela fome, miséria e epidemias, à privação da educação e dos direitos fundamentais de todo ser humano, além da destruição progressiva do equilíbrio ecológico de nosso planeta.

\section{A instituição}

Quem estuda publicidade sabe que a propaganda foi inventada, ora para vender produtos e serviços de uma organização, ora para divulgar sua “imagem institucional”. Os produtos e serviços não são anunciados, no entanto, em seu “estado bruto”, em sua suposta objetividade. O anúncio de cerveja vende imagens e fantasias sexuais, o anúncio de uma faculdade superior vende o futuro sucesso profissional do aluno, o partido político se diz arauto da democracia, dos direitos humanos. Isso quer dizer: toda organização toma como suporte valores e ideais (justiça, fraternidade) ou 
ideologias (felicidade, prazer, lucro), a fim de associá-los ao seu projeto de ação. Valores e ideologias são entidades abstratas que não correspondem, forçosamente, às práticas das organizações. Mas são essas abstrações que justificam, discursivamente, seu sentido ou sua existência. Em vez de se anunciar como fonte de acidentes e mortes no trabalho, de corrupção, da má qualidade dos serviços, as organizações públicas e privadas se vestem com slogans como cidadania, gozo, beleza, lucro, preservação da natureza.

Tais abstrações são manipuladas a fim de forjar a cultura interna ou o imaginário da organização. Todo governo se diz democrático, mesmo se pratica a ditadura. Toda escola, primária ou superior, mesmo buscando essencialmente o lucro, afirma que seu ideal é a educação, o saber. Toda igreja prega, dentro de suntuosos templos, que seu fundamento é a pobreza, o amor. Os bancos que mais pilharam a população brasileira, principalmente nos últimos governos, vendem felicidade e segurança para famílias, jovens e idosos.

O que é, pois, uma instituição? Quando dizemos que a universidade é uma instituição, não nos referimos à sua estrutura burocrática ou à sua contabilidade, mas à função social de formar profissionais cidadãos, de transmitir saber ou valores éticos. Ora, tais valores precisam ter visibilidade, ter sua face concreta, em uma organização. Por isso os dois termos estão estreitamente ligados. Falamos, então: instituição universitária, instituição governamental, instituição científica, financeira, religiosa, guerreira, e assim por diante. Não existe instituição abstrata, assim como não existe organização desprovida de um ideário que a sustente, por mais que este seja meramente instrumental.

Para explorar um pouco mais o conceito de instituição, proponho, talvez de maneira lúdica, certas distinções entre os mundos humano e animal. Ou entre natureza e cultura. Tomo então os animais como máquina biológica, programada pelos instintos. Nesse registro, eles são absolutamente acabados. Não precisam aprender a ler, estudar ou trabalhar, nem tornar-se sábios, ricos ou poderosos. Já basta o que a natureza lhes deu. Não têm 
projetos de vida nem ambição de serem renomados artistas, empresários, cientistas ou chefes do tráfico de drogas. Nem desejam, coletivamente, ser campeões do mundo, cultuar heróis, construir as sete maravilhas da floresta.

Eles não têm, como os humanos, bichos inacabados, consciência ou angústia, relativas ao tempo e à morte. Não correm atrás das "ilusões necessárias”, como poder, glória, nobreza, reconhecimento, imortalidade. Em outras palavras, o homem está condenado à sobrevivência simbólica, mais que à biológica. E isso o move a criar cultura, a criar história. Abramos parênteses para lembrar que cultura e história se fazem através de uma atividade que só ao homem pertence, isto é, o trabalho.

Criamos cultura até quando atendemos às nossas necessidades básicas: o jeito de fazer nossa comida, de construir uma casa, de fazer sexo; ou quando atendemos aos nossos desejos, nas esferas afetiva, intelectual, estética, social: estudamos, fazemos política, música e poesia, rezamos, sonhamos, fazemos guerra, destruímos o semelhante e a natureza. Por isso, a criação cultural é um caldeirão de práticas éticas e antiéticas, justas ou injustas, de misérias e solidariedades.

O que isso tem a ver com a noção de instituição? Voltemos aos animais: elefantes, borboletas ou leões nunca fundaram igrejas, partidos políticos, universidades, sindicatos, exércitos ou gangues. Nunca instituíram aniversários, feriados, missa, diploma, casamento, eleições, dia das mães, dia da pátria ou de finados. Numa visada filosófica ou antropológica ampla, podemos dizer que todas essas criações culturais são fruto de nossas angústias e desejos, diante da ameaça do outro, do desconhecido da vida e da morte.

Outra coisa: toda instituição/organização, para se sustentar, precisa da adesão racional e principalmente afetiva de seus membros. Ela se diz portadora de princípios sagrados, divinos. Ora, o sagrado, o transcendente, é aquilo que inquestionável, intocável. Lembremos a história de Moisés, um ambicioso ex-administrador de província, no Egito do faraó Akhenaten. Moisés queria governar um povo - ali estavam os judeus - e lhe impor o monoteísmo da história egípcia. Mas o que ele fez para tornar sua lei 
incontestável? Subiu ao topo do Monte Sinai, escondeu-se ali e voltou trazendo as "tábuas da Lei", dizendo tê-las recebido diretamente de Deus, que só ele viu. Cabia ao povo acreditar ou não em sua história e aceitar sua lei, mas como lei divina, não como "lei mosaica".

Todas as instituições/organizações fazem a mesma coisa: seus "discursos fundadores" remetem ora a preceitos divinos, ora a ideais ou valores que devem ser interiorizados como expressão da verdade, do bem, da justiça ou outros conceitos "intocáveis". Elas pretendem, assim, orientar ou regular a vida social. Para isso, é preciso que os seus membros (dirigentes, dirigidos, simpatizantes) interiorizem tais valores. André Lévy escreve que as instituições são “(...) o conjunto de regras e dos valores que definem a ordem social, as obrigações que se impõem a cada um e que tornam possíveis as transações e as trocas" (LÉVY, 2001, p. 132).

Em outras palavras: para que uma coletividade confie, apoie e participe de uma instituição (igreja, governo, universidade, partido político, empresa, sindicato etc.) é fundamental que seus membros estejam afinados com seus pressupostos ideológicos e com seu programa de ação. É nesse sentido que Lévy acrescenta:

(...) as instituições (...) só podem cumprir seu papel, na medida em que são vistas como intangíveis, sustentadas por realidades de uma ordem superior, transcendente e sagrada; invisíveis e imateriais, essas realidades —o Poder, a Lei, o Saber, a Justiça... — não podem, no entanto dispensar uma representação concreta que figura a unidade e a realidade do corpo social: edifícios e lugares (Assembleia nacional, Arco do Triunfo); hora do dia ou dias do ano reservados para feriados, celebrações ou comemorações que lembram os acontecimentos do passado e constituem parte do imaginário social; assim como personagens (padres, presidentes, juízes...) aos quais o título, o hábito ou um objeto de que são os únicos detentores (cetro ou coroa, carro de luxo...) conferem um estatuto fora do comum que transcende sua individualidade enquanto pessoa; mas as instituições estão também representadas nos Escritos — livros sagrados, tábuas da Lei, textos constitucionais, regulamentos afixados- que às vezes se confundem com as narrativas, nas quais a história mítica do grupo ou 
a de seus personagens ilustres é contada da forma mais sugestiva e dramática possível (LÉVY, 2001, p. 132).

Em sua obra Organisation en Analyse, Eugène Enriquez define a organização como um sistema cultural, simbólico e imaginário. Como sistema simbólico, ela "oferece uma cultura, quer dizer, uma estrutura de valores e de normas, uma maneira de pensar, um modo de apreensão do mundo, que orientam a conduta de seus diversos atores” (ENRIQUEZ, 1992 p. 35). Isso leva a representações sociais historicamente constituídas, depois interiorizadas, desembocando em hábitos de pensamento e de ação, visando a uma obra coletiva.

No registro simbólico, os seus fundadores reais ou imaginários se tornam heróis ou mitos unificadores. Além disso, ela institui ritos de iniciação ou de passagem, inventa sagas que sustentam a memória coletiva, a fim de legitimar e dar uma significação prévia às suas práticas. A organização se faz, ela mesma, um objeto a ser interiorizado. Mas isso tem um preço: ela exige que seus membros sintam orgulho pelo trabalho que executam, à maneira de uma causa a defender, uma missão salvadora a cumprir —o que funciona com uma forma de controle afetivo e intelectual.

Quanto ao sistema imaginário, Enriquez nos aponta suas duas faces, ou seja, o imaginário motor e o imaginário enganador. No primeiro, a organização permite o exercício da imaginação criadora, no trabalho sem repressões e regras imperativas. Mesmo sendo “desreal”, é o imaginário que fecunda o real. Sem ele, o desejo se detém, é ele que introduz a diferença, a invenção, é ele que alimenta os projetos comuns, as utopias, as práticas sociais inovadoras. Ele opera rupturas na linguagem e nos atos, preserva o sonho e a possibilidade de mudança. Já o imaginário enganador (mistificador)

(...) tenta prender os sujeitos nas armadilhas de seus próprios desejos de afirmação narcisista, no seu fantasma de onipotência ou em sua demanda de amor, julgando-se forte para responder a seus desejos, naquilo que eles têm de mais excessivo e de mais arcaico, como se pude-se transformar as fantasias em realidade (ENRIQUEZ, 1992, p. 37). 
Nesse caso, continua o autor, a organização se declara capaz de proteger seus membros do risco da perda de identidade, da angústia de fragmentação, fornecendo-lhes couraças sólidas, através de status e papéis, misturando a identidade do indivíduo com a identidade da organização.

Enriquez ainda observa que, entre os dois tipos de imaginário, as organizações tendem a alimentar, mais frequentemente, o imaginário mistificador que o imaginário motor. Este último é dificilmente suportável para ela, pois supõe a criatividade feliz, a palavra livre, a capacidade de tudo questionar, de transgredir, o prazer da vida em comum, o humor e a leveza, que são indispensáveis para o exercício da reflexão. "Desse modo, o imaginário motor constitui um verdadeiro desafio às regras de funcionamento que regem as organizações, mesmo as mais flexíveis" (ENRIQUEZ, 1992, p. 38).

Ao longo da história, as organizações se sustentaram, intuitivamente, nessas três dimensões: cultural, simbólica e imaginária, a fim de poder dar sentido à vida de seus membros. Nos dias atuais, essa estratégia é construída metodicamente. A organização quer se erigir como uma microssociedade, para que seus membros se identifiquem a ela como uma nação, um Estado, ela quer, afinal, ocupar o lugar de um sagrado transcendental.

Enriquez ainda define a organização através de sete diferentes categorias ou instâncias. Além da instância propriamente organizacional, entrelaçada à institucional, ele também aponta as dimensões mítica, socialhistórica, grupal, individual e pulsional. Observe-se que a problemática do poder, analisada pelo autor em outra obra (ENRIQUEZ, 2007) é essencial à abordagem psicossociológica, pois perpassa todas essas instâncias.

Apesar de cada uma dessas instâncias merecerem uma análise cuidadosa, faço aqui rápidas considerações sobre a instância pulsional. Enriquez diz que é mais fácil estudar as organizações com base nas pulsões de morte que nas pulsões de vida. Com efeito, ao alimentar o imaginário mistificador, elas querem fazer crer que a pulsão de vida é o único princípio de sua ação. Daí sua ênfase na eficiência, no dinamismo, na mudança, 
tentando forçar as ideias de coesão e harmonia. Na verdade, tal prática está mais próxima da compulsão à repetição, ao criar mitos ou ideologias massivas, homogeneizadas, ou modos de controle sociopolítico que fazem dos indivíduos servidores de uma causa inquestionável, impedindo-os de se manifestar como sujeitos, impedindo a desordem criadora. A organização não suporta os desviantes, os contestadores, ao sustentar o estado de alienação, em seu interior.

\section{A intervenção psicossociológica}

É a partir das considerações acima que vou abordar, sucintamente, a prática específica da psicossociologia, ou seja, a intervenção psicossociológica (IP). É desnecessário dizer que ela se distingue das intervenções positivistas, autoritárias e, em geral, simplificadoras, típicas dos modos de gestão baseados na eficácia, na eficiência, na equivocada qualidade total. O psicossociólogo não é administrador, economista, ideólogo ou estrategista de partidos políticos, pastor ou padre de igrejas.

Qual uma primeira grande diferença? Estes agentes, em geral, já têm objetivos prévios, quando chamados a intervir. Isso remete a uma prática de expertise diretiva, quando não autoritária: propostas prontas, conselhos, receitas. A IP supõe, ao mesmo tempo, um saber e um não saber. Uma de suas posturas técnico-teóricas fundamentais é a escuta dos sujeitos, dos grupos, do coletivo. São eles que vão diagnosticar os conflitos, as crises organizacionais e/ou institucionais. Um de seus pressupostos, herdados de Lewin, é a pesquisa-ação que, por extensão, também é intervenção-ação, intervenção-participante. Segundo Dubost (2002), a intervenção psicossociológica consiste em dispor, com os atores de uma dada organização/instituição

(...) de dispositivos (enquete, discussão em grupo, análise de processos, observações...) facilitando as trocas entre todos os atores em questão e [facilitando] um trabalho baseado em suas percepções, representações, sentimentos, alguns desconhecidos ou reprimidos, quando não simplesmente emudecidos. Em outras palavras, trata-se 
de permitir aos atores compreender melhor o significado das situações vividas e como eles tomam parte nela, se possível, encontrando respostas aos problemas, mobilizando energia para esse fim (DUBOST, 2002, p. 392).

Importante ressaltar que esses dispositivos não são previamente definidos, pois o psicossociólogo, quando os propõe, acompanha e avaliza, torna-se, ele também, um de seus componentes, talvez o mais importante. Isto pressupõe uma análise permanente da maneira como ele se implica na intervenção, pois nunca é neutro, e sua postura (autoritária, laissez-faire, projetiva, paranoica) pode comprometer a análise. Por isso mesmo, não lhe cabe tomar decisões pelo grupo, sendo estas sempre provisórias, à medida que ocorrem "na continuidade de um movimento coletivo de conhecimento que é, ele mesmo, parte integrante do processo de mudança” (DUBOST, 2002, p. 392).

Esta postura supõe uma opção política fundamental, oposta à conduta autoritária de moldar, massificar ou reprimir o coletivo de sujeitos, em qualquer situação. A esse respeito, Barus-Michel (2002) comenta que o psicossociólogo, ao intervir numa organização, se vê diante de um desafio: de um lado, está o eixo que privilegia a eficiência organizacional, os objetivos mensuráveis da produção e da expansão. Ela escreve:

A eficiência está inserida em um presente imperativo, no qual amanhã dever hoje mesmo, em uma ação sem espaço de reflexão. A palavra, neste contexto, é supérflua, é perda de tempo, e a questão do sujeito não vem ao caso. Para que deveria o sujeito fazer perguntas, quando ele deve se juntar à sua organização pronta para a guerra, para a violência da concorrência, para a urgência da performance? (BARUS-MICHEL, 2001, p. 174)

De outro lado, está o eixo que privilegia o sentido, como aquilo que especifica a atividade humana, aquilo que, abstraindo a imagem do objeto, liga-o simbolicamente, agencia representações em cadeias significativas que possibilitam a troca, o controle, a invenção e o projeto, ou seja: "um imaginário e um pensamento que permitam apreender e conceber as 
relações dos seres e das coisas, construí-los no espaço e no tempo, atribuindo-lhes causas e finalidades" (BARUS-MICHEL, 2001, p. 173).

As observações acima apontam para mais um elemento essencial da intervenção psicossociológica, ou seja, sua dimensão clínica que, no entanto, não se confunde com as práticas terapêuticas ou psicanalíticas. Segundo Giust-Desprairies (2001), a psicossociologia é clínica, quando, numa situação concreta, atende a uma demanda num contexto de sofrimento, quando coloca a questão do sentido e do sujeito. E ainda: quando considera o indivíduo ou o grupo como interlocutor capaz de compreender as próprias dificuldades, de elaborar significações. Isso implica levar em conta componentes subjetivos e que a questão do sentido não está só na esfera privada ou individual, mas especialmente no social.

\section{Entre os espaços micro e microssociais}

A Psicossociologia é uma disciplina cujos eixos metodológicos articulam a prática que a caracteriza, isto é, a intervenção psicossociológica, com um permanente trabalho de teorização. Isso não significa, no entanto, que tais incursões teóricas se restrinjam às experiências de intervenção, no interior das organizações e instituições, em comunidades e outros grupos de dimensões restritas. Pelo fato de os espaços microssociais refletirem, serem atravessados ou reproduzirem elementos das estruturas sociais globais, a Psicossociologia também se debruça sobre temas políticos e psicossociológicos relativos aos espaços microssociais. Cabe lembrar, aliás, mesmo que só de passagem, a demarcação entre a Psicossociologia e a Sociologia Clínica, que não vamos discutir aqui, embora os pressupostos destas duas disciplinas sejam bastante convergentes e em diversos pontos se confundam, em especial em sua interpretação clínica — fundada basicamente em Freud— dos fenômenos político-sociais. Não é por acaso que grande parte das produções "sociológicas" desses autores tem aparecido em uma coleção intitulada Sociologie Clinique, dirigida por Vincent de Gaulejac. 
Apenas a título de exemplo, cito três obras recentes desta coleção, que podem ilustrar a leitura clínica de fenômenos políticos e dos sociológicos. A primeira delas, organizada por Max Pagès, é intitulada La violence politique (2003). O autor comenta, justamente, que os psicólogos e sociólogos clínicos, acostumados a analisar fenômenos de radicalização, regressão ou passagem ao ato, em escala microssocial, agora tentam ampliar essa análise ao plano societário global. Esta obra, dedicando-se especialmente ao "pós-11 de setembro" e ao conflito Israel-Palestina, discute o "inexplicável” da violência das guerras, dos massacres, dos genocídios, do terror revolucionário e contrarrevolucionário de outrora, bem como do terrorismo e do contraterrorismo de nossos dias. Os autores se interrogam, entre outras coisas, sobre os momentos e as forças que fazem um conflito escapar das racionalidades que o justificavam, na origem, transformando-se em paranoia coletiva, numa lógica persecutória que fabrica seus próprios inimigos. Ou sobre as relações entre demagogia e democracia, entre maturidade afetiva e maturidade política, além dos distintos envolvimentos dos cidadãos e dos dirigentes. O livro se fecha com uma entrevista a Edgar Morin, intitulada "Uma antropossociogênese da violência política", na qual ele discute, entre outras questões: a circularidade entre racionalidade e afetividade, a violência revolucionária, o lugar da religião, das crises, da regressão e da angústia, associadas à psicose e à paranoia de guerra, à cultura da vitimização política, tudo isso apontando para a ameaça de uma catástrofe planetária ou "para um desencadeamento louco da violência ... o mesmo sentimento interior que tive nos anos 1933-1936 ... uma máquina infernal estava em marcha, alguns tentavam pará-la, mas em vão" (PAGÈS, 2003, p. 203).

A segunda obra que cito é Le politique entre les pulsions et la loi, de Jacqueline Barus-Michel (2007). Neste livro, a autora discute o nascimento da política, com base no laço paradoxal que leva à cooperação entre o animal político - como Aristóteles definia o homem-e seus semelhantes, bem como às suas reações agressivas diante de toda dessemelhança real ou imaginária. Daí a luta incessante entre as pulsões e o imperativo, específico à espécie, de elaborar modos de viver-junto, ou seja, a luta entre a violência e 
o simbólico. O nascimento do político se confunde, então, com a emergência da lei. No entanto, a desorganização desse laço e o enfraquecimento do político conduzem à desordem e às feridas identidárias que liberam as pulsões destrutivas, tais como o terrorismo, as violências urbanas ou as condutas suicidas. Mas é neste contexto que a autora ainda afirma que a democracia é um sonho justo e razoável, no qual o poder pode ser partilhado, segundo as regras do direito. "Sem dúvida, é preciso ver nela a utopia doce, irrealizável, mas na qual é preciso perseverar, pois é da natureza do homem sonhar com o fazer história, e esta não pode ser senão aquela de suas esperanças abortadas” (BARUS-MICHEL, 2007, p. 21).

A terceira obra tem como título La face obscure des démocraties modernes (2002), de Eugène Enriquez e Claudine Haroche, e busca repensar o mal-estar das democracias modernas, discutindo as raízes do mal, da violência e da destrutividade das sociedades ditas civilizadas. Através de um diálogo entre a sociologia, a política, a psicologia e a psicanálise, estes dois autores se perguntam se seria ou não pertinente falar de uma patologia dessas sociedades, face a uma "tendência espontânea” dos grupos humanos em adotar condutas destrutivas. No que diz respeito especificamente ao mundo do trabalho, Enriquez observa que um dos traços das "sociedades doentes” é a relação entre perversão e psicologização. Ela não está marcada apenas pelas técnicas de controle da divisão do trabalho e das tarefas. No caso, “a perversão vai mais longe, na medida em que se torna perversão do indivíduo mesmo, quando este se toma como objeto... as pessoas podem se instrumentalizar, se reificar" (ENRIQUEZ, HAROCHE, 2002, p. 102). O ideal do indivíduo é, então, saber vender-se como um ótimo instrumento, aí residindo o seu gozo. O signo da perversão é a transformação das relações humanas em relações de objetos. Nesse contexto, é proibido falarmos de sofrimento, de imprevisibilidade, de falibilidade, pois o sujeito deve, definitivamente, desaparecer. Ademais, quando pensamos, historicamente, as relações de trabalho, é preciso ter em conta que a abolição da escravatura (só o escravo podia ser vendido como corpo, ele não era considerado como homem, mas como produto de outros homens) não está fundada apenas nas 
ideias reformistas ou desinteressadas, na evolução dos costumes, mas sobretudo na ideia geral da liberdade de empreender, gerada no movimento geral do Iluminismo e concomitante ao desenvolvimento do capitalismo, à construção das grandes empresas. Ora, isso demandava o aparecimento de indivíduos livres para vender sua força de trabalho, ou seja, o suposto trabalhador livre que, paradoxalmente, é aquele que pode ser explorado. “ $O$ capitalismo não precisa de escravos. Ele precisa de indivíduos que, no fim das contas, se autoalienem. Como pensava Diderot, ele precisa de escravos que acreditam ser cidadãos” (ENRIQUEZ, HAROCHE, 202, p. 104).

Referências

ARAÚJO, S.M. ; CIANALLI, D.L. Trabalho e sobrevivência - o mundo da vida sob ameaça: racionalidade ou irracionalidade? Sociedade $e$ Estado. v. 21, n. 2, p. 289-313, 2006.

BARUS-MICHEL, J. Intervir enfrentando os paradoxos da organização. In: ARAÚJO, José N.G.; CARRETEIRO, T.C. (orgs.). Cenários sociais e abordagem clínica. São Paulo: Escuta; Belo Horizonte: FUMEC, 2001, p. 171-185.

BARUS-MICHEL, J. Le politique entre les pulsions et la loi. Ramonville Saint-Agne: Éditions Érès, 2007.

DUBOST, J. Recherche-action et intervention. In: BARUS-MICHEL, J; ENRIQUEZ, E. \& LEVY, A. (orgs.). Vocabulaire de Psychosociologie. Ramonville Saint-Agne: Éditions Érès, 2002, p. 391-416.

ENRIQUEZ, E. Organisation en analyse. Paris: PUF, 1992.

. La face obscure des démocraties modernes. Ramonville SaintAgne: Éditions Érès, 2002.

. As figuras do poder. São Paulo: Via Lettera, 2007.

FREUD, S. O mal-estar da civilização. Edição Standard Brasileira das Obras Psicológicas Completas de Sigmund Freud, vol. XXI. Rio de Janeiro: Imago, 1974. (Texto original publicado em 1929).

LÉVY, A. Ciências clínicas e organizações sociais. Belo Horizonte: Autêntica, 2001. 
MARX, K. Manuscritos econômico-filosóficos. In: FERNANDES, F. Marx-Engels - História. (Grandes cientistas sociais: 36). São Paulo: Ática, 1983. (Texto original publicado em 1844).

MTE - MINISTÉRIO DO TRABALHO E EMPREGO / FUNDACENTRO. (2007). Acidentes de trabalho custam 10 por cento do PIB da América Latina. Notícias (boletim eletrônico do dia 11/04/2007). Disponível em www.fundacentro.gov.br/CTN/noticias.asp?Cod=358 Acesso em 17/08/2007.

OIT — Organização Internacional do trabalho. Disponível em www.ilo.org/public/portugue/region/eurpro/lisbon/html/hsst.htm Acesso em 23/05/2005.

PAGES, M. (org.) La violence politique. Ramonville Saint-Agne: Éditions Érès, 2003. 


\title{
O TRABALHO NA PERSPECTIVA DAS POLÍTICAS PÚBLICAS
}

\author{
Odair Furtado \\ Pontifícia Universidade Católica de São Paulo
}

$\mathrm{O}$

Brasil passou e vem passando por um forte ajuste no campo produtivo e financeiro. A forte crise do capitalismo que se abateu sobre o planeta a partir da década de 80, os efeitos da reestruturação produtiva resultante da informatização da produção, a crise financeira dos principais centros do capital em 1995 e a formalização do "Consenso de Washington" que definiu a política de controle do capital neste período executada de forma draconiana pelo FMI e Banco Mundial, tendo como gendarme a nação mais poderosa do planeta, produziram efeitos bastante conhecidos, discutidos e criticados.

A política financeira adotada pelo capitalismo e o processo de globalização e de reestruturação produtiva produziram no Brasil avanços, ajustes e problemas que afetam diretamente os trabalhadores, o mercado de trabalho e a relação de trabalho e emprego. No último período temos acompanhado um relativo crescimento do país e uma intensa discussão sobre as consequências da política de ajuste financeiro e produtivo tanto para o desenvolvimento de nossa economia quanto para o bem-estar do nosso povo. Nem sempre essas posições estão de acordo com a política definida e com suas ações realizadas.

É a partir da análise dessa conjuntura política e econômica que iremos discutir a perspectiva da política pública para o trabalho. Já há algum tempo (podemos colocar como marco o início do governo Fernando Henrique) que se busca a elaboração de uma política pública para minimizar os problemas em função do desemprego. Podemos dizer que não há, ainda hoje, um consenso sobre o problema. Não há acordo entre posições representadas pelos 
pesquisadores, pelo campo sindical, governamental e o dos empresários. Mesmo no campo progressista, que já foi mais homogêneo, temos divergências sobre os caminhos a percorrer para a elaboração de uma política pública eficiente que resolva o problema crônico da falta de emprego em nosso país. Mais emprego ou geração de renda? Autonomia do trabalhador ou segurança da carteira assinada? Novos caminhos para o socialismo ou programa assistencialistas? Autores como Singer e Dowbor divergem nesta questão e apresentam análises diferentes apontando para uma mesma perspectiva que é a da emancipação dos trabalhadores.

\section{Para Dowbor (2006)}

Quando olhamos experiências de organização social que claramente estão dando certo, desde Kerala muito pobre até a Suécia ou o Canadá muito ricos, o denominador comum é uma sociedade civil organizada e exigente, que obriga o Estado a prestar contas do destino dos recursos, e cria um ambiente onde as empresas privadas se vêm obrigadas a respeitar os interesses sociais e ambientais da região onde se implantam. As organizações da sociedade civil, neste sentido, são cada vez mais indispensáveis. Em termos de democracia econômica, a contribuição é essencial. É muito mais fácil manipular indivíduos isolados, ainda que sejam milhões, do que interesses sociais organizados. À medida que os mecanismos de concorrência de mercado são substituídos por oligopólios, cartéis e semelhantes, com poder planetário — grande parte das maiores economias do mundo são hoje empresas, e não países, com dirigentes que ninguém elegeu - a expressão organizada dos interesses da sociedade torna-se indispensável ao funcionamento da própria economia.

Mesmo concordando que o fundamental é a superação do capitalismo, há uma diferença entre Dowbor e Singer quanto ao tipo de organização necessária para que essa mudança ocorra.

São questões que estão colocadas na ordem do dia da discussão sobre políticas públicas e trabalho. Qual a consequência disso para o trabalhador e suas perspectivas políticas e principalmente, do ponto de vista da Psicologia Social, como se dá a produção de sentido sobre essas questões? Como o movimento operário e sindical está se posicionando frente a essa realidade? 
A organização dos trabalhadores hoje é suficiente para enfrentar a reorganização política do capital do ponto de vista de sua mundialização? Da transnacionalização da produção? Responder a essas questões é crucial para a reorganização do enfrentamento do capital e é o ponto central de nossa discussão no presente momento.

Wanderley Codo, do Instituto de Psicologia da UnB, partindo de seus trabalhos no Laboratório de Psicologia do Trabalho (do Instituto de Psicologia/UnB), pesquisas e publicações (CODO: 2004; CODO: 1995; CODO: 1992) defende que a superação do emprego pode representar uma vantagem para o trabalhador e que formas características de geração de renda no Brasil, como o comércio ambulante, estariam num estágio superior ao emprego do ponto de vista da alternativa que representa para o trabalhador no campo da alienação do trabalho, como é definido pelos autores marxistas. Outros autores argumentam que não há esgotamento do trabalho expressado através do emprego e sustentam esse argumento como Ricardo Antunes (Sentidos do Trabalho: 1999). Neste caso, parte de uma análise das condições de desenvolvimento do capitalismo no Brasil e o papel que o país ocupa no cenário produtivo mundial. Diz que há espaço para o crescimento econômico e que isso trará o aumento do emprego formal. Entretanto, a discussão não é de caráter econômico e não depende exclusivamente da conjuntura econômica e social. O que está em jogo é a organização dos trabalhadores e seu nível de consciência. A alternativa ao emprego é estratégia de sobrevivência ou forma superior de organização das relações de trabalho? O momento não oferece a base material para a resolução da questão, mas é possível identificar tendências.

Evidentemente, precisamos considerar que os autores citados tem mais concordâncias entre si do que discordâncias e que tais discordâncias se apresentam a partir da dimensão de estudo e pesquisa que cada um executa em seu campo de trabalho.

Neste caso, para nós é bom e importante acompanhar a sutileza do debate e principalmente utilizar esse parâmetro crítico como orientação para 
discutirmos a realidade brasileira, do ponto de vista das relações de produção e das relações de trabalho para além de uma mirada simplista que vê a reprodução no Brasil das tendências dos países europeus ricos e dos Estados Unidos da América.

Há um precedente importante que justifica a desconfiança do pesquisador em relação a argumentos que nos convencem por antecipação. Caio Prado (1979), em A Questão Agrária, apresenta um bom argumento para superar uma antiga crença dos marxistas brasileiros que militavam no Partido Comunista Brasileiro desde a sua fundação em 1920 até a década de 50. Era letra corrente que o Brasil havia passado por uma fase feudal durante o período das Capitanias Hereditárias e que resquícios dessa fase deveriam ser superados através da transição de um governo burguês que modernizasse o país. A organização do trabalho no campo através dos meeiros (que trabalhavam a terra em meias com o proprietário e dividiam a produção) comprovaria a forma feudal de produção. O meeiro seria uma espécie de servo da gleba dos barões do café. Prado, com A Questão Agrária e Cândido (1977) com Parceiros do Rio Bonito, desmontam essa teoria apontando que a relação de trabalho e produção dos meeiros era moderna e representava a forma capitalista de trabalho no campo.

Nosso argumento, seguindo a mesma lógica dos autores citados, coloca a seguinte questão: não estaremos nós frente a um fenômeno de antecipação, no Brasil, de uma nova organização mundial das relações de trabalho? Estamos querendo dizer que o Capitalismo mudou neste último período e o seu modo de organização transnacional, mundializado, exige uma nova relação de trabalho que estaria sendo forjado exatamente neste momento. A economia brasileira interessa a rede internacional e aqui ela encontraria o caldo de cultura necessário para o seu crescimento e desenvolvimento dessas novas relações de trabalho. Não somente em nosso país, mas também no restante dos países denominados de BRIC (Rússia, Índia e China) acrescidos do México e África do Sul. O pacote inclui a qualificação dos trabalhadores, os baixos salários, a mão de obra excedente (exército de reserva ampliado), a industrialização, o campo de consumidores finais de muitos dos produtos 
aqui fabricados, a organização financeira e a desregulamentação progressiva das leis trabalhistas, Todos os países citados acima, com maior ou menor potencial, apresentam tais características.

Da mesma forma que a crise do capitalismo da década de 1980 detonou a política do Welfare State esta nova reorganização efetuaria o ajuste para o próximo período, produzindo novos polos de produção mundial. Esta é uma hipótese possível para a crise de produção vivida pelos países mais ricos do planeta (G7) que gera desemprego estrutural (trabalhadores que não terão condições de voltar ao mercado de trabalho). O cenário é agravado com a chegada de imigrantes das antigas colônias que aumentam significativamente o exército de reserva. Gorz e Offe já analisaram essa condição apontando o fim do emprego, Offe, particularmente, faz uma análise contundente da perspectiva do capitalismo neste cenário a partir do território europeu e alerta para o risco da hegemonia da política neoliberal. Giddens, não vê saída para o próximo período e a "terceira via", na maneira como ele a define, trata-se de capitulação, mesmo que temporária, a esse campo hegemônico.

Os anos recentes alteram o cenário descrito do ponto de vista das chamadas "economias emergentes". Por pressão dos organismos internacionais de controle do capital, como FMI, Banco Mundial, por força das análises do mainstream do jornalismo econômico (Financial Times, The Economist, Wall Street Journal), tais economias realizaram acertos consideráveis e impulsionadas pela conjuntura econômica mundial favorável saíram fortalecidas. O Brasil é um caso exemplar desse tipo de acerto e receberá em breve o "investment grade" das agências internacionais de avaliação. $\mathrm{O}$ fato coroa a política de controle monetário e, ao mesmo tempo, significa a entrada considerável de recursos financeiros no país. Essa nova condição empresta alguma autonomia e possibilidade dos países chamados de "economia emergentes" de frequentarem, mesmo que como convidados de segunda categoria, o clube dos sete mais ricos. 
Sabemos, nós pesquisadores no campo da Psicologia Social, que mudanças estruturais na economia são acompanhadas de um correlato de crenças e valores que consolidam do ponto de vista subjetivo as transformações da realidade. Evidentemente, estamos considerando que a base estrutural e superestrutural do capitalismo permanece (ao menos por hora) intacta e que tais crenças e valores estarão submetidos ao quadro ideológico de manutenção das relações de produção. Entretanto, serão possíveis mudanças importantes nas relações de trabalho com manutenção das relações de produção? A questão é saber como a produção de sentido sobre o mundo do trabalho poderia trazer algum indicativo sobre essas possíveis mudanças.

De acordo com Furtado (2002), a relação dialética entre os campos subjetivos e objetivos, mesmo considerando a primazia da realidade, permite que os dois campos se interpenetrem. Essa relação dialética permite que as mudanças sociais sejam acompanhadas da crença na mudança. É o que Enriquez (1974) argumenta sobre o imaginário revolucionário da produção de utopias. Assim, podemos afirmar que a crença na mudança irá produzir o campo subjetivo favorável à mudança e o contrário, mesmo com condições materiais suficientes, pode não mobilizar suficientemente os sujeitos da ação na direção da mudança proposta.

O campo da Economia Solidária, para além dos trabalhos realizados por militantes das incubadoras tecnológicas de cooperativas populares, transformou-se em política pública (SINGER: 1999; SINGER \& SOUZA: 2000). Há a construção de um campo de produção de sentido alternativo ao capitalismo através de uma ação social e isso é repercutido através do gestor público, que torna o argumento político confiável (se o próprio governo defende é porque pode!).

A Economia Solidária trabalha, do ponto de vista das crenças e valores, na contramão das crenças e valores que sustentam o edifício da economia capitalista (Boaventura: 1996) e portanto, é possível falarmos em construção de uma alternativa social. Mas estarão as experiências 
cooperativadas construindo um modo de pensar alternativo ao capitalismo? Evidentemente, ao enfrentarmos esse assunto estamos tocando em um ponto muito delicado da teoria marxista: a definição de quem é o sujeito da transformação. Os marxistas ortodoxos argumentam que não houve mudança significativa e que esse sujeito permanece sendo a classe operária. Autores como Gorz (2006) e Offe (1994) falam no fim do emprego e por decorrência no fim da classe operária. Os lukacsianos (PINASSI \& LESSA: 2002) discutem sem negar a ortodoxia marxista, mas apontando o problema. Mesmo que este projeto de pesquisa venha a tocar na questão da ontologia do ser social (LUKÁCS: 1976), não é esse o foco e nem pretendemos chegar a essa profundidade abissal. A questão é encontrarmos indicativos a partir da análise do discurso de trabalhadores empregados e desempregados ou que encontraram alternativas seguras de renda sobre os sentidos do trabalho no presente momento e encontrarmos elementos que apontem para a mudança ou para a manutenção da forma capitalista de pensar (MARTINS, 1976). Perceber como as expectativas de mudança e de manutenção social se combinam e se apresentam no presente momento.

\section{Compromisso social e qualidade de vida}

O campo de discussão sobre o fim do emprego é compatível com o cenário em que se desenvolve: autores europeus e estadunidenses falando da realidade dos países mais ricos do planeta e da condição que a produção e relações de trabalho se encontram no presente momento. Incluindo nesta discussão o problema emergente da imigração e do crescente conflito étnico (como os conflitos recentes ocorridos na França) que produzem focos de xenofobia, discriminação e de intolerância. Entretanto, não é esse o cenário brasileiro (ou mesmo da América Latina). As condições de desenvolvimento da economia brasileira e as condições econômicas em que se encontra o planeta colocam o país numa situação peculiar de exploração e desenvolvimento. No momento, há aumento do acúmulo de riqueza entre os mais ricos e empobrecimento maior da população. Mas, como resultado do esforço social da política de ação social do governo federal (programa como 
Bolsa Família) há melhoria da condição de vida do segmento mais pobre da população e redução do número de pessoas que vivem abaixo da linha da pobreza. Estamos longe daquilo que se convencionou chamar de desenvolvimento sustentável (seja lá o que isso quer realmente dizer), patamar em que o país se livraria da sua condição de economia dependente e contaria com suas próprias forças para incrementar seu desenvolvimento econômico.

Ocorre que o ciclo de crescimento, mesmo se tratando de crescimento pouco mais que vegetativo, numa economia que está entre as dez maiores do mundo, produz efeitos visíveis e a queda dos índices de desemprego para patamares suportáveis (mas ainda muito altos) produz efeitos na organização social e na qualidade de vida da população. Um desses efeitos é o incremento de políticas públicas visando a melhoria das condições de vida da população em geral e a mais pobre em particular.

Podemos chamar a preocupação com a produção de políticas públicas que visem beneficiar diretamente a população em geral e a população mais pobre em particular como uma política baseada em compromisso social.

Como a política pública repercute no padrão de vida das pessoas? A política pública que visa a melhoria das condições de vida das pessoas tem caráter organizativo? Qual o tipo de organização que essa política produz? Ela é suficiente para mudar a qualidade de vida das pessoas mais pobres da população? Estas perguntas, do ponto de vista da Psicologia Social do Trabalho, repercutem o cenário de crenças e valores da população e a construção do que mencionamos, ao citarmos Enriquez, da perspectiva utópica. A crença no futuro é elemento importante para a organização do cotidiano e partimos da hipótese de que somente será possível a busca de alternativas de emprego e renda, do ponto de vista da Economia Solidária, se houver esperança de melhoria de condições de vida.

Buscando resposta para estas questões estamos apresentando, a partir do núcleo que coordenamos no Programa de Estudos Pós-Graduados da PUC-SP (NUTAS), um projeto de pesquisa cuja base teórica estará apoiada fundamentalmente na Psicologia Sócio-Histórica no que diz respeito às 
formas da linguagem como mediação (AGUIAR: 2001) e da produção de sentido pessoal e significações (AGUIAR, 2001 e 2006; GONZÁLEZ REY, 1997 e 2003). Partiremos das relações estabelecidas por Lev Vigotski ([1934] 1982) sobre a maneira de construção do psiquismo (consciência, pensamento) e a relação com o contexto social de produção de sentido. Para tanto, também usaremos como recurso a teoria bakhtiniana de dialogismo e produção de sentido e a visão construcionista social (ÍÑIGUES: 2002 ; SPINK, 1999; SPINK \& SPINK, 2006). No caso da Psicologia SócioHistórica, buscaremos nas falas dos sujeitos, a expressão de configurações psicológicas, sempre compreendendo que tais configurações se apresentam como construções sociais e materialmente constituídas. As configurações psicológicas permitem a relação entre a construção do sentido pessoal e o pensamento emocionado. Aqui, diferentemente do construcionismo social, a definição de sujeito é clara e evidente e nos serve para conectar a singularidade desse indivíduo com sua condição de ser humano genérico e produtor da história. É essa a relação que nos permite sair da análise estritamente psicológica e relacionarmos com um campo abstrato da consciência de classes da forma como a define Lukács (nos referimos ao Lukács de Per L'Ontologia dell'Essere Sociale).

Por outro lado, reconhecemos a capacidade do construcionismo social nos procedimentos de análise e formas de dialogismo como definido por Spink (1999). Assim, estaremos considerando, comparando e discutindo a relação entre a Psicologia Sócio-Histórica e o Construcionismo Social na vertente apresentada. Esta discussão teórica nos permitirá a avaliação do material coletado através de entrevistas e grupos focais que versarão sobre a história de vida dos nossos sujeitos, a construção de categorias de análise e a verificação da produção de sentido conforme apontado anteriormente.

O trabalho desenvolvido por Clot (2006), particularmente sobre a categoria ATIVIDADE, com o sentido de qual a valorização da atividade de trabalho pelos participantes do estudo, será também importante na análise que pretendemos realizar neste momento. Clot renova a concepção de atividade como foi elaborada por Leontiev e dá uma nova dimensão para essa 
categoria. No caso, Clot verifica que a atividade na situação de trabalho aparece como atividade prescrita e como atividade realizada. Há um campo de significação que se oculta nos interstícios da atividade na sua forma controlada e na sua forma executada. Como, numa cultura que relativiza os padrões morais e éticos, a diferença entre o formal e o informal se configura como interesse de análise para além das relações estritas de trabalho.

A categoria atividade é categoria importante para definirmos a condição de vida e de mudança de rumo (com foco nas políticas públicas e organização popular), mas é através das mediações que chegaremos até ela e uma das mediações fundamentais, como aponta Vigotski, é a linguagem. De acordo com Aguiar (2001):

Para compreender a fala de alguém, não basta entender suas palavras; é preciso compreender seu pensamento (que é sempre emocionado), é preciso apreender o significado da fala. O significado é, sem dúvida, parte integrante da palavra, mas é simultaneamente ato do pensamento, é um e outro ao mesmo tempo, porque é a unidade do pensamento e da linguagem (p. 130).

Assim, as condições para buscarmos o conjunto de crenças e valores dos sujeitos podem ser encontradas na decodificação do que pensam essas pessoas sobre o assunto abordado - trabalho, emprego, desemprego e geração de renda. A palavra com significado será, conforme aponta a autora, a unidade de análise. Outro aspecto que deve ser mencionado é o dos repertórios interpretativos, como apontam Spink \& Frezza (1999). Repertórios interpretativos e sentido pessoal fornecem a relação entre o campo de produção de significações e sua apropriação pelo sujeito, assim como a interferência pessoal no processo.

O procedimento será o de selecionarmos os grupos através de duas categorias de análise: um grupo de pessoas que moram e trabalham no bairro Pimenta, da cidade de Guarulhos e outro grupo de pessoas que somente moram no bairro e trabalham em outras regiões fora do polo industrial de Guarulhos (como o caso de empregadas domésticas que trabalham nos bairros mais ricos da cidade, operários que trabalham em São Paulo, trabalhadores 
que trabalham no bairro, mas não estão diretamente ligados ao polo industrial como os trabalhadores do setor informal que se autoempregam etc.). Nosso interesse é saber se há diferença entre os dois segmentos e se eles percebem as mudanças do bairro, da cidade e do país de forma diferente.

O bairro do Pimenta é um bairro consideravelmente industrializado na cidade de Guarulhos que se trata da maior cidade do Estado de São Paulo depois da Capital -1.300 mil habitantes. Possui um grande polo industrial, universidades, hospitais, um aeroporto internacional e é cortada por três grandes rodovias. Localiza-se na região metropolitana da cidade de São Paulo. O estudo neste bairro se justifica pelo perfil de seus moradores, já que o bairro se configura como um bairro operário e também pelo fato do bairro ter recebido importante investimento público neste último período. Combina a condição de moradores que hoje estão situados no grupo da chamada "nova classe média", grupo de famílias operárias, de pequenos comerciantes e prestadores de serviços, que há muito pouco tempo eram classificados como pertencentes ao grupo dos mais pobres. Como reagem aos apelos para a organização popular, como compreendem a presença da política pública que vem sendo implantada no bairro, qual a repercussão da melhoria da qualidade de vida do ponto de vista da consciência da mudança, como isso reverte em consciência de cidadania? Há decodificação crítica da política macroeconômica e consciência de sua aplicação para o bem-estar da população? Ou prevalece o individualismo e desinformação, ferramenta ideológica e forma de dominação?

Nossa hipótese de trabalho é que a melhoria da qualidade de vida permite uma melhor organização popular e que essa melhoria irá facilitar forças empreendedoras que garantem as condições necessárias para o desenvolvimento da economia solidária e forma de autoemprego que poderá se transformar em forma eficiente de geração de renda. Neste caso, tanto a concepção de Ricardo Antunes quanto a de Wanderley Codo estarão em plena consonância e poderemos falar em forma superior de organização da força de trabalho. Evidentemente, não esperamos encontrar o paraíso em 
Pimenta, mas indicativos de forma de inclusão e construção de consciência crítica que nos permita vislumbrar perspectivas de transformação social.

Um dos derivados desse trabalho pode ser a construção de indicadores que permitam a verificação dessa medida de bem-estar e consciência de si em outros bairros e cidades que apliquem uma política pública de forma consistente e responsável.

Referências bibliográficas

AGUIAR, W.M.J. Sentidos e Significados do Professor na Perspectiva SócioHistórica: relatos de pesquisa. São Paulo: Casa do Psicólogo, 2006.

Consciência e Atividade: Categorias fundamentais da psicologia Sócio-Histórica. In: BOCK, A.M.B. et al. - Psicologia SócioHistórica: uma perspectiva crítica em psicologia. São Paulo: Cortez, 2001.

- A pesquisa em Psicologia Sócio-Histórica: contribuições para o debate metodológico. In: BOCK, A.M.B. et al. Psicologia SócioHistórica: uma perspectiva crítica em psicologia. São Paulo: Cortez, 2001.

ANTUNES, R. Os Sentidos do Trabalho: Ensaio sobre a afirmação e a negação do trabalho. São Paulo: Boitempo. 1999.

BAUER, M.W. \& GASKELL, G. (eds.). Qualitative Researching with text, image and sound. A Practical Handbook. London: Sage, 2003.

CANDIDO, A. Os Parceiros do Rio Bonito. São Paulo: Duas Cidades, 1977.

CLOT, Y. A Função Psicológica do Trabalho. Petrópolis: Vozes, 2006.

CODO, W. (Org.). O Trabalho Enlouquece? Um encontro entre a clínica e o trabalho. Petrópolis: Vozes, 2004.

\& SAMPAIO, J.J. (Orgs.). Sofrimento psíquico nas organizações: saúde mental e trabalho. Petrópolis: Vozes, 1995.

FURTADO, O. As dimensões subjetivas da realidade: uma discussão sobre a dicotomia entre a subjetividade e a objetividade no campo social. São Paulo: Casa do Psicólogo, 2002. 
GONZALEZ REY, F. Sujeito e Subjetividade. São Paulo: Thomson, 2003. . Epistemología Cualitativa y Subjetividad. São Paulo: EDUC, 1997.

GORZ, A. Entrevista concedida a Vladimir Safatle e publicada no Jornal Folha de São Paulo, 2006.

IÑIGUEZ, L. Construcionismo Social. In: MARTINS, J.B. (org.) Temas em Análise Institucional e em Construcionismo Social. São Carlos: RIMA/Fundação Araucária, 2002.

DOWBOR, L. (2006). Democracia Econômica: um passeio pelas teorias. Extraído via internet de dowbor.org/artigos.asp Acesso em 04/09/2007.

LUKACS, G. Per l'ontologia dell'essere sociale. Roma: Riuniti, 1976.

MARTINS, J.S. Sobre o modo capitalista de pensar. São Paulo: Hucitec, 1978.

OFFE, C. Capitalismo Desorganizado. São Paulo: Brasiliense, 1994.

PINASSI, M.O. \& LESSA, S. (Orgs.) Lukács e a atualidade do marxismo. São Paulo: Boitempo, 2002.

PRADO JR., C. A Questão Agrária no Brasil. São Paulo: Brasiliense, 1979.

SINGER, P. Globalização e Desemprego: diagnóstico e alternativas. São Paulo: Contexto, 1999.

\& SOUZA, A.R. A Economia Solidária no Brasil: autogestão como resposta ao desemprego. São Paulo: Contexto, 2000.

SANTOS, B.S. Pela mão de Alice: o social e o político na pósmodernidade. São Paulo: Cortez, 1996.

SAWAIA, B. (org.) As Artimanhas da Exclusão: análise psicossocial e ética da desigualdade social. Petrópolis: Vozes, 1999.

SPINK, M.J. (org.). Práticas Discursivas e Produção de Sentido no Cotidiano: aproximações teóricas e metodológicas. São Paulo: Cortez, 1999.

\& SPINK, P. (orgs.) Práticas Cotidianas e a Naturalização da Desigualdade: Uma semana de notícias nos jornais. São Paulo: Cortez, 2006. 
VIGOTSKI, L.S. Pensamiento y Lenguaje. In: VIGOTSKI, L.S. Obras Escogidas. Tomo II. Madrid: Visor, 1982. 